LuCIA BARBosa Del PiCCHIA

\title{
ESTADO, DEMOCRACIA E DIREITOS NA CRISE DO CONSTITUCIONALISMO LIBERAL: UMA COMPARAÇÃO ENTRE O PENSAMENTO JURÍDICO FRANCÊS E O BRASILEIRO
}

Tese apresentada como requisito para a obtenção do título de Doutora, junto ao Departamento de Direito Econômico e Financeiro da FDUSP, sob orientação do Professor Titular Gilberto Bercovici. 


\section{AgRAdecimentos}

Se acertos há nessa tese, eles devem ser compartilhados com todos aqueles sem os quais não teriam sido possíveis. Em primeiro lugar, sou especialmente grata ao professor Gilberto Bercovici, pela confiança e pelo incentivo que vêm desde 2005, não medindo esforços para garantir uma orientação cuidadosa, a despeito da distância. Ao professor Carlos Miguel Herrera, meus sinceros agradecimentos por ter me recebido para um estágio de pesquisa de um ano na Universidade de Cergy-Pontoise, bem como pela disponibilidade para o diálogo e pela orientação comprometida, abrindo os caminhos para o estudo da doutrina constitucional francesa. Agradeço ainda aos professores Samuel Rodrigues Barbosa e José Maria Arruda de Andrade pelo estímulo e pelos valiosos comentários durante a banca de qualificação.

À Coordenadoria de Aperfeiçoamento de Pessoal de Nível Superior CAPES, sou grata por ter tornado possível o desenvolvimento de parte da pesquisa na França. Agradeço, ainda, à Procuradoria Geral do Município de São Paulo, por ter permitido que pudesse passar os últimos dois anos integralmente dedicada à pesquisa, licenciada de minhas atividades junto àquele órgão.

Essa tese é resultado de pesquisas em diversas bibliotecas espalhadas por diferentes cidades, em cujos acervos foram buscadas os registros históricos que constituem boa parte do material de análise. O trabalho de guarda, preservação e disponibilização de livros é fundamental, especialmente em se tratando de material histórico, e é na esperança de vê-lo incentivado e priorizado que registro meus agradecimentos, que faço na pessoa dos funcionários da Biblioteca da Faculdade de Direito da USP, Sras. Sônia Maria D’Angelis dos Santos, Rosângela Aparecida V. Pupo, Agostinha Cardoso Batista, Maria da Paixão Marques de Queiroz e do Sr. Jair B. Ferreira.

Um agradecimento especial aos amigos, tanto os novos, por tornarem menos árido o período de estadia no exterior, quanto os antigos, pela compreensão pela minha prolongada ausência, consumida pela pesquisa. Se não os nomeio para não correr o risco de injustiças, por um lado, por outro não poderia deixar de agradecer as contribuições pontuais para a tese de Andrea Laplane, Clara Castro, Ester Rizzi, Fabiana Rached, Gustavo Ribeiro, Lígia Winter, Lettícia Leite, Marcelo Hashimoto, Mariana Flesch, Paulo da Silveira, Tiago Tranjan, Raphael Neves, Sara Feitosa e Wendel Cintra.

À família, minha eterna gratidão pelo cuidado, pela confiança e pelo estímulo constante, nesse e em todos os demais projetos que assumi.

Por fim, a tese não teria sido possível sem o companheirismo, o carinho e a presença que superou distâncias do Fernando, a quem palavras seriam pouco para expressar meu agradecimento, e com quem aprendi que o que realmente importa não caberia jamais nessas linhas. 


\section{RESUMO}

A tese tem como objeto compreender, no campo da história das ideias jurídicas, a forma pela qual se equacionou a relação entre democracia e direitos sociais na Constituição brasileira de 1934, utilizando como perspectiva de análise e como baliza comparativa o constitucionalismo francês dos anos 1920 e 1930. Trata-se de um período de particular interesse para o estudo constitucional, tendo em vista a crise das premissas liberais, premissas que, por certo, haviam permitido a expansão democrática, mas que, até mesmo em função disso, se viram insuficientes como resposta única diante da irrupção da questão social. Na França, não há alteração constitucional, e é a doutrina do direito público que absorve a tarefa de responder à nova realidade, o que faz de diferentes modos. No Brasil, se por um lado as premissas liberais não são postas em prática, afastando a massificação democrática nos anos 1930, por outro lado a revolução que leva Getúlio Vargas ao poder e a necessidade de uma nova Constituição obrigam a Assembleia Constituinte a lidar com novas e velhas questões, isto é, tanto com a democracia liberal ainda por se concretizar quanto com os novos direitos sociais que marcam as Constituições modernas. O objetivo da tese é descrever de que forma se travou esse debate no processo constituinte brasileiro, por meio sobretudo dos registros da época, buscando identificar tanto influências quanto semelhanças e divergências com o caso francês, reposicionando a matéria na história das ideias jurídicas. 


\begin{abstract}
This work examines, from the standpoint of the history of legal ideas, the way in which the relation between democracy and social rights was dealt with in the Brazilian Constitution of 1934, using the French constitutionalism of the 1920s and 1930s both as an analytical perspective and as a point of comparison. This historical period has great interest to constitutional studies due to the crisis of liberal propositions that was taking place; propositions which, of course, had allowed a democratic expansion, but, and even because of that, had proved themselves insufficient as a unique response to the outburst of the so-called social question. In France, there is no change in the Constitutional regime, and it is the legal doctrine that assumes the task of responding in various ways to the new reality. In Brazil, on the one hand, the liberal propositions had not been fully materialized, something that restrained any significant democratic expansion during the 1930s. On the other hand, the revolution that had led Getúlio Vargas into power and the claim for a new Constitution forced the Constitutional Assembly to deal with both old and new problems, in other words, with both the liberal democracy yet to be materialized and the new social rights that characterized modern Constitutions. The aim of this work is to describe the way this debate developed during the Brazilian constitutional process, specially by analyzing the historical sources, and searching to identify influences from, as well as similarities and differences with the French case, repositioning the subject in the history of ideas.
\end{abstract}

\title{
RÉSUMÉ
}

Le but de ce travail de thèse est de comprendre, dans le domaine de l'histoire des idées juridiques, la façon dont s'est résolu le rapport entre démocratie et droits sociaux dans la Constitution brésilienne de 1934, en se servant du constitutionnalisme français des années 1920 et 1930 à la fois comme perspective d'analyse et comme point de comparaison. Cette période présente un intérêt particulier pour les études constitutionnelles, étant donné la crise des prémisses libérales qu'il y eut lieu ; prémisses qui, certes, avaient permis l'expansion démocratique et qui, pourtant et même en raison de cela, s'étaient montrées insuffisantes comme réponse unique à l'irruption du social. En France, il n'y eut pas d'altération constitutionnelle et c'est la doctrine du droit public qui assuma la tâche de répondre à la nouvelle réalité, ce qu'elle fit de diverses manières. Au Brésil, d'un côté les prémisses libérales n'avaient pas été mises en pratique, ce qui empêcha la massification démocratique pendant les années 1930. D'autre côté, la révolution qui emmena Getúlio Vargas au pouvoir et le besoin d'une nouvelle Constitution obligèrent l'assemblée constituante à faire face à des questions nouvelles et anciennes, à savoir, la démocratie libérale pas encore concrétisée et les nouveaux droits sociaux qui caractérisaient les Constitutions modernes. Il s'agit donc de décrire la manière dont s'est déroulé ce débat dans le procès constituant brésilien, par le moyen d'une recherche de registres historiques de cette époque, tout en cherchant soit les influences de la pensée française, soit les similarités et les différences par rapport au même, de façon à replacer le débat sur l'histoire des idées juridiques. 
Após a insurreição de 17 de Junho O secretário da União dos Escritores $\mathrm{Fez}$ distribuir panfletos na Alameda Estaline Em que se lia que, por culpa sua, O povo perdeu a confiança do governo E só à custa de esforços redobrados Poderá recuperá-la. Mas não seria Mais simples para o governo Dissolver o povo E eleger outro?

Bertolt Brecht, A Solução [in Poemas, Editorial Presença, 1976, p.82] 


\section{SUMÁRIO}

\section{PARTE I}

\section{PENSAMENTO CONSTITUCIONAL FRANCÊS NOS ANOS 1920 E 1930}

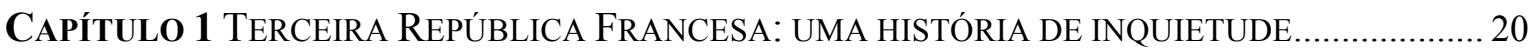

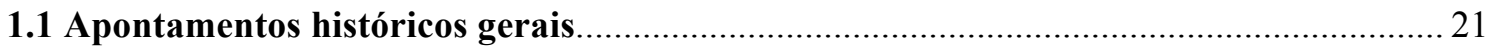

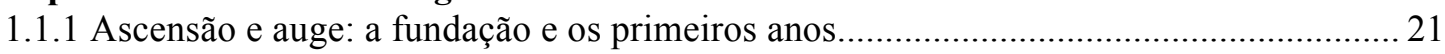

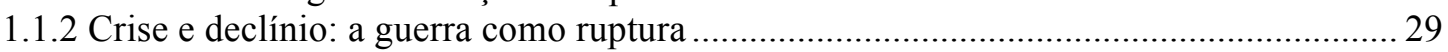

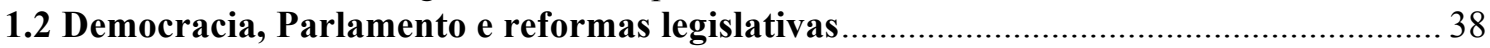

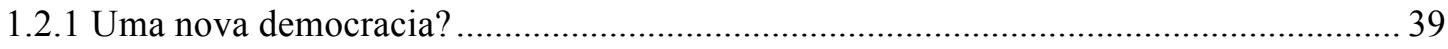

1.2.2 Novas leis e novas disputas no Parlamento ..................................................................... 46

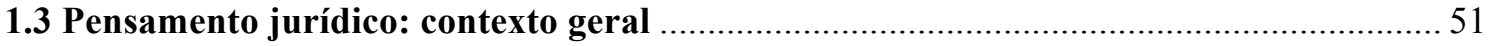

1.3.1 "Juristas inquietos": a belle époque como transformação do pensamento jurídico ........56 56

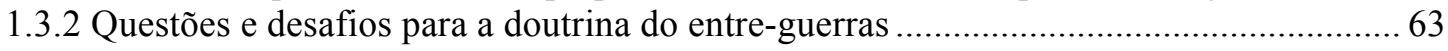

CAPítulo 2 JuRISTAS ClÁSSICOS: SITUANDO O PENSAMENTO CONSTITUCIONAL FRANCÊS

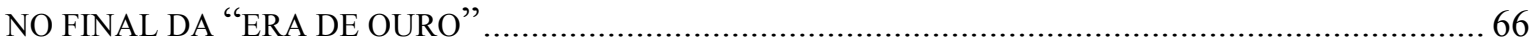

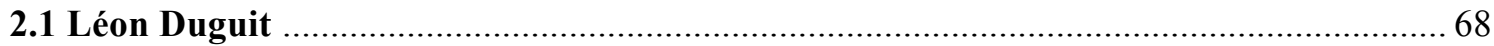

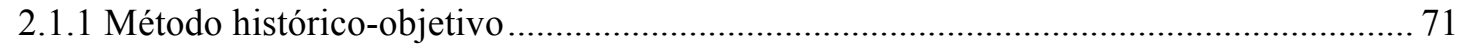

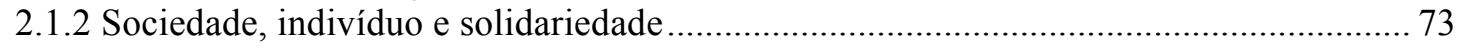

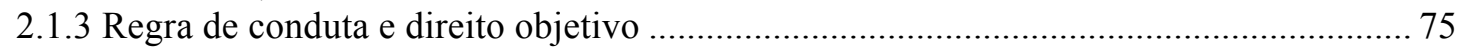

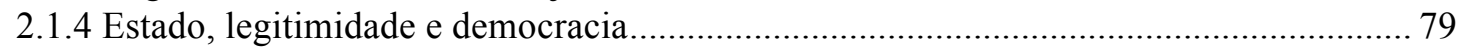

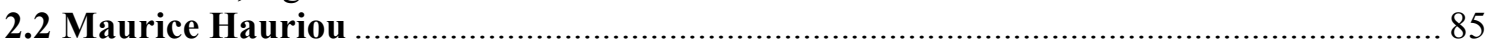

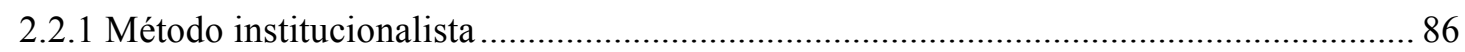

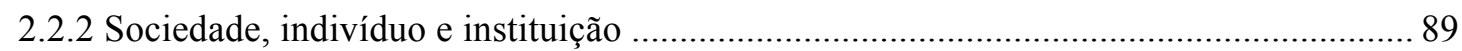

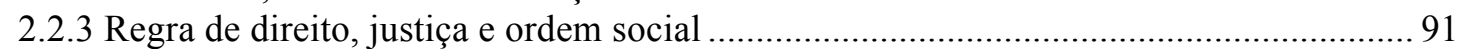

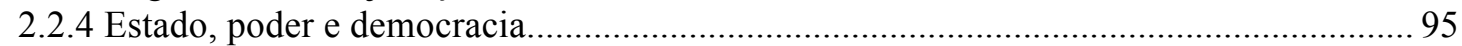

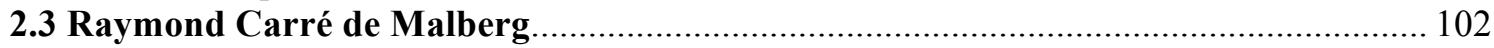

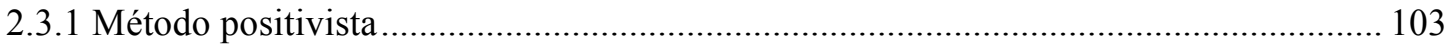

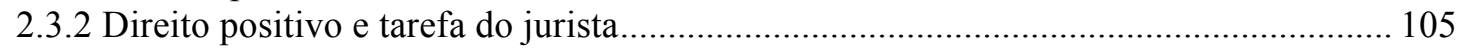

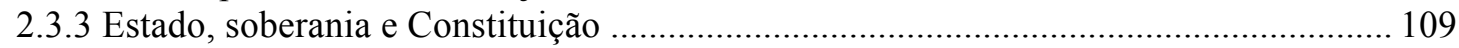

2.3.4 Soberania popular e democracia: um pensamento de transição ..................................... 113

2.4 Horizonte teórico deixado pelos clássicos: substancialização da ordem social vs.

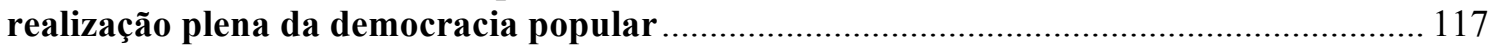

CAPÍTUlO 3 JuRISTAS PRAGMÁTICOS: A CRISE do CONSTITUCIONALISMO LIBERAL............. 120

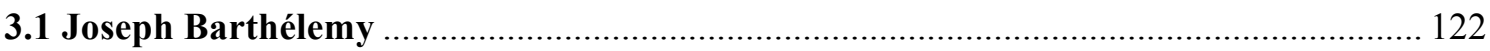

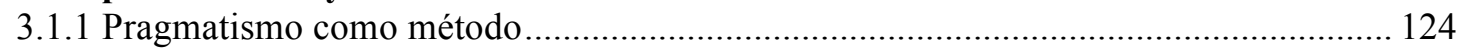

3.1.2 Anos 1920: sufrágio universal, democracia representativa e liberalismo......................... 129

3.1.3 O direito, a Constituição e a defesa da Terceira República ........................................ 136

3.1.4 Anos 1930: a transformação de um liberal ameaçado .................................................. 139

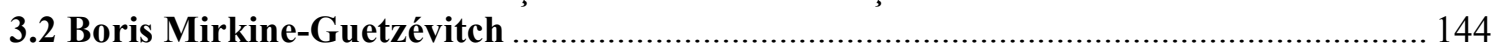

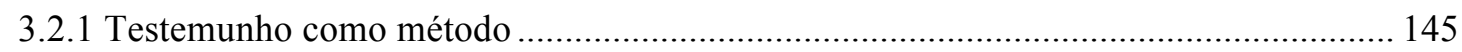

3.2.2 Direito e política: a tendência à racionalização do poder como traço comum às novas

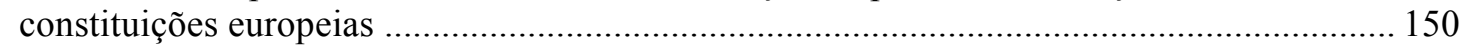


3.2.3 Democracia e novo parlamentarismo 155

3.3 René Capitant

3.3.1 Método, imperativo jurídico e subjetivismo: a retomada marginal da perspectiva teórica dos clássicos

3.3.2 Constituição, soberania e democracia

\section{PARTE II: ELABORANDO A CONSTITUIÇAO BRASILEIRA DE 1934}

Capítulo 4 Segunda República BRASILEIRA: RUPTURA E COMPROMISSO INSTÁVEL ...... 175

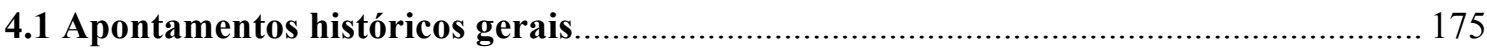

4.1.1 Da Primeira República à Revolução de 1930 ………………………............................ 177

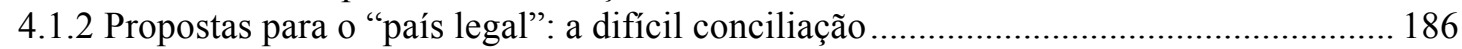

4.2 Aspectos institucionais e primeiras reformas legislativas (1930-1934) …..................... 195

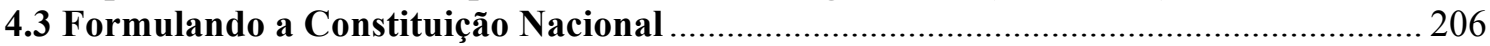

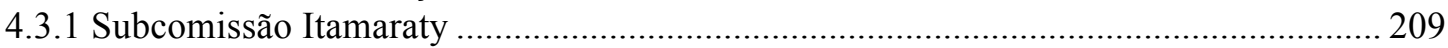

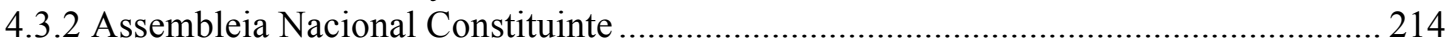

\section{CAPítulo 5 A CONSTITUINTE E SUA ÉPOCA: REFLEXÕES GERAIS SOBRE O MODELO DE} CONSTITUIÇÃO

5.1 Uma "Constituição de imaginação"? Tensão entre influência estrangeira e realidade nacional

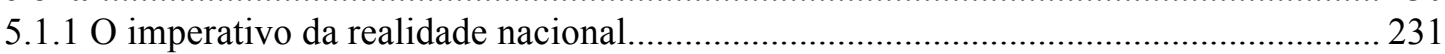

5.1.2 Os três planos da influência estrangeira....................................................................... 233

5. 2 Uma Constituição social: a crítica ao liberalismo e o papel do Estado ……................. 248

5. 3 Técnica jurídica e ideia de Constituição ..................................................................... 262

CAPÍTUlo 6 UMA CONSTITUIÇÃO MODERNA E SOCIAL: DEMOCRACIA E DIREITOS SOCIAIS

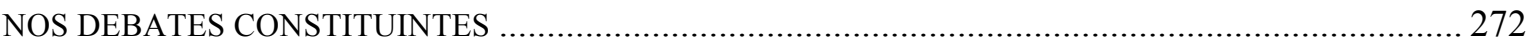

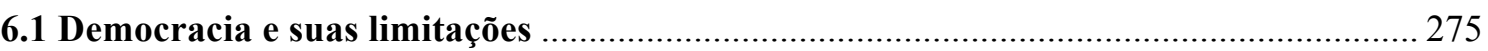

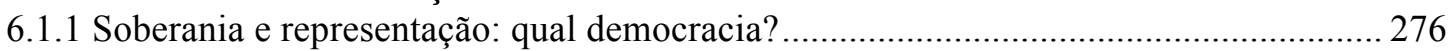

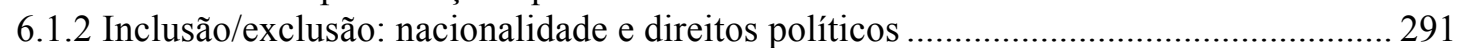

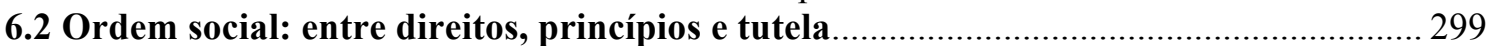

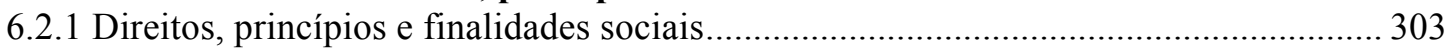

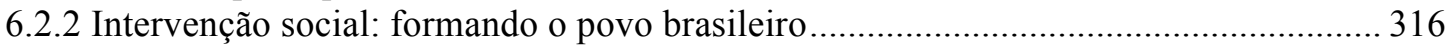

7 CONCLUSÃO CRISE DO LIBERALISMO, IRRUPÇÃO DO SOCIAL E DIREITOS: A VIRADA DO

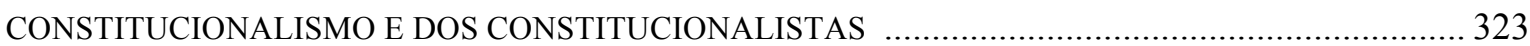

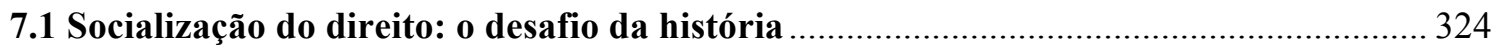

7.2 A resposta da doutrina constitucional francesa: o direito como fator de movimento .330 7.3 A resposta da Constituição brasileira de 1934: regulação social e democracia limitada

7.3.1 Influência francesa: reposicionando a história das ideias ............................................. 338

7.3.2 Processos comparados: a virada pragmática do constitucionalismo brasileiro............... 342 


\section{ANEXOS}

I. QUADRO COMPARATIVO: CONSTITUIÇÃO DE 1891, PROJETOS CONSTITUCIONAIS E CONSTITUIÇÃO DE 1934 (Tabela 1)

II. COMPOSIÇÃO DA ASSEMBLEIA NACIONAL CONSTITUINTE DE 1933/34 …….............................. 398

Tabela 2: Deputados por origem (representação política e representação profissional) ............. 398

Gráfico 1: representação política (I) - distribuição por profissões/formações ............................ 399

Gráfico 2: representação política (II) - local de estudos - formação: Direito ............................ 399

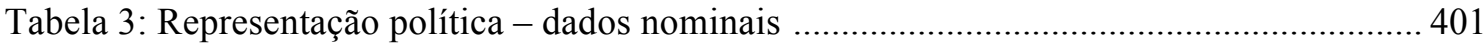

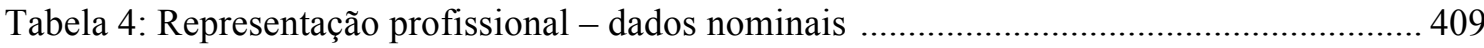

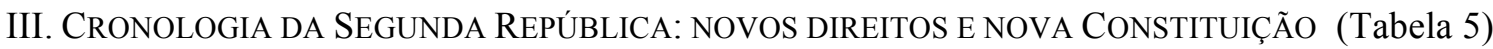

BibliografiA 


\section{INTRODUÇÃO}

"A década de 30 pertenceu, por inteiro, à polêmica do capital com o trabalho. Refletia não só a crise do capitalismo, senão também a poderosa arregimentação das forças trabalhistas com seu decisionismo histórico de ascender ao poder" $"$. Em diversos países, a ampliação do reconhecimento dos direitos liberais de igualdade formal, pressuposto básico para a extensão dos direitos políticos, especialmente do sufrágio universal, tornavam as novas democracias permeáveis às demandas populares. Por outro lado, a organização crescente dos trabalhadores indicava uma pressão pela construção da igualdade material, isto é, a equiparação dos níveis de vida, que se refletia sobretudo em demandas por direitos econômicos e sociais. O direito, especialmente o direito público, encontrava-se em uma encruzilhada, que indicava a impossibilidade de manutenção irrefletida das premissas liberais, organizadas em torno da proteção formal da liberdade individual. Era preciso ir além.

"A irrupção do social, com efeito, exige sua racionalização jurídica", escreve Carlos Miguel Herrera. É nesse sentido que Joseph Charmont fala, na França de 1903, em "socialização do direito": "Socializar o direito é torná-lo mais compreensivo, mais amplo do que era antes, estendê-lo do rico ao pobre, do possuidor ao assalariado do homem à mulher, - do pai ao filho, ou seja, é admiti-lo em benefício de todos os membros da sociedade, ${ }^{3}$.

O foco do trabalho é compreender, sob uma perspectiva interna ao pensamento jurídico, notadamente ao pensamento constitucional, a forma pela qual se processou e se racionalizou a irrupção do social, a socialização do direito, entendida a partir do confronto entre princípios da democracia liberal individualista e uma nova preocupação coletivista e social que é incorporada pelo direito.

Trata-se de uma questão ampla, que precisa ser melhor delimitada. Porém, antes disso, façamos um desvio para tornar claros os pressupostos teóricos da

\footnotetext{
1 BONAVIDES e ANDRADE, 2006, p. 273.

2 HERRERA, 2005, t.I, p. 9.

3 CHARMONT, 1903, p. 380. Nota geral sobre as traduções e citações: para os trechos consultados originalmente em francês, será adotada nesse trabalho tradução livre, de responsabilidade da autora, em que se privilegiaram, na medida do possível, as escolhas do texto original. Caso a citação venha em nota de rodapé, optamos por mantê-la conforme o original. Por fim, nas citações em português respeitar-se-á a ortografia atual do idioma.
} 
pesquisa que ora se propõe. Analisar esse momento de transição no direito significa, por um lado, aceitar as determinações, sobretudo políticas, que lhe são externas, mas também, por outro lado, situar-se em um espaço de investigação que seja propriamente jurídico, ou seja, que diga respeito às ideias e conceitos pertencentes, propriamente, ou ao menos pretensamente, ao campo do direito, da doutrina e da teoria jurídicas. Para tanto, é fundamental posicionar-se teoricamente na fronteira do direito com a política, no entredeux entre ambas as disciplinas. Partiremos, para isso, da proposta metodológica de Herrera $^{4}$.

De acordo com o autor, tradicionalmente a relação entre direito e política foi exposta sob uma perspectiva externa, que se confundia com o olhar sociológico. Tratase de tomar a perspectiva jurídica e a política como dois campos externos, unidos pela abordagem sociológica. "Partindo do caráter político das instituições jurídicas, chega-se a negar toda autonomia teórica à doutrina, que se vê reduzida a produzir uma explicação parcial (portanto, falsa) de seu objeto, se esse não cumpre o papel de guardião da ordem. Mais uma vez, esse tipo de análise termina por apreender a relação direito/política em termos de sobredeterminação do segundo sobre o primeiro, em uma lógica de exterioridade $"$. Termina por relegar ao direito um papel de violência simbólica, como na abordagem de Pierre Bourdieu $^{6}$, de legitimação da dominação política a partir da neutralização do direito pela crença em sua universalidade, uniformidade e coerência enquanto bloco autônomo de pensamento e normatividade.

Para Bourdieu, de forma esquemática e simplificada, o direito seria um campo, isto é, um universo dotado de autonomia relativa no qual se joga um jogo de acordo com determinadas regras e, para jogá-lo é necessário uma certa e indispensável cultura jurídica. O campo demanda crença no jogo, concordância quanto às suas regras e quanto à necessidade de jogá-lo de acordo com elas. Transgredir a regra apenas reafirma a onipotência do sistema, que a partir daí pode se consolidar com toda a sua pretensão de validade universal. A autonomia do campo se impõe sobretudo em relação à economia, diante de sua aspiração de pureza. Mas, para o autor, o direito faz parte da realidade econômica, que o determina de forma inegável e inafastável. A máscara da autonomia, que se afirma na crença no jogo, é a força própria do direito - produz-se como que uma “mágica", operada por conta da convicção dos indivíduos que vale a pena jogar o jogo. " $O$

\footnotetext{
${ }^{4}$ Cf. HERRERA, 2007, HERRERA, 2003.

${ }^{5}$ HERRERA, 2007, p. 86.

${ }^{6}$ Cf. BOURDIEU, 1991.
} 
direito não é o que ele diz ser, o que ele crer ser, isto é, algo de puro, de perfeitamente autônomo, etc. Mas o fato de se crer como tal, e que consegue se fazer crível, contribui para a produção de efeitos sociais completamente reais" ${ }^{\prime 7}$. Os juristas são, segundo ele, os "guardiões hipócritas de uma hipocrisia coletiva", hipocrisia que se traduz justamente na crença em sua universalidade e autonomia, que induz ao respeito às regras do jogo. Para além da crença, existem apenas as determinações sociais, especialmente econômicas, que determinam o conteúdo das regras e decisões, refutando-se, assim, a tese da autonomia pode-se falar apenas em uma autonomia simbólica, quase mágica.

Contudo, a perspectiva externa é limitada por tomar como ponto de partida a análise das instituições, e não dos conceitos jurídicos enxergados em suas descontinuidades. É possível proceder ao estudo do direito em sua perspectiva interna, identificando uma disputa política dentro da própria doutrina pela significação dos conceitos especificamente jurídicos - é nesse espaço que queremos situar nossa investigação.

Segundo a proposta de Herrera, "não podemos estudar a relação entre direito e política sem passar pela análise dessa 'mediação determinante' (Bourdieu) que é a doutrina jurídica" ${ }^{\prime \prime}$. Há um espaço entre o direito e sua teorização, um entre-deux, nem que seja apenas no nível da linguagem, que permite com que o direito seja ao mesmo tempo determinado e determinante das relações políticas e sociais. O direito é assim técnica e medida do social, que permite um estudo específico, interno, de história do pensamento jurídico capaz de identificar nas "transformações por deslocamentos (glissements)" dos conceitos uma disputa por seu conteúdo, lutas de significação (políticas).

O pressuposto dessa abordagem é de que há um interesse peculiar para a história social na análise dos conceitos internos a um determinado campo teórico, o direito, no caso, conforme sustenta Koselleck: "Na exegese de um texto, o interesse especifico no emprego de conceitos políticos e sociais, e a análise de sua significação revelam uma importância que concerne também à história social. Seus elementos de duração, de mudança e de futuro contidos em uma constelação política concreta aparecem na interpretação. Assim, diríamos, de modo ainda mais geral, que as realidades sociais e suas mudanças já são tematizadas"9.

\footnotetext{
${ }^{7}$ BOURDIEU, 1991, p. 91.

${ }^{8}$ HERRERA, 2007, p. 85

9 KOSELLECK, 1990, p. 103
} 
A proposta parte da separação entre direito positivo enquanto ordem e a teoria enquanto espaço do dissenso e do pensamento crítico, entre doutrina jurídica e dogmática, permitindo relativizar as continuidades ontológicas que frequentemente querem identificar os defensores de uma neutralidade e uma homogeneidade na doutrina e no pensamento jurídico. Queremos crer, especialmente, que também o texto do direito positivo é antecedido e determinado, em parte, pelos debates teóricos acerca das noções jurídicas, e que portanto carregam em si as divergências que lhe possam caracterizar. Daí a utilidade em se descrever, junto com a doutrina que lhe dá suporte, os debates que estão na origem das normas, e, especialmente, das Constituições.

"A empreitada teórica dos juristas de esquerda deixa descoberto, por sua radicalidade mesma, pelas tensões que desperta, em um discurso que funciona pela fixação, o projeto de pensar no direito o dinamismo das forças sociais, um lugar particular, onde se implanta essa relação entre direito e política. Um espaço científico, sob a forma de um 'entre-deux'. Isso porque ele opera como um local de junção entre o jurídico e o político, uma interface discursiva que não possui existência autônoma fora dos dois campos que lhe dão sua existência (...). É nesse 'entre-deux', de todo modo, que nós encontramos uma articulação entre as ideias políticas em sentido próprio, tais como se apresentam a nós desde o século XIX (conservadorismo, liberalismo, socialismo) e os conceitos jurídicos, uma conexão que se ilustra notadamente em noções como 'constituição', 'Estado de direito', 'direitos fundamentais', 'propriedade privada' etc. E a apropriação teórica desse espaço se apresenta, na história do direito (no sentido blochiano de uma história de juristas) como um procedimento intelectual específico, sistemático" $"$.

O objetivo do trabalho é, portanto, traçar uma história dos conceitos jurídicos, em perspectiva interna à doutrina jurídica e à reflexão jurídica, cotejando-a com a forma pela qual os conceitos foram manejados em um momento em que particularmente deles se demandava, qual seja, o momento constituinte. Contudo, a perspectiva interna ao direito não significa perder de vista a articulação entre o contexto jurídico e a realidade social como um todo, apenas centrar a análise nos sentidos que as determinações políticas impactam especificamente o pensamento jurídico. Vejamos de que forma se buscará por em prática essa postura, na pesquisa concreta.

Como mencionado, o pano de fundo maior da pesquisa é compreender de

${ }^{10}$ HERRERA, 2007, p. 91. 
que modo o direito incorporou as demandas sociais, canalizadas, concreta ou potencialmente, pelo jogo político institucional a partir da universalização do sufrágio e da expansão democrática. Julgamos que a Constituição e o direito constitucional são esferas particularmente interessantes em que pode ser buscada essa transição, considerando tratarse do direito mais próximo da política.

O objeto de análise eleito é, assim, a Constituição brasileira de 1934, e os debates jurídicos travados durante o processo constituinte, que servirão como fontes primárias. Como é sabido, foi uma carta política de vida curtíssima, o que implica na escassez de comentários e referências dentro da doutrina jurídica constitucional brasileira. De acordo com Eduardo Kugelmas, "talvez por sua duração efêmera, a Constituição de 1934 não tem recebido a merecida atenção de juristas, historiadores e cientistas sociais, sendo escassa a bibliografia sobre suas características básicas e sobre o processo de sua elaboração. Essa relativa desatenção parece-nos equivocada, já que o documento de 1934 é um excelente guia para o esclarecimento do complexo panorama político-ideológico de uma época de transição, proporcionando pistas preciosas para o estudioso" "11. É, assim, uma Constituição de uma época de transição, de crise dos velhos paradigmas e de busca por novos. Desnecessário lembrar que é a primeira vez em que se constitucionaliza um capítulo sobre ordem econômica e social no Brasil, fato que por si só merece atenção. Mas o interesse não se resume ao pioneirismo, apenas.

A Constituição de 1934 espelha o complexo panorama políticoideológico de uma época de particular interesse para a história e a teoria social brasileira, qual seja, o momento de virada na forma pela qual se enfrentava a chamada "questão social" no país. Deixa de ser "caso de polícia", como a qualificou o Presidente Washington Luís, e passa a ser elemento central das políticas do Estado. Por outro lado, é também o momento em que as forças políticas preocupavam-se, ao menos na retórica dominante, com a revisão das velhas práticas eleitorais da Primeira República, denunciando a distância entre as premissas liberais expressas na Carta de 1891 e a realidade de fraudes e manipulações das eleições. Democracia e direitos sociais estavam na agenda do novo governo, que, ademais, havia assumido em um contexto revolucionário, de ruptura com a velha ordem.

Os anos 1930, no Brasil, têm despertado particular interesse na teoria social e na historiografia nacional há décadas. Qual a utilidade de adicionar-se mais uma

${ }^{11}$ KUGELMAS, 1987 , p. 30. 
pesquisa sobre o assunto? A investigação preocupar-se-á em iluminar um aspecto talvez subvalorizado, qual seja, o debate de ideias propriamente jurídicas que se travou durante o momento constituinte. Lembrar que as inovações foram formuladas sobretudo por juristas, versados nas teorias contemporâneas mais atuais, não significa atribuir às ideias jurídicas vida própria, independente do contexto social e político mais geral. Significa apenas vislumbrar uma instância de reflexão quiçá relevante, tomando como pressuposto a existência de um mínimo de autonomia da linguagem do direito, que torna útil compreender a forma pela qual se dá a passagem de ideias propriamente políticas (liberalismo, corporativismo, autoritarismo etc.) para conceitos específicos do campo do direito, passíveis de constitucionalização, nesse "entre-deux" de que tratamos acima.

Para tanto, julgamos oportuno escolher uma lente de análise, uma baliza comparativa, capaz de indicar não apenas possíveis influências diretas, seu uso e sua inadequação, mas também servir como comparação sistemática, a partir de semelhanças e diferenças relevantes. Nesse sentido, elegemos a França do entre-guerras, ou melhor, a doutrina constitucional francesa do entre-guerras, menos por sua uniformidade, e mais pelo que representa de ruptura e de diversidade de respostas, reposicionando o direito e seu papel de integração social.

A escolha deveu-se, em primeiro lugar e sobretudo, à multiplicidade de referências, explícitas ou não, aos publicistas franceses durante o processo constituinte brasileiro - desnecessário ressaltar a relevância do direito público francês para a formação do brasileiro, desde o século XIX, bem como o lugar de destaque que a doutrina daquele país sempre teve nas salas de aula por aqui, formando não apenas juristas mas também políticos e deputados constituintes. Em segundo lugar, a baliza comparativa é útil também em razão de suas assimetrias: como se verá, diferente do Brasil, na França não houve nova Constituição, mantiveram-se as leis constitucionais de feições liberais, a democracia consolidada e massificada implicou em um Parlamento com composição bastante distinta da Assembleia Constituinte brasileira, e a doutrina assumiu, muito mais, a tarefa de incorporação e integração do social. Dessa forma, pôde servir aos constitucionalistas brasileiros. A pergunta que buscará ser respondida é, portanto: em que a doutrina constitucional francesa, e as peculiaridades daquele país, podem ajudar a compreender o momento constituinte brasileiro de 1934, em termos da equação democracia e direitos sociais, pressupondo, portanto, o movimento de socialização do direito comum aos dois países?

A tese está dividida em duas partes. A primeira delas será dedicada ao 
estudo da doutrina constitucionalista francesa dos anos 1920 e 1930, o que se fará a partir da escolha de alguns autores-chave, representativos das correntes de pensamento que vinham se consolidando no período. Estão agrupados em dois capítulos, separação não apenas cronológica, mas também relacionada com as suas visões, próximas ou distintas, do que deveria ser o objeto de estudo dos constitucionalistas, os caminhos e os conceitos que deveriam ser manejados e o papel do direito na relação com a ordem social. São autores que despertam particular interesse, esses que escrevem durante a Terceira República Francesa, como salienta Carlos Miguel Herrera: "Encontramos assim uma modalidade de jurista iconoclasta que se situa entre a tradição (dos conceitos, mas também das instituições) e a inovação"12.

Em um primeiro grupo figuram juristas de destaque antes mesmo da Primeira Guerra Mundial, no que ficou chamado de "período de ouro" do pensamento constitucional francês, quais sejam, Léon Duguit, Maurice Hauriou e Raymond Carré de Malberg. Todos podem ser considerados representantes do que Olivier Beaud chamou de "juristas clássicos" 13 , na medida em que cuidavam de fundar o direito constitucional como ramo autônomo baseado em conceitos e método próprio, mas não distante da política e de uma borrada fronteira com a ciência política. Articulavam teorias em torno de concepções cuidadosas de Estado, indivíduos, as relações entre eles, que implicavam em consequências particulares para o funcionamento do sistema político que garante legitimidade ao direito, tendo como ponto inescapável a democracia e o sufrágio universal. São eles que passam a se preocupar em teorizar um direito que não pode mais ser descrito apenas em torno do indivíduo abstratamente considerado e de sua vontade, era preciso ir além do método exclusivamente individualista que seria típico de um constitucionalismo liberal, e admitir preceitos sociais dentro do direito, que teria então reforçada sua tarefa de integração.

Em seguida, Joseph Barthélemy, Boris Mirkine-Guetzévitch e René Capitant são apresentados no capítulo seguinte, e a despeito de não possuírem a mesma estatura intelectual no entre-guerras, podem ser reunidos em função de sua nova perspectiva em relação ao direito constitucional. Sendo o contexto histórico diferente, também as respostas por eles oferecidas serão novas. O principal ponto a ser destacado, ao menos em relação aos dois primeiros autores, é a sua preocupação inicial em descrever não um direito capaz de garantir a resistência de determinados valores, mas sim um direito

${ }^{13}$ Exposta em BEAUD, 2000. 
permeável a mudanças. Nesse sentido, não se preocupam em formular um sistema íntegro e coeso teoricamente, mas sim em descrever realidades práticas e capacitar o direito constitucional para lidar, de forma eficiente, com elas. Também aqui serão analisadas as transições no pensamento dos autores, relacionadas à história, bem como o que pode ser sublinhado do período pelas reflexões de Capitant.

Ao tratar do pensamento jurídico de determinados autores, é preciso que se apresentem algumas ressalvas metodológicas que, por mais óbvias que sejam, não custam tornar explícitas. Antes de mais nada, ressalte-se, não se pode tomar a doutrina como um bloco coeso, e apresentar diferentes pensamentos não raro divergentes vem ao auxílio de tornar claras descontinuidades e divergências que caracterizam as teorias sobre o direito. Assim sendo, cada um dos autores trabalha com uma epistemologia própria, o que significa dizer que as noções particulares de Estado, direito ou democracia, por exemplo, variam entre eles. Mais ainda, há descontinuidades relevantes dentro do pensamento dos juristas, implicando em recusar tomá-lo como um bloco coeso, ou, em outras palavras, evitando o equívoco da "mitologia da coerência" de que fala Skinner". Ademais, não podem ser avaliadas de acordo com formas que lhe seriam externas, anacrônicas ou inadequadas, o que nos obriga a ter cautela ao aplicar paradigmas teóricos tais como liberalismo, corporativismo ou organicismo, buscando intenções ou falhas a partir de objetivos que o próprio autor não havia atribuído para sua teoria. Uma pesquisa rigorosa imporia tomá-los a partir daquilo que se propuseram, em seu tempo e contexto, com o instrumental de que dispunham e levando em consideração sua própria biografia intelectual e política. A despeito da humildade que a dificuldade da tarefa impõe ao pesquisador, é importante não perdê-la de vista e persegui-la tanto quanto possível, e é o que procuraremos fazer.

Mais ainda, não é possível compreender uma determinada teoria partindo apenas do texto em si, sem situá-la historicamente. Por isso, dedicaremos capítulos introdutórios a ambas as partes da tese em que buscaremos traçar linhas mais gerais sobre a história social e das instituições da França e do Brasil, bem como da doutrina jurídica e do direito, em perspectiva mais ampla. As exposições não devem ser tomadas como pesquisas exaustivas, mas sim como apresentação panorâmica, auxiliar na análise das questões que estavam colocadas ao direito pela sua época. Mas a tese situa-se, sobretudo, no plano da história das ideias e dos discursos.

${ }^{14}$ SKINNER, 1969, p. 16. 
$\mathrm{O}$ que nos conduz à segunda parte da tese, que cuida do processo constituinte brasileiro de 1933/34. Conforme indicado, começaremos por um capítulo que trata do contexto histórico do Brasil da Segunda República, recuperando elementos importantes da Primeira República e da Revolução de 1930, para a seguir tratar do Governo Provisório e das reformas normativas por ele implementadas, que digam especialmente respeito à democracia e aos direitos sociais no país. A seguir, passaremos à descrição do processo constituinte, a partir de suas instâncias de debate, atores e cronologia de acontecimentos.

Em seguida, podemos passar à análise dos debates constituintes propriamente ditos, que será feita nos capítulos 5 e 6 . Nesse caso, há uma assimetria de objetos que merece ser explicitada e esclarecida. Enquanto na parte I da tese trabalharemos com a retórica da doutrina jurídica constitucionalista, propriamente dita, na parte II o objeto central serão os discursos registrados nas atas do processo constituinte, tanto da Assembleia quanto da Subcomissão Itamaraty, formada para redigir o anteprojeto de Constituição. Serão feitas referências também à doutrina e a demais obras do período, mas os discursos compõem o material primeiro de pesquisa. Isso porque é esse, sobretudo, o objeto da tese, qual seja, descrever o processo de composição da Constituição brasileira de 1934 e sua gênese, tendo como foco peculiar as ideias e os debates jurídicos. A doutrina francesa não aparece com o mesmo status, como poderia ser caso fosse propriamente um trabalho de doutrina jurídica comparada, mas sim como instrumental de compreensão das ideias, dos temas e dos debates, permitindo, ainda, indicar a transição pela qual passava o direito constitucional.

Portanto, no capítulo 5 buscaremos nos aproximar das discussões a partir das questões mais amplas sobre o que deveria ser a futura Constituição, como estaria relacionada à realidade brasileira, como recepcionaria influências estrangeiras, como seria posicionada em relação à Constituição anterior e seus princípios liberais e qual o papel reservado à técnica jurídica nos discursos. Assentadas as visões mais gerais, o capítulo 6 será dedicado à análise, propriamente, dos debates constituintes sobre as questões relacionadas à democracia que se estaria fundando, bem como à regulação e aos direitos sociais, permitindo compreender se há, ou não, articulação entre o que se estava formulando. Assim chegaremos à conclusão, em que serão traçados os paralelos e as influências entre o Brasil e a França, na forma como o direito constitucional absorveu a questão social e forjou um novo paradigma de regulação daquele momento em diante, que passou a moldar as preocupações constitucionais futuras. 
Por fim, como observação final, vale lembrar qual a relevância que pode assumir uma tese que trata da história, e mais precisamente, da história das ideias no direito, sob a perspectiva interna, da doutrina e dos discursos. Queremos crer na valia de melhor elucidar origens e debates sobre determinadas noções e arranjos constitucionais, cotejados com suas influências e seu contexto histórico, como forma de possibilitar a identificação de continuidades - mas não de atemporalidades e conteúdos universais -, e, sobretudo, de transformações de sentido que passaram a assumir ao longo do tempo. Não há conteúdos universais e unívocos na doutrina jurídica, mas sim arranjos contingenciais, que merecem ser esclarecidos e situados historicamente. Conforme destaca Skinner, já é um senso comum constatar que "nossa sociedade coloca limitações irreconhecíveis sobre nossas imaginações. Merece, da mesma forma, tornar-se senso comum que o estudo histórico das ideias de outras sociedades deve ser empreendido como o meio indispensável e insubstituível de impor limites a essas limitações (...). Demandar da história do pensamento uma solução para os nossos problemas imediatos é cometer não apenas uma falácia metodológica, mas algo como um erro moral. Mas aprender com o passado -e não se pode aprender de outra forma - a distinção entre o que é necessário e o que é mero produto de nossos arranjos contingentes é aprender a chave da autoconsciência em si"15.

${ }^{15}$ SKINNER, 1969, p. 53. 
PARTE I

PENSAMENTO CONSTITUCIONAL

FRANCÊS NOS ANOS 1920 E 1930 


\title{
Capítulo 1
}

\section{TERCEIRA REPÚBLICA FranCESA: UMA HISTÓRIA DE INQUIETUDE}

\begin{abstract}
1.1 Apontamentos históricos gerais; 1.1.1 Ascensão e auge: a fundação e os primeiros anos; 1.1.2 Crise e declínio: a guerra como ruptura; 1.2 Democracia, Parlamento e reformas legislativas; 1.2.1 Uma nova democracia?; 1.2.2 Novas leis e novas disputas no Parlamento; 1.3 Pensamento jurídico: contexto geral; 1.3.1 "Juristas inquietos": a belle époque como transformação do pensamento jurídico; 1.3.2 Questões e desafios para a doutrina do entre-guerras
\end{abstract}

É impossível compreender o que se passa com a teoria e a doutrina em um determinado período sem ter em mente o contexto histórico geral em que se situa. A necessidade de fundamento histórico é ainda mais premente em se tratando de um trabalho que tem como um dos eixos o pensamento jurídico de outro país, a França, cuja história supõe-se ser menos próxima do que a brasileira. Contudo, é com a consciência de que aventurar-se em uma análise histórica é uma empreitada vasta e complexa, que jamais poderia ser esgotada em poucas linhas ou páginas, que inauguramos esse capítulo. Assumimos, assim, o risco de tratar da história e do debate sobre a Terceira República Francesa de forma panorâmica, sustentando que sem esse alicerce histórico e teórico nenhuma compreensão do pensamento seria possível. Como já dito, a pretensão do capítulo é servir de pano de fundo geral para os demais capítulos dedicados ao pensamento jurídico francês dos anos 1920 e 1930, nada mais. Não desconhecemos a existência de vastíssima bibliografia sobre os diversos assuntos aqui tratados. O objetivo aqui está longe de ser esgotá-la.

Tratar da Terceira República Francesa, em toda a sua longa extensão, é tratar de uma história de inquietude. Inquietude social, política, econômica, e inquietude que também se refletiu no pensamento, sempre preocupado em apresentar soluções para as crises, mais constantes do que as calmarias. É dessa história que se vai tratar a seguir.

Em primeiro lugar, de forma ampla, dividindo o período entre o que veio antes e depois da Primeira Guerra Mundial, permitindo compreender o conflito como um divisor de águas na história da Terceira República. Em seguida, trataremos da democracia, 
ou melhor, das suas transformações práticas, bem como das inovações legislativas e do Parlamento, propriamente dito. Ao final, situaremos nesse contexto, de forma ainda esquemática, o pensamento jurídico, permitindo compor um pano de fundo geral para os autores abordados nos capítulos 2 e 3 .

\subsection{APONTAMENTOS HISTÓRICOS GERAIS}

Antes de mais nada, é importante compreender, em linhas bastante gerais, as feições da Terceira República francesa, suas principais características e acontecimentos. Dado que não há teoria que não responda a uma realidade concreta, ainda que seu propósito seja justamente dissimulá-la, resta indagar: quais as determinantes históricas que merecem ser destacadas, na medida em que constituíam e condicionavam os dilemas da doutrina jurídica do período em foco?

A resposta a essa questão pode ser longa e controversa. A seguir apenas um breve esquema que servirá de suporte para as conclusões do trabalho. É importante pontuar, contudo, a Primeira Guerra Mundial como importante marco na organização social, política e econômica francesa, separando também os tipos de questões postas à teoria jurídica. Começaremos, portanto, por tratar dos aspectos gerais da sociedade francesa da fundação da Terceira República até a Primeira Guerra Mundial, período de ascensão e auge, para depois tratar da guerra e do período que se seguiu, que marcou o declínio da experiência republicana e culminou, como é notório, com a instalação do regime de Vichy e a ocupação da França pelos nazistas.

\subsubsection{Ascensão e auge: a fundação e os primeiros anos}

O fracasso francês na guerra franco-prussiana determina a queda definitiva do Segundo Império, comandado por Napoleão III. Em 12 de fevereiro de 1871, reúne-se a Assembleia Nacional, eleita quatro dias antes, e, muito embora sua maioria seja monarquista, elege Adolph Thiers chefe do Poder Executivo da República. O Tratado de Paz com a Prússia é assinado em 10 de maio do mesmo ano. É o início do período conhecido como Terceira República, que durou de 1871 a 1940, e é até os dias de hoje a experiência republicana francesa mais longeva. 
Os anos iniciais são marcados pela agitação social, inclusive em torno do próprio regime republicano. Diversas correntes de pensamento estão em disputa, e não demoram a ser representadas no Parlamento - desde socialistas, passando por republicanos radicais e moderados, até monarquistas. A democracia e o sufrágio universal aparecem como pedras angulares do novo regime republicano, permitindo a incorporação dos cada vez mais complexos conflitos sociais à disputa institucional, o que está na origem do que passam a ser dilemas apresentados ao direito e à teoria social de forma geral. Nas palavras de Léon Gambetta, "hoje deve-se admitir que a nação francesa está completamente mudada e que a democracia não é apenas um atributo dela: a democracia, ela é a França em si mesma, ela é por todos os lugares... O sufrágio universal é sua arca sagrada; é desse princípio do sufrágio universal que deve-se a partir de agora derivar toda a política. É preciso que nós também tenhamos um código político, e que esse código político seja intitulado 'Da política tirada do sufrágio universal"'1.

A primeira e grande eclosão do conflito social latente é, sem dúvida, a Comuna de Paris, experiência revolucionária que tem lugar na capital entre os meses de março e maio de 1871. A Comuna combina os ideais republicanos e patrióticos da Revolução Francesa de 1789 às aspirações socialistas difundidas na segunda metade do século XIX. As reformas implementadas durante o governo revolucionário em Paris espelham as pautas que permaneceram na ordem do dia durante a primeira fase da Terceira República, como medidas sociais e trabalhistas (regulamentação do trabalho noturno, interdição de qualquer desconto nos salários, paridade entre os sexos etc), e, especialmente, a separação entre Igreja e Estado e a laicização das escolas públicas.

A Comuna é vencida pelo exército do governo de Thiers, provisoriamente instalado em Versalhes, que se impõe violentamente na capital após a chamada semana sangrenta (22 a 28 de maio de 1871). O resultado são pelo menos 17.000 mortos, segundo os números oficiais (os historiadores divergem em relação aos números, havendo quem sustente serem mais de 30.000 mortos), muitos fuzilados ou sumariamente executados, a esmagadora maioria dos atingidos pertencendo às fileiras dos federados (reportam-se 877 mortos entre o exército de Versalhes). Há mais de 40.000 presos, alguns condenados à morte, e outros anistiados apenas em 1875.

Derrotada a Comuna, a república ainda é um equilíbrio instável de forças e está longe de ser um consenso efetivo. Do outro lado das tensões sociais, a maioria

\footnotetext{
${ }^{1}$ Discurso de Léon Gambetta ao Corpo Legislativo em 5 de abril de 1870, in DE BAECQUE, 1991, p. 138.
} 
monarquista na Assembleia (396 de 638 assentos $^{2}$ ) pressiona pela restauração do regime monárquico, mas está dividida entre legitimistas e orleanistas no debate sobre quem seria o soberano francês de direito. A recusa do conde de Chambord em aceitar a bandeira tricolor assegura a continuidade da frágil e jovem República. Aliás, uma marca dos anos inicias da jovem República seria justamente a constante resistência de determinados setores sociais, inclusive e especialmente da Igreja Católica, ao novo regime ${ }^{3}-4$.

Desde o início, portanto, é uma república constituída sobre divergências e tensões vivas, que progressivamente se refletiram na composição da Câmara dos Deputados, impondo uma nova questão ao parlamentarismo francês, qual seja, a necessidade de governar a partir de frágeis equilíbrios de interesses muitas vezes antagônicos. "O fato de a tradição nacional francesa ser a de uma ideologia revolucionária enquanto a constituição da Terceira República não era senão um compromisso provisório entre as forças republicanas e anti-republicanas era algo permanente e subjacente que determinou todo o seu desenvolvimento. O sistema de soberania parlamentar, que foi o que menos dividiu os franceses, era algo neutro, negativo que também os satisfazia pouco" $"$.

Se por um lado o Parlamento absorvia essas disputas sociais, sem dúvida um ganho da expansão democrática representada pela República, por outro lado a amplitude do espectro das divergências iria tornar cada vez mais difícil a composição de governos e coalizões minimamente coesas. A ampliação da democracia para as massas populares, que efetivamente passam a tomar parte do processo eleitoral, e a ameaça à ordem que isso poderia representar, estão na origem dos discursos sobre a "questão social", fórmula apressadamente negada pelos fundadores da república ${ }^{6}$, mas que está presente nos

\footnotetext{
${ }^{2}$ A primeira legislatura, eleita em 8 de fevereiro de 1871, era composta por 214 orleanistas, 182 legitimistas, 112 republicanos moderados, 72 liberais, 38 republicanos radicais e 20 bonapartistas. Dados disponíveis em http://www.assemblee-nationale.fr/ e http://www.france-politique.fr.

${ }^{3}$ Sobre a tênue ligação entre católicos, notadamente juristas, com os monarquistas, escreve Audren: “L'œuvre des juristes catholiques demeure assez discrète sur les liens qui l'unissent au comte de Chambord. Néanmoins, il ne fait aucun doute que certains de ses membres, proches de Lucien Brun, ardemment légitimistes, au début des années 1880, travaillent directement à la Restauration de la monarchie et élaborent, en secret, un plan d'action dans l'éventualité du retour du Roi", in AUDREN, 2008, p. 241.

${ }^{4}$ É interessante lembrar que a polêmica construção da Basílica de Sacré-Coeur, em Montmartre, Paris (simbolicamente o local onde a insurreição que levou à Comuna de Paris teve início), é aprovada no Parlamento em 28 de julho de 1873, e tem como origem a corrente monarquista, aliada ao conservadorismo católico. As disputas em torno da igreja seguiram no decorrer de sua construção, que durou até 1914, tendo inclusive sido votada, em 1882, a revogação da lei que decretava de utilidade pública do local onde seria erguida. Para uma interessante descrição do processo de construção, HARVEY, 2003, pp. 303/333.

${ }^{5}$ THOMSON, 1952 (1946), pp. 170/171.

${ }^{6}$ Nesse sentido, afirma Léon Gambetta: “Ce n'est pas que je nie en aucune manière les misères, les souffrances, les douleurs légitimes d'une partie de la démocratie. Ce n'est pas moi qui méconnaîtrai jamais ce qu'il y a de puissant dans de monde du travail, fruit de la science, de l'esprit d'association et aussi de
} 
debates que se deram durante toda a sua extensão. Está aí o constante desafio da República: "como instituir em torno do sufrágio universal um regime enfim sólido e estável ao mesmo tempo? (...) Para compreender o universo político dos Littré, Grévy, Ferry, Gambetta, não se deve jamais esquecer que dois espectros os assombram: o cesarismo e a revolução social" ${ }^{\prime 7}$.

Em 1875 são votadas leis constitucionais ${ }^{8}$, que refletem as divergências decorrentes de um novo regime em fase de implementação. As leis contêm disposições republicanas, como a garantia do sufrágio universal (restrito aos homens, contudo ${ }^{9}$ ), mas deixam ainda aberta a possibilidade de restauração monárquica. No ano seguinte, os republicanos obtém maioria nas eleições para a Câmara dos Deputados, com 363 assentos, e o regime parece dar um passo importante em direção à sua tormentosa estabilização.

Do ponto de vista demográfico, a França é claramente um país em transição acelerada para o capitalismo moderno. Vê-se a crescente urbanização e a alteração nas ocupações profissionais - a população rural passa de $71 \%$ em 1861 para $55,8 \%$ em $1911^{10}$; em 1906, 44,8\% da população estava vinculada a profissões agrícolas, $36,5 \%$ a profissões industriais, $10,5 \%$ a profissões comerciais e $8,2 \%$ profissões liberais ${ }^{11}$. Uma sociedade de transição, crescentemente urbana e industrializada, ao mesmo tempo em que mantém uma parcela agrária não desprezível, indicando o crescimento e a organização de uma burguesia industrial e de um operariado urbano que convive com proprietários agrícolas também organizados, todas forças políticas relevantes no período.

l'apparition des merveilles de la mécanique et de l'industrie. C'est tout un monde nouveau insuffisamment connu, qu'il faut étudier et qui, depuis trop longtemps, souffre et gémit. Oh! il faut se pencher de ce côté, jeter là à pleines mains la liberté et la clarté. Mais tenons-nous en garde contre les utopies de ceux qui, dupes de leur imagination ou attardés dans leur ignorance, croient à une panacée, à une formule qu'il s'agit de trouver pour faire le bonheur du monde. Croyez qu'il n'y a pas de remède social, parce qu'il n'y a pas une question sociale (...). Il n'y a pas, je le répète, de panacée sociale, il y a tous les jours un progrès à faire, mais non pas de solution immédiate, définitive et complète", discurso em Le Havre em 18 de abril de 1872, in BARRAL, 1968, p. 262.

${ }^{7}$ ROSANVALLON, 2000, p. 243.

${ }^{8}$ Costuma-se referir às leis constitucionais de 1875 como a Constituição francesa vigente durante toda a Terceira República. São três leis: a de 24 de fevereiro de 1875, que trata do Senado, a de 25 de fevereiro de 1875, que trata da organização dos poderes políticos (funções do presidente da República e da Câmara dos Deputados, que forma, juntamente com o Senado, a Assembleia Nacional), e a lei de 16 de julho de 1875 , que trata das relações entre os poderes públicos.

9 Apesar de ser tema frequente nos debates da época, inclusive jurídicos (vide, por exemplo, BARTHÉLEMY, 1920), o voto feminino sofria resistência, especialmente no Senado, só é implementado na França em 1945, após a liberação. Sobre a posição de Barthélemy na defesa do sufrágio feminino, situando-a no contexto do período, cf. SAULNIER, 2004, pp. 368/373.

${ }^{10}$ SEIGNOBOS, 1921, p. 405.

${ }^{11}$ SEIGNOBOS, 1921, p. 408. 
É uma época de continuidade do crescimento econômico e tecnológico iniciada durante o Segundo Império ${ }^{12}$, que assiste à vertiginosa expansão da indústria, das estradas de ferro (apenas para ilustrar o crescimento exponencial, a rede contava com $9.525 \mathrm{~km}$ em 1860, chegando a $51.217 \mathrm{~km}$ em $1912^{13}$ ) e do consumo energético, à fundação dos principais bancos franceses e de grandes sociedades anônimas, à criação de novas técnicas (como o motor elétrico e o motor a vapor), à difusão do automóvel, à invenção do avião, ao surgimento dos grandes magazines, enfim, à expansão do consumo e da produção de riqueza. A revolução na técnica e na indústria e a construção de uma nova imagem da modernidade tem como símbolo maior a realização das Exposições Universais em Paris em 1872, 1889 e em 1900. Também os meios de comunicação se transformam, com o crescimento dos correios, a popularização do telégrafo, a invenção do telefone, a ampliação da imprensa e da possibilidade de divulgação de informações e de pensamento. As artes e a cultura são marcadas por uma ruptura importante, com as vanguardas impressionistas rediscutindo o padrão estético dominante. A modernidade se apresenta.

Mas a mudança tecnológica e nos padrões de vida vem reforçar a tensão social, aprofundada pela crise econômica, resultante da guerra franco-prussiana, que perturba o país entre 1873 e 1895. De um lado, os conservadores se organizam a partir de inspirações militaristas e nacionalistas - como exemplifica a adesão ao multifacetado movimento de apoio ao general Boulanger ${ }^{14}$ - bem como da defesa do catolicismo. De outro lado, o movimento operário crescentemente organizado, influenciado pelas ideias de Karl Marx, Saint-Simon, Louis Blanc e Proudhon, discute propostas anarquistas e socialistas de organização do poder, tendo a última corrente expoentes da vida política nacional como Jean Jaurès e Jules Guesde.

A expansão industrial permitida pelo progresso técnico resulta na crescente organização do proletariado em sindicatos, autorizados pela Lei de 1884, e em greves conduzidas por esses sindicatos ${ }^{15}$. Os números são expressivos: em 1884 contam-se 68 sindicatos, passando para $1.926 \mathrm{em} 1893$ (com 402.000 filiados) e para $5.046 \mathrm{em} 1913$

\footnotetext{
${ }^{12}$ Para descrição e dados acerca dos progressos técnicos do período, cf. SEIGNOBOS, 1921, p. 409 e ss.

${ }^{13}$ SEIGNOBOS, 1921, p. 413.

${ }^{14}$ Boulangisme é como é conhecido o movimento politico que se formou, entre 1889 e 1891 , em torno do general Georges Boulanger, comandante do Exército francês na Tunísia e Ministro da Guerra em 1886/1887. Sustentando a necessidade de revisão das instituições e a convocação de uma nova constituinte, Boulanger amealha o apoio tanto da direita, dos monarquistas e dos patriotas quanto de setores da esquerda popular, e é eleito para a Câmara em 1889, cercado por pressões por um golpe de Estado, que resulta, ao final, em fracasso.

${ }^{15}$ Para uma análise do papel dos sindicatos na formação do Estado Francês da Terceira República, cf. JONES, 1993, pp. 55 e ss, e pp. 205 e ss.
} 
(1.027.000 filiados, dentre os quais 778.000 vinculados a sindicatos de grande porte, com mais de 10.000 membros) ${ }^{16}$. Entre 1890 e 1893, registra-se uma média anual de 368 greves e 302 grevistas, já em 1913 apontam-se 1.073 greves, com 220.000 grevistas $^{17}$. Em 1895 é criada a Confédération Générale du Travail (CGT), que defende o sindicalismo revolucionário, e em 1906 funda-se a Section Française de l'Internationale Ouvrière (SFIO), organizando as bases para um partido socialista. Em 1893, a esquerda obtém expressiva votação, elegendo 48 deputados socialistas, grupo que em 1914 já representa um quinto dos deputados eleitos.

Estamos diante de uma sociedade cada vez mais dividida, cada vez mais marcada por disputas políticas. A ameaça socialista conduz também o debate em torno da religião, principal pauta de confrontos da república em ascensão ${ }^{18}$. O catolicismo, especialmente, procura se consolidar como solução possível para os apelos de solidariedade e justiça social, sem que se tenha que recorrer ao socialismo, como se explicitou na resposta aos movimentos operários contida na encíclica papal Rerum Novarum, de 1891. A intervenção social da Igreja Católica nesse período, intercedendo na defesa de valores como a família e a propriedade privada, mas não do liberalismo, constituiu-se como um ponto de apoio ao catolicismo social, que avançou na organização de outras formas de defesa dos trabalhadores, como é o caso dos sindicatos trabalhistas católicos ${ }^{19}$.

O catolicismo, seja com seus militantes mais intransigentes, seja nas suas fileiras sociais, vai se constituir como uma das forças relevantes no debate político e social francês ao longo de toda a Terceira República, tendo filiados em todos os meios, inclusive no jurídico ${ }^{20}$. Ainda que não expressa, a adesão ao catolicismo social se fazia presente nas intervenções no debate público, seja no campo jurídico, seja na política, veiculando ora um anti-liberalismo, ora a defesa da possibilidade de integração social, à exemplo da integração e da solidariedade cristãs.

\footnotetext{
${ }^{16}$ SEIGNOBOS, 1921, p. 467.

${ }^{17}$ SEIGNOBOS, 1921, p. 467.

${ }^{18}$ Sobre o assunto, pronunciou-se diversas vezes Léon Gambetta, fundador da república: “(...) Vous sentez donc, vous avouez don qu'il y a une chose qui, à l'égal de l'Ancien Régime, répugne à ce pays, répugne aux paysans de France... C'est la domination du cléricalisme! Vous avez raison, et c'est pour cela que du haut de cette tribune je le dis, pour que cela devienne précisément votre condamnation devant le suffrage universel! Et je ne fais que traduire les sentiments intimes du peuple de France en disant du cléricalisme ce qu'en disait un jour mon ami Peyrat: Le cléricalisme? Voilà l'ennemi !", discurso na Câmara dos Deputados em 4 de maio de 1877, in BARRAL, 1968, p. 176.

${ }^{19}$ HOBSBAWN, 1996, p. 115.

${ }^{20}$ Sobre o assunto, vide AUDREN, 2008.
} 
$\mathrm{Na}$ virada do século, a questão religiosa é agravada pelo Affaire Dreyfus $^{21}$, no qual tomaram parte diversos juristas, e que tinha como origem principal o antissemitismo, ou talvez melhor dizendo, o catolicismo militante da direita francesa, a liberdade de crença e a separação Estado-Igreja, que só foi convertida em lei em 1905. A disputa entre correntes congregacionistas católicas e defensores da laicidade do Estado já estava entre os debates centrais da fundação e das primeiras décadas da Terceira República, disputa essa que se espalhou da capital à província, penetrou o meio jurídico e orientou as formulações teóricas de diversos dos autores clássicos.

Interessante nesse sentido a descrição de Seignobos, que escreve em 1921 a história do período: “A luta eleitoral pela posse do poder, complicada por uma concorrência profissional pela conquista da carreira política, levou o conflito até o fundo dos campos. A partir do momento em que os conselhos municipais passam a escolhem os eleitores senatoriais, todas as eleições se tornam políticas. A política, penetrando toda a vida social, separou a sociedade francesa em dois campos hostis; a separação, manifesta desde 24 de maio de 1873, se agravou pela concorrência entre a escola laica e a escola congregacionista. Do lado dos conservadores, se alinharam a nobreza e a alta burguesia, o clero, a maior parte da burguesia média e dos funcionários públicos, ficando os camponeses, artesãos e comerciantes na sua dependência e sob sua influência. O partido republicano reuniu a massa dos operários, dos camponeses proprietários, dos empregados e dos pequenos funcionários públicos, enquadrados como uma pequena minoria de burgueses. A rivalidade continua a gerar ressentimentos que rompem as relações pessoais; as famílias em luta deixam de se frequentar; tornou-se difícil antes de 1914 organizar uma festa em comum, um divertimento, uma obra de caridade. Cada um dos

\footnotetext{
${ }^{21}$ O Affaire Dreyfus, como se sabe, foi um debate que dividiu durante anos a sociedade francesa da virada do século XX. O oficial de artilharia do exército francês Albert Dreyfus havia sido condenado por alta traição em 1894, condenação levada a termo em um processo fraudulento, baseada em documentos falsos. Dreyfus foi vítima de antissemitismo, denunciado por Émile Zola no célebre artigo $J^{\prime}$ accuse...!, publicado no jornal L'Aurore em 13 de janeiro de 1898, no qual se lê: "Voilà donc, monsieur le Président, les faits qui expliquent comment un erreur judiciaire a pu être commise; et les preuves morales, la situation de fortune de Dreyfus, l'absence de motifs, son continuel cri d'innocence, achèvent de le montrer comme une victime des extraordinaires imaginations du commandant du Paty de Cam, du milieu clérical où se trouvait, de la chasse aux 'sales juifs' qui déshonore notre époque". O caso dividiu a França entre os partidários de Dreyfus, chamados dreyfusards, e os contrários, conhecidos como anti-dreyfusards. A questão tomou significativas proporções, e separou o país entre a setores ligados à direita católica, antissemita e restauracionista e setores ligados à esquerda anticlerical e republicana. A cisão na sociedade provocada pelo Affaire Dreyfus perduraria nas décadas seguintes, em diferentes formas, especialmente com os antigos militantes anti-dreyfusards engrossando as fileiras das ligas de direita nos anos 1930.
} 
campos tinha em sua cidade seu clube, sua fanfarra, seu médico, seu notário, seus fornecedores" 22 .

Do ponto de vista externo, também é um momento de inquietude e tensão, dadas as rivalidades econômicas, as disputas imperialistas, o reforço de sentimentos nacionalistas, a crescente militarização e a corrida armamentista das principais potências europeias, que já davam sinais concretos por exemplo na guerra dos Bálcãs (1912-1913). A ameaça de conflito generalizado na Europa está latente, e acaba por eclodir em 1914, com a Primeira Guerra Mundial: "Desde 1870, cada verão traz, confuso ou evidente, o perigo de um novo conflito. Há alguns anos, as crises agudas e os sinais sangrentos se multiplicam. O interesse pela politica estrangeira desperta de tempos em tempos em espasmos dolorosos. A França derruba então um ministro que lhe parece muito audacioso. Daí, acreditando ter descartado o perigo por essa manifestação de prudência miope, ela se desinteressa novamente do mundo e retoma seus sonhos pacíficos e suas querelas intestinas. Entretanto, um instinto obscuro e quase milagroso a impede de deixar seu exército se dissolver e a impede de paralisar completamente a ação de seus diplomatas. $\grave{A}$ despeito das hesitações e dos atrasos, esses últimos fizeram um bom trabalho entre 1897 e 1914"23.

Palco da consolidação da república, do sufrágio universal e de um certo liberalismo, de um lado, mas também de crescentes tensões e pressões internas e externas, as primeiras décadas da Terceira República foram marcadas pela inquietude e pela renovação da teoria. A inquietude que impulsionava vanguardas culturais e artísticas movimentava também o pensamento, que divergia em doutrinas e correntes cada vez mais apartadas. Daí o emblemático e um tanto quanto dramático diagnóstico que Paul Guérin apresenta em 1939, ao retraçar a história do período como o cenário de uma "indubitável crise do espírito", afirmando que "três doutrinas: materialismo, liberalismo e democracia resumem o movimento geral do pensamento das raças brancas no século XIX. Duas gerações de filósofos, economistas e políticos as formaram (...). Nos anos que precederam a guerra, as doutrinas se deformam e não encontram mais uma adesão completa. Nós assistimos ao começo da crise do espírito e das instituições" ${ }^{24}$.

\footnotetext{
22 SEIGNOBOS, 1921, p. 427.

${ }^{23}$ GUÉRIN, 1939, p. 44.

${ }^{24}$ GUÉRIN, 1939, pp. 21/22.
} 


\subsubsection{Crise e declínio: a guerra como ruptura}

"A data de 3 de agosto de 1914 separa os cumes de um passado feliz dos vales de nossos tempos atormentados" ${ }^{25}$. Trata-se da data da declaração de guerra da Alemanha à França, transformando em conflito armado a separação entre Tríplice Entente, os aliados França, Grã-Bretanha e Rússia, e Tríplice Aliança (Alemanha, Império AustroHúngaro e Itália, que inicialmente ficou neutra e posteriormente ingressou ao lado dos aliados), à despeito dos apelos pacifistas da Internacional Socialista ${ }^{26}$.

A guerra representou uma reorientação dos rumos sociais e políticos traçados anteriormente. "As luzes estão se apagando na Europa inteira. Não as veremos brilhar outra vez em nossa existência", afirmou Edward Grey, Secretário de Relações Exteriores Britânico [Foreign Secretary], ao ver as luzes da sede do governo inglês apagadas na noite em que a Grã-Bretanha e a Alemanha entraram em guerra ${ }^{27}$. Não é possível analisar o que se seguiu sem pontuar a guerra mundial como uma ruptura com a direção que se vinha seguindo até então. "A humanidade sobreviveu. Entretanto, o notável edifício da civilização do século XIX se dobra nas chamas da guerra mundial, já que seus pilares desmoronaram. Não há compreensão do breve século XX sem ela. Ele foi marcado por ela. Ele viveu e pensou nos termos da guerra mundial, mesmo quando as armas estavam silenciosas e as bombas não estavam explodindo. Sua história e, mais especificamente, a história de seus tempos iniciais de colapso e catástrofe, deve começar com a dos trinta e um anos de guerra mundial ${ }^{28}$.

A guerra mobilizou quantidades inéditas de recursos, homens e tecnologia, o que demandava uma coordenação mais centralizada. O esforço de guerra implicou no redesenho dos Estados nacionais envolvidos, com o aumento da estrutura e dos poderes do governo central para planejar e dirigir a economia. Uma primeira

\footnotetext{
${ }^{25}$ GUÉRIN, 1939, p. 3.

${ }^{26}$ Como explicita Jean Jaurès em um discurso de 25 de julho de 1914: "Il n'y a plus, au moment où nous sommes menacés de meurtre et de sauvagerie, qu'une chance pour le maintien de la paix et de le salut de la civilisation, c'est que le prolétariat rassemble toutes ses forces et que tous les prolétaires, français, anglais, allemands, italiens, russes, s'unissent pour que le battement unanime de leur cour écarte l'horrible cauchemar", disponível em http://www.assemblee-nationale.fr/13/evenements/lancement-tribunsdiscours.asp. O líder socialista foi assassinado dias depois, em 31 de julho de 1914, por Raoul Villain, um nacionalista francês, sem que tenha assistido à declaração de guerra. O julgamento de Villain, em 24 de março de 1919, causou comoção nacional, tendo o assassino sido absolvido, decisão sustentada pelos nacionalistas. Jaurès é uma figura histórica da esquerda francesa, e a transferência de seus restos mortais para o Panthéon, em 13 de novembro de 1924, durante o governo do Cartel de Gauches, foi acompanhada de grandiosa cerimônia popular. Cf. BONNEFOUS, 1959, t. III, pp. 34/36.

${ }^{27}$ Citado em HOBSBAWN, 1996, p. 22.

${ }^{28}$ HOBSBAWN, 1996, p. 22.
} 
transformação importante, daí decorrente, é o ganho de centralidade do Poder Executivo, diante do Parlamento. Não apenas na França, mas em diversos dos países em conflito, novas funções de coordenação mais geral são atribuídas ao Executivo. Ainda, recorre-se ao estado de sítio para garantir a estabilidade na condução nacional ${ }^{29}$. A novidade não se limitou ao período da guerra, mas impactou o regime democrático, inaugurando uma mudança estrutural na percepção da separação de poderes e na condução das políticas nacionais. O liberalismo clássico estava entrando em crise.

A centralização forçada impacta altera também a percepção em relação ao regime de liberdades, como testemunha Guérin: "a propriedade, a família, a livre concorrência, a preponderância do indivíduo e as atribuições reduzidas do Estado caracterizavam o liberalismo anterior à guerra. Esse estado do pensamento e das instituições existia sobretudo na França e nas sociedades anglo-saxãs. Entretanto, ele parecia progredir para outros países. A guerra interrompeu brutalmente essa evolução. Em menos de um ano, todas as grandes potencias do mundo salvo os Estados Unidos, foram submetidas a um regime de exceção (...). A ordem dos valores humanos foi subvertida e rebaixada: comer, beber e dormir tornaram-se preocupações imensas e que, no entanto, não dependiam mais do indivíduo. O Estado se ocupava delas (...). A economia totalitária reinava" ${ }^{30}$.

A vitória de França, EUA, Grã-Bretanha e Itália, oficializada pelo Tratado de Versalhes, de 28 de junho de 1919, em que a Alemanha aceitou os termos de paz, e pelos demais tratados, firmados com os outros países, não representou de forma alguma a retomada da situação econômica, social e política anterior. A guerra deixou consequências que transformaram definitivamente o futuro dos países envolvidos.

O saldo da Primeira Guerra Mundial dá conta de 8 milhões de mortos, sendo 1,4 milhões de franceses - $10 \%$ da população ativa e $27 \%$ dos homens de 18 a 27 anos -, e 3 milhões de feridos. Como resultado, a população francesa diminui para 38,7 milhões em 1919, uma redução de 1,1 milhão em relação a 1914, posteriormente voltando a subir, chegando a 41,8 milhões em 1931. O número insuficiente de jovens adultos nos anos 1934-39, apesar dos nascimentos durante a guerra, motiva o encorajamento da imigração - de menos de 4\% da população economicamente ativa em 1921, os imigrantes passam a representar de 7\% em 1931. Vale lembrar que a resistência a populações de

\footnotetext{
${ }^{29}$ Cf. BERCOVICI, 2008(a), pp. 264 e ss.
}

${ }^{30}$ GUÉRIN, 1939, p. 55. 
origem estrangeira está na base de movimentos nacionalistas que vão se formar durante o entre-guerras.

A produção industrial vê-se impulsionada diante das demandas de guerra, recorrendo também à mão-de-obra feminina, uma vez que boa parte da população masculina estava lutando nas trincheiras. Um passo importante para a mobilização das mulheres, que passam a ser mais engajadas nos problemas sociais (mas que, apesar disso, não conquistam o direito de voto senão depois da Segunda Guerra Mundial), bem como para a revisão do papel do Estado em relação à economia - de uma função de coordenação, típica do laissez faire, o Estado se vê obrigado a intervir diretamente na ordem econômica. A guerra confere aos problemas econômicos novas e assustadoras dimensões, provocando grande devastação de recursos naturais e da capacidade produtiva, que diminui em torno de $20 \%$ - vale lembrar que uma das medidas tomadas para financiar os custos de guerra foi o estabelecimento do imposto sobre a renda, em 1917, cuja permanência após o término do conflito vai dividir opiniões entre os partidos políticos ${ }^{31}$. No total, a guerra consumiu em torno de 150 trilhões de francos, cerca de $30 \%$ da riqueza francesa ${ }^{32}$. Era necessário que o Estado assumisse um papel ativo na recuperação econômica, mas isso significava que não poderia mais ser o mesmo Estado de antes.

"A guerra de 1914-1918, como se sabe, perturbou profundamente as relações anteriores do Estado com a sociedade, as exigências da mobilização industrial conduziram a um crescimento até então desconhecido da intervenção do poder público na economia. Mas a mobilização correspondente da mão-de-obra induziu, igualmente, uma profunda perturbação no sistema social. Solicitados como atores-chave do esforço de guerra, os operários se viram de repentinamente mais considerados" ${ }^{33}$.

A situação econômica do período é cenário de instabilidades, que naturalmente se refletem na sociedade. A França sai da guerra tendo perdido parte significativa de sua população economicamente ativa, de sua capacidade produtiva, bem como de sua capacidade de exportação, para os EUA e os novos países industriais. A dívida pública elevada força o recurso ao aumento da moeda em circulação e a empréstimos. O resultado é inflação, a desvalorização do franco e a elevação do custo de

\footnotetext{
${ }^{31}$ Cf. THOMSON, 1952 (1946), p. 192.

${ }^{32}$ Cf. THOMSON, 1952 (1946).

${ }^{33}$ ROSANVALLON, 2000, pp. 362/363.
} 
vida - apenas para ilustrar, os aluguéis são quase 100\% mais altos, em 1922, em relação a 1914, e os preços se multiplicaram por 3,5 durante os anos de guerra ${ }^{34}$.

A incerteza econômica reforçou a exigência da condução mais centralizada da economia, fora do Parlamento, e assumida pelo Executivo ${ }^{35}$. A consequência é a introdução dos décrets d'économie, medidas excepcionais autorizados pela lei de 22 de março de 1924, que permitiam que o Gabinete Poincaré instituísse austeridade fiscal, reforma administrativa e redução do déficit público. A prática de governo da economia por decreto só foi reforçada com a crise econômica e política dos anos $1930^{36}$. Tratemos então dos aspectos econômicos do entre-guerras, em que é possível se distinguir nitidamente um florescimento nos anos 1920 contraposto à crise e à radicalização nos anos 1930.

Sob o impulso da guerra e da condução centralizada das atividades econômicas, os anos 1920 são marcados por uma forte expansão industrial e uma dinamização de vários aspectos da sociedade no que ficou conhecido como les années folles. Economicamente, a França se beneficia do franco desvalorizado para aumentar a produção industrial, que cresce em média 10\% ao ano entre 1921 e 1929, em boa parte impulsionada pelas exportações. O estabelecimento de uma nova paridade com o ouro, formalizado em 1928 e conduzido por Raymond Poincaré após a desarticulação do Cartel des Gauches justamente pela dificuldade de lidar com os dilemas econômicos, levou em conta a desvalorização da moeda que tinha ocorrido, implicando em proteção da expansão industrial atingida. Aumento de lucros e da produtividade industrial, concentração industrial e financeira, são todos sintomas de um novo dinamismo da economia capitalista, euforia distribuída de maneira desigual entre a população. Apesar do baixo desemprego, os salários não crescem na mesma proporção dos lucros, e a prosperidade é desfrutada principalmente pelas elites e classes médias, deixando o operariado de fora da expansão do consumo, o que prenuncia a agitação social que se seguiria. Por outro lado, o clima de otimismo e de progresso favorece o surgimento de novas vanguardas artísticas, como as

\footnotetext{
${ }^{34}$ BONNEFOUS, 1959, vol. III, p. 396.

${ }^{35}$ Proliferam nesse sentido clamores pela condução mais centralizada do país, e inicia-se a busca e a cultura de um líder, como exemplifica o trecho de Halévy: "É por sua unidade que a França vive, que ao menos ela vivia; é pela lei escrita, declarada, aplicada. De Philippe-Auguste a Napoleão, digamos a M. Thiers, a França foi um país governado, a França teve chefes. Está ai o que falta de repente. Os reis desapareceram, e com eles os chefes de quem eles eram o apoio. No lugar de uma matéria ordenada pelas vontades $e$ inteligências lúcidas, encontramos uma matéria confusa, ordenada sem dúvida, uma vez que vive, age e reage, mas sobre um plano e de acordo com leis que nos são desconhecidas", in HALÉVY, 1931, p. 19.

${ }^{36}$ Vide BERCOVICI, 2008(a), p. 309.
} 
surrealistas e as dadaístas, e o franco desvalorizado atrai artistas de outros países para Paris, que é cenário de importantes encontros artísticos e literários.

Mas o florescimento econômico se vê interrompido nos anos 1930, com os efeitos da crise de 1929. Já em meados de 1930 começa uma baixa na produção industrial, e em 1931 o desemprego já é um problema social de dimensões consideráveis há registros de cerca de 600.000 desempregados em 1932, contra aproximados $290.000 \mathrm{em}$ 1929, e o número chega a quase 900.000 em 1935-36. As exportações, que enfrentavam dificuldades já com a estabilização do franco de 1928, estavam em ainda maior desvantagem com as desvalorizações do da libra (setembro de 1930) e do dólar (abril de 1933) e com a insistência francesa em manter o padrão-ouro. Apesar do relativo aumento do poder de compra, diante da desigual baixa nominal dos salários e dos preços, o desemprego galopante é uma preocupação que assombra as classes médias e baixas. As medidas do Front Populaire visam à combater esse problema reduzindo a jornada de trabalho e concedendo férias remuneradas, com algum sucesso - enquanto há $40 \%$ dos trabalhadores atingidos pelo desemprego parcial em 1935, o número diminui para 12\% no final de 1936 - mas gerando desconfiança entre os industriais ciosos do liberalismo econômico. Guérin comenta as medidas econômicas do Front Populaire, não sem ressaltar o perigo que representam pela restrição à liberdade e à "evolução econômica", afirmando que "os franceces, enfim, reagiram à sua maneira, retardando a evolução econômica. Nesse tocante, a aplicação das medidas do programa do Front Populaire de 1936 ao fim de 1939 sugere reflexões bem surpreendentes. Os resultados positivos da legislação social interromperam o movimento de concentração de empresas, tornaram a existência de grandes empresas dificil e favoreceram por outro lado a vida de todos os autônomos, artesãos, pequenos comerciantes e pequenos industriais, únicos que podem escapar às leis por estarem fora de seu campo de aplicação" ${ }^{\text {37 }}$.

O abandono tardio do padrão-ouro em outubro de 1936 colabora com um aumento da produção industrial, mas o franco continua sendo alvo de ataques especulativos que dificultam a saída completa da crise. Greves, do lado do operariado, e descontentamento com as alterações na legislação trabalhista e com o que veem como uma injustificada restrição das liberdades, do lado dos industriais, constituem um ambiente cada vez mais radicalizado. No entre-guerras, as questões econômicas passam a estar,

${ }^{37}$ GUÉRIN, 1939, p. 73. 
definitivamente, no centro da definição dos governos e das coalizões, e não raro difícultam a permanência de governos de esquerda ${ }^{38}$.

Fora da França grandes mudanças tinham reconfigurado a Europa durante o entre-guerras. Na Rússia, a revolução de 1917 dá novo fôlego ao movimento proletário em todos os países. Ainda, uma experiência importante nessa onda de reorganização social é a República de Weimar, na Alemanha (1919-1933), marcada pela forte presença da social-democracia reformista que influenciou socialistas e operários na Europa e, particularmente, na França. Por outro lado, surge uma nova expressão da direita nacionalista, mas não conservadora, com a ascensão do fascismo na Itália, em 1922, e, uma década depois, com Hitler, na Alemanha, em 1933, após a queda da República de Weimar. Aprofunda-se a distância entre a esquerda e a direita organizadas, entre a busca pela transformação e o medo de subversão da ordem.

Do ponto de vista jurídico, assiste-se à positivação de uma nova gama de direitos por toda a Europa, notadamente relacionados ao homem concreto inserido no mundo do trabalho (direitos sociais, incluindo os trabalhistas), e à promulgação de constituições que não apenas consagram esses direitos, como também modulam um Estado bastante diferente do Estado liberal clássico: um Estado que intervém na atividade econômica e que assume um papel mais ativo na regulação da totalidade da vida social. São marcas desse movimento as chamadas “constituições econômicas”, sendo a grande representante a Constituição alemã de 1919. A teoria constitucional liberal já não era suficiente para compreender esse novo período, como se verá no item 1.3, a seguir, e nos capítulos 2 e 3 .

A consequência, para a França do entre-guerras, é o aprofundamento das tensões sociais. O confronto entre as ditas "forças da ordem", que ganhavam adesões capitalizando o medo da "ameaça socialista", e as ditas "forças do movimento", justamente os movimentos operários que assumem o centro da arena política na moderna sociedade democrática e industrial, explicitava-se, representando-se no Parlamento e manifestando-se na sociedade, à despeito das tentativas de conciliação e coordenação ${ }^{39}$.

\footnotetext{
${ }^{38}$ Nessa direção, a afirmação de Karl Polanyi, ao descrever o colapso do sistema econômico internacional no entre-guerras: "In Belgium, France, and England the Left was thrown out of office in the name of sound monetary standards", in POLANYI, 2001 (1957), p. 25.

${ }^{39}$ Simbólico nesse sentido é o pronunciamento de André Tardieu, importante líder da direita francesa, Comissário do Governo e deputado de Seine-et-Oise, em 29 de agosto 1919, abordando o recém assinado Tratado de Versalhes: "Pour apprécier le Traité et pour fonder les raisons de confiance que je crois qu'il mérite, il faut se libérer, à droite et à gauche, de deux tyrannies et de deux superstitions: la tyrannie de l'habitude, la tyrannie du changement; la superstition de l'expérience et celle de la catastrophe", in BONNEFOUS, 1959, t. III, p. 52.
} 
De um lado, movimentos operários, socialistas e antifascistas se reestruturam e ganham organização. Em 1920, a partir de uma cisão da SFIO, confrontada com os dilemas da adesão à Terceira Internacional, é fundado o partido comunista (originalmente Section Française de l'Internationale Communiste, SFIC) no Congresso de Tours (20 a 26 de dezembro de 1920), dividindo as forças do movimento operário. Mas os partidos de esquerda se fortalecem como um todo, aumentando sua representação no Parlamento, e conseguem compor governos de maioria entre 1924-26 (Cartel des Gauches) e, depois, entre 1936-39 (Front Populaire). É também uma época de diversas greves, como as de fevereiro, março e maio de 1920, ou a greve geral de fevereiro de $1934^{40}$, que são duramente reprimidas.

É importante lembrar, contudo, que tais "forças do movimento" não podem ser identificadas com uma tentativa de subversão da ordem democrática, como propagandeado na ilusão que os movimentos de direita insistiam em tentar construir. Estava longe de ser majoritária entre os movimentos de esquerda a defesa de uma revolução insurrecional imediata - daí a clássica afirmação de Léon Blum, ao comentar o programa do Partido Socialista, de que a revolução "virá na sua hora histórica". Antes disso, era o próprio Marx quem, na introdução ao programa do Parti Ouvrier de 1880, considerava o sufrágio universal era um dos meios válidos para a busca da organização da classe operária, sufrágio que "seria então transformado do instrumento de fraude que foi até então em um instrumento de emancipação" ${ }^{41}$. Os movimentos populares reconheciam a importância e o potencial do sistema democrático. "A ignorância e o atraso das massas, seu comprometimento com a derrota da sociedade burguesa pela revolução social e a irracionalidade humana latente, tão facilmente explorados por demagogos, eram de fato uma causa para alarme. Contudo, os movimentos democráticos de massa mais imediatamente perigosos, os movimentos operários socialistas, eram na realidade, tanto em teoria quanto na prática, tão comprometidos com os valores da razão, da ciência, do progresso, da educação e da liberdade individual quanto qualquer um (...). Seu desafio era à economia, não ao governo constitucional e à civilidade. Não seria fácil considerar um governo comandado por Victor Adler, August Bebel ou Jean Jaurès como o fim da 'civilização como a conhecemos'. De qualquer forma, tais governos pareciam, até então, remotos $" 42$.

${ }^{40}$ Cf. TARTAKOWSKY, 1998, p. 89 e ss., BONNEFOUS, 1959, t. III, pp. 119 e ss.

${ }^{41}$ MARX, 2010 (1880), pp. 376/377.

${ }^{42}$ HOBSBAWN, 1996, p. 110. 
O medo da "ameaça socialista", supostamente a ameaça de tomada do poder autoritária e de fim da democracia liberal, assim, relacionava-se mais com uma imagem construída pelas forças de direita, que se reivindicavam "mantenedoras da ordem", do que com a estratégia do movimento operário socialista. Os movimentos de esquerda organizavam-se, sobretudo, em torno da busca de reformas que assegurassem a mesma igualdade política garantida pelo sufrágio universal no campo econômico, com bandeiras como República social e a democracia industrial. Isso não implicava a subversão completa da ordem, restrição à liberdade ou fim da democracia, até porque faziam-se representar de em proporções não desprezíveis no Parlamento, chegando inclusive a liderar governos.

De outro lado, construindo e capitalizando o medo dos socialistas, ampliam-se movimentos nacionalistas de direita, que passaram a se organizar em ligas. Menos apegados, esses sim, à democracia de massa, eles partilhavam ideias e valores como o antiparlamentarismo doutrinário e prático, a devoção ao Estado, a paixão pela ordem, o gosto pela força, o culto do líder, o flerte com a noção de ditadura de um partido e com o corporativismo ${ }^{43}$. Assim são formadas ligas como a Action française (1905), Jeunesses patriotiques (1924), lideradas por Taittinger, Solidarité française (1933), por Coty, e a Croix de feu (1927), sob a liderança do coronel de La Rocque ${ }^{44}$.

A nova direita combina chauvinismo, antiparlamentarismo e, não raro, antissemitismo, e está aliada à velha direita na crítica à "esquerda radical". A difusão do

${ }^{43}$ Vide RÉMOND, 1966, pp. 278 e ss, HOBSBAWN, 1996, pp. 124 e ss.. Para Rémond, as ligas alinhadas à direita, apesar de se valerem de ideias associadas ao fascismo, não podem ser facilmente classificadas de fascistas. "They borrowed only the ornaments of fascism, put on its finerym but threw aside its spirit. The league movement was simply the latest incarnation of the old Bonapartist tradition - Cesarism, authoritatian, and plebiscitarian - nationalism revised to fit current tastes and whose imitations did no more than replaster the façade with a whitewash of Roman fascism", in RÉMOND, 1966, p. 281. No mesmo sentido, afirma Hobsbawn: "Indeed, in the core countries of Western Liberalism - Britain, France and the USA - the general hegemony of the revolutionary tradition prevented the emergence of any mass fascist mouvements of importance. It is a mistake to confuse the racism of American Populists or the chauvinism of French Republicans with proto-fascism: these were mouvements of the Left", in HOBSBAWN, 1996, p. 121. O mesmo autor, todavia, acrescenta mais adiante o motivo pelo qual a distinção entre os conservadores de direita e os fascistas não é simples de ser traçada: "One reason why it was so difficult after the war to distinguish between wholehearted French fascists and pro-German collaborators on one hand, and the main body of support for Marechal Pétain's Vichy regime on the other, was that there was in fact no clear line. Those whose fathers had hated Dreyfus, the Jews and the bitch-Republic - some Vichy figures were old enough to have done so themselves - shaded intensibly into the zealots for a Hitlerian Europe. In short, the 'natural' alliance of the Right between the wars went from traditional conservatives via old-style reactionaries to the outer fringes of fascist pathology. The traditional forces of conservatism and counterrevolution were strong, but often inert. Fascism provided them both with a dynamic and, perhaps even more important, with the example of victory over the forces of disorder", in HOBSBAWN, 1996, pp. 123/124. Contudo, para o propósito do presente capítulo, que é traçar um panorama bastante geral e esquemático da história da França nos anos estudados, deixaremos de lado a discussão sobre o enquadramento das ligas de direita francesas como fascistas, bastando apenas a identificação de suas principais bandeiras, especialmente antiparlamentares, seu flerte com o autoritarismo, e sua constituição em oposição ao que classificavam como "forças da desordem".

${ }^{44}$ Citados por CAPITANT, 1972. Cf. RÉMOND, 1966, pp. 275 e ss., THOMSON, 1952 (1946). 
medo atingia inclusive a democracia em si, na medida em que sustentava-se na crença de que as instituições estavam tomadas por movimentos nocivos, que podiam comprometer a ordem. A ordem e a nação, e não necessariamente a democracia e o Parlamento, eram os valores a serem preservados. "Na década de 1920, tanto a velha quanto a nova direita estavam atacando o socialismo (e o comunismo) marxistas como um mal incubado na democracia liberal" ${ }^{\prime 45}$.

Os políticos e partidos mais alinhados à direita controlaram alguns dos governos do entre-guerras, a começar pelo que se seguiu ao conflito bélico. Nas eleições de 1919, um clamor por "união" deu origem a uma aliança burguesa que excluia tanto os resíduos de tradicionalismo e monarquismo católico, quanto, e principalmente, a representação da classe trabalhadora ${ }^{46}$. Forma-se então o Bloc National, momento em que a ideia de nação foi definitivamente apropriada pela direita: "quem não estava com ele [com o Bloc National] era contra a nação (...). Dali em diante, a Direita monopolizaria a palavra, a ideia e, se possível, a realidade por trás delas" ${ }^{\prime 47}$. Direita e nacionalismo se identificam, e elegem como seu principal inimigo os movimentos socialistas.

Novas questões ganham a ordem do dia, fruto da nova sociedade do pósguerra. Movimentos sociais organizados, bem como corporações e bancos, colocam a economia no centro do debate, com demandas por uma "democracia industrial", de um lado, e pelo corporativismo, de outro. "O mais amplo contraste entre a França de antes da guerra e a de depois foi a substituição das questões dinásticas e clericais por questões econômicas e financeiras. O poder crescente dos bancos e das empresas, de um lado, e dos sindicatos e movimentos socialistas e comunistas, de outro forçaram para o centro da arena politica problemas que estavam previamente latentes ou eram suficientemente secundários para serem manejados de forma fragmentada"48 49 .

\footnotetext{
${ }^{45}$ MAIER, 1988 (1975), p. 8.

${ }^{46}$ Cf. MAIER, 1988 (1975), pp. 91 e ss.

${ }^{47}$ RÉMOND, 1966, p. 259.

${ }^{48}$ THOMSON, 1952 (1946), p. 182.
}

49 Assim o alerta de Léon Blum, ao tratar da reforma governamental, tema que está no centro dos debates do final dos anos 1930: "Avis aux réformateurs : s'ils tiennent tant à éviter les crises ministérielles, c'est contre la crise économique qu'ils doivent nous aider à lutter tout d'abord. Deuxième avis : à la généralité de la crise vient s'ajouter la particularité du tempérament national. De même que la 'conjoncture' présente est une de celles où le problème est le plus difficile, de même la France est un des pays du monde où la solution est la moins aisée", in BLUM, 1936, p. 213. O mesmo autor afirma: "Le problème de la stabilité politique se pose aujourd'hui dans des conditions particulièrement défavorables. La stabilité politique suppose, en effet, un minimum de stabilité économique, et, par surcroît, c'es en période d'instabilité économique que l'instabilité politique provoque les réactions les plus aiguës et les plus dangereuses", in BLUM, 1936, p. 211. 
A nova realidade é especialmente sentida pelos liberais, já que suas ideias já não mais dão conta de garantir a manutenção da ordem e dos arranjos entre elite e povo que anteriormente estavam protegidos por um Estado não interventor e uma democracia baseada na igualdade formal entre cidadãos enquanto indivíduos abstratamente considerados. Não por outra razão falam em "crise da liberdade", "crise da democracia” e outras tantas crises. "A liberdade não tem mais, sem dúvida, definição. Ela não se mede senão à medida em que é restringida. Não se testa senão no momento em que dela somos privados. Não se desfruta dela senão observando a escravidão de outrem. Ela é questão de memória e de comparação. Mas não se lamenta senão aquilo que já se conheceu bem. Nossa geração sofre vivamente seu declínio. É pouco provável que nossos filhos provem do mesmo sentimento. Temamos desejá-la novamente muito tempo depois de sua morte" ${ }^{\text {"50. }}$. Não por outra razão muitos dos que estavam preocupados com a garantia dos antigos arranjos sociais se veem instados a aderir a outras ideias, flertando com o corporativismo e com tendências mais radicais que estavam sendo experimentadas nos países vizinhos.

"Os anos do imediato ante-guerra (1936-1939) são anos-chave: entre uma classe dominante cuja inquietude sobre seu próprio destino leva a condenar uma nação inteira, e o mundo operário que se recusa a fazer sua revolução, anunciada desde muito tempo, abre-se um abismo de incompreensão, de medo e por vezes mesmo de ódio" $" 51$.

Como se sabe, o período termina com o fim trágico da Terceira República: invasão da França pelo exército alemão em 10 de maio de 1940 e armistício em 25 de junho, dividindo o país em território ocupado pelos nazistas e território controlado pelo governo de Vichy. Mas é justamente a tensão social que antecedeu a esse fim que interessa compreender do ponto de vista do pensamento jurídico, as primeiras respostas do direito à incorporação da democracia e de demandas sociais, impondo uma redefinição do papel do Estado.

\subsection{Democracia, Parlamento e reformas legislativas}

O sufrágio universal e a consequente incorporação dos diferentes setores sociais ao Parlamento implicou em uma significativa produção legislativa, que buscou responder às demandas de uma sociedade em transformação. A democracia de massas

51 DUBY e MANDROU, 1984, p. 327 
garantiu uma legislação moderna, que refletiu as novas demandas. Por outro lado, o Parlamento vai se tornando o espelho de uma sociedade permeada por tensões e diferentes correntes e disputas políticas, e torna-se cada vez mais difícil constituir um governo de maioria coerente, colocando em xeque o modelo de parlamentarismo liberal delineado pelas leis constitucionais de 1875 .

Apesar de não ter havido mudança da ordem constitucional, é evidente que o período do entre-guerras já não mais presenciou um Estado liberal como formatado na origem da Terceira República. $\mathrm{O}$ arcabouço legal, a jurisprudência produzida e as disputas dentro do Parlamento denunciavam, na prática, uma crise da estrutura liberal de governo e representação, impondo como desafio aos teóricos do direito constitucional e do Estado o desafio de dar conta de um novo modelo de Estado.

\subsubsection{Uma nova democracia?}

O problema colocado aos "pais fundadores" da Terceira República, nas palavras de Pierre Rosanvallon, era "como instituir em torno do sufrágio universal um regime enfim sólido e estável ao mesmo tempo?" $" 52$. A questão é fundamentalmente dirigida aos teóricos da democracia e do direito constitucional, colocados em primeiro plano no projeto de estabilização da nova República e proteção contra as ameaças de ruptura da ordem. É em meio a essas questões que se forma a geração dos chamados clássicos do direito constitucional, como Adhémar Esmein (1848-1913), Léon Duguit (1859-1928), Maurice Hauriou (1856-1929), Léon Michoud e Carré de Malberg (1861-1935). No capítulo 2, tratar-se-á de alguns desses autores mais detidamente, bastando por ora traçar um plano geral das questões a eles apresentadas, que giravam em torno da nova democracia, do sufrágio universal e do governo representativo.

Seguindo, em linhas bastante gerais, a análise de Rosanvallon ${ }^{53}$, temos que em um primeiro momento, a resposta vem a partir da elaboração do projeto de "República absoluta". Mantendo a desconfiança em relação às possíveis consequências da expansão do sufrágio, o desafio era construir bases para uma certa limitação teórica da democracia. Essa era a questão colocada aos pensadores no início da República: fornecer

${ }^{52}$ ROSANVALLON, 2000, p. 243.

${ }^{53}$ ROSANVALLON, 2000, p. 239 e ss. 
elementos para conciliar o sufrágio universal às premissas liberais de representação e democracia.

Importante para isso foi a distinção recorrentemente referida nos trabalhos acadêmicos do período - e que buscava suas origens na Revolução Francesa, especificamente nos regimes de 1791 e 1793 - entre soberania nacional, vinculada à ideia abstrata de nação una e indivisível, e soberania popular, ligada à noção fragmentária de povo como massa heterogênea, concreta e historicamente situada ${ }^{54}{ }^{55}$. "Se a soberania não reside em um todo reunido, do qual nenhum grupo ou setor do povo se pode apropriar, ele é então de ordem distinta daquela que poderia resultar da perspectiva 'rousseauniana' de um contrato social organizador de um poder coletivo. Ela é ao mesmo tempo a manifestação de um poder [puissance] e o princípio de uma limitação de todas as pretensões de falar em nome da totalidade social. A soberania da nação é, por esse motivo, indissociável da forma representativa do governo, uma vez que a formação do interesse geral não pode resultar senão de uma interpretação e de uma formatação organizada. Ela é ao mesmo tempo democrática e liberal, para dizer as coisas de outro modo" ${ }^{\text {"E }}$. É importante chamar a atenção para a função da distinção entre soberania nacional e soberania popular, inclusive para que seja possível melhor compreender a revisão do pensamento de Carré de Malberg, tratada no próximo capítulo (item 2.3.4).

Os eleitos eram vistos, antes de tudo, como uma elite selecionada, capaz de perceber a vontade da nação como unidade. A ideia de representação desvinculada da de mandato imperativo, construção doutrinária anterior, apenas reforçava a identificação de uma aristocracia eletiva. Nas palavras de Edmond Villey, "o regime representativo supõe a superioridade do eleito, que deve comandar e não obedecer ${ }^{\prime 57}$. A política passa a se constituir como uma profissão, um métier, e assim surge o debate sobre a remuneração dos representantes e da constituição de uma classe política.

Mas se a "República absoluta" com a qual sonhavam os "pais fundadores" constituía-se em teoria sobre um ideal e uma crença - o ideal de uma

\footnotetext{
${ }^{54}$ Cf. ESMEIN, 1909; CARRÉ DE MALBERG, 1920 [2004]. Para uma análise das origens e significados da distinção entre soberania nacional e soberania popular, vide BERCOVICI, 2008(a), pp. 134/154.

55 "Au people multiple et changeant, infigurable en sa totalité concrète puisque toujours subsistent des vies et des voix qui ne sont pas prises en compte (ne serait-ce que celles des enfants ou des femmes alors exclues des urnes), se substitue ainsi le corps dense de la nation, dont la complétude ne peut procéder que d'une interprétation et d'une reconstruction, l'érigeant en sujet par nature abstrait. Puissance 'théorique' de la nation et limitation 'pratique' du pouvoir du peuple vont sur cette base aller de pair", in ROSANVALLON, 2000, pp. 248/149.

56 ROSANVALLON, 2000, pp. 250/251.

${ }^{57}$ Edmond VILLEY, La souveraineté nationale. Revue du droit public, t. XXI, jan-fev 1904, p. 23, apud ROSANVALLON, 2000, p. 253.
} 
aristocracia política emancipada que conciliasse governo representativo e sufrágio universal em um "Parlamento de sábios e experts" a crença na intangibilidade do regime e de suas bases - o modelo na prática não cessou de sofrer contestações.

Nesse sentido os questionamentos de Maurice Deslandres (1862-1941), jurista engajado ao catolicismo social, colaborador das Semaines Sociales ${ }^{58}$, ao diagnosticar a crise da ciência política e a necessidade de renovação da disciplina: " $a$ democracia representativa, termo de evolução política das sociedades modernas, ou ao menos grande patamar de descanso onde elas devem deter longamente o curso de sua ascensão em direção a formas superiores de governo, essa ideia não é hoje em dia muito generalizada entre nós? Não parece que nosso regime político, ao envelhecer, adquire uma sorte de intangibilidade? Não parece que a ideia da possibilidade, da oportunidade, de uma reforma constitucional só pode pertencer aos revolucionários por profissão? Não houve estupefação e escândalo quando os homens moderados falaram da necessidade de transformação das nossas instituições políticas?" "59. Para o autor, a novidade era que as instituições políticas passaram a ser um instrumento, e a situação econômica e social, a finalidade, em razão das transformações sociais da época, como a acentuação das desigualdades e da luta de classes, as doutrinas filosóficas como o materialismo e o positivismo, e o regime político que, “fazendo do 'número'o 'soberano', deu às massas a vontade de se servir de sua soberania em seu beneficio, sem buscar aperfeiçoar o sistema político, 60 . Não havia lugar para aspirações abstratas ou para uma aristocracia política em tempos de democracia de massas, já consolidada, em que era necessário responder a demandas muito mais concretas, especialmente relacionadas com a igualdade material, não simplesmente formal.

Proliferam contestações teóricas ao governo representativo e ao parlamentarismo, sendo recorrente de um lado o diagnóstico de "crise", seja da democracia, seja do governo representativo ou seja do Estado, e, de outro, o clamor por uma reforma constitucional. Ao mesmo tempo, o Parlamento se transforma, na sua composição, na relação de seus membros com os eleitores e no papel que desempenha na sociedade, sem que haja reforma substancial das leis constitucionais e da instituição em

\footnotetext{
${ }^{58}$ Cf. AUDREN, 2008, p. 255 e ss.

${ }^{59}$ DESLANDRES, 1900, p. 15.

${ }^{60}$ DESLANDRES, 1900, p. 18.
} 
$\mathrm{si}^{61}$. "Tornou-se banal dizer que mesmo que tenhamos uma Constituição escrita, é uma outra que praticamos", afirma Deslandres ${ }^{62}{ }^{63}$.

Cada vez mais compostos por membros defensores de seus eleitores, de grupos de interesse, e respondendo às pressões de coletivos sociais, o Parlamento aproxima-se de ser um espelho da sociedade, torna-se o locus de enfrentamento das forças sociais externas, distanciando-se do modelo de autonomia na percepção do suposto interesse da nação enquanto unidade abstrata. Daí, inclusive, a eclosão de críticas aos parlamentares pela sua prolixidade e verborragia, pelos seus fastidiosos discursos, pela sua deficiente formação, pela vulgaridade dos temas tratados nas falas, pelo encarecimento dos custos da manutenção da máquina parlamentar etc - são críticas que aparecem inclusive em Joseph Barthélemy ${ }^{64}$. "Pode-se dizer que o Parlamento não é mais do que o eco do lado de fora. Todo discurso que lá se pronuncia provém de uma inspiração exterior. Toda lei que lá se vota não é senão a consagração de decisões tomadas em tal sociedade, em tal agrupamento extra-parlamentar" ${ }^{65}$, segue Deslandres, prenunciando, como jurista engajado, um "governo de opinião", que seria o abandono do governo representativo e o advento de uma forma rudimentar de democracia direta, "de democracia com o povo não mais como titular nominal, mas como depositário efetivo da soberania" ${ }^{\text {.66 }}$.

Evidencia-se a impossibilidade de combinar de forma duradoura uma cultura social democrática a uma convicção política aristocrática. "Não são, portanto, as instituições que mudaram. Nenhuma ruptura social é igualmente a causa. São, simplesmente, os hábitos [mœurs] e as práticas que remodelaram sensivelmente a vida das instituições e mudaram seu espírito" ${ }^{\text {"67. }}$

\footnotetext{
${ }^{61}$ Sobre as reformas de 1919 e de 1927, que alteraram o sistema de votação, e seus impactos (combinando representação proporcional e voto de maioria, e regulando o escrutínio de listas), vide THOMSON, 1952 (1946), RÉMOND, 1966, p. 262 e ss., BONNEFOUS, 1959, t. III, p. 21.

${ }^{62}$ DESLANDRES, 1900, p. 28.

${ }^{63}$ Vide, por exemplo, a afirmação de Louis Reynaud: "Il est trop évidente d'ailleurs que ces diverses déformations, chez nous, d'un système de gouvernement qu'il ne faut pas juger entièrement sur elles, ont été grandement favorisées par la façon dont nous l'avons presque toujours conçu et appliqué, par ce vice capital de la plupart de nos Constitutions démocratiques, de celle de 1875 tout spécialement, qui consiste dans la faiblesse du pouvoir exécutif, dans l'absence de tout contrepoids à la fantaisie d'un Parlement que rien ne protège contre ses propres erreurs : absurdité que nous devons à l'illuminisme démagogique de Rousseau. Ce n'en sont pas moins là de graves abus, qui montrent combien difficile est le maniement du régime démocratique, même pour un peuple comme le nôtre, hautement civilisé, plein de bonne volonté, patriote malgré quelques défaillances, et qui a fourni, sinon toujours, du moins le plus souvent, à la Démocratie, un personnel d'hommes d'État et des hauts fonctionnaires de première valeur. Serait-ce donc que la Démocratie est en elle-même un mode de gouvernement défectueux, reposant sur des principes faux, et condamné à l'impuissance pour le bien ?", in REYNAUD, 1938, p. 199.

${ }^{64}$ Vide os comentários em SAULNIER, 2004, pp. 412/415.

${ }^{65}$ DESLANDRES, 1900, p. 34.

${ }^{66}$ DESLANDRES, 1900, p. 34.

${ }^{67}$ ROSANVALLON, 2000, p. 260.
} 
Rosanvallon fala em duplo giro característico do final do século XIX: "uma revolução silenciosa do sistema político, no plano dos fatos. Mas também uma ruptura no método de consideração das questões politicas. A abordagem normativa, por muito tempo dominante, vai pouco a pouco ceder lugar às análises mais factuais. Ao debate anterior sobre valores e formas desejáveis de organização política se sucede uma preocupação de descrever, para melhor compreender, o advento de uma nova era política" ${ }^{68}$. O movimento de abandono das pretensões de teorização mais abstrata do sistema político, características da geração dos clássicos do direito constitucional, formada no período de consolidação do regime, se intensifica após a guerra, e reforçando a tendência mais descritiva e pragmática na ciência do direito, como se verá na comparação entre os autores abordados no capítulo 2 e 3.

A nova era política vê suas contradições se aprofundarem após a guerra. Por um lado, como mencionado no item 1.1.2, o rearranjo da separação de poderes e o uso do mecanismo do estado de sítio reforçaram a percepção de crise da democracia liberal. Como afirma Bercovici, tratando do uso do estado de exceção durante a Primeira Guerra Mundial, "a adoção dos plenos poderes não implica, necessariamente, em ditadura, apenas demonstra a existência de uma crise. Mas esta crise, embora não seja da democracia em si, é da democracia representativa, pois demonstra a incapacidade do parlamento lidar com as situações excepcionais" ${ }^{69}$. O Poder Executivo capitaliza seu fortalecimento, obtido com a assunção de funções de coordenação durante a guerra, e alguns autores passam a defender a importância da função do presidente, inspirados pelo modelo norte-americano. Ao mesmo tempo, questiona-se o Parlamento como centro da soberania, posição que ele assumia na abordagem tradicional. A mudança dá margem a um diagnóstico de crise do velho modelo liberal, crise essa que é capitalizada pelas forças sociais de forma consideravelmente distinta.

A organização e a radicalização das forças sociais acentua o tom das críticas, portanto, e exige novas respostas, desde as capazes de conferir mais densidade e consistência ao ideal democrático até as propriamente antiparlamentaristas e até mesmo antidemocráticas, que veem como solução a ruptura com as premissas de democracia liberal vigentes desde a fundação da República.

Por um lado, o rearranjo na separação dos poderes e o fortalecimento do Executivo, heranças da guerra, aliado ao já recorrente diagnóstico de crise da democracia

${ }^{68}$ ROSANVALLON, 2000, p. 245.

${ }^{69}$ BERCOVICI, 2008(a), p. 285. 
dá lugar à defesa da "racionalização" e autonomização da administração, da criação de um corpo de autoridades técnicas "profissionalizado" e da tecnocracia, restringindo a importância do Parlamento. A denúncia da “'tarântula democrática' se torna um dos lugares comuns da imprensa de direita e de extrema direita que evoca com deleite sua definição do político: 'um homem nulo em termos de ideias pessoais, de instrução mediocre, que compartilha os sentimentos e as paixões gerais da multidão, "70. As forças ligadas à direita organizam-se assim em torno de movimentos nacionalistas, que se valem da difusão da crença em uma ameaça de subversão da ordem pelos socialistas e partidos de esquerda, para elevar o tom das críticas ao parlamentarismo, flertando inclusive com soluções autoritárias que já estavam sendo implementadas nas vizinhas Itália e Alemanha.

Por outro lado, a crescente industrialização, acompanhada da organização do operariado e da sindicalização, dá força às reivindicações por uma "democracia industrial", termo importado dos EUA e da Grã-Bretanha, onde desde o final do século XIX já se falava em industrial democracy. O chefe da CGT, Léon Jouhaux, protesta por direitos em matéria econômica equivalentes à igualdade direitos de participação garantidos pelo sufrágio universal ${ }^{71}$. Nesse sentido surge o debate em torno do controle operário, da participação na gestão das fábricas, de uma colaboração de classes. Os anseios de democratização que vinham se consolidando no campo político chegam à esfera econômica da produção ${ }^{72}$.

Não se pode deixar de lembrar que o movimento conselhista, que recoloca em novos termos os anseios revolucionários dos socialistas após 1917, ganha força no entre-guerras. Assim segue a crítica de Lênin ao Parlamento e sua defesa dos sovietes, bem como a experiência da República de Weimar, e o esforço de implementação dos conselhos econômicos ${ }^{73}$. A social-democracia apresenta-se como alternativa, sustentando a possibilidade de, a partir de reformas institucionais e políticas, inaugurar-se uma democracia econômica que avança da igualdade formal para a igualdade material, inclusive com controle compartilhado das indústrias, como transição rumo ao socialismo. $\mathrm{Na}$ França, essa linha de pensamento orienta autores como Georges Gurvitch, que trata do

\footnotetext{
${ }^{70}$ ROSANVALLON, 2000, p. 369, citando Émile Faguet, Le Culte de l'incompetence, Paris, 1910, p. 29.

${ }^{71}$ Cf. ROSANVALLON, 2000 , p. 363.

72 "À la notion de souveraineté, les syndicats font succéder celle du travail, car si nous ignorons où est le souverain populaire, fiction désormais liberticide, nous savons bien où est le travailleur, rude réalité émancipatrice", afirma Maxime Leroy, jurista que se dedicou ao estudo do sindicalismo. In Les Techniques nouvelles du syndicalisme, 1921, p. 204, apud ROSANVALLON, 2000, p. 372.

${ }^{73}$ Sobre a República de Weimar, vide BERCOVICI, 2004 e HERRERA, 2011.
} 
Direito Social ${ }^{74}$. Entram, assim, na ordem do dia bandeiras como "controle operário", "democracia industrial", "república do trabalho", "constitucionalismo de usina" e "democracia operária" 75 .

Proliferam propostas de reforma do sistema político, que incorporem as novas demandas sociais. Ganham força as ideias que pretendem relativizar a distinção Estado-indivíduo, um dos pilares da tradição individualista da Revolução Francesa, para inserir como atores sociais os grupos intermediários, como associações e sindicatos. " $O$ liberalismo político do século XIX criou o 'cidadão', indivíduo desmembrado da família, da classe, da profissão, do meio cultural, da coletividade econômica aos quais pertencia e confiou a ele, a fim de que ele exercesse facultativamente, o direito de intervir no governo do Estado (...). Mas virá a era da revolução econômica e da industrialização. Com elas, uma maior especialização e divisão do trabalho farão renascer, de fato em um primeiro momento, de direito em seguida, os grupos que as leis da Revolução tinha pretendido dissolver (...). É preciso então substituir à democracia clássica uma democracia na qual todos os cidadãos sejam representados na medida dos interesses que possuem como membros de um grupo e não da opinião que possuem como cidadãos. A democracia individualista é ultrapassada" ${ }^{76}$. Nesse sentido, por exemplo, as propostas de representação orgânica, profissional ou de interesses, ou ainda o voto familiar, às quais adere inclusive Duguit, mas que podem servir tanto à direita quanto à esquerda. Nesse sentido também a tentativa de reestabelecer formas de mandato imperativo, de modo a vincular o parlamentar à sua base eleitoral, e romper com a ideia clássica de representação, ideia essa que também era questionada por propostas como a do referendo.

O entre-guerras é palco, assim, de novas demandas e questionamentos do regime democrático, e clamores por reformas. Alarga-se o espectro do político e das possibilidades de se pensar a democracia, com a inclusão de reivindicações de direitos de igualdade e participação econômica, equivalentes aos direitos políticos, ao mesmo tempo em que se reforçam as tentativas de limitação e cerceamento do espaço de deliberação, com o fortalecimento do Executivo, a defesa do insulamento burocrático, a "racionalização", a valorização da tecnocracia etc, tendo um horizonte autoritário. A democracia e o pensamento liberal estão cada vez mais sob fogo cruzado, e os juristas da época se veem instados a formular novas respostas, como se verá nos capítulos seguintes.

\footnotetext{
${ }^{74}$ Cf. GURVITCH, 1946. Sobre o autor, vide HERRERA, 2009, e Dossier Gurvitch, 1986.

${ }^{75}$ ROSANVALLON, 2000, p. 373.

${ }^{76}$ SAULNIER, 2004, pp. 79/80.
} 


\subsubsection{Novas leis e novas disputas no Parlamento}

Do ponto de vista do Parlamento, as respostas às novas questões foram sendo dadas por meio de inovadora legislação. Diversas leis promulgadas no período permitiram a construção de um arcabouço jurídico de proteção social e dos trabalhadores, e de garantia das liberdades individuais, e, especialmente coletivas. Arnaud ${ }^{77}$ salienta a revisão dos papéis estabelecidos no Código Civil, como por exemplo na lei de 1895 que regulamenta a capacidade civil da mulher casada, ou na de 1900, que a permite exercer a advocacia, ou ainda, na lei de 1907 que regula o livre salário da mulher casada. Desde 1884 já estava estabelecida a permissão do divórcio. Para tratar da questão social, e das exigências de reformas e ampliação de direitos, surgem as leis que garantem a obrigatoriedade do ensino, bem como sua laicidade (1882), precedida pela lei que estabelece a gratuidade do ensino primário (1881). A separação da Igreja e do Estado é finalmente estabelecida por lei em 1905.

As aspirações de direitos trabalhistas e coletivistas do movimento operário são, também, objeto de reconhecimento jurídico. Em 1881 promulga-se lei afirmando a liberdade de reunião, seguidamente aperfeiçoada e ampliada ${ }^{78}$. Um mês mais tarde, vota-se a liberdade de imprensa. Em 1901 acaba a proibição aos "clubes" (associações). Diversas regulamentações trabalhistas são votadas, como a lei de 1874 sobre a interdição do trabalho de menores de 12 anos e proibição do trabalho noturno e subterrâneo em minas de mulheres, a lei de 1892 sobre a limitação da jornada de trabalho (10 horas diárias para mulheres, 10 ou 11 horas para menores de 21 anos em determinados tipos de indústria, estendida em 1900 para ambos os sexos), a lei de 1890 sobre a criação de delegados dos trabalhadores encarregados de fiscalizar a salubridade das condições de trabalho, a lei de 1893 sobre a higiene e a segurança dos trabalhadores, a lei de 1906 sobre o descanso semanal obrigatório de no mínimo $24 \mathrm{~h}$. Desde 1884 já havia legislação sobre a liberdade sindical, em 1895 aparecem as leis sobre caixas de aposentadoria, seguro e previdência dos mineradores, estendida a todos os trabalhadores em 1905. Em 1898 regulamentam-se os acidentes de trabalho e em 1910 surge o "Código do Trabalho e da Previdência Social”.

\footnotetext{
77 ARNAUD, 1975, pp. 81 e ss.

${ }^{78}$ Sobre a legislação do periodo, cf. ARABEYRE, HALPÉRIN e KRYNEN, 2007, SZRAMKIEWICZ e BOUINEAU, 1989, pp. 520 e ss.
} 
Em 1919, promulga-se uma importante lei sobre convenções coletivas, e já em 1936, o governo do Front Populaire abre caminho para os acordos de Matignon, que fixam o direito de férias remuneradas (congés payés), a semana de trabalho de 40 horas, o regime de convenções coletivas, conciliação e arbitragem para conflitos coletivos do trabalho, a criação do Office $d u$ blé (destinado à eliminação da especulação e à estabilização do preço do trigo), a reforma do Banque de France, com controle governamental, e a nacionalização das docas.

A jurisprudência, em um primeiro momento mais conservadora, rechaçando o direito de greve, por exemplo ${ }^{79}$, passa a ser sensível às mudanças ${ }^{80}$, especialmente diante dos esforços da doutrina jurídica. A instabilidade no Parlamento e nas instituições políticas levou, também, a um redirecionamento dos conflitos para as estruturas jurídicas, aparentemente mais estáveis. Assim, por exemplo, a maior importância que assumiu o Conséil d'État no período. E os juristas não só contribuíram do ponto de vista teórico, como se verá. Foram também atores políticos ${ }^{81}$.

Porém, se reformas legislativas traduziam para o direito as demandas de uma sociedade em transição, por outro lado essa nova feição institucional não representou uma refundação constitucional, como ocorrera em diversos outros Estados europeus no mesmo período. Isso não significa que não tenha havido pressão para tanto, diante das significativas alterações políticas e sociais. Apesar de constituir-se grupo para estudo da reforma constitucional, do qual fez parte, inclusive, Joseph Barthélemy, resistente à ideia no início, liberal como era, e apesar de pequenas alterações nas leis constitucionais de

\footnotetext{
${ }^{79}$ Por exemplo, na decisão de 15 de maio de 1907 da Cour de Cassation.

${ }^{80}$ Cite-se aqui o caso do Juiz Paul Magnaud, que absolveu uma mulher por furto famélico, e, num outro julgamento, absolveu um rapaz que não conseguia emprego e que era acusado de mendicância e vadiagem; absolveu uma mulher acusada de adultério tendo fundamentado sua sentença no entendimento de que não havia prejuízo público mas apenas para a vida dos próprios cônjuges; e, através de inúmeras decisões surpreendentes para a época, pretendeu a descriminalização do adultério, o reconhecimento do que depois se tratou como estado de necessidade, avançou no sentido do direito de greve, de segurança do trabalho, da valorização da mulher e sua igualdade em relação ao homem, etc. Em 1906 será eleito deputado pelo partido radical-socialista, mandato em que tentou sem nenhum sucesso reformas legislativas na área penal, sobretudo. Para uma análise das decisões do Juiz Magnaud, cf. WEYL e PICARD WEYL, 1975.

${ }^{81} \mathrm{De}$ acordo com dados compilados por Ji-Hyun Jeon, tratando dos juristas vinculados ao Partido Socialista, foram contabilizados 251 membros do SFIO, 220 advogados (dos quais havia 4 advogadas), 11 professores, 6 avoués [figura essencialmente francesa, é o jurista que exerce função de oficial ministerial encarregado dos atos necessários à postulação e instrução nas cortes de apelação], 6 magistrados, 3 notários e 5 doutores em direito. Destes, 64 foram eleitos deputados, e 82, conselheiros regionais. Também exerciam participação dentro das estruturas partidárias, tomando parte nas deliberações e contribuindo com sua formação jurídica. As atividades de "militantes-especialistas" impuseram aos juristas também a necessidade de elaboração teórica dos ideais partidários, fazendo com que publicassem manuais para as classes operárias (como é o caso de Léon Agnery, Vincent Auriol, Ernest Lafont, Georges Ducos de la Haille, Pierre Laval e Firmin Verdier exemplos fornecidos por JEON, 2005, p. 53.), bem como de fornecer aconselhamento jurídico ou representar a classe operária em atividades jurisdicionais. in JEON, Ji-Hyun, Quelques jalons pour une histoire des juristes au sein du Parti Socialiste - SFIO (1905-1939), in HERRERA, 2005, pp. 45-60.
} 
1875 durante os anos 1920, certo é que essas mantiveram-se como base constitucional de matriz liberal durante toda a vigência da Terceira República Francesa. Em um Parlamento crescentemente polarizado, um processo amplo de reforma ou de refundação constitucional poderia representar riscos que não estavam dispostos a correr naquele momento.

Como visto, o Parlamento progressivamente conformava-se, como visto, como locus da divergência e das crescentes dificuldades de consenso, o que impunha também uma sucessão vertiginosa de gabinetes ministeriais. "Se a função de um governo democrático é ser um espelho ou um negativo fotográfico - refletindo ou reproduzindo precisamente os conflitos entre as forças sociais e políticas - a república funcionou suficientemente bem. Se a função de um governo democrático é algo mais concreto do que isso, se é servir à boa vida e ao bem-estar geral da maioria dos cidadãos e agir como "empecilho aos obstáculos" [hinderer of hindrances] à prosperidade e à segurança nacionais, ela não funcionou tão bem" ${ }^{82}$.

A democracia parlamentar, diante das crescentes tensões sociais, está em crise também na França, à semelhança do que acontecia com a República de Weimar, na Alemanha. O entre-guerras é marcado por diversos governos ministeriais (43 gabinetes entre 1918 e $1940^{83}$, que duraram, muitas vezes, poucos meses ou dias), polarizações entre partidos de direita e de esquerda no Parlamento, e delegações do poder legislativo ao Governo (Executivo). É interessante notar que a pluralidade de correntes e de tendências políticas no Parlamento impõe um número expressivo de partidos e um largo espectro de opiniões representadas, desde a direita da Union démocratique républicaine (ERP, depois URP) até a extrema esquerda do Partido Comunista Francês.

A sucessão de coalizões indica desde logo a dificuldade em compor um governo que tenha maioria coerente, e René Capitant ${ }^{84}$ nota a tendência reiterada de alianças de esquerda terminarem em governos mais conservadores, dada a incapacidade de implementar um projeto progressista, como acontece na segunda (1924-1928) e na quarta legislaturas (1932-1936), sem falar do Front Populaire. A opinião expressa nas urnas tem dificuldades em se concretizar em governos, e há uma progressiva radicalização tanto da esquerda quanto da direita no entre-guerras.

A primeira legislatura (1919-1924) marcou, como mencionado anteriormente, a constituição de uma união burguesa da nova e da velha direita que

\footnotetext{
${ }^{82}$ THOMSON, 1952 (1946), p. 171.

${ }^{83}$ Apenas à título comparativo, a Va. República francesa (1959-dias atuais) contou apenas com 19 gabinetes.

${ }^{84}$ Cf. CAPITANT, 1972, p. 57 e ss.
} 
compuseram o Bloc National, que oscilava entre conservadorismo tradicionalista e um novo centro não reacionário, inicialmente sob a liderança de Clemenceau ${ }^{85}$. Em seguida, um primeiro governo em que a esquerda conseguiu compor maioria, na segunda legislatura (1924-1928), com a adesão dos Radicais, o chamado Cartel des Gauches, que se inicia sob o comando de Édouard Herriot. Contudo, os socialistas, que possuem 30 cadeiras, dão apoio reticente à nova maioria. A crise monetária, a inflação, a resistência à proposta de imposto sobre o capital, e a necessidade de estabilização do franco, aliada à instável maioria, são responsáveis pela sucessão de gabinetes efêmeros, terminando com uma virada conservadora do governo, que recorre a um governo de união nacional com a volta de Poincaré em $1926^{86}$.

A direita antiparlamentar ganha espaço, reforçando o antifascismo na esquerda (que vai ser organizar em torno do Rassemblement Populaire), e o espectro de variação política se amplia nas legislaturas seguintes, aumentando os conflitos. Proliferam escândalos, e os gabinetes se sucedem. O quadro de instabilidade se aprofunda com a quinta legislatura (1936-1940), em que os partidos de esquerda obtém vasta maioria no Parlamento $^{87}$ e constituem o Front Populaire, sob o slogan "Pão, Paz e Liberdade", escolhendo Léon Blum para chefiar o governo. Entre 1935-38, boa parte da esquerda consegue se unir para constituir o Front ${ }^{88}$, que reuniu 386 cadeiras do Parlamento. O sufrágio universal e o regime democrático davam mostras de que as tensões sociais poderiam chegar ao governo e às instituições, especialmente ao Parlamento.

$\mathrm{O}$ desafio era manter uma coerência e a possibilidade de estabelecer um sentido coeso dentro do movimento. Constava do programa do Front Populaire a tentativa de unir os movimentos de esquerda em um só governo: "O comitê entende que cada partido, cada organização, participante do Rassemblement populaire, pode se juntar à ação comum sem abdicar em nada de sua doutrina, de seus princípios e de seus fins

\footnotetext{
${ }^{85}$ Cf. MAIER, 1988 (1975), p. 91 e ss. "This premonitory skirmish suggested that a consistent rightist course was to remain beyond reach, hence the conservative and nationalist protest that would later develop into a right-wing fronde against ministries relying on the votes of the center. From the perspective of 1919 or 1924 , the Bloc National represented a profound swing to reaction. This divisions of French opinion, however, permitted a bourgeois and nationalistic, but not a reactionary consensus to triumph at the polls. Ironically, this may have strengthened parliamentarism, not weakned is as the Radicals hinted. Happy with the outcome of the elections, French business interests did not yet take refuge in corporatist efforts for bypassing the Assembly or authoritarian dreams of suppressing it", in MAIER, 1988 (1975), p. 109.

${ }^{86}$ Cf. CAPITANT, 1972, MAIER, 1988 (1975), p. 458 e ss.

${ }^{87} \mathrm{O}$ partido comunista atingiu 72 cadeiras, o socialista, 149, os demais partidos de esquerda, outras 55 , republicanos, radicais e radicais-socialistas, 110, centro-direita, 113, e direita, 111.

${ }^{88}$ Cite-se, por exemplo: Ligue des droits de l'homme, Comité de vigilance des intellectuels antifascistes, Comité mondial contre le fascisme et la guerre, Mouvement d'action combattante, Parti républicain radical et radical-socialiste, Parti socialiste SFIO, Parti communiste, Union socialiste et républicaine, Confédération générale du travail (CGT), Confédération générale du travail unitaire.
} 
particulares. Ele está vinculado, por outro lado, à apresentação de soluções positivas aos problemas essenciais atualmente apresentados perante a democracia francesa. É assim que, na ordem politica, ele define as medidas indispensáveis para assegurar o respeito à soberania nacional, exprimida pelo sufrágio universal, e para garantir as liberdades essenciais (liberdade de opinião e de expressão, liberdades sindicais, liberdade de consciência e laicidade) - que, na ordem internacional, ele apresenta as condições para a salvaguarda e para a organização da paz, segundo os princípios da Liga das Nações -e que, na ordem econômica e financeira, ele se filia à luta, no interesse das massas trabalhadoras e poupadoras, contra a crise e contra as organizações fascistas que

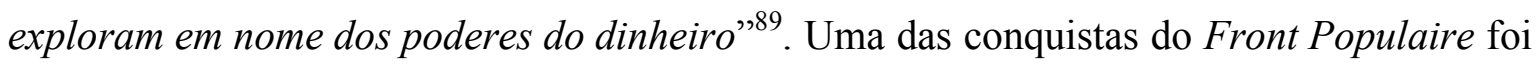
justamente os acordos de Matignon, anteriormente referidos, decorrência também da mobilização popular, após um mês de greves e ocupações.

A última virada para a direita se dá justamente com a retirada dos socialistas do governo, em 1938, substituídos pelos republicanos de centro (concertação republicana). Aumentam as dificuldades trazidas pela instável situação econômica. Após um mês de governo, em abril o Senado derruba Léon Blum, que havia tentado liderar uma nova coalizão. Mas o governo de centro-direita de Édouard Daladier, que se seguiu, não teria muito tempo: assiste à invasão de Hitler à Polônia (setembro de 1939), seguida da declaração de guerra de França e Inglaterra à Alemanha. A ofensiva ocidental culmina com a invasão da França em 13 de maio de 1940, e Paris cai sob o domínio alemão em 14 de junho do mesmo ano.

Convocado já em Vichy, o Parlamento, de maioria antifascista, então confere todos os poderes a uma personalidade ligada a um partido protofascista, o Marechal Pétain, a quem o Parlamento delega, por meio da lei constitucional de 10 de julho de $1940^{90}$, plenos poderes para que possa promulgar nova constituição, pondo fim à Terceira República Francesa. "Tal foi o resultado extremo do regime representativo: uma delegação do poder constituinte"

\footnotetext{
${ }^{89}$ Preâmbulo do programa do Front Populaire, in DE BAECQUE, 1991, pp. 141/142.

90 'L'Assemblée nationale a adopté, Le Président de la République promulgue la loi constitutionnelle dont la teneur suit : Article unique. L'Assemblée nationale donne tout pouvoir au gouvernement de la République, sous l'autorité et la signature du maréchal Pétain, à l'effet de promulguer par un ou plusieurs actes une nouvelle constitution de l'État français. Cette constitution devra garantir les droits du travail, de la famille et de la patrie. Elle sera ratifiée par la Nation et appliquée par les Assemblées qu'elle aura créées. La présente loi constitutionnelle, délibérée et adoptée par l'Assemblée nationale, sera exécutée comme loi de l'État. Fait à Vichy, le 10 juillet 1940".

${ }^{91}$ CAPITANT, 1972, p. 75.
} 


\subsection{Pensamento JURídico: CONTEXTo Geral}

No campo do pensamento jurídico, a fase inicial da Terceira República é um momento de revisão das doutrinas anteriores, especialmente diante da necessidade de fundamentar e legitimar a República nascente. A teoria jurídica francesa confrontava-se, de um lado, com a tradição nacional legalista, herança da já desgastada Escola da Exegese, e, de outro, com o desenvolvimento de uma nova abordagem em relação ao direito na vizinha Alemanha.

O primeiro desafio era a superação da Escola da Exegese, movimento teórico que surgiu tanto com a promulgação do Código Civil em 1804, quanto com a necessidade de refundar as bases do pensamento jurídico francês diante dos ideais da Revolução Francesa. Os exegetas ${ }^{92}$, como se sabe, identificavam o direito à lei, e sustentavam a busca pela vontade do legislador como única tarefa possível do jurista. Enxergavam um direito ao mesmo tempo fundado em premissas de direito natural, plasmado na declaração de direitos individuais e nos princípios norteadores do Código Napoleão, e percebido como a vontade geral da nação, enquanto unidade, manifestada por meio da lei pelo legislador que a representa.

A crítica a esse movimento - classificado por Michel Troper de "nevrose jurídica"93, em razão da excessiva limitação do campo de estudo do jurista imposta pela máxima de que todo direito estava na lei - no último quadrante do século XIX, marcou o início da Terceira República Francesa. Assistiu-se, no período, justamente à tentativa dos juristas de construir o direito como ciência autônoma, fundada em premissas e em método próprios, em consonância com o ideal cientificista que florescia em geral, em todas as áreas, e à exemplo do que já acontecia na Alemanha. O jurista, como teórico, ganha centralidade.

"Na França, o século XIX termina com a descoberta do BGB [Bürgerliches Gesetzbuch, Código Civil Alemão], que acentua e confirma o aparente envelhecimento do Código civil de 1804. Se há uma lição de Portalis que é bem esquecida, é a que trata da idade dos códigos. Nesse final do século XIX, ninguém mais diz que um código novo é uma 'ferramenta inconveniente'. O tema central da teoria jurídica francesa é o da antiguidade do Código civil, da sua excessiva antiguidade. O racionalismo gera aqui um evolucionismo primário. Havia tomado um século para tecer os fios da

${ }^{92}$ Sobre a Escola da Exegese francesa, cf. BONNECASE, 1924, BONNECASE, 1933.

${ }^{93}$ GRZEGORCZYK, MICHAUT e TROPER, 1992, p. 40. 
codificação na trama cerrada da tradição jurídica anterior, e no entanto esse trabalho mal havia avançado e os juristas já começam a falar da revolta do direito ou dos fatos contra o código. Outros como François Gény, Raymond Saleilles, René Demogue... compreendem que os intérpretes estão mais em causa do que o Código" "94. Os franceses voltam os olhos com admiração para a vizinha Alemanha, e para sua ciência do direito racional e formalizada, por um lado, diante da crítica à Exegese e aos obstáculos que o movimento colocou ao desenvolvimento da doutrina, mas também com suspeita e crítica, por outro, cientes de que a solução para a transformação do direito deveria ser eminentemente nacional, incorporando a tão louvada quanto por vezes distorcida tradição teórica francesa.

$\mathrm{Na}$ Alemanha, a busca pela constituição do direito como ciência autônoma marcou o século XIX. Não se pode esquecer, antes de mais nada, que o país tem uma trajetória política bastante distinta da francesa, seja pela recente unificação, em 1871, mantendo os regionalismos e a descentralização bastante vivos, seja por constituir-se como império, e não como república. Os juristas estavam pensando um direito que funcionasse para garantir a ordem de um Estado Imperial, sem ter que lidar com as novas e modernas pressões que a democracia e o sufrágio universal vieram impor à ciência do direito do outro lado do Reno.

A defesa de método e princípios próprios, a precedência do Estado, como pessoa jurídica dotada de poder de dominação irresistível, em relação ao direito, o combate ao direito natural e a defesa do direito positivo, a centralidade do indivíduo e do direito subjetivo, são todos elementos da nova ciência que se consolidava a partir das teorias dos juristas alemães. Premissas condizentes com um Estado aristocrático e que necessitava legitimar-se enquanto Estado-nação moderno, unificado e forte, diante dos movimentos liberais, mas que não serviriam tão bem para uma República democrática onde o Parlamento eleito por sufrágio universal detinha a soberania.

A genealogia do pensamento alemão do século XIX, e suas filiações e desenvolvimentos, é matéria complexa, que extrapola o objetivo desse trabalho ${ }^{95}$. Basta, por ora, reter algumas das asserções que marcaram a doutrina alemã do período, transformações no pensamento às quais não ficou indiferente a doutrina francesa, como se verá nos capítulos 2 e 3 .

\footnotetext{
${ }^{94}$ ATIAS, 1991, p. 241.

${ }^{95}$ Para uma análise aprofundada, cf. STOLLEIS, 2001, LARENZ, 1991, WILHELM, 1980, WIEACKER, 1967.
} 
Em linhas bastante gerais, o direito, para se consolidar como ciência autônoma, precisa de um método próprio. O indivíduo é posicionado no centro do sistema jurídico, que passa a se articular a partir de premissas independentes das demais instâncias sociais, como a economia e a política, valendo-se para tanto de abstrações, especialmente relacionadas à existência de um sujeito de direito abstrato, livre e dotado de vontade, sendo a tarefa do ordenamento jurídico a proteção de seu plexo de direitos subjetivos.

A concepção dessa abordagem, no direito privado (comum e romanista) é atribuída à Escola Histórica, cujo expoente maior é Friedrich Karl von Savigny (17791861), e é depois empregada por Georg Friedrich Puchta (1798-1846). O transporte da proposta metodológica para o direito público foi feito por Carl Friedrich von Gerber (18231891), que formulou sua teoria sobre os direitos subjetivos públicos, movimento posteriormente consolidado com a obra de Paul Laband (1838-1918). Georg Jellinek (1851-1911) usa as ferramentas do positivismo formalista na concepção de uma teoria do Estado puramente jurídica. Dadas as referências teóricas centrais, vejamos, em linhas bastante gerais, os fundamentos dessa evolução.

O fenômeno jurídico passa a ser compreendido em torno do indivíduo, de sua vontade e de sua liberdade. É o que está por trás do pensamento de Savigny, ao construir a noção de relação de direito a partir do direito subjetivo: "o direito, se nos o consideramos tal como na vida real, nos rodeia e nos penetra de todos os lados, nos aparece como um poder do indivíduo. Dentro dos limites deste poder, a vontade do indivíduo reina, e reina a partir do consentimento de todos. É este poder ou faculdade que chamamos direito, e alguns o chamam direito em sentido subjetivo. $O$ direito não se manifesta jamais mais claramente do que quando, negado ou atacado, a autoridade judiciária reconhece sua existência e sua extensão" ${ }^{96}$. O direito fundado no indivíduo é produto social: não do social como ambiente de conflitos, mas sim do social como depositário de uma história interna do povo, animado por um princípio vital que impulsiona a evolução das instituições e dos princípios jurídicos, o espírito do povo (volksgeist). Cabe ao jurista perceber, detectar nas produções culturais e tradicionais de um povo seu peculiar conteúdo jurídico, de forma a dizer o que é o direito. Nesse ponto a discordância do autor com a escola codificadora francesa: o direito não é produto da vontade do legislador, mas sim a norma socialmente produzida e percebida pelos juristas, é o "direito dos professores". Puchta transforma a lógica orgânica de Savigny em uma

${ }^{96}$ SAVIGNY, 1858, p. 7. 
dogmática estática, dando centralidade à pirâmide ordenada de conceitos jurídicos formais. No lugar do método histórico originalmente proposto por Savigny, propõe uma "genealogia dos conceitos", recomendando que o estudo jurídico científico busque traçar uma cadeia lógica das ideias, institutos, desta forma atingindo a almejada verdade científica. Ele dá o passo para a formalização completa do direito científico calcado no indivíduo abstrato.

O direito passa a ser concebido dentro dessa tradição privatista, portanto, como um poder, uma faculdade, do indivíduo, bem como como um sistema fechado de ordenações, que se articulam a partir de lógica própria, distinta das demais instâncias sociais, notadamente a economia e a política. Nada mais adequado ao pensamento jurídico moderno do que esta visão.

A visão foi transposta para o direito público por Gerber, que defendia um estudo do direito apartado de considerações históricas externas e, sobretudo, da política. $\mathrm{O}$ esforço segue sendo o de escamotear o nexo concreto das ideias com a realidade social, sua natureza de complemento ideal das condições materiais, e instituía um rígido dualismo entre ideia e ciência "real" das coisas ${ }^{97}$.

Laband aprofundou o uso do método exclusivamente jurídico, que lhe permitiu sustentar uma ideia bastante abstrata de Estado, sustentado na Herrschaft, ou seja, no seu poder de dominação, doutrina que vai influenciar os franceses. "A simples transposição de princípios e de regras de direito civil às relações de direito público certamente não é útil para ter um conhecimento exato destas últimas: esta maneira 'civilista' de tratar o direito público não é conveniente. Mas frequentemente a condenação do método 'civilista' esconde a repugnância ao tratamento do direito público de uma maneira 'jurídica', e, buscando apartar os princípios de direito privado, rejeita-se verdadeiramente os princípios de Direito, para os substituí-los por considerações filosóficas e políticas. Sem dúvida, na verdade, a ciência do direito privado atingiu um tal avanço sobre todas as outras disciplinas do Direito que estas não devem recear seguir a escola da primeira, melhor desenvolvida; no estado atual da literatura de direito público e em particular de direito público do Império, há bem menos a temer em vê-la inspirada em demasia no direito civil, que em vê-la perder todo seu caráter jurídico e cair ao nível da literatura política de jornal" ${ }^{98}$.

\footnotetext{
${ }^{97}$ WILHELM, 1980, p. 129.

${ }^{98}$ LABAND, 1900, pp. 4/5.
} 
Jellinek avança mais um passo na concepção de um direito autônomo, ao formular sua teoria do Estado. Não é inconsciente das diversas possibilidades de conceituar e descrever o Estado moderno. Apenas entende que uma descrição exclusivamente jurídica deve abstrair todo e qualquer elemento que lhe seja externo, que não pertence à dogmática e à formalidade interna ao direito enquanto sistema hermético de normas e princípios. Assume a ciência jurídica como uma ciência de abstrações: "Os conceitos jurídicos não respondem a nenhuma substância concreta, nenhum objeto material no mundo exterior corresponde a eles. (...) O mundo jurídico é um mundo de ideias"99.

Em seu sistema pretensamente capaz de ter validade universal, daí ser uma "teoria geral”, o Estado aparece como unidade jurídica suprema, personificado e que, à semelhança dos indivíduos, é capaz de atos de vontade. Esses atos de vontade. Contudo, sua vontade é qualificada pelo poder de dominação irresistível e soberano, juridicamente qualificado (Herrschaft). Estado é, assim, “a corporação formada por um povo, dotada de um poder de mando originário e assentada em um determinado território, ou (...) corporação territorial dotada de um poder de mando originário" ${ }^{\prime 100}$.

$\mathrm{Na}$ Alemanha, portanto, o movimento era de reforçar a separação do direito das demais instâncias sociais, dotá-lo de método próprio e fundá-lo sobre conceitos abstratos de homem, Estado e vontade, o que poderia ser conveniente e útil para um Estado que se formava como um império. " $O$ direito, o qual surgia junto com as relações reais $e$ existia somente como parte integrante dessas relações, se separava depois progressivamente das relações econômico-políticas, tornava-se 'abstrato' e conquistava uma existência autônoma em instituições e princípios exatamente determinados, de forma que ao final desse processo de objetivação, o direito mesmo dominava as relações reais e finalmente não era mais expressão dessas relações, essas é que eram expressões do direito" ${ }^{101}$. Mas a França, e sua recém fundada República, não poderia seguir cegamente essa direção.

Às portas do século XX, portanto, a doutrina jurídica francesa deparavase com o desafio de constituir o direito como ciência, e teria que fazê-lo de acordo com a tradição nacional. Isso significava, contudo, enterrar definitivamente a Escola da Exegese, com sua supervalorização da busca pela vontade do legislador, incorporar criticamente o

\footnotetext{
99 JELLINEK, 1958, p. 86.

${ }^{100}$ JELLINEK, 1958, p. 147.

${ }^{101}$ WILHELM, 1980, p. 89.
} 
que se vinha produzindo na Alemanha, mas, sobretudo, responder a uma realidade social em constante mutação, na consolidação de uma República liberal e democrática.

\subsection{1 "Juristas inquietos":} a belle époque como transformação do pensamento jurídico

Na França, a proclamação da República e o novo cenário social nacional e internacional representaram novas demandas para o direito. Por um lado, ele devia fazer face à tendência cientificista, afirmando-se ciência autônoma, distinta das demais instâncias sociais. Por outro lado, não poderia fazê-lo ignorando a realidade histórica, especialmente as novas demandas sociais. A aderência teórica e prática de um direito calcado no homem abstrato e em seus direitos subjetivos, que visavam à preservação de sua liberdade, seria progressivamente questionada. Ainda, não seria mais útil à estabilização do regime republicano insistir na já decadente crença na onipotência do legislador, que agora era um Parlamento de feições completamente transformadas pelo sufrágio universal. Qual direito, qual método jurídico, qual ideia de Estado e qual democracia responderiam melhor aos desafios presentes? A dificuldade na formulação de uma resposta única e consensual marcou os inquietos anos iniciais da Terceira República.

Com a instituição do sufrágio universal (masculino) e a transferência efetiva de decisão para a maioria da população, passou a ser preciso pensar um direito que tivesse como sujeito esse indivíduo concreto, socialmente inserido e coletivamente organizado, um homem que possui demandas da vida prática, que se traduzem na necessidade de garantias de condições específicas - como aquelas relacionadas ao mundo do trabalho - e de prestações do Estado, como os serviços públicos.

A nova república estava em busca de uma filosofia, que levasse em conta a irrupção do social, as consequências da revolução industrial, o significativo movimento de reformas legislativas, a tensão entre holismo e individualismo, as querelas religiosas e o reposicionamento do Estado como motor do progresso ${ }^{102}$. Um direito que garantisse a estabilidade da nova ordem, e que, portanto, absorvesse a política e a função de legitimação, seria um desafio colocado aos juristas durante boa parte da República. A letra fria do texto constitucional não é capaz de responder ao desafio, era preciso uma teoria que legitimasse o regime sem subversão da ordem.

${ }^{102}$ HAKIM e MELLERAY, 2009, p. 3. 
"O direito constitucional do começo da Terceira República era totalmente distinto. A transição política em direção a um regime republicano e democrático não se faz em um dia ou no dia seguinte, apesar das petições de princípio ou das declarações solenes de frações republicanas durante os anos 1870. Mesmo que tenham vocação a legitimar o novo regime, os textos constitucionais votados não levaram a cabo o período transitório. Na realidade, um longo período de incerteza constitucional se abre durante os anos 1870, que não será finalizado senão com a Primeira Guerra Mundial. A aventura boulangista, o affaire Dreyfus, as condutas sindicais no começo do século, a separação da Igreja e do Estado etc, são ocasiões de mobilização a favor ou contra o regime constitucional" ${ }^{\prime 103}$. É um período de instabilidade, e o direito é chamado a cumprir um papel central na tentativa de conciliação em torno da nova ordem.

Era preciso garantir a estabilização do próprio regime, neutralizando a forma republicana e garantindo a continuidade da ordem e do arranjo social entre novas e velhas elites. A cátedra de direito constitucional, recentemente reorganizada, surge como recurso político voltado à essa finalidade. Desde 1852, o direito constitucional não fazia parte, oficialmente, das matérias nas faculdades de direito do Estado ${ }^{104}$, e a comparação com a Prússia, após a derrota francesa, apenas evidenciava a deficiência do país na formação de teóricos capacitados para legitimar novo Estado republicano. É assim que o direito é chamado a se misturar à política, apesar das resistências dentro das faculdades justamente em razão desse caráter político do direito constitucional ${ }^{105}$.

Em novembro de 1871, é inaugurado o doutorado em direito constitucional na Faculdade de Direito de Paris, mas apenas em 24 de julho de 1889 é promulgado um decreto autorizando a reforma dos cursos de direito e criando cursos semestrais de elementos de direito constitucional ${ }^{106}$. Assim, nos anos 1880-1890, a missão dos professores de direito constitucional, confrontados com as enxutas leis constitucionais de 1875 , era a de inventar não apenas uma disciplina, mas também o "papel social" do

\footnotetext{
${ }^{103}$ SACRISTE, 2011, p. 384.

${ }^{104}$ SACRISTE, 2002, p. 80.

105 "Dès lors, on peut comprendre que les professeurs de droit civil s'opposent à l'instauration, au sein de leurs enceintes neutralisées, d'un cours si fortement lié aux intérêts proprement politiques que ce cours de droit constitutionnel. Non seulement ce dernier leur apparaît en effet comme susceptible de contester leur impartialité, au principe même de leur discours de justifications professionnelle, mais en outre il apparaît également comme susceptible de remettre en cause la domination qu'ils exercent au sein du corps professoral. À la neutralité politique constitutive du rôle professoral, le droit constitutionnel, une fois défini par les fractions républicaines au pouvoir, oppose ouvertement un objet explicitement politisé", in SACRISTE, 2002, p. 74.

${ }^{106}$ SACRISTE, 2011, p. 389.
} 
professor de direito constitucional ${ }^{107}$. Já em 1895, uma reforma nos cursos de doutorado em direito introduz a divisão reconhece a importância crescente do direito público e da economia política, e em 1896 o concurso de agregação ${ }^{108}$ em direito é dividido em direito privado e criminal, direito público, história do direito e ciências econômicas. O direito absorve, para dentro da disciplina, especificamente no crescente ramo do direito público, os desafios da política e da nova República, buscando dar a eles uma solução estabilizadora e aparentemente neutra, tipicamente jurídica.

Mas qual doutrina daria conta de explicar o direito e uma Constituição em uma sociedade marcada por tensões sociais que assumem o centro da arena política por meio da democracia e do sufrágio universal? Que tipo de teoria seria capaz de, ao mesmo tempo, legitimar a República e absorver os conflitos garantindo a manutenção da ordem e da dominação das novas e velhas elites? A resposta não foi uma doutrina homogênea e monolítica, como muitas vezes tende a se autocompreender a doutrina jurídica. Pelo contrário.

A acelerada marcha da modernidade e a interpenetração recente entre direito e política refletiram nos juristas um pensamento de inquietude, como afirma Julien Bonnecase $^{109}$ utilizando-se da expressão de Daniel-Rops ${ }^{110}$, notabilizada também por Paul Cuche $^{111}$. Trata-se da "geração de juristas inquietos". Depois de um século XIX em que se tinha uma concepção estática do direito, equivalendo à lei escrita, o início do século XX assistiu à inquietude dos juristas diante das novas questões sociais e do desafio de estabilização da ordem, o que colocava em xeque a perspectiva liberal, individual e pretensamente neutra de abordagem do direito e da sociedade. Era preciso buscar uma nova forma de compreender o direito, condizente com o novo tempo, que desse conta de responder às aspirações ao mesmo tempo individuais e sociais.

Ainda, o catolicismo social penetrava os meios jurídicos por meio da proliferação não só de seus adeptos, mas também de congressos, publicações e núcleos nas

\footnotetext{
${ }^{107}$ FOULQUIER e SACRISTE, 2010, p. 15.

${ }^{108}$ Concurso nacional de agregação do ensino superior é a seleção pública oficial de professores para todas as universidades francesas.

109 BONNECASE, 1933, p. 88

110 "La malaise essentiel vient sans aucun doute du fait que tout homme, par le sentiment qu'il a de son unité individuelle, participe à son insu à une notion de totalité et universalité, en dépit de toutes les analyses, mais se sent incapable d'y accéder. D'où les deux formes actuelles de l'inquiétude: l'une, qui tend à unifier l'homme en le haussant jusqu'à la signification qu'il s'accorde à lui-même et qu'il assigne à son destin, l'autre, qui tend à le déchirer, à multiplier ses postulations, et qui, dans la machine, trouve un moyen commode d'augmenter la force de chacun des pouvoirs autonomes qu'elle a disséqués", DANIEL-ROPS, apud BONNECASE, 1933, p. 94.

${ }^{111}$ Cf. CUCHE, 1929.
} 
faculdades de direito. A instabilidade social e a necessidade de fornecer novas soluções, condizentes com a prática integradora católica, especialmente depois da Encíclica Rerum Novarum, conduziam as críticas ao individualismo jurídico e a defesa de um direito social. É nesse sentido que Charmont fala em "socialização do direito": "Socializar o direito é torná-lo mais compreensivo, mais amplo que era antes, estendê-lo do rico ao pobre, do possuidor ao assalariado - do homem à mulher, - do pai ao filho, ou seja, é admiti-lo em beneficio de todos os membros da sociedade"112.

Mas como responder ao desafio de socialização dentro da moldura liberal-individualista clássica? Os juristas não podiam fazê-lo sem colocar em questão o pensamento anterior. E, mais do que isso, não eram mais capazes de enfrentar as novas questões com uma resposta que fosse unânime e uniforme dentro da doutrina. "As divisões se acusam gravemente em uma sociedade francesa que enfrenta sucessivamente a Comuna, o nascimento da República, o boulangisme, o affair Dreyfus, a separação da igreja e do Estado... Nessa época, o liberalismo muda de alma e de significado; colocado na defensiva, ele enrijece-se e torna-se o alvo ideal para aqueles que vão pretender descobri-lo no direito civil do século XIX ${ }^{\text {"113. }}$.

Bonnecase justifica o diagnóstico de geração de juristas inquietos afirmando: "Desde cerca de um século, as gerações que os precederam admitiram sem discussão que toda ordem jurídica tinha em sua base direitos absolutos e imprescritíveis do indivíduo, que a harmonia social era realizada quando todos esses direitos pudessem florescer sem confrontar com aqueles do vizinho e que enfim o Direito - com D maiúsculo - não tinha outra missão senão assegurar sua pacífica coexistência. Mas então no final do século passado e no começo desse se revela uma inegável discordância entre essas concepções e as realidades às quais elas devem se adaptar, discordância produzida pela prodigiosa intensificação da solidariedade social sob todas as suas formas, politica, econômica e moral... Feitas tais constatações, os juristas de quem eu falo creram que deviam se colocar em busca de uma concepção da ordem jurídica que respondesse às necessidades e às aspirações de seu tempo" $" 114$. O autor fala inclusive em "novo mal do século", que orientou as respostas dos juristas, chamadas por ele de "romantismo jurídico", uma das saídas para superar a crise do individualismo.

112 CHARMONT, 1903, p. 380.

113 ATIAS, 1991, p. 246.

114 BONNECASE, 1933, p. 89. 
Partindo de diagnóstico semelhante, chamando o período de "tempo das perturbações", Arnaud ${ }^{115}$ esquematiza de forma panorâmica as principais questões que estavam postas aos juristas da época, sistematização da qual nos valeremos a seguir.

Em primeiro lugar, os princípios fundamentais do Código Napoleão estavam postos em questão, por meio da contestação do individualismo, do voluntarismo, do subjetivismo e do moralismo jansenista.

O individualismo e o voluntarismo estavam postos em questão, a uma, pela degradação dos papéis sociais estabelecidos no Código, por exemplo, com a revisão do estatuto da mulher - leis sobre capacidade da mulher casada (1895), permissão de exercer a advocacia (1900) e regulamentando seu livre salário (1907). A duas, pela tomada em consideração das aspirações coletivas, do ponto de vista legal, com o desenvolvimento das liberdades coletivas - por exemplo, com a emblemática autorização da liberdade de associação, em 1881 - e com a liberação dos sindicatos, pela lei da liberdade sindical de 1884. E, do ponto de vista doutrinário, com as teorias solidaristas e socialistas, “conscientes da defasagem notória existente entre o individualismo legal e as aspirações coletivas desenvolvidas pelo progresso e pela concentração da industrialização"116, e com o "desapontamento" da autonomia da vontade, quando se passa a vincular o direito não pode mais à vontade do homem abstrato, mas sim a um ideal de justiça socialmente construído.

A contestação do subjetivismo vem com a introdução da ideia de pessoa moral (pessoa jurídica) no direito francês, por uma decisão de 1891, e sobretudo pela teoria de Léon Michoud, consolidada em sua obra La Théorie de la Personnalité Morale, de 1932. Aparece, ainda, com a deterioração da concepção de propriedade como direito subjetivo quase ilimitado e com a introdução da noção de função social da propriedade. Por fim, o subjetivismo é posto em causa com a transformação na responsabilidade, com deslocamentos progressivos na direção de uma teoria da responsabilidade objetiva.

O moralismo jansenista é contestado a partir da transformação nos costumes, por exemplo com a legislação que reestabelece o divórcio (1884), bem como pela abertura do método de julgamento das lides judiciais representada pelo emblemático caso do "bon juge Magnaud" 117 , que julgava por equidade, a partir de valores independentes do direito positivo, tidos como a ele superiores, muitas vezes contra o texto

115 ARNAUD, 1975, pp. 73 e ss.

116 ARNAUD,1975, p. 86.

${ }^{117}$ Sobre o assunto, ver os já mencionados WEYL e PICARD WEYL, 1975, ARNAUD, 1975. 
expresso da lei. Em contraste, o diagnóstico de uma "crise moral" associada aos "tempos modernos" orienta uma política repressiva, uma "cruzada moralista", reforçada pelo adensamento do catolicismo, com o combate ao absinto, à pornografia, à prostituição etc, personificados pelo senador René Berenger ${ }^{118}$.

Em segundo lugar, as concepções fundamentais da Exegese estavam, também elas, em questão. O Código Civil já não mais funciona como legislação central, aparecendo em paralelo outras disciplinas como o direito comercial, o direito penal, e, no caso específico desse capítulo, o direito público e os primórdios da ciência política. Os antigos métodos também são contestados, com a abertura para o reconhecimento de outras fontes do direito que não o texto de lei e com a preocupação em dotar o direito de feição científica, empreitada especialmente cara a François Gény ${ }^{119}$.

Do ponto de vista da forma de governo, a clássica concepção liberal de soberania nacional incarnada pelo Parlamento, que se legitimava pelo suposto poder de expressão da vontade geral, começava a ser relativizada, especialmente diante da problemática posta pela ampliação democrática e pelos debates sobre novas formas de representação da vontade popular. "Em teoria, é o princípio representativo que prevalece, segundo o qual os eleitos são os representantes da nação e não os mandatários dos eleitores. Na prática, o povo não se contenta em ser o titular nominal da soberania. Ele queria, cada vez mais, retomar sua autoridade vis-à-vis à de seus representantes; em outros termos, ele queria ser não o soberano de um dia, mas o titular real da soberania. Quer se quisesse ou não, o crescimento da vontade popular sobre as orientações da vida política se faz sempre mais sensível. Nessas condições, defender o regime representativo terminaria por significar preferir a preservação de uma moldura puramente formal às evoluções concretas da sociedade" ${ }^{, 120}$.

Parte dos reposicionamentos e inquietudes deve ser tributada à influência do catolicismo, significativamente forte nos meios jurídicos. Como nota Audren, "o que mais chama a atenção é que os artesão mais convincentes da renovação da ciência jurídica na virada do século XX (de Saleilles a Gény, passando por Charmont, Demogue, Hauriou, Michoud, Deslandres ou ainda Cuche) pertencem a essa comunidade de

\footnotetext{
${ }_{118}$ Para uma detalhada análise desse movimento, cf. STORA-LAMARRE, 2005, pp. 27 e ss.

${ }^{119}$ Cf. GÉNY, 1995 (1889), GÉNY, 1914.

120 PINON, 2003, p. 53.
} 
católicos ativos e que assim se reivindicam. Esse laço entre engajamento católico e renovação metodológica é por demais sistemático para ser ignorado" ${ }^{\prime 21}$.

Audren identifica nos debates em torno da exegese bíblica um horizonte comum a vários juristas católicos, presente na renovação metodológica que marcou a virada do século. Ainda que comprometidos com a liberdade científica e não defendam uma ciência jurídica católica, propriamente, tais juristas estavam pondo em prática a tentativa de construção de uma nova ciência jurídica não calcada sobre o individualismo abstrato, mas sim sobre a realidade social, e para isso precisavam de um novo método ${ }^{122}$. "Nas mãos dos juristas católicos, o desvio pelo método de observação permite sem nenhuma dúvida mascarar, atrás das formas da neutralidade científica, jogos políticos muito explícitos. Mas, opondo a observação ao método a priori, eles esperam igualmente sair de uma guerra de princípios (princípios republicanos contra princípios católicos) em benefício da força demonstrativa da 'realidade social' que eles estimam favorável às suas análises. O método geométrico deve recuar diante do método de observação" ${ }^{\text {123 }}$. Resta saber qual observação e qual recurso à história deverá caracterizar o novo método.

De forma geral, portanto, o início do século XX assiste a um expressivo desenvolvimento da doutrina francesa de forma geral, e à fundação de uma doutrina constitucionalista consistente, ainda que heterogênea, pensada como fundamento de legitimidade do novo regime e como garantia da ordem e da estabilidade. Preocupada com oferecer respostas às modernas questões sociais e políticas, mas também em constituir-se como um saber científico, a doutrina aparece não como uma unidade coesa, mas como uma multiplicidade de contribuições, de matizes teóricos e filiações práticas, inclusive religiosas, sensivelmente distintas. "Esse momento doutrinal pode assim ser compreendido como o da aparição da fisionomia própria à doutrina francesa, doutrina amplamente professoral, doutrina preocupada em operar a sistematização do direito, mas igualmente doutrina dividida entre sua intimidade com o Palácio [com a política] e com seu desejo de ciência, entre seu desejo de perpetuar sua autonomia tradicional exercida principalmente no mundo judiciário e administrativo e sua busca por legitimidade positivista" ${ }^{2124}$.

Assim se constitui a doutrina constitucional francesa clássica, que busca conciliar preocupações teórico-filosóficas de fundo a questões pragmáticas, de forma a fundar um novo pensamento constitucional para uma nova democracia. São expoentes

\footnotetext{
${ }^{121}$ AUDREN, 2008, p. 235.

122 AUDREN, 2008, p. 267.

${ }^{123}$ AUDREN, 2008, pp. 267/268.

${ }^{124}$ HAKIM e MELLERAY, 2009, p. 6.
} 
dessa geração Adhémar Esmein, Léon Duguit, Maurice Hauriou, Léon Michoud e mesmo Carré de Malberg, mesmo que sua produção tenha se concentrado no entre-guerras.

\subsubsection{Questões e desafios para a doutrina do entre-guerras}

Assim a caricatura do jurista concebida por Jules Romains em 1927 e apresentada em sua novela descritiva do cotidiano parisiense da época, Les hommes de bonne volonté: "Ao direito, para fazer o auditório estremecer com prazer, é preciso criticar sem receios a República, o Parlamento, o sufrágio universal, insinuar, por exemplo, a propósito de uma lei recente, que ela é forçosamente mal feita, já que os deputados são forçosamente uns imbecis..." ${ }^{125}$.

O entre-guerras é palco do acirramento dos conflitos sociais, como visto. De um lado, temos a organização dos partidos de esquerda, que conseguem compor maiorias para comandar o governo, além de intervirem crescentemente no debate público e ganharem adesão das massas, com manifestações, greves e outras demonstrações, pleiteando que a democracia política se estenda também para a economia. O pleito de democracia industrial, as novas demandas reforçadas pelas experiências externas como a República de Weimar e o bolchevismo, o manejo das instituições da democracia liberal para ganhar espaço e poder no Parlamento, tudo isso se apresentava como um passo complicador da "questão social" de antes da guerra. Por outro lado, aparecem com força no cenário as ligas de direita, reforçadas pelo verniz moderno protofascista, que se valem do cenário para disseminar o medo da ameaça de radicalização e subversão da ordem.

Antes da Primeira Guerra Mundial, o desafio era formular uma teoria constitucional consistente, apta a legitimar a República e a democracia liberal em bases condizentes com os dilemas da sociedade francesa. Por isso René Capitant, ao escrever sobre Carré de Malberg, afirma que o papel da primeira geração seria o de inventar o direito constitucional ${ }^{126}$. Não à toa fazem parte desses debates fundadores acentuadas

\footnotetext{
125 Apud WALINE, 1977.

${ }^{126}$ Sobre o papel e as referências dos fundadores do direito constitucional, tratando especificamente de Carré de Malberg, escreve Capitant: "Il fut, en effet, un des pionniers, un des fondateurs du droit constitutionnel en France. Il aimait à rappeler avec un sourire, devant de jeunes collègues fraîchement émoulus du concours et dont la tâche se trouve aujourd'hui singulièrement facilitée par l'apport de la génération précédente, quelles difficultés lui avaient réservées ses premières exploitations. Qui trouvait-il alors pour le guider? De grands noms, certes, de philosophes, de politiques, d'historiens, de poètes ou de romanciers : Montesquieu, Rousseau, Sieyès, Chateaubriand, Benjamin Constant, Lamartine ou Victor Hugo, qui ont décrit la séparation des pouvoirs, défini ou exalté la démocratie, analysé le régime parlementaire, mais rien qui
} 
divergências sobre método e sobre os pilares da teoria do Estado e da teoria jurídica, como a própria percepção sobre o Estado e o direito. Os constitucionalistas clássicos se indagam sobre a maneira de construir uma ciência jurídica moderna, que incorpore ao mesmo tempo a democracia e a "questão social" dentro de uma teoria coesa, que pouco se distingue das preocupações típicas das ciências políticas.

No entre-guerras, a realidade é outra, e consequentemente também os dilemas são outros. Os juristas vão progressivamente abandonando a pretensão de teorizar a totalidade do político, enxergando um cenário em sensível mutação. O Parlamento, locus de crescentes disputas e tensões sociais, perde sua relevância como centro da soberania nacional, papel tradicionalmente a ele atribuído pelo liberalismo clássico. Há um crescente clamor por centralização do comando, na medida em que as sucessivas dificuldades econômicas exigem cada vez mais a ação concertada, técnica e célere do Estado, que passa a intervir na economia. A lei não mais é concebida de forma teórica como expressão da vontade geral, mas passa a ser encarada de forma mais pragmática, como instrumento de governo.

O constitucionalismo liberal, como formulado para servir de alicerce para a nova República, está sob fogo cruzado, e é mais frequente se falar em crise do que em consolidação ou plena realização. Temas como Estado, nação, soberania, indivíduo e sociedade passam a ficar de fora da dogmática jurídica, que preocupa-se em descrever o direito e as instituições de forma muito mais pragmática.

Fora da França, o novo cenário social e político está na origem de um novo constitucionalismo, de feições distintas daquele que marca a tradição liberal clássica. Sobre ele, escreve Bercovici: "Neste contexto de ebulição social, a manifestação do poder constituinte não vai poder ser bloqueada e o resultado será uma alteração profunda nas estruturas constitucionais e estatais. As constituições do século XX não representam mais a composição pacífica do que já existe, mas lidam com conteúdos políticos e com a legitimidade, em um processo contínuo de busca de realização de seus conteúdos, de compromisso aberto de renovação democrática. Não há mais constituições monolíticas, homogêneas, mas sínteses de conteúdos concorrentes dentro do quadro de um compromisso deliberadamente pluralista, como em Weimar. A constituição é vista como um projeto que se expande para todas as relações sociais. O conflito é incorporado aos textos constitucionais, que não representam mais apenas as concepções da classe privé," in CAPITANT, 1936, p. 4. 
dominante, pelo contrário, tornam-se um espaço onde ocorre a disputa político-jurídica. A discussão sobre soberania e sobre poder constituinte retorna com força" ${ }^{\text {"27 }}$.

$\mathrm{Na}$ França, pelo contrário, ainda que proliferem propostas de reforma institucional e inclusive de revisão constitucional, não é a Constituição formal que se encarrega de fazer frente às novas demandas sociais. É a doutrina constitucional quem tenta absorvê-las a partir de respostas modernas, admitindo o direito ora como instrumento de resistência, ora como fator de movimento. Temos como hipótese que o entre-guerras é palco justamente da admissão da doutrina constitucionalista pragmática da tarefa de absorção da política, permitindo que o direito funcionasse como fator de movimento, seja para a efetiva transformação (para os juristas comprometidos com o pensamento de esquerda), seja de forma a preservar o arranjo de forças sociais. Mudar para permanecer como está.

${ }^{127}$ BERCOVICI, 2008(a), pp. 294/295. 


\title{
CApítulo 2
}

\section{JURISTAS CLÁSSICOS: \\ SITUANDO O PENSAMENTO CONSTITUCIONAL FRANCÊS NO FINAL DA "ERA DE OURO"}

\begin{abstract}
2.1 Léon Duguit; 2.1.1 Método histórico-objetivo; 2.1.2 Sociedade, indivíduo e solidariedade; 2.1.3 Regra de conduta e direito objetivo; 2.1.4 Estado, legitimidade e democracia; 2.2 Maurice Hauriou; 2.2.1 Método institucionalista; 2.2.2 Sociedade, indivíduo e instituição; 2.2.3 Regra de direito, justiça e ordem social; 2.2.4 Estado, poder e democracia; 2.3 Raymond Carré de Malberg; 2.3.1 Método positivista; 2.3.2 Direito positivo e tarefa do jurista; 2.3.3 Estado, soberania e Constituição; 2.3.4 Soberania popular e democracia: um pensamento de transição; 2.4 Horizonte teórico deixado pelos clássicos: substancialização da ordem social $v s$. realização plena da democracia popular
\end{abstract}

As transformações sociais e políticas descritas no capítulo anterior colocam para a ciência jurídica francesa dos anos 1920 um desafio particular: como elaborar uma solução jurídica adequada e moderna, diante da insuficiências da compreensão liberal clássica, dotando o direito, ao mesmo tempo, de autonomia e unidade científica, e de capacidade de responder às novas demandas sociais?

“O sufrágio universal se tornou uma conquista que ninguém mais poderia sonhar seriamente em recolocar em causa, qualquer que seja a profundidade das dúvidas e das reticências que subsistam para muitos. Como aceitar, então, esse poder social ao mesmo tempo prevenindo seu possível antiliberalismo? Como de uma 'força brutal' fazer uma 'força regrada', como transformar uma 'ferramenta de revolução' em um 'instrumento politico', para retomar os termos de um Édouard Laboulaye? Essas são as questões de toda uma geração. Uma página decisiva é virada com ela"

A resposta do direito constitucional clássico, na acepção de Beaud ${ }^{2}$, tinha sido, desde antes da guerra, incorporar ao direito, sempre no campo teórico, as preocupações políticas, buscando refletir em termos jurídicos acerca da complexidade do Estado, da sociedade e do direito, e fornecer respostas condizentes com uma doutrina

${ }^{2}$ Cf. BEAUD, 2000. 
consistente. De acordo com o autor, há dois traços comuns que unem as grandes teorias do direito constitucional clássico. Por um lado, elas têm um objeto comum, uma ambição, que é fundar uma ciência do direito público, a partir da pretensão de cientificidade já mais consolidada no campo do direito privado, o que passa "por uma reivindicação não somente da juridicidade do direito público, mas também de uma especificidade desse direito, de sua dogmática jurídica e de sua metodologia"3. Por outro lado, apesar de reivindicarem seu pertencimento ao campo do direito, não podem deixar de concebem o direito público a partir de sua relação com o Estado, como um direito político, portanto.

Como ilustração desse direito constitucional clássico, escolhemos para esse capítulo três autores centrais do pensamento constitucional e de teoria do Estado do chamado "período de ouro", a "belle époque" da Terceira República: Léon Duguit, Maurice Hauriou e Raymond Carré de Malberg ${ }^{4}$. A preocupação comum a todos era construir uma reflexão teórica dentro do direito público que desse conta de explicar o Estado, sua legitimidade, sua fundação e sua limitação pelo direito. Para tanto, debruçaram-se sobre temas posteriormente alijados do campo de estudo tipicamente jurídico, temas esses que passaram depois a pertencer à ciência política, como a relação entre indivíduo e sociedade, a democracia e a legitimidade do poder. Chegam a ser chamados de "juristas teóricos", justamente por buscarem refletir de forma abrangente sobre esses elementos da vida política, inserindo-os dentro de uma reflexão propriamente jurídica, com pretensões de cientificidade.

Sobre a centralidade dos três juristas, escreve René Capitant em 1937: “ $A$ ciência do direito público foi dominada na França, desde o começo do século, por três homens, cujos métodos e doutrinas eram muito distintos, mas de quem a influência foi igualmente profunda e que acabaram de falecer sucessivamente, com poucos anos de intervalo: Léon Duguit, Maurice Hauriou, Raymond Carré de Malberg"”.

São autores que possuem extensa e complexa obra teórica, e não é a intenção desse trabalho resumi-la em algumas páginas. O que se pretende é ressaltar, por um lado, as diferenças de abordagem de cada autor em relação ao direito, ao Estado e à democracia, resultando em respostas bastante diversas à irrupção das reflexões sociais no direito, e por outro a semelhança na concepção teórica acerca do objeto do direito e na

\footnotetext{
${ }^{3}$ BEAUD, 2000, p. 89.

${ }^{4}$ Sobre a relevância dos autores como expoentes do direito constitucional no início do século XX, na França, cf. CAPITANT, 1937, BEAUD, 1997, WALINE, 1977.

5 Cf. PINON, 2003.

${ }^{6}$ CAPITANT, 1937, p.81.
} 
qualidade de problema a ser enfrentado. O que está por trás das distintas teorias é um novo Estado, e uma nova relação política, que se estabelece com a crise do liberalismosubjetivista como solução de conjunto, e os desafios que a democracia de massas coloca ao parlamentarismo. Mas o que aparece como resposta são reflexões que se pretendem teorias gerais e coesas, que partem de premissas bastante definidas sobre Estado, direito e democracia.

Escolhemos analisar, mais especificamente, apenas a produção de Duguit, Hauriou e Carré de Malberg formulada após a Primeira Guerra Mundial, ou seja, sua obra mais madura e, diríamos, menos difundida e menos representativa do núcleo central de seu pensamento, como ficou conhecido, muito embora carreguem em si os pressupostos lançados pela obra anterior. Contudo, como visto, o entre-guerras é o momento de radicalização das posições políticas na França, bem como de surgimento de novas constituições em diversos países da Europa. A realidade estava mudando, e os autores reagiram à mudança, mantendo, contudo, a proposta de abordagem do direito constitucional que chamamos clássica. É isso que se pretende apresentar a seguir.

\subsection{LÉON DUGUIT}

Léon Duguit (1859-1928) ${ }^{7}$ termina seu doutorado na Faculdade de Direito de Bordeaux (conforme a prática da época, com uma tese em direito romano - Du principe de la théorie des risques dans les stipulations - e outra em direito francês - Les conflits de législation relatifs à la forme des actes civis) em 1882, ano em que é aprovado no exame de agregação - no mesmo concurso de Maurice Hauriou, curiosamente. Após um período em Caen, torna-se professor na Faculdade de Direito de Bordeaux em 1886, onde conhece Émile Durkheim, cujas ideias irão influenciar decisivamente sua proposta metodológica e sua visão sobre o direito e sobre o Estado. Sua participação política é limitada, participando apenas como conselheiro local em Bordeaux (1908-1912). Dedicase sobretudo à carreira acadêmica, não apenas como reitor da Universidade de Bordeaux, função que exerce de 1919 até a sua morte, mas também internacionalmente, proferindo conferências influentes em diversas cidades (Buenos Aires, Nova Iorque, Santiago, Madrid, entre outros). A carreira internacional de Duguit é responsável, inclusive, pela influência que o autor terá no direito público da América Latina, inclusive no Brasil, sendo

\footnotetext{
${ }^{7}$ Sobre a biografia de Duguit, vide PISIER-KOUCHNER, 1976, PACTEAU, 2010, PINON, 2003.
} 
sua teoria bastante popular no ensino do direito constitucional das primeiras décadas do século XX. Reforçando a difusão internacional de sua obra, o francês participa, por exemplo, da organização da faculdade de direito do Cairo, e fundando em 1927 o Instituto Internacional de Direito Público, junto com Hans Kelsen ${ }^{8}$, com quem já havia criado, um ano antes, a Revue internationale de théorie du droit. Um último aspecto de sua vida pessoal que vale a pena ser mencionado é a perda de um de seus filhos no front da Primeira Guerra Mundial.

Com relação à sua obra, deve-se mencionar a publicação já em 1901 do primeiro volume em que expõe sua abordagem sobre a teoria do Estado e o direito constitucional, L'État, le droit objectif et la loi positive, seguida pela continuação, L'État, les gouvernants et les agentes, em 1903. A primeira edição de seu Traité de Droit Constitutionnel, em cinco volumes, aparece em 1911, e é seguida de uma segunda edição entre 1921 e 1925, e da terceira, em 1927, em que apresenta revisões nos dois primeiros volumes. A seguir, como recorte, trabalharemos sobretudo com a contribuição contida nessa terceira edição, de 1927.

A obra de Léon Duguit, em geral, pode ser compreendida sob duas perspectivas: uma crítica e negativa, que causou grande impacto na ciência jurídica das primeiras décadas do século XX, e outra construtiva e propositiva, cuja relevância não se faz sentir tão grandemente ${ }^{9}$. É dentro dessa chave que o próprio autor faz seu balanço, com a consciência de que sua contribuição teórica foi mais potente na desconstrução ou na crítica às visões normativistas e "metafísicas" do direito do que na proposição de uma nova metodologia teórica de compreensão da disciplina. "É antes de tudo, e eu o reconheço de bom grado, uma obra negativa. Eu me esforcei para contestar as noções tradicionais de direito subjetivo, sujeito de direito e soberania. Já tentei edificar uma construção jurídica sobre a ideia de regra de direito. Talvez esteja iludido, mas persisto em pensar que as objeções que me foram dirigidas não arruinaram completamente minha empreitada.

\footnotetext{
${ }^{8}$ Sobre a relação entre Léon Duguit e Hans Kelsen, cf. HERRERA, 1997.

9 A divisão é proposta por Pinon: "Bâtisseur, Léon Duguit le fut sans aucun doute, d'une pensée originale, audacieuse, dotée d'une indéniable force persuasive, régénératrice en un mot. Mais en premier lieu, il dut se résoudre à détruire, à déblayer la littérature juridique des hypothèses, des fictions et autres obstacles métaphysiques qui selon lui l'encombraient. On le présente facilement comme l'incarnation de la révolte contre 'une attitude intellectuelle momifiée' (...). La doctrine duguiste peut donc se dessiner en deux versants, l'un négatif, radicalement critique, où tous les éléments de la puissance étatique y sont pourchassés. L'autre, beaucoup plus constructif, est fondé sur une méthode expérimentale et laisse apparaître une conception objectiviste du droit; limiter les gouvernants par le droit s'y impose comme son impératif scientifique majeur", in PINON, 2010, p. 524.
} 
Espero que tenha a força e o tempo de retomá-la e conduzi-la ao bom fim: esse será o objeto dos dois volumes que seguirão" ${ }^{\prime 10}$.

Do ponto de vista crítico, o jurista teve desde o início como adversárias as teorias subjetivistas que vinham de se consolidar na Alemanha e na França do final do século XIX. Na Alemanha, como visto, o direito se afirma como ciência autônoma em grande medida apoiando-se na noção de um Estado personificado, dotado de um poder de dominação irresistível (Herrschaft), capaz de positivar as regras jurídicas, conforme as construções de Laband, Gerber e Georg Jellinek. O Estado como sujeito de direito, à semelhança do indivíduo, e sua "vontade" é a origem da força obrigatória do direito. Como tal, não possui limitações, a não ser oriundas de si mesmo, a partir da autolimitação. Na França, a legitimidade do direito também está tradicionalmente vinculada à origem das normas, produto do poder de dominação decorrente da soberania da nação, herança teórica da Revolução Francesa, muito embora a concepção seja muito mais política do que jurídica, quando comparada com a alemã. Esquematicamente, temos que o Estado positiva o direito na medida em que personifica a nação, essa por sua vez consistindo em uma unidade distinta da soma dos indivíduos que a integram, nos termos da contribuição de Rousseau.

Duguit orientou sua produção teórica no sentido da desconstrução de tal abordagem do direito e do Estado, que situa no poder estatal ilimitado e superior ao direito a legitimidade da norma jurídica, assemelhando-o à vontade livre do indivíduo abstrato. $\mathrm{O}$ autor vai direcionar contra tal pensamento uma verdadeira "empreitada de destruição", como afirma Pinon ${ }^{11}$. Contudo, no final de sua obra, a crítica ao esquema normativista e voluntarista vem claramente acompanhada pela tentativa de substancialização do direito, ao recorrer especialmente à noção de justiça e reforçar sua concepção de solidariedade social, o que lhe vale ser chamado de jusnaturalista. Vejamos de que forma a crítica ao modelo liberal-voluntarista clássico orienta uma teoria que compreende o direito como momento de integração social por meio da realização da solidariedade, não sem alertas para o perigo da radicalização política, e, em especial, sindical.

${ }^{10}$ DUGUIT, 1927, p. XVII.

${ }^{11}$ PINON, 2010, p. 524. 


\subsubsection{Método histórico-objetivo}

Para compreender a teoria de Léon Duguit, é importante entender sua metodologia e as críticas dela decorrentes. Sua preocupação metodológica fundava-se na busca por combater o que chamava de conceitos a priori, ideias abstratas e gerais classificadas por ele como metafísicas típicas da teoria jurídica alemã, tais como "unidade" e "pluralidade", ou "soberania" e "direito subjetivo". "O homem teve sempre a necessidade de explicar o visível pelo invisivel, de colocar em segundo plano o fenômeno que ele constata diretamente, atrás de uma entidade invisivel que funciona para ele como suporte a causa eficiente do fenômeno que ele constata" 12 A teoria que ele reputa como "tradicional"13, especialmente alemã, explicaria os fenômenos a partir de suas supostas causas imateriais, tais como Deus, o princípio vital, a alma, e caberia à verdadeira ciência livrar-se do recurso a tal tipo de explicação.

O jurista de Bordeaux busca opor a essa visão o método que chama de histórico-sociológico, também chamado realista, o único segundo ele capaz de responder aos anseios de cientificidade no campo do direito. Procede, portanto, à construção de uma nova base metodológica para o direito, apta a "desmistificá-lo", a partir de uma diferente abordagem sobre a relação entre indivíduo, sociedade e Estado. Não se trata de construir uma teoria sem qualquer conceito abstrato, mas sim de deduzi-los, a posteriori, da observação dos fatos sociais, e de refutar o que ele classifica como metafísica individualista, que não se apoia em experiências concretas, mas em postulados de "essência" ou "substância".

Herdeiro do positivismo metodológico de Auguste Comte, Duguit parte da proposta e da análise sociológica de Émile Durkheim, sobretudo das unidades básicas de sua teoria, os fatos sociais, que "consistem em maneiras de agir, de pensar e de sentir exteriores ao indivíduo, dotadas de um poder de coerção em virtude do qual se lhe impõem" $" 14$.

No prefácio à terceira edição de seu Traité de Droit Constitutionnel (1927), insiste em afirmar seu método, mesmo que já considere não ser uma atitude "na moda da época": "eu continuo pensando que a observação e o raciocínio sobre os dados

\footnotetext{
12 DUGUIT, 1927, p. 18.

${ }^{13}$ Para uma crítica à classificação das teorias alemãs do Estado e francesas da nação como "tradicionais", cf. LE FUR, 1932, p. 188.

${ }^{14}$ DURKHEIM, 2000, p. 48.
} 
de observação são os únicos instrumentos de investigação que o homem possui para chegar a descobrir a pequena parcela de verdade que lhe é dado conhecer. Eu continuo pensando que no domínio do direito não podemos chegar a soluções ao mesmo tempo práticas e justas senão descartando todos os conceitos a priori e toda a vã dialética que lhe pretendemos associar. Eu continuo pensando notadamente que todas as construções que nos esforçamos em edificar em direito público e em direito privado sobre os conceitos a priori de direito subjetivo e de sujeito de direito estão arruinadas. Tenho um profundo respeito pelas crenças religiosas sinceras, admiro os sonhos metafísicos traduzidos em bela linguagem, mas nem umas nem outros fizeram nada para a descoberta da verdade cientifica" $^{15}$. Apesar disso, ao tratarmos do método de Duguit no entre-guerras, é importante mencionar um pequeno deslocamento importante.

Como mencionado, Duguit escreve seu primeiro livro de destaque em 1901, e continua sua produção intelectual até sua morte, em 1928. Em 1927, Duguit publica a terceira edição dos dois primeiros tomos de seu Tratado, dedicados, respectivamente, à regra de direito e ao problema do Estado (tomo I) e à teoria geral do Estado (tomo II). Por certo, a realidade que tem diante de si já não é a mesma que tinha no início do século, considerando a profundidade e a velocidade das transformações sociais que marcaram o período, de que destacamos especialmente a Primeira Guerra Mundial, a ascensão do fascismo e a Revolução Russa.

O autor não ignora tais transformações, escrevendo que "desde 1901, data em que publiquei meu livro L'État, le droit objectif et la loi positive, eventos consideráveis, talvez os maiores da história, se consumaram, trazendo profundas transformações para as vidas dos povos civilizados. Examinando-os friamente, separandose tanto quanto possivel de toda ideia preconceituosa ou tendenciosa, continuo convencido de que tais eventos vieram confirmar as doutrinas que expus há vinte anos" "16. A reedição de seu tratado aparece, assim, em um contexto explícito de disputa de ideias, e Duguit se dedica a reafirmar seu pensamento em contraposição a doutrinas crescentemente estatistas e totalizantes. Por outro lado, adiciona à sua abordagem a preocupação com fundamentos morais no direito, substancializando-o.

As últimas contribuições do autor aparecem quase como um apelo de um certo liberalismo que se vê perdendo espaço em um novo mundo, uma resistência ao surgimento de Estados totalitários: "Diz-se, muito justamente, que a guerra que acaba de 
terminar não foi exatamente o choque entre dois grupos de nações, mas sim o choque entre suas ideias. Ela foi a luta entre a ideia de Estado potência comandante, soberana, contra a ideia de Estado colaboração de membros de um mesmo grupo nacional, trabalhando em conjunto pela realização da justiça e do bem-estar. A ideia do Estado potência, afirmada por todos os publicistas e juristas alemães, se chocou contra a ideia de Estado colaboração, de que a França é iniciadora e que venceu nas margens do Marne e nas ravinas de Verdun. A França saberá, apesar das dificuldades e das vitórias momentâneas da estupidez e do mal, assegurar sua completa realização" ${ }^{17}$.

Adiciona à sua teoria, assim, uma pretensão idealista, que entende conciliável com o positivismo e com o método científico de que é tão cioso. Isso porque não se trataria de um ideal metafísico, mas que estaria na "penetração recíproca e cada dia mais intima e mais profunda das inteligências e dos corações, no trabalho cotidiano de cada indivíduo pelo bem comum, na realização constante do fato social que é simplesmente a interdependência dos indivíduos" ${ }^{\prime 18}$. Apesar de nem sempre de modo explícito, a teoria passa progressivamente a comportar um viés prescritivo, para além da descrição sociológica, que é justamente esse idealismo positivista que autoriza o reconhecimento da existência supostamente objetiva de uma escala de valores sociais. Nesse sentido, a observação dos acontecimentos históricos conduz à reedição revista de sua obra, que assume cada vez mais características de uma petição em defesa de um individualismo que entra em crise, como se verá.

\subsubsection{Sociedade, indivíduo e solidariedade}

Seguindo a análise teórica proposta em Divisão do Trabalho Social, de Durkheim, Duguit compreende o processo de individualização como paralelo ao processo de socialização. $\mathrm{O}$ indivíduo é produto da divisão do trabalho, e quanto mais inserido socialmente na lógica de cooperação e progresso, mais consciente de sua própria individualidade e de sua função na reprodução do todo social e no progresso do coletivo. $\mathrm{O}$ que está na base de sua teoria é também a tentativa de refundação da relação indivíduosociedade, rejeitando a visão dualista e antitética, bem como as teorias subjetivistas.

${ }^{17}$ DUGUIT, 1927, pp. XI/XII.

${ }^{18}$ DUGUIT, 1927, pp. XVIII/XIX. 
Mas não se trata de uma teoria anti-individualista e, portanto, anti-liberal. A existência primordial da sociedade, realidade observável como fato social, está calcada na consciência individual. "O fato irredutivel, que está no começo de todos os fenômenos de que o homem é fato, é o pensamento individual consciente de si mesmo"19. O problema, contudo, das teorias individualistas é buscar entender o conteúdo do pensamento individual, procurando nele o traço fundador da sociedade. "O conteúdo desse pensamento pode ser exclusivamente social. O homem talvez tenha pensado a sociedade antes de pensar a si mesmo; o homem, talvez, não pense senão porque é um ser social; a única realidade objetiva é, talvez, a sociedade. Que importa? O conteúdo da consciência é (...) exclusivamente social; mas a consciência é exclusivamente individual"20.

Segundo Pisier-Kouchner, "na realidade, Duguit pretender criticar mais o subjetivismo do que o individualismo, apesar de muito frequentemente confundir os dois termos. Ele parece admitir uma distinção entre individualismo e liberalismo: é individualista a teoria que toma o indivíduo como fonte do direito (mas trata-se nesse caso do subjetivismo propriamente dito). É liberal a doutrina que toma o indivíduo como finalidade, e nesse sentido, Duguit se vê como anti-individualista, mas liberal"21.

A ação é a manifestação exterior da vontade definida pelo pensamento individual. Impossível determinar o conteúdo dessa vontade, bem como se ela é livre, como querem buscar os subjetivistas e voluntaristas. Certo é que a ação sempre visa a um resultado, cuja realidade objetiva, o conteúdo, também é impossível de análise objetiva $a$ priori, como vontade. "Homens que têm consciência de si mesmos, que pensam, que querem, que agem em vista de um objetivo consciente, está aí a única realidade do mundo social. Toda filosofia, todo direito, toda moral, toda política, toda sociologia, em uma palavra, devem partir disso"22. Mas o indivíduo não existe isolado, enquanto abstração fundadora da sociedade.

A sociedade aparece como fato primário imanente, composta pelos indivíduos e representada em suas consciências não como um ato de escolha livre - já que a existência de tal liberdade absoluta é indemonstrável nas bases científicas e metodológicas do autor - mas como uma associação voltada à finalidade de minimizar o sofrimento, ou de maximizar o bem-estar de todos. "Dizer que o homem é um ser vivente e organizado é dizer que ele morre. Ora, é um fato de observação que o homem morre mais

\footnotetext{
${ }^{19}$ DUGUIT, 1901 (2003), p. 25.

${ }^{20}$ DUGUIT, 1901 (2003), p. 27.

${ }^{21}$ PISIER-KOUCHNER, 1976, p.36.

${ }^{22}$ DUGUIT, 1901 (2003), p. 29.
} 
rápido se fica isolado dos outros homens. De outro lado, o homem sofre; a dor não é uma palavra vã, como queria a filosofia estóica; ele é sim uma realidade, a mais incontestável das realidades. Ora, é ainda um fato de observação que a soma dos sofrimentos humanos é menor quando o homem vive em relação com outros homens (...). De fato o homem sofre, sabe que sofre e quer sofrer menos e, de fato, ele sofre menos se vive em um grupo humano, ${ }^{, 23}$.

Insustentável, portanto, a tese contratualista clássica da existência do homem abstrato e em estado de natureza, que por ato de vontade livre funda a sociedade. Socialização e individualização são fatos socialmente observáveis e processos que caminham paralelos. E mais, são processos que se desenvolvem historicamente como evolução, ordem e progresso. A mediação entre ambos os processos, o laço que une os homens em sociedade, é a solidariedade.

Insustentável, da mesma forma, o direito como plexo de garantias da liberdade do indivíduo, pré-existente à sociedade, ou ainda o direito como positivação de um ato de vontade. Duguit rejeita, assim, a noção de direito subjetivo, calcada na preservação da vontade livre do indivíduo abstrato, conceitos que o autor entende como metafísicos e indemonstráveis a partir de seu método científico.

\subsubsection{Regra de conduta e direito objetivo}

A solidariedade é a regra de conduta, a lei de finalidade (loi de but) que emana da sociedade e é percebida individualmente pelas consciências como relação básica da vida coletiva, expressão máxima da interdependência social. A solidariedade se impõe como regra que autoriza a valoração dos atos a partir da adequação de sua finalidade aos preceitos de integração e de interdependência por ela impostos. Não se trataria, em princípio, de uma lei de causalidade ou de um preceito que se impõe como decorrência de uma emanação superior, uma moralidade universal, mas sim de uma ordenação decorrente da observação da vida coletiva, e das finalidades histórica e concretamente determinadas.

A regra de conduta tem um duplo conteúdo: submissão de todos os atos aos objetivos de solidariedade social e proibição de todos os atos com objetivos contrários à solidariedade social. Assim, nasce da consciência da solidariedade social, variando na sua aplicação (conteúdo), uma vez que os objetivos são imanentes da realidade histórico-

\footnotetext{
${ }^{23}$ DUGUIT, 1901 (2003), p. 31.
} 
cultural $^{24}$, mas imutável na sua origem, seu princípio fundador, que é a noção de solidariedade percebida pelas consciências individuais. A regra de conduta tem conteúdo variável, conforme a evolução da civilização e seu progresso, e conforme o estágio da divisão do trabalho, descartando-se assim a existência de preceitos imutáveis e absolutos, como postulariam as teorias jusracionalistas ou jusnaturalistas. O único elemento imutável é o laço de solidariedade que une os indivíduos em sociedade, e sobre o qual se funda a regra.

A regra de conduta impõe a moral e o direito, indiferenciáveis do ponto de vista lógico. Em uma tentativa de estabelecer a diferença, o jurista entende que a moral determina o valor intrínseco do ato (bom ou mau em si), enquanto que o direito determina valor social, relativo, do ato (conforme ou não à solidariedade social). Dedicará seus últimos estudos à análise justamente dos valores sociais e do "sentimento de justiça" responsáveis pela atribuição do caráter jurídico às normas sociais.

O direito é portanto imanente da vida em sociedade e dos laços de solidariedade por ela impostos. Nesse sentido, é um direito objetivo, e não tem como ponto de partida o sujeito e o plexo de direitos que o circundam de forma a garantir sua autonomia e liberdade, como preceituam as correntes subjetivistas e voluntaristas. O direito é objetivo na medida em que é a regra de conduta que regula as relações de interdependência social. Direito subjetivo, para o autor, é uma categoria que poderia ter valor do ponto de vista da mera técnica jurídica, mas não como explicação teórica do direito e da legitimidade do sistema e do ordenamento.

A legitimidade do direito não reside na sua força obrigatória derivada do poder de coerção titularizado pelo Estado. A coerção é simples decorrência da juridicidade da norma, que é legitimada pela sua finalidade, de acordo com a adequação aos preceitos de solidariedade que unem os homens em sociedade, e, posteriormente adiciona o autor, de acordo com o sentimento de justiça percebido pela massa das consciências individuais.

O Estado não aparece portanto como condição necessária à positivação do direito, que pode existir sem que haja qualquer autoridade constituída, como no caso citado por Duguit das sociedades esquimós, em que não há diferenciação política, mas há regras e repressão, desorganizada, à sua violação. A organização social da sanção em torno da figura da autoridade estatal, com o progresso da civilização, não é a origem do direito, mas simples evolução dos agrupamentos humanos. A força obrigatória das normas já

24 "Le contenu de la règle objective est un contenu de fait, toujours en voie de transformation, varient avec le temps et le pays", in DUGUIT, 1901 (2003), p. 99. 
existia antes disso, e estava ligada ao fato social que une os indivíduos em um coletivo, o princípio superior que é a solidariedade - "o direito é muito menos a obra do legislador do que o produto constante e espontâneo dos fatos" ${ }^{25}$. A força obrigatória deriva da constatação de que há uma intervenção da força social (chamada força material do grupo) para garantir a imposição da sanção.

O direito é anterior e superior ao Estado, e é produto das relações sociais, existindo para limitá-lo. Aparece junto com a aparição dos agrupamentos humanos. "Uma norma social pode ser qualificada de norma jurídica na medida em que a massa dos espíritos admite que a reação social que provoca a sua violação pode ser socialmente organizada pelo emprego da coação ou, em outros termos, quando o emprego da coação contra o violador desta norma não produz reação social. (...) A norma social não é outra coisa senão a lei inerente do fato social. (...) O que nos permite afirmar que em um dado momento uma norma social se transformou em norma jurídica é quando a massa das consciências individuais chegou a compreender que a sanção material desta norma pode ser socialmente organizada" ${ }^{26}$. Restaria, então, o problema de diferenciar as regras jurídicas das demais regras sociais, como a moral.

Para tanto, o autor adicionou, já na segunda edição de seu tratado, uma noção complementar ao fundamento de legitimidade do direito objetivo, para além dos laços de solidariedade, justamente ao afirmar que o que determina esse direito objetivo, as fronteiras entre o jurídico e o antijurídico seria um "sentimento de justiça” percebido pela "massa das consciências individuais". "Para que haja uma regra de direito, é preciso que a sanção de uma regra social pelo emprego da força coletiva seja conforme ao sentimento que se tem da justiça comunitária e da justiça distributiva no momento considerado, que a não sanção dessa regra seja contrária a esse duplo sentimento"27. Retoma, assim, noções tradicionalmente vinculadas ao jusnaturalismo, especialmente a justiça distributiva e retributiva à semelhança das construções de Aristóteles e de Tomás de Aquino, para delimitar o campo do que seria socialmente aceito como direito objetivo.

Nessa linha seguem suas últimas formulações ${ }^{28}$, não consolidadas em um formato acabado, sobre a relação entre direito e valores sociais. Em suas anotações para uma conferência sobre o tema, publicadas por Bonnard, afirma a importância da atribuição

${ }^{25}$ DUGUIT, 1975, p. 171. No mesmo sentido, Duguit afirma: “Ce qui fait la règle de droit, ce n'est pas la décision du législateur positif, c'est la conscience que cette règle doit recevoir des gouvernants une sanction positive et organisée", in DUGUIT, 1927, p. 112.

${ }^{26}$ DUGUIT, 1927, p. 81.

${ }^{27}$ DUGUIT, 1927, pp. 124-125.

${ }^{28}$ Publicadas e comentadas por Roger Bonnard em BONNARD, 1932. 
de valor a um ato, ao mesmo tempo em que afirma que "o valor de um ato se determina por sua conformidade ao real, ao ser" ${ }^{29}$, buscando conciliar a ideia de valores sociais ao método realista e à refutação de conceitos metafísicos. Identificaria a possibilidade de determinação de valores verificados não como verdades reveladas, universais e ahistóricas, mas sim como atribuições imanentes de uma dada sociedade em concreto, mas que ao mesmo tempo permitissem concluir que instituições como o respeito da autonomia da pessoa humana, da palavra dada e da propriedade privada considerada a partir de sua função social seriam princípios de todo país civilizado ${ }^{30}$.

Comentando tais anotações, e tentando garantir a consistência da teoria de seu mestre, tendo em vista as críticas a conceitos metafísicos que a constitui, Roger Bonnard escreve que Duguit "considerava que o ideal, base dos valores sociais, não é constituído por um certo ideal superior irreal. Ele tem sua base no real, a saber, no fato social, na solidariedade social que constitui sua substância, e ele consiste na realização da solidariedade pela atividade humana, na conformidade dessa atividade às leis da solidariedade. É assim que essa atividade adquire um valor social" ${ }^{31}$. O recurso ao sentimento de justiça e à percepção de valores sociais em paralelo à pretensão realista, de acordo com a pretensão progressivamente idealista e prescritiva de sua teoria, foi alvo de críticas e acabou por revelar as fragilidades da contribuição construtiva do pensamento, como se verá.

“Quando então um ato emanado dos governantes se impõe à obediência dos governados, não é porque emana de uma pretendida vontade superior investida de um pretendido direito subjetivo de comando, mas porque, por hipótese, ele é, por seu objeto e por sua finalidade, conforme ao direito objetivo da coletividade considerada" ${ }^{\sharp 2}$. O direito não é a política da força, como diz Ihering, mas o poder político é a força colocada a serviço do direito $^{33}$. O problema que se coloca seria justamente definir o limite entre o justo e o injusto, a partir da percepção de um ideal de justiça concretamente identificado na massa das consciências individuais.

\footnotetext{
${ }^{29}$ BONNARD, 1932, p. 9.

${ }^{30}$ BONNARD, 1932, p. 10.

${ }^{31}$ BONNARD, 1932, 15.

${ }^{32}$ DUGUIT, 1927, pp. 673/674.

${ }^{33}$ DUGUIT, 1927, p. 677.
} 


\subsubsection{Estado, legitimidade e democracia}

Descartando o poder de dominação estatal como fundamento da positivação do direito, e refutando a centralidade da noção de sujeito de direito, Duguit discorda frontalmente das teorias que personificam o Estado ${ }^{34}$. O direito não é produto da vontade do Estado, pelo contrário, ele existe como limitação do poder estatal. O Estado é apenas um fato de força, uma relação entre governantes e governados. "A verdade é que $o$ poder político é um fato que não contém em si nenhuma característica de legitimidade ou ilegitimidade. Ele é o produto de uma evolução social de que o sociólogo deve determinar a forma e marcar os elementos (...). Em todos os grupos sociais que qualificamos de Estado, tanto os mais primitivos e os mais simples, como os mais civilizados e os mais complexos, encontramos sempre um fato único, individuos mais fortes que os outros, que querem e podem impor sua vontade aos outros. Pouco importa que esses grupos sejam ou não sejam fixados sobre um território determinado, que eles sejam ou não sejam reconhecidos por outros grupos, que eles tenham uma estrutura homogênea ou diferenciada, o fato é sempre idêntico: os mais fortes [materialmente, religiosamente, economicamente, moralmente, intelectualmente ou numericamente] impõem sua vontade aos mais fracos" ${ }^{\prime 35}$.

Nesse sentido, não vislumbra qualquer diferença entre os diversos regimes políticos, todos fatos de força, imposição da vontade dos governantes: "Não encontraremos nenhuma diferença de natureza entre o poder de um chefe de horda e aquele de um governo moderno composto por um chefe de Estado, por ministros e câmaras. Mais uma vez, há uma diferença de grau, mas não de natureza. O fato social é, no fundo, idêntico nos dois casos"36. A relativização do papel do Estado vis-à-vis ao direito fez com que o autor recebesse inúmeras críticas, sobretudo qualificando-o de anarquista $^{37}$. Não há fundamento, do ponto de vista da ciência positiva, para a legitimação

\footnotetext{
${ }^{34}$ Como, notadamente, as teorias de Gerber, na Alemanha, e de Michoud e Esmein, na França.

${ }^{35}$ DUGUIT, 1927, p. 655.

${ }^{36}$ DUGUIT, 1927, p. 537.

${ }^{37}$ Foi sobretudo Maurice Hauriou quem formulou esse tipo de contestação à teoria de Duguit, sustentando que a desvalorização do Estado pelo jurista e a identificação da possibilidade de existência de um direito independente do poder estatal poderiam conduzir à defesa de uma sociedade sem Estado, anarquista. Após um extenso debate explicitado na obra dos dois autores, Duguit escreve: "On m'a accusé d'être un anarchiste. Hauriou m'appelle anarchiste de la chaire. J'ai répondu que l'anarchie consiste à nier la légitimité de tout acte de contrainte politique et que ce n'était pas être anarchiste de dire que la puissance gouvernante ne peut se légitimer par son origine, mais seulement par le but qu'elle poursuit, qu'elle s'impose légitimement lorsque et seulement lorsqu'elle s'exerce conformément au Droit social. Hauriou réplique que le tout est de s'entendre et qu'il continue de qualifier anarchiste une doctrine 'où le pouvoir n'a pas de vertu
} 
de um poder de dominação estatal por sua origem, afastando-se assim a noção de soberania.

A ideia de soberania recolocaria a exigência de se constituir teoricamente um sujeito abstrato que a detenha (portador, Träger), questão para a qual o autor não enxerga solução que escape às noções metafísicas, e que seja assim compatível com seu método "realista e sociológico". "A soberania como direito não pode ser definida senão como um poder de vontade (...) Evidentemente, nos exprimimos mais corretamente dizendo que a soberania é o poder, o direito de uma vontade, o direito de dar ordens incondicionadas, o direito de uma vontade de não se determinar jamais senão por si mesma. Em todo caso, o sujeito desse direito é um sujeito de vontade"38. Esse sujeito varia conforme a teoria adotada: o príncipe (Herrscher), a nação personificada (como nas teorias francesas), ou o Estado em si e para si (como nas alemãs). De todo modo, não há possibilidade de sustentar cientificamente a existência de um sujeito dotado de tal poder de dominação irresistível, razão pela qual não pode ser a soberania o fundamento de legitimidade do Estado.

A soberania, para o autor, explicou-se historicamente por duas correntes, uma teocrática, fundando-a no poder divino, e outra democrática, fundando-a na suposta "vontade geral". Mas em ambos os casos, a crítica dirigida é a mesma: não é possível explicar a existência de uma vontade superior à individual. Nada mais é do que um sofisma a afirmação de Rousseau de que "cada um, se dando a todos, não se dá a ninguém". "Na verdade (...), essa pretendida vontade geral não se exprime jamais senão por meio de uma maioria, e o poder público, o poder de comandar, pertence a uma maioria que impõe sua vontade a uma minoria" ${ }^{39}$.

juridique propre, où la volonté des gouvernants est considérée comme n'étant pas d'une nature autre que celle des gouvernés..., une doctrine où il n'y a pas de théorie de la légitimité du pouvoir, tirée de l'origine de celui-ci...'. Il ajoute qu'il n'insistera pas davantage. Moi non plus je $n$ insisterais pas davantage. Anarchiste si l on veut; je n'ai pas peur des mots. Anarchiste ma doctrine; j'accepte l'épithète et je maintiens la doctrine si elle peut contribuer à débarrasser une fois pour toutes la science juridique des concepts métaphysiques qui l'encombrent encore. Anarchiste, si l'on veut, ma doctrine, si elle peut arriver mieux que toute autre à limiter juridiquement le pouvoir de l'État et à fonder véritablement une règle de Droit déterminant le sens et l'entendue des actes gouvernementaux. J'espère démontrer que ma doctrine qualifiée d'anarchiste, outre qu'elle s'adapte seule aux faits sociaux actuels, peut seule atteindre ce double desideratum, et aussi qu'elle assure l'obéissance aux décisions légitimes des gouvernants bien mieux que la affirmation solennelle du prétendu principe d'autorité, principe vide de sens et de contenu", in DUGUIT, 1927, t. I, p. 654. Sobre o debate, as proximidades e as distinções entre as teorias de Duguit e Hauriou, ver, além das obras dos próprios autores, MILLET, Marc, L. Duguit et M. Hauriou, quarante ans de controverse juridico-politique (18891929), in HERRERA, 2005, t. I, pp. 85/111, EISENMANN, 1930, FARIAS, 1999.

${ }^{38}$ DUGUIT, 1927, p. 593.

39 DUGUIT, 1927, p. 583. 
No que diz respeito especificamente às teorias democráticas, é importante compreender a abrangência da crítica de Duguit. De seu pensamento, decorre a impossibilidade lógica de legitimação do poder pelo seu fundamento democrático, ou por sua vinculação à expressão da soberania popular ou nacional. "Eu chamo de democráticas todas as doutrinas que colocam a origem do poder politico na vontade coletiva da sociedade submetida a esse poder e que ensina que o poder político é legítimo porque e somente porque ele é instituído pela coletividade que o rege. Ora, essas doutrinas, em dois de seus mais ilustres representantes, Hobbes e J.-J. Rousseau, levam à onipotência política e à subordinação completa e sem limites do indivíduo"40.

O poder não pode se legitimar pela sua origem, seja fundada no direito divino, seja na soberania do povo, fundamentos equivalentes ${ }^{41}$ e afastados pelo autor, na medida em que não seriam capazes de estabelecer uma limitação objetiva e concreta ao poder estatal. Ele rejeita enfática e reiteradamente o que chama de dogma da vontade geral - para ele, não há vontade geral una e superior à soma das vontades individuais, mas apenas, no caso da democracia, a vontade da maioria que se impõe como um fato, e não como fundamento de legitimidade.

Mas isso não significa que seja contrário à ampliação do sufrágio e ao processo democrático. Apenas entende que o sufrágio universal não é consequência lógica da ideia de soberania popular, e refuta a possibilidade teórica de vinculá-los como fundamento da legitimidade do poder estatal. "Mais do que ninguém eu creio que é bom e justo que a maior quantidade possível de individuos seja associada ao poder político em um dado país, e eu estimo que o progresso consiste antes de tudo em elevar o grau de cultura geral e fazer participar do poder público um número cada vez maior de indivíduos. Em uma palavra, o sufrágio universal regulamentado e organizado é o ideal em direção ao qual desejo que caminhem todos os Estados. Consequentemente, compreenderia a defesa do princípio da soberania popular se tivesse por consequência lógica o sufrágio universal (...). A verdade lógica é que na doutrina da soberania nacional é a pessoa coletiva que possui a soberania, e os cidadãos tomados individualmente não tem dela senão uma pequena parcela. Eles não tem direito algum de participar do exercício da

\footnotetext{
40 DUGUIT, 1927, pp. 570/571.

41 “a vontade da coletividade é superior à vontade individual. Por quê? Por ser coletiva, a vontade do grupo não é menos vontade humana, e não se pode demonstrar que uma vontade humana possa se impor a uma outra vontade humana. Diz-se que a Revolução substituiu o direito divino do rei pelo direito divino do povo, é verdade; já que a afirmação que a coletividade tem o poder legítimo de comandar porque é uma coletividade é uma afirmação de ordem metafísica ou religiosa, tanto quanto a afirmação do direito divino dos reis" in DUGUIT, 1927, pp. 582/583.
} 
soberania. Em consequência, o sufrágio universal não deriva, logicamente, do princípio da soberania nacional" ${ }^{, 42}$.

Da mesma forma que atribui importância ao sufrágio, ressalta o papel dos corpos sociais intermediários, rejeitando a contraposição absoluta Estado-indivíduo. "Quero dizer somente que a atividade individual é tanto mais intensa quanto mais o homem faz parte de um maior número de grupos sociais. O homem sendo por natureza um ser social, sua atividade só pode se exercer no seio de um grupo, sua atividade será evidentemente maior e mais fecunda quanto mais ele pertença a grupos. Como a família se desagrega cada vez mais, como a comuna deixa de ser um grupo social coerente, o homem do século XX só pode encontrar essa vida social intensificada nos sindicatos profissionais ${ }^{, 43}{ }_{-} 44$.

Daí a importância que atribui ao sindicalismo, que pensa ser "um movimento profundo e irresistivel, tendente, como eu digo desde 1908, a dar uma estrutura definida às diversas classes sociais. Persisto pensando que em um futuro próximo ele levará a uma transformação profunda de nossa organização política. (...) para mim o sindicalismo não é um partido ou uma doutrina, ele é um fato de considerável monta, que é tanto causa quanto consequência da desaparição do Estado de regalias e jacobino" ${ }^{45}$. Enxerga no sindicalismo a possibilidade de integração social, refutando ao mesmo tempo o que chama de "sindicalismo bolchevique", com ideais de derrubada da burguesia, motivo pelo quê é crítico às greves, especialmente nos serviços públicos. " $O S$ eventos que tiveram curso no mês de maio de 1920, onde a consciência nacional se insurgiu contra as tentativas criminosas de greve geral, onde o país venceu o inimigo do interior como em 1918 ele venceu o inimigo do exterior, são a evidente demonstração (...) [de que] ele [o sindicalismo] não é um instrumento de guerra e de divisão social, ele é, ao contrário, um meio potente de pacificação e de união (...). Devemos ver no sindicalismo um movimento que tende a dar uma estrutura jurídica definida às diferentes classes sociais, isto é, aos grupos de indivíduos que já estão ligados por uma semelhança de necessidades na divisão do trabalho social e, ao mesmo tempo, por uma comunidade mais estreita de interesses (...). Agora se estabelece uma coordenação dentro das diversas classes, que reduz a mínimo as lutas sociais e que ao mesmo tempo protege fortemente o

${ }^{42}$ DUGUIT, 1927, pp. 585/586.

${ }^{43}$ DUGUIT, 1927, p. 665.

${ }^{44}$ Sobre a possibilidade de reler Duguit, utilizando seu pensamento para a compreensão do arranjo institucional atual, especialmente o papel dos corpos intermediários face ao Estado na Europa contemporânea, vide PINON, 2010.

${ }^{45}$ DUGUIT, 1927, p. 589. 
indivíduo inserido em seu grupo contra as reivindicações das outras classes e contra o arbitrio do poder central" ${ }^{\prime 4}$. Por essa razão, é defensor da representação classista, sendo referido como principal influência para a introdução da ideia no Brasil.

Para Duguit, o Estado só é legítimo se agir de acordo com os objetivos de solidariedade social e, posteriormente, com o sentimento de justiça, prestando os serviços públicos - a legitimidade não é, portanto, decorrência da soberania que confere ao Estado poder de dominação irresistível. O serviço público aparece como noção contraposta à de soberania, no pensamento do autor: ao invés de enxergar uma legitimação do Estado pela origem, um poder de dominação irresistível e soberano, desloca a legitimação para a atividade estatal e sua adequação aos laços de solidariedade. Considerando a existência de uma regra anterior e superior ao Estado, que baliza tanto a ação humana quanto a estatal, há para o autor parâmetros de julgamento de condutas, conformes ou não à solidariedade, que autorizam traçar os limites entre o jurídico e o antijurídico, bem como entre o legítimo e o ilegítimo.

O Estado aparece, portanto, como uma cooperação de serviços públicos, na clássica definição de Duguit. A preocupação está em deslocar a legitimidade da origem para a finalidade da atividade estatal, assim como a análise da relação sociedade-indivíduo é deslocada da vontade livre para a cooperação solidária. O poder só é legítimo pela maneira pela qual é exercido.

Trata-se de uma teoria que, conforme afirmou Laski, "teve o notável mérito de forçar os espíritos à uma revisão de seu pensamento, mérito mais raro do que geralmente se admite. A influência do livro de Duguit sobre a sua geração pode ser comparada àquela do Espírito das Leis, há dois séculos. Discípulos e adversários foram obrigados a readaptar suas concepções à nova perspectiva que lhes era indicada"47. Inegável o papel de Duguit em questionar os fundamentos da ciência jurídica que vinha se consolidando no início do século XX, consciente de que o novo cenário social e político pedia uma nova visão sobre o direito e sobre o fundamento de legitimidade do Estado, diante do inconveniente de identificá-lo com a vontade soberana de um Parlamento que agora contava com representação plural, produto da massificação democrática. Era preciso encontrar um outro fundamento de legitimidade, e Duguit vai buscá-lo não no Estado e em sua origem, mas em um suposto sentimento de solidariedade que une e integra os indivíduos em uma sociedade desprovida de conflitos. Mas como identificar o conteúdo

\footnotetext{
${ }^{46}$ DUGUIT, 1927, p. 664.

${ }^{47}$ LASKI, 1932, p. 121.
} 
dessa lei social, dentro de uma teoria que se pretende coesa na objetividade e na crítica aos conceitos a priori? A questão atormentou os últimos anos de vida de Duguit.

Ao relacionar a norma jurídica ao justo, o autor insere uma dimensão valorativa à análise que terá dificuldade em conciliar com seu método objetivo e realista a identificação do valor social que está de acordo com o justo não é decorrência da mera observação dos fatos sociais. Nesse sentido as objeções formuladas por Le Fur: "é impossível passar do fato ao direito. Como todos os fatos tem o mesmo valor do ponto de vista científico, não se pode fazer uma escolha entre eles (...). Do simples fato é impossível derivar o dever (...). Duguit, fazendo da justiça um simples sentimento subjetivo, cai forçosamente no arbitrário; ele é, desse ponto de vista, muito mais subjetivista do que os tradicionalistas aos quais dirige suas críticas" ${ }^{\prime 4}$. Le Fur apresenta suas críticas para concluir que é necessário, para definir o justo, recorrer aos valores sociais, que só podem ser definidos a partir do recurso à metafísica, tão combatida por Duguit. "Duguit nunca levou ao fundo essa questão da objetividade do direito, e é por isso que seu sistema carece de base sólida. Parece, entretanto, que à medida em que atribui maior importância à ideia de justiça ao lado do fato puro da solidariedade, seu direito objetivo tende a se tornar um decalque do direito natural" ${ }^{\prime 4}$.

Apesar de sua abordagem distinta, a crítica de Laski é semelhante: " $D a$ mesma maneira que os escolásticos insistiam no fato de que o direito positivo é válido na medida de sua conformidade com o direito natural e o direito divino, Duguit afirma que a validade do direto positivo depende de sua conformidade com as pretensões supremas da solidariedade social (...). Mas, por essa argumentação, sua doutrina cessa de ser positiva enquanto independente de premissas metafísicas. Ela se torna uma doutrina do justo conduzida tanto pelos governantes quanto pelos governados, dependendo a justiça, a todo momento, de sua capacidade de demonstrar que cada pretensão particular da doutrina pode ser validada por um recurso à Razão. É por essas razões que estimo que a doutrina de Duguit é muito mais preciosa por seu aspecto crítico que por seu aspecto construtivo" $"$.

De se ressalvar, contudo, que se há interesse nas críticas de Duguit às teorias voluntaristas e subjetivistas, há também interesse no estudo da solução por ele proposta. Não à toa Le Fur apressa-se em reivindicar o crescente peso da análise valorativa

\footnotetext{
${ }^{48}$ LE FUR, 1932, pp. 195/196.

${ }^{49}$ LE FUR, 1932, p. 204.

${ }^{50}$ LASKI, 1932, p. 132.
} 
que identifica solidariedade e sentimento de justiça como um decalque do direito natural. Há, em Duguit, uma teoria substancial, que parte do indivíduo e da sociedade organizada para identificar uma regra que os une, que os integra e que é capaz de dirimir conflitos, e é essa regra, a solidariedade (que posteriormente é associada a um determinado conjunto de valores sociais conformes ao sentimento de justiça), que se apresenta como fundamento de legitimidade do Estado. Assim, pode enxergar na organização da sociedade em torno de grupos intermediários, como os sindicatos, sobretudo, um passo importante na coordenação de classes na consecução dos objetivos de solidariedade comuns a todos.

\subsection{MAURice HaUriou}

Maurice Hauriou (1856-1928) faz seus estudos de direito também em Bordeaux, onde, em 1879, defende sua tese de doutorado (Étude sur la contradictio. Des contrats à titre onéreux entre époux en droit français). Após duas tentativas fracassadas, disputa o mesmo concurso de agregação que Duguit, em 1882, em que obtém o primeiro lugar. Passa então a lecionar em Toulouse, universidade de que se torna reitor entre 1906 e 1926. Não tem problema em se apresentar abertamente como um conservador liberal ${ }^{51}$, sendo também bastante ligado ao catolicismo e aos debates relacionados à teologia, o que fica nítido em seu pensamento.

O jurista constrói seu pensamento sobre o direito e o Estado a partir da tentativa de superação das correntes subjetivistas e objetivistas, buscando conciliá-las na teoria da instituição. Trata-se da explicação da fundação, duração e continuidade do direito e do Estado, que combina elementos subjetivos e objetivos. Filia-se aos grandes teóricos da época, construindo uma análise que alia aspectos descritivos e normativos, uma maneira de compreender o direito e o social característica dos clássicos, que seria posteriormente abandonada.

Para Georges Vedel, em Hauriou "a vida social é tomada como um objeto global. Não se pode distinguir, senão como processos analíticos, o conhecimento do jurista, o conhecimento do sociólogo, o conhecimento do político, mas é possível acessar um conhecimento total, um conhecimento global ${ }^{, 52}$. Nesse sentido, não se pode classificar propriamente suas reflexões no direito ou na ciência política, tal como percebemos

\footnotetext{
${ }^{51}$ FOULQUIER, 2009, p. 1.
}

${ }^{52}$ VEDEL, 1969, p. 98. 
atualmente esses campos teóricos, sendo esse o aspecto peculiar do pensamento do período. O direito que Hauriou quer compreender é inserido socialmente, impregna a sociedade, que está, ela mesma, em relação com o universo ${ }^{53}$.

Também em Hauriou há uma tentativa de construção do direito como ciência, a partir do método institucionalista. A proposta separa a dimensão objetiva da subjetiva, o impulso do sujeito para a ação e a reação do coletivo, as demandas de justiça e a estabilização decorrente da ordem social. O direito está justamente nessa dinâmica, mas, sobretudo, na estabilização, na imposição de limites à liberdade individual. Consciente de seu tempo, é um democrata, mas entende que o poder, concentrado nas mãos de uma elite de governantes, é a noção jurídica central, na medida em que garante o poder de coerção, a dominação, a ordem e a integração social: "a ordem social é aquilo que nos separa da catástrofe $^{, 54}$.

\subsubsection{Método institucionalista}

Acreditando que a separação entre ciência e prática, no direito, é ilusória, sustenta um método de análise que é ao mesmo tempo descritivo e normativo, diríamos, permitindo compreender o direito como "ciência de ação". É nessa dualidade que Vedel identifica, ao mesmo tempo, o sincretismo metodológico de Hauriou, e sua complexidade que por sua vez explica o interesse que sua obra desperta, com sua "contraditória riqueza" ${ }^{\circ 5}$.

"O método de Hauriou é composto de uma série de vai-e-vens de tipo dialético, levados à cabo em uma síntese entre dois pontos de vista aparentemente distintos e opostos entre os quais o pensamento do autor, indo de um polo a outro, se esforça em realizar uma série de reconciliações" ${ }^{~} 56$. Segundo Vedel, o método do jurista de Toulouse é marcado pelo vai-e-vem entre validade jurídica e existência social, entre a multiplicidade contraditória dos fatos e a unidade ideal dos conceitos, entre o social como existência e o ideal moral como essência, e entre o conhecimento científico e a prática.

O jurista descreve seu método como sendo a observação combinada da história e do direito comparado. A história considerada por ele não é analisada de maneira

\footnotetext{
${ }^{53}$ HAURIOU, André, 1969, 131.

${ }^{54}$ HAURIOU, 1927, p. 23.

${ }^{55}$ VEDEL, 1969, p. 99.

${ }^{56}$ VEDEL, 1969, p. 99.
} 
minuciosa, consistente e sistemática, é antes vista como "grandes afrescos comportando efetivamente uma parte não negligenciável de interpretação" ${ }^{, 57}$. Por outro lado, o recurso ao direito comparado não deixa de atribuir superioridade aos sistemas jurídicos ligados à tradição ocidental, que possui as "obras-primas clássicas que deverão triunfar", como verdades reveladas pela tradição, especialmente do ponto de vista moral - "o bloco de obras-primas clássicas, desde as verdades cientificas até as belezas e santidades morais, sem contar as obras literárias, plásticas e musicais, é uma massa tão eloquente que torna dificil lhe repudiar o testemunho. (...) as jovens gerações, desabituadas do jogo estéril da análise crítica pelas realidades da vida e reabituadas pelos esportes à disciplina da ação e do empreendimento, se tornarão mais uma vez naturalmente sensíveis às verdades reveladas pela dramática empresa da civilização humana" ${ }^{\text {"58. }}$.

Por fím, é de grande relevância destacar a forte influência católica no pensamento de Maurice Hauriou, que de resto é constantemente explicitada em sua obra: "convém me catalogar como um positivista comtista que se tornou positivista católico, isto é, como um positivista que vai até utilizar o conteúdo social, moral e jurídico do dogma católico, $^{, 59}$.

É a partir desse método sincrético, ao mesmo tempo descritivo e lógico, normativo e pragmático, caracterizado pelos "vai-e-vens" dialéticos de que fala Vedel, que Hauriou busca elaborar uma teoria de equilíbrios dinâmicos, que pudesse ter o potencial de superar as divergências entre as vertentes objetivistas e subjetivistas da época. Transitando entre ciência política e direito, combina diferentes chaves de compreensão do todo social para ao mesmo tempo descrever um sistema complexo - historicamente construído, mas também subjetivamente revelado - e prescrever posturas, em um momento em que a pureza do direito não era tomada como valor, e direito e política não estavam separados por fronteiras simbólicas.

Trataremos, para efeitos desse estudo, do pensamento sintetizado nos últimos escritos de Maurice Hauriou, notadamente em seus artigos Théorie de l'institution et de la fondation (essai de vitalisme social), de 1925 e L'ordre social, la justice et le droit, de 1927, bem como na reedição de seu Précis de Droit Constitutionnel, buscando ressaltar sua visão sobre o direito, o Estado e a formação da ordem social e da ordem constitucional. É marcante, no autor, a tentativa de superação das correntes subjetivistas e objetivistas, que

\footnotetext{
${ }^{57}$ VEDEL, 1969, p. 102.

${ }^{58}$ HAURIOU, 1925(a), p. 66.

59 HAURIOU, 1916, p. XXIV.
} 
sozinhas não seriam capazes de fundamentar uma teoria do direito e do Estado capaz de fazer face aos anseios de cientificidade no campo jurídico.

De acordo com o autor, o direito subjetivo está ligado a tudo aquilo que se mantém por uma vontade consciente de sujeitos determinados, enquanto que o direito objetivo descreve o que se mantém por si mesmo, por "ideias subconscientes", dualismo que coexistiria na doutrina como um "sábio compromisso". "No meio do século XIX, esse compromisso foi denunciado pela organização de um sistema ultra-subjetivista que, cinqüenta anos mais tarde, provocou a formação de um sistema ultra-objetivista, e é assim que se comprometeu a querela" ${ }^{\circ 0}$.

O subjetivismo, como formulado por Gerber, Laband e Jellinek, baseiase no sujeito de direito, em sua vontade criadora e na personificação do Estado, caracterizado por sua vontade irresistível capaz de positivar o direito e dotá-lo de força obrigatória. Mas como explicar as regras derivadas dos costumes? E como sustentar a existência do direito antes do aparecimento do Estado? Para Hauriou, o sistema subjetivista seria falho por deixar de explicar a continuidade, "porque o poder de vontade pode ser entendido como descontínuo" $"$.

Por outro lado, o objetivismo, tal como formulado por Duguit, considera a regra de direito como algo existente em si, que passa a ser o suporte de toda existência jurídica. Contudo, "se é verdade que as regras de direito são, para as instituições, um elemento de conservação e de duração, não saberíamos disso concluir que elas sejam o agente de sua criação. É todo o problema: trata-se de saber onde se encontra, na sociedade, o poder criador; se são as regras de direito que criam as instituições, ou se são as instituições que geram as regras do direito, graças ao poder de governo que elas contém" ${ }^{\text {62 }}$. O meio social possuiria, para o autor, uma força meramente inercial, capaz de fazer prevalecer as regras postas, mas não capaz por si próprio de criá-las sem intervenção subjetiva.

Os subjetivistas tomariam a ação pela duração, enquanto que os objetivistas tomariam a duração pela ação, "des-historicizando" o Estado ou diluindo o direito na história, sem intervenção subjetiva na sua criação: "O sistema subjetivista declarou que o nascimento do Estado não pertence à história, o que significa amputar do direito a operação de sua fundação; o sistema objetivista, por outro lado, é conduzido a

\footnotetext{
${ }^{60}$ HAURIOU, 1925(a), p. 4.

${ }^{61}$ HAURIOU, 1925(a), p. 6.

${ }^{62}$ HAURIOU, 1925(a), p. 7.
} 
admitir que a formação das regras de direito apenas pertencem à história, vez que a regra não possui nada de jurídico até ser aceita como obrigatória pela massa de consciências, o que demanda tempo"63.

\subsubsection{Sociedade, indivíduo e instituição}

A teoria da instituição, que conduz de forma progressivamente consolidada a reflexão do autor, é formulada para conciliar elementos subjetivos e objetivos tanto na compreensão do Estado quanto do direito, buscando incorporar ao pensamento jurídico os problemas da dinâmica social a partir da reflexão sobre a fundação e sobre a continuidade das instituições. A dinâmica entre a ação, notadamente individual, e a reação, social, bem como a ideia de equilíbrio entre as forças, permeiam as explicações que Hauriou constrói sobre o direito e o Estado, na tentativa de superar a dualidade subjetivismo-objetivismo. "O impulso do indivíduo representa a ação e aquele dos grupos a reação destinada a equilibrá-lo" ${ }^{\circ 4}$.

A sociedade, para o autor, seria melhor descrita pelo equilíbrio entre os elementos objetivos - aqueles que ultrapassam as consciências individuais, tais como a regra de direito e as instituições sociais (a ordem social) - e os elementos subjetivos, como o poder as paixões e a vontade humana.

Contudo, é importante destacar que, mesmo que Duguit tenha enxergado no autor uma teoria fundamentalmente objetivista ${ }^{65}$, é o próprio Hauriou quem vai, afinal, afirmar a primazia da dimensão individual sobre a coletiva ${ }^{66}$. Mesmo os elementos objetivos repousam sobre ideias, percebidas pela subjetividade. A ordem social é individualista, e o equilíbrio deve preservar sobretudo a liberdade do indivíduo, em sua dimensão subjetiva. "A via subjetiva seria o bom caminho para passar ao objetivo; $e$ aquilo que seria marca da verdade para o regime moderno é que, colocando em primeiro lugar a liberdade e o poder, chegamos facilmente à ordem, e, ao contrário, colocando em primeiro lugar a ordem é bem dificil retornar ao poder e à liberdade" ${ }^{\text {67 }}$.

A evolução social seria obra, do ponto de vista da ação, dos indivíduos, e das ideias por eles formuladas. O meio social é sobretudo inercial, não tem iniciativa, ação,

${ }^{63}$ HAURIOU, 1925(a), p. 9.

${ }^{64}$ HAURIOU, 1927, p. 60. Cf. HAURIOU, 1925(a), p. 29, EISENMANN, 1930, p. 252.

${ }^{65}$ DE LAUBADÈRE, 1969, p. 215.

${ }^{66}$ HAURIOU, 1925(b), p. 67.

${ }^{67}$ HAURIOU, 1925(b), pp. 67 e 99, apud EISENMANN, 1930, p. 258. 
apenas reação. "O meio social tem apenas uma força de inércia que se traduz em um poder de reforço das iniciativas individuais quando ele as adota, ou, ao contrário, de inibição e de reação quando ele as reprova, mas ele não tem por si mesmo nenhuma iniciativa ou nenhum poder de criação; é impossível que produza uma regra de direito criadora que, por hipótese, seja anterior àquilo que se trataria de criar" ${ }^{\text {68 }}$. Daí a comparação do meio social com "cordeiros de Panurge", destinados a serem eternamente guiados ${ }^{69}$, meio que nunca poderá ser tomado como fator determinante de impulso originário para quaisquer processos sociais.

Em sua crítica ao objetivismo, "o objetivo é estático, e é porque ele é estático que aparece sua incompatibilidade com a vida (...). Pela negação do poder subjetivo de criação do direito, o movimento jurídico, que resulta sobretudo das forças subjetivas, foi interrompido, a menos que nos encontremos sob o império de uma norma que, por exceção, afirme o princípio da liberdade, como por exemplo aquela que estabelece a liberdade das convenções"70. A liberdade e o indivíduo são a origem da ordem social e do sistema jurídico, bem como o objetivo a ser garantido por eles.

A rejeição da supremacia do coletivo sobre o individual e a escolha eminentemente individualista conduzem o autor à refutação veemente das ideias socialistas, em que supostamente o motor da evolução seriam as determinações e impulsos coletivos. "Isso condena o socialismo, que supõe a vida social concebida como se realizando dela mesma e para ela mesma, enquanto que ao contrário o individualismo a concebe como se realizando pelos homens, como eles a veem, e para eles" ${ }^{\text {"71 }}$. Os fatos sociais e o movimento na história estão assentados, para o jurista de Toulouse, na ação de individualidades, contida pela reação do meio social. É nessa dinâmica que se insere sua abordagem institucionalista do direito e do Estado.

Hauriou permeia sua teoria desde cedo com ideias que levariam à formulação da teoria da instituição ${ }^{72}$, completada no artigo publicado em 1925, La théorie de l'institution et de la fondation (essai de vitalisme social). Nele, escreve: "uma instituição é uma ideia de obra ou de empresa que se realiza e dura juridicamente em um meio social; para a realização dessa ideia, um poder se organiza (...), por outro lado, entre os membros do grupo social interessado na realização da ideia, produzem-se

\footnotetext{
${ }^{68}$ HAURIOU, 1925(a), p. 7.

${ }^{69}$ HAURIOU, 1925(b), p. 45.

${ }^{70}$ DE LAUBADÈRE, 1969, p. 218, citando trechos do artigo Le pouvoir, l'ordre, la liberté et les erreurs de systèmes objectivistes.

71 EISENMANN, 1930, p. 259.

${ }^{72}$ Para um histórico da teoria da instituição no pensamento de Maurice Hauriou, cf. MARTY, 1969.
} 
manifestações de comunhão dirigidas pelos órgãos do poder e regulamentadas por procedimentos" ${ }^{73}$.

Ele retoma a classificação, já presente em Principes de Droit Public, das instituições em dois tipos: instituição-coisa e instituição-pessoa, que se distinguem pela interiorização ou não da ideia de obra nos limites de uma corporação. Na instituiçãopessoa, corporação, “o poder organizado e as manifestações de comunhão dos membros do grupo se interiorizam na moldura da ideia de obra; depois de ter sido objeto da instituição corporativa, a ideia se torna sujeito da pessoa moral que se destaca em um corpo constituído" ${ }^{74}$. A instituição-pessoa, de que o Estado é o grande exemplo, personifica-se, adotando Hauriou a teoria da pessoa moral, ou pessoa jurídica, diríamos.

A regra de direito é o exemplo maior de instituição-coisa, por outro lado, na medida em que as manifestações de comunhão e o poder organizado não são interiorizados na moldura da ideia de obra, que não é personificada em uma corporação. "Ela vive no corpo social, por exemplo no Estado, emprestando desse seu poder de sanção e se beneficiando das manifestações de comunhão que nele se produzem. Ela não pode dar origem a uma corporação porque ela não é um princípio de ação ou uma empresa, mas, ao contrario, um principio de limitação" 75 .

\subsubsection{Regra de direito, justiça e ordem social}

O direito é visto como um sistema de imposição de limites ao exercício da liberdade individual, ainda em uma visão liberal: "as regras de direito são limites transacionais impostos às pretensões de poder individuais e àquelas dos poderes das instituições" ${ }^{\text {"76}}$. São regulamentações antecipadas de conflitos, que emprestam do Estado seu poder de sanção e sua legitimidade, conferida pelas manifestações de comunhão produzidas internamente a ele.

"Assim, o papel do legislador é aquele do agrimensor que estabelece as balizas entre os campos de atividade; as leis orgânicas sobre as liberdades individuais, a lei de imprensa, a lei das associações, a lei sobre a liberdade de ensino, as leis civis sobre a liberdade de contratos ou sobre a livre disposição da propriedade individual, mesmo em

\footnotetext{
73 HAURIOU, 1925(a), p. 10

${ }^{74}$ HAURIOU, 1925(a), p. 10.

75 HAURIOU, 1925(a), p. 11.

76 HAURIOU, 1925(a), p. 8.
} 
suas disposições que parecem construtivas não são em realidade balizas e limites. Daí a máxima tradicional da ordem individualista de que 'tudo aquilo que não é proibido por lei é permitido', ou melhor 'tudo aquilo que não é proibido por lei, e que é obra da vontade individual, é válido juridicamente ${ }^{\text {,77. }}$.

$\mathrm{Na}$ base da sociedade estão as liberdades civis e econômicas do indivíduo, de que as liberdades políticas são consequência, compondo os princípios fundamentais garantidos pelo direito. $\mathrm{O}$ direito tem como pedras angulares a garantia da ordem social e da justiça individualistas, é a ars boni et cequi ao mesmo tempo em que ars stabilis $^{78}$, e é esse papel de preservação o seu fundamento último de legitimidade, acima do Estado, do direito positivo e da constituição.

A justiça é um conceito constante, transcendente e de conteúdo ahistórico e imutável, é o "Bem”, noção "pela qual o direito se apoia sobre a moral e que caminha na direção da liberdade espiritual"79. Apesar de conceito ideal, a justiça pode ser realizada progressivamente, porém, cada realização particular tem valor de justiça absoluta, infinita. Já a ordem social, noção de conteúdo mutável, é a "empreitada de estabilização do estado social por uma estrutura equilibrada" ${ }^{\prime 80}$. A ordem social está em constante evolução, admitindo progressivamente demandas de justiça, ao mesmo tempo em que entrando em conflito com as doses de justiça que ainda não foram incorporadas, e nessa dinâmica produz equilíbrios provisórios de forma a estabilizar a vida social. Entre ordem social e justiça existe uma relação platônica semelhante à existente entre objeto e ideia, explicitada pelo autor na comparação da primeira a uma simples maquete de estátua, e da segunda ao ideal de beleza plástica" . "Já há justiça na ordem social mais bruta, mas retoques sucessivos devem incorporá-la sempre de forma crescente" ${ }^{\natural 2}$.

As disputas políticas são sempre a luta entre os partidários da ordem (partidos conservadores, moderados ou reacionários) e os partidários da justiça (partidos reformistas ou revolucionários). Hauriou posiciona-se nessa disputa, afirmando a prevalência da ordem social sobre a justiça: "a ordem social é um elemento das sociedades mais primordial que a justiça. Devemos nos resignar a essa constatação. A ordem social estabelecida é o que nos separa da catástrofe; em sua maioria, os homens, nos países

${ }^{77}$ HAURIOU, 1925(a), p. 8.

${ }^{78}$ HAURIOU, 1927, p. 69.

${ }^{79}$ HAURIOU, 1927, p. 50.

${ }^{80}$ HAURIOU, 1927, p. 50.

${ }^{81}$ HAURIOU, 1927, p. 51.

${ }^{82}$ HAURIOU, 1927, p. 51. 
civilizados, preferem suportar uma certa dose de injustiça a arriscar a catástrofe" ${ }^{\prime \prime 3}$. E, no final dos anos 1920, com as tensões sociais crescentes, e o movimento socialista ganhando espaço, Hauriou coloca-se de forma bastante explícita, afirmando que na disputa entre os defensores da ordem social e os defensores da justiça, "a catástrofe mais temivel é a perda ou a destruição do capital”, , a ser evitada pela manutenção da ordem.

A ordem social é o "mínimo de existência", enquanto que a justiça é o "luxo" que pode ser progressivamente incorporado, desde que não ameace a ordem e o equilíbrio postos. "Existe um limite: os retoques [de justiça] não devem comprometer o equilibrio estático da construção. A ordem social democrática realiza mais justiça social que a aristocrática, mas também a experiência a demonstra mais frágil, porque a igualdade na liberdade compromete seu equilíbrio estático, que está na base do poder e da autoridade, 85 .

De acordo com o autor, a história da humanidade é a empreitada de estabilização do estado social por uma estrutura racional e equilibrada, o que levou à sedentarização das populações. A ordem social é construída progressivamente para, sobretudo, garantir as necessidades de produção, e é essa a marcha da civilização que ele considerava estar se acelerando, sob a influência dos Estados Unidos. Os partidos coletivistas e comunistas, que reivindicam a justiça, estariam errados por propor sistemas de ordem social incompatíveis com os "países civilizados" porque incapazes, justamente, de garantir as necessidades de produção. Ordem social, Estado e sistema capitalista liberal são, assim, essencialmente identificados em seu pensamento.

A ordem social é resultado tanto de necessidades naturais - elementos objetivos - quanto, e sobretudo, de ideias. Nesse sentido, Hauriou fala em uma "empreitada voluntária da formação da ordem social", onde predominam as energias e os impulsos subjetivos de criação, responsáveis pela ação, equilibrados pela reação do grupo. Assim se formam as "grandes ideias diretrizes" e as "crenças civilizadoras", "destinadas a fornecer as bases espirituais ao sistema individualista, a confortar as vontades individuais e a frear seus impulsos transgressores" $" 86$. Esse o papel, fundamentalmente, das ideias morais e religiosas, que são reveladas, e não formuladas. "As ideias objetivas existem no

${ }^{83}$ HAURIOU, 1927, p. 49.

${ }^{84}$ HAURIOU, 1927, p. 58.

${ }^{85}$ HAURIOU, 1927, p. 51.

${ }^{86}$ HAURIOU, 1927, p. 56. 
vasto mundo, incorporadas às coisas que nos rodeiam; nos momentos de inspiração, nós as encontramos e as livramos de seu invólucro [gangue]"87.

Cabe às elites intelectuais o papel proativo, a ação, na revelação de tais ideias diretrizes: "os lazeres proporcionados a uma elite pelo excedente de riqueza produzido permitiu a ela uma vida cerebral mais intensa, do que resultou a descoberta das ideias" ${ }^{\prime 88}$. No mesmo sentido, os princípios jurídicos fundamentais, que compõem a ordem social, são descobertos por uma elite, enquanto que a "massa das consciências médias" é reativa, e dá apenas seu assentimento, ou no máximo incorpora subjetivamente as ideias já reveladas $^{89}$. Daí alguns elementos aristocráticos em sua teoria.

Assim o direito, como afirmação da ordem social, sobretudo, e das doses de justiça a ela incorporadas, aparece como garantia da liberdade individual, princípio básico da vida social e econômica. E "assim a ordem individualista se impõe juridicamente ao Estado, na medida em que é superior mesmo às regras do direito positivo interno" $" 90$ - compreende-se, portanto, a importância do costume como fonte do direito na teoria $^{91}$, ligado à preservação da liberdade individual pelas práticas reiteradas e incorporadas socialmente como ordem, bem como a abertura para o reconhecimento de um direito pré-estatal e não positivo, relacionado à ideia de nação. Tais garantias fundamentais, consuetudinariamente consolidadas, constituiriam a base para o que ele vai chamar de constituição social, separada da constituição política.

Apesar de seu esforço em apoiar sua teoria na história e no direito comparado, Hauriou não exclui uma abertura para o reconhecimento de um direito supra e pré-estatal, aproximando-se do direito natural ao conceber uma justiça universal e valores individualistas de liberdade anteriores e limitadores do Estado. “A afirmação do monopólio jurídico do Estado não impede M. Hauriou de escrever que o direito está submetido ao Estado em certos pontos, e em outros, é o Estado, pelo contrário, que está submetido ao direito, de que resulta um equilíbrio que ele utilizou em sua teoria do controle de constitucionalidade ${ }^{, 92}$. A conformidade dos atos às liberdades fundamentais inscritas na ordem social e de justiça é, em última análise, o que lhes vai garantir valor jurídico. Também há, assim como em Duguit, a preocupação com a limitação do Estado por

\footnotetext{
${ }^{87}$ HAURIOU, 1925(a), p. 16.

${ }^{88}$ HAURIOU, 1927, p. 61.

${ }^{89}$ EISENMANN, 1930, p. 259.

${ }^{90}$ EISENMANN, 1930, p. 264.

${ }^{91}$ Para uma breve descrição do espaço "um pouco hesitante" do costume dentre as fontes do direito em Hauriou, cf. EISENMANN, 1930, p. 269, nota 1

92 EISENMANN, 1930, p. 269.
} 
princípios fundamentais, revelados de maneira similar ao raciocínio aplicado pelo direito natural, princípios esses especialmente relacionados à liberdade individual.

Não por outra razão Eisenmann afirma que Hauriou pode ser classificado entre os defensores do direito natural, pois "ele admite que esse direito possui uma existência objetiva, nas ideias no sentido platônico e em Deus, que é seu centro. Mas separando-se da grande maioria dos juristas contemporâneos que aderem a essa noção de um 'ideal de moralidade e de justiça objetiva' - ele recusa-se a reduzir esse direito natural a uma simples 'coleção de preceitos de justiça' de conteúdo variável; a ideia de um direito natural evolutivo parece uma 'imaginação' não desprovida de perigos; o direito natural é portanto um 'corpo de direito contendo uma ordem social' bem particular e determinada: a ordem individualista, ordem 'de direito comum "'93.

\subsubsection{Estado, poder e democracia}

Seguindo na sucinta descrição da teoria da instituição que ora fazemos, temos que as instituições-pessoa, ou instituições corporativas, são propriamente as corporações, de que o Estado é o exemplo maior. Caracterizam-se por serem personificadas, por certo, e por possuírem uma existência dinâmica e temporalmente delimitada. Hauriou empreende um grande esforço teórico para demonstrar o funcionamento das instituições personificadas, procurando sobretudo descrever sua fundação e sua continuidade de um ponto de vista jurídico. Para ele, seriam elementos das instituições-pessoa a ideia de obra, o poder organizado e as manifestações de comunhão.

A ideia de obra ou de empresa a se realizar em um grupo social, também chamada de ideia diretriz é o elemento mais importante da instituição corporativa, e não se confunde com finalidade ou a função dela. Não é a finalidade porque não é externa à instituição, bem como porque "na ideia diretriz há um elemento de plano de ação e organização em vista da ação que ultrapassa singularmente a noção de finalidade" ${ }^{94}$ - a diferença entre ideia diretriz e finalidade é assemelhada à distinção entre programa de ação e resultado. Por outro lado, não é também a função da instituição, uma vez que "a função não é senão uma parte já realizada ou, ao menos, já determinada da empresa; subsiste na

93 EISENMANN, 1930, p. 251.

${ }^{94}$ HAURIOU, 1925(a), p. 13. 
ideia diretriz uma parte de indeterminado e de virtual que nos leva para além da função" ${ }^{\text {95. }}$.

Hauriou, em muitas passagens, utiliza como exemplo a sociedade anônima, e neste caso faz uso da comparação para aproximar a ideia-diretriz da noção de objeto social da companhia. Trata-se do escopo último que norteou a fundação da instituição e que permanece existindo de forma contínua para garantir sua permanência, sua continuidade.

Da mesma forma que a concepção de justiça, a ideia diretriz é percebida subjetivamente pelos "espíritos" de forma descontínua, mas tem existência objetiva nos subconscientes, segundo o jurista, sendo a sua afirmação uma operação de descoberta, de libertação de seu invólucro, de revelação. “Apesar da glosa subjetiva dissimulada pelos conceitos de cada um dos aderentes, uma ideia de obra que se propaga no meio social possui uma existência objetiva e é, aliás, essa realidade que a permite passar de um espírito a outro e de se refratar diferentemente dentro de cada um sem todavia se dissolver e desaparecer" $" 96$.

O grupo de pessoas interessadas na realização da ideia-diretriz, ao aderirem a ela, tornam-se seus aderentes, "acionistas" ou sujeitos. São aqueles que, segundo o autor, correm um risco pessoal na realização ou não da obra, autorizando uma comparação do Estado a uma empresa privada. Trata-se justamente de um elemento subjetivo, de adesão voluntária à ideia diretriz que existe objetivamente. Nesse sentido, Vedel descreve o pensamento de Hauriou como uma teoria de "adesão política", ou, em linguagem mais moderna, como uma "teoria do consenso" "97.

O segundo elemento da instituição-pessoa é o poder organizado posto a serviço da ideia para a sua realização. Trata-se da organização da instituição moldada de forma a realizar a ideia de obra. No caso do Estado, estavam inseridos como princípios desta organização a separação de poderes e o regime representativo.

O terceiro e último elemento são as manifestações de comunhão que se produzem no grupo social a respeito da ideia e de sua realização, justamente o fenômeno de consciência pelo qual a ideia diretriz da obra passa ao estado subjetivo. "A comunhão de ideia produz um acordo de vontades sob a direção de um chefe; ela não comporta somente o assentimento intelectual, mas a vontade de agir e o começo do gesto que, por um risco

\footnotetext{
95 HAURIOU, 1925(a), p. 13.

96 HAURIOU, 1925(a), p. 15.

97 VEDEL, 1969, p. 101.
} 
assumido, vincula todo o ser à causa comum; em uma palavra, é uma comunhão de ação"98.

As instituições corporativas surgem a partir de operações de fundação, e se mantém em uma “continuidade descontínua". A fundação é o momento de interiorização da ideia diretriz na instituição, desmembrado em momentos sucessivos de incorporação e personificação e explicado a partir de método comparativo com a psicologia (o que chama de "psicologia corporativa"). Hauriou busca explicar a personificação das instituições, pessoas morais coletivas, a partir do estudo da personalidade moral individual. Parte do postulado de que a sociedade é obra psicológica em que há tanto ações e reações recíprocas do espírito humano (elemento subjetivo) e quanto ideias objetivas, bases das instituições (elemento objetivo) ${ }^{99}$. No ser humano, a alma é sua ideia de obra, que interage com conflitos de consciência, "lutas interiores", instintos, paixões, todos os chamados "psiquismos elementares do corpo", passando a partir disso ao seu estado subjetivo e realizando seu destino. Ideia diretriz é, assim, um princípio vitalista, que equilibra a crise constante na qual vive o homem.

Comparando-se com o Estado, temos que este é marcado por vários conflitos, crises. A incorporação se dá quando os órgãos do governo, com seus poderes de vontade, passam a atuar sob o comando da ideia diretriz, perseguindo sua realização. Neste ponto adquire uma individualidade objetiva, tanto mais caracterizada quanto mais se identifica a nação com seu governo, sem que ainda se fale de manifestações de comunhão por parte dos cidadãos. A continuidade da ideia é garantida, ainda que de forma precária, em seu estado objetivo, na medida em que é objetivamente introduzida como finalidade (diretriz) da organização estatal.

“O Estado é incorporado a partir do momento em que atinge o estado de governo representativo. Então, um primeiro trabalho de interiorização é atingido, no sentido de que os órgãos do governo, com seus poderes de vontade, agem para o bem comum na moldura da ideia diretriz do Estado. Nesse estado, o Estado possui uma individualidade objetiva, ele se torna uma potência para o direito internacional, tanto mais caracterizada quanto mais a nação for incorporada ao seu governo, não que produza manifestações de comunhão com ele, mas se deixando passivamente conduzir por ele ${ }^{\# 100}$. Trata-se do governo de um poder minoritário, que não conta com as manifestações ativas

\footnotetext{
98 HAURIOU, 1925(a), p. 21.

${ }^{99}$ Cf. HAURIOU, 1925(a), p. 52

${ }^{100}$ HAURIOU, 1925(a), p. 26.
} 
de comunhão, mas apenas com a sujeição passiva, motivo pelo que a continuidade é instável.

A partir do momento em que há a participação dos cidadãos, que interferem nas decisões dos órgãos do governo, há a interiorização da ideia de obra, uma vez que já podemos identificar manifestações de comunhão. Quando a ideia passa a ser percebida subjetivamente pelos "espíritos", a própria diretriz passa ao seu estado subjetivo, e se dá a personificação da instituição. "O Estado é personificado a partir do momento em que atinge o estado da liberdade política com participação dos cidadãos no governo. Então, um segundo trabalho de interiorização é atingido, no sentido de que, na moldura da ideia diretriz, se produzem então manifestações de comunhão dos membros do grupo que participam das decisões dos órgãos do governo representativo (eleições, deliberações de assembléias, referendos etc)" ${ }^{\prime 101}$. A instituição, então, é personificada e ganha o status de "pessoa moral".

Assim, a instituição se personifica quando a ideia diretriz é incorporada tanto objetivamente (como objetivo do poder organizado) quanto, e sobretudo, subjetivamente (como percepção individual dos membros). Trata-se, contudo, de um equilíbrio dinâmico, continuamente descontínuo, sucessivamente reafirmado. É dessa forma que a instituição garante sua duração, sua continuidade. "A instituição é um conjunto generalizado de equilíbrios sociais que são, ao mesmo tempo, políticos, econômicos e jurídicos. A ideia de 'equilíbrio' pretende reconstituir uma espécie de unidade prática, uma unidade que se faz na pluralidade, pois é composta de elementos múltiplos" $" 102$.

Temos, portanto, a teoria que explica a personalidade moral das instituições, sobretudo do Estado, e sua característica mais importante é a continuidade. Essa é garantida não por uma relação de pertencimento a um sistema jurídico abstrato e apartado da realidade, como postularia o positivismo voluntarista de Carré de Malberg, por exemplo, mas sim pela constante interação com a ordem social concreta que renova repetidas vezes as manifestações de comunhão e a autoridade conferida ao poder organizado, ambas voltados para a plena realização da ideia-diretriz.

A noção de Estado e a de ordem protetora das liberdades individuais, em Hauriou, são indissociáveis. O Estado é uma instituição fundada em um especial equilíbrio econômico e político, que determina a separação das duas esferas, "isto é, o fato que o

101 HAURIOU, 1925(a), p. 26.

102 FARIAS, 1999, p. 102. 
poder público e a propriedade das coisas e dos meios de produção não estão nas mesmas mãos: no regime de Estado, o poder de aplicar, nos casos adequados, aos indivíduos as medidas de restrição e o poder de alimentá-los não pertencem às mesmas pessoas; o governo, que detém o primeiro, abandona o outro aos particulares. Em sintese, não há Estado senão o Estado burguês" ${ }^{103}$. Cabe ao Estado, portanto, proteger a vida civil do povo, em especial garantindo suas liberdades e não interferindo na esfera econômica de ordenação da sociedade.

Nesse sentido, define o Estado como "organização política e jurídica que, graças a um poder público centralizado e soberano, assume o protetorado da vida civil de uma população sedentária sobre um dado território formando assim uma comunhão nacional ${ }^{104}$. São elementos do Estado, em boa medida de acordo com uma visão tradicional da teoria do Estado seguida por Hauriou: a ideia-diretriz, o território, a população e o poder. A ideia diretriz do Estado é justamente a realização do protetorado da vida civil, isto é, da liberdade privada, dos cidadãos, que prevalece sobre a vida política. Cabe ao Estado a garantia das liberdades individuais e do máximo de paz ${ }^{105}$ e segurança, em uma acepção bastante próxima à liberal clássica. Já o território é o limite da circunscrição da competência do Estado.

A população, por sua vez, é um elemento do Estado na medida em que sedentária, suficientemente numerosa e dotada de uma vida civil "desenvolvida". Forma uma comunhão, "isto é, tem o sentimento de interesses comuns e o desejo de satisfazê-los pela união" ${ }^{, 106}$, e nesse sentido, ao tomar consciência de sua unidade moral e de seus interesses comuns, constitui a nação. A nação é formada por fatores históricos (guerras, invasões, calamidades etc), mas também étnicos (raça ${ }^{107}$, língua, religião etc) e de parentesco espiritual (unidade moral nacional). É à nação que se vinculam os princípios fundamentais pré-estatais, consolidados pelo costume, base da Constituição social. Estado e nação aparecem como entidades exteriores, uma à outra, cada uma com seu direito - o

\footnotetext{
103 EISENMANN, 1930, p. 260.

104 HAURIOU, 1925(b), p. 5.

105 "On doit chercher une définition de la paix sociale qui soit positive et non pas négative, c'est-à-dire qui ne consiste pas à affirmer que la paix est le contraire de la guerre ou du désordre. De ce point de vue, on peut avancer que la paix est l'état d'une société dans laquelle les causes de désordre et de conflits sont éliminées, avant d'avoir pu produire leurs effets nocifs, par des solutions raisonnables et objectives qui vont taire les passions subjectives", in HAURIOU, André, 1969, p. 135.

106 HAURIOU, 1925(b), p. 7.

${ }^{107}$ Hauriou fala em raça comum com elemento da nação, mas critica o pangermanismo e a defesa da depuração racial alemã já em questão na época. Apesar de discordar da existência de uma "raça pura", em razão da mestiçagem, é curiosa sua afirmação de que "les races supérieures sont le résultat d'une mestissage hereux; la race anglaie est anglo-saxonne; la race française, gallo-romaine et franque..." HAURIOU, 1925(b), p. 9.
} 
Estado com o direito positivo e a nação com seu direito pré e extra-estatal - e cada uma titular de poderes distintos e antagônicos - a soberania de governo e a soberania de sujeição, que é justamente o direito de opor ao Estado as liberdades individuais ${ }^{108}$. A soberania de sujeição, vinculada à nação, é um limite à soberania de governo, reafirmando a tese dos princípios fundamentais vinculados aos costumes que limitam o Estado.

O poder, finalmente, é um elemento central na teoria. Diferentemente de Duguit, para quem o Estado é um fato de força, a simples distinção governantesgovernados, Hauriou tem como pedra angular de sua teoria a demonstração do poder como um fato jurídico. Não por outra razão, enquanto Duguit é associado à teoria do serviço público, Hauriou é associado à teoria do poder, da puissance. O poder é necessário porque não há agrupamento humano que possa se organizar sem a imposição e sem coerção (contrainte sociale).

Depois de identificar o poder como uma "livre energia da vontade que, graças à sua qualidade, assume o empreendimento do governo de um grupo humano impondo as restrições necessárias, pela criação contínua da ordem e do direito" ${ }^{109}$, identifica dois elementos componentes dessa energia criadora: um qualitativo, a competência e a autoridade moral, e outro quantitativo, o poder de dominação.

A autoridade é o poder fundado na competência, e consiste na "energia espiritual devida a uma certa qualidade ou valor da vontade e da inteligência, que permite a uma elite política assumir o empreendimento do governo fazendo-se obedecer pelos outros homens em nome da ordem" $" 110$. Corresponde ao chamado poder minoritário. Por outro lado, o poder de dominação é o poder de vontade que se faz obedecer por meio da força de coerção. É o poder que repousa sobre a força conferida pelo sufrágio, um poder de maioria, "energia indiscutível que inspira o temor"111.

Assim como a paixão deve ser subordinada à razão, os anseios de justiça à ordem social, também o poder majoritário, o poder de dominação, deve ser subordinado à autoridade - "em princípio, todos os comandos do poder do Estado podem ser objeto de uma discussão prévia à execução, salvo nos casos e nas categorias de casos em que a existência ou a legítima defesa do Estado exigem a obediência imediata"112. Essa

${ }^{108}$ EISENMANN, 1930, p. 267.

${ }_{109}$ HAURIOU, 1925(b), p 11, apud EISENMANN, 1930, p. 272.

110 EISENMANN, 1930, p. 272.

${ }^{111}$ HAURIOU, 1929, p. 25.

112 HAURIOU, 1925(b), p. 13. 
subordinação é que garante o atributo jurídico do poder, e mais uma vez fica evidenciada uma certa tendência aristocrática da teoria.

O jurista rejeita teorias que não veem justificativa para o poder, como a de Duguit, bem como aquelas que o assentam sobre teorias exclusivamente individuais (que apresentam o risco da aristocracia) ou coletivas (que apresentam o risco de imporem restrições à liberdade individual), julgando conciliar as duas últimas. Para ele, justifica-se a partir de três fatores a supremacia do poder minoritário. Em primeiro lugar, "a base da autoridade dos governantes está no consentimento dos governados"113, nas manifestações de comunhão a partir das quais a ideia diretriz do Estado é incorporada subjetivamente pelos cidadãos aderentes. Em seguida, o poder justifica-se pelo "direito de superioridade da elite", afirmando explicitamente Hauriou que as "vontades de certos homens são superiores como tais às vontades de outros homens, superiores em qualidade, bem entendido"114. Por fim, a justificativa última é teológica: "enquanto proveniente de Deus, o poder é naturalmente orientado em direção à razão, à justiça e ao bem comum; ele é respeitoso da ordem social e das liberdades dos cidadãos; ele não é abusivo nem tirânico" ${ }^{115}$.

Apesar de identificar um poder vinculado à superioridade das elites, é certo que Hauriou era um jurista consciente de seu tempo, também ressaltando a importância da democracia, e especialmente do controle democrático do poder por meio de mecanismos de participação popular como o referendo. Escreve como conclusões em uma longa nota de rodapé: “ ${ }^{o}$. Uma oligarquia parlamentar é necessária. Ela o é enquanto elite política e para manter nas democracias uma categoria de homens políticos que não sejam unicamente os representantes de interesses econômicos; desse ponto de vista, é indispensável que as democracias conservem o regime representativo que é o único capaz, pelo jogo regular das eleições, de constituir e de sustentar essa oligarquia de dirigentes políticos; $2^{\circ}$. Mas essa obrigação parlamentar tem uma tendência natural a aumentar continuamente seu poder, e, por consequência, a exagerá-lo. Esse pessoal político, composto por alguns milhares de membros, contando os deputados e senadores em exercício, aqueles que o foram e os que esperam tornar-se, os jornalistas que estão a seu serviço, e sua clientela imediata, tende a eliminar toda influência que não seja de origem eleitoral, e a fazer crescer constantemente o poder das assembleias e sobretudo a se

113 EISENMANN, 1930, p. 274.

${ }^{114}$ HAURIOU, 1925(b), pp. 170-172, apud EISENMANN, 1930, p. 274

${ }^{115}$ HAURIOU, 1925(b), apud EISENMANN, 1930, p. 275. 
eternizar no poder; $3^{\circ}$. É preciso encontrar um contrapeso político à oligarquias parlamentar, no interesse da liberdade, de início, e da boa gestão dos negócios, em seguida, pois todo poder não controlado negligencia sua função. Não se deve esperar encontrar esse contrapeso político na dualidade de Câmaras; o Senado e a Câmara dos Deputados são igualmente compostos do mesmo pessoal, um cursus honorum regular faz com que os deputados passem ao Senado após um certo tempo; por consequência, não se controlam. Da mesma forma, não se pode contar com a censura dos partidos, nem com a dos eleitores; em toda a máquina eleitoral parlamentar se estabeleceu o estado de espírito caracterizado pela expressão república dos camaradas: troca de serviços, e não de controle. Sozinho, um elemento de governo direto pode realizar esse contrapeso político. De fato, é preciso ver com que infalivel instinto os parlamentares se insurgem contra o referendo" ${ }^{\prime 16}$.

É coerente com sua teoria a defesa do governo representativo comandado por elites políticas, que percebem, ou revelam, a ideia-diretriz de seu tempo e detém a competência e a autoridade moral para o exercício do governo (poder minoritário) - e nesse sentido não podem se confundir os homens políticos com meros representantes de interesses econômicos, mas são, antes de tudo, responsáveis pela proteção política da vida civil, e das liberdades individuais. A participação política dos cidadãos, desde que orientada por essa ideia-diretriz e pela comunhão de interesses que assegura à nação sua unidade moral e ao Estado, seu poder de dominação (poder majoritário), e só assim, pode garantir o controle do regime representativo, exercendo sua soberania de sujeição.

\subsection{Raymond Carré de Malberg}

Raymond Carré de Malberg (1861-1935) também é considerado um dos juristas maiores do direito constitucional clássico francês ${ }^{117}$. O fato de ter nascido em Estrasburgo, na região da Alsácia, tendo inclusive perdido seu pai na frente de batalha da guerra franco-prussiana (1870) é extremamente relevante para a compreensão de sua trajetória intelectual, marcada pelo patriotismo francês militante. Não à toa vai substituir Paul Laband em Estrasburgo, em 1919, após a reincorporação da Alsácia pela França, encarregando-se do ensino de direito público francês. Antes disso, ao passar a agregação

\footnotetext{
${ }^{116}$ HAURIOU, 1929, p. 346, nota 4.

${ }^{117}$ Sobre a biografia de Carré de Malberg, cf. BEAUD, 1997.
} 
em 1890, tinha sido professor em Caen e Nancy (onde também ensina François Gény). Sua formação não é específica em direito público (defende tese intitulada Histoire de l'exception en droit romain, em 1889) e no início de sua carreira contribui com ensinamentos sobre direito civil e direito romano. Sua "virada publicista", como referido por Beaud ${ }^{118}$, é marcada pelo surgimento do direito constitucional como disciplina na França, especialmente com a publicação, em 1896, de Eléments de droit constitutionnel et de droit comparé, de Adhémar Esmein, dentro do clima geral de apelo ao direito como suporte da República.

Carré de Malberg é um dos grandes autores que vai contribuir para a constituição do papel do professor de direito constitucional, especialmente marcado pelo patriotismo e pela tarefa de ensinar direito constitucional na região anteriormente dominada pelos alemães - daí sua teoria ser também uma resposta às teorias alemãs, fundamentada nos ideias da Revolução Francesa. Começa, então, a redigir seu tratado sobre teoria do Estado em 1910, e o conclui em 1914, mas só é publicado em 1920, após a guerra, com o título Contribution à la théorie générale de l'État, com a ressalva de que, justamente, é uma obra que se refere à "era de ouro" do direito constitucional francês, consciente de que a guerra traria uma mudança significativa nas premissas das quais tinha partido ao escrever. Faremos referencias ao trabalho, mas centraremos a exposição nas obras posteriores do autor, especialmente nos artigos Considérations théoriques sur la question de la combinaison du referendum avec le parlementarisme, de 1931, e Réflexions très simples sur l'objet de la science juridique, de 1935, bem como ao livro de 1931 La Loi, expression de la volonté générale: Étude sur le Concept de la Loi dans la Constitution de 1875, em que fica clara a reformulação de seu pensamento a partir da progressiva incorporação de preocupações democráticas, e da consideração dos desafios que se apresentavam naquele momento histórico.

\subsubsection{Método}

O positivista jurídico, como se sabe, é o teórico que só reconhece como regra de direito a norma positiva, para quem o único direito válido é o direito criado e positivado pelo homem ${ }^{119}$. Para determinar se uma norma é válida, há dois tipos de

\footnotetext{
${ }^{118}$ BEAUD, 1997, p. 227.

${ }^{119}$ Para uma tipologia das diversas correntes do positivismo jurídico, cf. GRZEGORCZYK, MICHAUT, e TROPER, 1992.
} 
investigação: primeiro, do ponto de vista formal, se foi emitida por autoridade titular de competência atribuída por lei (seja pela norma fundamental, seja por normas dela decorrentes), depois, do ponto de vista material, se a norma em questão não está em contradição com a norma fundamental, com a Constituição ou com normas dotadas de valor superior.

Nesse sentido, Carré de Malberg afirma que "no estado atual de organização social, o estatuto jurídico que rege os indivíduos em suas relações mútuas ou com a coletividade nacional é determinado unicamente, no seio dessa coletividade, por regras que foram editadas de fato, às quais farão eventualmente observar as autoridades organicamente constituidas para o exercício do poder público ou estatal da nação" ${ }^{20}$. Apenas o direito positivado por autoridade competente, em conformidade com as normas do ordenamento, constitui a regra de direito, e à nenhuma norma supostamente anterior ou superior à essa norma posta pode ser atribuído conteúdo jurídico.

“O positivismo jurídico consiste em não admitir, como critério do valor jurídico de uma norma, senão sua conformidade - formal e material - com uma norma tomada como padrão dos valores jurídicos, em um sistema jurídico determinado, e que chamamos norma fundamental (Ex.: Constituição de um Estado, Pacto da Sociedade das Nações, decretos dos Concílios ecumênicos na Igreja católica etc)"121.

O positivismo jurídico não se confunde com o positivismo sociológico, corrente à qual Léon Duguit julga se filiar. Como visto, o positivismo sociológico é o método que considera apenas o fato socialmente observável como matéria de análise para o jurista. O direito é, nesse caso, "o que é efetivamente aplicado na prática como regra de direito em um dado país e em um dado momento"122.

Carré de Malberg é positivista na medida em que considera como regra de direito apenas a norma proveniente de autoridade competente, que vincula os cidadãos a partir de seu caráter coercitivo. “Em nossas sociedades estatalmente organizadas, não há de fato direito preciso, firme e garantido, com o qual os indivíduos possam efetivamente contar e ao qual são necessariamente adstritos a se submeter, senão aquele que é consagradado por uma disposição ou uma decisão formais, emanadas dos detentores qualificados e autorizados pelo poder público, dito poder de Estado" ${ }^{123}$.

${ }^{120}$ CARRE DE MALBERG, 1935, p. 192.

121 WALINE, 1933, p. 524.

${ }^{122}$ WALINE, 1933, p. 526

${ }^{123}$ CARRE DE MALBERG, 1935, p. 193. 
À questão de saber o que é a norma jurídica válida, responde dizendo que é aquela emanada de autoridade cuja competência é originada do poder público, sendo por isso dotada de força coercitiva. O jurista da Alsácia segue, assim, tradição teórica que vinha de se consolidar na Alemanha, com a transposição do chamado método exclusivamente jurídico para o campo do direito público, operada, como visto, por autores como Gerber, Laband e Jellinek ${ }^{124}$.

\subsubsection{Direito positivo e tarefa do jurista}

"Somente a regra editada por autoridades capazes de coerção se impõe a mim com um império, do que resulta que a necessidade de me conformar ao seu conteúdo depende de um poder exterior à minha livre vontade e também de um poder que possui os meios diretos e irresistiveis de intervir sobre mim para sua [da regra] execução. É porque estamos de acordo em reservar às regras que preenchem essas condições o nome de regras de direito positivo. E é nesse sentido também que é permitido dizer que o Estado é o criador do direito" ${ }^{125}$. Portanto, a norma é jurídica se e somente se é proveniente de uma autoridade dotada de poder de coerção e contém uma sanção diretamente derivada desse poder. O direito depende do Estado como poder de dominação irresistível, e pertence ao campo do direito a regra que se vale de tal poder para impor uma sanção organizada e imediata no caso de seu descumprimento.

A obrigatoriedade do direito, sua validade e sua eficácia são atreladas, assim, à previsão de sanção para hipótese de inobservância da norma posta, e não vinculadas a qualquer conteúdo substancial da norma, em conformidade com preceitos pressupostos de justiça ou moral. A sanção provém da relação da positivação da norma

\footnotetext{
${ }^{124}$ Sobre a leitura atenta de Carré de Malberg dos alemães, escreve René Capitant: "S'il est une influence qui se soit exercée sur elle à son origine et dont elle ait gardé quelque trace, c'est l'influence de la doctrine allemande, dont la production, en matière de philosophie du Droit et de Droit public, n'a cessé d'être abondante au cours du XIX siècle. A défaut de juristes français à consulter, Carré de Malberg lut attentivement les cuvres des Jhering, des Gierke, des Gerber, des Jellinek et des Laband. Sa parfaite connaissance de la langue germanique, ses préoccupations d'homme de l'Est, ses attaches alsaciens le portaient naturellement à suivre et à connaître le mouvement de la pensée allemande et lui permirent de pénétrer très avant dans cette connaissance. Son livre, par les citations et les discussions presque constantes qu'il comporte des juristes d'outre-Rhin, révèle le contact étroit qu'il maintenait avec eux. Pour la plus grande parte du public juridique français, il est l'interprète par excellence de la doctrine allemande, qui ne est et ne lui restera bien souvent connue qu'à travers ses analyses et ses critiques", in CAPITANT, 1936, p. 5.

${ }^{125}$ CARRE DE MALBERG, 1935, p. 194.
} 
com a autoridade competente para tanto, que se vale para isso da parcela de soberania a ela assegurada pelo seu poder de dominação irresistível e ilimitado.

“Ainda e sobretudo, essas regras tem por traço distintivo tomar como fundamento de sua virtude obrigatória não necessariamente seu mérito intrínseco, isto é, uma qualidade de legitimidade que seria originária de sua conformidade a preceitos superiores de moral ou outros, e que justificariam assim as sanções que acompanham seus dispositivos, mas simplesmente o fato de que esse dispositivo foi erigido pela autoridade pública competente em 'lei de Estado', como diz a fórmula francesa de promulgação dos atos legislativos; e essa condição de origem é tanto indispensável quanto suficiente para fundar sua validade e sua eficácia" ${ }^{126}$.

A autoridade positiva a norma e lhe determina a sanção, que não é mediata e diferida no tempo, e não depende das manifestações da massa de consciências, à exemplo da regras derivadas do costume ou da tradição. Trata-se de uma sanção imediata, específica e organizada, conforme coloca Waline: "a sanção de uma regra de direito é uma execução direta e forçada por meios humanos, aqueles que são especialmente próprios a todo poder público organizado" ${ }^{127}$. A particularidade de seu imediatismo confere à sanção da norma jurídica seu diferencial em relação às demais normas, para o teórico.

Não faz parte das funções do jurista a criação do direito, escreve Carré de Malberg $^{128}$. Não há qualquer tarefa jurídica que compreenda a criação, a identificação ou a revelação das fronteiras entre o jurídico e o não jurídico. Distancia-se de Duguit e Hauriou nesse ponto, na medida em que não sustenta a existência de nenhuma ordem ou regra de direito anterior e superior à norma positivada pelo Estado - o direito não é revelado, mas sim positivado pela autoridade estatal.

Por um lado, sustenta que "convém prestar homenagem aos juristas que, não se contentando em constatar o direito que denominam positivo, elevam seus olhares $e$ suas pesquisas na direção de problemas mais altos do que aqueles da ciência do direito propriamente dita" ${ }^{129}$. Por outro lado, entende que a tarefa do jurista é bem mais "modesta", consistindo em "pesquisar, precisar, definir, interpretar, para deduzir as

126 CARRE DE MALBERG, 1935, p. 195.

127 WALINE, 1961, p. 27.

128 CARRE DE MALBERG, 1935, p. 197.

129 CARRE DE MALBERG, 1935, p. 196. 
consequências, os elementos constitutivos da ordem reguladora criada e garantida pelos meios do poder público" ${ }^{" 130}$.

Não exclui a possibilidade de uma ordem moral e de uma noção de justiça, que possam até mesmo aparecer remotamente como fundamento de legitimidade da ordem jurídica. Apenas entende que essas "verdades" morais ou de justiça não têm o condão de constituir a base para uma teoria especificamente jurídica do Estado ${ }^{131}$. Ao comparar direito e moral, Carré de Malberg elenca algumas das que chama de “enfermidades incuráveis" do direito ${ }^{132}$ : o direito trata os homens como são, não como poderiam ser; o direito não estabelece soluções adaptadas às particularidades de cada caso, mas sim soluções gerais, tendo em vista uma situação média, que via de regra não existe na realidade; o direito se ocupa apenas de manifestações exteriores, na medida em que interessam imediatamente o bem estar da comunidade, e não se preocupa com a esfera das intenções, dentro das consciências individuais; o direito só leva em conta o que pode ser provado, o que faz com que seja condenado ao formalismo, por vezes tratando a aparência como a realidade. "Todas as observações nos conduzem a reconhecer que o fundamento da regra de direito está longe de ser exclusivamente de ordem moral, ele está inserido também, e em grande medida, em considerações de ordem prática e utilitária" ${ }^{133}$.

"É ilógico aplicar indistintamente a denominação de direito a dois tipos de regras de essências tão diferentes. Uma dessas fontes do direito, aquela que se impõe à obediência dos cidadãos, tem por característica especifica, como M. Hauriou ele mesmo o declara, ser proveniente da soberania governamental. Assim se torna impossível considerar como direito o outro tipo de regra, aquela que não é nem editada pelo soberano, nem obrigatória para os sujeitos. Em vão dir-se-á que as ordens do soberano não possuem senão um valor provisório e não podem pretender senão uma autoridade prévia, a verdade é que a lei editada pelo legislador não pode ser revisada, corrigida, melhorada senão por um ato de vontade do mesmo legislador, de que o poder aparece assim como se impondo de um modo constante e definitivo (...). Longe de ser dualista, o sistema do direito é uno na medida em que sua formação depende invariavelmente do poder do legislador" ${ }^{134}$. Faz parte do ordenamento jurídico, como norma, os enunciados provenientes de autoridade competente para positivar o direito, e para vincular sanção ao

\footnotetext{
130 CARRE DE MALBERG, 1935, p. 197

131 WALINE, 1933, p. 22.

132 CARRE DE MALBERG, 1935, p. 203, nota 1.

133 CARRE DE MALBERG, 1935, p. 203, nota 1.

${ }^{134}$ CARRÉ DE MALBERG, apud WALINE, 1961, p. 29 (o autor não faz referência à fonte).
} 
seu descumprimento, competência essa conferida pelo poder de dominação que adjetiva a soberania estatal - está aí o fundamento último de validade do sistema, equiparada à legitimidade, e excluindo quaisquer considerações sobre a existência de um direito fora do Estado, ou anterior a ele.

O autor questiona com veemência, assim, a existência de um direito natural. Admite considerações sobre bem e mal e justo e injusto, para além da vontade estatal, provenientes de uma "fonte superior". Mas essas considerações escapam totalmente ao domínio do direito. "Podemos estar profundamente convencidos do valor transcendente dos preceitos que derivam dessa fonte suprema, contudo, seremos ainda assim obrigados a reconhecer que na ordem das realidades sociais não pode existir um direito propriamente dito anterior à lei do Estado. (...) Assim, de nada serve dizer que o Estado se limita a reconhecer o direito, uma vez que ele o reconhece livre e soberanamente. E então, mesmo que ele o reconheça falsamente, seja por cálculo, seja por erro, as regras que ele edita têm do ponto de vista estritamente jurídico um valor positivo inegável, dado que são sancionadas pelo poder irresistivel do qual dispõe o Estado" ${ }^{135}$.

Não há direito superior ou anterior ao Estado: “o direito pressupõe portanto necessariamente uma autoridade pública capaz de coagir os indivíduos à observação dos comandos que ela mesma edita" ${ }^{\text {136 }}$, afirma Waline ao tratar de Carré de Malberg. Por essa razão, não se pode reconhecer como jurídica regra proveniente de costume, de práticas sociais reiteradas, e não formalmente positivada, diferente do que sustentariam Hauriou e Duguit. O problema não é reconhecer que há regras de ordem moral ou de justiça, mas sim saber a quem incumbe apreciar o que é justo e razoável, ou seja, a quem incumbiria delimitar as fronteiras do direito. É o legislador que cria o direito, e os valores que leva em consideração nesse processo não pertencem ao campo de investigação do jurista. O direito só existe enquanto objeto de estudo e reflexão após sua positivação pela autoridade estatal.

O papel do jurista, assim, não é de legislação, mas sim de interpretação. Por essa razão a distinção entre as funções de lege ferenda, estranha ao jurista, e de lege lata, típica do jurista, que deve se debruçar sobre a lei criada, sobre a lei positiva: “o jurista não tem, por seu turno, nada a preencher à lex ferenda; ele opera somente a serviço da lex lata. Não lhe cabe refazer o mundo jurídico, mas somente constatar como

${ }^{135}$ CARRÉ DE MALBERG, 2004 (1920), pp. 57/58, nota de rodapé 6.

136 WALINE, 1933, p. 25 
esse mundo é feito"137. Ainda que se afirme um direito natural, é preciso que uma autoridade intervenha para conferir força coercitiva a tais regras "reveladas"138.

\subsubsection{Estado, soberania e Constituição}

A ordem jurídica é estabelecida pelo poder público por ato de vontade, cuja origem, finalidade e motivação são estranhas ao jurista e à ciência do direito. Carré de Malberg, assim, filia-se ao positivismo jurídico e é metodologicamente individualista e voluntarista. Ao jurista cabe a tarefa de interpretar o direito posto, e para tanto se vale de uma "técnica e de um juridismo, nos quais o formalismo tem um lugar considerável, se não preponderante" 139 .

O direito se justifica pelas necessidades às quais satisfaz. Assim como em Jellinek, as investigações sobre a origem e a legitimidade do Estado não pertencem, na teoria, ao campo do direito. Rejeitando tanto a teoria contratualista de Rousseau quanto o organicismo de Gierke, alija para a esfera extrajurídica a questão da fundação do Estado em perspectiva histórica e política, diríamos, para postular que "do ponto de vista jurídico, com efeito, a questão não é saber quais são as causas profundas que suscitaram o Estado, mas sim qual é o ato positivo que lhe dá diretamente nascimento" ${ }^{\text {140. }}$.

$\mathrm{O}$ ato jurídico a partir do qual se cria o Estado é justamente a Constituição. A origem da Constituição, assim como a do Estado, deve ser tomada, para a ciência jurídica, portanto, como um simples fato ${ }^{141}$. De acordo com Waline, "o direito enquanto instituição humana, sendo posterior ao Estado, isto é, nascendo somente quando formado o poder do Estado, não pode se aplicar à formação mesma do Estado. É vão querer investigar um fundamento jurídico para o Estado fora de sua organização inicial" ${ }^{142}$.

Estado e Constituição são fatos primários e extrajurídicos. "Para $o$ jurista positivista, o valor da Constituição é um postulado sem o qual não há direito possivel, como o postulado de Euclides deve ser aceito a priori se queremos fazer

${ }^{137}$ CARRE DE MALBERG, 1935, p. 198

${ }^{138}$ CARRE DE MALBERG, 1935, p. 201.

139 CARRE DE MALBERG, 1935, p. 197.

${ }^{140}$ CARRÉ DE MALBERG, 2004 (1920), p. 55.

141 "a organização inicial do Estado é um fato puro: pretender investigar a gênese jurídica dessa organização é querer resolver um problema insolúvel. Da mesma forma a Constituição primitiva do Estado, que se confunde com essa organização inicial, não é senão um fato puro, para o qual é impossivel assinalar uma origem jurídica", in CARRÉ DE MALBERG, 2004 (1920), p. 68.

${ }^{142}$ WALINE, 1961, p. 33. 
geometria euclidiana"143. A Constituição é produto de um poder constituinte originário, que aparece como poder de fato, e não de direito. Na realidade, é esse poder originário que, ao dar origem à Constituição, funda o Estado. Nas palavras de Héraud, “o Estado e, por ai mesmo o direito, seria portanto posterior à Constituição. Disso resulta que a operação constituinte originária é um evento histórico, mas não jurídico, um puro fato que o direito seria impotente para compreender" ${ }^{\prime 144}$.

O poder originário é ilimitado, sinônimo de soberania absoluta, e desaparece no momento em que dá origem à Constituição, que surge justamente para limitá-lo e enquadrá-lo dentro de uma moldura jurídica. "O poder originário é o único poder sobre o qual podemos dizer que não tira sua juridicidade da ordem jurídica, justo o oposto, a ordem jurídica deve a ele sua juridicidade"145. É o que Hédaud qualifica como o ponto de contato entre o Sein (ser) e o Sollen (dever-ser), na medida em que aparece como uma constatação de fato, não como a afirmação de um princípio. É do poder originário que deriva o poder de dominação irresistível exercido pelo Estado para positivar o direito e impor a sanção.

O poder constituinte originário é aquele que é detido pelo soberano, de acordo com o princípio monárquico, e pelo povo, em uma democracia, e é anterior e fundador da ordem constitucional. "Há uma essência comum entre a monarquia e a democracia que consiste no fato de que o monarca e o povo exercem seu poder em virtude de um direito pessoal, anterior à constituição, e não de um direito constitucional. Em uma e outra hipótese, um órgão permanece titular de um poder que não é constitucionalizado. Ao contrário, de acordo com o princípio de soberania nacional, todo órgão exerce necessariamente um poder derivado da constituição e é por isso que Carré de Malberg pode sustentar que o Estado é a personificação da nação"146.

Em um primeiro momento de sua produção intelectual, Carré de Malberg parte da soberania nacional para enxergar a Constituição como fundadora da ordem jurídica e o Estado enquanto personificação da nação abstrata, e dota o Parlamento de poder constituinte derivado, na medida em que oriundo da soberania - nesse sentido, sua formulação do conceito de Estado Legal ${ }^{147}$.

\footnotetext{
143 WALINE, 1933, p. 523.

144 HÉRAUD, 1961, p. 80.

145 HÉRAUD, 1961, p. 83.

146 MAULIN, 2003, p. 98.

${ }^{147}$ De acordo com a definição de Marie-Joëlle Redor, Estado Legal é aquele em que "tout acte de puissance administrative presuppose une loi à laquelle il se rattache et don't il est destiné à l'exécution", in REDOR, 1992.
} 
O Parlamento aparece inicialmente em Carré de Malberg tanto como órgão legislativo quanto como titular do poder constituinte derivado. Daí também a noção francesa de governo representativo, que identifica no Parlamento a representação da nação enquanto todo unitário e enquanto vontade una e consensual, e não como representação do povo em seu dissenso, cuja vontade prevalece por maiorias instáveis.

A nação aparece como entidade jurídica abstrata e una, dotada de vontade unificada e continuidade no tempo, que institucionaliza o poder de dominação na medida em que adstrito pela ordem constitucional. É titular da soberania, e é representada pelos órgãos do Estado. A nação se distingue da soma dos indivíduos que a compõe, e é a fonte da vontade geral, que por sua vez é distinta da vontade da maioria da população. Trata-se de uma entidade que só existe enquanto abstração, à qual se vincula a soberania .

Mas, diferente da teoria alemã da autolimitação e do poder de dominação titularizado pelo Estado - a Herrschaftsgewalt, que corresponderia à ideia de puissance para o francês há que se distinguir poder de dominação de poder constituinte, que decorre da soberania, que é justamente a nação abstrata, em uma primeira fase do autor alsaciano. Puissance não se confunde com soberania. Carré de Malberg, avaliando a noção em abordagem histórica, fala em três acepções de soberania. A primeira refere-se à perspectiva internacional, e corresponde ao que se conhece como soberania externa, ou seja, a independência dos Estados na ordem internacional. A segunda diz respeito ao conjunto de poderes compreendidos na puissance estatal, e identifica-se justamente com esse poder de dominação que pertence à nação e é exercido em nome dela pelo conjunto de órgãos estatais. Por fim, soberania confunde-se com o órgão ou a pessoa que ocupa a posição de titular supremo desse poder de dominação.

Para Carré de Malberg, enquanto na Alemanha a soberania concentra-se no titular do poder de dominação, a tradição francesa - na qual se inclui - vincula a soberania à nação, em última análise, e de forma mediada pelo Estado por meio de seus órgãos. Aos titulares do Estado, os governantes, resta apenas o exercício do poder de dominação, em nome da soberania, representando a nação ou o povo. $O$ Estado caracteriza-se, em termos jurídicos, pela puissance, sendo a soberania uma qualidade, um jeito de ser, um grau dessa puissance, desse poder de dominação. O raciocínio permite conciliar a teoria eminentemente positivista do direito e do Estado com a tradição revolucionária francesa, na medida em que dá abertura para a incorporação da ideia de soberania nacional ou popular. 
O Estado, tomado como fato cuja fundação escapa ao domínio de investigação do direito, é responsável pela positivação do direito nos limites da Constituição, bem como pela imposição da sanção em caso de descumprimento da norma, isto é, em caso de ruptura da situação de normalidade, que equivale à situação de colaboração de todos os indivíduos em uma sociedade.

Para que seja restabelecida a normalidade, faz-se necessário dotar o Estado de atributo capaz de tornar sua força irresistível, daí sua característica peculiar, a puissance, o poder de dominação. "O peculiar das coletividades estatais (...) é que elas possuem, como resultado de uma puissance que não pertence senão a elas e que encontra sua afirmação em seu sistema de direito positivo, a faculdade de impor a vontade geral, mesmo aos membros que se opõem, e de levar assim a totalidade dos cidadãos a uma unidade, cuja formação não pode ser impedida por nenhum deles, nem tampouco rompida simplesmente pela sua oposição"148.

Ao Estado incumbe, assim, a garantia de observância do sistema do direito positivo, de forma a manter a colaboração que está na base da sociedade. Essa garantia se realiza através das de sanções juridicamente previstas, aplicáveis justamente porque a autoridade estatal detém o poder de dominação irresistível, a puissance, sua característica peculiar.

A partir daí, o Estado coloca-se, então, como uma unidade dotada de existência autônoma e juridicamente personificada. É uma unidade de pessoas e uma unidade no tempo. O Estado aparece como uma realidade jurídica na medida em que personifica a nação, sujeito de direitos no qual se afirma a unidade de um determinado povo sobre um determinado território, unidade essa que se estende no tempo (continuidade).

Nesse sentido, argumenta Bercovici: "Para Carré de Malberg, a ideia do Estado como pessoa jurídica representa uma teoria puramente jurídica que dá conta da unidade do Estado, bem como de sua permanência no tempo. A comunidade estatal possui unidade pela sua organização, com a sucessão de gerações formando um sujeito único e invariável e uma vontade única que se exprime pelos seus órgãos regulares, constituindo a vontade coletiva da comunidade. A nação só age juridicamente organizada, se tornando uma pessoa jurídica pelo fato de se constituir em Estado. Portanto, para Carré de Malberg, a soberania nacional equivale à personalidade jurídica do Estado, identificando

${ }^{148}$ CARRÉ DE MALBERG, 2004 (1920), p. XIV. 
a soberania nacional e a soberania estatal. A nação é soberana enquanto pessoa jurídica superior aos seus membros individuais. O Estado é, ao mesmo tempo, uma pessoa coletiva e uma pessoa soberana. Esta definição assegura a dimensão exclusivamente jurídica da sua teoria do Estado, pois o Estado só existe por sua constituição" ${ }^{149}$. Essa construção dá conta de responder aos anseios de limitação do poder do Estado sem que se tenha que recorrer à pura teoria da autolimitação alemã, e sem que se lance mão de um direito natural, superior ao próprio Estado.

\subsubsection{Soberania popular e democracia: um pensamento de transição}

Se em um primeiro momento Carré de Malberg identificava o poder constituinte derivado, decorrente da soberania vinculada à nação, ao Parlamento, posteriormente aparece em seus trabalhos a preocupação com a limitação do poder também desse Parlamento, resignificando a soberania para vinculá-la ao povo, de maneira mais direta. Trata-se de um movimento de releitura do poder parlamentar, importante se quisermos compreender o sentido da democracia na fase final da obra do autor, e descrito no artigo Considérations théoriques sur la question de la combinaison du referendum avec le parlementarisme, publicado na Revue du Droit Public em $1931^{150}$.

O jurista parte, para isso, da distinção entre regime parlamentar, nos moldes britânicos, e regime representativo, à moda francesa. De acordo com ele, o regime representativo francês institui-se após a Revolução Francesa, na Constituição de 1791, como soberano não apenas em relação ao rei, mas também em relação ao povo. Segundo a leitura de Capitant, "a assembleia é assim identificada à nação e exerce de fato a soberania que pertence teoricamente à essa [à nação]. A vontade que ela exprime não é aquela de seus membros, mas sim a da nação, concebida não apenas como uma pessoa moral, mas como a universalidade dos cidadãos, que, nos termos do artigo 6 da Declaração de direitos, são pessoalmente e individualmente representados pelo parlamento. Em resumo, pelo artifício da ficção representativa, a vontade do parlamento é assimilada à vontade geral e se beneficia assim da soberania que pertence a essa última"151.

\footnotetext{
${ }^{149}$ BERCOVICI, 2008(a), pp. 264/265.

${ }^{150}$ Sobre a mudança na concepção de soberania em Carré de Malberg, cf. MAULIN, 2003, BEAUD, 1994, CAPITANT, 1961, PINON, 2003.

${ }^{151}$ CAPITANT, 1961, p. 134.
} 
Ao pretender uma assembleia distanciada da vontade do povo concretamente considerado, o regime representativo da soberania nacional, diferentemente do regime parlamentar inglês, assume uma feição essencialmente antidemocrática, e Carré de Malberg julga necessário e desejável que se evolua da soberania nacional para a soberania do povo, denunciando a origem burguesa da primeira teoria. " $E$ banal lembrar que, nas intenções dos fundadores do regime representativo, o objetivo efetivo desse regime devia ser estabelecer e garantir a dominação preponderante da classe burguesa sobre a massa popular, o regime eleitoral sendo organizado, na época revolucionária, de modo que a Legislatura fosse composta apenas dessa classe (...). Na verdade, seu desenho era de ordem fortemente prática: relegar o povo a um papel simplesmente eleitoral" ${ }^{\prime 152}$.

O poder do Parlamento francês seria, assim, tradicionalmente fundado sobre a ideia de representação da vontade geral combinada com o conceito de soberania nacional - "ele é soberano, de início, na medida em que, como representante da vontade geral, é dotado de um poder que domina de modo transcendente as competências de todas as autoridades estatais outras que não ele mesmo; ele é soberano, paralelamente, vis-à-vis ao povo por ele representado, na medida em que os cidadãos são excluídos da faculdade de enunciar por si mesmos, sobre os objetos tratados por decisões de seus deputados eleitos, uma vontade outra que não o conteúdo dessas decisões"153, escreve Carré de Malberg sobre o assunto, recuperando as posições de Sieyès na assembleia nacional de 1789 e esboçando sua tese sobre a dominação dos representantes sobre os representados na tradição política francesa. Contudo, tal construção jurídica que situa a soberania no Parlamento tem por consequência final justamente alijar o povo da decisão política, e por essa razão termina por ser antidemocrática.

É essa a razão pela qual Carré de Malberg fala em "misticismo revolucionário": "Ao final de nosso estudo, parece que a crítica surge e se impõe por si mesma, tão manifesta é a contradição que se estabelece entre a ideia primeira de onde provém a teoria da lei expressão da vontade geral e os resultados positivos aos quais essa teoria finalmente levou. Esses resultados podem ser resumidos em uma palavra: a ideia de soberania da vontade geral foi explorada para fundar o poder soberano do Parlamento em si mesmo (...). Como admitir que, em nosso direito público, as decisões emanadas do Parlamento tenham podido ser apresentadas como produções da vontade popular,

${ }^{152}$ CARRE DE MALBERG, 1935, p. 236.

153 CARRE DE MALBERG, 1931(a). 
enquanto a Constituição mantém sistematicamente os cidadãos excluídos de sua formação" ${ }^{\prime 154}$.

Ressaltando a importância do jurista na revelação do elaborado mecanismo de afastamento do povo do poder, e indicando sua faceta visionária, escreve Capitant: "Em suma, Carré de Malberg desvela o mistério sagrado na sombra do qual estava conservado o princípio sobre o qual repousava a legitimidade da soberania parlamentar. Acontece que esse princípio é uma ficção, isto é, o contrário da verdade. $O$ mistério não é mais uma mentira. A legitimidade colapsa. Essa demonstração, feita em 1931, não teria um caráter profético?"155.

É a partir dessa crítica que Carré de Malberg aproxima-se, progressivamente, das ideias de soberania popular do regime democrático francês de $1793^{156}$. Sustenta a necessidade de controle do poder do Parlamento a partir da substituição de uma ideia de soberania fictícia para uma real soberania do povo, por meio de reformas do sistema de participação popular na tomada de decisões políticas. É por isso que se dedica ao estudo dos regimes parlamentares, e que trata de mecanismos de participação popular, como o referendo. Reconhece à Constituição de 1793 o mérito de ser coerente com as premissas democráticas sobre as quais estava fundada, uma vez que "no momento em que, de fato, baseamos o poder do Estado e de seus órgãos sobre a ideia de soberania da vontade geral, torna-se manifestamente impossível recusar voz deliberativa, e mesmo voz decisiva, àqueles de quem a vontade geral toma sua consistência, isto é, aos cidadãos reunidos para esse fim em um colégio uno e indivisivel (...). É obrigatório concluir que não somente o referendo e o parlamentarismo não são irreconciliáveis um com o outro, mas que há uma relação imediata e inelutável entre os conceitos que serviram para fundar o poder parlamentar e as instituições democráticas que permitem à comunidade dos cidadãos de fazer ouvir sua voz"157.

É preciso reconhecer que a soberania não pertence ao Parlamento, mas sim ao povo, que deve dispor de mecanismos democráticos para o seu exercício. "Nos Estados que justapõem ao poder legislativo das Câmaras a possibilidade de demandas

\footnotetext{
154 CARRE DE MALBERG, 1931(b), p. 215.

155 CAPITANT, 1961, p. 143.

${ }^{156}$ Vale ressaltar a existência de opiniões em contrário, como a de Michel Virally, que escreve que " $L$ 'idée de souveraineté nationale, pour Carré de Malberg - et je crois vraiment que, même jusqu'à la fin de sa vie et dans ses derniers ouvrages, il est resté fidèle à cette idée - constituait vraiment la clé de voûte de nos institutions et elle devait le rester", in VIRALLY, 1961, p. 170.

157 CARRE DE MALBERG, 1931(a), p. 237
} 
populares de referendo, é o povo que sobe ao nível supremo pela aquisição do poder de pronunciar a recusa ou a adoção definitiva das decisões parlamentares. De imediato, o Parlamento encontra-se reposicionado ao nível de simples autoridade: ele não representa mais a vontade geral senão na medida em que investiga e propõe a expressão que entende conveniente dar a essa; ele não cumpre senão um ofício de funcionário público. $O$ verdadeiro soberano é então o povo, armado do meio jurídico que o permite estatuir em última instância, isto é, de declarar se a decisão emitida pelas Câmaras como expressão da vontade geral é conforme ou não à vontade da comunidade popular em si"158.

É assim que em seus escritos finais passa a propor uma reforma do parlamentarismo francês, que deveria deslocar seu fundamento da soberania nacional para a soberania popular, o que representaria um avanço de democratização do sistema político. E, nessa direção, defende o mecanismo do referendo como solução para a limitação do poder parlamentar, até mesmo como solução para as disputas partidárias, que levam à "soberania da vontade do partido atualmente no poder" 159 , o que é uma opressão intolerável. A intervenção popular aparece como forma de reafirmar a vontade geral, que não pode ser cindida em disputas partidárias, já que "a vontade do corpo dos cidadãos, mesmo se inspirada pelo espírito do partido, apresenta, ao menos, o caráter de vontade popular; e então, a ideia de vontade do partido se apaga, de alguma maneira, diante a ideia de vontade geral, uma vez que, em uma tal consulta popular, é o povo tomado em seu conjunto que é chamado a se pronunciar (...). Com ainda mais razão, a combinação do referendo propriamente dito com o parlamentarismo teria por efeito, em um país como o nosso, colocar por sobre os partidos, entre os quais se dividem as assembleias eleitas, o povo estatuindo em sua massa universal e independente de filiações a grupos especiais. E assim se encontraria reestabelecida em seus direitos essenciais essa vontade geral, sobre a primazia da qual foi edificado originariamente o sistema do parlamentarismo francês ${ }^{\prime 160}$.

Assim, Carré de Malberg posiciona-se sobre uma nova realidade, deslocando seu pensamento para teorizar sobre uma legitimidade assentada na soberania do povo, e na participação do povo, contra um Parlamento que já não mais pode ser tomado como soberano absoluto. O movimento permite que Capitant conclua: " $E$ se refugiando no silêncio do pensamento que ele observou o campo da política, tão cheio de

${ }^{158}$ CARRE DE MALBERG, 1931(a), p. 229.

159 CARRE DE MALBERG, 1931(a), p. 243.

160 CARRE DE MALBERG, 1931(a), p. 244. 
ruido, de movimento e de paixão. Ele se privou, sem dúvida, de conhecê-lo em toda a sua complexidade. Mas mais seguramente do que se misturando em sua agitação, ele percebeu e exprimiu as leis que a governam. Ele foi uma dessas nobres figuras de clérigo que, na virada do século, em outro tempo rezavam pelo mundo e hoje em dia pensam por ele»161.

\subsection{HORIZONTE TEÓRICO DEIXADO PELOS CLÁSSICOS: SUBSTANCIALIZAÇÃO DA ORDEM SOCIAL VS. REALIZAÇÃO PLENA DA DEMOCRACIA POPULAR}

Inauguramos o capítulo com a retomada o cenário social e político da época, que se traduziu em uma questão colocada à doutrina jurídica, qual seja, como transformar a força do sufrágio universal, que havia se tornado brutal com a partir da massificação da democracia, em uma força regrada, capaz de preservar os valores liberais transformando-os? De certa forma, como anunciamos no capítulo anterior, a realidade de um Parlamento em disputa e de facções sociais organizadas e não raro conflitantes aumentou a responsabilidade da doutrina jurídica, que se viam confrontada com a necessidade de absorção da política, alterando os fundamentos do direito sem que fosse alterada a ordem constitucional.

Um primeiro grupo de autores, a que chamamos clássicos, seguindo Beaud, procurou dar resposta à indagação a partir de sistemas teóricos que articulassem de forma coerente e integrada conceitos abstratos, desconsiderando fronteiras ainda não consolidadas entre direito e política. A solução passava, assim, por atribuir um sentido coeso às noções de Estado, indivíduo e direito, descrevendo fundamentos de legitimidade $\mathrm{e}$ mecanismos de coerção social. São clássicos, conforme já mencionado, porque partem da pretensão de, dessa forma, fundar uma ciência do direito público a partir de método e princípios próprios, sem deixar, contudo, de concebê-lo como um direito político. Mas a solução dada por cada um dos autores têm particularidades relevantes.

Léon Duguit preocupa-se, sobretudo, em inaugurar uma abordagem que chama sociológica do direito, baseada em um método objetivo, que partisse do conceito durkheimiano de fato social para descrever o funcionamento de uma ordem social fundada na solidariedade entre os indivíduos. O relevante, aqui, são os laços que unem os indivíduos em sociedade, como percebidos por suas consciências, e a integração harmônica de todos em um coletivo que independe do Estado. O Estado, aliás, não é senão um fato de

161 CAPITANT, 1936, p. 12. 
força e só pode ser avaliado em termos de legitimidade a partir das finalidades que persegue, se conformes à solidariedade social. Sua visão dos laços de integração que unem os indivíduos permite que valorize o papel dos corpos sociais intermediários, desde que organizem interesses em prol da coordenação entre as classes, decorrência "natural" da divisão do trabalho e da regra de conduta que é ditada pela solidariedade. Assim, pode ao mesmo tempo valorizar o sindicalismo enquanto elemento integrador (que merece inclusive ser representado politicamente), mas combatê-lo no que tem de conflitivo (as greves, por exemplo). O dilema, na teoria, é determinar quais são as pretensões supremas de solidariedade social que devem ser reconhecidas como direito, ponto que o autor não consegue responder sem derivar para uma teoria do justo, sem incorrer no mesmo problema que vinha denunciando, qual seja, a busca de um fundamento metafísico para o direito. É então que, já no final de sua carreira, começa a discutir um "sentimento de justiça" capaz de distinguir o jurídico do antijurídico, e que fixa valores sociais a serem preservados, que embora não fossem a-históricos, incluiriam, naquele momento, a autonomia individual e a propriedade privada, desde que cumprida sua função social, por exemplo. A incompatibilidade entre sua proposta original e a substancialização da regra de conduta que se viu instado a promover enfraquecem a proposta teórica, que é mais saudada pelo seu conteúdo crítico do que pelo seu conteúdo propositivo.

Nesse sentido, Maurice Hauriou consegue com mais sucesso elaborar uma teoria capaz de atribuir um conteúdo substantivo ao direito constitucional, e identificá-lo aos valores liberais. Partindo de um método que julga combinar elementos objetivistas e subjetivistas, enxerga o direito na dinâmica entre demandas de justiça conceito constante e transcendente, diferente de Duguit - e evolução da ordem social, dando preferência ao seu papel de estabilizador e promotor de equilíbrios provisórios. Posiciona-se entre os partidários da ordem, especialmente da ordem liberal, enquanto "mínimo de existência", na medida em que ao direito incumbe preservar as liberdades básicas do indivíduo, que fazem parte das grandes ideias diretrizes reveladas justamente no processo de formação da ordem social. Ao posicionar a ordem individualista e liberal como princípio básico da constituição social e do direito, em sua existência objetiva e ideal, também ele identifica-se com a substancialização do direito que seria próxima ao jusnaturalismo. O Estado, por sua vez, é o poder organizado em que se combinam a ação condutora das elites políticas (poder minoritário) à legitimidade atribuída pelas manifestações de comunhão da maioria, explicitadas por meio do sufrágio. Sua tarefa, em 
última análise, é funcionar como o protetorado da vida civil, exercendo para tanto seu poder para garantir uma determinada ordem, a liberal.

Tanto em Duguit quanto em Hauriou termina por haver, portanto, a tentativa de incorporar ao direito uma determinada concepção substancializada de ordem social. Partem da premissa de um corpo social integrado e cooperativo, desprovido de conflitos, ou melhor, em que os conflitos eventualmente existentes devam ceder em nome do equilíbrio e da ordem geral, ou em nome da solidariedade que, em última instância, unifica a todos. A perspectiva permite aos juristas, em última análise, dizer o que deve e o que não deve ser considerado como direito, a partir de suas considerações, de natureza substancial, não apenas procedimental, sobre a ordem social e sobre as regras de solidariedade.

Em Carré de Malberg, a perspectiva é distinta, como visto, especialmente se considerarmos as ênfases que sua obra assumiu no entre-guerras. A partir do positivismo jurídico, recusa identificar a validade da norma a qualquer conteúdo material, substancial, à conformidade com preceitos de ordem, justiça ou moral. Não é tarefa do jurista criar o direito, ou revelar verdades morais ou sociais, mas sim trabalhar a partir da norma dada, e com isso rejeita a existência de um direito que não tenha origem no Estado, enquanto unidade soberana personificada. A colaboração social é garantida pelo Estado não a partir de regras ou de ideias que o precedem, mas sim a partir da observância das normas postas segundo o procedimento fixado pelo poder constituinte soberano, que no final de sua obra passa a ser o povo, em lugar da nação - não é demais lembrar que já nos anos 1920, nação e nacionalismo eram ideias que tinham sido apropriadas por um movimento político específico, ligado à direita. A integração social é, portanto, resultado da submissão à vontade soberana do povo, que também não se confunde com uma mistificada representação da vontade geral da nação no Parlamento. A consequência maior é a defesa da necessidade de recuperar a democracia e a decisão popular como fundamentos últimos de legitimidade do Estado e do direito, impondo uma revisão do regime parlamentar de forma a realizar plenamente o ideal democrático-popular.

São essas as linhas de resposta apresentadas pelos autores clássicos, que assumem como projeto teórico fundar o direito constitucional como ramo autônomo a partir de uma visão integrada de Estado, indivíduos, grupos sociais e democracia. Resta saber de que forma as preocupações dessa doutrina clássica foram incorporadas e desenvolvidas, ou, por outro lado, abandonadas pelo direito constitucional que se seguiu. 


\section{Capítulo 3}

\section{JURISTAS PRAGMÁTICOS: A CRISE DO CONSTITUCIONALISMO LIBERAL}

3.1 Joseph Barthélemy; 3.1.1 Pragmatismo como método; 3.1.2 Anos 1920: sufrágio universal, democracia representativa e liberalismo; 3.1.3 O direito, a Constituição e a defesa da Terceira República; 3.1.4 Anos 1930: a transformação de um liberal ameaçado; 3.2 Boris MirkineGuetzévitch; 3.2.1 Testemunho como método; 3.2.2 Direito e política: a tendência à racionalização do poder como traço comum às novas constituições europeias; 3.2.3 Democracia e novo parlamentarismo; 3.3 René Capitant; 3.3.1 Método, imperativo jurídico e subjetivismo: a retomada marginal da perspectiva teórica dos clássicos; 3.3.2 Constituição, soberania e democracia; 3.4 Direito, política e ação: liberalismo $v s$. democracia

"A febre das paixões políticas que queimava naqueles tempos, as veias da França, me davam o gosto pelos espetáculos do fórum. Eu fui um frequentador assíduo das grandes sessões da Câmara. Eu completava ali minhas experiências de teatro popular. O palácio Bourbon era, então, na minha percepção, o primeiro teatro de Paris. Sua trupe era inigualável" . O trecho ilustra bem a crescente radicalização das posições políticas na Assembleia Nacional do entre-guerras, onde políticos representantes de interesses os mais opostos debatiam de forma inflamada, dificultando a composição de governos estáveis e a formação de consensos.

Como o direito constitucional, enquanto direito político, poderia responder a esse cenário? A doutrina clássica, como visto, buscou incorporar a irrupção do social a uma doutrina teoricamente consistente e fundamentada, que absorvesse a teoria do Estado e se colocasse em pé de igualdade com o nascente ramo da ciência política. Mas, conforme destaca Beaud ${ }^{2}$, o entre-guerras assiste ao surgimento de uma nova doutrina, que abandona essa preocupação teórica abstrata e se dedica a uma descrição mais operacional da prática constitucional e institucional, sendo por isso chamada de pragmática. Segundo ele, Joseph Barthélemy é o grande responsável por essa virada, qual seja, a renúncia da

\footnotetext{
${ }^{1}$ R. ROLLAND, Mémoires et fragments de Journal, Paris, Albin Michel, 1953, p. 296, apud SAULNIER, 2004, p. 395, nota 17.

${ }^{2}$ BEAUD, 2000, pp. 89 e ss.
} 
doutrina constitucional à sua vinculação intrínseca com a teoria do Estado e à busca pelo diálogo mediado pelos mesmos termos com a ciência política.

Um direito operacional e descritivo, focado no costume e na prática constitucional, permeável a mudanças, seja da Constituição, seja da própria ideologia dominante, é essa a caricatura do objeto de análise do jurista pragmático. A partir desse momento, apenas em sentido lato o constitucionalista é o jurista que recorre também à ciência política e à história das ideias políticas ${ }^{3}$. O constitucionalista em sentido estrito é mais pragmático em relação à sua disciplina.

A postura é condizente, também, com juristas politicamente mais engajados, conscientes de que o direito deve estar a serviço de seu tempo, sem se embarricar por trás de concepções teóricas muito herméticas. A velocidade das mudanças exigia um direito mais permeável do que propunha o velho constitucionalismo liberal em crise, e a postura pragmática exigia aceitar essa crise e reagir a ela apresentando novas soluções, sem se agarrar a convicções que pouco a pouco se desfaziam no ar.

Esse capítulo tratará de juristas que escreveram em meio a essa nova realidade do entre-guerras, quais sejam, Joseph Barthélemy, Boris Mirkine-Guetzévitch e René Capitant, e que levaram em consideração essa abordagem pragmática, sem necessariamente a adotar. Diferente do capítulo anterior, não podemos igualá-los em termos de estatura intelectual. Barthélemy é um jurista de renome, professor da Faculdade de Direito de Paris, que já em 1926 publica seu tratado de direito constitucional. Tem uma obra vasta e complexa, que não poderia ser nem de longe esgotada nesse capítulo, mas da qual trataremos naquilo em que aponta para inovações e deslocamentos importantes para o nosso estudo. Mirkine-Guetzévitch, por outro lado, não deixa contribuições teóricas de fôlego, mas cumpre um importante papel sistematizando as novas Constituições europeias do entre-guerras e propondo, ainda que não de forma aprofundada, uma leitura comum do processo. Sua obra é bastante difundida internacionalmente, inclusive no Brasil, onde teve um livro traduzido e publicado logo em 1933, e que, como se verá no capítulo 5, ganha projeção no momento constituinte nacional, figurando como obra de bolso de muitos juristas da época. Por fim, René Capitant aparece como um jovem jurista, que sucede Carré de Malberg em Estrasburgo, de onde observa de perto a Alemanha de Weimar e depois, do nacional-socialismo, situando-se na contracorrente ao reivindicar o retorno ao direito constitucional clássico.

\footnotetext{
${ }^{3}$ Cf. BEAUD, 2004, p. 12, nota 25.
} 
São também juristas muito mais engajados, e muito menos encastelados em suas cátedras do que os abordados no capítulo anterior, sendo esse engajamento importante para a compreensão de sua obra. É bastante significativo o fato de que serão apresentados neste capítulo as teorias do Ministro da Justiça do governo de Vichy (Barthélemy), de um russo de origem judaica naturalizado francês e duas vezes exilado (Mirkine-Guetzévitch) - uma em função da Revolução Russa, outra em razão do antissemitismo da França ocupada - e de um membro da Resistência alinhado ao gaullismo de esquerda (Capitant). São juristas de seu tempo, e sua produção teórica é também reflexo disso.

\subsection{JOSEPH BARTHÉLEMY}

É impossível tratar de Joseph Barthélemy (1874-1945) sem ter consciência de sua trajetória acadêmica e política ${ }^{4}$, que não se resume ao fato de ter sido Ministro da Justiça do governo de Vichy. Nascido em Toulouse, é ali que realiza seus estudos, tendo como mestre Maurice Hauriou. Conclui seu doutorado em 1900, com uma tese de destaque em que já enuncia o que será uma das bases de seu pensamento (Essai d'une théorie des droits subjectifs des administrés dans le Droit administratif français). É aprovado na agregação em direito público em 1906, e começa a lecionar em Montpellier. Sua vasta produção acadêmica o destaca desde logo no meio dos constitucionalistas, e em 1913 é chamado à Faculdade de Direito de Paris, sucedendo no mesmo ano Adhémar Esmein na École libre des sciences politiques. Publica enormemente entre 1904 e 1920, período em que também se destaca na advocacia. Em 1919, candidata-se e é eleito para a Câmara dos Deputados como deputado do département de Gers, compondo o Bloc National, e fundando e presidindo o grupo de centro-direita Action républicaine et sociale.

Sua carreira acadêmica é então combinada com uma intensa e apaixonada carreira política, militando a favor de ideais liberais, como o sufrágio universal, incluindo o feminino, e a representação proporcional. Reelege-se para a segunda legislatura do entre-guerras, como "republicano de esquerda", e é vice-presidente da Alliance républicaine démocratique, um dos grandes partidos conservadores da época, que

\footnotetext{
${ }^{4}$ Cf. introdução de Jean Barthélemy e Arnaud Teyssier a BARTHÉLEMY, 1989 (pp. 19/29), SAULNIER, 2004 , pp. 125 e ss., MARTINEZ, 1998, pp. 30 e ss.

5 "Un républicain de gauche est un homme du centre que le malheur des temps oblige à siéger à droite", afirma Joseph Barthélemy, in BARTHÉLEMY, 1989, p. 23.
} 
contribui para a queda do Cartel des Gauches. Participa das delegações francesas na Liga das Nações em diversas oportunidades (1922, 1923, 1926, 1927). Contudo, Barthélemy não se reelege em 1932, e é derrotado também em 1936, quando inicia uma oposição aguerrida contra o Front Populaire, denunciando o que chama de antiliberalismo do governo em artigos jornalísticos, especialmente no jornal Le Temps, que administra.

Sua carreira tem seu ápice, como ele mesmo o reconhece em suas memórias $^{6}$, com a aceitação do posto de Ministro da Justiça (Garde de Sceaux) do governo de Vichy. Entre 26 de janeiro de 1941 e 27 de março de 1943, colaborou com o novo governo, elaborando um projeto de Constituição ou ainda assinando leis antissemitas ${ }^{7}$. Detido após a liberação, Barthélemy falece na prisão em 1945. A colaboração com o regime de Vichy é sem dúvida o grande fato associado ao nome de Joseph Barthélemy ${ }^{8}$. É também o que coloca a maior questão não apenas sobre o autor, mas sobre o pensamento liberal conservador do entre-guerras: como pode um liberal aderir a um governo autoritário? Barthélemy exemplifica de maneira ímpar a crise do liberalismo no pensamento constitucional e político, a impermanência da velha ordem e a necessidade de repensar o Estado e o direito diante da nova realidade social, questão de fundo que orienta

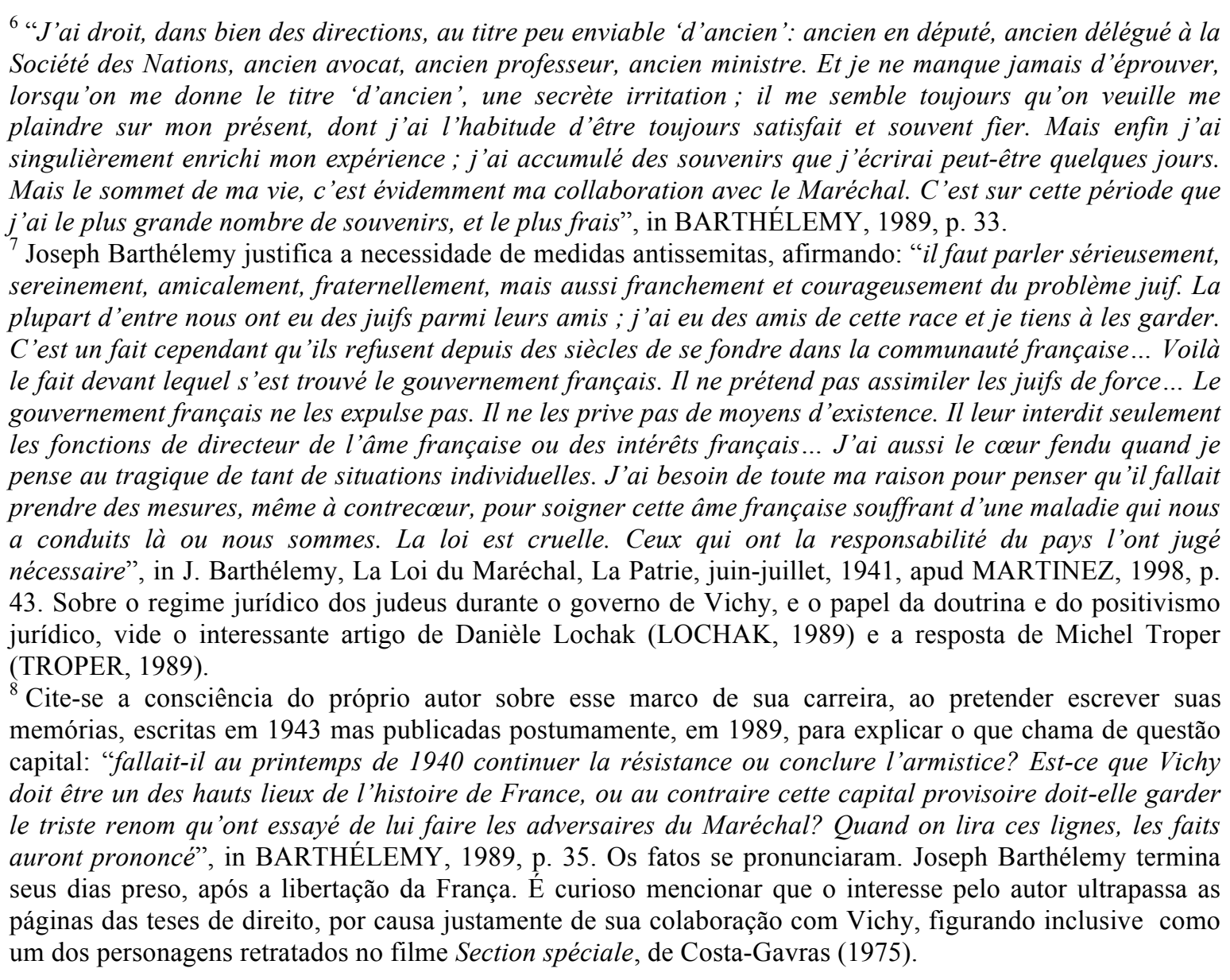


esse trabalho. Não se furtou em se posicionar, em se engajar, e coube à história pronunciarse sobre a sua escolha.

Esse item será dedicado à exposição panorâmica das principais ideias de Barthélemy, permitindo não apenas traçar um paralelo com os autores tratados no capítulo anterior, mas também compreender a transformação no pensamento constitucional de que o autor é testemunha e partícipe. Por certo, não será possível cobrir suas mais de sessenta obras e mais de uma centena de artigos publicados, e foi necessário selecionar alguns textos emblemáticos, sobretudo, de sua visão sobre a democracia, a Constituição e o direito, e da transição que ele sofre já nos anos 1930, com o progressivo abandono do liberalismo. Trataremos, especialmente, do pensamento exposto no Traité de Droit Constitutionnel, escrito com Paul Duez ${ }^{9}$ (primeira edição em 1926, e segunda em 1933, reeditado em 1983), bem como em seus ensaios sobre a crise da democracia (1928 e 1931) e em Valeur de la liberté et adaptation de la République (1935).

\subsubsection{Pragmatismo como método}

Barthélemy deixa clara sua intenção de propor uma nova abordagem ao direito constitucional, diferente da dos autores clássicos, ao afirmar, no prefácio da primeira edição de seu Traité de Droit Constitutionnel: "longe de nós a ideia presunçosa de pretender fazer melhor que nossos predecessores, nos é suficiente ter querido fazer de outra maneira"10. Mas qual seria essa nova maneira que Barthélemy propõe, e que o distingue dos autores abordados no capítulo anterior? A resposta está justamente na virada pragmática do direito constitucional, por ele defendida.

Já na conclusão de sua tese de doutorado, o autor recusava-se a buscar construir uma teoria universalizável do direito dos administrados perante à Administração, preferindo deixar um espaço para a política: “deve-se ter o sentido da evolução do relativo (...). O particular tem direitos, mas a coletividade tem os seus (...). O conflito de seus direitos com o dos administrados gera problemas complexos que se colocam todos os dias diante do Conselho de Estado. Aliás, parece-nos dificil chegar a uma definição jurídica absoluta dos direitos dos administrados (...). Um pouco de arbitrário será sempre

\footnotetext{
${ }^{9}$ Sobre a relação entre os autores na redação do Traité, escreve Beaud, a partir de sua análise da correspondência entre Barthélemy e Duez: "La correspondance entre les deux homes témoigne d'une véritable inégalité dans la répartition des tâches; Barthélemy a une tâche de conception, et Duez d'exécution", in BEAUD, 2000, p. 92.

${ }^{10}$ BARTHÉLEMY; DUEZ, 1926, p. 5.
} 
necessário nas engrenagens do mecanismo social" "1. A proposta de Barthélemy está justamente na aceitação dessa necessidade do direito de incorporar o arbitrário, abdicando da tentativa de compor uma teoria abstrata, universal e a-histórica. Dedica-se a refletir sobre um direito concretamente considerado, que atende a demandas reais e que se molda politicamente. Trata-se de um direito que carrega em si a possibilidade do movimento, o que pode ser paradoxalmente necessário para a manutenção da ordem em uma sociedade em profunda transformação como a do entre-guerras.

Ao comentar a originalidade de Barthélemy, Beaud ${ }^{12}$ ressalta que o jurista estava diante do desafio de renovar uma disciplina, o direito constitucional, já edificada em bases suficientemente sólidas e francesas pelos fundadores. Como construir uma abordagem do direito constitucional original? A resposta foi dada a partir do reforço do pragmatismo, da observação da realidade concreta, sem o peso da preocupação com um sistema teórico abstrato: "a originalidade do método constitucional exaltado por Barthélemy consiste em fundar a nova ciência do direito sobre a observação dos fatos politicos"13.

Barthélemy já vinha realçando a importância do método histórico, em oposição ao método exclusivamente jurídico de inspiração alemã, ao comentar as obras de Adhémar Esmein e Léon Duguit. Ele enfatiza, sobretudo, a força da observação da realidade concreta, especialmente política, na reflexão jurídica.

Em Esmein, o autor destaca o método histórico que o jurista clássico teria seguido, método esse que privilegiaria "a observação em primeiro lugar, o testemunho do bom senso em seguida, o apelo ao bom senso do leitor enfim" ${ }^{14}$, em detrimento de construções abstratas típicas dos juristas do direito público alemão ${ }^{15}$. Esmein

${ }^{11}$ BARTHÉLEMY, Joseph, Essai d'une théorie des droits subjectifs des administrés dans le Droit administratif français, pp. 196/197, apud SAULNIER, 2004, p. 122.

${ }^{12}$ Cf. BEAUD, 2000, pp. 98 e ss.

13 BEAUD, 2000, p. 100.

${ }^{14}$ BARTHÉLEMY, 1910, p. 185.

15 "Que l'on compare les écrits de ceux qui sont arrivés au droit constitutionnel par la grande route de l'histoire et de ceux qui y sont venus par les simples chemins du droit : et on verra surgir des différences tranchées. Celui qui n'est que juriste, s'efforcera tout d'abord de poser le principe premier auquel il pourra se rattacher ses déductions logiques, les légistes du droit public allemand s'emparent ainsi d'un postulat sur l'État, sur le Herrscher, sur le Souverain, et travaillent, dans des constructions dont l'ingéniosité séduit, à grouper tout autour l'ensemble de leurs développements. Pour l'historien, les idées et les principes ne sont que des produits; des produits naturels, inévitables, fatals de l'évolution de la conscience générale de l'humanité; ils s'offrent dès lors à lui comme des organismes vivants au naturaliste; il en recherche l'origine, en décrit la formation, en expose le développement. Pour l'historien, les principes qui doivent fixer l'attention et méritent l'analyse sont ceux en faveur desquels s'est produite l'adhésion du sentiment universel. Ces principes une fois dégagés, l'historien les soumet à l'épreuve de la conscience individuelle; ce n'est qu'en dernier lieu qu'il essaiera de faire partager au lecteur son sentiment individuel', in BARTHÉLEMY, 1910, p. 185. 
deve ser elogiado, segundo Barthélemy, por se esforçar em realçar a realidade da política, para além das teorias constitucionais, uma vez que o ideal do método histórico "é a crítica das instituições por seus resultados; seria preciso pesquisar a influência que elas exerceram sobre a prosperidade, a liberdade, a ordem e a tranquilidade da nação. A história política é o complemento necessário da história constitucional"16.

Nesse sentido, Esmein aproximar-se-ia da ciência inglesa, mais do que da alemã $^{17}$, o que, segundo Beaud, é válido também para Barthélemy, apesar do último reivindicar-se "no meio do caminho entre os cumes gelados da doutrina alemã e o positivismo concreto da doutrina anglo-americana, [onde] haveria lugar para um método constitucional propriamente francês. Ele não pode deixar de dar um espaço importante às outras doutrinas: soberania, representação, separação de poderes. Essas doutrinas tiveram um tal papel na formação da compleição constitucional do povo francês que deixá-las de lado seria desconhecer os fatos em si mesmos" "18. Trata-se de uma falsa simetria opor os dois métodos de pensamento, segundo Beaud ${ }^{19}$, e Barthélemy está muito mais próximo do pragmatismo inglês, não escondendo sua admiração por James Bryce, por exemplo.

Sobre Duguit, Barthélemy ressalta sua filiação ao que chama de "escola teórica" do direito constitucional, em oposição à "escola descritiva ou histórica", na medida em que está em busca da "verdade, de toda a verdade" 20 . Ao mesmo tempo em que "não se limita à descrição morta da obra dos constituintes - como jurisconsulto realista, ele [Duguit] a apresenta a nós como viva e ativa", o tratado de Duguit "abunda em teorias" 21 . Apesar de reconhecer a vantagem de admitir como fundamento de sua teoria o conceito de solidariedade que, como o de justiça, razão, moral ou honestidade, é relativo e varia conforme o tempo e o lugar, Barthélemy identifica uma inconsistência, um "furo", no pensamento de Duguit, que é justamente pretender que o fundamento da solidariedade, e de toda a sua teoria, seja a verdade científica.

"Há um salto no escuro para passar do fato ao direito; falta uma argola, a mais importante, talvez, na corrente de desenvolvimentos, há um furo na teoria (...).

\footnotetext{
${ }^{16}$ BARTHÉLEMY, 1910, p. 187.

17 "La sagesse, la modération, le sens pratique, le souci des transitions nécessaires, toutes les qualités, en un mot, dont on a voulu faire une sorte de monopole au profit des Anglais, sont la marque des solutions que professe le professeur E. aux problèmes les plus graves du droit constitutionnel", in BARTHÉLEMY, 1910, p. 188.

${ }_{18}^{8}$ BARTHÉLEMY; DUEZ, 1926, p. 7.

${ }^{19}$ Cf. BEAUD, 2000, p. 99.

${ }^{20}$ BARTHÉLEMY, 1908, p. 155.

${ }^{21}$ BARTHÉLEMY, 1908, p. 155.
} 
Tenho a convicção, com efeito, da inaptidão absoluta do raciocínio científico isolado para fundar a moral, o direito ou a justiça. Os filósofos à procura do fundamento metafísico da moral chegam, mais cedo ou mais tarde, a um momento em que são interrompidos por um

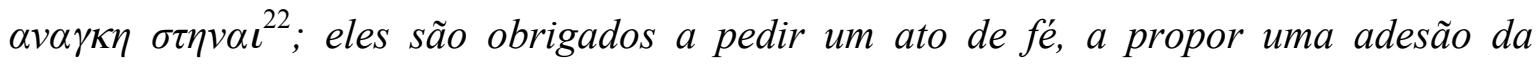
consciência, a formular um imperativo categórico. O propósito do esforço científico deve se contentar em recuar o máximo possível o momento em que se é reduzido, por falta de possibilidade de provar, a pedir a adesão da consciência" ${ }^{23}$. Daí classificar Duguit entre os adeptos do direito natural ao buscar um fundamento para o direito na solidariedade (" $a$ solidariedade é um fato (...). Por que os governantes devem favorecer esse fato em detrimento de algum outro? Por que os governados devem se conformar a essa regra em detrimento da lei homo homini lupus?"24). Apesar disso, concorda com a preocupação de Duguit de subordinar o exercício do poder político a regras jurídicas. Assim sendo, distancia-se da pretensão cientificista que flerta com a identificação de um fundamento quase metafísico, ou abstrato, para o direito, mas concorda com a tarefa do jurista de encontrar limitações jurídicas para o poder político. Já anunciava sua filiação pragmática, portanto.

Barthélemy faz referência, em suas obras, ao apego da doutrina à elegantia juris de suas construções, furtando-se a reconhecer o que seriam lacunas práticas, isto é, os pontos em que a teoria, apesar da coesão abstrata, deixa de responder concretamente às reivindicações que se apresentam perante o direito, tais como boa organização administrativa, medidas para o recrutamento administrativo, garantias de que a Administração cumprirá seus deveres, entre outros" ${ }^{25}$. "Joseph Barthélemy reivindica, assim, valores como o bom senso, o pragmatismo, o real, o 'terreno', em face de uma comunidade cientifica que, com suas especulações bastante sábias sobre o Estado de Direito, desliza cada vez mais nas rotinas metafísicas" se tornaria um leitmotiv daquele autor mencionar a "torre de marfim" na qual estão trancafiados alguns juristas ${ }^{27}$.

\footnotetext{
${ }^{22}$ Grosso modo, a expressão, do grego antigo, remete a uma espécie de necessidade de fundação, à criação de um fundamento para o pensamento para além do qual não se investiga, um ponto na especulação filosófica em que, para agir, é preciso se interromper, como a própria citação mencionada deixa claro. Agradeço a Marilia Lykaki, Gustavo Ribeiro e Tiago Tranjan pela colaboração na tradução.

${ }^{23}$ BARTHÉLEMY, 1908, p. 160.

${ }^{24}$ BARTHÉLEMY, 1908, p. 160.

${ }^{25}$ Cf. SAULNIER, 2004, p. 122.

${ }^{26}$ SAULNIER, 2004, p. 122.

${ }^{27}$ Escreve sobre Duguit, por exemplo, que "il ne faudrait pas croire d'ailleurs que M. D. reste impassible dans la tour d'ivoire de ses principes... ”, in BARTHÉLEMY, 1908, p. 156.
} 
Abandonando o recurso a "mitos", "ficções" ou "dogmas políticos", o jurista deixa de lado a pretensão de constituir uma doutrina nos moldes dos fundadores do direito constitucional, combatendo a tendência à "escolástica jurídica" que seria emblemática dos clássicos ${ }^{28}$. Ao defender um direito constitucional que se preocupe com a prática das instituições e a história política, torna evidente seu engajamento militante na construção de uma síntese entre esse ramo do direito e a política. Trata-se de uma mudança metodológica importante, que permite que o direito assuma um papel ativo não apenas na manutenção das instituições, mas também na sua transformação. E assim um autor que começa bastante cioso de sua convicção liberal pode vislumbrar uma mudança de posição, inclusive teórica, para a garantia da correlação de forças que originalmente estava protegida pelos valores liberais e que passa a ser ameaçada justamente com seu aprofundamento.

“Contrariamente à maior parte dos juristas de seu tempo, o direito não lhe parece um instrumento de resistência, mas um fator de movimento. À equação: os progressos do direito devem entravar a democracia ou coroá-la, ele apresenta, desde 1915, essa resposta penetrante: 'esquece-se com frequência que a concepção das relações jurídicas do Estado e dos particulares varia conforme nos encontremos sob a Monarquia absoluta, sob um regime constitucional ou enfim sob um regime democrático. Com a chegada definitiva da democracia republicana, deveria normalmente coincidir uma precisão maior dos direitos dos particulares perante o Estado, um progresso da submissão do Estado ao direito, o desenvolvimento das ideias de justiça - que é a consequência necessária do governo democrático - como, aliás, é a causa de seu estabelecimento' (...). Joseph Barthélemy sempre teve uma propensão pelo concreto. Esse temperamento explica, em parte, sua atração pela política, que vai conferir um caráter profundamente original à sua obra, uma vez que ciência e experiência serão nela intimamente misturadas, até o fundo",29.

Como consequência do método pragmático, temos um direito constitucional muito mais calcado na prática das instituições do que em seu fundamento teórico - daí Beaud afirmar que há um tipo de realismo constitucional implícito na teoria de Barthélemy ${ }^{30}$. Trata-se de um direito que abandona as preocupações com a teoria do Estado e com a teoria constitucional, características dos clássicos do capítulo anterior, e

\footnotetext{
${ }^{28}$ BEAUD, 2000, p. 100.

${ }^{29}$ SAULNIER, 2004, p. 123. O trecho citado é de BARTHÉLEMY, Joseph, Le principe de la réparation intégrale des dommages causés para la guerre (1915), pp. 57/58.

${ }^{30}$ BEAUD, 2000, p. 206.
} 
que é mais permeável, portanto, às constantes e aceleradas mudanças na prática jurídica e institucional. É o próprio autor quem declara os propósitos pragmáticos de sua teoria, afirmando que "em uma hora ao mesmo tempo tão grave e tão apaixonadamente interessante, em que nós vivemos, ficamos impressionados com a miséria de um pensamento que não fosse voltado à ação"31.

\subsubsection{Anos 1920:} sufrágio universal, democracia representativa e liberalismo

Seguindo sua proposta pragmática, que nomeia positivista e realista ${ }^{32}$, Barthélemy descarta investigações abstratas sobre o Estado, sua análise e sua definição teórica, opondo-se aos autores clássicos. Em postura significativa, inclusive diante da concepção contemporânea sobre o que deva ser um tratado de direito constitucional, afirma que "é em um tratado de direito público geral, melhor do que aqui, que uma teoria do Estado encontra seu lugar" "33. É sintético e simplista em seus propósitos, sustentando que pretendia "mais descrever o Estado do que o definir", para fornecer a singela descrição: " $a$ Estado é uma sociedade organizada, submetida a uma autoridade politica e ligada a um território determinado" "34. Assim, o capítulo sobre os elementos do Estado tem apenas cinco páginas em seu tratado de direito constitucional, contrastando com a proposta dos autores apresentados no capítulo 2 .

Preocupa-se, isso sim, com o princípio democrático, que, junto com o governo representativo, a separação de poderes e a supremacia da Constituição, compõe os princípios consagrados pelas leis constitucionais de 1875. Ao tratar da soberania no Estado (souveraineté dans l'État), sustenta que “o Estado não é senão uma abstração jurídica; são de fato os governantes que colocam em prática essa soberania. Mas quem devem ser os governantes no Estado? A quem essa soberania abstrata do Estado deve ser atribuida concretamente? O problema, destaquemo-lo, não é um problema de legitimidade jurídica, na medida em que quando o tivermos resolvido, o titular do poder de comandar não terá essa faculdade superior e metafísica que imprimiria a todos os seus atos um caráter legítimo ou justo. Ele deverá sempre se submeter ao direito e à justiça - a determinação do titular da soberania no Estado é uma questão ao mesmo tempo de fato, de

\footnotetext{
${ }^{31}$ BARTHÉLEMY; DUEZ, 1926, p. 7.

${ }^{32}$ BARTHÉLEMY; DUEZ, 1933, p. 88.

${ }^{33}$ BARTHÉLEMY; DUEZ, 1933, p. 284.

${ }^{34}$ BARTHÉLEMY; DUEZ, 1933, p. 284.
} 
oportunidade e de justiça" ${ }^{35}$. E com isso coloca o assento na questão da democracia, do sufrágio universal e do governo do povo por seus representantes.

Um pensamento voltado à ação conduz Barthélemy a uma defesa intransigente, nos anos 1920, da democracia e do sufrágio universal. Convicto da liberdade como um valor a ser preservado, o autor acredita nos postulados da democracia liberal. " $A$ democracia é o único governo conforme à razão. Com efeito, o essencial do ser razoável é que ele seja governado por ele mesmo e não pelos outros; ora, no governo democrático, todos são governados por todos, consequentemente, cada um é governado por cada um, de forma que o governo democrático é o mais conforme à razão" ${ }^{\text {"36 }}$. O voto é então um direito social que pertence ao indivíduo que, por sua vez, deve exercê-lo no interesse da sociedade - o voto é, portanto, um direito a exercer uma função ${ }^{37}-{ }^{38}$.

Assim como seus contemporâneos, Barthélemy observa um aumento no papel do Estado na economia e na sociedade, impulsionado também pela ampliação da participação popular na gestão do poder público. E o faz, zeloso do liberalismo econômico, portanto não sem desconfiança em relação a esse "espírito novo" 39 que toma conta do poder público e reorienta a ação estatal. Por outro lado, observa também parte da doutrina alertar para uma aparente incompatibilidade entre o sufrágio universal e o regime parlamentar.

Como destacamos no capítulo 1, especialmente no item 1.2.1, muitos juristas e teóricos da época já vinham falando em crise do regime parlamentar, confrontados com uma nova composição do Parlamento, produto da também recente

${ }^{35}$ BARTHÉLEMY; DUEZ, 1933, p. 52.

${ }^{36}$ BARTHÉLEMY, 1920, p. 16. O postulado é praticamente repetido oito anos depois: "Le propre d'un être raisonable est de se conduire lui-même; le système de la démocratie est celui dans lequel les citoyens se conduisent eux-mêmes ou par des répresentants qu'ils choisissent librement; donc il est le plus rationnel", in BARTHÉLEMY, 1928, pp. 586/587.

${ }^{37}$ BARTHÉLEMY, 1920, p. 17.

${ }^{38}$ Barthélemy não se dedica muito à polêmica que opõe o sufrágio como direito ou como função, em respeito ao seu método realista e prático, que recusa pretensões mais abstratas. "Joseph Barthélemy n'attribue qu'une mince importance à ce débat. Pour lui, cette querelle ne relève pas d'un choix 'originaire'. Elle est seulement le vêtement scolastique de la polémique qui oppose ceux qui, par sentiment sont partisans du suffrage restreint, à ceux qui penchent instinctivement en faveur de l'universalité. Pour lui, ce débat est donc 'dépourvu de sincérité fondamentale [et] dénué d'intérêt'. Pareil dédain pour les joutes théoriques classiques renforcent sa réputation d'auteur réaliste", in SAULNIER, 2004, pp. 355/356, citando BARTHÉLEMY, Joseph, L'organisation du suffrage et l'expérience belge (1912), p. 36.

39 "On peut dire que dans les peuples de l'Europe occidentale domine, à l'heure actuelle, la tendance à attendre de l'État une amélioration de la situation économique du plus grand nombre. C'est ce qu'on appelle en gros la tendance socialiste (...). Mais on ne peut nier que cette orientation législative nouvelle ait été brusquement précisée et accélérée par la généralisation du suffrage [qui] (...) a imprégné tous les pouvoirs publics d'un esprit nouveau, leur a inspiré la préoccupation d'intérêts qui jusque-là avaient été en quelque peu négligés", in BARTHÉLEMY, Joseph, Démocratie et politique étrangère. La démocratie et la diplomatie. La démocratie et la guerre. La démocratie des nations (1918), p. 374, apud SAULNIER, 2004, p. 348. 
democracia de massas. Alguns se apressam em condenar o sufrágio universal pela "decadência" da representação parlamentar, e em até mesmo louvar o que viam como benefícios de um regime censitário. Para esses autores, "a incompetência dos representantes, sua dependência perante os eleitores e, mais genericamente, a transformação do governo em um jogo agitado e por vezes estéril datam da chegada brutal das massas em uma mecânica delicada que, na origem, não tinha outro objetivo senão promover a colaboração entre o rei e a burguesia" ${ }^{\text {40 }}$. Assim parte da doutrina critica o regime parlamentar, a incompetência dos representantes, a imperícia dos legisladores, a futilidade dos temas tratados no Parlamento, enfim, a nova feição da democracia francesa.

Barthélemy, contudo, em princípio não compartilha dessas críticas e, especialmente, das consequências reformistas que delas decorrem. Pelo contrário. A partir de sua crença na abordagem pragmática das instituições e do direito constitucional, adota uma posição menos conservadora diante do sufrágio universal, o que lhe valeu até mesmo elogios do campo da esquerda. Ele apressa-se em defender o regime parlamentar e democrático como uma evolução histórica, como um fato social, quase como uma força da natureza ou como uma fatalidade, nos dirá Saulnier ${ }^{41}$. "Compreender-se-ia imperfeitamente o alcance das disputas em torno do sufrágio universal se se enxergar nelas outra coisa que não a luta das forças sociais. A batalha pelo sufrágio universal é um episódio do assalto das classe novas contra a burguesia, detentora do poder político (...). A concessão do sufrágio a todos não era senão a tradução jurídica de um fato social, o poder que tinha conferido às massas operárias a consciência da força da maioria numérica" ${ }^{42}$.

A democracia liberal e representativa deve ser preservada e defendida não apenas como um fato, mas também como um símbolo da evolução das civilizações: “um povo é tanto mais civilizado quanto mais ele sente a necessidade de se governar a si mesmo, e quanto mais ele também tem direito a se governar a si mesmo. Eu digo ainda que o dever dos governantes é de conduzir os povos na direção de sua maioria. E eu concluo enfim que a liberdade democrática é o regime dos povos maiores" ${ }^{\text {"43 }}$. Essa defesa

\footnotetext{
${ }^{40}$ SAULNIER, 2004, pp. 348/349.

${ }^{41}$ Cf. SAULNIER, 2004, pp. 353 e ss.

42 BARTHÉLEMY, Joseph, L'organisation du suffrage et l'expérience belge, pp. 749/752, apud SAULNIER, 2004, p. 354.

${ }^{43}$ BARTHÉLEMY, 1928, pp. 666/667.
} 
da racionalidade do sufrágio universal fez de Barthélemy um dos apoiadores da ampliação do direito de voto às mulheres, inclusive ${ }^{44}$.

O sufrágio universal é um fato, portanto, mas um fato que coloca novos desafios aos liberais, sobretudo diante da incorporação das demandas populares ao jogo político-institucional. Como uma abordagem pragmática do direito deve lidar com essa nova realidade, de forma a preservar antigos arranjos? Ou ainda, qual a utilidade do sufrágio universal que torna desejável preservar a democracia representativa a partir de uma defesa tão apaixonada?

Barthélemy é direto: "a lição dos fatos é que o sufrágio universal é a grande força estática, conservadora da era moderna. Na Alemanha, o referendo repeliu o confisco dos bens dos príncipes ${ }^{45}$. Na França, suas oscilações são insignificantes, ele avança em um movimento lento e contínuo. Um dos chevau-légers ${ }^{46}$ da Assembleia nacional, M. de Belcastel, dizia que o sufrágio universal é a 'fonte impura mas única do poder'. Para um povo maior, é também a única fonte legítima" ${ }^{\natural 7}$. Ou seja, para o autor, o sufrágio universal pode funcionar como um mecanismo de conservação da ordem, na medida em que cumpre uma função de integração das classes populares ao jogo político, garantindo que as tensões e conflitos sociais tenham um espaço, um canal aberto, onde possam se exprimir com regularidade, e institucionalizando os antagonismos outrora anárquicos e dispersos. Nada mais direto do que o trecho citado por Sauliner, ao comentar a posição de Barthélemy em relação à incorporação do povo às disputas institucionais propiciada pela nova democracia: “a partida está então perdida pela burguesia? Na verdade, não, já que 'a batalha pelo sufrágio universal é um episódio do assalto das classes novas contra a burguesia detentora do poder politico. Mas em um regime de sufrágio generalizado, a burguesia não renunciou - e eu não peço dela uma nova noite de

\footnotetext{
${ }^{44}$ Vide BARTHÉLEMY, 1920.

${ }^{45} \mathrm{O}$ autor refere-se, aqui, à proposta de confisco sem indenização dos bens dos príncipes, inicialmente proposta pelo KPD (Partido Comunista Alemão) em 1925. No referendo, realizado em 1926, a esmagadora maioria votou favoravelmente à proposta, atendendo à campanha dos partidos e movimentos de esquerda. Contudo, apesar da expressiva participação popular, o quórum de $50 \%$, que havia sido exigido por uma manobra parlamentar do presidente Paul von Hindenburg, não foi atingido e a medida fracassou. A opinião de Barthélemy de que o fato exemplifica o caráter conservador do sufrágio universal em si é questionável, na medida em que o sucesso e a grande mobilização favorável à proposta de confisco poderiam indicar, da mesma forma, a força transformadora do sufrágio e da participação política.

${ }^{46}$ Literalmente, "cavalo-leve", mas a expressão refere-se genericamente a uma das unidades de cavalaria francesa da época das guerras napoleônicas, conhecida como cavalaria ligeira.

${ }^{47}$ BARTHÉLEMY, 1928, p. 666.
} 
4 de agosto $^{48}$ - a burguesia não renunciou a exercer uma ação preponderante e mesmo diretiva" ${ }^{\prime 4}$.

"Os conflitos passam da rua ao fórum (...). A conservação pelo progresso. Tal poderia ser o lema de Joseph Barthélemy. É preciso ter inteligência no momento em que se deve abrir a porta para que o povo se encarregue de arrombá-la. É, aliás, por não ter meditado sobre esse axioma que a monarquia de Julho pereceu. $O$ sufrágio universal é uma falsa revolução que evita a verdadeira revolução. É nesse espirito que Joseph Barthélemy preconiza sua consagração definitiva" ${ }^{\text {"50 }}$. Não se trata, portanto, de tentar frear ou reverter o movimento que altera o jogo de forças político com a ampliação da participação democrática, mas sim de tentar formatá-lo de modo a assegurar que não interfira com os princípios liberais e com a distribuição de papéis sociais, ou seja, buscando conter excessos, aceitando a mudança para garantir que ela não implique em transformação radical.

Nesse sentido, sua defesa intransigente do individualismo, como herança da Revolução Francesa, que opõe Estado e indivíduo abstrato, refutando a consideração de grupos intermediários - tais como associações ou sindicatos - como atores políticos a serem reconhecidos. Daí sua hostilidade em relação às visões, que lhe são contemporâneas, que buscam considerar o homem situado, a nação como um conjunto não de indivíduos, mas de relações de produção, de trabalho ou de atividades diversas, visões das quais decorrem propostas como a representação de classes ou de interesses, como aparece em Duguit $^{51}$. Daí também sua recusa ao corporativismo, que, segundo ele, é sempre acompanhado por alguma forma de ditadura, afirmando: "parece-me, entretanto, que o corporativismo tem sobretudo como objeto mascarar a supressão das liberdades políticas $"$ "52.

As ditaduras e os regimes de supressão das liberdades são repudiados por esse liberal dos anos 1920, na medida em que "nascem de um mal-estar do Estado, da

\footnotetext{
${ }^{48}$ Referência a 4 de agosto de 1789 , data da abolição dos privilégios pela Assembleia da Revolução Francesa.

${ }^{49}$ SAULNIER, 2004, p. 112, citando BARTHÉLEMY, Joseph, L'organisation du suffrage et l'expérience belge, p. 7.

${ }^{50}$ SAULNIER, 2004, pp. 358/360.

${ }^{51}$ Vide por exemplo sua crítica ao fascismo, ao afirmar que "le fascisme prétend remplacer la conception démocratique des droits des individus para la conception nouvelle des droits des syndicats : le citoyen fait place au producteur (...). L'individu doit céder sa place au syndicat", para concluir que "c'est par cet étouffement de la pensée que le fascisme répugne le plus profondément au tempérament traditionnel du peuple français", in BARTHÉLEMY, 1928, pp. 602 e 608.

${ }_{52}$ Joseph Barthélemy em prefácio a JOLLY, 1935, p. XII.
} 
desordem nos espíritos e nas coisas, da carência de um mínimo de autoridade",53. A democracia representativa, contudo, supõe, segundo ele, um estado de equilíbrio, que não está livre de oscilações. O período é cenário dessas oscilações que sustentam um diagnóstico de crise da democracia. Está olhando, em 1928, especialmente para a Rússia, para a Itália e para a Espanha, onde a democracia parlamentar, segundo ele, está em recuo, chegando a falar em uma "febre mediterrânea das ditaduras" " 54 . Nossos pais fizeram revoluções em série; eles derramaram seu sangue pela democracia, o regime representativo e o sistema de assembleias. Seria grave que a opinião francesa perdesse a fé na República constitucional (...). Aliás, o ceticismo em relação às instituições existentes não se completa por aquilo que poderia ser seu corolário: a adesão a um outro regime (...). O desejo de uma 'outra coisa' não é para todos um 'não importa quem'

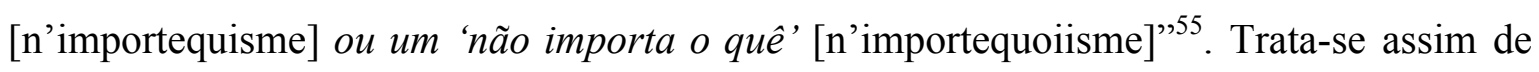
um autor em busca de uma maneira de preservar a democracia liberal, "salvando-a" de suas crises a partir de soluções vinculadas ao direito constitucional.

A primeira delas é reforçar o papel do chefe, de uma liderança, dentro do regime parlamentar ${ }^{56}$. Também nesse sentido a crítica ao voto aberto (público) dos deputados, bem como à possibilidade de reeleição, o que torna os representantes mais submissos aos interesses particulares de seu eleitorado. O jurista identifica ainda uma crise dos partidos, especialmente ilustrada pela recusa do partido socialista a engajar-se em governos com os quais não concordasse ${ }^{57}$. Sugere a necessidade de revisão da forma dos debates no Parlamento, tornando mais eficiente sua atividade legislativa de modo a responder ao novo modelo de Estado em construção ${ }^{58}$. Por fim, trata do que chama de "perigo sindicalista": Barthélemy não pretende lutar contra uma realidade concreta, que é o fortalecimento dos sindicatos, mas entende que é preciso conter o abuso do sindicalismo,

${ }^{53}$ BARTHÉLEMY, 1928, p. 589.

${ }^{54}$ BARTHÉLEMY, 1928, p. 592.

${ }^{55}$ BARTHÉLEMY, 1928, p. 629.

${ }^{56}$ Cf. BARTHÉLEMY, 1928, pp. 631 e ss.

57 "Le parti socialiste - et c'est peut-être une responsabilité qui lui est légère - a contribué de 1924 à 1926 à fausser le régime. Il a prétendu à être un élément composant de la majorité, à en être même le facteur dominant et il a refusé d'accepter de participer au gouvernement (...). Bien des socialistes à l'heure actuelle se rendent compte que l'heure est venue de descendre au milieu des réalités qui ne se plient pas facilement aux volontés a priori des hommes", in BARTHÉLEMY, 1928, pp. 636.

58 "Les séances sont nombreuses parce que les lois elles aussi se multiplient; et à leur tour, les lois se multiplient parce que les besoins auxquelles elles répondent se multiplient également. Les fonctions de l'État sont devenues infiniment complexes; il n'est plus seulement législateur, juge et gendarme; il est devenu hygiéniste, il est devenu paternel; il vielle à la santé publique, il lutte contre la maladie, la vieillesse, la misère, contre toutes les faiblesses et contre toutes les infériorités de l'homme. Toutes ces fonctions se traduisent par des réglementations nouvelles ; ces réglementations par des lois", in BARTHÉLEMY, 1928, pp. 647/648. Nesse sentido, compara o Parlamento a uma usina construída antes da guerra, que precisa ser remanejada e reconstruída para fazer face a um crescimento vertiginoso da demanda (p. 650). 
afirmando que "há regras essenciais sem as quais as sociedades políticas, incapazes de viver, seriam condenadas a vegetar em uma completa anarquia (...). É urgente reconstituir nesse país a concepção, extraída da Constituinte, de que a nação é soberana, de que ela delega o exercício da soberania às Câmaras e ao governo, e que os funcionários são servidores (...). Aos agrupamentos será admitido emitir sua voz, não ordens" ${ }^{\text {"59 }}$.

Barthélemy aparece, assim, como um autor que se alia aos liberais, mas não de uma maneira facilmente classificável como conservadora. Enxerga na encampação das ideias de sufrágio universal e de democracia representativa a única maneira de preservar seu liberalismo, a partir de uma proposta mais pragmática em relação ao Estado e ao direito, que pode se assumir como fator de movimento, de promoção de mudança. Mas não qualquer movimento, mas sim aquele direcionado aos objetivos que julga corretos, notadamente a garantia da liberdade. "Nossas conclusões são claras. O exame dos fatos e o estudo da crise nos confirma em nossas doutrinas democráticas e liberais. A liberdade tem seus inconvenientes e seus perigos, mas ela continua sendo a melhor garantia dos interesses sociais; os governos têm necessidade de serem resistidos, de terem seus erros, suas negligências e seus desajustes continuamente denunciados" ${ }^{" 60}$. Por isso vincula-se à ideia clássica de democracia política, que assegura a liberdade formal e permite que " $O$ povo se atribua a si mesmo seus próprios beneficios" "61, em oposição às tentativas que lhe eram contemporâneas de recolocar o problema em termos de democracia social, focada na igualdade econômica material e concreta, em que, segundo ele, os benefícios viriam do alto. O indivíduo abstrato e sua liberdade estão no centro de seu pensamento, aceitando as mudanças de sua época, mas apenas de acordo com um esquema que, pragmaticamente, entende ser melhor para a preservação do status quo burguês.

É justamente em razão de sua defesa da democracia liberal que, curiosamente, o francês nos conta, como conclusão de seu longo artigo de 1928 sobre a crise da democracia representativa, uma pequena história sobre o conde de Cavour, o liberal que ocupou o posto de Primeiro Ministro com a unificação da Itália. Um deputado teria confrontado o conde italiano: "Ah! Sua tarefa seria mais fácil sob um regime absoluto!", ao que Cavour teria respondido "Você esquece que, sob um regime absoluto, eu não teria querido ser ministro, e, aliás, eu não teria podido me tornar ministro. Eu sou o que sou porque eu tive a sorte de ser um ministro constitucional... O governo

\footnotetext{
${ }^{59}$ BARTHÉLEMY, 1928, pp. 639 e 641.

${ }^{60}$ BARTHÉLEMY, 1928, p. 665.

${ }^{61}$ BARTHÉLEMY; DUEZ, 1933, p. 62.
} 
parlamentar tem seus inconvenientes, como todos os outros governos, mas é, contudo, o melhor. Eu posso me impacientar com certas oposições, repudiá-las com vivacidade, mas, refletindo sobre isso, eu felicito-me de ter que combatê-las, porque elas me obrigam a explicar melhor minhas ideias, a redobrar os esforços para convencer a opinião geral. Um ministro absoluto comanda, um ministro constitucional tem necessidade de persuadir para se fazer obedecer. Ora, eu quero persuadir a todos de que tenho razão. Creia-me: a pior das Câmaras é preferível à melhor das antecâmaras" $" 62$.

\subsubsection{O direito, a Constituição e a defesa da Terceira República}

Joseph Barthélemy dedica boa parte da sua obra dos anos 1920 e início dos anos 1930 à defesa da Terceira República e de suas instituições, especialmente de sua Constituição. É com muita reticência que assiste aos projetos de reforma constitucional, ao que só vai se mostrar mais flexível a partir de meados de 1933, em razão do adensamento e da inevitabilidade da tendência. Mas o jurista, em sua obra, distribui elogios ao modelo constitucional francês, entendendo que a melhor posição para os liberais como ele seria buscar preservá-lo.

Sua defesa da Constituição, que, vale lembrar, era bastante sintética e compunha-se de leis regulamentando competências, a organização dos poderes e a relação entre eles, era também uma defesa da supremacia do direito sobre a política. A posição do autor já estava marcada desde sua tese de doutorado, em que sustentava a necessidade de responsabilização jurídica dos funcionários públicos, ampliando a possibilidade de interessados valerem-se do recurso por excesso de $\operatorname{poder}^{63}$.

A democracia, segundo ele, é caracterizada pela superioridade da Constituição, aspecto fundamental da "religião do Direito"64. A Constituição é a norma fundamental, acima dos poderes, que organiza a democracia, e sua supremacia só pode ser limitada pelo estado de necessidade e pela resistência à opressão. Assim, as leis constitucionais de 1875, tais como uma "religião sem dogma" 65 , consagram os princípios fundamentais que para ele devem ser mantidos na base da República, especialmente por serem escritas e rígidas, bem como por serem enxutas e sintéticas. Vale lembrar que um

\footnotetext{
${ }^{62}$ BARTHÉLEMY, 1928, p. 663.

${ }^{63}$ Recours pour excès de pouvoir, grosso modo, uma espécie de correspondente francês do mandado de segurança, processado perante a jurisdição administrativa.

${ }^{64}$ BARTHÉLEMY; DUEZ, 1933, p. 183.

${ }^{65}$ BARTHÉLEMY; DUEZ, 1933, p. 49.
} 
dos temores de Barthélemy em relação aos projetos de reforma constitucional era justamente a questão: qual reforma? "Nós vivemos um período bem interessante, mas ele o é mais pelo fervilhar do que pela clareza das ideias" ${ }^{" 66}$. Olhando para o exemplo de Weimar, vê riscos, e conclui: "essa experiência fortifica nosso vínculo à nossa constituição prática e "pedestre" ${ }^{\prime 67}$.

Não descarta a existência de regras superiores, especialmente à medida que a realidade se transforma em ritmo acelerado. A primeira delas, como visto, é a liberdade individual. Mas isso não significa que vá construir a partir daí uma teoria do direito abstrata ou metafísica, que flerte com o direito natural: "qualquer que seja nosso profundo vínculo com os princípios da liberdade política, nós estimamos que eles são produto da oportunidade política, mais do que da técnica jurídica"68.

No mesmo sentido, de acordo com a sua percepção, não haveria nenhuma característica intrínseca ao princípio da legalidade que implicasse, desde antemão, restrição à ação parlamentar. "A questão da legalidade deve ser cuidadosamente distinguida de um problema vizinho: aquele dos limites jurídicos que se impõem ao parlamento na confecção da lei, problema oriundo da filosofia jurídica, que apela à existência de um direito superior à lei. O problema da legalidade é mais pé no chão [terre à terre], na medida em que concerne simplesmente à obediência à lei editada, já feita. A partir daí, a ideia de legalidade não carrega em si mesma nenhum limite à ação do parlamento na elaboração de regras de direito" ${ }^{\text {"9 }}$. A legalidade, segundo ele o princípio fundamental da liberdade moderna ${ }^{70}$, determina a submissão de todos às regras juridicamente válidas, que não são definidas segundo critério formal, de fácil aplicação mas contrário à realidade. Os atos normativos são definidos segundo seu conteúdo, na medida em que apresentarem as características de generalidade e permanência e de obrigatoriedade, imperatividade, e é a partir da deliberação sobre ele, política, que assumem força obrigatória. Ademais, são legítimos, para ele, nesse momento, de acordo com sua fonte, ligada às instituições da democracia liberal.

A preocupação fundamental de Barthélemy é em analisar experiências concretas - daí fazer referências constantes à realidade de outros países, como os EUA, a Suíça ou a Alemanha -, mostrar dados, apresentar soluções que lhe parecessem tanto

\footnotetext{
${ }^{66}$ BARTHÉLEMY; DUEZ, 1933, p. 903.

${ }^{67}$ BARTHÉLEMY; DUEZ, 1933, p. 902.

${ }^{68}$ BARTHÉLEMY; DUEZ, 1933, p. 37.

${ }^{69}$ BARTHÉLEMY; DUEZ, 1933, p. 193.

${ }^{70}$ BARTHÉLEMY; DUEZ, 1933, p. 726.
} 
politicamente condizentes com as premissas liberais quanto juridicamente eficientes. Tal é o caso, por exemplo, do referendo. E a Constituição francesa é um exemplo de carta adaptada e adaptável, produto da história e duradoura, que merece ser louvada e preservada. "A Constituição saiu lentamente, laboriosamente, da força das coisas, da necessidade histórica, das entranhas mesmas da realidade (...). E se ela pôde durar tanto tempo, é preciso crer que ela é particularmente adaptada às nossas necessidades" "71. Por isso seu apego a ela, e sua demora em participar dos debates sobre a reforma constitucional.

Em razão da importância que confere à Constituição, o francês é de certa forma seduzido pela ideia de um controle de constitucionalidade, que seria uma solução interessante não fosse pela contaminação do judiciário francês pela política ${ }^{72}$. " $A s$ garantias contra a opressão parlamentar, no estado atual de nossos costumes, não devem ser nas exceções de inconstitucionalidade perante os tribunais. É preciso organizar o Parlamento de maneira a reduzir a um mínimo as chances de aparecimento de leis inconstitucionais e a desenvolver o espírito de legalidade em seu seio: um bicameralismo sincero, a reforma do regulamento interno, o recurso ao referendo, nos parecem preferiveis, para esse propósito, a uma arma muito pesada, colocada nas mãos de um poder excessivamente fraco para poder manejá-la com certeza e segurança"73.

Estrategicamente comprometido com a democracia liberal e com o sufrágio universal, e politicamente vinculado à preservação da ordem social, rejeitando transformações profundas, Barthélemy faz da Constituição de 1875 sua aliada, ainda que provisória, ressaltando a supremacia do Estado de direito e da ordem sobre a política. "Em definitivo, o pensamento que se destaca para a próxima época (...) é o de um regime democrático, liberal, representativo e parlamentar: qualquer coisa como a Monarquia de Julho [de 1830] apoiada sobre o sufrágio universal. E foi a concepção que finalmente triunfou na elaboração constitucional de $1875^{, 74}$. É com isso que conclui pela necessidade de manutenção da Constituição, já que "uma das mais eminentes qualidades do nosso organismo constitucional é sua maleabilidade, sua capacidade de adaptação ao meio, sua aptidão para atravessar as circunstâncias mais difíceis (...). As molduras constitucionais,

\footnotetext{
${ }^{71}$ BARTHÉLEMY; DUEZ, 1933, p. 44.

72 "La politique au prétoire est une chose détestable”, BARTHÉLEMY; DUEZ, 1933, p. 226.

${ }^{73}$ BARTHÉLEMY; DUEZ, 1933, p. 226

${ }^{74}$ BARTHÉLEMY; DUEZ, 1933, p. 48.
} 
quaisquer que sejam, não duram senão graças ao equilibrio de interesses, e na medida em que não agem por empurrões exageradamente veementes" ${ }^{\prime 75}$.

Assim, mantém-se na defesa das instituições diante de uma doutrina que recorrentemente menciona crises, inquietudes, incertezas, e de uma realidade política concreta que assistia à veloz sucessão de gabinetes e à dificuldade na composição de maiorias duradouras e coesas. Reitere-se: trata-se mais de uma estratégia pragmática do que verdadeiramente de uma preservação da coerência de sua teoria constitucional como jurista. "De fato, Joseph Barthélemy não adota a abordagem de um constitucionalista em relação à instabilidade governamental. Ele minimiza sua importância, 'desdramatiza' [dédramatise] o fenômeno, porque ele o vislumbra mais com os olhos de um homem que, por ter se misturado à política, viu todos os dias que ela não entravava a marcha do Estado" $" 76$.

\subsubsection{Anos 1930: a transformação de um liberal ameaçado}

"É, concordo, um contraditório destino aquele de um homem que, toda a sua vida, defendeu a liberdade, e que estreou no governo em um regime autoritário, que submeteu a liberdade ao eclipse mais completo que conheceu em séculos. Mas eu pergunto a todo homem de boa-fé se seria possivel salvar o país e a sociedade nesse terrivel periodo de crise com os métodos dos tempos de paz e de prosperidade. Meu papel consistiu em tentar salvar tudo aquilo que podia ser salvo, em impor à 'pessoa humana' somente os sacrificios exigidos pelas circunstâncias. Eu expus esses princípios perante o Conselho de Estado, na presença do Marechal. Eu critiquei o gosto da ilegalidade pela ilegalidade (...). Eu nunca permiti que essas afrontas à liberdade e à legalidade fossem consideradas como a aplicação de uma doutrina, mas, ao contrário, como medidas de exceção exigidas pelas circunstâncias e justificadas somente por essa exigência" ${ }^{77}$. Essas são as palavras com as quais Barthélemy tenta justificar sua trajetória, mais uma vez explicitando sua postura intelectual e política pragmática e, de certa forma, sua flexibilidade em aderir a teorias de ocasião, desde que condizentes com seu compromisso com a manutenção da ordem social. É claramente um testemunho de um liberal que se sentiu ameaçado em suas convicções pelo clima político e social, e que transformou seu pensamento - o que se deu, é justo

\footnotetext{
${ }^{75}$ BARTHÉLEMY; DUEZ, 1933, p. 900.

${ }^{76}$ SAULNIER, 2004, p. 408.

${ }^{77}$ BARTHÉLEMY, 1989, p. 34.
} 
dizer, anos antes de sua adesão ao governo de Vichy. E que, assim, abandona seu liberalismo clássico para mostrar-se flexível a teorias, diríamos, menos democráticas, no sentido que vinha atribuindo ao termo.

Alguns autores debatem sobre qual o exato momento em que ele “atravessou o Rubicão", como coloca Saulnier, que sugere o ano de $1935^{78}$, que é a data de publicação de Valeur de la liberté et adaptation de la République. É o ano, também, em que participa da criação de um comitê técnico para a reforma do Estado, "que elabora um projeto estabelecendo uma verdadeira separação de poderes e organizando um poderoso poder judiciário" 79 . Antes disso, em 1934, já havia escrito um artigo apoiando o projeto de reforma constitucional de Gaston Doumergue, que se tornou naquele ano presidente do Conselho de Ministros. O fato é que a virada de Barthélemy não é apenas uma transformação pessoal, trata-se de um momento de mudança geral do cenário político, social e econômico francês.

Como visto no capítulo 1, já em 1932 a crise econômica dava sinais de que o otimismo e o florescimento dos anos 1920 seriam deixados para trás, abrindo uma época de desemprego e dificuldades financeiras e sociais. São "les années tournantes", os anos da virada, em que a antiga fé na capacidade integradora da democracia e do sufrágio universal começava a ruir no campo da direita e do centro liberal.

Barthélemy se mostra ainda incerto quanto à revisão constitucional, mas, especialmente, temeroso do que pode resultar dos distúrbios da massa de eleitores, "que pouco se interessa pelas questões de técnica constitucional (...), sofre de desordem e teria uma certa tendência, se ela [a desordem] se perpetuar, a se alinhar a toda medida que colocasse fim nela" ${ }^{\prime 0}$, especialmente diante do marasmo econômico, do desemprego, da incerteza, enfim, do cenário francês de 1934. "Nossa época se caracteriza pela agitação de todas as colunas do templo do bom senso. Certo, havia utópicos em qualquer tempo, mas eles eram menos perigosos quando ficavam na margem. Hoje, eles estão no poder ou perto do poder $" 81$. Por isso, aceita discutir a reforma constitucional proposta. Mais tarde, vai escrever, sobre sua mudança de posição: "não fui eu quem mudou, foram as circunstâncias" ${ }^{\prime \prime 2}$.

\footnotetext{
${ }^{78}$ SAULNIER, 2004, p. 488.

${ }^{79}$ BARTHÉLEMY, 1989, pp. 26/27 (introdução).

${ }^{80}$ BARTHÉLEMY, 1934, p. 227.

${ }^{81}$ BARTHÉLEMY, 1934, p. 229.

${ }^{82}$ BARTHÉLEMY, 1935, préface, p. V. Exemplifica metaforicamente sua postura: "Un père de famille possédait une automobile ancienne avais fort bien construite, où l'on poucait entrer sans être contraint de se coucher. Cependant les enfants la troivaient fort démodée et le pressaient d'en changer. Le père résista
} 
Procura, nesses termos, limitar o papel que vinha sendo cogitado para o Conselho Nacional Econômico, restringindo-o a figura meramente consultiva. Isso porque queria evitar o avanço em direção a um Estado mais e mais interventor, sob a sombra do corporativismo. Em suas palavras: "flutua, na atmosfera política, todo um sistema de nebulosidade: quer-se reconstruir o Estado no plano econômico, pretende-se criar o Estado corporativo, pensa-se em integrar o sindicalismo no Estado, está-se pronto para substituir as Câmaras pelos ateliês etc. É possível que o presidente do Conselho tenha querido fazer sacrifícios à moda do dia (...). Quero que exista um órgão de consulta (...). Mas ir além, elaborar em face do Parlamento político um Parlamento rival, não dotado apenas de um poder de aconselhamento, seria ruim. Seria criar a desordem. $O$ Parlamento econômico não fará nada, ou fará mal" 83 . Assim reafirma sua adesão ao individualismo. Pede ainda o reforço da autoridade governamental, do Executivo, e a centralização do controle das despesas.

Mas a chegada ao poder do Front Populaire, em 1936, potencializa sua frustração com o regime democrático tal como praticado e com suas consequências. "Para alguns, a vitória do Front Populaire nas eleições seguintes constitui uma fonte suplementar de exasperação. Para esses pessimistas, ela é um tipo de declaração de guerra à razão, ao bom senso, um impulso a mais na engrenagem que conduziu à crise de todos os valores clássicos. Joseph Barthélemy faz parte desse grupo dos angustiados. Como Tardieu, ele vê no Front Populaire 'a expressão terminada da mentira democrática" ${ }^{\circ 4}$. E assim passa a não apenas denunciar o que entende como riscos à democracia liberal, mas também a defender a existência de princípios superiores, que constituem o fundamento moral do Estado - notadamente o indivíduo e a liberdade, que associa à tradição da Revolução Francesa - e que limitam a amplitude sobre a qual pode deliberar a maioria democraticamente eleita. "Ele pertence a essas elites que a irrupção das massas na sociedade derrota", afirma Saulnier ${ }^{85}$, um liberal que se vê ameaçado e instado a relativizar sua crença na democracia e no sufrágio.

longtemps. Mais un jour, la voiture fit sentir, dans les côtes, de dangereuses hésitations. Les enfants étaient près de triompher. On allait avoir une voiture neuve. Le père décida seulement qu'on procéderait à une revision d'usine. Je suis un revisionniste dans le genre de ce père de famille prudent. Je reste plein d'admiration pour le mécanisme constitutionnel à base d'esprit pratique, de sagesse, de modération, de compromis, que nous a légué l'Assemblée Nationale. Mais je ne saurait pas prétendre que chacun de ses rouages le plus secondaires a été construit dans la perfection et qu'il y est resté. Je ne suis pas intransigeant que sur les principes. En matière politique, j'ai une croyance: la démocratie ; j'ai une foi : la liberté; j'ai une religion : la patrie", in BARTHÉLEMY, 1935, préface, pp. V/VI.

${ }^{83}$ BARTHÉLEMY, 1934, pp. 232/233.

${ }^{84}$ SAULNIER, 2004, p. 475.

${ }^{85}$ SAULNIER, 2004, p. 485. 
Qualificando o Contrato Social, de Rousseau, como um "evangelho de opressão" "86 Barthélemy sustenta que "é preciso afirmar um direito superior à vontade em si da maioria (...). Nós cremos, com a Revolução Francesa e com a Declaração de Direitos, que há princípios superiores, cuja realização varia conforme o país, a época, o povo, mas que constituem um ideal, que o legislador ele mesmo não saberia violar" ${ }^{\prime 87}$. As liberdades individuais não existem sem democracia, mas o problema de que trata decorre da constatação de que, segundo ele, pode haver democracia sem liberdades individuais. A liberdade é o valor básico a ser preservado, a liberdade como uma oposição à intervenção do Estado, como "a livre respiração dos cidadãos", "ar respirável do mundo, oxigênio da sociedade", que "se sente, mais do que se define" 88 . Está perplexo diante dos regimes italiano, alemão e soviético, restritivos da liberdade, e das modernas revoluções, que suprimem a democracia política em nome de um estatismo, sinônimo de corporativismo ${ }^{89}$, e afirma: "o cimento comum das ditaduras modernas é em definitivo a negação do direito comum, proclamado pela Revolução Francesa" ${ }^{\text {"90 }}$. Inquieta-se com a nova concepção de homem que se forma, em detrimento do "homem livre, do homem não condicionado pelo Estado, do homem que era capaz de encontrar sua dimensão não na coletividade, mas em si mesmo e em suas próprias virtudes" ${ }^{\prime 1}$.

Barthélemy denuncia que a construção da ideia de democracia social se dá em detrimento da de democracia política. "Está cada vez mais na moda assumir como sem importância a democracia política. Só conta a democracia social. A primeira é a palha, a segunda, o grão" ${ }^{92}$. A democracia política é aquela para o povo, mas também pelo povo. "A democracia social decorre, na verdade, de um declive natural e necessário da democracia política. Se, com efeito, a Revolução Francesa foi de início burguesa, é que a história, como a natureza, não dá saltos, e o progresso lento e contínuo é sua grande lei" ${ }^{\prime 93}$. Desconfia das decisões da maioria, justamente porque coloca em questão a liberdade de que o cidadão inserido em um contexto desbalanceado entre Estado e indivíduo

\footnotetext{
${ }^{86}$ BARTHÉLEMY, 1935, p. 16.

${ }^{87}$ BARTHÉLEMY, 1935, p. 20.

${ }^{88}$ BARTHÉLEMY, 1935, p. 10/12 e 77.

89 "Si je ne vois pas d'une façon très précise où va le corporatisme, je sais de manière certaine d'où il s'éloigne: c'est de la liberté politique et économique, en même temps que de l'esprit de la Révolution française. Est-ce donc qu'il était équivaudrait à un retour en arrière? On n'en peut pas douter. Il ne faut pas en être trop vivement surpris", in BARTHÉLEMY, 1935, p.119.

${ }^{90}$ BARTHÉLEMY, 1935, p. 67.

${ }^{91}$ SAULNIER, 2004, p. 479.

${ }^{92}$ BARTHÉLEMY, 1935, p. 127.

93 BARTHÉLEMY, 1935, p. 130.
} 
desfrutaria para decidir. A maioria, como origem democrática, não é mais a fonte de legitimidade da norma.

Essa abordagem permite que Barthélemy coloque em questão a relação legalidade-legitimidade que vinha defendendo como produto da democracia. "Quando se contesta a legitimação pela fonte, é preciso propor um regime de substituição. O primeiro, senão o mais anódino, ao menos o mais corrente, é aquele da legitimidade pela eficiência. A decisão é boa, não porque ela foi tomada pelo maior número [de pessoas], mas porque ela está cercada de todas as garantias que dão a ciência e a competência. Joseph Barthélemy sempre se alinhou a essa filosofia que superpõe ao critério da fonte do poder aquele de seu exercício (...). Defende-se então uma concepção de legitimidade pela 'consciência': o poder permanece legítimo se, de fato, ele segue alinhado às suas finalidades" $"$. Assim pode opor governo legal e governo legítimo para, inclusive, defender Franco na guerra civil espanhola, no artigo La solidarité des gouvernements légitimes, publicado em 1937. Da mesma forma, a mudança de postura autoriza a defesa de um fundamento moral do Estado, composto por fórmulas vagas como dever, trabalho, honra, segundo explica Saulnier ${ }^{95}$.

A década de 1930, assim, assiste a uma transformação significativa de Joseph Barthélemy. O crescimento da presença dos partidos socialista e comunista no Parlamento, até a composição do Front Populaire, o desassossego provocado pela crise econômica, o crescimento das vozes de descontentamento, os ecos da revolução russa, o fascismo e o nazismo, enfim, as tensões da realidade democrática francesa e os novos interesses que se apresentam ameaçam a convicção de um liberal de que a garantia da igualdade formal e da democracia política poderia absorver e integrar as novas pressões sociais.

O autor sentiu a necessidade de rever sua postura, e de apegar-se a um modelo substancial de Estado e de democracia para preservar a ordem que desejava ver assegurada. De alguma forma, essa mudança de pensamento autorizou, legitimou e escusou, para Barthélemy, sua adesão ao governo autoritário e corporativista de Vichy, que afastou por completo a Constituição de 1875, em nome da "salvação do país e da sociedade nesse terrível período de crise" após a ocupação da França pelas tropas alemãs.

\footnotetext{
${ }^{94}$ SAULNIER, 2004, p. 491.
}

95 SAULNIER, 2004, p. 493. 


\subsection{BORIS MIRKINE-GUETZÉVITCH}

Boris Mirkine-Guetzévitch (1892-1955) nasceu em Kiev e estudou em Petrogrado ${ }^{96}$, onde participou de movimentos universitários liberais, tendo inclusive sido condenado à deportação para a Sibéria em razão de um artigo que desagradou o governo czarista, mas conseguiu evitar o cumprimento da pena. Tornou-se professor de direito internacional em Petrogrado em 1917. Com a queda do czarismo, naquele mesmo ano, sustenta a implementação de um regime democrático de tipo ocidental, simpatizando com as propostas mencheviques e sociais democratas, mas vê suas ideias derrotadas pela revolução bolchevique de outubro. Refugia-se, então, em Odessa e passa a escrever artigos contrários ao regime, o que lhe garante uma condenação à morte e o obriga a deixar o país rumo à França em 1920, país onde desenvolve extenso trabalho intelectual e cuja nacionalidade vem a adotar. Contudo, a ocupação alemã e as políticas antissemitas de Vichy obrigam Mirkine-Guetzévitch, de origem judaica, a deixar a França em novo exílio, dessa vez para os EUA. Em Nova Iorque, colabora com a criação da École libre des hautes études (hoje incorporada pela New School for Social Research), onde se torna diretor da faculdade de direito e ciência política. Passa o resto de sua vida dividindo-se entre a França e os EUA.

Durante sua carreira, participa de conferências em vários países do mundo e dirige alguns importantes centros de pesquisa, como por exemplo o Instituto de Direito Comparado da Universidade de Paris. Com Joseph Barthélemy, colega e parceiro intelectual, co-dirige a Bibliothèque d'histoire politique et constitutionnelle $\mathrm{e}$ a Bibliothèque parlementaire et constitutionnelle contemporaine. É autor de importantes obras, como Les nouvelles tendances du droit constitutionnel, de 1928, Les Constitutions de l'Europe nouvelle, de 1930, e Les Constitutions européenes, de 1951, sempre interessado no direito constitucional comparado. Suas obras são traduzidas para diversos idiomas e influenciam a elaboração das novas constituições do século XX, inclusive a Constituição brasileira de 1934 - vale mencionar a tradução para o português de As novas tendências do direito constitucional em 1933, combinando argumentos de suas obras de 1928 e 1930.

Sua história de perseguições e exílios, sua formação jurídica e sua preocupação política fazem de Mirkine-Guetzévitch um autor-chave do período dos anos

\footnotetext{
${ }^{96}$ Atualmente chamada de São Petersburgo, a cidade foi chamada de Petrogrado entre 1914 e 1924 , e de Leningrado, entre 1924 e 1991.
} 
1920-1930, não tanto pela extensão ou densidade teórica de seu pensamento, mas mais pela capacidade de observação e síntese do movimento pelo qual passava o direito constitucional. Não é demais lembrar que o entre-guerras é palco da promulgação de uma série de novas Constituições, em países com mudança de regime (revolucionária ou não), como Tchecoslováquia (1918), Alemanha (1919), Finlândia (1919), Estônia (1919/1920), Áustria (1920), Irlanda (1921), Polônia (1921), Turquia (1924) e Grécia (1927). São Constituições que seguem um padrão novo, distinto das estatutárias, sintéticas e formais típicas do modelo liberal de Estado, na medida em que pretendem disciplinar parcelas maiores da vida social, garantir direitos, fixar compromissos para o futuro e formatar um Estado mais interventor na ordem econômica.

Propondo-se a sintetizar, a partir de seu ponto de vista liberal, matizado pelo reconhecimento da relevância e da inevitabilidade dos novos direitos sociais, as tendências do novo constitucionalismo, o jurista oferece uma coletânea de textos precedida pelas suas considerações pessoais. Vejamos de que forma o autor sistematiza essas tendências, articulando-as em torno das noções de democracia liberal e de supremacia do direito, premissas combinadas por seu diagnóstico da finalidade comum às Constituições, que identifica como sendo o processo de racionalização do poder.

\subsubsection{Testemunho como método}

Mirkine-Guetzévitch preocupa-se em compreender seu tempo em termos de política, realidade histórica comparada e direito, enfrentando questões que podem ser relacionadas ao direito comparado, ao direito internacional público, às liberdades públicas. Mas é fundamentalmente dentro do campo do direito constitucional que o autor busca enquadrar sua contribuição. "Em Mirkine, o direito constitucional figura como o ponto de engate de todas as outras [disciplinas], ele o percebe como a disciplina de cruzamento [discipline carrefour] por excelência"97_98. Assim, propõe-se a "indicar as principais

\footnotetext{
${ }^{97}$ PINON, 2008, p. 184.

98 Apesar de vinculá-lo ao direito constitucional, seguindo a autocompreensão de Mirkine-Guetzévitch, Pinon destaca a progressiva adesão do autor à ciência política, à medida em que se torna mais pessimista em relação às novas tendências do constitucionalismo europeu, citando: "Après la guerre, et sourtout dans les dernières années, avec la crise économique et politique qui sévit en Europe, les institutions ont subi des transformations radicales. La doctrine n'a pas suivi les événements; elle opère encore avec des notions 'classiques'. Cette rupture entre la vie et la science devient de plus en plus profonde. Une des causes de ce divorce entre la pratique nouvelle et la théorie en retard, est que cette dernière reste trop attachée à la méthode formaliste. Elle ne tient pas suffisament compte du fait que le droit constitutionnel exige constamment l'application de la méthode de la sciende politique", in B. MIRKINE-GUETZÉVITCH, Pleins
} 
tendências das novas constituições da Europa do pós-guerra [Primeira Guerra Mundial]"99, escolhendo descrever as constituições dos novos Estados criados após a guerra, dos Estados já existentes anteriormente, mas que modificaram radicalmente seus regimes políticos, e dos Estados que se submeteram a mudanças territoriais importantes ${ }^{100}$ - tais são os casos, por exemplo, da Alemanha, da Áustria, da Polônia e da Tchecoslováquia. Para tanto, adota método que define como histórico-empírico, isto é, estuda "as formas do direito público em seu empirismo histórico, em sua realidade"101, aproximando-se da proposta pragmática de Barthélemy, uma vez que, sob a perspectiva de testemunha do novo constitucionalismo, limita ao máximo a análise teórico-abstrata e descarta conferir à sua obra uma dimensão normativa ou prescritiva ${ }^{102}$.

Reafirma com frequência em seus escritos pretender uma descrição estática dos textos constitucionais e das tendências comuns neles consolidadas. "O ponto de vista dinâmico é da competência da política, e não do direito" "103. Assim repete querer dedicar-se à apresentação e ao estudo das constituições formais, compreendidas como " $O S$ atos que são reconhecidos pelo direito constitucional de um país como Constituição, isto é, os atos do poder constituinte (...). Em nossa coletânea (...) nós nos limitaremos às constituições em sentido formal ${ }^{\prime 104}$.

Sempre ressalvando seu objetivo estático, formal (talvez com a pretensão de ser juridicamente neutro), de descrição pura dos textos constitucionais para a partir deles derivar tendências comuns, o jurista russo mostra-se, contudo, profundamente consciente da história e da política em suas escolhas e em seus posicionamentos. Afirma: "Devemos observar que entre os textos e a vida política real existe, em certos países, uma fatal antinomia", que é por ele significativamente exemplificada pela constatação de que "se por várias razões históricas houve, em certas constituintes, uma maioria de partidos da esquerda, os anos que se seguiram, como já assinalamos, modificaram as relações das

pouvoirs sur le régime parlementaire, Annales de l'Institut de droit comparé de l'Université de Paris, 1938, p. 69-70, apud PINON, 2008, p. 194.

${ }^{99}$ MIRKINE-GUETZÉVITCH, 1928, p. 5.

${ }^{100}$ MIRKINE-GUETZÉVITCH, 1930, p. 5.

${ }_{101}^{101}$ MIRKINE-GUETZÉVITCH, 1933, p. 143.

${ }^{102}$ Ao tratar do referendo, por exemplo, afirma: "Une solution simple pour ou contre le referendum ne peut être fondée que sur quelque principe abstrait. Le devoir de la science politique n'est pas de donner des réponses dogmatiques, mais de définir les tendances de telle ou telle institution du droit constitutionnel", in MIRKINE-GUETZÉVITCH, 1934, p. 2.

${ }^{103}$ MIRKINE-GUETZÉVITCH, 1933, p. 42, MIRKINE-GUETZÉVITCH, 1928, p. 14. Ao fazer referência ao livro As novas tendências do direito constitucional, buscaremos adotar a tradução brasileira da obra, procurando indicar a referência em ambas as obras.

${ }^{104}$ MIRKINE-GUETZÉVITCH, 1930, p. 14. 
forças politicas. A crise da democracia esteve na ordem do dia" ${ }^{" 105}$. Ao compilar os textos das novas Constituições, traz também uma reflexão sobre eles, a partir de um pensamento constitucional que lhe é próprio ${ }^{106}$.

Mirkine-Guetzévitch adota o caminho da técnica constitucional e da descrição comparada das novas constituições europeias para, de certa forma, derivar delas sua posição liberal (ainda que mitigada), democrática e convicta na defesa do Estado de Direito, apesar de fazê-lo não sem fartas ressalvas metodológicas. "Não expomos em nossa obra nenhuma doutrina política; contudo, devemos dizer, desde já, conforme o nosso ponto de vista, que a técnica constitucional tem seus métodos, seus processos, mas não constitui um fim. A técnica constitucional é somente 'um meio'. O direito constitucional é um processo técnico para assegurar a liberdade política e a técnica constitucional é a técnica da liberdade. A democracia permanece, no direito público moderno, como um postulado e como um critério (...) A democracia, repitamos, é o princípio teleológico da técnica constitucional. Atrair a atenção do pensamento jurídico para as novas tendências do direito constitucional da democracia, eis o fim do nosso livro" $" 107$.

Sua empreitada é então, em primeiro lugar, profundamente consciente da história e de seu tempo. Segundo ele, são fatores predominantes para o novo constitucionalismo a guerra e a sequência de agitações sociais que se seguiu à Revolução Russa. “A guerra colocou brutalmente o problema da liberação dos povos. As potências aliadas a inscreveriam em seus programas políticos e entre os objetivos essenciais a serem atingidos. Essa liberação nacional, por diversas razões históricas, era concebida pelos chefes da opinião pública aliada e pelos líderes desses povos como liberação democrática"108. E as mesmas lideranças, "sob a influência da Revolução Russa (...), eram obrigadas a fazer algumas promessas a seus povos"109. As "massas fatigadas, e frequentemente arruinadas pela guerra" estavam "naturalmente inclinadas a escutar as vozes da vingança social e da destruição, os apelos violentos dos partidários do regime soviético" 110 , diante da inexistência, nesses países, de uma "classe média politicamente madura que pudesse servir de base e de suporte para uma democracia republicana"11.

\footnotetext{
${ }^{105}$ MIRKINE-GUETZÉVITCH, 1933, p. 42, MIRKINE-GUETZÉVITCH, 1928, p. 14.

106 "En réalité, ce labeur intense de compilation et de publication ne doit pas éclipser la pensée constitutionnelle propre à l'auteur. Sur bien des points, elle mériterait même de figurer en bonne place dans l'historiographie de la doctrine française", in PINON, 2008, p. 196.

${ }^{107}$ MIRKINE-GUETZÉVITCH, 1933, p. 28 (prefácio).

${ }^{108}$ MIRKINE-GUETZÉVITCH, 1930, p. 6.

${ }^{109}$ MIRKINE-GUETZÉVITCH, 1930, p. 7.

${ }^{110}$ MIRKINE-GUETZÉVITCH, 1930, p. 8.

${ }^{111}$ MIRKINE-GUETZÉVITCH, 1930, p. 8.
} 
Assim o poder é tomado pelas forças de esquerda, que impulsionam um novo constitucionalismo, "mas um ou dois anos mais tarde, novas eleições resultam em uma maioria totalmente diferente, e, sob nossos olhos, as novas formas democráticas se enchem de um conteúdo social absolutamente oposto; e nós assistimos em certos lugares à transfiguração das constituições" $" 12$.

Dessa forma, Mirkine-Guetzévitch situa a crise da democracia nos países do novo constitucionalismo como uma disputa entre as forças de esquerda e de certa forma próximas ou influenciadas pelo regime soviético, forças essas que impulsionaram os novos textos, e as novas maiorias eleitorais que passam a ocupar os Parlamentos, não tão inclinadas a dar mais passos na direção da transformação social preconizada pelas cartas políticas. Já em 1928 escrevia que “a democracia devia entrar em luta, senão com os partidários do antigo regime, que nesse momento não ousavam se declarar, ao menos abertamente, a menos com as velhas tradições e usos. Às vezes a herança do passado se encontrava mais forte que a vontade criadora dos novos governantes"113. E em muitos países, a transição acelerada de um regime a outro fazia com que não tivessem uma tradição democrática consolidada. Vale lembrar que ele não está tratando do caso francês, em que não houve mudança de Constituição no entre-guerras.

As novas Constituições são, portanto, fruto de um conflito entre as novas forças e as tradições locais, potencializadas por uma reorganização dos setores conservadores. São marcadas por uma crise da democracia sequer consolidada. MirkineGuetzévitch propõe-se a traçar um testemunho desse movimento constitucionalista na Europa. É significativa sua discordância com a visão de Ferdinand Lassalle sobre as Constituições - o alemão afirmava que elas "não modificavam por si mesmas a vida política, os textos constitucionais não fazem senão exprimir a relação real de forças que existe em tal país entre a reação e a liberdade" ${ }^{\text {114 }}$. Para o russo, a posição não mais se sustenta no século XX, em que a luta se dá entre outras forças e a Constituição por vezes é um mecanismo de movimento, mais do que a representação estática de uma realidade dada.

"Hoje não se pode dizer, por exemplo, que o sufrágio universal, proclamado nas constituições, não criou realidades políticas; o próprio fato de levar para

\footnotetext{
${ }^{112}$ MIRKINE-GUETZÉVITCH, 1930, pp. 8/9.

${ }^{113}$ MIRKINE-GUETZÉVITCH, 1930, p. 9.

${ }^{114}$ MIRKINE-GUETZÉVITCH, 1930, p. 13, citando a opinião expressa por F. Lassalle em um discurso na Assembleia de Berlim em 1862 sobre a "essência da constituição". "Os problemas constitucionais não são problemas de direito, mas do poder, a verdadeira Constituição de um país somente tem por base os fatores reais e efetivos do poder que naquele país regem, e as Constituições escritas não têm valor nem são duráveis a não ser que exprimam fielmente os fatores do poder que imperam na realidade social: eis ai os critérios fundamentais que devemos sempre lembrar", in LASSALLE, 1933.
} 
a vida politica grandes massas humanas é um acontecimento que merece atenção, é um fator que, senão imediatamente, ao menos num futuro mais ou menos próximo, pode mudar a correlação real das forças. Eis porque, muito embora a vida política, em certos paises, se afaste nitidamente dos textos constitucionais, muito embora as formas constitucionais envolvam um conteúdo social oposto, os novos textos não deixam de ser eles, por si mesmos, elementos de progresso. Enfeixam em si as possibilidades de passagem da democracia proclamada à democracia realizada, no dia em que o texto da constituição englobar a totalidade da vida política do país. Os métodos segundo os quais as constituições poderão reinar sobre todos os aspectos da vida do futuro em construção, e a análise das possibilidades que se apresentam neste ou naquele país em particular, são da competência da política, e não do direito" ${ }^{, 115}{ }_{-}^{116}$.

Tal como seu colega Joseph Barthélemy, Mirkine-Guetzévitch está, assim, admitindo a Constituição e o novo direito como fatores de movimento. Apesar de sua preocupação em expressar sua intenção meramente descritiva, adotando o testemunho estático das Constituições como método, há um conteúdo implícito substancial em sua obra, que reside justamente na sua defesa da democracia, da supremacia do direito e da posição genericamente liberal. A democracia seria o regime racional, para o qual naturalmente evoluem as modernas Constituições, e implicaria na supremacia do direito, aí sua pretensa descrição do movimento comum do constitucionalismo europeu. É importante não esquecermos de que se trata de um imigrante vindo da Rússia que escapa do regime soviético, e que observa a realidade francesa do final dos anos 1930, para melhor situar sua obra teórica.

Assim seu diagnóstico da tendência geral a um processo dinâmico de racionalização do poder por meio da Constituição: "o direito constitucional geral não é algo imutável, ele se modifica segundo as ideias e os fenômenos políticos da vida. Ele é estreitamente ligado ao ideal democrático, não porque os teóricos do direito constitucional sempre foram democratas, mas porque a democracia expressa em

\footnotetext{
${ }^{115}$ MIRKINE-GUETZÉVITCH, 1933, pp. 44/45; MIRKINE-GUETZÉVITCH, 1930, pp. 13/14.

${ }^{116}$ É importante destacar que, segundo assinala Pinon (PINON, 2008, pp. 192 e ss.), Mirkine-Guetzévitch também transforma seu pensamento a partir dos marcantes eventos dos anos 1930 na Europa, abandonando um certo otimismo em relação às novas Constituições e ao seu potencial de constituir, como fator de movimento, os valores democráticos na sociedade. A mudança de posição fica clara após a Segunda Guerra Mundial: "Quelques trente-cinq ans d'études politiques nous ont appris la relativité constitutionnelle. Les textes ne créent pas la démocratie : les hommes, les mours, les traditions, les partis sont les éléments les plus importants d'une constitution démocratique (...). La science du 'gouvernement', c'est la science politique", in B. MIRKINE-GUETZÉVITCH, Les problemes constitutionnels, Revue du droit public et de la science politique en France et à l'étranger, 1946, p. 17-20, apud PINON, 2008, p. 194.
} 
linguagem jurídica é o Estado de direito, é a racionalização jurídica da vida, porque o pensamento jurídico consequente leva à democracia, como única forma de direito do Estado"117. Vejamos a seguir de que forma descreve esses traços comuns das Constituições europeias, e como os liga ao processo de racionalização.

\subsubsection{Direito e política: a tendência à racionalização do poder como traço comum às novas constituições europeias}

Faz parte do diagnóstico que Mirkine-Guetzévitch tem de seu tempo, portanto, a centralidade da Primeira Guerra Mundial e da Revolução Russa no impulso para uma nova onda constitucionalista na Europa, capitaneada em um primeiro momento pelas forças de esquerda, mas que logo tiveram que lidar com novas maiorias eleitorais, em que representantes mais conservadores ou convictos da necessidade de preservação da ordem burguesa estavam dispostos a disputar o significado das novas Cartas. Mas de qualquer forma o autor é otimista ao relacionar o impulso de mudança à busca pela libertação dos povos, que para ele só poderia estar ligada à democracia.

Curiosamente, aponta o organicismo alemão como uma das forças tradicionais que mitigam esse impulso de libertação dos povos, que identificava com a democracia individualista. $\mathrm{Na}$ Alemanha, assim, "os redatores da Constituição, ao mesmo tempo em que criaram os elementos da democracia formal, não puderam escapar ao ponto de vista tradicional orgânico e, aceitando as concepções orientais da democracia individualista, os completaram e emendaram, de um lado proclamando os princípios socialistas, e de outro se esforçando para aproximar o novo mecanismo jurídico do Reich e da concepção orgânica do Estado" ${ }^{\text {118. }}$.

Apesar dessa necessidade de composição de forças, há em todas as Constituições uma tendência comum, que abrange todas as novas figuras que nelas estão presentes de maneiras peculiares. Trata-se da tendência à racionalização do poder, ou seja, a ampliação do espectro de matérias sujeitas à regulação jurídica, do "conjunto de regras destinadas a preservar a estabilidade do governo na ausência de uma maioria parlamentar estável", nas palavras de Pinon ${ }^{119}$.

A racionalização significa a consagração do Estado de direito combinado com o ideal democrático, como forma mais racional de regulação da vida social. $\mathrm{O}$ direito

\footnotetext{
${ }^{117}$ MIRKINE-GUETZÉVITCH, 1930, p. 15.

${ }^{118}$ MIRKINE-GUETZÉVITCH, 1930, p. 10.

${ }^{119}$ PINON, 2008, p. 188.
} 
absorve as demandas políticas e passa a vigorar de modo supremo sobre todas as instâncias sociais. "Os textos constitucionais não expressaram somente o poder do número da maioria; retomando uma feliz expressão de um escritor francês ${ }^{120}$, vemos aparecer, não somente a 'democracia de fato', mas também a 'democracia de direito', que se traduz pela racionalização da 'vontade geral', a 'vontade do povo', justificando-se não somente porque ela é a 'vontade' da maioria, como também porque ela se enquadra em formas que asseguram a expressão mais racional e mais justa dessa 'vontade', aproximando o Estado livre da verdadeira antropocracia" ${ }^{\prime 12}$. Em outro texto, menciona o Estado de direito como o estado razoável e mais racional, aquele que se apoia sobre os dados do intelecto humano, “não apenas uma antropocracia, mas também, em um grau igual, senão maior, uma raciocracia [ratiocratie]"122.

O papel da ciência e da técnica jurídica é então ampliado, na formação dessas "Constituições dos professores", em que se busca submeter a política ao direito. Assim, o jurista russo destaca o papel de Hugo Preuss na Constituição alemã, ou de Hans Kelsen, na austríaca. "Apesar dos textos serem o resultado de diversos compromissos políticos, de acordos entre partidos, o papel da técnica jurídica é contudo muito importante. Os teóricos do direito exerceram sua influência (...). Os críticos mais detalhistas devem reconhecer que nas novas constituições se reflete a ideia da supremacia do direito, a ideia de unidade do direito: toda a vida do Estado é baseada no direito e penetrada por ele. Assiste-se ao processo da racionalização do poder, à tendência a submeter ao direito todo o conjunto da vida coletiva"123.

Trata-se de um processo de racionalização da vida pública em todas as suas instâncias, que implica inclusive em ir além da garantia de direitos de liberdade típicos do positivismo jurídico liberal do século XIX, que considera como eixo do direito o indivíduo abstrato e isolado. O jurista vê nas novas Constituições um avanço em relação a essa visão, na medida em que elas incorporam à lista de direitos consolidada na Declaração universal dos direitos do homem e do cidadão, fruto da Revolução Francesa, novos direitos de caráter social. "Evidentemente, nenhum dos direitos envelheceu, mas a lista em si é incompleta para o século XX: a vida atual exige não somente a salvaguarda de todos os

\footnotetext{
${ }^{120} \mathrm{O}$ autor faz referência a Guy-Grand, La démocratie et l'après-guerre (1922), pp. 12, 275.

121 MIRKINE-GUETZÉVITCH, 1933, pp. 40/41, MIRKINE-GUETZÉVITCH, 1930, p. 11. A menção à "anthropocratie", antropocracia, é acompanhada da referência a T. G. Masaryk, Les problèmes de la démocratie (1924), p. 56.

${ }^{122}$ MIRKINE-GUETZÉVITCH, 1928, p. 52.

${ }^{123}$ MIRKINE-GUETZÉVITCH, 1930, pp. 10/11.
} 
direitos da Declaração de 1789, mas ainda a dos novos direitos nascidos da evolução da vida social" ${ }^{\prime 24}$.

Apesar de não se deter muito na análise, Mirkine-Guetzévitch é consciente de que tais direitos têm origens diversas. Em alguns lugares, são fruto das pressões socialistas e a tentativa de composição social democrata, como no caso da Alemanha ${ }^{125}$. Contudo, "mesmo nos países onde o poder constituinte foi confiado a elementos mais moderados e mais afastados da doutrina socialista, vê-se se afirmar nos textos das Constituições a existência de direitos 'sociais" "126. Direitos sociais não estão, portanto, necessariamente vinculados à força da esquerda representada no Parlamento, nem mesmo à força da democracia enquanto ideia em si e enquanto mecanismo de escolha do poder constituinte. "Nós estamos então na presença de um fato curioso: a introdução de elementos sociais nas Declarações de direitos não tem relação direta com a proporção maior ou menor de democratismo de um dado país. A aparição dos novos elementos sociais não é somente o resultado da participação dos socialistas na obra da assembleia constituinte; os direitos sociais aparecem também nas Constituições que foram redigidas com uma fraca participação ou mesmo sem o concurso dos socialistas" ${ }^{127}$. Faz a constatação para logo a seguir dizer que pouco importa a razão pela qual os elementos sociais apareceram nas Constituições, bastando verificar que de fato apareceram e afirmaram-se como tendência do novo constitucionalismo - a constatação poderia dialogar com o que veio a acontecer no Brasil, com a Constituição de 1934, como se verá.

Nesse ponto, Mirkine-Guetzévitch é enfático e preciso na análise das transformações pelas quais passava o direito, e o direito constitucional em especial: “ $A s$ novas Constituições foram redigidas em uma época em que nenhum partido político pôde ignorar a questão social. No século XX, o sentido social do direito não é mais uma doutrina, não é mais uma escola jurídica, é a vida em si mesma. Também não é mais possivel distinguir entre o indivíduo político e o indivíduo social; nós assistimos à transformação, não somente da teoria geral do Estado, mas também da doutrina dos direitos individuais. O Estado não pode mais se limitar a reconhecer a independência

\footnotetext{
${ }^{124}$ MIRKINE-GUETZÉVITCH, 1928, p. 42.

125 "Si nous examinons les origines de la constitution allemande, nous voyons que c'est la social-démocratie allemande qui a protégé la république contre les assauts du bolchevisme”, in MIRKINE-GUETZÉVITCH, 1928 , pp. 42/43.

${ }^{126}$ MIRKINE-GUETZÉVITCH, 1928, p. 43.

${ }^{127}$ MIRKINE-GUETZÉVITCH, 1928, pp. 43/44.
} 
jurídica do indivíduo, ele deve criar um mínimo de condições necessárias para assegurar a sua independência social"128.

As novas Constituições são o exemplo máximo da tentativa de racionalização da vida pública, com isso querendo dizer também que visam englobar a totalidade da vida social, como a família, a escola etc, dentro da moldura do direito. A pretensão não necessita de concretização, os direitos assegurados não dependem, necessariamente, de efetividade, podendo ser uma simples intenção, já que "o valor $d a$ tentativa não é diminuído pelo fato de que em certos Estados esses 'direitos sociais' ficaram no papel. De início, o texto da Constituição tem um valor educativo para a população; e, em seguida, os parágrafos proclamando os direitos sociais definem uma tendência, e marcam o começo de um novo processo de garantia dos direitos sociais que deve se realizar no futuro" ${ }^{\prime 29}$. Assim, o novo constitucionalismo aponta para a realização no futuro da ordem constitucional, não para a garantia da situação presente. O direito é considerado como um fator de movimento, de transformação, e não como uma simples fotografia da realidade destinada a proteger as liberdades individuais contra qualquer intervenção pública.

Apesar de diagnosticar a tendência à socialização do direito, dentro de um movimento maior de racionalização, o jurista não se preocupa em situar-se dentro do debate individualistas versus coletivistas (ou solidaristas), preferindo uma postura pragmática: "em nosso método histórico-empírico, o centro de gravidade se transporta naturalmente da discussão entre individualistas e solidaristas para a realidade constitucional concreta" ${ }^{130}$. Assim admite a propensão da doutrina a considerar o homem social, situado, em lugar do homem abstrato, dessa forma alargando o espectro de obrigações de prestação positiva dos Estados a partir da inclusão de novos direitos fundamentais, que chama de direitos sociais. Ao mesmo tempo, enxerga a inclinação à limitação dos direitos clássicos como uma possibilidade, por vezes perigosa, aberta pelos novos direitos. Diferentemente dos clássicos apresentados no capítulo anterior, MirkineGuetzévitch não pretende desenvolver uma doutrina baseada na tomada de posição teórica acerca da questão, bastando para as finalidades a que se propõe, portanto, o diagnóstico da realidade constitucional concreta.

\footnotetext{
${ }^{128}$ MIRKINE-GUETZÉVITCH, 1928, p. 44.

${ }^{129}$ MIRKINE-GUETZÉVITCH, 1928, p. 45.

${ }^{130}$ MIRKINE-GUETZÉVITCH, 1933, p. 145.
} 
Nesse processo, democracia e direitos sociais podem, segundo o autor, ser produto de movimentos e forças até mesmo opostos. O homem socialmente considerado, de um lado, é um dos eixos do novo direito, sendo a interdependência social, a solidariedade, a ordem pública ou qualquer dos conceitos que se queira utilizar para denotar a dimensão coletiva do direito, o outro eixo. "A partir dai, dois processos simultâneos: de um lado, entre os direitos individuais fundamentais figura pouco a pouco a defesa da pessoa social, e de outro lado, em nome de um princípio objetivo, a solidariedade, a ordem pública etc (nós não queremos vincular a constatação do fato a nenhuma doutrina determinada). Em nome desse princípio social superior, assiste-se a uma limitação de certos direitos fundamentais, em particular do direito de propriedade ${ }^{131}$. Mirkine-Guetzévitch cita, sobretudo, o direito de propriedade como exemplo de limitação sofrida pelos direitos fundamentais em nome desse princípio superior.

Além disso, aponta para o fato de que a possibilidade de limitação aos direitos fundamentais, combinada com a ausência de controle de constitucionalidade das leis, dá à legislação ordinária desses países a possibilidade de alterar garantias básicas, como por exemplo no caso da obrigatoriedade do ensino religioso consagrada na Polônia e com isso nota, novamente, que nem sempre a inclusão dos direitos sociais deve ser tributada à intervenção dos partidos e correntes socialistas nos Parlamentos. "Assim, ao lado da definição das liberdades individuais, há reservas que limitam o alcance do princípio proclamado. Essa imperfeição evidente de certas Constituições se explica por razões políticas particulares. Aqui a herança do passado age de encontro ao processo de racionalização democrática" ${ }^{\prime 32}$.

Esse processo de racionalização da vida pública, de tomada da política pelo direito, de triunfo da Constituição, é uma tendência que ele relaciona a diversos traços comuns às novas Constituições. Em primeiro lugar, refere-se ao princípio da soberania popular. Cita ainda as instituições e mecanismos políticos, como o governo parlamentar em uma nova forma e a Câmara Alta. Trata ainda do federalismo transformado e da consagração absoluta do sufrágio universal, sendo que a maior parte das Constituições adota o sistema de representação proporcional. Por fim, aborda a questão do referendo e da iniciativa popular, técnicas que reconfiguram o parlamentarismo, desviando-se da representação clássica.

${ }^{131}$ MIRKINE-GUETZÉVITCH, 1928, p. 44.

${ }^{132}$ MIRKINE-GUETZÉVITCH, 1928, p. 47. 
É com um certo otimismo, progressivamente mitigado, que descreve a tendência de racionalização do poder que se opera com o novo constitucionalismo. A supremacia da Constituição e do direito e o triunfo do Estado de direito e da democracia como expressão da razão são, para o autor, as diretrizes das novas sociedades do entreguerras. O direito é, então, voltado para o futuro, com papel educativo e transformador da realidade, e, combinado com a democracia, pode promover a integração da massa trabalhadora, que recentemente se tornara agente político na tomada de decisões. É assim que Mirkine-Guetzévitch nos apresenta as novas Constituições, a partir de seu método "histórico-empírico", evitando ao mesmo tempo buscar determinações históricas e conflitos políticos específicos, ou construir uma análise fundamentada em uma base teórica abstrata mais profunda. Limita-se a uma breve síntese esquemática que destaca esse processo de racionalização, em que combina tendências muitas vezes díspares - como é o caso anteriormente referido dos direitos sociais versus democracia - em uma mesma dinâmica. O outro eixo do processo, que vale ser reiterado, é o importante peso que a democracia tem em sua análise.

\subsubsection{Democracia e novo parlamentarismo}

"A racionalização do poder, enquanto se mostra como tendência a envolver no campo do direito o conjunto social da vida, enquanto se mostra como tentativa para substituir o fato meta-jurídico do poder, pelo direito escrito - é a evolução progressiva do Estado de direito, da democracia"133. Estado de direito e democracia são, portanto, evoluções racionais da vida política de um povo. Estado de direito é o ideal que, segundo ele, define o direito do poder do Estado, enquanto que a democracia define a origem desse poder ${ }^{134}$ - são ambos, portanto, expressões da racionalização do poder, tendência das Constituições europeias do entre-guerras.

A democracia corresponde à busca dos povos pela sua libertação, potencializada após a guerra e a Revolução Russa, e é uma constante nos novos textos constitucionais, ainda que os correspondentes regimes se desviem de sua realização. “Formalmente, as novas constituições marcam a vitória e o fortalecimento da democracia. Evidentemente, entre a ideia do governo popular e sua expressão legislativa, não há coincidência total. $O$ direito formal não segue sempre a ideia social, e frequentemente a 
luta do direito novo contra o velho continua na esfera das relações públicas, mesmo quando o princípio democrático já tenha sido sancionado por um parágrafo da constituição" ${ }^{\prime 135}$. Mas de qualquer modo a democracia corresponde ao Estado de direito, como dois lados da mesma moeda, e assim é ao mesmo tempo ideal político e jurídico que deve circunscrever o trabalho dos juristas. O direito constitucional, como "técnica da liberdade", deve portanto consagrar a vitória da democracia e instrumentalizar sua afirmação concreta. É, assim, uma visão finalista do direito ${ }^{136}$, que assume a tarefa de concretizar e resguardar a democracia, que não é senão a realização da liberdade em si.

Assumindo a democracia como missão, refuta o diagnóstico de crise, voz corrente na época, que vinculava a ampliação democrática, por vezes constitucionalizada, à instabilidade política e social e às dificuldades de funcionamento do parlamentarismo clássico. "Os adversários da democracia chegam mesmo a declarar que as novas constituições não fizeram senão demonstrar a falência do parlamentarismo, e que o fato de existir um desacordo entre os textos e a vida política real prova o fracasso total da doutrina democrática (...). A crise provem não de um excesso de democratismo inscrito na constituição, mas sim do contrário; é uma crise da psicologia nacional e não das instituições democráticas e é por isso que, a despeito dos textos inteiramente democráticos, a vida foge dessas fórmulas jurídicas, sob a influência das antigas tradições" $" 137$.

Contudo, o jurista russo faz ressalvas em relação ao tipo de parlamentarismo que é consagrado nas novas Constituições, demonstrando um certo ceticismo em relação à possibilidade de superarem as instabilidades dos governos que se seguiram. "As Constituições revolucionárias são sempre redigidas em um momento em que a opinião pública, ainda sob a influência do passado, é inspirada numa profunda desconfiança para com o poder executivo. E o defeito comum de todas as Constituições revolucionárias está em não darem a necessária competência ao Executivo, estabelecendo o primado absoluto do Legislativo" ${ }^{138}$. O ponto fraco é justamente o não reconhecimento de que um Executivo democrático tem uma importante função na nova forma de organização política, especialmente porque "as crises econômicas e financeiras exigem soluções rápidas. Mas o Executivo é fraco, e por mais poderoso que seja nos textos legais,

\footnotetext{
${ }^{135}$ MIRKINE-GUETZÉVITCH, 1930, p. 11.

${ }^{136}$ Conforme assinala Pinon, em PINON, 2005, p. 75, nota 76, concordando com a interpretação de André Hauriou.

${ }^{137}$ MIRKINE-GUETZÉVITCH, 1933, p. 43; MIRKINE-GUETZÉVITCH, 1930, pp. 12/13.

${ }^{138}$ MIRKINE-GUETZÉVITCH, 1933, p. 25.
} 
o Legislativo, peiado pela luta dos partidos, muitas vezes sem experiência e sem prática parlamentar, torna-se, na realidade, um poder fraco e incapaz (...). O Estado está desacreditado assim como a democracia" ${ }^{\prime 39}$.

É dessa forma que sustenta, em linhas gerais, antecipando a posição de autores do pós-guerra, segundo Pinon ${ }^{140}$, uma abordagem suavizada da separação de poderes ${ }^{141}$, em que tanto o Executivo ganha mais espaço quanto mecanismos de participação popular direta, como o referendo, passam a cumprir o papel de uma certa mediação entre os poderes. Ainda que crítico ao excesso de centralidade que o Parlamento ainda tem nas novas Constituições, que vê como resquício de uma tradição do passado, Mirkine-Guetzévitch enxerga nelas um novo parlamentarismo, na medida em que "não se limitam a formular em termos gerais e vagos a responsabilidade política dos ministros. Ao contrário, as diversas Constituições estabeleceram, com mais ou menos precisão, o próprio princípio do parlamentarismo; introduziram igualmente o processo interessante do voto de desconfiança, germe de uma nova forma de processo constitucional do parlamentarismo" ${ }^{\prime 142}$. Trata-se de um parlamentarismo novo, em que não se pode mais colocar no Poder Legislativo a superioridade política, a soberania absoluta.

O Executivo, na verdade, é que tem a primazia política, é a base do regime parlamentar. Na medida em que se apoia na maioria parlamentar, e que é composto por um quadro técnico preparado, é o Executivo que impulsiona inclusive as novas leis, é a "alma da legislação (...), a maior força criativa da democracia moderna; se o parlamento vota as leis, é o executivo que as prepara e obriga o parlamento a votá-las. Ignorar essa transformação capital do Executivo é ignorar a evolução parlamentar" ${ }^{\prime 13}$.

O Parlamento já não é mais o órgão central na formulação da regulação da ordem social e política, já não é mais o locus máximo da soberania, passando a atuar em conjunto com o Executivo. "A vida política atual é de tal forma complexa que diversos problemas da vida social devem receber uma regulamentação administrativa e não legislativa, e, por outro lado, é o Executivo que deve desemprenhar o papel mais importante no processo legislativo. Para preparar uma lei, é preciso ter à disposição

\footnotetext{
${ }^{139}$ MIRKINE-GUETZÉVITCH, 1933, p. 26.

${ }^{140}$ Cf. PINON, 2008, pp. 201 e ss.

141 "Le caractère du pouvoir législatif moderne, le rôle du cabinet parlementaire, le changement profond qui est survenu dans les rapports entre législatif et exécutif, tout cela transforme la signification politique de l'Exécutif et du Législatif', in MIRKINE-GUETZÉVITCH, 1934, p. 8.

${ }^{142}$ MIRKINE-GUETZÉVITCH, 1933, p. 188.

${ }^{143}$ MIRKINE-GUETZÉVITCH, 1934, p. 9.
} 
especialistas, é preciso poder recorrer às competências técnicas de um grande número de cientistas, de administradores, de funcionários..."144.

Pinon organiza os princípios em torno dos quais Mirkine-Guetzévitch organiza seu diagnóstico do novo parlamentarismo: “1) a luta eleitoral conduz, no caso dos grandes partidos organizados, à luta pelo poder; 2) o chefe do partido vencedor é efetivamente promovido a chefe do governo enquanto que os outros quadros do partido ocupam os outros postos ministeriais; 3) o partido majoritário detém então ao mesmo tempo o poder executivo e o poder legislativo; 4) o governo pode se considerar como 'órgão do povo' porque ele sai assim das eleições, mas por intermédio da maioria parlamentar; 5) sustentado pela Câmara, legitimado pela eleição, o governo torna-se a 'alma da legislação', o Parlamento não fazendo senão homologar o programa do partido majoritário" ${ }^{45}$.

Justamente por entender que há um crescente e importante papel técnico do Executivo na elaboração das leis, que não são, via de regra, um momento pontual, mas parte de um programa legislativo - ou da elaboração de uma política - maior, que o autor não considera ser o referendo legislativo compatível com o regime parlamentarista moderno, ao refletir sobre as propostas de revisão constitucional em debate na França dos anos 1930. E, naquele momento, já anunciava um certo pessimismo novo em relação às perspectivas concretas da democracia na Europa. "As novas constituições europeias do pós-guerra adotaram esse amálgama do parlamentarismo e do referendo. Mas a maior parte dessas constituições estão mortas; o regime parlamentar, em geral, fracassou nas novas Repúblicas da Europa central e oriental. E o amálgama do parlamentarismo e da votação popular também fracassou. Os povos para os quais esse amálgama foi inventado não estavam nem prontos nem preparados para a democracia, para o funcionamento do regime parlamentar" 146 .

Se de início Mirkine-Guetzévitch parecia crer-se diante de um movimento de florescimento da democracia e do Estado de direito, que queria enxergar como o triunfo da razão, em Constituições que apontavam para a educação política e para a criação de uma nova sociedade no futuro, o desfecho da história é para ele uma certa decepção. Passa a encarar com pessimismo iniciativas de expansão da democracia, como o referendo, e, sem abandonar a convicção democrática, sustenta a importância de um Poder

\footnotetext{
${ }^{144}$ MIRKINE-GUETZÉVITCH, 1934, p. 9.

${ }^{145}$ PINON, 2008, p. 207.

${ }^{146}$ MIRKINE-GUETZÉVITCH, 1934, p. 6.
} 
Executivo fortalecido e tecnicamente preparado para enfrentar as constantes crises econômicas e sociais.

Assim experimenta a crise do constitucionalismo liberal, como testemunha das novas Constituições, em princípio otimista em relação às possibilidades de futuro nelas inscritas, para finalmente considerá-las mortas. Não muito tempo depois é, ele também, forçado a exilar-se pela segunda vez, em razão da instauração do governo de Vichy e suas políticas antissemitas, chanceladas pelo Ministro da Justiça, seu antigo colega Joseph Barthélemy.

\subsection{René CAPITANT}

Filho do renomado professor de direito privado Henri Capitant, René Capitant (1903-1970) faz seus estudos na Universidade de Paris, publicando sua tese de doutorado em 1928 (Introduction à l'étude de l'illicite - Tome I - L'impératif juridique (la règle de droit)), e logo é aprovado no concurso de agregação. Em 1930 segue para Estrasburgo, com Charles Eisenmann e Marcel Prélot, onde assume, um ano depois, a cadeira de direito constitucional deixada por Carré de Malberg. Ali, tem contato com as ideias sociais e observa de perto o processo que leva à tomada do poder pelo nacionalsocialismo, na vizinha Alemanha. É a partir desse contato que redige seus escritos sobre o nazismo, entre 1933 e 1938, reunidos e publicados em 2004 sob o título Face au Nazisme (1933-1938).

Durante o entre-guerras, o jovem Capitant dedica-se sobretudo à produção teórica e à vida acadêmica, sendo, porém, digna de destaque sua participação durante alguns meses como ministro do gabinete de Léon Blum. A posição de acadêmico contrasta com seu perfil mais conhecido de homem político engajado, que o autor assume a partir da Segunda Guerra Mundial. Sua discordância com o governo de Vichy o leva a solicitar sua transferência para a faculdade de direito de Argel em 1941, e também a aderir à Resistência, no Mouvement Combat. A proximidade com Charles De Gaulle, que lhe garante a imagem de "gaullista de esquerda", o leva ao cargo de Ministro da Educação no governo provisório de 1944, logo após a libertação. Volta a ser ministro outras vezes, elege-se deputado em três legislaturas (1946-1951, 1962-1967, 1967-1968), e torna-se um influente presidente da Comissions des lois de 1962 a $1965^{147}$.

\footnotetext{
${ }^{147}$ Informações em BEAUD, 2004, pp. 7 e ss., e em
} 
Assim como Barthélemy e Mirkine-Guetzévitch, Capitant é um jurista que não pode ser compreendido sem ter em mente sua profunda ligação com seu tempo e seu engajamento político. Mas é um jurista diferenciado, cuja preocupação engajada não faz com que rejeite, enquanto cientista do direito, a abordagem teórica abstrata, digna dos autores clássicos do direito constitucional, ao menos se analisarmos sua produção acadêmica do entre-guerras. De acordo com Beaud, "a segunda guerra mundial marcou uma cisão capital na vida de René Capitant, fazendo dele principalmente um homem de ação, inicialmente um resistente, e em seguida, um político, o que não deixaria mais de ser de 1944 até a sua morte"148. É por isso que sustenta como hipótese de que "os escritos mais representativos de seu talento de jurista são, paradoxalmente, seus 'textos de juventude', isto é, aqueles que ele escreveu antes dos quarenta anos" ${ }^{\text {149_- }}{ }^{150}$. Trataremos a seguir de seus textos de juventude, produzidos durante o entre-guerras, a partir de 1928, mais precisamente, quando da publicação de sua tese de doutorado. A análise concentrarse-á na sua tese, propriamente - Introduction à l'étude de l'illicite - Tome I-L'impératif juridique (la règle de droit) - e nos artigos em que trata da teoria do direito de forma ampla, e da teoria constitucional, mais precisamente, La coutume constitutionnelle (1930), Le droit constitutionnel non écrit (1934) e Les propos d'Alain ou l'ideologie de la Troisième République (1935).

Trata-se de um jurista generalista, que se movia, com facilidade, entre o direito público e o privado, e um teórico por temperamento, que "queria sempre abordar os problemas sob o ângulo dos princípios" $" 151$. Distancia-se, assim, da tradição pragmática que vinha sendo inaugurada e é, de certa forma, um dos últimos representantes de um direito constitucional que se movia entre a dogmática da doutrina e a zetética da ciência política e da teoria do Estado. Adota-se aqui a tese de Beaud de que, muito embora inequivocamente consciente e vinculado à sua realidade histórica, Capitant "era um jurista atípico, cuja inclinação para a teoria do direito e do direito constitucional contribuiu para isolá-lo em um país onde a doutrina prefere se refugiar no 'empirismo ${ }^{152}$ quando analisa o direito positivo" ${ }^{\prime 153}$.

\footnotetext{
http://www.assemblee-nationale.fr/sycomore/fiche.asp?num dept=1426 (consulta em 29/03/2012).

${ }^{148}$ BEAUD, 2004, p. 13.

149 BEAUD, 2004, p. 11.

150 "Je dois avouer que mon œuvre scientifique est modeste; les études qui la composent sont généralement brèves; elle est plus riche des ouvrages que j'ai médités que de ceux que j'ai publiés", in Discurso de agradecimento pronunciado na Universidade de Keïo, em 9 de junho de 1960, apud BEAUD, 2004, p. 14.

${ }_{151}^{15}$ BEAUD, 2004, p. 13.

${ }^{152}$ Citando a expressão empregada pelo próprio René Capitant, no prefácio à tese de Maroger, p. III.

${ }^{153}$ BEAUD, 2004, p. 16.
} 


\subsubsection{Método, imperativo jurídico e subjetivismo: a retomada marginal da perspectiva teórica dos clássicos}

René Capitant é ambicioso em seu projeto teórico. Sua tese de doutoramento sobre o ilícito e a regra de direito é uma contribuição que se situa no campo da teoria do direito, em que busca dialogar com Hans Kelsen e sua Allgemeine Staatslehre, sobretudo, mas também com os clássicos franceses Carré de Malberg, Duguit e Gény. Posiciona-se, portanto, na defesa de uma ciência do direito com preocupações mais abstratas, que absorva as questões da teoria do Estado e do direito, bem como da ciência política, no contrafluxo de seus contemporâneos. "Ele entende, a propósito de uma questão jurídica qualquer, se distanciar da atitude do 'positivista' ou do 'prático ávido' [praticien avide] para quem 'muitas controvérsias (...) parecem sem resultado' e 'muita liberdade doutrinária (...) parece levar para longe da realidade jurídica'. Essa crítica do empirismo jurídico contém, no interior, seu próprio programa: renovar, graças à contribuição da teoria, as questões jurídicas, recusar o liberação da doutrina à jurisprudência etc" ${ }^{\text {154 }}$.

Se tal postura intelectual era voz corrente antes da Primeira Guerra Mundial, nos anos 1930 a defesa de uma ciência jurídica preocupada com especulações teóricas de fundo, mais abstratas, fazia de Capitant um jurista marginal ${ }^{155} \mathrm{em}$ sua época, em que predominavam as abordagens pragmáticas, na linha da virada proposta por Barthélemy. Nesse sentido, seu comentário presente no artigo em que destaca a importância de Carré de Malberg, afirmando que "ele não fez e não pretendeu fazer uma descrição política. Ele se situa, portanto, em um ponto de vista completamente oposto ao dos autores ingleses que descrevem os regimes a partir de seus costumes, de suas práticas, ressaltando os fatos, de preferência os mais pitorescos, reportando anedotas (...), segundo um método essencialmente empírico e que não lhes permite invocar os princípios senão em reflexões cheias de humor (...). Alguns constitucionalistas franceses seguiram essa escola. Carré de Malberg praticou um outro método. Ele sistematicamente negligenciou, senão desprezou, a observação direta dos fatos. Ele não buscou nem desejou um posto nas assembleias legislativas. Ele não fundou suas conclusões em uma experiência direta $e$ pessoal do poder. Ele permaneceu voluntariamente um teórico" ${ }^{\text {"156. }}$.

Não é sem admiração que se refere, portanto, à postura intelectual e metodológica de seu mestre Carré de Malberg, percebendo a virada pragmática à qual se

\footnotetext{
${ }^{154}$ BEAUD, 2004, p. 20, citando trechos do prefácio de René Capitant à tese de Maroger, p. III.

${ }^{155}$ BEAUD, 2004, p. 18.

${ }^{156}$ CAPITANT, 1937 , pp. $87 / 88$.
} 
havia submetido o direito constitucional no entre-guerras. Capitant pretendia retomar, em certa medida, a proposta dos clássicos. Isso significava, de início, rejeitar a posição de subordinação que o direito constitucional tinha assumido em relação à ciência política. $\mathrm{O}$ jurista acreditava que especulações teóricas mais abstratas sobre o direito e sobre o Estado deveriam seguir fazendo parte do campo do direito público, convicção sobre a qual desenvolveu seu pensamento.

A posição fica clara ao explicitar o propósito de sua tese, quando indica o que entende seria a maneira correta de abordar a questão da fraude à lei: "A fraude à lei é uma teoria interessante, a condição de que seja estudada por comparação à noção de violação da lei, ou, mais amplamente, de violação da regra de direito, isto é, à noção de ilícito. Quanto à violação da regra de direito, o estudo supõe necessariamente o da regra de direito em si mesma. A regra de direito é um imperativo? Qual imperativo? Condicional ou categórico?" "157. A investigação pretende, portanto, questionar os conceitos básicos, fundamentais, do Direito enquanto ciência, solução que o coloca na contramão das tendências que lhe eram contemporâneas.

Dessa forma, amplia o grau de abstração de seu estudo, buscando situar seu posicionamento teórico a partir da forma como compreende os conceitos mais fundamentais do direito, como regra de direito e imperativo jurídico, caminho que somente seria adotado por um jurista na contracorrente de sua época, em que predominariam as análises de uma dogmática mais instrumental e aplicada. "Sob o pretexto de estudar o imperativo e o ilícito, seu autor [Capitant] propunha nem mais nem menos do que uma definição do direito que deveria lhe permitir tomar partido acerca de questões clássicas da filosofia do direito: a natureza da regra de direito e a questão de sua unicidade, o fundamento do direito, a distinção entre direito positivo e direito natural, entre positivismo jurídico e jusnaturalismo, a noção de fonte do direito etc..."158.

Para Capitant, deve-se distinguir entre o imperativo e o indicativo, entre a constatação e a vontade, a consciência e a ação, a teoria e a prática, entre o ser e o dever ser. Segue Kelsen ao afirmar que há uma oposição entre a lei natural, o sein, e a norma, o müssen (ou sollen, em Kelsen) ${ }^{159}$. A lei natural decorre da ideia de necessidade, de coerção, enquanto que o imperativo deve ser definido independente das noções de necessidade ou de liberdade. "Não há outra necessidade na lei natural que a seguinte: o

\footnotetext{
${ }^{157}$ CAPITANT, 1928, Avant-propos.

${ }^{158}$ BEAUD, 2004, p. 24.

${ }^{159}$ CAPITANT, 2004 (1928), p. 66.
} 
que foi, foi; o que é, é, o que será, será. Mas o que será? Isso não é determinado"160. Da lei natural deriva uma coerção física, enquanto que da norma, uma coerção moral. "Por um lado, a norma ou regra se opõe à lei natural, na medida em que uma suprime a liberdade daquilo que rege, enquanto a outra a deixa subsistir, e supõe mesmo por definição a liberdade do sujeito. A lei natural coage, a regra se propõe ao livre-arbitrio. Mas, por outro lado, a norma também é coercitiva. É obrigatória, faz nascer um dever, se impõe à vontade do sujeito" $" 161$.

Distingue claramente os planos do ser e do dever ser, rejeitando assim qualquer explicação do direito como fato social observável - o direito é produto da vontade, é uma decisão consciente, e não se explica como fato. A ciência, sobretudo a sociologia, é útil ao guiar a escolha dos meios que podem favorecer esta ou aquela conduta, mas não servirá como mecanismo de determinação, de escolha, acerca de qual conduta deve ser favorecida pela norma ${ }^{162}$. A escolha é feita não no plano do ser, da mera observação científica, mas situa-se no campo da vontade e da consciência humanas, enquanto imperativo categórico. $O$ direito não pode ser analisado em termos de causalidade, como na análise das ciências naturais, já que a norma não pode ser vista como uma decorrência única e natural de uma relação de coisas, ela não é causada por algo, mas fundada ou efetiva, enquanto produto de uma escolha voluntária e subjetiva. Criticando as correntes que sustentam a abordagem sociológica do direito, fundada em Durkheim, afirma que "os dados científicos são incapazes de, sozinhos, dar origem a um imperativo categórico" $" 163$. O mesmo raciocínio serve para descartar as correntes do direito natural objetivo, que pretendem derivar o direito não da vontade, mas da convivência em sociedade puramente considerada, orientada por uma regra de conduta, ou de uma concordância de consciências natural, que fundaria imperativos também naturais. Com isso refuta as propostas de Duguit e de Hauriou.

\footnotetext{
${ }^{160}$ CAPITANT, 1928, p. 2.

${ }^{161}$ CAPITANT, 1928, p. 3.

162 "La Science nos guide dans le choix des moyens; elle nous est d'aucun secours dans le choix des fins à donner à notre activité. Elle nous dit ce qui crée la richesse, la santé, la solidité... Mais elle ne nous dit pas si notre idéal doit être la richesse ou la pauvreté, le plaisir ou la douleur. Cette vérité a été méconnue par Durkheim et par ses disciples et cela constitue, à nos yeux, le reproche fondamental à adresser à l'école sociologique. Cette école cherche, en effet, à fonder une règle d'action catégorique sur des données purement scientifiques. Or cette tentative est contradictoire en soi. (...) Mais à supposer que la Science sociale arrive à déterminer pour tous les types de société ce qui est normal et ce qui est anormal, en résulterait-il autre chose pour l'homme qu'une règle d'action purement conditionnelle? Evidemment non. La Science sociale indiquerait à l'homme ce qui est normal, ce qui est anormal; elle lui indiquerait en même temps les moyens qui favorisent le normal ou qui entraînent l'anormal, mais elle ne lui dirait toujours rien en ce qui concerne le choix entre le normal et l'anormal", in CAPITANT, 1928, p. 16.

${ }^{163}$ CAPITANT, 1928, p. 17.
} 
O direito aparece, portanto, como um imperativo categórico, uma verdadeira regra de ação que orienta condutas por meio da coerção. "Somente o imperativo categórico é verdadeiramente uma regra de ação. O imperativo condicional é uma regra de ação simplesmente eventual. Somente o imperativo categórico é uma regra de ação imediata. Agir é, com efeito, não somente eleger um meio, mas também eleger uma finalidade. A escolha de um meio é uma preparação da ação. Mas a ação não é possível senão depois da escolha de uma finalidade. Ora, o imperativo condicional prescreve somente um meio, enquanto que o imperativo categórico prescreve igualmente uma finalidade. Ora, o direito é uma regra de ação. Ele ordena a sociedade. Ele é um plano de ação para os indivíduos. Os indivíduos devem agir conforme o direito. É por isso que a regra do direito é categórica" ${ }^{164}$.

A moral, tal como o direito, é composta por imperativos categóricos, na acepção kantiana. Mas em sentido estrito, os ramos se opõem. A distinção não se dá pelo conteúdo, já que o direito é suscetível de assumir qualquer conteúdo ${ }^{165}$, mas pela finalidade. "O imperativo jurídico é posto em vista da realização da ordem social (essa ordem social se chama o justo). O imperativo moral é posto em vista da realização de uma ordem individual no sujeito (essa ordem individual se chama o bem)" ${ }^{, 166}$. E, mais ainda, a passagem do direito ideal ao direito positivo implica em distanciar-se ainda mais da moral.

Capitant, entretanto, diverge de Kelsen em alguns dos aspectos cruciais de sua teoria. Em primeiro lugar, no que diz respeito à tensão entre validade e eficácia no direito, bem como à distinção que estabelece entre direito positivo e direito ideal. $\mathrm{O}$ momento fundamental do direito, para o francês, é o reconhecimento da norma pela generalidade dos sujeitos, e não a maneira pela qual é recebida como válida dentro do ordenamento jurídico enquanto sistema fechado. $\mathrm{O}$ direito aparece como ideal, em um determinado momento, mas o que lhe confere positividade é a sua aceitação pela massa dos indivíduos, é a sua obediência. " $O$ direito positivo é o direito obedecido; o direito não obedecido é o direito ideal. O direito positivo implica, portanto, o direito ideal, como toda noção implica a noção contrária. Toda uma escola jurídica, a escola do positivismo jurídico, contudo, descarta a noção do direito ideal, e ensina que não há senão o direito positivo" 167 . Mas a questão é saber qual é o elemento central que confere positividade à

\footnotetext{
${ }^{164}$ CAPITANT, 1928, p. 97.

${ }^{165}$ CAPITANT, 1928, p. 173.

${ }^{166}$ CAPITANT, 1928, p. 174

${ }^{167}$ CAPITANT, 1928, p. 123.
} 
norma, se sua fonte - a lei formal, o legislador, a vontade do Estado enquanto pessoa jurídica etc - ou se sua aceitação - o povo enquanto legislador supremo, a massa social etc.

"Uma das intuições mais brilhantes do jovem autor consiste em mostrar que uma regra de direito não é necessariamente o comando de um superior vis-à-vis um inferior. Isso porque a regra existe somente pelo reconhecimento por outrem, por seu destinatário" ${ }^{168}$. Em linhas bastante gerais, é assim que desloca o debate da validade para a eficácia, em discordância com Kelsen, fazendo da massa popular e de sua adesão consciente e voluntária à norma o mecanismo de sua positividade. Daí a importância não apenas dos costumes, mas dos princípios constitucionais, do direito não escrito.

O jovem francês é bastante enfático ao criticar a noção de norma fundamental: "Kelsen encontrou-se vinculado à sua definição inicial, segundo a qual a validade de uma regra de direito consiste na sua conformidade com uma regra superior. Ora, essa definição é inexata. Com efeito, se se considera a regra posta diretamente pela massa social, a regra normativa, ela é válida porque é posta pela massa social, porque é geralmente aceita, sem que haja nenhuma necessidade de buscar, para explicar sua validade, uma norma superior atribuindo competência à massa social. O critério da positividade de uma regra não é somente, como diz Kelsen, que pertença a uma cadeia de normas que se condicionam umas às outras. É preciso ainda que essa cadeia tenha sua fonte na massa social, única legisladora do direito positivo por essência. O que falta à teoria de Kelsen é uma definição suficientemente aprofundada da noção de direito positivo. $O$ direito positivo não pode ser definido como o direito 'válido', já que uma validade absoluta não tem sentido. A validade de uma regra não existe senão aos olhos de certos indivíduos, isso quer dizer que a validade de uma regra é o reconhecimento por certos indivíduos de que uma regra é válida, obrigatória, oboedienda. Essa validade é ideal se ela é reconhecida por uma minoria dentro do grupo social. Ela é positiva se é reconhecida pela generalidade do grupo social. Partindo dessas definições, pode-se considerar o direito positivo como uma pirâmide, assim como faz Kelsen. Mas no topo dessa pirâmide encontra-se não uma norma fundamental, mas um legislador supremo, que é a massa social"'169.

A segunda divergência fundamental com Kelsen é a perspectiva a partir da qual olha para o direito. O método de Capitant é antes de tudo subjetivista, ao contrário do objetivismo kelseniano. Ao definir o imperativo como "uma regra de ação formulada

\footnotetext{
${ }^{168}$ BEAUD, 2004, p. 31.

${ }^{169}$ CAPITANT, 1928, p. 163.
} 
pela consciência, isto é, em função dos dados indicativos" $" 170$, atribui centralidade aos pontos essenciais de sua teoria: a regra como uma ação resultante da escolha, do julgamento consciente do sujeito de uma determinada finalidade visada ${ }^{171}$. A regra é portanto produto da consciência que assim a reconhece e atribui consequência a ela, convertendo-a em ação e garantindo sua obediência.

Capitant faz questão de reforçar seu apego ao individualismo ao escrever Les propos d'Alain ou l'idéologie de la Troisième République. Nele, o francês defende que há uma ideologia que legitima e explica a Terceira República, que é justamente o individualismo representado pelo pensamento de Alain, o codinome do filósofo Émile Chartier (1868-1951).

Em um momento em que os liberais mais convictos começavam a abdicar de suas crenças, ameaçados pela ampliação da representação de partidos socialistas e comunistas no Parlamento, e em que ganhava espaço o corporativismo, o jurista é enfático ao sustentar que o indivíduo é a origem e a finalidade da sociedade, e que tal concepção é umbilicalmente vinculada ao espírito democrático. Para Capitant, o indivíduo precede a sociedade e o progresso é justamente a luta do indivíduo contra a sociedade em busca de sua liberdade. "A sociedade é o ser coletivo, é a horda primitiva, com a sua consciência coletiva, seus movimentos de paixão, de medo, de ódio ou de cólera, é o animal social presente em cada homem; é o chamado obscuro da raça, o instinto atávico, todos os poderes míticos que se apossam da alma e reprimem a razão" ${ }^{\text {172 }}$.

O indivíduo é o fim da sociedade, mas isso não significa anarquia, pelo contrário, reforça a necessidade do Estado, já que "o homem não pode nem deve viver isolado (...). Toda a civilização humana é fundada sobre a divisão do trabalho e a cooperação de forças. Ora, a ação coletiva não é possível senão pela subordinação comum a um poder de comando (...). A obediência é sobretudo a condição da ordem, que é ela mesma a condição da liberdade"173.

\footnotetext{
${ }^{170}$ CAPITANT, 1928, p. 5.

171 "Un impérative est un jugement porté par sa conscience. Je juge mon action et celle d'autrui d'après les données de ma conscience. Si ces données se modifient, mon jugement sera autre. Aujourd'hui, voici ce que je considère comme bien et juste. Si demain, ma conscience s'est modifiée, cela même qui me semblait juste pourra me sembler injuste. Qui engagera son jugement pour toute sa vie? Qui s'engagera à ne pas brûler ce qu'il aura adoré? Qui niera les conversions? Qui niera la prédication? 'Une pensée vient quand elle veut, et non que moi je veux' ainsi l'a dit Nietzche. Or, c'est de nos pensées que dépendent nos actions et nos jugements", in CAPITANT, 1928, p. 31.

${ }_{172}$ CAPITANT, 2004 (1935), p. 211.

${ }^{173}$ CAPITANT, 2004 (1935), p. 213.
} 
Portanto, na base da doutrina individualista está a liberdade, afirmaria Alain, como herdeiro da tradição de 1789, o que não excluiria nem mesmo o socialismo, “já que o socialismo, na sua tradição sentimental, é outra coisa senão a busca apaixonada da justiça?"174. A ameaça ao individualismo é o que ele chama de "mito social", o pensamento que busca submeter o Estado a uma razão superior aos indivíduos. " $E$ preciso que o Estado seja laico, isto é, laicizado, trazido do reino dos deuses para o reino dos homens, retirado dos fins divinos e entregue aos fins humanos. Alain se dirige contra a teocracia, contra a monarquia, que é sempre de direito divino, e sobretudo contra esse deus novo que se apodera dos povos e os subjuga aos seus fins cruéis e sangrentos: o nacionalismo. Isso quer dizer que ele recusa fazer da Pátria - e ele deveria dizer, em face dos nacionalismos modernos, da nação, da raça, do Volk - o fim supremo do Estado" "175. O único fim admissível do Estado é o homem, a justiça e a humanidade, o que não pode ser separado da democracia. A democracia tem como tarefa "liberar o individuo do império social e organizar a sociedade para os fins do indivíduo" ${ }^{176}$.

Mais uma vez, Capitant posiciona-se na contracorrente de sua época, ao retomar a metodologia clássica do direito para defender uma essência fundamental tanto da ciência jurídica quanto da Terceira República, combinando direito constitucional e ciência política; essa essência seria o indivíduo e a democracia que dele não se pode separar, na medida em que é o mecanismo pelo qual os indivíduos se governam a si mesmos. A doutrina jurídica, então, reabsorve o papel de racionalizar a irrupção do social, reagindo à realidade histórica com novas e pretensamente mais adequadas soluções teóricas, deixando de ser uma mera descrição pragmática das instituições e de seus mecanismos de funcionamento. Em Capitant, a retomada significa, sobretudo, o reacoplamento entre individualismo e democracia, que vinha sendo questionado pelas teorias que buscavam sustentar a existência de conteúdos substanciais, de ordem liberal, no direito, conteúdos que precederiam e superariam a livre deliberação democrática.

\subsubsection{Constituição, soberania e democracia}

A ideia de Constituição é a chave de compreensão do pensamento de Capitant - não à toa dedicou-se ao direito constitucional, sucedendo Carré de Malberg em

\footnotetext{
${ }^{174}$ CAPITANT, 2004 (1935), p. 214.

${ }^{175}$ CAPITANT, 2004 (1935), p. 215.

${ }^{176}$ CAPITANT, 2004 (1935), p. 212.
} 
sua cátedra. Constituição, para ele, é uma noção completamente impregnada da noção de costume $^{177}$, não enquanto direito natural, mas enquanto direito não escrito, oposto ao direito escrito. O francês explicita sua divergência com a maioria dos demais publicistas, inclusive seus mestres, para quem "tudo o que não é escrito cai no domínio do fato e da política, e não poderia ser visto como regra de direito", afirmando, em contrário, que "o intérprete desconhece que a 'positividade' é a única questão a ser resolvida, é, portanto, saber se a noção de direito escrito exclui ou admite a noção de costume. Ora, longe de excluí-la, ela a supõe ${ }^{„ 178}$. Assim sendo, o costume constitucional ocupa um lugar de destaque, no topo da sua concepção de pirâmide jurídica, já que, como visto, positividade para ele relaciona-se com eficácia, mais do que com validade das normas. E o costume reflete o momento de efetiva vigência, da obediência material às normas.

Não se trata, contudo, de criticar o direito escrito e sua defasagem em relação à realidade. $\mathrm{O}$ jurista defende a importância do direito escrito, afirmando inclusive que "se é verdade que nosso direito escrito está atrasado em relação aos fatos, a crítica visa o legislador, mais do que o sistema de direito escrito"179. O ponto é apenas ressaltar o que chama de momento de positividade da norma, especialmente relevante ao se falar da Constituição, que é relacionado com o costume. O direito escrito é importante - e inclusive ampliá-lo é a tendência que Capitant identifica em sua época -, mas ele pressupõe o direito não escrito.

Capitant é cauteloso ao delimitar sua compreensão de costume, distanciando-se da corrente que enxergava na jurisprudência o momento de afirmação das práticas jurídicas habituais. Ele a vê, ao contrário, como a "revanche do juiz sobre o legislador" ${ }^{\prime 180}$. Cita criticamente Hauriou, que, em sua visão aristocrática e confiante nas elites intelectuais como sujeito proativo da condução dinâmica do direito, via na jurisprudência a fonte moderna do costume. "Mas, na realidade, costume e jurisprudência têm como único traço comum não serem obra do legislador, mas eles se opõem profundamente na medida em que um é obra de uma autoridade social, o juiz, e o outro é produto direto da sociedade na qual está em vigor. Assim, a jurisprudência é uma variação do direito escrito, e não do costume"

${ }^{177}$ CAPITANT, 2004 (1930), p. 285.

${ }^{178}$ CAPITANT, 2004 (1930), p. 298.

${ }^{179}$ CAPITANT, 2004 (1930), p. 284.

${ }^{180}$ CAPITANT, 2004 (1930), p. 284.

${ }^{181}$ CAPITANT, 2004 (1930), p. 284/285. 
Mas qual seria o lugar do costume? Para ele, o direito constitucional reserva um lugar de destaque ao costume. "Se o corpo mesmo do nosso direito é hoje em dia escrito, o costume subsiste no topo do edifício jurídico; na pirâmide jurídica, os degraus superiores são costumeiros; nosso direito, por mais escrito que seja, tem contudo permanentemente sua fonte e seu fundamento no costume, já que a noção de constituição é impregnada da noção de costume" ${ }^{\text {182 }}$. Ao olhar para as constituições em vigor, tanto as mais antigas, como a francesa, quanto as recentes, como a alemã, a austríaca ou a polonesa, afirma que é preciso reconhecer que as fórmulas nelas contidas não dão conta da vida política nacional, tendo em conta as constantes e cada vez mais acirradas dificuldades de aclimatação do parlamentarismo. "As regras essenciais do funcionamento dos órgãos politicos, aquelas que regulamentam suas respectivas competências, que delimitam seu verdadeiro lugar na hierarquia de competências, são ditadas pelos costumes e vão de encontro ao texto da nossa Constituição" ${ }^{\text {183 }}$. Mas não são os textos que definem uma Constituição, e sim a forma como é exercida na prática, e é justamente a partir da abertura do direito promovida pela incorporação a ele (e mesmo pela proeminência) do costume enquanto fonte da positividade, que Capitant recoloca a doutrina jurídica em lugar de destaque na compreensão política e social de seu tempo.

“Ora, se se leva em consideração a verdadeira noção de constituição, se se fala de força e não de forma constitucional, se a constitucionalidade de uma regra reside não no procedimento de sua criação, mas no degrau que ela ocupa na pirâmide jurídica (e essa terminologia deveria ter esclarecido aqueles de quem a tomo), então a noção de costume constitucional cessa de ser contraditória; eu posso mesmo dizer que o costume é essencialmente constituinte e que a constituição, no seu degrau superior, é necessariamente costumeira. Ora, que é o costume, senão as regras diretamente postas pela nação, não escritas, isto é, escritas no pensamento e na consciência dos indivíduos que compõem o grupo social, conhecidas por essa razão, sem serem publicadas, obedecidas sem serem impostas? O que é o costume, senão a consciência e a vontade nacionais? E se a nação é soberana, se ela é o constituinte supremo, e se os outros poderes são necessariamente constituídos por ela, não é o costume, pelo qual ela se exprime, que está na base de toda ordem jurídica? A fonte de toda constituição não é costumeira?" 184 .

\footnotetext{
${ }^{182}$ CAPITANT, 2004 (1930), p. 285.

${ }^{183}$ CAPITANT, 2004 (1930), p. 286.

${ }^{184}$ CAPITANT, 2004 (1930), p. 292.
} 
Dessa forma, restitui o sentido jurídico da soberania nacional, enquanto atributo do constituinte supremo que é o povo, legitimidade fundamental das normas. Ainda, vincula soberania e democracia, e vai além: "Mas o que nós chamamos então soberania ou democracia é somente, visto de perto, a participação da nação na elaboração do direito escrito, a organização de meios escritos de manifestação da vontade nacional, e é evidentemente sempre como efeito dessa tendência, já denunciada, de absorver todo direito no direito escrito que se pode confundir a democracia com a legislação popular escrita" "185. A soberania implica mais do que a participação na elaboração do direito escrito, e a nação, ao manifestar sua vontade ao obedecer ou não ao direito, escrito ou não escrito, está apenas exercendo-a em sua plenitude: “já que o direito positivo não é senão o que se aplica realmente e do qual as prescrições são seguidas, o que se confunde com a sociedade que o rege (...). O direito pode receber o conteúdo do legislador, mas é a nação que terá sempre sua vigência"186.

É assim que conclui pela importância de a doutrina jurídica abrir-se para o direito não escrito, para o costume, que é pressuposto e interfere no direito escrito e em sua ampliação e transformação. O costume é, para Capitant, "o direito imprescritível do presente a se realizar, da inquietude a se renovar, e, como a consciência sempre móvel e corrente tira dessa mobilidade mesma a permanência e a identidade do Ser, assim o costume, no curso da História, reaviva a cadeia das constituições destroçadas" ${ }^{\text {"187 }}$.

Além de reivindicar a retomada da postura intelectual dos clássicos, o jurista está propondo, dessa maneira, uma abertura da doutrina e da ciência do direito à história e à política. Contudo, essa abertura não desconsidera a autonomia relativa do direito, pelo contrário. É justamente a partir da teoria abstrata e particularmente jurídica que Capitant busca promover a abertura do direito, isto é, ele parte de uma perspectiva interna ao direito, manejando conceitos pertencentes ao seu léxico próprio - como norma, Estado, soberania e Constituição - para sustentar uma abordagem diferenciada em relação à política e à história. A consequência de fundo é uma doutrina mais permeável à democracia de massas e à nova realidade social, por um lado, mas que não perca a dimensão individual do processo, afastando o risco de propostas autoritárias ou corporativistas. "A teoria da Constituição de René Capitant o força a colocar em primeiro plano as ideias politicas e constitucionais que se tornam fatores explicativos da história

\footnotetext{
185 CAPITANT, 2004 (1930), p. 292.

${ }^{186}$ CAPITANT, 2004 (1930), p. 293.

${ }^{187}$ CAPITANT, 2004 (1930), p. 295.
} 
constitucional. Indiretamente, mas necessariamente, a doutrina sai engrandecida desse elogio do direito não escrito e da história, uma vez que é ela a melhor a lhes decifrá$\operatorname{los}^{\prime 188}$.

\subsection{DiREITO, POLÍTICA E AÇÃO: LIBERALISMO VS. DEMOCRACIA}

Abrimos essa exposição citando um relato que dava conta da curiosidade quase teatral que atraía expectadores às sessões do Parlamento francês, no final dos anos 1920. Com efeito, o período é marcado pela radicalização das posições e pelas tensões entre as forças políticas, e os juristas não poderiam ficar alheios, especialmente os juristas que se caracterizavam pelo seu engajamento ou por sua proximidade com a política.

É nesse sentido que Joseph Barthélemy falava em sair da torre de marfim e enfrentar a realidade concreta. Para ele, isso significou justamente a formulação de uma nova abordagem para o direito constitucional, que não pretendesse, como a dos clássicos, fundamentar a teoria em verdades científicas, em abstrações metafísicas, ou em dogmas políticos. Ao direito caberia debruçar-se sobre a prática das instituições e a história política, inclusive comparada. Procura pensar um direito capaz de ser instrumento de movimento, que não estivesse preso à função de fator de resistência, de manutenção de uma ordem que já não mais corresponde à realidade dos fatos. O direito constitucional que defende não está mais preocupado em compor-se dentro da moldura de uma teoria do Estado ou de uma teoria constitucional consistente, coesa e universalizável; em lugar de definir o Estado, quer descrevê-lo. Não é muito distante da posição de Boris MirkineGuetzévitch, que se dedica à descrição do novo constitucionalismo europeu, procurando identificar nele traços comuns, um deles sendo justamente sua abertura a tornar-se não uma fotografia de uma dada sociedade, mas um fator de movimento. Trata-se de um direito constitucional voltado para o futuro, para a construção de uma determinada sociedade cuja idealização lhe é externa, já que pertence ao campo da política.

A democracia liberal e o sufrágio universal aparecem, em um primeiro momento, tanto para Barthélemy quanto para Mirkine-Guetzévitch, como o principal valor a ser garantido pelo direito constitucional. Para o primeiro, a posição é estratégica, na medida em que via na democracia liberal a garantia de conservação da ordem na era moderna, integrando as classes populares à política institucional a partir da canalização

${ }^{188}$ BEAUD, 2004, p. 43. 
regular e constante de suas demandas e evitando, assim, conflitos, que passam da rua ao fórum. A posição combina-se com uma defesa intransigente e liberal clássica do individualismo, e com a refutação de qualquer consideração ou incorporação política de grupos intermediários, na linha de uma democracia social. Para o russo, ainda otimista, o direito constitucional moderno caminharia no sentido da racionalização, isto é, da incorporação de parcelas cada vez maiores da regulação social ao seu texto. Abandona a pretensão meramente descritiva ao situar a democracia como o regime racional para o qual todas as constituições evoluiriam, como perspectiva de futuro, mas insiste no direito constitucional como técnica da liberdade.

Porém, ambos os autores assistem às rápidas transformações na realidade, e a perda de espaço da perspectiva liberal em nome de demandas sociais e socializantes. Barthélemy, um democrata por estratégia e um conservador quanto ao arranjo de forças por convicção política, vê sua crença na capacidade integradora do sufrágio universal ser abalada, quando então desloca seu pensamento para também identificar a substancialização do direito, ao qual atribui conteúdos mínimos. Assim passa a defender a existência de princípios superiores, que constituem o fundamento moral do Estado, sendo esses princípios especialmente relacionados ao indivíduo e à sua liberdade, mas conteriam também fórmulas abertas como dever, trabalho e honra. São valores que limitariam a amplitude sobre a qual pode deliberar o corpo eleito democraticamente. A legitimidade da legislação transfere-se de sua origem democrática para a sua finalidade, compatível com a eficiência técnica e o fundamento moral do Estado.

Mirkine-Guetzévitch também passa a ver com pessimismo o novo constitucionalismo, sobretudo ao perceber as tendências não raro contraditórias que estão na base da positivação das garantias e liberdades individuais, dos direitos políticos e democráticos e dos novos direitos sociais. Esse novo amálgama de direitos pode significar a limitação de uns em nome de outros, implicando talvez em restrição aos direitos de liberdade, que entendia como sendo o vetor central do direito constitucional. Nesse ponto, portanto, democracia e liberdade podem seguir rumos conflitantes, já que acredita, inclusive, que os povos para quem o amálgama foi inventado não estavam nem prontos nem preparados para exercer seu poder de participação democrático.

Por fim, René Capitant, tal como Carré de Malberg, aparece como exceção. Em um momento de virada pragmática do pensamento constitucionalista, o autor volta a defender a forma de pensar dos clássicos, procurando identificar um conteúdo teórico abstrato que dê integridade ao direito constitucional. Novamente, o fundamento do 
direito é o indivíduo, e é em sua autonomia de fixar normas a si mesmo, e na sua consequente obediências às normas postas, que reside sua validade. $\mathrm{O}$ povo é o legislador supremo, e o indivíduo enquanto origem e finalidade da norma é o responsável pela produção do direito, inclusive por meio do costume. A Constituição é aquilo que se exerce na prática, e nesse sentido não pode ser compreendida como o instrumento de uma elite política, nem cerceada por conteúdos substantivos que a doutrina quer imprimir ao direito. Pensar o direito a partir do indivíduo é, para ele, reacoplá-lo à democracia, e não abdicar dos valores liberais que sustentaram a Terceira República. 
PARTE II

ELABORANDO A CONSTITUIÇAO BRASILEIRA DE 1934 


\section{Capítulo 4}

\section{SEGUNDA REPÚBLICA BRASILEIRA: RUPTURA E COMPROMISSO INSTÁVEL}

4.1 Apontamentos históricos gerais; 4.1.1 Da Primeira República à Revolução de 1930; 4.1.2 Propostas para o "país legal": a difícil conciliação; 4.2 Aspectos institucionais e primeiras reformas legislativas (1930-1934); 4.3 Formulando a Constituição Nacional; 4.3.1 Subcomissão Itamaraty; 4.3.2 Assembleia Nacional Constituinte

Inauguramos a parte I dessa pesquisa com um capítulo sobre a história social e política, bem como das ideias jurídicas, da França do entre-guerras. A premissa é a de que é impossível desenvolver um trabalho voltado à compreensão das ideias jurídicoconstitucionais sem ter em mente, ao menos de forma panorâmica, o contexto em que se apresentam. Assim sendo, dedicamos um capítulo daquela parte à perspectiva histórica mais geral, como introdução aos capítulos analíticos. É o que faremos igualmente aqui, nesta Parte II.

Trataremos, portanto, de forma esquemática, da origem da Revolução de 1930 e dos desafios, políticos e teóricos, que dela resultaram. A seguir, passaremos pelos aspectos institucionais e pelas reformas legislativas do Governo Provisório, que dura de 1930 a 1934, com a promulgação da Constituição. O último item será uma introdução propriamente dita aos demais capítulos, recuperando o processo constituinte e seus atores, desde a Subcomissão Itamaraty, responsável pela elaboração do anteprojeto de Constituição, até a Assembleia Nacional Constituinte. O pressuposto é o de que estamos, tal como no primeiro capítulo, assumindo os riscos de uma revisão apressada da história, com as evidentes lacunas decorrentes da limitação de seu espaço na pesquisa total, adicionando a isso a suposição de um maior conhecimento prévio do leitor da história e da historiografia brasileiras do que dos equivalentes franceses.

\subsection{APONTAMENTOS HISTÓRICOS GERAIS}

"A Constituição efetiva de um país não existe senão nas relações de força em um país; as Constituições escritas não possuem valor e duração senão se forem a 
expressão exata das relações de força, tais como são na sociedade”, escreve Lassale ${ }^{1}$. A Constituição é produto de seu tempo. Dizer e reafirmar o óbvio, como talvez se venha fazendo ao longo desse trabalho, tem importância, para que não se perca de vista a relação entre direito, política e realidade social, sobretudo em um estudo que pretende focar-se nas ideias jurídico-constitucionais. Fixa-se como pressuposto inescapável a relação de determinação, ainda que parcial, do contexto social sobre a Constituição, que é produto das relações de força concretas e dos debates teóricos que as acompanham em um determinado momento histórico, filtrada pela linguagem relativamente autônoma do direito.

Assim sendo, não se pode estudar a Constituição de 1934 sem compreender o contexto histórico de que é fruto, as forças políticas que o determinam ou que são determinadas por ele e as ideias que se apresentam ao debate. O país vinha de uma ruptura da ordem anterior, chamada de Revolução ${ }^{2}$, liderada pelas forças reunidas em torno da Aliança Liberal, movimento que tinha deposto o presidente, impedido a posse do eleito e colocado em seu lugar Getúlio Vargas. Inaugura-se o período chamado de Governo Provisório, denominação que destaca a transitoriedade do regime e a intenção de restabelecimento da ordem constitucional em novas bases. Do ponto de vista da história das ideias, é o período de consolidação de um pensamento que se pretendia tipicamente nacional, de viés autoritário, fundado na crítica à importação de modelos que se vinha praticando até então, especialmente na Constituição de 1891. Trata-se de um dos períodos mais estudados na história recente do Brasil, divergindo a historiografia em polêmicas que já podem ser consideradas temas clássicos no pensamento social brasileiro. Portanto, se é preciso tratar do contexto histórico e do debate na história das ideias, por um lado, por outro lado esse não é o foco do trabalho, bastando, aqui, apenas pontuar alguns dos fatos e questões que serão instrumentais para a conclusão final, reportando-nos às indicações bibliográficas de pé de página para aprofundamento.

\footnotetext{
${ }^{1}$ LASSALLE, 1900 (1862).

${ }^{2}$ Não se desconhece a existência de uma corrente da historiografia que questiona a qualificação de "revolução" à transição de 1930, devendo o verdadeiro momento revolucionário ser localizado em 1928, e relacionado à ação do Bloco Operário Camponês (BOC) - trata-se aqui, especialmente, das teses que se articulam em torno da leitura de Edgard de Decca, 1930: O silêncio dos vencidos (1981). A questão é profícua, relacionando-se inclusive com a polêmica em torno do termo revolução, ou de sua variação democrático-burguesa. Não nos interessa suscitá-la, bastando por ora ficar com a denominação recorrente, qual seja, "Revolução de 1930", para tratar do episódio. Por certo, estamos assumindo a posição segundo a qual o aspecto predominante em 1930 foi o de descontinuidade, o de ruptura, em um sentido frouxo de revolução, ainda que não se possa relevar que a complexidade do processo social implicou, também, em continuidades. Para o assunto, cf. FERREIRA e PINTO, 2006, pp. 22 e ss., FAUSTO, 1988, pp. 15 e ss.
} 


\subsubsection{Da Primeira República à Revolução de 1930}

A Revolução de outubro de 1930 é inaugurada com o movimento armado liderado pelos Estados de Minas Gerais, Rio Grande do Sul e Paraíba, que culmina com a deposição, no dia 24 daquele mês, do presidente Washington Luís e com o bloqueio da posse do eleito Júlio Prestes. Como se sabe, os Estados dissidentes haviam lançado, no ano anterior, a Aliança Liberal, que sustentava a candidatura presidencial de Getúlio Vargas contra o candidato indicado pela oligarquia paulista, em desrespeito à alternância que vinha sendo observada anteriormente (chamada "política do café-com-leite"). Levantando suspeitas de fraude eleitoral e em meio a uma crise econômica e política, potencializada pelo assassinato de João Pessoa, candidato à vice-presidência pela chapa de Vargas, os dissidentes dão início a uma revolta que enfrenta pouca resistência por parte do governo federal, e que se vê bem sucedida em pouco tempo. No dia 3 de novembro, Vargas substitui-se no poder à Junta Provisória de Governo, ocupando a chefia do chamado Governo Provisório.

É preciso dar um passo atrás, para compreender a ruptura que a Revolução de 1930 representou. De modo geral, a Primeira República é marcada por uma economia eminentemente agrário-exportadora, organizada a partir de latifúndios produtores, o que se reflete sobremaneira na organização política do país. É de Victor Nunes Leal a análise clássica sobre a correlação entre propriedade de terras, poder privado, e poder político local, o coronelismo ${ }^{3}$. As lideranças políticas regionais controlavam os votos, a partir da ampla jurisdição e poder que detinham sobre seus dependentes e sobre a população local, que havia sido incluída no processo político com a proclamação da República e o fím do critério censitário - bem entendido que se trata da população masculina e alfabetizada. A partir dessa espécie de moeda de troca, que é o voto, as lideranças barganhavam com o governo estadual vantagens e conveniências para a manutenção de seu poder, bem como represálias aos seus adversários, fundando compromissos políticos que se renovavam com o passar do tempo ${ }^{4}$. Dessa forma, o poder público republicano e o poder privado, que se compõe em acordos entre as oligarquias rurais, fortalecem-se lado a lado, comprometendo-se também na composição do poder central. Por certo, a descrição do funcionamento desse sistema é complexa, e não cabe

\footnotetext{
${ }^{3}$ Vide LEAL, 1997 (1948), a quem nos reportamos para a descrição clássica do sistema de compromissos políticos e econômicos durante a Primeira República.

${ }^{4}$ Cf. FERREIRA e PINTO, 2006, pp. 4/5.
} 
aqui, bastando reter, apenas, a descentralização política como eixo principal, a definição dos governos a partir de acordos entre as oligarquias locais e a predominância dos interesses privados dos latifundiários na determinação política da nação ${ }^{5}$.

Do ponto de vista econômico, a principal atividade era a exportação de produtos agrícolas, cultivando-se café, açúcar, borracha e fumo. O café ocupava lugar de destaque, e "a burguesia cafeeira detém em última análise o poder, por intermédio do eixo São Paulo-Minas, reunindo as duas oligarquias mais poderosas, a partir da eleição de Prudente de Moraes (1894)" ${ }^{\prime}$. As oligarquias preponderantes, paulista e mineira, alternamse no poder central, no que ficou conhecido como "política do café-com-leite", garantindo com isso incentivos à produção cafeeira, e acomodando, ao mesmo tempo, oligarquias de segunda grandeza e os chamados Estados satélites ${ }^{7}$. Ela se estabiliza com a chamada política dos governadores, montada por Campos Sales, empossado presidente em 1898, a partir da qual se estabelecem relações de igualdade entre os Estados dominantes e a União. "Extraindo sua força, em última instância, da grande propriedade agrária, ela exprime entretanto menos o 'coronel' do interior, vinculado apenas ao meio rural, do que os interesses de conjunto de classe, condensando os grupos produtores, comerciais e financeiros ligados ao cafe",

A composição de forças permite uma simbiose entre interesses econômicos privados e políticas econômicas governamentais, especialmente focadas na garantia da economia cafeeira. A queda de preços do café no mercado internacional forçava desde há muito a intervenção do governo para assegurar ao setor a viabilidade do negócio, com práticas de controle cambial e até mesmo compra, estoque e destruição de parcelas da produção, passando por endividamento externo. Criaram-se, para tanto, entidades públicas diretamente responsáveis pelas políticas governamentais destinadas à economia cafeeira, como o Instituto de Defesa Permanente do Café (IDPC, 1922), o Instituto Paulista de Defesa do Café (IPDC, 1924), posteriormente chamado Instituto do Café do Estado de São Paulo (1926). Diga-se, desde logo, que a intervenção frequente do governo para disciplinar preços e oferta de café é uma prática de difícil conciliação teórica com as premissas do laissez faire econômico consolidadas na Carta de 1891, contradição

\footnotetext{
${ }^{5}$ Para um balanço historiográfico do período, até o final dos anos 1980, ver GOMES e FERREIRA, 1989.

${ }^{6}$ FAUSTO, 2005 (1970), p. 120.

${ }^{7}$ FERREIRA e PINTO, 2006, p. 5.

${ }^{8}$ FAUSTO, 2005 (1970), p. 121.
} 
do liberalismo brasileiro ${ }^{9}$ que não deixará de ser apontada na Constituinte de 1933/34, como se verá.

O arranjo possui nuances e interpretações extensas e variadas, que deixaremos de fora, mas aproveitando a descrição apenas para caracterizar a prevalência política na sociedade brasileira da Primeira República de grupos de produtores agrícolas, agrupados em oligarquias regionais, ou melhor, estaduais, que, além de deter poder econômico privado, controlavam o poder político até mesmo para a manutenção de suas posições. Dentre elas, destacavam-se as grandes oligarquias, especialmente mineira e paulista, que estão na base da composição de forças políticas do período, que lograva, ainda que de forma instável, manter o controle do poder central e dos poderes estaduais, por meio do controle do eleitorado pelos coronéis (o conhecido "voto de cabresto") valendo-se de compra de votos, arregimentação de eleitores e mesmo de fraudes eleitorais, bastante frequentes.

Vale lembrar que grande parte da população brasileira, cerca de $70 \%$ em $1920^{10}$, vinculava-se a ocupações agrárias, e os trabalhadores viviam em "condições que não se afastavam muito dos tempos da escravidão" "11, com baixos salários e relações de trabalho precárias. A taxa de alfabetização, em 1920, era de 24,5\%, e apenas Distrito Federal e Rio Grande do Sul superavam os 30\% - a título comparativo, é útil mencionar que a França, no mesmo período, tinha $89 \%$ de sua população de 10 anos ou mais alfabetizada $^{12}$. Os analfabetos estavam excluídos da participação eleitoral, resultando em um corpo eleitoral muito restrito - não chegava a $8 \%$ da população, sendo o comparecimento eleitoral efetivo durante a Primeira República inferior a 3\%, à exceção das eleições de 1930. Mesmo os aptos a exercerem direitos políticos estavam sujeitos ao poder político dos coronéis. "Era generalizado o receio de sair às ruas em dias de eleição devido à violência dos capangas a serviço dos candidatos" $" 13$. Antes disso, as oligarquias em geral compunham-se para a indicação de candidatos (até porque arregimentar eleitores e comprar votos tornava as eleições caras) o que resultava em eleitos com mais de $70 \%$ dos votos na maioria das eleições presidenciais. "De qualquer modo, a conclusão que se pode

\footnotetext{
${ }^{9}$ Conforme aponta Wanderley Guilherme dos Santos, "as relações de trabalho no setor agrícola da economia jamais chegaram a se aproximar das condições da acumulação laissez-fairiana clássica", fato que aponta como "arquiconhecido", in SANTOS, 1979, p. 71. Do mesmo modo, as relações entre produção privada e poder público também não mantiveram a independência pregada pelo liberalismo econômico, na medida em que o crescimento da economia brasileira sempre dependeu das políticas de governo.

${ }^{10}$ Dados em CARVALHO, 2003, p. 102.

${ }^{11}$ CARVALHO, 2003, p. 101.

${ }^{12}$ Dados em CARVALHO, 2003, p. 100.

${ }^{13}$ CARVALHO, 2003, p. 105.
} 
tirar dos dados apresentados era que o eleitorado, o povo das eleições, o povo político oficial, por si só, era incapaz de constituir qualquer ameaça ao sistema"14, conclui José Murilo de Carvalho. Sem dúvida, as camadas populares não podem ser vistas como uma ameaça de efetiva subversão da ordem pela via eleitoral, mas com isso não se quer dizer que pudessem ser tidas em posição de absoluta passividade. Se não são sujeito na ação que levou à Revolução de 1930, não deixavam de figurar como uma pressão latente sobre o status quo oligárquico, que via-se na necessidade de lidar com a "questão social"15.

Por outro lado, já nos anos 1920 não é desprezível a formação de uma burguesia industrial urbana. Sobretudo localizada em São Paulo e no Rio de Janeiro, o setor industrial compunha-se de unidades de pequeno porte voltadas à produção de bens de consumo para os trabalhadores, sendo predominantes os ramos têxteis e de alimentos. Como aponta Boris Fausto, "a indústria se caracteriza, nessa época, pela dependência do setor agrário-exportador, pela insignificância dos ramos básicos, pela baixa capitalização, pelo grau incipiente da concentração"16. Apesar da existência de pontos de tensão entre o setor agrário e o industrial, que organizava-se em associações e começava a pressionar por incentivos à dinamização do setor (sobretudo erigindo medidas protecionistas de restrição às importações), predomina a complementaridade básica entre eles, e a incapacidade dos industriais de apresentar um projeto alternativo de

\footnotetext{
${ }^{14}$ CARVALHO, 2003, p. 107.

${ }^{15}$ Nesse sentido, a ressalva de Weffort: "já no processo de abertura da crise da oligarquia, seria necessário dar atenção ao fato de que a ausência das massas na insurreição não pode ser entendida como indicadora de uma passividade global de seu comportamento. Elas se encontram ausentes da ação, mas presentes para qualquer das duas facções em conflito, como uma pressão permanente sobre o status quo oligárquico. Suas lutas, que se estenderam por todas as primeiras décadas do século, embora não tenham conduzido a claras projeções de transformações políticas, parecem ter sido suficientes para apresentar-se às minorias dominantes como um problema real e, até certo ponto, como uma ameaça”, in WEFFORT, 1989, p. 75.

${ }^{16}$ FAUSTO, 2005 (1970), p. 37 . Vide pp. 36/69 para sua caracterização e análise do setor industrial do período. No mesmo sentido, afirma Robert Rowland: "As possibilidades de que se desenvolvesse, no Brasil, um setor industrial orgânico e relativamente autônomo foram liquidadas (se é que existiram) pela política econômica livre-cambista adotada depois da Independência. A indústria surgiu a partir do último quartel do século XIX no âmbito de uma economia agroexportadora consolidada, a ela complementar e subordinada. A forma de integração do Brasil dentro da economia mundial, como exportador de produtos primários e importador de produtos manufaturados, determinou a interdependência estrutural entre o setor exportador e a indústria. Produzia-se localmente só o que não era importado (...). Como consequência, não se formou um setor industrial orgânico e os industriais não se constituíram em grupo de pressão autônomo e coeso, preferindo solicitar favores, individualmente, dos cafeicultores que detinham o poder político. Por causa da interdependência estrutural entre a indústria e o setor agroexportador as possibilidades de acumulação de capital na indústria dependiam mais da ação do Estado na elevação dos custos da concorrência estrangeira do que da sua intervenção no mercado da força de trabalho. Isto, mais o fato de que, como imigrantes, muitos industriais estavam marginalizados dentro do sistema politico, fez com que até pelo menos 1930 eles se comportassem como agregados políticos dos cafeicultores", in ROWLAND, 1974, pp. 11/12. Para uma análise detalhada, ver DRAIBE, 2004, pp. 23 e ss.
} 
desenvolvimento do país ${ }^{17}$, refutando-se a tese dualista, que vê na divergência entre os setores o impulso da Revolução de $1930^{18}$. Com isso, o setor industrial posicionava-se, ao mesmo tempo, como dependente do setor agrário, mas também como crítico das visões anti-industrialistas, que não raro se manifestavam, inclusive na Constituinte de 1933/34, ansiosas por afirmar a "vocação agrária nacional".

A existência de um setor industrial nascente tem como decorrência direta a formação de uma classe operária urbana, praticamente o único extrato das camadas populares que se encontra mais ou menos organizado no final da Primeira República. Mas estava longe de ser majoritário - conforme dados do recenseamento de 1920, 13\% das ocupações nacionais estava ligada à indústria, com absoluto predomínio dos Estados e cidades maiores, sobretudo São Paulo e Distrito Federal ${ }^{19}$. Zélia Lopes da Silva ${ }^{20}$ descreve as condições de vida precárias desses trabalhadores nas cidades, homens, mulheres e crianças, cumprindo longas jornadas de trabalho e recebendo salários diferenciados (indicando a inexistência de critérios claros usados pelos empresários para a fixação de salários e as consequentes desigualdades, na base da reivindicação do movimento sindical por paridade e de salário mínimo) e progressivamente deteriorados. Assim, organizam-se e promovem greves, reivindicando uma legislação social eficaz - "seu ponto alto verificouse nas greves de 1917-19 em São Paulo e no Rio de Janeiro. Em 1917 houve 45 greves na capital e 29 no interior do Estado de São Paulo"21, contando com a participação, reportada, de mais de 60 mil trabalhadores - que são sistematicamente reprimidas pelos governos. As greves têm como um dos efeitos potencializar a importância da organização do setor dos empregadores em associações de classe, como o já existente Centro Industrial do Brasil (CIB, 1904) e o posterior Centro das Indústrias do Estado de São Paulo (CIESP, 1928). Despertam atenção também para a questão dos imigrantes, que não raro estão no centro dos conflitos, presença que, da mesma forma, é respondida com repressão por parte do governo, que já em 1921 editava a Lei de Expulsão de Estrangeiros. A lei permitia a expulsão sumária de imigrantes envolvidos em agitação social - vale notar que o impulso

\footnotetext{
${ }^{17}$ Em artigo posterior, Fausto aceita parcialmente algumas das críticas à sua posição, admitindo que "os estudos mais recentes demonstram que a articulação dos empresários, pelo menos a partir da década de 20, no terreno da organização do trabalho no interior das fábricas e na defesa de seus interesses específicos (proteção tarifária, taxa cambial etc) tinha alcance maior do que supunha" (FAUSTO, 1988, p. 11), mas insiste em diferenciar capacidade de organização e intervenção política da burguesia industrial e capacidade de formular um projeto de hegemonia, elemento que entende que esta não possuía.

${ }^{18}$ A referência aqui é Nelson Werneck Sodré, e sua obra Formação histórica do Brasil (1962).

${ }^{19}$ Dados e análise em CARVALHO, 2003, p. 100.

${ }^{20}$ Para uma descrição detalhada do perfil e da composição da classe operária brasileira, ver SILVA, 1990, pp. 20/43. Vide também CARVALHO, 2003, pp. 107/109.

${ }^{21}$ CARVALHO, 2003, p. 108.
} 
de controle da nacionalidade e de expulsão dos estrangeiros "indesejáveis" encontrará eco na Constituição de 1934. Tratando da organização popular, não se pode esquecer, ainda, que em 1922 era fundado o Partido Comunista Brasileiro (PCB) que, na maior parte do tempo na ilegalidade ${ }^{22}$, organizava-se para participar da disputa política institucional.

A questão da nacionalização da força de trabalho deve ser tratada, também, como um fator em si relevante para a sociedade da época. Conforme aponta Luiz Felipe de Alencastro ${ }^{23}$, o que acontece por volta de 1930 é a territorialização do mercado de trabalho nacional, que desvincula-se do padrão anterior, amplamente baseado na mãode-obra imigrante. Com isso quer ressaltar o decrescente fluxo de imigrantes e o crescente fluxo de migrações internas, especialmente direcionadas ao Estado de São Paulo, o que determina a revisão da postura do poder público - o Estado de São Paulo elimina a subvenção oficial à imigração em 1927, por exemplo. A consequência disso é a necessidade de incorporação política e ideológica de uma massa de trabalhadores nacionais, um desafio que se apresentaria ao governo resultante da Revolução de 1930. “Enquanto o mercado de trabalho foi predominantemente alimentado pelo tráfico negreiro e pela imigração - enquanto a economia brasileira comia os trabalhadores crus -, o poder politico encontrava-se em face de trabalhadores mantidos em situação de infracidadania. Nessas condições o discurso ideológico resumia-se praticamente ao diálogo entre as classes dirigentes (a burocracia imperial e republicana) e as classes dominantes (as oligarquias regionais). A partir do momento em que a reprodução ampliada da força de trabalho se territorializa - quando a economia passa a comer trabalhadores cozidos -, o discurso ideológico não pode mais evoluir intramuros no estreito espaço do poder. Doravante era preciso uma 'linha de massa', uma ideologia que encobrisse o sentido e a orientação do cotidiano, que justificasse as relações complexas unindo dominantes e dominados $" 24$.

O movimento operário e a nova composição do mercado de trabalho, inclusive rural, que deixa de ser constituído por indivíduos mantidos em situação de infracidadania (escravos, e depois imigrantes), não são de forma alguma desprezíveis no cenário social e político da época. A avaliação de sua força política às vésperas de 1930 é ponto de divergência na historiografia, conforme já mencionado, mas as evidências parecem indicar que, apesar de não poderem ser considerados determinante para os eventos

\footnotetext{
${ }^{22} \mathrm{O}$ partido só teve funcionamento legal, nessa época, de março a junho de 1922 e de janeiro a agosto de 1927 (CARONE, 1974, p. 352).

${ }^{23}$ Cf. ALENCASTRO, 1987a.

${ }^{24}$ ALENCASTRO, 1987a, p. 20.
} 
que se seguiram, tampouco terem atuado como influência direta nos rumos do país com a Revolução, são um elemento importante para a compreensão do processo, sendo inadequado enxergar nas camadas populares apenas passividade. Sem dúvida esse novo cenário está na origem da nova perspectiva que será assumida em relação à questão social após 1930, que havia sido reveladoramente tratada por Washington Luís, Presidente da República entre 1926 e 1930, como "caso de polícia". A questão social demandava um reposicionamento na agenda política nacional, e o movimento revolucionário buscaria dialogar com essa nova realidade.

Mas há outros elementos-chave para a análise da Revolução de 1930, e do Brasil que se seguiu. Após a Primeira Guerra Mundial, a insatisfação crescente com a condução e com as condições das Forças Armadas Brasileiras, bem como, de forma mais ampla, com o esquema oligárquico de revezamento de poder (que, segundo os tenentes, havia "transformado o país em vinte feudos cujos senhores eram escolhidos pela política dominante ${ }^{\# 25}$ )levou os oficiais de patentes intermediárias - coronéis e sobretudo os tenentes, que tinham a sua promoção cada vez mais lenta, o que os tornava numerosos - a organizarem-se em um movimento, o tenentismo. Originalmente agrupados em torno de ideias difusas, vinculadas ao nacionalismo e à centralização política, com destaque para o papel dos militares na política e para um embrião de autoritarismo, o tenentismo é responsável por insurreições contra o governo durante os anos $1920^{26}$ - cite-se a revolta dos Dezoito do Forte de Copacabana, de 5 de julho de 1922 (o primeiro 5 de julho), a revolta de 1924 (o chamado segundo 5 de julho) e a Coluna Prestes, entre 1924 e 1927.

O programa tenentista é bem pouco consistente, no início, articulado em torno de propostas como "a reforma da Constituição, a limitação da autonomia local, a moralização dos costumes políticos e a unificação da justiça e do ensino, assim como do regime eleitoral e do fisco" ${ }^{, 27}$. Valem-se da crítica à contradição entre a retórica liberal e as práticas eleitorais das oligarquias regionais, crítica essa que dialogava especialmente com

\footnotetext{
${ }^{25}$ FERREIRA e PINTO, 2006, p. 12.

${ }^{26}$ Conforme aponta José Murilo de Carvalho, a peculiaridade da história brasileira explica a possibilidade de as Forças Armadas comportarem-se como oposição ao governo oligárquico: "Como a independência se fez sem guerra civil, não surgiram no Brasil os caudilhos militares ligados à grande propriedade da terra. $O$ Exército formou-se em ambiente politico de predomínio civil (...). Em 1930, os jovens militares ainda eram uma força de oposição à elite civil. A experiência adquirida desde 1922, os contatos civis da oposição, deu a eles maior visão política, ideias mais claras sobre reformas políticas e, sobretudo, econômicas e sociais. Como em 1889, eram favoráveis a um governo forte que, usando a linguagem positivista, chamavam de ditadura republicana. Esse governo deveria ser usado para centralizar o poder, combater as oligarquias, reformar a sociedade, promover a industrialização, modernizar o país. Apesar de não ser democrático, o tenentismo era uma força renovadora", in CARVALHO, 2001, p. 96/97.

${ }^{27}$ FERREIRA e PINTO, 2006, p. 12.
} 
as camadas médias urbanas, para defender uma solução elitista, conduzida pelo Exército, que fosse capaz de livrar o país de sua velha política. “ $O$ 'elitismo' tenentista se revela, desde logo, na estratégia revolucionária: a insurreição desligada das classes populares, incapazes de superar a passividade e promover, por suas próprias mãos, a derrubada das oligarquias. Mas a intervenção da força armada visa também 'prevenir excessos" 28 , quase como em um programa de salvação nacional.

Apelando diretamente às camadas sociais urbanas médias, com suas críticas ao corrompido sistema eleitoral da Primeira República, a causa tenentista contava com sua simpatia, de onde não se pode inferir um vínculo ideológico absolutamente coeso $^{29}$. "À medida em que, sobretudo nos seus níveis mais baixos [das camadas médias], começava a se manifestar uma consciência crítica, esta assumia formas jurídicomoralistas e opunha à prática política das oligarquias as fórmulas abstratas de uma democracia liberal" ${ }^{30}$, escreve Rowland, para quem as camadas médias mobilizavam-se ideologicamente inspiradas por um certo liberalismo. A tentativa de combinação de um pensamento elitista com a defesa da correção das práticas eleitorais que fundavam-se sobre premissas democrático-liberais já indicava, em si, uma tensão. Enquanto não se pode excluir a existência de parcela da pequena burguesia urbana que flertava com as promessas tenentistas de salvação militar, por outro lado não se pode também vislumbrar uma aproximação total de ideias entre classes médias e tenentes. Ambos convergiam na defesa do voto secreto, das liberdades individuais e de um nacionalismo difuso ${ }^{31}$, o que está longe de representar uma harmonia total, como quer fazer crer Virgínio Santa Rosa ${ }^{32}$.

\footnotetext{
${ }^{28}$ FAUSTO, 2005 (1970), p. 89. No mesmo sentido, Gilberto Bercovici: “A revolução deveria ser feita de forma autônoma ao povo, que não soube romper com sua passividade para derrubar as oligarquias e o Exército seria a proteção da nação contra a eventual indisciplina popular", in BERCOVICI, 2008(b), p. 25, nota 2.

${ }^{29}$ Conforme apontam Marieta de Moraes Ferreira e Surama Conde Sá Pinto, a historiografia diverge na interpretação do tenentismo, especialmente em relação à sua origem ou seu vínculo com as camadas médias urbanas. Para uma breve descrição das correntes historiográficas, vide FERREIRA e PINTO, 2006, pp. $13 / 14$.

${ }^{30}$ ROWLAND, 1974, p. 10.

${ }^{31}$ FAUSTO, 2005 (1970), p. 93.

${ }^{32} \mathrm{O}$ autor identifica a coesão e o impulso revolucionário de tenentes e camadas médias como fator decisivo para a Revolução de 1930, escrevendo: "Desde os primórdios do rompimento das fileiras das oligarquias dominantes, a partir dos discursos dos líderes mineiro e gaúcho na tribuna da Câmara dos Deputados, as classes médias urbanas principiaram a colher os frutos da situação. Antes de tudo, como vantagem incial, a polarização súbita das diversas oposições regionais, em torno do bloco coordenador dos situacionismos dissidentes, provocou o fortalecimento instantâneo de nossa vida partidária, associaram-se incontinenti para a grande batalha. As minorias dos núcleos urbanos, o eleitorado das metrópoles estaduais, surgiram repentinamente arregimentadas como uma força coesa e poderosa. As vozes abafadas pela tacanhez tumultuosa das minorias, os votos perdidos graças à grosseria formidável do nosso sistema eleitoral, tudo isso se ergueu de chofre, para engrossar as hostes do aglomerado de esperanças e descontentamentos variados e desconexos que se chamou Aliança Liberal...", in SANTA ROSA, 1976 (1933), p. 50.
} 
Os anos 1920 começam, para o Brasil, como tempos de crise. As disputas em torno das eleições de 1922 já indicam a possibilidade de um racha entre as grandes oligarquias paulista e mineira e as oligarquias médias, do Rio de Janeiro, Pernambuco, Bahia e Rio Grande do Sul, que se organizam em uma chapa concorrente, a Reação Republicana, encabeçada por Nilo Peçanha ${ }^{33}$. 1922, é importante lembrar, é também o ano de fundação do PCB e da Semana de Arte Moderna, ambos indicativos de um país em transição. Após um período de relativa estabilidade durante o governo Washington Luís, com a repressão às revoltas tenentistas, a crise econômica de 1929 - que representou uma contenção internacional de crédito e a superprodução de café seguida de queda violenta dos preços do café, liquidando o programa de estabilização do governo - e o início de um novo processo de sucessão presidencial voltam a trazer incerteza para a situação política nacional. A divergência entre Minas Gerais e São Paulo na indicação do candidato abre espaço para outras disputas e pretensões entre as demais oligarquias, e forma-se a Aliança Liberal como força opositora, sob o lema "representação e justiça". A base de sustentação da Aliança Liberal eram as oligarquias dissidentes de Minas Gerais, Rio Grande do Sul e Paraíba, que contavam com uma ala jovem (Virgílio de Melo Franco, José Américo, Oswaldo Aranha, Getúlio Vargas, Lindolfo Collor etc., a chamada “geração de 1907”, ano de sua formação universitária) disposta a alcançar o poder pela via das armas, se necessário, mas também grupos de oposição de vários Estados, como o Partido Democrático criado em 1926 em São Paulo, e facções civis e militares descontentes ${ }^{34}$. Derrotados em eleições cercadas por denúncias de fraudes, que dão a vitória ao situacionista paulista Júlio Prestes, recorrem de fato às armas para depor o presidente.

O problema está em como interpretar a Revolução de 1930, identificando as determinações e forças políticas predominantes. A historiografia vem tratando do assunto há décadas, e por certo nossa contribuição não será dedicada a esclarecer ou mesmo a entrar em detalhes na polêmica. Mas é importante que se compreenda que uma das razões que explicam as divergências é justamente a falta de uma orientação política clara no movimento de 1930, a não ser o impulso de derrubada da Primeira República, ou de seu esquema de revezamento de poder entre as grandes oligarquias, especialmente paulista e mineira.

\footnotetext{
${ }^{33}$ Para um histórico e para as diferentes interpretações historiográficas sobre a Reação Republicana, vide FERREIRA e PINTO, 2006, pp. 6/11.

${ }^{34}$ Cf. FAUSTO, 2005 (1970), pp. 128 e ss., FERREIRA e PINTO, 2006, p. 15.
} 
A tese, hoje clássica, apresentada por Boris Fausto nos anos setenta é a de que a Revolução de 1930 é resultado de tensões intra-oligárquicas, fortalecidas pelos movimentos militares dissidentes que queriam romper com o arranjo de forças da Primeira República e pela suscetibilidade das classes médias urbanas à retórica da renovação. " $E m$ síntese, a crise de hegemonia da burguesia cafeeira possibilita a rápida aglutinação das oligarquias não vinculadas ao café, de diferentes áreas militares onde a oposição à hegemonia tem características específicas. Essas forças contam com o apoio das classes médias e com a presença difusa das massas populares. Do ponto de vista das classes dominantes, a cisão ganha contornos nitidamente regionais, dadas as características da formação social do país (profunda desigualdade de desenvolvimento de suas diferentes áreas, imbricamento de interesses entre a burguesia agrária e a industrial nos maiores centros), e as divisões 'puras' de fração - burguesia agrária, burguesia industrial - não se consolidam e não explicam o episódio revolucionário"35. A Revolução é o resultado, assim, da composição provisória e instável de forças de natureza e programas muito heterogêneos, que não podem, isoladas, oferecer as bases para a legitimidade do Estado, colocando como desafio ao novo governo revolucionário estabelecer um compromisso entre elas capaz de responder a todas as pressões sem se subordinar exclusivamente a nenhuma.

\subsubsection{Propostas para o "país legal”: a difícil conciliação}

"A Aliança Liberal apresentava-se como um remanso acolhedor para todos os descontentamentos e todas as esperanças. O pobre, o milionário, o operário, o funcionário, o comunista, a feminista, todos podiam confiar na serenidade de ação do candidato por ela indicado" ${ }^{, 36}$. Reuniam-se, todos, em torno da reivindicação por reformas na estrutura política nacional, a partir da constatação de falência do modelo da Primeira República. O desafio, contudo, era conciliá-los todos em torno de uma mesma proposta que garantisse legitimidade à nova ordem.

A vitória do movimento revolucionário, composto por forças tão plurais, é também, e como consequência dessa heterogeneidade, a abertura de um vazio de poder, diante da cisão das classes dominantes e da incapacidade de quaisquer das facções classistas assumirem-no hegemonicamente. Deposto o governo, a Aliança Liberal perde 
sua razão de ser, diante do enorme dissenso entre os grupos que a compõe. Assim, impõese a formação de um novo compromisso entre as elites dirigentes, de modo a garantir nacionalmente a autoridade do novo governo. Para Weffort, "o novo governo terá, portanto, que se mover sempre dentro de uma complicada faixa de compromissos e conciliações entre interesses diferentes e por vezes contraditórios. De nenhum dos grupos participantes - as classes médias, os grupos menos vinculados à exportação e os setores ligados à agricultura do café - se poderia dizer que teria assegurado para si as funções de hegemonia politica. Por outro lado, nenhum desses grupos tem condições para oferecer as bases de legitimidade do novo Estado, para apresentar seus próprios interesses particulares como expressão dos interesses gerais da nação"37.

Do ponto de vista econômico, é também possível falar em abertura da possibilidade de diversificação da produção nacional e dos rumos da economia, diante da crise de 1929, e não à toa a historiografia insiste em apontar a Revolução de 1930 como marco para a compreensão do processo de industrialização no Brasil. Não se trata de ver no movimento o choque entre os interesses dos industriais e do setor agrário, como se o estabelecimento da dominância do capital industrial como novo eixo de acumulação capitalista estivesse abstratamente inscrito nas condições estruturais do processo. De acordo com o que aponta Sônia Draibe, " a severidade do colapso que atingiu frontalmente a economia mercantil-exportadora abriu diferentes alterativas de desenvolvimento capitalista" 38 ao país. Com as possibilidades abertas, a direção política do Estado, que conduziria as mudanças, passa a ser central para a vitória de quaisquer que fossem os interesses em jogo, e a política assume uma dimensão ainda mais relevante. Diante da ausência de direção capaz de impor um projeto hegemônico, era preciso encontrar um novo modelo que congregasse, de forma minimamente estável, as forças sociais, tanto vitoriosas quanto derrotadas.

O relativo colapso do modelo anterior, sem que surgisse outra força capaz de se impor hegemonicamente, portanto, aponta para uma necessidade, ainda que apenas enquanto horizonte normativo, da promoção de algum tipo de compromisso entre as facções. Tal constatação de forma alguma implica em afirmar que de fato se tenha atingido um equilíbrio concreto. Pelo contrário, o período pós-1930 foi marcado por indecisões e instabilidades. Contudo, para que se atingisse algum tipo de equilíbrio de forças políticas, era preciso que o governo se constituísse, também, a partir de um

\footnotetext{
${ }^{37}$ WEFFORT, 1989, pp. 77/78.

${ }^{38}$ DRAIBE, 2004, p. 25.
} 
programa minimamente coerente, desafio que se prolonga até a Constituinte de 1933/34. Aqui entra, propriamente, o debate central da tese, que se situa no plano das ideias jurídicas apresentadas, e do formato adotado pela nova Constituição para, é a hipótese, tentar atingir pragmaticamente esse compromisso.

Uma das bases de sustentação do movimento revolucionário aglutinavase em torno da denúncia da falta de correlação entre o liberalismo da Constituição de 1891 e as práticas políticas das elites dirigentes durante a Primeira República, a recorrente denúncia da distância entre o "país real” e o "país legal”. Assim, Victor Nunes Leal entendia o coronelismo como "resultado da superposição de formas desenvolvidas do regime representativo a uma estrutura econômica e social inadequada" 39 . Conforme já destacado, as pautas liberais-moralizadoras abstratas apelavam às camadas médias urbanas, como por exemplo na bandeira de combate às fraudes eleitorais, de garantia do voto secreto e de controle das eleições por um poder neutro, ou melhor, não tão comprometido com os interesses em jogo como os Legislativos estaduais. A orientação está consolidada no mote "representação e justiça".

Não se deve esquecer, também, que ao menos em teoria o liberalismo era a ideologia das oligarquias cafeeiras. As premissas liberais faziam da Constituição de 1891, consistentemente, um exemplar teórico "escorreito e íntegro" 40 dessa corrente, permitindo ver na Primeira República o "coroamento ideológico do liberalismo"41. É esse mesmo liberalismo teórico, aliado à reivindicação de reconstitucionalização do país, que aparece na retórica da revolta paulista de 1932, a chamada Revolução Constitucionalista. Não à toa, os industriais paulistas aliam-se pela via de um certo liberalismo, durante a Constituinte de 1933/34, aos deputados da Chapa Única por São Paulo unido. Não se pode falar que tivessem um projeto nacional amplo e organizado, mas é possível, portanto, falar em um certo liberalismo que unificava o setor empresarial, enquanto projeto, mas que tinha implicações bastante limitadas, "com a ressalva de que se tratava de um liberalismo pragmático, sem maiores preocupações doutrinárias. Nas condições de confronto de classe claramente desigual, o liberalismo significava em termos concretos conceder o menos possível, tanto no plano dos direitos dos trabalhadores como das normas internas da organização do trabalho"42. Ainda que dependessem fortemente da intervenção estatal,

\footnotetext{
${ }^{39}$ LEAL, 1997 (1948), p. 40.

${ }^{40}$ BONAVIDES E ANDRADE, 2006, p. 25.

${ }^{41}$ BONAVIDES e ANDRADE, 2006, p. 25.

${ }^{42}$ FAUSTO, 1988, p. 14. A posição é a expressão de uma concordância, ainda que nuançada, com o pensamento de Luiz Werneck Vianna, em VIANNA, 1999 (1976).
} 
como já visto, os industriais apegavam-se retoricamente aos valores liberais como reação às novas ideias que acompanhavam a revolução, de modo a preservar suas velhas posições.

Isso porque o período é de reação antiliberal, em parte sustentada em um pensamento político autoritário em vias de consolidação no Brasil. Está fora dos objetivos centrais da tese investigar, em detalhes, essa corrente de pensamento que vem mobilizando, há décadas, um profícuo debate dentro do campo da história das ideias políticas, especialmente dedicado à compreensão da elaboração de um modelo descritivo da realidade nacional especificamente brasileiro, conforme veiculado por autores como Alberto Torres, Oliveira Vianna, Francisco Campos ou Azevedo Amaral. Mas é importante ter, como pano de fundo para a análise do debate constituinte, e sobretudo para o arranjo jurídico decorrente dele, uma ideia das interpretações sobre o Brasil que vinham sendo propostas, cujos impactos veremos com mais cautela ao analisar o debate constituinte, nos capítulos seguintes.

Esse pensamento de linha autoritária tem como principal ponto de partida, de um lado, o diagnóstico da singularidade da trajetória histórica brasileira e, de outro, a consequente necessidade da formulação de uma resposta também singularmente nacional. O primeiro passo deve ser, portanto, identificar na história os problemas e desafios do presente, e as saídas viáveis para a política racional, por eles determinada, pressupondo a existência de uma correlação unívoca entre realidade e modelo político ${ }^{43}$. E esse percurso está apoiado na crença positivista na possibilidade de uma análise objetiva, como no caso de Oliveira Vianna: "o que me inspira é o mais absoluto sentimento de objetividade: somente os fatos me preocupam e somente trabalhando sobre eles é que infiro e deduzo. Nenhuma ideia pré-concebida. Nenhuma preocupação de escola. Nenhuma limitação de doutrina. Nenhum outro desejo senão o de ver as coisas como as coisas são - e dizê-las como realmente a vi" ${ }^{\circ 4}$. Se a posição lembra Léon Duguit, não é mera coincidência, Problemas de política objetiva, livro de Vianna de 1930, tem como epígrafe justamente uma frase do autor francês ${ }^{45}$, que, portanto, serviu de influência declarada. O deslocamento proposto aqui é importante: em lugar de entender que as mesmas instituições produzem os mesmos efeitos políticos, segundo um dedutivismo jurídico-formal, propõe-se que é da análise objetiva da realidade que deve derivar o

\footnotetext{
${ }^{43}$ LAMOUNIER, 1986, p. 364.

${ }^{44}$ VIANNA, 1933, p. 46.

45 “Je suis le premier à rechercher les constructions juridiques; mais encore faut-il qu'elles soient une synthèse de la réalité ; sinon elles sont une pure opération de l'esprit, elles ne répondent à rien, elles sont sans valeur, comme sans utilité", frase atribuída a Duguit sem mencionar fonte, in VIANNA, 1930, epígrafe.
} 
modelo político. "A construção de modelos institucionais não constitui, a rigor, neste sentido, exercício de imaginação política, mas sim aplicação de capacidade técnicocientífica" ${ }^{" 46}$, sendo a tarefa da sociologia produzir o diagnóstico que conduzirá à correta "terapêutica". Não por acaso é esse o tema da mensagem inaugural de Oliveira Vianna na recém-fundada Escola de Sociologia e Política de São Paulo, em 1933. A formulação desse pensamento autoritário coincide, justamente, com a institucionalização das atividades científico-sociais no país, não apenas com a fundação da Escola de Sociologia e Política, mas também da Faculdade de Ciências Políticas e Econômicas do Rio de Janeiro (1919) e da Faculdade de Filosofia, Ciências e Letras de São Paulo (1934), momento que costuma ser entendido como o divisor de águas entre o período "pré-científico" e o "científíco" da produção intelectual brasileira ${ }^{47}$.

O diagnóstico proposto é complexo, e possui nuances próprias conforme o autor. De modo bastante simplificado, pode-se dizer que o ponto de partida mais ou menos comum é a constatação de uma sociedade pouco integrada, bastante atomizada, ou não solidária, sujeita ao controle político das lideranças locais, que sobrepõem poder privado ao poder público, como efeito reverso do liberalismo desajustado. O dilema do liberalismo no Brasil seria justamente constituir-se como sistema político sem o necessário acoplamento à sociedade, na medida em que o Brasil não possuiria uma sociedade liberal, mas parental, clânica e autoritária, adotando o léxico de Oliveira Vianna ${ }^{48}$. A sociedade brasileira seria, então, amorfa, apolítica, incapaz de organizar-se de forma autônoma, e incapaz, por isso mesmo, de participar do processo político à moda liberal - está também embutida aqui, como consequência, a crítica ao artificialismo dos partidos políticos durante a Primeira República.

O desafio de integração não poderia ser resolvido pela lógica competitiva de mercado, dentro da qual o conflito seria uma dimensão inafastável, nem pela visão individualista dos processos sociais. Há uma tarefa não resolvida de constituir a sociedade, organizada e livre da ameaça dos conflitos, que seriam irracionais e deveriam ser controlados. Essa era a tarefa que deveria ser assumida pelo Estado a partir da superação do idealismo liberal, segundo essa linha de pensamento: renovar-se de forma a capacitar-se

\footnotetext{
${ }^{46}$ LAMOUNIER, 1986, p. 365.

${ }^{47}$ Cf. SANTOS, 2002, p. 30, para quem “até o segundo quartel do século XX produziram-se ensaios sobre temas sociais, a partir de então produziu-se ciência" (p. 31). Para a reconstrução histórica da formação do "pensamento científico-social brasileiro", vide pp. 19/71 (Paradigma e História).

${ }^{48}$ SILVA, 2008, p. 242.
} 
para promover a organização e a integração social, dentro de uma função tutelar e paternalista.

A consequência é que o projeto deve convencer aqueles que estão em condição de ação renovadora, em oposição aos que figuram como simples objetos e destinatários dessa renovação, o que nos revela seu elitismo subjacente. "O ideólogo anseia pelo fortalecimento do Estado a fim de organizar e dar direção harmônica à sociedade, e entende que esse projeto, necessariamente altruísta e racional, requer somente a persuasão das elites e um emprego limitado e temporário da força, até criar as condições objetivas para o esclarecimento dos menos esclarecidos, entre os quais se contam, naturalmente, os adversários do momento"49. Novamente, a questão que volta a ser central é a composição entre as elites, para que possam por em prática o projeto autoritário.

As críticas de Francisco Campos vão nesse sentido, procurando demonstrar de que forma a transição para uma sociedade de massas revela a irracionalidade de fundo que a democracia liberal tenta dissimular: "A técnica de formação, ou de organização, em um foro comum, do conglomerado caótico das opiniões individuais, de cuja condensação num polo único se constitui a opinião pública, é o arsenal com que o liberalismo contribui para o aparelhamento intelectual da democracia: a liberdade de reunião, de associação, de imprensa e das demais manifestações de pensamento. Segundo o postulado liberal, o processo político, passando por essas fases de tratamento ou de elaboração forense, dá em resultado decisões conformes à razão, ou ao critério de justiça ou de verdade (...). Durante algum tempo, o sistema pode funcionar segundo as regras do jogo, porque o processo político se limitava a reduzidas zonas humanas e o seu conteúdo não envolvia senão estados de tensão ou de conflito entre interesses mais ou menos suscetíveis de um controle racional e acessíveis, portanto, ao tratamento acadêmico das discussões parlamentares. De repente, porém, amplia-se o quadro: o controle político abrange massa cada vez mais volumosa de interesses, entre os quais o estado de conflito tende a assumir a forma de tensão polar, refratária aos processos femininos de persuasão da sofística forense, e as zonas humanas do poder veem aumentadas, em escala sem precedentes, a sua área, a sua densidade, e sobretudo a sua inquietação consequente à instabilidade das relações dinâmicas entre os centros de interesse de cujo contato resulta, efetivamente, a centelha das decisões políticas. Verifica-

${ }^{49}$ LAMOUNIER, 1986, p. 370. 
se, então, que a concepção forense do mundo, construída pelo liberalismo para uma fase eminentemente benigna de tensão ou de conflito econômico e político, de cujos estados de ênfase se compõe a substância da história, conseguira apenas dissimular, graças às formas atenuadas e à escala reduzida do processo político, a irracionalidade que é da sua essência e constitui o seu caráter específico" ${ }^{, 50}$. O liberalismo estava claramente no centro das críticas dessa vertente de pensamento autoritário, liberalismo que ao mesmo tempo continuava fornecendo suporte para o impulso de reforma do regime da Primeira República, liberal apenas na fachada. A dificuldade de conciliação entre as diferentes propostas em jogo é evidente.

Em lugar de apontar para a produção de uma conciliação, o período do Governo Provisório assiste a uma radicalização das posições. Passada a desarticulação das correntes que compuseram o movimento de 1930, os tenentes organizam-se como força própria, em torno do Clube 3 de Outubro, nome em homenagem à data de início da Revolução. Sob a direção de nomes como Juarez Távora, Pedro Ernesto e Góis Monteiro e com sede no Rio de Janeiro, faz-se representar em quase todos os Estados não como partido, mas como movimento, marcado por instabilidade e conflitos internos. Em 1933, o diagnóstico dos tenentes era revelador, desconfiando da possibilidade de representação efetiva do debate de ideias nacional por meio dos partidos e das eleições, então em curso, para a Assembleia Constituinte: "Em toda parte, ação e reação (...) A revolução desencadeada pelo excesso opressor encontrou um povo sedento de liberdade e de justiçam mas indeciso entre sistemas vários, sem correntes formadas de opinião, sem congregação em torno de verdadeiros programas de tudo o que em suma permite a luta eleitoral legítima" ${ }^{51}$. Já cientes da inexistência de um programa único de suporte para o governo e para a ordem constitucional, articulam-se na proposição das pautas que entendem devam fazer parte da futura Constituição, tais como "intangibilidade da soberania nacional”, instituição da representação profisssional, centralização política, "organização das classes profissionais para a reivindicação dos seus direitos políticos, econômicos e sociais", "facilitada, auxiliada e garantida" pelo Ministério do Trabalho, criação de conselhos técnicos, manutenção do direito de propriedade, "subordinando-o porém, através de todas as suas modalidades, aos imperativos originados de sua finalidade social", e "concepção das forças armadas nacionais como fator mais eficiente e

\footnotetext{
${ }^{50}$ A política e o nosso tempo (conferência no salão da Escola de Belas Artes, em 28 de setembro de 1935), in CAMPOS, 1941, pp. 19/20. Para uma análise mais detalhada da trajetória intelectual de Francisco Campos, ver SEERLANDER e CASTRO, 2010.

${ }^{51}$ Manifesto publicado em A Platéa, 22/04/1933, in CARONE, 1974, p. 267.
} 
imprescindível ao fortalecimento dos laços de coesão nacional", entre outros ${ }^{52}$. Os tenentes garantem sua sustentação no início do Governo Provisório, uma aliança que será posteriormente rompida, em nome da necessidade de homogeneização do aparelho militar ${ }^{53}$.

De uma ruptura com o tenentismo, recusando-se a apoiar o movimento armado de 1930, sai, para aderir ao comunismo, aquele que viria a ser a liderança histórica do PCB, Luís Carlos Prestes. Apresentando outra proposta à disputa, é ele quem escreve: “A revolução brasileira não pode ser feita com o programa anódino da Aliança Liberal. Uma simples mudança de homens, um voto secreto, promessas de liberdade eleitoral, de honestidade administrativa, de respeito à Constituição e moeda estável e outras panaceias, nada resolvem, nem podem de maneira alguma interessar à grande maioria da nossa população, sem o apoio da qual qualquer revolução que se faça terá o caráter de uma simples luta entre as oligarquias dominantes. Não nos enganemos. Somos governados por uma minoria que, proprietária das terras, das fazendas e latifúndios e senhora dos meios de produção e apoiada nos imperialismos estrangeiros que nos exploram e nos dividem, só será dominada pela verdadeira insurreição generalizada, pelo levantamento consciente das mais vastas massas das nossas populações dos sertões e das cidades" ${ }^{24}$. Assim conclamava as massas a uma revolução agrária e anti-imperialista. Em 1934, retorna de temporada na União Soviética para organizar o PCB, e dá início à fase da frente ampla e popular do partido, então na ilegalidade, que se une a diversas facções populares e de classe média, sob ideologia antifascista, para formar a Aliança Nacional Libertadora (ANL).

Por outro lado, e antes disso, as oligarquias paulistas, retiradas do governo pelo movimento de 1930, também organizam-se em torno de uma reação, que se materializou na revolta que durou entre julho e outubro de 1932. Sob a bandeira da reconstitucionalização e das premissas liberais, e acreditando contar com o apoio de outros Estados, especialmente Minas Gerais, os paulistas dão início, em 9 de julho, à revolta armada. Isolados, são logo derrotados pelo governo federal. Vencidos nas armas, não deixam de trazer à pauta a demanda pela reconstitucionalização, latente na sociedade, uma vez que constava da plataforma da própria Aliança Liberal e que já tinha se expressado na convocação de eleições por decreto anterior à revolta. Contudo, é importante não perder de

\footnotetext{
${ }^{52}$ Vide documento publicado em A Platéa, 03/11/1932, in CARONE, 1974, pp. 261/263.

${ }^{53}$ FAUSTO, 2005 (1970), p. 139

${ }^{54}$ Luís Carlos Prestes, Manifesto de Maio de 1930, disponível em http://www.marxists.org/portugues/prestes/1930/05/manifesto.htm (acesso em 05/03/2012).
} 
vista a distância entre as reivindicações concretas e os interesses declarados dos paulistas, como lembra José Murilo de Carvalho: "Sua causa era aparentemente inatacável: a restauração da legalidade, do governo constitucional. Mas seu espírito era conservador: buscava-se parar o carro das reformas, deter o tenentismo, restabelecer o controle do governo federal pelos Estados"

Não se deve esquecer, por fim, da fundação da Ação Integralista Brasileira, em outubro de 1932. Inspirados por ideias fascistizantes, e contando com quadros como Plínio Salgado, Goffredo da Silva Telles Jr. e Miguel Reale, os integralistas combinavam uma mitologia nacionalista à defesa do "princípio da autoridade", hierarquia, ordem e disciplina, bem como do direito de propriedade, vislumbrando a possibilidade de resolução da questão social "pela cooperação de todos, conforme a justiça e o desejo que cada um nutre de progredir e melhorar", e pela refutação do "individualismo desenfreado, assinalador da fisionomia do sistema econômico liberal-democrático" ${ }^{56}$. O Estado Integralista seria justamente aquele "livre de todo e qualquer princípio de divisão", sem conflitos, completamente integrado. O movimento foi, no início, capitalizado por Getúlio Vargas, que acaba por dissolvê-lo apenas no Estado Novo, em 1937 (o que não os impede de organizar um contragolpe malsucedido em 1938).

O momento é de profusão de ideias e inquietude, portanto. Partindo do lema liberal (da Aliança Liberal, justamente), "representação e justiça", a Revolução de 1930 dá-se em um momento que se aproxima muito mais de dissenso quanto aos programas de renovação do que de consenso quanto à nova hegemonia que sustentará o governo revolucionário. Orientado pela oposição às velhas práticas, e confrontado com as consequências da crise econômica, o governo revolucionário tem em mãos o desafio de recolocar um novo programa, político e econômico, para um país em disputa. Não apenas as facções sociais são distintas, mas também os programas teóricos são cada vez mais distintos, e as posições radicalizam-se. Há que se promover reformas que inaugurem um homem novo e uma pátria nova, resultado da descontinuidade que é a marca da ruptura com a ordem em 1930, mas não há um projeto hegemônico a partir do qual construí-las. Essas reformas podem ser decorrentes de um novo modelo constitucional, capaz de dar conta desse compromisso, ou, diante de sua dificuldade, podem ser implementadas de forma autoritária, pelo governo revolucionário.

${ }^{55}$ CARVALHO, 2001, p. 100.

${ }^{56}$ AIB, Manifesto de Outubro, in CARONE, 1974, pp. 309/315. 
A ausência de um projeto que congregue forças de forma a se impor hegemonicamente deixa o caminho aberto para o descolamento da figura do chefe do Executivo do jogo político, assumindo a posição de árbitro ou mediador. “ $A$ unidade da classe dominante só poderia ser mantida afastando-a do exercício direto do poder e dando ao poder executivo uma margem de manobra com respeito a todas as frações de classe" ${ }^{\circledR 57}$, o que resulta na maior autonomia do poder central ${ }^{1}$. A observação poderia dialogar com a análise de Alfredo Bosi da postura de Vargas em seus tempos de política sul rio-grandense, quando, orientado pelo positivismo comtiano, assumia um lugar que parecia ser o de um "sábio ordenador que só intervém quando as carências de uma classe (...) exigem, pela intermediação dos poderes públicos, a suplência de outra classe (...). A carreira ideológica de Getúlio Vargas seria coerente com o princípio de um Estado suficientemente forte para mediar tanto os conflitos nos setores das classes dominantes como as tensões entre estas e os trabalhadores" $" 58$. Os primeiros anos da década de 1930 são, assim, marcados pela condução centralizada e mediadora das reformas pelo Chefe do Governo Provisório, sem contudo perder de vista o horizonte de reconstitucionalização do país.

\subsection{ASPECTOS INSTITUCIONAIS E PRIMEIRAS REFORMAS LEGISLATIVAS (1930-1934)}

Oficialmente, o Governo Provisório é instituído por meio do Decreto $\mathrm{n}^{\mathrm{o}}$ 19.398, de 11 de novembro de 1930, que funciona, materialmente, como uma Constituição provisória $^{59}$. O decreto estabelece que o Governo Provisório reunirá todas as funções do Poder Executivo e do Poder Legislativo, enquanto não eleita a Assembleia Constituinte para a reorganização constitucional do país. Confirma-se a dissolução do Congresso Nacional e suspendem-se as garantias constitucionais, salvo o habeas corpus. É mantida a Constituição Federal e as Estaduais, bem como a legislação ordinária, que estão contudo sujeitas a alteração unilateral pelo Governo Provisório ou por seus delegados. Juridicamente, era o reconhecimento da autoridade do poder de fato que se havia apossado do governo com a revolução do mês anterior, e a atribuição de poderes quase ilimitados ao Chefe do Governo Provisório. A partir daí, Getúlio Vargas concentra poder suficiente para dar início à implementação das reformas que compunham sua plataforma revolucionária,

\footnotetext{
${ }^{57}$ ROWLAND, 1974, p. 16.

${ }^{58}$ BOSI, 2003 (1992), pp. 287/288.

${ }^{59}$ Nesse sentido, ver BERCOVICI, 2008(b), p. 26, nota 3, e as referências ali indicadas.
} 
por meio de decretos que, na ausência do Congresso, valeriam como lei mesmo diante da Constituição.

A construção de uma "pátria nova", ideal decorrente da Revolução, implicava na urgência de medidas concretas, no plano institucional, que dessem substância ao ideal. "O trabalho de reconstrução, que nos espera, não admite medidas contemporizadoras. Implica o reajustamento social e econômico de todos os rumos até aqui seguidos. Não tenhamos medo à verdade. Precisamos, por atos e não por palavras, cimentar a confiança da opinião pública no regime que se inicia" ${ }^{60}$ - assim Vargas inaugura seu período como autoridade máxima do Governo Provisório, reconhecendo a necessidade de reformas imediatas para confirmar a autoridade que obteve em decorrência das armas. Era preciso construir uma nova institucionalidade, ainda que provisória, marcada tanto pelo sentido do novo quanto pela necessidade de estabilização. "A chefia do Estado nas mãos do ex-candidato presidencial e a promessa da constituinte faziam parte de um mesmo todo: o esforço de manutenção das linhas gerais de procedimento dentro de um contexto revolucionário, que se caracteriza exatamente pela ruptura dessas linhas"61. As primeiras normas jurídicas do período subsequente à Revolução espelham, portanto, o impulso de refundação da ordem em outros termos, bem como a garantia de um procedimento, de um mínimo de legalidade para o governo revolucionário, restando subjacente e prorrogada a promessa de reconstitucionalização.

Um dos primeiros passos é a criação do Ministério do Trabalho, Indústria e Comércio (Decreto $\mathrm{n}^{\mathrm{o}} 19.443$, de 26 de novembro de 1930), cujo posto máximo é atribuído a Lindolfo Collor, bem como do Ministério da Educação e Saúde Pública (Decreto $n^{\circ} 19.402$, de 14 de novembro de 1930), atribuído a Francisco Campos. Faziam parte do programa de reconstrução nacional de Vargas a "difusão intensiva do ensino público" para o quê "justificar-se-á a criação de um Ministério de Instrução e Saúde Pública”, bem como "instituir o Ministério do Trabalho, destinado a superintender a questão social, o amparo e a defesa do operariado urbano e rural" ${ }^{\prime 62}$. São os dois ministérios que simbolizam, no plano da organização da Administração Pública, a remodelagem do Estado de modo a equipá-lo para seu papel de intervenção no e direção do social.

\footnotetext{
${ }^{60}$ Discurso de posse de Getúlio Vargas no Governo Provisório, 3/11/1930, in CARONE, 1974, p. 15.

${ }^{61}$ GOMES, 1986, pp. 14/15.

${ }^{62}$ Cf. discurso de posse de Getúlio Vargas no Governo Provisório, 3/11/1930, in CARONE, 1974, p. 16, itens 3 e 15 .
} 
Fazia parte da construção da retórica do novo consolidar a ideia, a simbologia, de que as reformas sociais representavam uma reorientação radical dos rumos e uma transformação na forma de lidar com a questão social. É nesse sentido que se insere na "mitologia estadonovista" a convicção de que a revolução de 30 fora um marco divisor, "quando a partir de então a chamada 'questão social' teria deixado de se constituir num 'caso de polícia', passando o Estado a disciplinar o mercado de trabalho em benefício dos assalariados" ${ }^{\prime 63}$. Essa é a crença que quer reforçar Lindolfo Collor em seu discurso de posse: "a existência da questão social entre nós nada tem de grave ou de inquietador: ela representa um fenômeno mundial, é demonstração de vida, de progresso. O que de inquietador aparece no Brasil é a preocupação de ignorar oficialmente a existência de problemas dessa natureza e desse alcance" ${ }^{\text {} 64}$. Contudo, é importante relativizar essa visão de novo, na medida em que olhar para os fatos é reconhecer que sobretudo a partir dos anos 1920 havia no Brasil um movimento de expansão dos direitos trabalhistas, ainda que focalizado e incipiente. Por certo há uma mudança com o movimento de 1930, mas ela não pode ser associada ao momento de inauguração completa da legislação trabalhista no país, mas talvez ao momento em que a legislação social assume outra função, mais central, dentro da simbologia política nacional.

A Primeira República assiste, assim, à formulação de alguns projetos de Código do Trabalho, e uma preocupação difusa em promulgar leis protetoras dos trabalhadores, como exemplifica a criação, em 1918, da Comissão de Legislação Social, ou, antes disso, a lei de 1907 sobre organização sindical ${ }^{65}$. O Tratado de Versalhes, de 1919, representa uma pressão de fora para avanços, na medida em que obriga os países signatários a assegurar o direito de associação, salário mínimo, jornada de oito horas, proteção aos menores, igualdade salarial etc. As novas Constituições, como a do México (1917) e a de Weimar (1919) também continham normas trabalhistas, forjando um novo modelo de tratamento constitucional da questão social que serviria de inspiração a outras nações. No Brasil, as greves de 1917 reforçavam a necessidade de expandir o rol de garantias formais de direitos dos trabalhadores, e a década de 1920 assiste a progressos, como a criação em 1923 do Conselho Nacional do Trabalho, a estruturação de caixas de aposentadorias e pensões nas empresas de estradas de ferro (Lei $\mathrm{n}^{\circ} 4.682 / 1923$ - conhecida

\footnotetext{
${ }^{63}$ VIANNA, 1999 (1976), p. 57.

${ }^{64}$ COLLOR, 1990, p. 181 (discurso de posse no Ministério do Trabalho, 1/12/1930)

${ }^{65}$ Para uma visão mais detalhada dos antecedentes da legislação trabalhista brasileira, vide VIANNA, 1999, pp. 68/94, SANTOS, 1979, pp. 17/29, bem como a introdução de Mário de Almeida Lima a COLLOR, 1990, especialmente pp. 21/70, e MORAES FILHO, 1978 (1952), pp. 182/216.
} 
como "Lei Eloy Chaves"), a garantia de férias (Lei n4.982/1925, regulamentada pelo Decreto $\left.n^{\circ} 17.496\right)$ e o seguro-enfermidade, por exemplo. Presencia ainda o surgimento de propostas de sistematização e melhorias das normas, contando inclusive com uma referência constitucional à competência do Congresso Nacional de legislar sobre o trabalho (art. 34, 29), dispositivo introduzido pela reforma de 1926, que flexibiliza o ideal liberal não-intervencionista traçado no texto original. Mas as reformas antes de 1930 são ainda esparsas e atrasadas em relação à experiência internacional, muito aquém do que reivindicava a Aliança Liberal. Nesse sentido, Mário de Almeida Lima avalia, enfaticamente, reforçando a mitologia que se havia criado: "tudo se vinha fazendo com incrivel atraso, rigorosamente a reboque dos acontecimentos e sob a pressão crescente dos trabalhadores e das associações de classe. E encontrando, ademais, resistências inimagináveis. Dentro e fora do Congresso" "66. Luiz Werneck Vianna traz uma avaliação mais ponderada: "comparativamente à ação dos anos 30, a presença do Estado é notoriamente débil, mas nem por isso ineficaz" ${ }^{\prime 67}$.

Sem pretender esgotar ou mesmo reproduzir as frutíferas polêmica que permeiam o pensamento social brasileiro há décadas, é possível, contudo, considerar sem grandes riscos que há uma mudança substantiva no tratamento da disciplina normativa do social a partir de 1930, passando a questão ao centro da arena política. A criação do Ministério do Trabalho representa justamente a intenção de tratar oficialmente a questão social como uma política central dentro da nova ordem, regulando direitos de forma sistemática e cada vez mais universalizada, e avançando na fiscalização de sua eficácia, com o auxílio de órgão específico, o Departamento Nacional do Trabalho (Decreto $\mathrm{n}^{\circ}$ 19.671-A, de 4 de fevereiro de 1931). Não se pode desprezar a importância de físcalizar o cumprimento da legislação trabalhista como fator decisivo de sua eficácia, como aponta Evaristo de Moraes Filho: “A nossa legislação do trabalho somente começou a ser cumprida quando passou a ter atrás de si órgãos fiscalizadores e aplicadores de

\footnotetext{
${ }^{66}$ Introdução de Mário de Almeida Lima a COLLOR, 1990, p. 64.

${ }^{67}$ VIANNA, 1999 (1976), p. 94. Antes de Werneck Vianna, como o próprio autor aponta, Evaristo de Moraes Filho já apontava para a existência de disciplina normativa do trabalho anterior a 1930, afirmando que "não se pode assim fixar a atenção unicamente sobre um homem, quando se tratava de uma maturação normal de todo um processo social, progressivo e cumulativo", in MORAES FILHO, 1978 (1952), p. 219. Do ponto de vista econômico, Wanderley Guilherme dos Santos entende que a diferença entre os dois períodos está na esfera atingida pelas normas, na medida em que as leis sociais pós-1930 "atingem diretamente o processo de acumulação", de forma efetiva e sem precedentes, ver SANTOS, 1979, pp. 29 e ss.
} 
penalidades. Eram eles a real sanção do novo direito (...). E esta tarefa foi o cuidado imediato da Revolução de outubro"68_ ${ }^{69}$.

Nesse sentido, promulgam-se diversos decretos, a começar pelo $\mathrm{n}^{\mathrm{o}} 19.770$, de 19 de março de 1931, que regula os sindicatos e determina a unicidade e o controle direto do Ministério sobre as organizações, consideradas "órgãos de colaboração com o Poder Público" (art. 6). Na exposição de motivos da norma, Maurice Hauriou e Léon Duguit são mencionados como "grandes mestres do direito público dos nossos tempos", que teriam sido responsáveis por demonstrar que "o século XX tem marcado o seu rumo na conquista de um novo status social: a expressão jurídica de interdependência econômica das classes (...). Guiados por essa doutrina, nós saímos fatalmente do empirismo individualista, desordenado e estéril, que começou a bater em retirada há quase meio século, para ingressarmos no mundo da cooperação social, em que as classes interdependem umas das outras e em que a ideia do progresso está subordinada à noção fundamental da ordem" ${ }^{, 70}$. Interessante notar que as referências explícitas a doutrinas e autores estrangeiros reforçam uma das interpretações sobre as origens da legislação trabalhista brasileira, de que teria sido uma importação, uma idealização, uma "ideia fora de lugar", como aponta o líder sindical comunista Roberto Morena: "Muitas dessas leis foram produtos da cabeça do ministro do Trabalho e tiveram pouca relação com as coisas como elas eram. Certamente foram aprovadas sem consulta ao trabalhador e sem nenhuma discussão pública. Naquela época, como hoje, havia muita legislação, mas pouco cumprimento" ${ }^{, 71}$. No capítulo seguinte, veremos de que forma a crítica aparece também em relação à Constituição, figurando como constante na produção jurídica nacional, que com frequência é tomada como uma importação de ideias descoladas da realidade nacional. Por ora, vale reter a referência aos franceses nas origens da nova legislação social brasileira, o que recuperaremos como análise na conclusão dessa tese.

Seguem-se, durante o Governo Provisório, os decretos $n^{\circ} 21.186$, de 23 de março de 1932, e no 21.364 , de 4 de maio de 1932, que garantem a jornada de trabalho de oito horas para comerciários e industriários, respectivamente, nos termos do Tratado de

\footnotetext{
${ }^{68}$ MORAES FILHO, 1978 (1952), pp. 215/216.

${ }^{69}$ Para uma problematização da opinião, discutindo com mais cuidado a aplicação concreta da legislação trabalhista, ver a exposição sobre a CLT e a "política do jeitinho" em FRENCH, 2002, pp. 42/45.

${ }^{70}$ COLLOR, 1990, pp. 106/107 (Exposição de Motivos do Decreto n ${ }^{\circ}$ 19/770 (19/03/1931).

${ }^{71}$ Citado, sem referência, em FRENCH, 2002, p. 37. Crítica semelhante é veiculada por José Segadas Vianna, Ministro do Trabalho entre 1951-1953, para quem Collor "procurou com o apoio de Getúlio, aplicar muitas coisas europeias que não eram aplicáveis aqui. De fato, a legislação social e trabalhista brasileira, em geral, havia sido escrita mais com um olho na Europa do que na realidade da situação brasileira", também citado em FRENCH, 2002, p. 37.
} 
Versalhes. O decreto $\mathrm{n}^{\mathrm{o}} 20.465$, de $1^{\mathrm{o}}$ de outubro de 1931, reformula Caixas de Assistência e de Pensão, o decreto $n^{o}$ 21.417-A, de 17 de maio de 1932, regulamenta o trabalho da mulher e proíbe distinção salarial para igual trabalho, e o decreto $n^{\circ} 22.042$, de 3 de novembro de 1932, estabelece as condições de trabalho do menor na indústria. É criado um importante instrumento de controle e fiscalização pública das normas trabalhistas, qual seja, a carteira profissional, sob a responsabilidade do Ministério do Trabalho - Decreto $\mathrm{n}^{\mathrm{o}}$ 21.175, de 21 de março de 1932 (regulamentado pelos Decretos n ${ }^{\circ} 21.580$, de 29 de junho de 1932 e $\mathrm{n}^{\mathrm{o}} 22.035$, de 29 de outubro do mesmo ano). Formula-se, ainda, o projeto de regulamentação de um salario mínimo, a partir de inquéritos censitários conduzidos pelo Ministério do Trabalho para apurar número de pessoas das famílias e média mensal de gastos que comporiam uma "cesta básica", de modo a verificar as necessidades mínimas regionais do trabalhador ${ }^{72}$. "Assim, da agenda de demandas do sindicalismo, legalmente organizado em 1907, acrescida de novos itens que a própria dinâmica do processo de acumulação veio a gerar, apenas a fixação do salário mínimo não estava já atendida, ou regulado, quando, em 1934, as relações jurídicas entre o movimento sindical, o Estado e os empregadores dão significativo passo à frente" ${ }^{, 73}$.

Inaugura-se assim uma nova fase da legislação trabalhista no Brasil, inspirada pela crença de que a solução para a questão social passava por tratá-la como um desafio de integração dos trabalhadores na ordem social, partindo das premissas de interdependência e cooperação, e, por que não, solidariedade entre as classes, de que fala Lindolfo Collor na justificativa dos novos decretos. A interpretação dessa nova fase é objeto de extensa polêmica no pensamento político e social brasileiro, que, apesar de não poder ser ignorada, não constitui o ponto central desse estudo. Em apertada síntese, diverge-se quanto ao caráter dos novos direitos, se como outorga ou dádiva, como queria fazer transparecer a mitologia estadonovista ${ }^{74}$, se como conquista efetiva do movimento operário, ou ainda como tentativa, inspirada pelo corporativismo, de colocar sob o controle

\footnotetext{
${ }^{72}$ Cf. COLLOR, 1990, p. 133

${ }^{73}$ SANTOS, 1979, p. 30, destaque no original.

${ }^{74}$ A referência aqui não podia deixar de ser o pensamento de Oliveira Vianna. A posição pode ser bem exemplificada pelas palavras de agosto de 1933 de Salgado Filho, que substituiu Lindolfo Collor no Ministério do Trabalho em 1932, e posteriormente foi eleito deputado federal classista (representante dos profissionais liberais) nas eleições legislativas de 1934: "O Governo Provisório, Governo de fato, Governo Ditatorial, é, senhores, o Governo mais legalista que tem tido o Brasil. A prova está em que tendes uma legislação que vos foi concedida sem nenhuma exigência, imposição ou pressão de qualquer ordem, mas espontaneamente. E isso é exatamente o que constitui o traço predominante que nos coloca, em matéria de legislação social, acima de todos os países. O que se chama de reivindicações trabalhistas não foram jamais obtidas em qualquer país como estão sendo aqui verificadas. No Brasil não há reivindicações nesse assunto. Há concessões. Concessões do Governo aos eficientes colaboradores, que são os homens do trabalho, quer braçal, quer intelectual", in CARONE, 1974, p. 226.
} 
político do Estado a classe operária, como garantia da "paz do trabalho"75, produzindo uma identidade heterônoma da classe trabalhadora.

Há que se refutar interpretações unívocas, que perdem em vislumbrar a complexidade que caracteriza a questão. É inegável que os direitos trabalhistas aparecem em um contexto de avanço do Estado sobre a disciplina e a tutela da sociedade, especialmente da classe operária, que mal se organiza e já está sujeita ao controle estatal, sob a lógica da cooperação. Talvez a posição de Bosi responda com mais propriedade a essa complexidade, ao enxergar dois princípios por trás da política social desde sua gênese no governo sul rio-grandense de Borges de Medeiros: "o primeiro, que no contexto do Brasil oligárquico, se poderia chamar progressista, consistia em acolher e sancionar com a autoridade do Executivo certas reivindicações tópicas dos trabalhadores urbanos que já demandavam redução da jornada, melhores condições de vida na fábrica e salários menos vis; o segundo, que certamente se pode chamar de centralizador, e que atribuía ao Estado a função de mediar e, nos casos extremos, arbitrar os conflitos entre operários e patrões" ${ }^{76}{ }_{-}^{77}$. Entendemos ser essa uma importante contradição mal resolvida a ser pontuada: o duplo registro, progressista e autoritário, que orienta a legislação social no Brasil.

Mas a renovação institucional haveria de ser mais ampla, para além da legislação trabalhista, assim como o duplo registro na sua condução. É dessa forma que, por meio do Decreto $\mathrm{n}^{\mathrm{o}} 19.459$, de 6 de dezembro de 1930, se havia determinado a

\footnotetext{
${ }^{75}$ Vide ROWLAND, 1974, pp. 25 e ss., VIANNA, 1999 (1976), pp. 57 e ss. Para esse último, um aspecto pouco analisado da legislação trabalhista seria justamente a função que cumpriria, pós-1930, dentro do arranjo corporativo, de "restringir a ação e a organização operárias" (p. 58). Assim, Werneck Vianna pode concluir que "o peculiar do Estado pós-30 não se encontra numa maior intensidade de leis trabalhistas, mas na sua inclusão numa ordem corporativa" (p. 60). O papel de controle e enquadramento do poder público em relação à classe operária também está apontado por Luiz Felipe de Alencastro, que ao analisar o perfil e a composição da força de trabalho em torno de 1930, e verificar seu descolamento dos fluxos migratórios, conclui que "a Revolução de 30 situa-se na convergência de uma dupla mutação. Em primeiro lugar, o mercado de trabalho se territorializa, fenômeno inédito desde o século XVII, quando o trabalho escravo africano começa a sobrepor-se ao trabalho forçado indígena. Em segundo lugar, o Estado deixa de intervir na captação de proletários estrangeiros para cuidar do enquadramento do proletariado nacional. À luz dessas transformações compreende-se melhor o novo patamar ideológico onde evoluirá o debate político e cultural brasileiro", in ALENCASTRO, 1987a, p. 20.

${ }^{76}$ BOSI, 2003 (1992), p. 295. O autor estende a interpretação para a legislação trabalhista e a CLT, identificando também nelas esse "duplo registro, progressista e autoritário".

${ }^{77}$ Remetemo-nos para aprofundamento, em sentido que poderia dialogar com as observações de Bosi, à tese de Ângela de Castro Gomes, para quem 'o sucesso do projeto político-estatal - do 'trabalhismo' - pode ser explicado pelo fato de ter tomado do discurso articulado pelas lideranças da classe trabalhadora, durante a Primeira República, elementos-chave de sua autoimagem e de os ter investido de novo significado em outro contexto discursivo. Assim, o projeto estatal que constitui a identidade coletiva da classe trabalhadora articulou uma lógica material, fundada nos benefícios da legislação social, com uma lógica simbólica, que representava estes beneficios como doações e beneficiava-se da experiência de luta dos próprios trabalhadores", in GOMES, 2005, pp. 24/25.
} 
instituição de uma comissão Legislativa, sob a presidência do Ministro da Justiça, encarregada de "elaborar os projetos de revisão ou reforma da legislação civil, comercial, penal, processual da justiça federal e do Distrito Federal, de organização judiciária do Distrito Federal, e de outras matérias indicadas pelo mesmo ministro" (art. $1^{\circ}$ ). O Decreto $\mathrm{n}^{\mathrm{o}}$ 19.684, de 10 de fevereiro de 1931, estabeleceu a divisão da Comissão Legislativa em subcomissões, sendo uma das mais importantes a encarregada da revisão da legislação eleitoral, composta por Assis Brasil, João Chrysóstomo da Rocha Cabral e Mario Pinto Serva $\left(\operatorname{art.} 2,19^{\circ}\right)^{78}$. Por certo, se um dos problemas centrais que motivaram a Revolução de 1930 eram as fraudes e ausência de controle das eleições durante a Primeira República, um dos símbolos concretos da mudança seria a elaboração de uma lei eleitoral que garantisse, de fato, um novo funcionamento da democracia no país.

Essa nova lei seria o Código Eleitoral, veiculado pelo Decreto $n^{0} 21.076$, de 24 de fevereiro de 1932. A norma foi produto de muitas reuniões e debates ${ }^{79}$, em um processo de gestação arrastado, que foi ao final especialmente impulsionados pelo novo Ministro da Justiça, o jurista gaúcho Maurício Cardoso, “legítimo representante das forças

\footnotetext{
78 “Art. 2 As subcomissões ficam assim compostas:1 - Código Civil - Drs. Clovis Belivácqua, Alfredo Bernardes da Silva e Eduardo Spínola. $2^{\circ}$ - Código Penal - Drs. João Martins de Carvalho Mourão, Antônio Evaristo de Moraes e Mario de Bulhões Pedreira. $3^{\circ}$ - Código Comercial - (parte terrestre, excluídas as matérias atribuídas a outras subcomissões) - Drs. Waldemar Ferreira, Raul Fernandes e Targino Ribeiro. $4^{\circ}$ Propriedade Industrial - Drs. Descartes Drummond de Magalhães, Edgard Ribas Carneiro e Arnoldo Medeiros da Fonseca. $5^{\circ}$ - Debêntures, Cambiais, Cheques, Contas assinadas, Títulos ao portador - Drs. Paulo Maria de Lacerda, Francisco Barbosa de Rezende e Sizinho Rodrigues. $6^{\circ}$ - Falências - Drs. Antônio Moutinho Doria, Francisco Carneiro Monteiro de Salles e Jorge Dyott Fontenelle. $7^{\circ}$ - Direito Marítimo Drs. Edgard de Castro Rebello, Hugo Gutierres Simas e José Figueira de Almeida. $8^{\circ}$ - Direito Aéreo - Drs. Carlos da Silva Costa, Almachio Diniz e Deodato Maia. $9^{\circ}$ - Lei de Minas - Drs. João Pandiá Calogeras, Augusto de Lima e Luiz Frederico Sauerbronn Carpenter. $10^{\circ}$ - Código de Águas - Drs. Alfredo Valladão, José de Castro Nunes e Ignácio Veríssimo de Mello. $8^{\circ}$ - Direito Aéreo - Drs. Carlos da Silva Costa, Almachio Diniz e Deodato Maia. $9^{\circ}$ - Lei de Minas - Drs. João Pandiá Calogeras, Augusto de Lima e Luiz Frederico Sauerbronn Carpenter. $10^{\circ}$ - Código de Águas - Drs. Alfredo Valladão, José de Castro Nunes e Ignácio Veríssimo de Mello. $11^{\circ}$ - Organização Judiciária do Distrito Federal, Registos Públicos, Ofícios de Justiça, Regimento de Custas e Assistência Judiciária - Drs. Armando Vidal Ribeiro, José Sabóia Viriato de Medeiros e Olympio de Carvalho Araújo Silva. $12^{\circ}$ - Código de Processo Civil do Distrito Federal e da Justiça Federal - Drs. Abelardo Saraiva da Cunha Lobo, Antônio Pereira Braga e José Philadelpho de Barros e Azevedo. $13^{\circ}$ - Processo Penal do Distrito Federal e da Justiça Federal, inclusive processo policial - Drs. Melciades Mario de Sá Freire, Astolpho Vieira de Rezende e Candido Luiz Maria de Oliveira Filho. $1^{\circ}$ Regime Penitenciário (inclusive manicômio Judiciário) - Drs. Candido Mendes de Almeida, José Gabriel de Lemos Britto e Heitor Pereira Carrilho. $15^{\circ}$ - Naturalização, entrada e expulsão de estrangeiros - Drs. Francisco de Paulo Lacerda de Almeida, João Chrisóstomo da Rocha Cabral e Haroldo Teixeira Valladão. $16^{\circ}$ - Código de Menores e Conselho de Menores - Doutores Zeferino de Faria, Arthur Cumplido de Santana e Nilo Carneiro Leão de Vasconcellos. $17^{\circ}$ - Estatuto dos Funcionários Públicos - Drs. Francisco de Avelar Figueira de Mello, Euzébio de Queiroz Lima e José de Miranda Valverde. $18^{\circ}$ - Seguros - Drs. José Augusto Barreto de Mello Rocha e Décio Coutinho. 19 - Drs. Assis Brasil, João Chrysóstomo da Rocha Cabral e Mario Pinto Serva" (Decreto n ${ }^{\circ} 19.684$, de 10 de fevereiro de 1931).

${ }^{79}$ Ângela Castro Gomes destaca a discussão do anteprojeto de código eleitoral em uma comissão revisora composta por juristas provenientes dos grandes Estados, tais como Sampaio Dória (SP), Juscelino Barbosa (MG), Mário de Castro (PE), Bruno de Mendonça Lima e Sérgio de Oliveira (RS), Adhemar de Faria e Octavio Kelly, (RJ), in GOMES, 1986, pp. 15/16, nota 12. Gilberto Bercovici chama atenção para a influência das ideias de Assis Brasil no resultado final - para a análise, ver BERCOVICI, 2008(b), pp. 28/30.
} 
engajadas na campanha pró-constitucionalização" ${ }^{\circ 0}$. O código representou um aceno aos defensores de que se institucionalizasse, legalmente, a nova ordem, contra os tenentes que denunciavam a "precipitação", que poderia comprometer os rumos políticos revolucionários diante da necessidade de composição entre diferentes forças sociais que uma norma jurídica representava ${ }^{81}$.

Contudo, os tenentes demonstram sua força, garantindo a inclusão no código de medida não originalmente prevista: a representação profissional. "Segundo depoimento de Augusto do Amaral Peixoto, a inclusão da representação de classes no código eleitoral de 1932 fora uma clara demonstração de força e prestígio do clube 3 de outubro, pois o texto original do decreto não a previa. Entretanto, já em mãos de Getúlio Vargas, a medida fora anexada por insistência de alguns tenentes, o que, inclusive, chegara a contribuir para o afastamento do ministro Maurício Cardoso da pasta da $J_{\text {ustiça }}{ }^{\text {"82 }}$. A posição é confirmada pelo relato de Virgínio Santa Rosa, para quem a inclusão da representação classista marcou "mais uma vitória da corrente revolucionária sobre as correntes políticas ${ }^{\prime \prime 3}$.

A representação profissional era, contudo, apenas uma dentre as importantes inovações do Código Eleitoral, que estendia o direito de voto às mulheres, assegurando que todos os brasileiros maiores de 21 anos e alfabetizados passariam a compor o corpo político nacional (permaneciam excluídos, contudo, mendigos e praças de pré, à semelhança do que já ocorria anteriormente). Era criada a Justiça Eleitoral, que, transferindo o controle das eleições do Poder Legislativo para os magistrados, dava um passo decisivo no combate às fraudes características do período anterior. Por fim, o Código garantia mais efetivamente o voto secreto ${ }^{84}$, medida considerada básica para a moralização

\footnotetext{
${ }^{80}$ GOMES, 1986, p. 15. É interessante lembrar que tanto Maurício Cardoso quanto Lindolfo Collor demitiram-se de seus ministérios em março de 1932, na sequência do espisódio do "empastelamento" do jornal Diário Carioca, constando da carta de demissão de Collor suas reticências quanto ao processo revolucionário, a demora da reconstitucionalização e as medidas autoritárias de censura: "São de ontem as minhas pregações na tribuna parlamentar e na imprensa da Aliança Liberal em favor da liberdade de opinião (...). Devo afirmar a V. Excia (...) que se me fosse dito que a Revolução se faria precisamente para manifestar e sufocar essa liberdade que é a pedra angular das sociedades organizadas, eu não teria sido como fui um dos elementos mais decisivos na conspiração que deflagrou no movimento de 3 de Outubro", in COLLOR, 1990, p. 222. Cf. verbete COLLOR, Lindolfo, em Dicionário Histórico-Biográfico Brasileiro (CPDOC-FGV).

${ }^{81}$ Para a posição dos tenentes, vide SANTA ROSA, 1976 (1933), pp. 83 e ss.

${ }^{82}$ GOMES, 1986, p. 17.

${ }^{83}$ SANTA ROSA, 1976 (1933), p. 90.

84 " $O$ sigilo do voto foi aperfeiçoado com duas medidas. A primeira delas era a obrigatoriedade do uso de sobrecarta (envelope) oficial, no qual os eleitores deveriam inserir a cédula eleitoral. A sobrecarta deveria ser uniforme e opaca, numerada e rubricada pelos membros da mesa eleitoral. Assim, evitava-se a prática comum na Primeira República de os partidos utilizarem os envelopes de cores, tamanhos e formatos diferentes para controlar o voto dos eleitores. A segunda medida foi a introdução de um lugar indevassável
} 
das práticas políticas no país. Apesar de não por fim em definitivo às práticas de coação eleitoral tão características do coronelismo brasileiro, como aponta Victor Nunes Leal ${ }^{85}$, a nova legislação eleitoral representou sem dúvida um avanço significativo no combate ou minimização das fraudes. "Através dessas duas inovações (justiça federal e voto secreto), o código estava, ao menos institucionalmente, realizando uma verdadeira reforma no que se referia às bases de legitimidade do Estado, respondendo, sem dúvida, às pressões políticas do movimento das camadas médias e do proletariado urbano, ocorrido na década passada" ${ }^{\prime 6}$. Concretizavam-se, com ele, pontos da maior importância do programa da Aliança Liberal, especialmente relacionados com o combate às fraudes nas eleições e a moralização do processo político nacional. Por outro lado, ao manter a restrição do direito de voto dos analfabetos, o código não pode ser confundido com a institucionalização da democracia de massas no país. Pelo contrário, um reduzido corpo eleitoral que dele seria decorrente, na medida em que mais de $60 \%$ da população ainda era analfabeta, ainda indicava uma democracia bastante limitada, como se verá adiante.

A garantia das premissas típicas da democracia liberal é acompanhada, assim, pela introdução de um modelo representativo de classes, construído em oposição às a elas. Novamente, a orientação é dúbia, marcada pela indefinição e pela busca de conciliação dos programas, seja a determinação de ampliação do corpo eleitoral e da lisura do procedimento democrático, seja o impulso de controle da representação pelo governo, a partir da instituição de forma de representação organizada a partir do poder público e de sua tutela sobre os sindicatos. Nesse caso, talvez como inverso do da legislação trabalhista, o registro progressista está na afirmação dos valores liberais, enquanto que o autoritário reside na tentativa corporativista de controle do processo democrático. Assim enterram-se

(cuja porta ou cortina deviam estar fechadas) onde o eleitor pudesse colocar a cédula na sobrecarta oficial. Os partidos e candidatos que quisessem podiam enviar previamente as cédulas para as mesas eleitorais, que as colocariam à disposição do eleitor", NICOLAU, 2004, pp. 38/39. As garantias constam do artigo 57 do Código Eleitoral.

85 "O código de 1932, aperfeiçoado pela reforma de 35, apesar dos louvores que mereceu, não punha fim à costumeira coação dos partidos oficiais. Não nos referimos à coação direta e material no dia do pleito ou no ato de votar. Nem era esta a mais frequente modalidade de compressão do voto na vigência das leis anteriores. Aludimos à coação difusa mas efetiva, que em muitos lugares precede às eleições no interior do país; ao ambiente de insegurança adrede criado para os eleitores da oposição, que nos menores municípios toda gente conhece; à violência preparatória, atual ou iminente, manifestada com pertinácia em pequenas ou grandes façanhas, dias, semanas e até meses a fio. Só para esse tipo de coação não havia remédio no código, segundo a interpretação restritiva que lhe deu o Tribunal Superior Eleitoral", in LEAL, 1997 (1948), pp. 260/261. A observação parece deslocada, mas não é, na medida em que ajuda a compreender a predominância inconteste da bancada governista na Assembleia Nacional Constituinte, como o autor observa, fruto do reiterado governismo das lideranças políticas locais.

${ }^{86}$ GOMES, 1986, p. 17. 
de vez as aspirações liberais, ainda que meramente retóricas, de restrição à atuação do Estado na economia.

Por fim, é de se destacar dentre o conjunto de reformas do período do Governo Provisório a edição do Código de Minas, por meio do Decreto no 24.642, e do Código de Águas, Decreto $\mathrm{n}^{\circ} 24.643$, ambos de 10 de julho de 1934, ou seja, dias antes da promulgação da nova Constituição. Ambos compõem um marco na reorientação do papel do Estado em relação à economia, posicionando-se como interventor de modo a promover o desenvolvimento do país por meio da atuação direta e da regulação dos bens públicos, como água, subsolo, jazidas minerais e demais recursos energéticos. As normas regulam o aproveitamento industrial dos recursos hídricos e separam a propriedade do solo e do subsolo, dotando o Estado de mecanismos de intervenção econômica que the serão extremamente úteis a partir dai ${ }^{87}$. "Inicia-se um amplo esforço de elaboração legislativa, com a criação das Comissões Legislativas. E em dois setores principais, o Governo Provisório vai estabelecer regime inteiramente novo, prenunciadores do Direito público econômico nascente, o regime das águas e energia elétrica, e o regime das minas. Em ambos os casos, os novos códigos, regulando a matéria, afastam-se claramente das simples disposições privatistas, para dar ao Estado poderes os mais amplos, transformando as relações contratuais de Direito privado em relações de Direito público, nas quais se tinha como objetivo principal o interesse público" ${ }^{\$ 8}$.

Diante disso, o que se vê durante os anos de Governo Provisório é um esforço sem precedentes para a composição de um novo estatuto jurídico-institucional abrangente, capaz de ao mesmo tempo responder aos anseios que motivaram a Revolução de 1930, especialmente ligados a uma moralização das práticas políticas e a uma nova percepção da questão social, bem como de reformular o papel do Estado na regulação social e econômica. Tratava-se de lançar os alicerces para um Brasil moderno, com uma legislação igualmente moderna, permitindo ver nelas as medidas que de fato reestruturam e reformam o Estado brasileiro, à margem da Constituição que viria, conforme argumenta Bercovici $^{89}$. É de fato um conjunto de normas que promovem mudanças substantivas, comparáveis a uma refundação constitucional, mas que não seriam suficientes para afastar

\footnotetext{
${ }^{87}$ Sobre o histórico da regulamentação das minas no Brasil, vide VENÂNCIO FILHO, 1998 (1968), pp. 145/160. Sobre o histórico da legislação acerca de águas e energia hidráulica, ver VENÂNCIO FILHO, 1998 (1968), pp. 187/203, bem como BERCOVICI, 2011.

${ }^{88}$ VENÂNCIO FILHO, 1998 (1968), p. 33.

${ }^{89}$ Cf. BERCOVICI, 2009, pp. 725/727.
} 
a necessidade de que fossem amparadas por uma nova Constituição, fruto de deliberação democrática, ainda que limitada.

\subsection{Formulando a CONSTituição NaCiONAL}

O Brasil seguia sem uma Constituição desde a Revolução de 1930, situação que foi se tornando, progressivamente, motivo de desconforto, até mesmo pela sua incompatibilidade com o próprio programa da Aliança Liberal que, como visto, passava pela instituição de uma nova ordem constitucional. Por mais que os interesses por trás da chamada Revolução Constitucionalista de 1932 pudessem ser distintos das reivindicação anunciada, não parecia evidente que o Governo Provisório tivesse intenção de apressar o processo de reconstitucionalização do Brasil. Perpetuando a situação provisória, um governo revolucionário com poderes ampliados alinhava-se tacitamente com os defensores da prorrogação da volta à ordem constitucional, especialmente o grupo ligado ao tenentismo. Por outro lado, é certo que mesmo antes do movimento paulista eclodir, já havia sido editado, além do Código Eleitoral, o Decreto n ${ }^{\circ} 21.402$, de 14 de maio de 1932, que fixava em 3 de maio de 1933 a data para a realização de eleições para a Assembleia Nacional Constituinte. Como fundamento, considerava o decreto "a utilidade de abrir desde logo, como trabalho preparatório às deliberações da Assembleia Constituinte, um largo debate nacional em torno das questões fundamentais das organizações políticas do país". Abrir um largo debate era um pré-requisito para a formação de um novo compromisso, mas as diferentes forças políticas existentes na sociedade de fato pareciam indicar para o governo a dificuldade em transformar o debate em texto constitucional capaz de dar estabilidade à nova ordem.

O retorno do Brasil ao regime constitucional aparecia, por vezes, como prematuro, nas manifestações dos atores da época. Assim até mesmo as manifestações de Vargas, como por exemplo em discurso de maio de 1932: "Em face da herança calamitosa, deixada pela primeira República, consistiria excesso de otimismo supor que, em curto prazo, fosse possível restituir à Nação sua vida normal, sem risco de reincidir, pelo menos parcialmente, nos antigos erros que a levaram à ruína. Compreende-se que o restabelecimento da normalidade constitucional, antes da revolução produzir seus efeitos imediatos e benéficos, seria apenas a restauração do passado, com as causas determinantes do movimento reivindicador. Se isso sucedesse, legitimar-se-ia o argumento 
negativista, frequentemente invocado, de que lhe fora objetivo substituir homens, e não renovar instituições, quadros e métodos de governo. Toda essa decomposição, a que tivemos de aplicar o remédio heróico da força, se processou no decorrer de quarenta anos de regime constitucional. Seria critério simplista, senão ingenuidade, acreditar que tudo estaria saneado com a volta automática do país à legalidade, que propiciara aquele deplorável estado de coisas. Semelhante terapêutica fatalmente falharia, quando empregada em debelar males antigos, crônicos e profundos" $"$. A fala tem subentendida a ideia de que a volta da ordem constitucional poderia representar um retrocesso para o movimento revolucionário, na medida em que impediria a renovação e a correção dos "velhos erros" a que se propunham. "Parece certo que a intenção do Governo Provisório era completar a reorganização das estruturas políticas e institucionalizar o novo papel do Estado antes de permitir a reconstitucionalização do país" ${ }^{91}$, analisa Rowland. A posição de Vargas era acompanhada pelos tenentes, para quem os "constitucionalistas ferrenhos" acreditam "que a simples promulgação de uma lei básica, assegurando os direitos e deveres em inofensivas folhas de papel, fará cessar imediatamente o mal-estar generalizado e a confusão que mora nas almas. É confiar demasiado num mero estatuto político. Santa simplicidade!"92.

O receio da prematuridade da reconstitucionalização, segundo aponta Vera Cepêda, está ligado à "consciência de inúmeros atores e textos do período o sentimento de transição, de mudança drástica, combinada ou agravada pela ausência de uma direção claramente constituída" ${ }^{93}$ - a ausência de consenso em torno de uma direção clara podia indicar o risco de discutir a nova ordem constitucional em um fórum de representantes mais amplo. Alguns entendiam que a transição precisaria da tutela autoritária do Estado, enquanto outros enxergavam nela o caminho para superar o ranço oligárquico e realizar enfim o ideal republicano enterrado pelas práticas da Primeira República. Acreditava-se na realização de uma revolução lenta, que seria capaz de consolidar novos valores a partir das "forças do novo", mas que precisava de tempo para enterrar de vez a velha política. “Assim, parte das perspectivas que geraram a mudança, como a defesa intransigente do voto livre e de eleições idôneas, bem como de uma nova engenharia constitucional, ficaria em suspenso em função do receio de que a democratização precipitada permitisse o retorno exatamente das práticas e elites que se

\footnotetext{
${ }^{90}$ VARGAS, 1932, p. 14.

${ }^{91}$ ROWLAND, 1974, p. 17.

92 SANTA ROSA, 1976 (1933), p. 85.

${ }^{93}$ CEPÊDA, 2009, p. 220.
} 
procurara banir com a revolução"94.

Contudo, o governo de fato não poderia durar mais muito tempo. Apesar de não haver um consenso forte em torno da conveniência da elaboração desde logo de uma nova Constituição, na prática, a solução tornava-se inevitável, seja por conta do movimento paulista, seja em razão da crescente insustentabilidade da contradição entre um governo autoritário e a plataforma da Aliança Liberal, ou seja em função da rearticulação oligárquica que via na Constituição uma forma de reposicionar-se como elite dominante, restringindo os poderes de Vargas ${ }^{95}$. As correntes anticonstitucionalistas estavam enfraquecidas $^{96}$. O desafio de formular a Constituição, portanto, é também o desafio de encontrar uma solução para o novo arranjo de forças promovendo a conciliação das velhas oligarquias - sejam as dominantes e insatisfeitas com a Revolução, sejam as que impulsionaram o movimento em razão de sua exclusão do jogo político majoritário no final dos anos 1920 - e as novas forças sociais, incluindo as camadas médias urbanas, os tenentes, as Forças Armadas e o setor industrial nascente. Assim a difícil tarefa constitucional, equilibrar-se entre reacionarismo e progresso, fornecendo uma solução de compromisso capaz de fundamentar uma Segunda República brasileira, moderna e social.

Se a Constituição é inevitável, por um lado, o processo constituinte, esse sim, poderia ser controlado. Apesar de calcado em premissas democráticas, especialmente diante da inescapável reforma eleitoral que já se havia implementado com o Código de 1932, o processo de reconstitucionalização deveria ser tutelado com mão firme pelo Governo Provisório, que até então exercia, isolado, o poder político de fato, na ausência de uma clara lei constitucional e de um Parlamento que o pudessem limitar. "De fato, as constituições não prevêem o procedimento para a formação do poder constituinte. Neste sentido, o controle deste processo representa um valioso recurso do poder para quem ocupa a chefia do governo, uma vez que assegura margens de interferência concreta, tanto na determinação das futuras regras do jogo político quanto pela possibilidade de atuar paralelamente ao desenrolar dos acontecimentos na Assembleia" ${ }^{, 97}$. Dessa forma, o mesmo decreto que convocava eleições, determinava, antes disso, a criação de uma comissão incumbida de elaborar o anteprojeto da Constituição, sob a presidência do Ministro da

\footnotetext{
${ }^{94}$ CEPÊDA, 2009, p. 222.

95 "Para certos setores oligárquicos, afastados do poder em seus Estados (...) ou que se consideraram preteridos na composição do governo central (...) a constitucionalização passa a significar a possibilidade de retomada das posições políticas a que julgavam ter direito. Dessa forma, o objetivo mais imediato da constitucionalização era o desalojamento dos elementos tenentistas dos postos que então detinham, através do movimento de contestação do regime de força vigente", GOMES, 1986, p. 25.

${ }^{96}$ Para uma análise mais detalhada do processo, vide GOMES, 1986, pp. 18/19.

${ }^{97}$ GOMES, 1986, p. 19.
} 
Justiça e Negócios Interiores (art. $1^{\circ}$ ). Do mesmo modo, o Regimento Interno da Assembleia é formulado pelo Governo Provisório (Decreto $\mathrm{n}^{\mathrm{o}} 22.621$, de 5 de abril de 1933).

A Assembleia Constituinte, que deveria ser composta por representantes políticos eleitos nos Estados, mas também pela novidade dos representantes classistas, contaria com um anteprojeto formulado pela comissão governamental, portanto, para orientar seus trabalhos. Se a Constituição de 1934 costuma ser referência de um novo paradigma constitucional para o Brasil, é também porque é produto de amplos debates prévios à sua promulgação, que resultaram em um texto que condensa, nem sempre em um esquema absolutamente coeso, as ideias políticas e jurídicas da época, não à toa mencionada como "um excelente guia para o esclarecimento do complexo panorama político-ideológico de uma época de transição, fornecendo pistas preciosas para o estudioso" 98 . Vale lembrar que o processo de reconstitucionalização extravasava os ambientes dos gabinetes e plenários, e estava no centro do debate público do período, sendo tratado diariamente nos principais jornais, que publicavam inclusive extratos das atas das reuniões da Subcomissão Itamaraty e da Assembleia Nacional Constituinte. Debate-se a nova Constituição não apenas nos círculos jurídicos, mas na sociedade em geral, prova disso são os diversos projetos de Constituição que se fazem publicar no período.

O segundo eixo do presente estudo, focado na crise do constitucionalismo liberal no pensamento jurídico, em perspectiva comparada, é composto pela análise das ideias em debate durante esse processo constituinte brasileiro. Mas, antes disso, é preciso dedicar algumas linhas à trajetória da reconstitucionalização, seus atores, suas fases e suas determinações, sem o que as ideias não poderiam ser compreendidas e situadas.

\subsubsection{Subcomissão Itamaraty}

O movimento paulista, que durou de julho a outubro de 1932, acabou por retardar a instalação da comissão constitucional, cujos trabalhos foram disciplinados somente em $1^{\circ}$ de novembro de 1932 , pelo Decreto $n^{\circ} 22.040$. A composição da comissão ${ }^{99}$

\footnotetext{
${ }^{98}$ KUGELMAS, 1987, p. 30.

${ }^{99}$ Para compor a Comissão Constitucional, foram indicados: Joaquim Francisco de Assis Brasil, Afrânio de Mello Franco, Oswaldo Aranha, José Américo de Almeida, Arthur Ribeiro, Agenor de Roure, Antônio
} 
não pode ser considerada reflexo da hegemonia política de algum grupo determinado, pelo contrário, indica uma tentativa de composição de distintos grupos de interesse, tendo Vargas como o mediador externo, postura condizente com a afirmação de uma ideologia "acima das classes", na melhor herança positivista. A Comissão seria presidida pelo Ministro da Justiça, Francisco Antunes Maciel Filho, que deveria designar um terço de seus membros para compor uma subcomissão encarregada da elaboração de fato do anteprojeto. O documento, uma vez concluído, deveria ser remetido ao Chefe do Governo Provisório (art. 13). Tal Comissão Constitucional foi selecionada por Getúlio Vargas de forma a contar com representantes de setores distintos e de certa forma plurais da sociedade, pluralidade, porém, adstrita às correntes de pensamento das elites intelectuais urbanas $^{100}$.

Logo são selecionados os membros da Subcomissão, que ficou conhecida como Itamaraty, em razão do local que passou a ser a sede de suas reuniões, a sala de leitura da Biblioteca do Palácio Itamaraty (as primeiras sessões se deram na residência de seu presidente, Afrânio de Mello Franco, então Ministro das Relações Exteriores). Os integrantes são escolhidos de forma a compor um grupo sobretudo de acadêmicos, proveniente das elites intelectuais, ainda que representantes de correntes de pensamento distintas. Apesar de suas diferenças, a grande maioria possuía formação em Direito $^{101}$, formando um conselho de notáveis, familiarizados com as doutrinas jurídicas contemporâneas, bem como com as novas Constituições europeias do entre-guerras.

Compõem a Subcomissão Itamaraty Agenor de Roure, Antônio Carlos, Antunes Maciel (Ministro da Justiça), Artur Ribeiro (Ministro do Supremo Tribunal

Carlos Ribeiro de Andrade, Carlos Maximiliano Pereira dos Santos, Pedro Aurélio de Góis Monteiro, Francisco Solano Carneiro da Cunha, Francisco Luiz da Silva Campos, João Mangabeira, Francisco Cavalcanti Pontes de Miranda, Francisco José de Oliveira Vianna, Alceu de Amoroso Lima, Américo Brasílio Silvado, Serafim Valandro, Francisco Oliveira Passos, Bertha Lutz, Nethércia Silveira, Henrique Stepple Junior, José do Castro Nunes, Themístocles Brandão Cavalcanti, Astolpho Vieira de Resende, Vítor Vianna, Agrícola da Câmara Lobo Bethlém, Luiz Viigler, Prudente de Moraes Filho, Álvaro Cumplido de Sant'Anna, Leopoldino Freire, César do Rego Monteiro Filho, in SILVA, 1991, p. 68.

${ }^{100}$ Conforme analisa Zélia Lopes da Silva, "a composição traduziu a tentativa de contemporizar os diferentes interesses da chamada sociedade civil, incorporando às discussões da nova Carta os movimentos de emancipação feminina, os interesses católicos, as preocupações da burguesia industrial, além de representação de São Paulo", in SILVA, 1991, p. 70.

${ }^{101}$ Agenor de Roure tinha outro diploma superior (Odontologia), e o General Góis Monteiro, militar de carreira, comumente se compreendia como deslocado naquele ambiente de intelectuais, posteriormente relatando: "Senti-me, de certa maneira, deplacé, não só porque fui nomeado para substituir um oficial de grande cultura, o General Tasso Fragoso, que declinou do convite que lhe fora feito nesse sentido, como também porque, sendo militar, só podia nela figurar pelos meus conhecimentos profissionais, como uma espécie de consultor técnico", in COUTINHO, Lourival, O General Góis depõe. Rio de Janeiro, Ed. Coelho Branco, 1956, p. 236, apud AZEVEDO, 2004, pp. XIX/XX (introdução de Walter Costa Porto). 
Federal) ${ }^{102}$, Assis Brasil ${ }^{103}$, Carlos Maximiliano, José de Castro Nunes ${ }^{104}$, General Góis Monteiro, João Mangabeira, José Américo de Almeida (Ministro da Viação e Obras Públicas) ${ }^{105}$, Francisco José de Oliveira Vianna, Oswaldo Aranha (Ministro da Fazenda), Prudente de Morais Filho, Themístocles Cavalcanti e Solano da Cunha ${ }^{106}$. Themístocles Cavalcanti é designado secretário da mesa, função que passa a ser exercida por Otto Prazeres a partir da $10^{\mathrm{a}}$ Sessão, e Carlos Maximiliano é o relator geral do projeto de Constituição.

$\mathrm{Na}$ Subcomissão Itamaraty, aparecem os primeiros choques entre democratas liberais e figuras mais críticas, seja influenciadas pelo corporativismo e pelos modelos fascistizantes, seja ligadas ao socialismo, ainda que apegadas aos valores liberais (caso de João Mangabeira). "Percorrendo-se as opiniões manifestadas nos debates, notase a existência de uma espécie de inclinação fascistizante nos espíritos revolucionários dos mais jovens. Góis Monteiro exprimia um nacionalismo militarista, desconfiado das tradições liberais e da técnica democrática clássica, que, de resto, conhecia muito pela rama. Oliveira Vianna - grande figura intelectual - tinha as convicções sociologicamente aristocráticas e autoritárias, que compendia em toda a sua obra de discípulo direto de Alberto Torres. José Américo e Oswaldo Aranha flutuavam nas indecisas aspirações de uma justiça social e de uma organização estatal influenciadas pelos novos modelos ditatoriais da Europa. João Mangabeira era o ilustre jurista e o insigne orador de sempre; como sempre brilhante e impetuoso, cedendo, às vezes, às perigosas impressões de momento, que vestia com roupagens sedutoras da sua dialética e de sua contraditória cultura, ao mesmo tempo liberal à maneira de Rui e esquerdista à maneira da filosofia marxista" 107 .

\footnotetext{
${ }^{102}$ Artur Ribeiro deixa formalmente de tomar parte dos trabalhos a partir da $22^{\mathrm{a}}$ Sessão, em razão de sua divergência quanto à unidade da magistratura - rechaçada no anteprojeto, mas afirmada no texto final da Constituição

${ }^{103}$ Apesar de indicado, não há notícia de que Assis Brasil tenha participado das sessões da Subcomissão, havendo notícia de sua intervenção por carta ou telegrama, ou ainda por meio da leitura de suas obras - a intervenção refere-se, sobretudo, ao debate sobre a distribuição das cadeiras entre os Estados na Câmara dos Deputados, tratando do sistema representativo. Vide por exemplo: 12a Sessão, pp. 214/216, $14^{\mathrm{a}}$ Sessão, p. $259,19^{a}$ Sessão, p. 329 (todas da Subcomissão Itamaraty). Nota geral sobre as citações das atas da Subcomissão Itamaraty: todas as referências às sessões e manifestações da Subcomissão Itamaraty referemse à compilação das atas em AZEVEDO, 2004, referência que fica desde logo mencionada, consta da bibliografia final e não será repetida nas citações seguintes, onde se fará constar apenas a menção ao orador, à sessão e à página correspondente.

${ }_{104}^{104}$ Apenas toma parte a partir da $38^{\mathrm{a}}$ Sessão.

${ }^{105}$ Participa até a $7^{\text {a }}$ Sessão, depois afasta-se.

${ }^{106}$ Apenas toma parte a partir da $38^{\mathrm{a}}$ Sessão.

${ }^{107}$ FRANCO, 1955, pp. 1409/1410.
} 
A descrição dos personagens proposta por Afonso Arinos, ainda que carregue nas tintas, dá uma ideia das inclinações ideológicas principais, que indicam desde logo um embate de ideias de difícil conciliação. Nesse sentido, Kugelmas entende que a Subcomissão "foi um verdadeiro microcosmo do panorama ideológico e político do momento, incluindo alguns dos principais líderes políticos da Revolução de 30 - como Osvaldo Aranha, José Américo e o General Goes Monteiro -, juristas da tradição liberal da 'República Velha' - como Carlos Maximiliano -, e defensores do autoritarismo e do corporativismo, como Oliveira Vianna"108. A unanimidade entre seus membros existe apenas sobre a necessidade de se produzir uma obra de conciliação e compromisso, a partir de transações mútuas - é em função, justamente, da convicção de que "uma Constituição, salvo a hipótese da vitória de uma revolução social, será sempre uma fórmula de equilibrio e transação entre ideias, correntes e interesses, que atuam num meio social determinado"109, que João Mangabeira entrega-se posteriormente à função, a pedido do jornal Diário Carioca, de defender o anteprojeto, que subscreve "sem restrições".

A primeira reunião da Subcomissão se deu em 11 de novembro de 1932, quando debateu-se o método de trabalho. Convergindo na proposta de apresentação de projetos parciais pelos membros e a indicação de Carlos Maximiliano para relatoria geral, a sessão se encerra. Na reunião seguinte, distribuem-se os capítulos ou matérias constitucionais da seguinte forma: Conselho Nacional: Mello Franco, José Américo e Prudente de Morais; Família, Educação, Ordem Econômica e Social: José Américo, João Mangabeira e Oliveira Vianna; Defesa Nacional, Organização das Forças Armadas e Policiais dos Estados: Góis Monteiro; Poder Judiciário: Arthur Ribeiro e Antônio Carlos; Política Econômica e Financeira: Antônio Carlos, Agenor de Roure e Oswaldo Aranha; Direitos e deveres fundamentais e cidadania: Mello Franco e Themístocles Cavalcanti ${ }^{110}$. A partir daí, seguem-se as sessões com os debates sobre os temas, conforme as propostas dos relatores parciais. As atividades da Subcomissão Itamaraty encerram-se na $51^{\text {a }}$ Sessão, em 5 de maio de 1933, logo a tempo para o envio do anteprojeto ao Governo Provisório, para eventual revisão e posterior encaminhamento à Assembleia Nacional Constituinte.

As discussões centram-se sobre os dispositivos e institutos mais concretos que serão produto da nova Constituição, de modo que as opiniões gerais sobre o modelo de Estado e sobre o novo direito público que se delineava ficam dissolvidos antes

\footnotetext{
${ }^{108}$ KUGELMAS, 1987, p. 31.

${ }^{109}$ MANGABEIRA, 1934, pp. 9/10.

${ }^{110}$ Cf. $2^{\text {a }}$ Sessão (Subcomissão Itamaraty), p. 15.
} 
de aparecerem como discursos mais gerais, como acontece na Assembleia Constituinte. A premissa fundamental era a de que se estavam reunindo para buscar um consenso, um compromisso, uma solução que representasse um acordo entre as diversas convicções ideológicas dos membros da Subcomissão, especialmente entre liberais e críticos. Dessa forma, os principais debates se dão, de modo esquemático, em torno da representação profissional, da organização judiciária, da supressão do Senado e criação do Conselho Supremo, da responsabilização do Presidente da República e dos ministros de Estado, da Segurança Nacional e do estado de sítio, e do federalismo versus centralização política. Conforme sistematiza Ângela de Castro Gomes, as principais conclusões consolidadas no anteprojeto, que contou com 129 artigos, foram "supressão do Senado e criação do Conselho Supremo; instituição do legislativo formado de uma câmara única, a Assembleia Nacional; eleições diretas para o Legislativo; participação dos ministros no Legislativo; rejeição da representação de classes, consagração da legislação trabalhista e da concernente à nacionalização e proteção da economia; legislação sobre educação, saúde, funcionalismo e família, e legislação sobre segurança nacional"111.

De modo geral, os membros da Subcomissão vinculam-se ao resultado final $^{112}$, e têm em João Mangabeira o principal defensor do anteprojeto, inclusive naquilo que ele tem de eclético. Assim, afirma: "Os que acusam o anteprojeto de não haver adotado integralmente uma doutrina, e, procurando conciliar divergências, ter caído no erro do ecletismo, realçam, exatamente nisso a sua virtude, ou o seu acerto, de fugir aos extremismos de qualquer natureza, conservando-se no meio termo da harmonização dos interesses, condição essencial a qualquer lei de grande porte (...). Constituição sem ecletismo, expressão total e absoluta de um sistema, somente será possível, quando, após uma revolução social triunfante, uma grande personalidade impuser ao seu partido vitorioso o predomínio de sua inteligência, seu prestígio e sua vontade. É o caso da Constituição Soviética. Não era, nem poderia ser, o caso da revolução brasileira de 930, em cujo leito desaguavam correntes partidárias de pontos opostos, em cujo bojo se abrigavam os interesses mais antagônicos, em cujas fileiras se atropelavam as ideias mais adversas, numa escala cromática, que se distendia do vermelho das reivindicações

\footnotetext{
${ }^{111}$ GOMES, 1986, pp. 22/23.

${ }^{112} \mathrm{O}$ General Góis Monteiro assume uma postura dúbia, explicitando novamente sua posição ao afirmar: "Julga admirável o trabalho dos companheiros de comissão naquilo que pode apreender e julgar, mas, doutrinariamente, como se sabe, é contra o Estado como foi previsto no projeto. Como disse o sr. João Mangabeira, não é pelo regime democrático. Mais tarde, os responsáveis pelos destinos do Brasil hão de se convencer de que ainda é cedo para entrarmos nesse regime, tal como foi instituído em 1889 e que nós, de certa maneira, mantivemos", in 51 a Sessão (Subcomissão Itamaraty), p. 1024.
} 
marxistas ao negro da reação clerical"113. O trecho explicita o desafio constitucional brasileiro, qual seja, o de promover um acordo mínimo entre as diferentes linhas de pensamento da época, de modo que o resultado, ainda que eclético, consiga servir como compromisso para o que será o governo e o país futuros. É esse o esforço do anteprojeto elaborado como ponto de partida para os trabalhos da Assembleia Constituinte, que a partir da erudição dos juristas membros da Subcomissão, apresenta-se como a compilação das ideias em voga na época sobre a Constituição em seu formato social. Consequentemente, dificilmente o resultado seria um anteprojeto passível de ser qualificado como "escorreito e íntegro" em espelhar tal ou qual doutrina, como fora classificada a Constituição de 1891. Pelo contrário, é uma composição eclética, antes de tudo, ainda que disputada pelas diferentes tendências, que querem ver nele um texto liberal ou socialista, a depender de quem o avalia.

Nos capítulos seguintes, analisaremos de modo geral a tônica dos debates, especialmente a percepção geral dos membros da Subcomissão sobre a nova Constituição e o modelo de Estado a ser instituído, no capítulo 5. No capítulo 6, o foco será compreender de que forma aparecem as questões ligadas à democracia e à disciplina do social nas intervenções, às quais se pode ter acesso por meio das atas publicadas, que segundo Góis Monteiro, "registram fielmente tudo quanto se passa e vota na subcomissão" 114 .

\subsubsection{Assembleia Nacional Constituinte}

Em 3 de maio de 1933, organizam-se eleições para a escolha dos 214 representantes políticos, tomando como circunscrições eleitorais os Estados, o Distrito Federal e o Território do Acre de acordo com as regras do recém-criado Código Eleitoral $^{115}$. Poderiam registrar-se candidatos filiados a partidos, ligados a listas de

\footnotetext{
${ }^{113}$ MANGABEIRA, 1934, pp. 10 e 13.

${ }^{114}$ Góis Monteiro, 30 ${ }^{\text {a }}$ Sessão (Subcomissão Itamaraty), p. 610.

${ }^{115}$ Conforme explica Jairo Nicolau, "pelo novo sistema, os nomes dos candidatos deviam ser impressos ou datilografados em uma cédula. Podia-se votar em tantos nomes, independente de partidos, quantos fossem as cadeiras do Estado na Câmara dos Deputados mais um (...). Havia um sistema de apuração que privilegiava o primeiro nome da lista (chamado de primeiro turno). Os votos dados aos candidatos que encabeçavam cada cédula eram somados para se obter a votação final de cada partido. Calculava-se o quociente eleitoral (número de eleitores que compareceram dividido pelo número de cadeiras a serem ocupadas). Cada partido elegia tantas cadeiras quantas vezes atingisse o quociente eleitoral e os candidatos mais votados de cada partido eram eleitos. Como eram computados os votos para os nomes que não encabeçavam a lista de cada cédula? Eles eram somados e os nomes mais votados (portanto, um sistema majoritário) ficavam com as cadeiras não ocupadas depois da distribuição do quociente. Essa segunda parte da distribuição de cadeiras recebia o nome de segundo turno", in NICOLAU, 2004, pp. 40/41.
} 
eleitores ou avulsos, com registro no Tribunal Regional Eleitoral, e quase todos tinham atuação restrita às circunscrições eleitorais. "Apesar das denúncias sobre a manutenção das fraudes em diversas regiões do país, os cronistas da época eram unânimes em reconhecer a legitimidade dos dois pleitos realizados nos anos 1930 para a Câmara dos Deputados [em 1933 e 1934]"116. Concorreram ao todo 802 candidatos $^{117}$, sendo interessante notar que apenas nos Estados maiores havia um número muito maior de candidatos por vaga ${ }^{118}$.

Os dados de alistamento e comparecimento eleitoral, contudo, são um dado importante, a que se deve prestar atenção. Mesmo com a extensão do sufrágio facultativo às mulheres, apenas $3,9 \%$ da população brasileira alistou-se para votar (1.438.000 pessoas, em uma população de 36.974 .000$)^{119}$, e $3,3 \%$ compareceu efetivamente às eleições ${ }^{120}$, o que nem de longe pode ser considerado como massificação da democracia ${ }^{121}$ - vale lembrar que a França já registrava participação eleitoral de 23,4\% da população na década de 1930 , que termina com $48 \%$ de participação ${ }^{122}$. A baixa participação eleitoral é produto das significativas restrições ao direito de voto, excluindo analfabetos, praças de pré, aspirantes a oficial e suboficial, guardas-civis e quaisquer funcionários da fiscalização federal ou local - cumpre lembrar a estimativa de que $60 \%$ da população brasileira adulta era analfabeta ${ }^{123}$. Ela é inferior à participação nas eleições presidenciais de 1930, últimas realizadas em escala nacional, em que 5,6\% dos brasileiros compareceram às urnas ${ }^{124}$.

\footnotetext{
${ }^{116}$ NICOLAU, 2004, p. 42.

${ }^{117}$ Sendo importante lembrar que vários políticos estavam impedidos de concorrer ao pleito por força do Decreto $\mathrm{n}^{\circ} 22.194$, de 9 de dezembro de 1932, o chamado "decreto das inelegibilidades".

${ }^{118}$ Para um quadro detalhado, vide GOMES, 1986, p. 24.

${ }^{119}$ Dado em NICOLAU, 2004, p. 38.

${ }^{120}$ Dado em NICOLAU, 2003, p. 272. Conforme aponta Mônica Karawejczyk, a reconstrução dos dados eleitorais anteriores a 1945 não é tarefa fácil, diante da dispersão dos documentos, salientando a existência de dados compilados pelo Tribunal Superior Eleitoral apenas a partir das eleições de 1945, justamente, in KARAWEJCZYK, 2010, p. 205 e nota 13.

${ }^{121}$ Para Jairo Nicolau, é o pleito de 1945 , em que o comparecimento eleitoral superou a marca de $10 \%$, e o número de eleitores cadastrados cresceu em 329\%, que representa um marco, colocando o país no rol das democracias de massas, in NICOLAU, 2004, p. 46 e NICOLAU, 2003, p. 273.

${ }^{122}$ Dados em NICOLAU, 2003, p. 276.

${ }^{123}$ Dado em NICOLAU, 2003, p. 262.

${ }^{124}$ Dado em CARVALHO, 2003, p. 104, tabela X, bem como em NICOLAU, 2003, p. 271, que alerta, contudo, para sua possível imprecisão, diante das constantes fraudes que ocorriam nas eleições durante a Primeira República. Segundo CARVALHO, 2003, p. 104, tabela X, 1.890 .000 eleitores tomam parte nas eleições de 1930 - também salientando para o fato de que as estatísticas não são totalmente confiáveis - e em KARAWEJCZYK, 2010, p. 206 consta informação publicada no jornal Correio do Povo, de 3 de maio de 1933, dando conta de que um total de 1.284.904 eleitores participaram do pleito de 1933, um decréscimo, portanto, do número anterior, a despeito da ampliação do eleitorado promovida pelo Código Eleitoral, e um total pouco significativo da população brasileira da época.
} 
Mas baixa participação eleitoral não significava uniformidade dos partidos políticos em disputa. Chamando atenção para o fato de que houve uma "explosão do número de partidos e de listas de candidatos", Jairo Nicolau aponta que a maior bancada, composta por 31 deputados do Partido Republicano Mineiro, representava apenas $15 \%$ do total ${ }^{125}$. Ângela Castro Gomes também destaca a multiplicidade de partidos e o fracasso quase que completo da tentativa de união em torno de programas mínimos, à exceção dos casos da União Cívica Nacional, no Norte e Nordeste, e da Liga Eleitoral Católica, importante formação extrapartidária ${ }^{126}$. As eleições de 3 de maio consagram a vitória dos novos partidos regionais, e a incapacidade de unificação nacional de programas.

Para um observador desatento, a variedade de partidos poderia indicar uma variedade de correntes sociais representadas na Assembleia Constituinte, tornando complexos os acordos políticos. Por certo, havia diversas correntes ideológicas, desde liberais convictos até autoritários de tendências fascistizantes, passando por socialistas e nacionalistas, o que reforçava a necessidade, já presente desde a Subcomissão Itamaraty, de que a Constituição fosse uma obra de compromisso, forçando transações e acordos entre diversas partes. A lei constitucional não seria produto de uma doutrina única, mas sim uma conciliação pragmática, e por vezes contraditória, entre correntes de pensamento distintas. Porém, a diversidade ideológica não significa que o Parlamento tinha se tornado o espelho da sociedade brasileira da época. A uma, porque são muito poucos os brasileiros que de fato exerceram o direito de voto, como visto nos números sobre comparecimento eleitoral. A duas, porque os perfis e trajetórias políticas e profissionais dos deputados não eram tão distintos assim. Um primeiro e mais importante dado, na medida em que buscamos analisar, especificamente, as ideias jurídicas da Constituinte, é que dentre os 214 deputados não classistas, 128 possuíam formação em Direito, ou seja, 59,8\% do corpo de representantes políticos da Assembleia era composto por juristas. Outros 45 deputados (21\%) tinham formação em medicina, 10 em engenharia e 5 em Farmácia ${ }^{127}$. Apenas no perfil de 7 deputados da representação política não consta indicação de formação superior ou vínculo às Forças Armadas ou a instituição religiosa. As idades próximas indicam que muitos dos deputados foram colegas nos bancos da faculdade, mesmo que eleitos por Estados distintos - entre os juristas, 34 passaram pela Faculdade de Direito de São Paulo,

\footnotetext{
${ }^{125}$ NICOLAU, 2004, p. 41.

${ }^{126}$ GOMES, 1986, pp. 20/21.

${ }^{127}$ Para a compreensão adequada dos dados mencionados, é importante destacar que alguns dos deputados tinham dupla formação, outros realizaram seus estudos em mais de uma faculdade. Todos os dados foram extraídos de GODINHO e ANDRADE, 1934, e estão detalhados no Anexo II dessa tese.
} 
30 pela do Rio de Janeiro, 28 pelo Recife, além de 12 pela de Belo Horizonte e 11 pela da Bahia. Entre os médicos, a maioria, 24, são formados pela Faculdade de Medicina do Rio de Janeiro, e outros 15 pela Bahia. De resto, mencione-se a presença de 3 padres católicos e de um pastor protestante entre os Constituintes, além de significativa bancada de militares (são ao menos 23$)^{128}$.

Não é uma Assembleia plural do ponto de vista do perfil dos deputados, portanto. Pelo contrário. É sobretudo um fórum de políticos-juristas, mais propenso a debates sobre a doutrina jurídica, com potencial reduzido de constituir-se, de fato, como uma caixa de ressonância da sociedade brasileira da época, como um todo. Não à toa as ideias e os autores franceses acabam sendo mencionados em diversos discursos, inclusive como signo de distinção e de preparo do deputado. Demandas populares externas são mencionadas, vez por outra, especialmente nos discursos dos deputados classistas, mas na prática a Assembleia refletia a tentativa de rearranjo das forças políticas das antigas oligarquias, complicado pelo aumento do espectro de ideias políticas à disposição.

De se ressalvar, contudo, que a Assembleia Nacional Constituinte contou com um outro polo de representação que alterava um pouco o perfil do conjunto de deputados: trata-se da bancada classista, inovação introduzida por Vargas nas eleições de 1933. De acordo com o Decreto $n^{\circ} 22.653$, de 20 de abril de 1933, a Assembleia contaria com uma quota de quarenta representantes classistas, oriundos das entidades profissionais reconhecidas pelo Ministério do Trabalho. A escolha dos representantes foi disciplinada pelos decretos 22.696, de 11/05/33, 22.745, de 24/05/33 e 22.940, de 14/07/33, e seria acompanhada de perto pelo Governo Provisório. Seriam vinte representantes dos empregadores (dentre os quais 3 profissionais liberais) e vinte dos empregados (dentre os quais 2 funcionários públicos), escolhidos por eleição a realizar-se no Distrito Federal, sob a presidência do Ministro do Trabalho, Indústria e Comércio. Tinham direito de voto os sindicatos reconhecidos pelo Ministério até 20 de maio de 1933. Organizar-se-iam votações separadas por setor, feitas a partir de delegados eleitores escolhidos entre os sindicatos reconhecidos ${ }^{129}$. Em 20 de julho daquele ano, dá-se a escolha dos representantes dos empregados, e cinco dias depois, a dos empregadores ${ }^{130}$.

\footnotetext{
${ }^{128}$ Para uma visão de conjunto da representação política na Assembleia Nacional Constituinte, ver Anexo 2. ${ }^{129}$ Cf. SILVA, 1991, pp. 70/72.

${ }^{130}$ A escolha dos representantes dos empregadores se deu em eleições indiretas, nas quais votaram os delegados-eleitores provenientes dos seguintes Estados: 27 do Distrito Federal, 20 de São Paulo, 11 de Minas Gerais, 9 do Rio Grande do Sul, 5 do Rio de Janeiro, 1 do Paraná e 1 de Sergipe. Dados em GOMES, 1986, p. 448 e em SILVA, 1991, p. 75. O destaque a ser dado, portanto, é para São Paulo e Distrito Federal, que
} 
Para o Governo Provisório e seu chefe, a representação profissional, além de atender aos anseios do tenentismo e das correntes críticas à democracia liberal clássica, de certa forma, poderia implicar no reequilíbrio de forças políticas ${ }^{131}$. Isso porque a Assembleia seria composta pelos representantes políticos, escolhidos nos Estados sob a influência das oligarquias tradicionais, mas também por deputados classistas, em tese afastados do jogo político da Primeira República, apresentando-se como "um meio eficaz de neutralizar a ação dos blocos políticos dos Estados hegemônicos" "132. Nesse mesmo sentido, Afonso Arinos de Melo Franco entendia que "estes representantes classistas formavam a bancada com que Vargas esperava anular o peso das representações dos grandes Estados. Aproveitara o modelo do fascismo italiano" $" 133$.

Nas bancadas classistas concentravam-se os deputados com perfil diferente dos demais. Do lado dos empregadores, a bancada foi escolhida a partir das já tradicionais associações de classe patronais - como FIESP (Federação das Indústrias do Estado de São Paulo), CIB (Confederação Industrial do Brasil) e FIRJ (Federação das Indústrias do Rio de Janeiro) $)^{134}$-, organizadas segundo os termos do novo decreto de sindicalização. Grande parte dos integrantes da bancada possuía formação técnica, como engenharia e medicina, diferenciando-se do perfil dos representantes políticos, em grande parte bacharéis em Direito. Assim é que Ângela de Castro Gomes chama atenção para o fato de que, em seus discursos, não raro desculpam-se pela falta de habilidade ao tratarem de "questões políticas" para as quais seria necessário conhecimento jurídico, mas falam com autoridade sobre assuntos econômicos e sociais, com os quais teriam mais familiaridade, assumindo, assim, "uma postura que buscava assimilar duas dimensões atribuídas a esse tipo de representação: seu caráter não partidário e seu caráter

\footnotetext{
dominam a escolha dos representantes, em função de sua proeminência econômica na indústria e no comércio.

${ }^{131}$ Vera Cepêda lembra com propriedade os dois loci de origem da proposta de representação classista, o Clube 3 de Outubro e o Governo Provisório, ressaltando a distinção de estratégias políticas nos dois casos. Para os tenentistas a ideia vinha concretizar a postura do movimento sobre Estado e sociedade, baseada na tradição de pensamento brasileira encabeçada por Alberto Torres e Oliveira Vianna: "a proposta tenentista apropriava-se de um longo debate dentro do pensamento social brasileiro, questionando a ausência de valores (e estruturas) individuais que garantissem o correto funcionamento de instituições liberais democráticas (que pressupõem auto-interesse bem compreendido, competição e norma cogente da maioria), e outro ângulo formulando uma via mais socialmente coesa para pensar o Estado a partir da nação e não do indivíduo". Por outro lado, para Vargas a proposta poderia ter uma utilidade mais estratégica e imediata, na medida em que "poderia funcionar como meio de diminuir a hegemonia política representativa do ancien régime que, com certeza, retornaria ao poder com as eleições estaduais - era instrumental, antes de qualquer coisa", in CEPÊDA, 2009, pp. 227/228.

${ }_{132}$ WOLKMER, 1989, p. 72.

${ }^{133}$ FRANCO, 1981, p. 125.

${ }^{134}$ Cf. GOMES, 1986, pp. 450/451.
} 
técnico" ${ }^{\text {"135 }}$. Vale destacar que 8 , dentre os 17 representantes dos empregadores, possuíam formação em engenharia, contra apenas 2 médicos e 2 bacharéis em direito. A representação dos empregadores contava com os mais significativos nomes da liderança empresarial da época ${ }^{136}$, sobressaindo-se como oradores frequentes, especialmente Roberto Simonsen e Horácio Lafer, que frequentemente compunham-se com a bancada paulista. Apesar de apegados aos valores liberais, entendiam de um lado a necessidade de apoio do Estado ao setor industrial nascente, inclusive com intervenção e protecionismo (e preocupavam-se em abrir canais de acesso à tomada de decisões, daí a defesa dos Conselhos Técnicos), e, de outro, a inevitabilidade das garantias sociais, adotando uma visão integradora, de concessão de direitos como pressuposto de harmonia entre as classes, como se verá.

Do lado dos empregados, o crescente enquadramento sindical desde o Decreto 19.770, de 1931, indicava uma penetração maior do sindicalismo governamental nos núcleos operários ${ }^{137}$. São 282 os sindicatos reconhecidos pelo Ministério, aptos a eleger seus delegados-eleitores. No resultado final, predominam os deputados oriundos dos setores de comércio e transportes, e não da indústria, fenômeno explicado pela concentração de sindicatos nesse último setor ${ }^{138}$. A bancada divide-se: de um lado, a autodenominada "minoria proletária", de oposição ao Governo Provisório, composta dos deputados João Vitáca, Vasco Toledo, Acir Medeiros e Valdemar Reikdal 139, "que afirmam o princípio irreconciliável da luta entre o capital e o trabalho. Para esse grupo, as leis sociais, embora beneficiem o trabalhador, não passam de tapeação, uma vez que a questão trabalhista continuava para o governo um caso de polícia"140; de outro lado, uma "maioria adesista" ao governo, tais como Edmar de Carvalho, Eugênio Monteiro de Barros e o líder Francisco Moura, que "entendem a legislação social como uma questão de justiça do trabalho" ${ }^{" 141}$. Alguns dos deputados se identificam com os tenentes, como no caso de Alberto Surek, Luís Martins e Silva e Ewald Possolo. De forma geral, concentram-se nos

\footnotetext{
${ }^{135}$ GOMES, 1986, p. 454.

${ }^{136}$ Como notam SILVA, 1990, p. 8 e GOMES, 1986, p. 454. Para um quadro detalhado sobre cada um dos representantes da bancada dos empregados, ver o Anexo II da tese, bem como SILVA, 1991, Anexo I, pp. 220/254, além dos dados constantes de GODINHO e ANDRADE, 1934.

${ }^{137}$ GOMES, 1986, pp. 469/471.

${ }^{138}$ GOMES, 1986, p 474.

${ }^{139}$ GOMES, 1986, p. 475.

${ }^{140}$ SILVA, 1991, p. 87.

${ }^{141}$ SILVA, 1991, p. 87.
} 
debates sobre os temas sociais, e na reivindicação de constitucionalização dos direitos já garantidos pelo Governo Provisório ${ }^{142}$.

A Assembleia Constituinte é marcada também pela Liga Eleitoral Católica, liderada pelo Cardeal do Rio de Janeiro, Dom Sebastião Leme, e secretariada por Alceu Amoroso Lima. Vamireh Chacon lembra que "o episcopado católico (...) pendia para o polo conservador" ${ }^{143}$, influenciado pela reação antiliberal contida na doutrina social da Igreja, e defensor de uma regulação menos laica das atividades estatais e da vida pública - assim a forte resistência ao divórcio e a proposta do ensino religioso facultativo, ambas questões nas quais sagraram-se vitoriosos na Constituinte. A influência da bancada católica nos assuntos da constituinte é ampla, e o maior símbolo de sua força é a inclusão, bastante polêmica, da referência a Deus no preâmbulo, incluída pela Emenda $n^{\circ} 10$, sob a justificativa de que "satisfará, naturalmente, à alma cristã brasileira, trabalhadora, bondosa e pacífica, que haja no preâmbulo da sua Constituição uma palavra de pensamento no Criador, embora se escreva da tábua da sua lei a independência dos dois poderes espiritual e temporal..."144.

De se mencionar, ainda, a pequena bancada de deputados vinculados às esquerdas - mas não ao Partido Comunista, que estava na ilegalidade -, pertencentes aos grupos que apostavam na relevância estratégica da disputa democrática, enquanto não estivessem dadas as condições para a transformação completa da ordem burguesa. Articulam-se em torno de uma frente de esquerdas, capitaneada pela Liga Comunista, que em 11 de julho de 1933 anuncia a fundação da Frente Única Antifascista (FUA) ${ }^{145}$. Alguns deputados que veiculam as ideias socialistas na Constituinte, eleitos pelo Partido Socialista, são Zoroastro Gouveia ${ }^{146}$, o pastor Guaracy Silveira ${ }^{147}$ e Lacerda Werneck, e são responsáveis por discursos frequentes e combativos nos debates constituintes, mas bastante minoritários e, por isso, em geral malsucedidos nas disputas. Deve ser dado destaque, por fim, à primeira participação eleitoral das mulheres na história brasileira.

\footnotetext{
${ }^{142}$ Para um quadro detalhado sobre cada um dos representantes da bancada dos empregados, ver Anexo II bem como SILVA, 1991, Anexo II, pp. 255/271, além dos dados constantes de GODINHO e ANDRADE, 1934.

${ }^{143}$ CHACON, 1987, p. 160.

${ }_{145}^{144}$ REIS, 1934, p. 81. Para a polêmica e críticas, ver nota 1 , pp. $81 / 82$ da mesma obra.

${ }^{145}$ Para mais detalhes sobre as forças políticas de esquerda e suas ideias, no período constituinte, vide CASTRO, 1995, que entende que a ação da Liga Comunista e do Partido Socialista, nos anos 1930, "lançaram algumas das bases de uma 'cultura política' de esquerda que a partir dos anos 1940 defenderá uma via revolucionária que privilegia a democracia como elemento estratégico e não meramente tático, como considerava o PCB" (p. 86).

${ }^{146}$ De acordo com Chacon, o deputado era "socialista, adepto do austromarxismo de Otto Bauer" (CHACON, 1987, p. 155).

147 "pretenso socialista moderado" (CHACON, 1987, p. 155).
} 
Tendo sido garantido o sufrágio feminino facultativo pelo Código Eleitoral de 1932, é eleita a deputada Carlota de Queiroz, pelo Estado de São Paulo. Não se pode dizer que teve participação central na Constituinte, no geral apoiando a bancada paulista em suas emendas, especialmente as que preveem assistência e garantia do direito à educação ${ }^{148}$.

São os deputados eleitos nos Estados, especialmente naqueles responsáveis pelas maiores bancadas, que dão o tom do compromisso que marcaria o resultado final da Constituição. Os trabalhos finais da Assembleia assistiram à recomposição entre as bancadas dos grandes Estados - Minas Gerais, Rio de Janeiro, Rio Grande do Sul e até mesmo São Paulo - que se uniram em torno de consensos mínimos, especialmente consolidados nas chamadas "emendas de coordenação". De outro lado, o bloco das pequenas bancadas, especialmente vinculadas às demandas tenentistas, isto é, mais centralizadoras, articulavam as minorias, que, contudo, obedeciam às mesmas regras do jogo e reforçavam o caráter situacionista da Assembleia, como ressalta Ângela de Castro Gomes. "Em suma, como lembrava Raul Fernandes em seu discurso de saudação ao chefe do governo provisório, no dia da instalação dos trabalhos constitucionais, a Assembleia fora formada por políticos que, em sua absoluta maioria, haviam apoiado a Revolução de 1930"149. Mas uma identificação apressada das grandes bancadas com conservadorismo e volta dos velhos arranjos oligárquicos não é totalmente adequada, já que estavam todos comprometidos com a formatação de um novo Estado, interventor e social, diferente do velho ideal liberal da Constituição de 1891. Tratava-se de constituir "pelo alto" um novo modelo para um velho compromisso, incluindo novos elementos, que dizem respeito, sobretudo, à nova abordagem da questão social que se impunha.

Em 15 de novembro de 1933, a Assembleia Nacional Constituinte tem sua sessão de instalação, com abertura solene feita pelo Chefe do Governo Provisório, Getúlio Vargas, e aceitação, em um primeiro momento, do Regimento que havia sido formulado (Decreto $\mathrm{n}^{\mathrm{o}} 22.261$, de 7 de abril de 1933). A Constituinte, e seu governismo generalizado, caracterizou-se pela influência do Governo Provisório e especialmente de Vargas, desde o início resistente em perder o controle do "processo revolucionário", em

\footnotetext{
${ }^{148}$ Cf. discursos em 13/03/1934 (vol. XI, pp. 268/281) e 14/04/1934 (vol. XIV, pp. 491/512). No primeiro deles, afirma a "tese que defende desde o início destas palavras, de que ambos os sexos se completam e precisam ser nivelados nas suas obrigações", quando então autoriza um jocoso e simbólico aparte de Agamenon Magalhães, que indica a posição inferiorizada com que as mulheres ainda eram aceitas na política: "Aliás, essa concorrência das mulheres aos homens atenua a concorrência entre as mulheres (Risos)" (in vol. XI, pp. 273/274). Para uma análise sobre a primeira participação eleitoral feminina, vide KARAWEJCZYK, 2010.

${ }^{149}$ GOMES, 1986, p. 43.
} 
relação que não deixou de ser pontuada, também, por tensões, a começar pela própria questão do regimento ${ }^{150}$.

O Regimento Interno autorizava a participação de Ministros de Estado em plenário, independente de convocação pela Assembleia (art. 53 e parágrafos), prerrogativa que permitiu que Oswaldo Aranha, então Ministro da Fazenda, fosse escolhido líder da maioria, cargo que ocuparia até o final de 1933, quando foi substituído por Medeiros Netto, também conduzido com o apoio de Vargas. Apesar de apressar-se em emitir nota oficial afirmando que o Governo não teria líder na Assembleia, e que "a Constituição será obra exclusiva da Assembleia, sem a sua intervenção, cingindo-se o Governo, no assunto, a defender os pontos de vista resguardados na Lei Orgânica e referentes aos fundamentos do regime" ${ }^{\prime 151}$, certo é que as atividades da Constituinte foram acompanhadas de perto por Vargas, não sem protestos entre os deputados.

O primeiro desses conflitos, justamente sobre a possibilidade de o Governo Provisório impor o regimento da Assembleia Constituinte coloca uma primeira grande questão ao direito público da época, que motivou uma consulta sobre o assunto a Hans Kelsen, que em 14 de outubro de 1933 envia seu parecer. O jurista austríaco entende que "admitindo que o Governo Provisório é a mais alta autoridade legislativa que saiu diretamente da revolução, sem dúvida daquele governo depende determinar a convocação e a competência da Assembleia Nacional Constituinte" "152. Por ter surgido como um "órgão criado por outro órgão", por ter se formado "pelo caminho legal”, e por não possuir, assim, características de um órgão originário e supremo, a Assembleia Constituinte, independente de seu nome, "não tem o caráter de criadora da Constituição, mas de executora da elaboração da Constituição"153. Com esse raciocínio, Kelsen legitima a possibilidade de o Governo Provisório impor um regimento à Assembleia, norma que, inclusive, estabeleça balizas para a atividade constituinte, determinando desde logo, por exemplo, a forma republicana e federativa que a carta política deverá confirmar. Independentemente das intenções que sustentaram o movimento revolucionário, do que constar de seu programa de reivindicações, o Governo Provisório "possui os poderes que quer possuir, sob a condição

\footnotetext{
${ }^{150}$ O livro de Hélio Silva 1934 - a Constituinte pode ser mencionado como relato dos trabalhos da Assembleia, cotejados com as questões que mobilizavam Vargas e a política brasileira da época, incluindo, além de discursos políticos, cartas, telegramas e outros documentos que dão conta da relação entre Constituinte e Governo Provisório. Vide SILVA, 1969.

${ }^{151}$ Nota de 13 de novembro de 1933, mencionada em SILVA, 1969, p. 70.

${ }^{152}$ KELSEN, (1933) 2000, p. 6.

${ }^{153}$ KELSEN, (1933) 2000, p. 6.
} 
de que possa obter geralmente a obediência às suas prescrições" ${ }^{154}$, e não pode ser obrigado a transmitir a totalidade dos seus poderes a uma Assembleia Nacional Constituinte por ele criada, conclui o jurista. Legitima-se, assim, a prevalência soberana do Governo Provisório sobre a Assembleia Constituinte.

As polêmicas e a relação confusa com o Governo Provisório se estendem. Logo no início dos trabalhos, em 16 de novembro de 1933, Medeiros Netto apresenta uma moção pela qual a Assembleia Constituinte convalidaria os poderes contidos no Decreto $\mathrm{n}^{\mathrm{o}}$ 19.398, que instituiu o Governo Provisório. Há protestos, especialmente dos que reivindicam seja conferida uma anistia ampla aos exilados, aos que tiveram direitos cassados, perderam seus cargos, e pede-se que a votação da moção implique em um ato de conciliação política e de pacificação. Mas a questão traz consigo novamente o debate jurídico mencionado no parágrafo anterior. O parecer de Kelsen sobre a soberania e a competência da Assembleia Nacional Constituinte é lembrado nos discursos como um impedimento à submissão da moção ao plenário: se a Assembleia possuía competência limitada apenas à elaboração da Constituição, e se portanto não era soberana, não poderia, logicamente, convalidar atos do governo de fato, esse sim soberano, já que não estava em posição superior a ele. Seguem-se discursos tratando da noção teórica da soberania, ou de sua crise, com farta referência aos franceses, as quais retomaremos adiante, no capítulo 6 (item 6.1.1). Ao final, a polêmica é superada - menos teoricamente do que pragmaticamente, ou "por solidariedade política", como coloca Odilon Braga ${ }^{155}-\mathrm{e}$ a moção é aprovada, compondo-se Assembleia e Governo Provisório e anunciando como seriam solucionadas questões semelhantes na futura carta política. O mesmo Medeiros Netto, em 21 de fevereiro, apresentaria nova indicação polêmica de inversão da ordem dos trabalhos, requerendo que a Assembleia elegesse desde logo o Presidente da República, antes de promulgada a Constituição. A manobra, muito criticada nos discursos em

\footnotetext{
${ }^{154}$ KELSEN, (1933) 2000, p. 7.

${ }^{155}$ Odilon Braga, 16/11/1933, vol. I, p. 185. A referência à aprovação da moção por "solidariedade política", mais do que por consistência teórica, deve ser destacada como mais um sinal da distinção entre a esfera do discurso jurídico teórico e aquela do discurso jurídico político, que por vezes pode ficar obscurecida pelas abundantes remissões doutrinárias que os deputados constituintes fazem questão de fazer constar em seus discursos. Contudo, a preocupação central na esfera da Assembleia Nacional Constituinte é antes de tudo com a acomodação política, e não com a consistência teórica. Nota geral sobre as citações das atas da Assembleia Nacional Constituinte: ao longo do trabalho, serão feitas referências a discursos compilados nas atas da Assembleia Nacional Constituinte, ficando desde logo indicada a fonte bibliográfica, qual seja, (1936), Annaes da Assembleia Nacional Constituinte - organizados pela Redação dos Annaes e Documentos Parlamentares. Rio de Janeiro: Imprensa Nacional, vol. I a XXII. A partir daqui, por economia, quando estivermos citando as atas, mencionaremos apenas o nome do constituinte responsável pela manifestação, a data em que foi feita, o volume dos anais onde foi registrada e a página, reportando-nos à bibliografia final para a referência completa.
} 
plenário, acaba por malograr, mas tem como efeito aumentar a pressão pela conclusão apressada dos trabalhos da Constituinte. Portanto, se por um lado a Assembleia reunia-se com o objetivo de promover um compromisso, sobretudo entre as velhas oligarquias destronadas pela Revolução, mas também entre os novos elementos classistas, por outro lado o Governo Provisório mostrava desde logo sinais de receio em relação ao resultado, preocupando-se não apenas em fiscalizar os trabalhos, mas também em ordená-los na medida do possível.

É com esse formato peculiar, uma Constituinte julgada não propriamente soberana, em termos absolutos, mas executora de tarefa soberanamente imposta pelo governo de fato, que os trabalhos se desenvolvem. Assim, conforme previsto no art. 19 do Regimento Interno, em 27 de novembro, forma-se um novo coletivo, uma comissão constitucional conhecida como Comissão dos 26 , em razão do número de membros que a compõem (um representante por Estado, mais um proveniente de cada categoria profissional ${ }^{156}$ ). É presidida por Carlos Maximiliano, sendo Levi Carneiro o vice presidente e Raul Fernandes o relator geral. A Comissão dos 26 tinha como atribuição dar parecer sobre o anteprojeto constitucional, formulando substitutivo a ser apresentado ao plenário da Constituinte. Apesar dos protestos de Nogueira Penido ${ }^{157}$, representante dos funcionários públicos, manteve-se a regra contida no Regimento de que nenhum deputado alheio à Comissão poderia tomar parte em seus debates (art. 20). Dividem-se as matérias entre os membros, para parecer e apreciação das emendas - são 1.244 no total, recebidas até 21 de dezembro.

A Comissão elabora um primeiro substitutivo, apresentado ao Plenário a partir de 22 de janeiro de 1934, e, após desistirem de votação artigo por artigo, a partir da emenda de Marques dos Reis, instituem-se comissões revisoras ${ }^{158}$, compostas pelo(s)

\footnotetext{
${ }^{156}$ Leopoldo da Cunha Mello (AM), Abel Chermont (PA), Adolfo Soares (MA), Pires Gaioso (PI), Waldemar Falcão (CE), Alberto Roselli (RN), Pereira Lira (PB), Solano da Cunha (PE), Manoel de Góis Monteiro (AL), Deodato Maia (SE), Marques dos Reis (BA), Fernando de Abreu (ES), Raul Fernandes (RJ), Sampaio Corrêa (DF), Odilon Braga (MG), Cincinato Braga (SP), Domingos Velasco (GO), Generoso Ponce (MT), Antônio Jorge (PR), Nereu Ramos (SC), Carlos Maximiliano (RS), Cunha Vasconcelos (AC), Vasco Toledo (rep. prof. - empregados), Euvaldo Lodi (rep. prof. - empregadores), Levi Carneiro (rep. prof. profissionais liberais), Nogueira Penido (rep. prof. - funcionários públicos). O volume XI dos anais da Constituinte é dedicado aos trabalhos da Comissão.

${ }^{157}$ Cf. Anais da Constituinte, vol. XI, pp. 8/9.

158 "Para melhor metodização e maior rapidez dos trabalhos de elaboração do projeto constitucional, propomos: 1) Ficam aceitos, em princípio, os substitutivos apresentados pelos relatores parciais e organizados à vista do anteprojeto e das emendas; 2) Fica instituída a Comissão Revisora desses substitutivos parciais, a qual se comporá do presidente da Comissão dos 26, do vice-presidente, do relatorgeral e, em cada substitutivo, do relator ou dos relatores parciais; 3) Essa comissáno fará reunião de cada substitutivo parcial e organizará o projeto geral, modificando-o em cada case e a seu juízo; 4) Organizado
} 
relator(es) respectivo(s) e por Carlos Maximiliano, Levi Carneiro e Raul Fernandes, que devem reapreciar o substitutivo em 20 sessões. Era mais uma das "transgressões" ao Regimento Interno, como coloca Levi Carneiro ${ }^{159}$, feita em nome da agilidade dos trabalhos. Em 25 de fevereiro, começa a revisão do projeto resultante e finalização do substitutivo. Depois dos debates finais, o substitutivo é publicado em 7 de março, seguindo proposta da Comissão de Polícia que visava apressar os trabalhos, com a sugestão de que sua aprovação pela Assembleia, para o que se estabeleceria prazo de 48 horas, implicaria em tornar prejudicado tanto o anteprojeto quanto emendas apresentadas. $\mathrm{O}$ substitutivo $\mathrm{n}^{\mathrm{o}}$ 1-A/34 é aprovado em bloco em primeira discussão, em 13 de março, e inicia-se o segundo turno de 30 dias de debates. Nesse momento, as grandes bancadas compõem-se em uma comissão que reaprecia o substitutivo e apresenta as "emendas de coordenação", cujo objetivo era veicular os consensos possíveis no bloco majoritário e garantir a aprovação da maioria dos seus interesses ${ }^{160}$. Em 5 de abril, são computadas outras 1.962 emendas e reúne-se novamente a Comissão dos 26, dividida em oito subcomissões, para sua apreciação. O Governo Provisório pede urgência na conclusão dos trabalhos, bem como a elaboração de "leis fundamentais, orgânicas e adicionais" à Constituição, em mensagem de 10 de abril ${ }^{161}$, e o novo substitutivo chega para votações por capítulos, no plenário, em 7 de maio. Em 8 de junho, concluem-se as deliberações, inclusive as polêmicas em torno das Disposições Transitórias, e nomeia-se uma Comissão de Redação, composta por Raul Fernandes, Godofredo Vianna e Homero Pires, encarregada de apreciar as novas 714 emendas.

Finalmente, em 14 de julho chega-se a uma redação definitiva, e a Constituição Federal pode ser promulgada em 16 de julho de 1934. Getúlio Vargas é eleito Presidente da República pela Assembleia no dia seguinte ${ }^{162}$. Encerra-se, assim, o processo político com a confirmação "democrática” da liderança política, eleita para mandato com duração até 3 de maio de 1938, e com uma Constituição que vinha sendo gestada desde maio de 1932, por mais de 2 anos, e que é promulgada e vem a durar, formalmente, apenas

este projeto, será ele submetido à aprovação da Comissão em conjunto", in CARNEIRO, 1936, p. XXVI, também mencionado em GOMES, 1986, p. 40, nota 42.

${ }^{159}$ CARNEIRO, 1936, p. XXVII.

${ }^{160}$ Cf. GOMES, 1986, pp. 45/46, CARNEIRO, 1936, pp. 33 e ss. Entre os membros da comissão, figuram Alcântara Machado, João Guimarães, Odilon Braga, Raul Fernandes, Clemente Mariani e Agamenon Magalhães.

${ }^{161}$ Para o documento integral, ver BONAVIDES e ANDRADE, 2006, Anexo, "Textos relacionados com a Constituinte de 1933-1934", item 11, pp. 721/722.

${ }^{162}$ Getúlio Vargas recebe 175 votos, Borges de Medeiros, 59, Góis Monteiro, apontado como principal concorrente, apenas 4, Protógenes Guimarães, 2. Raul Fernandes, Artur Bernardes, Afrânio de Mello Franco, Oscar Weinschenk, Paim Filho e Levi Carneiro recebem, todos, um voto. Cf. GOMES, 1986, p. 55. 
cerca de 3 anos e 4 meses. Aliás, em novembro de 1935 já havia sido decretado estado de emergência (motivado pela Intentona Comunista), suspendendo, na prática, a ordem constitucional.

A análise do complexo processo de formulação da carta constitucional, pode indicar, desde logo, algumas de suas determinações de conteúdo. Em primeiro lugar, vemos a criação de fóruns restritos de debates, fechados e isolados, compostos quase que integralmente por juristas de formação - as únicas exceções são Euvaldo Lodi (representante dos empregadores, engenheiro) e Vasco de Toledo (representante dos empregados, comerciário). É quase um conselho de notáveis, como fora a Subcomissão Itamaraty, especialmente familiarizados com o universo das doutrinas jurídicas contemporâneas. Em segundo lugar, a tentativa de formulação de uma Constituição mais extensa, em uma época de profundas divergências políticas, determina que sejam apresentadas centenas de emendas, o que indica a complexidade da tarefa conciliatória. Em paralelo às divergências, o processo de deliberação é acelerado, inclusive por pressão do Governo Provisório, evitando-se a deliberação artigo por artigo e dando-se preferência para votações em bloco. As tarefas de revisão são transferidas para comitês cada vez menores de deputados, em prejuízo de um debate mais ampliado, detalhado e cauteloso.

Ângela de Castro Gomes chama atenção para o fato de que no processo pode-se enxergar uma tentativa de compromisso, principalmente entre as grandes bancadas, que compunham-se por meio de concessões mútuas e adesão ao governo - as emendas de coordenação são o símbolo desse esforço. "Desde o período dos trabalhos da 'Comissão dos 26' as lideranças mais expressivas da Assembleia - seu presidente, o presidente da comissão e o líder da maioria - promovem a aproximação e acomodação dos pontos de vista das mais importantes e numerosas bancadas, tendo em vista uma solução conciliatória capaz de assegurar o continuismo de Vargas (...). A conciliação é construida à base de concessões mútuas, isto é, de ganhos parciais para ambas as partes, mas inegavelmente significa uma aliança tática entre Vargas e as forças políticas que lideram as grandes bancadas estaduais"163. Não à toa, as bancadas e correntes minoritárias e os tenentes sentem-se progressivamente descontentes com o resultado, e Levi Carneiro nota isso em um comentário sintomático: "as modificações introduzidas no anteprojeto [pelo substitutivo] - com o abandono dos dispositivos extremados deste - provocaram a crítica veemente do Sr. João Mangabeira e o manifesto do Club 3 de outubro. O projeto

${ }^{163}$ GOMES, 1986, p. 44. 
não era, no entanto, obra exclusiva dos próprios membros permanentes da subcomissão. Eles tiveram a preocupação de acolher a média das opiniões em conflito" ${ }^{164}$.

Enquanto comitês mais seletos analisam o texto da Constituição propriamente dito, os debates em plenário concentram-se sobre temais mais gerais sobre o que deveria ser a lei constitucional e sobre as questões da atualidade política. As minúcias são novamente conferidas a coletivos menores, o que indica, também, as diferentes camadas das temáticas dos discursos - enquanto na Subcomissão Itamaraty os temas relacionavam-se com as disposições mais concretas da lei constitucional, no plenário da Assembleia discutia-se em um plano mais geral, o sentido mais amplo da futura carta política.

No campo das ideias, o momento é, como visto, de crise e de inquietude, em que se confrontavam, em diversas nações, um liberalismo em crise e um social emergente, implicando, mesmo para manutenção da ordem, a necessidade de mudanças, de um novo arranjo. Quais os pontos sensíveis nos debates do anteprojeto ao texto final da Constituição, que digam respeito especialmente ao modelo de democracia e de regulação social a ser implementado? A partir das questões e polêmicas, seria possível identificar as determinações para as normas constitucionais, dentro de um diagnóstico de busca por um compromisso estável? Sendo assim, de que modo o direito absorveu, na norma constitucional, as novas preocupações sociais do Estado, na tensão entre direitos políticos e direitos sociais? Tendo a história aqui apresentada, e os problemas e desafios da realidade concreta dela decorrentes, como pano de fundo, os próximos capítulos, dedicados propriamente à análise dos debates constituintes, procurarão responder a essas indagações.

${ }^{164}$ CARNEIRO, 1936, p. XXVII. 


\section{Capítulo 5}

\section{A CONSTITUINTE E SUA ÉPOCA: REFLEXÕES GERAIS SOBRE O MODELO DE CONSTITUIÇÃO SOCIAL}

5.1 Uma "Constituição de imaginação"? Tensão entre influência estrangeira e realidade nacional; 5.1.1 O imperativo da realidade nacional; 5.1.2 Os três planos da influência estrangeira; 5.2 Uma Constituição social: a crítica ao liberalismo e o papel do Estado; 5.3 Técnica jurídica e ideia de Constituição

No capítulo anterior, apresentou-se, em linhas gerais, o contexto histórico que precedeu o início do processo constituinte no Brasil dos anos 1930, destacando-se a dificuldade originada pela Revolução de 1930, qual seja, a consolidação de uma nova ordem ausente um grupo social e um projeto capaz de impor-se hegemonicamente. A heterogeneidade social, inclusive e principalmente entre as elites oligárquicas e mesmo industriais, demandava uma solução de compromisso, que passava também pela reorientação da abordagem da questão social. De 1930 a 1934, o que vemos é a tentativa do Governo Provisório de implementar uma extensa agenda de mudanças, particularmente relacionadas com a elaboração de normas que dissessem respeito à regulação do social, notadamente do trabalho, bem como à imposição de novas práticas político-eleitorais, respondendo, nesse caso, às reivindicações que compunham a base da Aliança Liberal. Contudo, o governo de fato já não mais tinha condições de sustentar-se sem o amparo de uma ordem constitucional, e vê-se instado a iniciar o processo de reconstitucionalização, ainda que a decisão, considerada por alguns prematura, estivesse longe de ser consensual. Assim, aponta uma comissão encarregada de formular um projeto de Constituição, e realiza eleições para a Assembleia Nacional Constituinte, que é responsável pela promulgação da nova Carta política em 16 de julho de 1934.

Traça-se, assim, o pano de fundo dos debates constitucionais, à cuja análise, que é o centro desse estudo, podemos passar sem mais demora. "A Assembleia Constituinte reunida em 1933 contrastava com a de 1891, inicialmente pelo entusiasmo com que a população a acolheu, ao contrário da indiferença que envolveu a primeira Constituinte republicana. Os constituintes eram em número de 214 [referência ao número apenas dos representantes políticos, não computados os classistas], entre os quais uma 
inovação e peculiaridade: 40 deputados 'classistas' (...). As correntes de pensamento mais diversas estavam ai representadas, pois além dos 'classistas', viam-se, ainda, deputados como Zoroastro Gouveia e Lacerda Werneck, eleitos pelo Partido Socialista. As preocupações parecem adquirir âmbito nacional (...). As mulheres votaram pela primeira $v e z "$. Assim, Bonavides e Andrade situam a origem da vocação social da Constituição de 1934. Talvez haja aí um exagero na consideração da amplitude da representação popular presente na Assembleia Nacional Constituinte, mas não há exagero ao avaliar que seria uma carta política permeada pela preocupação social e econômica de âmbito nacional. A questão social deixa, em definitivo, de ser caso de polícia e torna-se assunto para as Constituições, no Brasil.

Se movimento em direção à socialização é claro, por um lado, por outro são suas origens diversas. Apesar de significativamente mais uniforme do que a sociedade brasileira do período, como visto, é certo que na Constituinte se fizeram representar distintas linhas de pensamento, que reivindicariam distintos sentidos para a lei fundamental. Parcela significativa dos constituintes, influenciados pelas doutrinas democráticas francesas da época, e ciosos das premissas básicas da Carta de 1891, vinha defender os valores liberais, defesa que ganha em importância diante das crescentes ameaças autoritárias, no Brasil e no mundo. Um segundo grupo estava imbuído do diagnóstico, também presente na doutrina francesa, de falência do constitucionalismo liberal, e buscava alternativas dentro do amplo espectro de possibilidades em circulação no debate de ideias do período, desde o fascismo ao socialismo. A Constituição deveria significar uma conciliação, uma transação entre não apenas entre as facções sociais (oligarquias regionais, burguesia industrial, tenentes etc.), mas também entre as diversas correntes de pensamento, na esperança de, pragmaticamente, promover-se um equilíbrio, ainda que provisório.

Começaremos abordando a nova Constituição de um ponto de vista mais geral, discutindo de que forma ela foi gestada e idealizada, em seu conjunto. Para isso, trataremos da relação conflituosa dos juristas e políticos com as influências estrangeiras, confrontados com a premência de apresentar uma solução eminentemente nacional. Em seguida, veremos de que forma estava presente a crítica ao individualismo, de um ponto de vista geral, na retórica dos constituintes, e de que modo isso se liga a um movimento mais geral na história das ideias constitucionais. Por fim, é importante mencionar o papel do

\footnotetext{
${ }^{1}$ BONAVIDES e ANDRADE, 2006, p. 325.
} 
Direito e da técnica, singularmente valorizados no momento constituinte, e quais as implicações que deles decorrem. Tudo isso para traçar um panorama geral, permitindo compreender o caminho pelo qual se pensou a introdução do social nas Constituições brasileiras, especialmente confrontado com a democracia, a partir do caso paradigmático e pioneiro que foi a Constituição de 1934.

\subsection{UMA "CONSTITUIÇÃO DE IMAGINAÇÃO"? TENSÃO ENTRE INFLUÊNCIA ESTRANGEIRA E REALIDADE NACIONAL}

Como ressaltado no capítulo anterior, o movimento surgido da Revolução de 1930 partia também de um diagnóstico de inadequação da Constituição de 1891 à realidade brasileira. Conforme diagnosticou Oliveira Vianna, em seu artigo de $1924^{2}$, a carta política anterior estava irremediavelmente marcada por um "desacordo entre seus princípios e as condições mentais e estruturais do povo", texto e a realidade nacional ${ }^{4}$. A observação de Vianna é relevante, uma vez que uma Constituinte formada notadamente por intelectuais e juristas, eleitos por uma quase insignificante minoria, e proveniente das elite de melhor formação do país, inevitavelmente seria inspirada pelas doutrinas estrangeiras, e corria o risco de seguir pelo mesmo caminho idealista, se não tivesse em conta a premissa de observar a realidade nacional.

O grande desafio colocado à empreitada constituinte era, portanto, equacionar a relação entre o trabalho intelectual e teórico envolvido em buscar não apenas legislações, mas também doutrinas contemporâneas que servissem de apoio à tarefa de elaborar uma Constituição moderna, fruto de seu tempo, e a necessidade de que ela fosse um produto da realidade brasileira, em harmonia com as particularidades nacionais. Uma Constituição ao mesmo tempo moderna em suas bases teóricas, e aplicável à realidade, consciente do passado mas voltada para o futuro, capaz de representar e moldar a nação e a nova República, em conformidade com as tradições nacionais e prevenindo problemas que poderiam "contagiar" o país. Não seria tarefa simples.

\footnotetext{
${ }^{2}$ Cf. CARDOSO, 1981 (1924). O argumento de Oliveira Vianna foi ampliado no livro de mesmo título, $O$ idealismo da Constituição, de 1927, e reeditado em 1939, dessa vez para criticar também a Constituição de 1934.

${ }^{3}$ VIANNA, 1981 (1924), p. 108.

${ }^{4}$ VIANNA, 1981 (1924), p. 109. O diagnóstico é repetido no Programa do Clube 3 de Outubro, que fala em uma "disparidade entre a teoria [por trás do texto constitucional de 1891] e a prática", resultando no que classifica como garantias que na verdade seriam mentiras, tais como a liberdade de opinião, o direito de voto, o sistema representativo, a independência entre os três poderes e a inexistência de privilégios, entre outros, in Programa do Clube 3 de Outubro, vol. III, p. 189.
} 


\subsubsection{O imperativo da realidade nacional}

Era preciso, assim, em primeiro lugar criar uma lei constitucional coerente e integrada à realidade brasileira, diferente do que simbolizava para muitos a carta anterior, que seria extremamente teórica e pouco aderente à vida política e social nacional. Teria a simples previsão no papel de institutos e instituições, inspirados em modelos de outros países, sido suficiente para formatar, simbolicamente, a recém-instituída República democrática brasileira, dispensando o trabalho de colocá-los em prática? Oliveira Vianna é incisivo ao criticar os republicanos de 1891, aqueles que o Programa do Clube 3 de Outubro vai chamar de "idealistas de 89 ", , por sua "crença no poder transfigurador das formas escritas", la para logo coisa viva e atuante: as palavras tinham o poder mágico de dar realidade $e$ corpo às ideias por elas representadas"7.

Essa mesma crítica é recorrente nos discursos da Assembleia Constituinte, que alertam com frequência para os riscos de se elaborar uma "Constituição de imaginação", nas palavras de Arruda Falcão: "Pergunto à Assembleia, indago de todos os Srs. Constituintes: a que sistema, a que método obedeceu o trabalho da Comissão anteparlamentar $^{8}$, e a que normas, a que diretrizes, a que bases vão ser subordinadas a confecção do parecer e a aprovação do projeto constitucional? Iremos ter uma constituição de imaginação, iremos aprovar, aqui, como se aprovou em 1891, um trabalho de bacharéis, aquilo que Wilson chamou um documento de doutores de gabinete" "․ No mesmo sentido, Augusto de Lima expressa não apenas a necessidade de uma Constituição que seja o espelho do "corpo vivo da Nação", mas também que seja um produto mais da observação positivista do sociólogo do que da erudição dos publicistas europeus: "há uma Constituição, Senhores, que é superior, que é proeminente a todas as constituições escritas: é a constituição que faz parte do próprio corpo vivo da Nação, é a constituição que se forma na lentidão da evolução de uma raça, é a constituição que se organiza nas tradições, na engrenagem da estrutura das famílias, unidades sociais, é a constituição que evolui enfim, sob o panorama vivo de um país, que não se contenta com a indumentária e vestimentas externas, exóticas, por mais risonhas, por mais liberais, por mais promissoras

\footnotetext{
${ }^{5}$ Programa do Clube 3 de Outubro, vol. III, p. 190.

${ }^{6}$ VIANNA, 1981 (1924), p. 108.

${ }^{7}$ VIANNA, 1981 (1924), p. 108.

${ }^{8}$ Referência à Subcomissão Itamaraty.

${ }^{9}$ Arruda Falcão, 20/11/1933, vol. I, p. 280.
} 
que sejam. Senhores, o Brasil deve ser visto, não através das lentes eruditas dos publicistas europeus. O Brasil deve ser visto pelo sociólogo, observador e experiente das coisas" $" 10$.

De acordo com a observação de Oliveira Vianna, o fracasso do regime de 1891 deveria ser atribuído à ausência de aderência à realidade nacional das instituições formuladas e previstas na Constituição, invertendo a convicção propalada pelos próprios republicanos. "Para eles [os primeiros republicanos], a causa do fracasso não estava no regime, tal como foi ideado na Constituição; mas apenas nos homens - ou porque 'inexperientes', ou porque 'corruptos' (...) os republicanos da Constituinte constituíram um regime político baseado no pressuposto da opinião pública organizada, arregimentada e militante. Ora, esta opinião não existia entre nós: logo, ao mecanismo idealizado pelos legisladores de 91 faltava o sopro inspirador do seu dinamismo. Daí a sua falência" ". Em lugar de atribuir o fracasso ao despreparo do povo ou das elites governantes, Oliveira Vianna chama atenção para o inverso. A Constituição é que teria sido formulada em desacordo com a realidade do país, em que não havia povo suficientemente organizado de modo a constituir um substrato ativo não apenas para garantir um processo eleitoral fundado na disputa de ideias e de programas, mas também para seguir mantendo-se como uma "pressão política de fora" (pressure from without, citado em inglês pelo autor). Diante dessa realidade, como esperar que funcionasse uma democracia de tipo liberal, nos moldes ingleses ou americanos? Do diagnóstico derivaria, como se verá mais a seguir, a defesa da urgência em se formar o povo brasileiro, educar a população para que se constituísse em uma classe de eleitores e uma opinião pública mais consistente, de modo a permitir a “adequada" realização da democracia.

Por ora, é importante reter um primeiro alicerce que estava por trás das análises que eram voz corrente quando da elaboração da Constituição de 1934: a convicção de que se deveria buscar uma solução eminentemente nacional, guardando um descrença em relação às doutrinas estrangeiras e ao excesso de abstração e intelectualismo na atividade constituinte. "Ora, nós não podemos continuar a cultivar esse ingênuo estado d'alma de estetas de Constituições. O nosso objetivo não será a 'harmonia', nem a 'beleza', mas, sim a 'conveniencia' e a 'adaptação'. O que devemos querer não são regimes belos ou harmônicos, mas sim regimes convenientes e adaptados ao nosso

\footnotetext{
${ }^{10}$ Augusto de Lima, 23/01/1934, vol. VI, p. 364.

${ }^{11}$ VIANNA, 1981 (1924), p. 109.
} 
povo" ${ }^{\prime 2}$, conclui Oliveira Vianna em seu texto de 1924. No mesmo sentido, enfatiza o constituinte Arruda Falcão, ressaltando ainda a importância do positivismo sociológico, das ciências de observação, em detrimento de abstrações teóricas: "o trabalho de uma Constituição há de ser como todo trabalho científico, não o fruto da imaginação ou da ciência de inspiração, mas, realmente, dos métodos positivos e de observação, que examinam os fenômenos sociais, coordenando os fatos gerais, destacando os erros a corrigir" ${ }^{\prime 13}$. Ou ainda, Odilon Braga, reportando-se aos anseios a ele transferidos durante os debates de que tomou parte sobre a nova Constituição: "Com efeito, o espirito dominante nas reuniões, nas conferências, nas palestras de que tive a honra e o encanto de participar, foi sempre o da mais comovedora brasilidade, empenhando-se todos na descoberta das fórmulas que fizessem a economia das divergências irredutiveis e dentro das quais coubessem todos os interesses e aspirações respeitáveis, quer do Norte, do Centro ou do Sul ${ }^{14}$.

\subsubsection{Os três planos da influência estrangeira}

Apesar da recorrência do diagnóstico de que era necessário criar uma Constituição adaptada à realidade nacional, tanto a Subcomissão Itamaraty quanto a Assembleia Nacional Constituinte eram compostas predominantemente por intelectuais, na maioria juristas, deixando, como visto, de ser um retrato da diversidade de formações e níveis culturais que compunha a sociedade brasileira da época. Disso resulta, em boa medida, o oposto do que se vinha tratando, um segundo vetor forte que pontua os debates constitucionais, qual seja, o destacado refinamento teórico das polêmicas, inspiradas não apenas pela legislação e pela doutrina estrangeiras, mas também pela realidade de outros países. Assim, Afonso Arinos, destaca a notável qualificação de seu pai, Afrânio de Mello Franco, para presidir a Subcomissão, informando da sua "profícua ação" ao desempenhar o difícil trabalho ali envolvido, especialmente diante de sua formação intelectual, que o tornava versado nas teorias jurídicas contemporâneas, inclusive e principalmente estrangeiras: "Afora o exame e encaminhamento das teses jurídicas, nas quais intervinha referindo precedentes do nosso direito e da doutrina internacional, inclusive da mais moderna que, apesar de todos os encargos da pasta, se esforçava por investigar e

\footnotetext{
${ }^{12}$ VIANNA, 1981 (1924), p. 118.

${ }^{13}$ Arruda Falcão, 20/11/1933, vol. I, p. 282.

${ }^{14}$ Odilon Braga, 03/05/1934, vol. XVI, pp. 252/253.
} 
absorver, havia, ainda, o problema de fundir em orientação homogênea e construtiva das tendências e aspirações representadas por homens de formação tão vária como aqueles que integravam o grupo" 15 . A descrição é muito mais a de um trabalho intelectual e acadêmico, que envolvia amplo conhecimento das doutrinas estrangeiras, do que de um esforço de observação da realidade nacional, induzindo a partir dela as soluções pertinentes.

É indiscutível, portanto, que os trabalhos orientaram-se também pela influência estrangeira, que aparece em incontáveis menções explícitas e implícitas ao longo dos debates, lado a lado com a preocupação em adaptá-las à realidade brasileira. $\mathrm{O}$ próprio Programa do Clube 3 de Outubro aponta nesse sentido, ao destacar a importância de olhar para outros povos: “É preciso não repetir o erro dos idealistas de 89. Aproveitamos as conquistas de outros povos, as lições da política mundial, o adiantamento [sic] da sociologia, mas sem perdermos a noção da realidade brasileira e sem abjurarmos as tradições nacionais" $"$.

A referência a outros países se dá em três planos, mencionando-se em primeiro lugar, as realidades estrangeiras, especialmente europeias, propriamente ditas, em seguida, as novas legislações, notadamente as novas Constituições do entre-guerras e, por fim, a doutrina publicista e constitucional que vinha sendo produzida fora do Brasil.

É lugar comum repetir a frase retirada de um discurso de Antônio Carlos de 1929: "Façamos a revolução antes que o povo a faça"17. Muito mais do que referir-se a um contexto histórico brasileiro de revolução popular iminente - descontada a Revolução de 1930 que, como visto, não representou de fato ameaça às elites nacionais ou subversão da ordem pelas camadas populares - a frase tem em si implícita também a referência ao contexto internacional, marcado pela ascensão das camadas populares organizadas ao poder. Não apenas na Rússia de 1917, mas em diversos outros países, como na França, a incorporação do povo ao jogo político institucional vinha sendo vista como ameaça à manutenção da democracia liberal e da ordem burguesa.

No Brasil, por um lado, havia uma recusa em enxergar qualquer semelhança com outros contextos. Como visto, o momento era de combater o que se via como um impulso tradicional de raciocinar a partir do exemplo de outros países, buscando “traduzir males estranhos", conforme aponta Oliveira Vianna: "Disse Eça de Queiroz que,

\footnotetext{
${ }^{15}$ FRANCO, 1955, p. 1409.

${ }^{16}$ Programa do Clube 3 de Outubro, vol. III, p. 190.

${ }^{17}$ Há referência à frase inclusive na curta biografia do deputado em GODINHO e ANDRADE, 1934, p. 150.
} 
dos males que afligiam Portugal, uns eram devidos ao próprio temperamento do povo, mas que outros eram 'traduzidos do francês'. Com os nosso podemos dizer a mesma coisa. Dos males que nos têm afligido desde a nossa emancipação em 22, uns resultam das condições mesmas da nossa formação social, mas outros são simples translações dos males alheios em vernáculo: e os idealistas republicanos, os construtores da Constituição de 24, infelizmente parece terem-se devotado mais aos males dessa última espécie do que aos males da primeira categoria. Excelentes tradutores de males estranhos, péssimos intérpretes dos nossos próprios males. É natural, pois, que a sua obra máxima - a Constituição Federativa - não tenha sido outra coisa senão uma obra doutrinariamente bela, mas fatalmente voltada ao fracasso imediato" ${ }^{21}$.

Por outro lado, a observação do estrangeiro e a presença constante de outras realidades na retórica dos debates era inevitável, já que o cenário internacional era premente: a democracia em crise, governos instáveis e efêmeros, regimes fascistas e socialistas em ascensão, incerteza quanto ao futuro.

Na Constituinte de 1933/34, os discursos que se referem à comparação entre a realidade brasileira e a internacional apontam para dois caminhos. O primeiro deles é reforçar a ideia de uma integração harmônica de classes inerente à peculiar trajetória brasileira, e às suas tradições, rechaçando o potencial no Brasil de uma trajetória de conflito à exemplo do que se observa em outros países. O segundo caminho é alertar para o risco de problemas sociais futuros, seja em virtude de "contágio externo", seja porque tais problemas fariam parte do processo evolutivo por que passam todas as sociedades civilizadas (e nesse sentido seriam "inevitáveis"), recomendando que se aprenda com a experiência estrangeira, de modo a prevenir ou amortecer tais conflitos - repetindo o lema de Comte, "prever para prover". A realidade de outros países funciona portanto, em primeiro lugar, como baliza comparativa, permitindo avaliações recorrentes de que no Brasil não há conflitos de classe acirrados, e em segundo lugar, como alerta em relação ao futuro, ora indicando o risco de contágio, ora a inevitabilidade de se lidar com os "problemas sociais" antes que apareçam na prática.

\footnotetext{
${ }^{18}$ VIANNA, 1981 (1924), p. 105. Fábio Sodré faz menção a ela em uma paródia: “Eu bem podia, Sr. Presidente, se fosse representante da burguesia, parodiando $V$. Ex., naquela frase célebre, tantas vezes lembrada nesta Casa, afirmar: 'Socializemos os meios de produção antes que o povo o faça'. Entretanto, como Deputado socialista, eu peço, Srs. Constituintes. que ao traçarmos a nova carta constitucional, façamo-lo com inteligência, abrigando, desde logo, o braço produtor contra a ganância e a especulação do patrão - sem abalar a sociedade nos seus fundamentos, procurando conciliar o predomínio do capital com a exigência do braço - elevando o nível de vida do proletário, preservando-o das endemias, dando assistência, instrução e conforto. É sem dúvida em torno dos direitos e deveres, das regalias e dos sofrimentos que cabem aos indivíduos de cada classe - que se agita a questão social”, 17/11/1933, vol. I, p. 400.
} 
Assim o discurso de Levi Carneiro, tratando dos fundamentos que apontam para a prudência e utilidade da cópia de outras Constituições: "E a cópia que se está fazendo, que se fez, que se tem feito, sempre, das Constituições de uns povos por outros nada mais significa que a correspondência de um mesmo momento histórico; é a identidade fundamental das questões sociais, das questões humanas; é aquele mesmo substractum de todas as sociedades; é o contágio dos problemas sociais e políticos que, em cada fase da vida humana propagam, igualmente, em todas as nações no estádio mais ou menos aproximado de civilização ${ }^{19 "}$.

Sobre a harmonia entre as classes e a distância dos problemas europeus, afirma João Guimarães: " $A i$ [nos debates sobre a ordem social e econômica] é que se acentua, mais diretamente, a influência das necessidades ocasionais e, principalmente, a influência da elite cultural do nosso País que, avançando mais do que o espírito da população brasileira do interior, marca o seu objetivo muito além da nossa realidade, querendo transplantar para o nosso meio princípios, regras, preconceitos que na mentalidade do povo ainda não despontavam, porque a grandeza de nossa Pátria, a facilidade de nossa vida, a simplicidade de nossa gente, não lhe permitem sentir entre as suas aspirações atuais, essas que atormentam os povos europeus. Contudo, cumpre que, desde já, dentro da nossa Constituição, se firmem preceitos e regras que possam servir para o futuro (...). O fundo da nossa organização político-psíquica, talvez remanescente de nossos precedentes etnográficos, indica que a base da relação entre o trabalhador e o patrão, em nosso País, tem por alicerces o afeto e o coração (Muito bem) (...). Queremos criar entre as duas classes o antagonismo profundo que se encontra nos países europeus mais adiantados" ${ }^{20}{ }_{-}^{21}$. De forma sintética, o diagnóstico é de certa maneira compartilhado

\footnotetext{
${ }^{19}$ Levi Carneiro, 02/12/1933, vol. II, p. 42. No mesmo sentido, ressalta Belmiro de Medeiros (09/01/1934, vol. V, p. 504): “É um erro grave de observação pretender aplicar-se ao Brasil princípios e regras de administração municipal ou estadual, vigentes em outros países, que não tenham com o nosso afinidades politicas ou identidade de interesses (...). Constituições transcritas podem ser monumentos jurídicos dignos de admiração; jamais, entretanto, preencherão seus fins, porque transformam-se em 'repositórios de doutrinas' quando devem ser simplesmente 'instrumento de governo'. De fato, senhores, uma Constituição só se justifica como instrumento de governo".

20 João Guimarães, 14/04/1934, vol. XIV, pp. 481 e 483.

${ }^{21}$ No mesmo sentido, a afirmação de Morais Leme: "Os corações empedernidos se abrandam com a educação e a religião. Demais, a fortuna é uma roda: quantos proletários não se tornaram burgueses! e quantos burgueses não se tornaram proletários! Não há, portanto, nessas classes, uma fixidez, que impeça o franco entendimento entre elas. Demais, os corações e as consciências agem como forças propulsoras", in Morais Leme, 27/02/1934, vol. VIII, p. 521. Ou ainda, as ponderações de Pinheiro Lima sobre a "luta" entre sindicalismo e democracia, com referências inclusive a Duguit, concluindo por rechaçar a comparação entre o Brasil e os demais países, especialmente europeus, na medida, entre outros pontos, que aqui "não há luta de classes" sendo "dever politico essencial promover a colaboração cordial do sindicalismo com a democracia, para o que deve esta evitar que nas organizações das classes produtoras e do trabalho penetre o elemento politico, perturbador da cordialidade que deve reinar entre ambos", in A ação da bancada paulista "por São
} 
pelos representantes classistas dos empregadores ${ }^{22}$, como na fala de Roberto Simonsen: "em nosso país o problema social, se existe, não se apresenta com as caracteristicas de compreensão e extorsão, que motivaram a luta de classes nas velhas civilizações" ${ }^{23}$. Por outro lado, a posição era contestada por uma ou outra voz dissonante, especialmente dentro da "minoria proletária", resistente à maioria adesista dos representantes dos empregados ${ }^{24}$. O discurso de Valdemar Reikdal é exemplo dessas vozes: "cada um dos movimentos do homem está sempre dentro do principio de suas necessidades econômicas. Partindo dessa lógica, encontramos o antagonismo de interesses entre o proletariado e os parlamentos burguesmente organizados. É, portanto, considerando esse princípio como uma realidade histórica que não acredito, absolutamente, seja possivel haver conciliação entre o capital e o trabalho, porquanto jamais alguém iria concordar pacificamente em diminuir as probabilidades de sua vida econômica em favor de uma classe que também tem necessidade de reivindicar suas próprias necessidades" ${ }^{25}$.

Ainda que se rechace no discurso hegemônico a existência de conflitos de classe no Brasil, acreditando-se em uma relação harmônica entre o capital e o trabalho,

Paulo unido' na Assembleia Constituinte, apud ALMEIDA, 2010, p. 182.

${ }^{22}$ De acordo com Zélia Lopes da Silva, a postura que qualifica como "negação da política" perpassa o pensamento dos representantes patronais, unânimes nas críticas aos regimes existentes e aos políticos, constatação que permite estender a perspectiva de Roberto Simonsen aos demais deputados classistas empregadores. "Embora a burguesia industrial admita a existência de 'pontos de vista diferentes' entre trabalhadores e patrões, defende o princípio de 'colaboração entre as classes', criticando as posturas operárias radicais que preconizam uma relação irreconciliável entre capital e trabalho", in SILVA, 1991, p. 93.

${ }^{23}$ Roberto Simonsen, 30/01/1934, vol. VII, p. 127.

${ }^{24}$ Assim, manifesta-se Martins e Silva, debatendo com o socialista Zoroastro Gouveia: "para mim, um dos problemas mais importantes para a pacificação da nossa Pátria, é a questão social. (Palmas). É necessário que nós, que agora aqui respondemos pelo futuro do País, firmemos as nossas conviç̧ões, dando ao Brasil uma legislação social capaz de, pelo menos, solucionar em parte, a questão social, resolvendo-a sem entrechoques violentos e sem derramamento se sangue dos nossos compatriotas (...). Dou a exemplificação: posso afirmar que, dentro do meu Estado, existe uma federação trabalhista que se orienta debaixo de um só ponto de vista. Pois bem, ali não há entrechoques sérios entre o capital e o trabalho, porque os nossos proletários só visam a grandeza da Pátria, pleiteando os seus direitos dentro do espirito da lei (Aplausos)"

Zoroastro Gouveia: "não apoiado; os trabalhadores nacionais hão de estar, forçosamente, contra a organização capitalista, porque somente a luta contra o capitalismo representa a libertação do trabalho universal"

Martins e Silva: "É a opinião pessoal de V. Ex., que argumenta apenas de um ponto de vista teórico" Zoroastro Gouveia: "O trabalhador brasileiro é sempre o escravo do capitalismo, nos cacauais da Bahia, nos cafezais de S. Paulo e nas fábricas de Pernambuco"

Martins e Silva: "V. Ex. está argumentando pelo que ouviu dizer, ao passo que eu falo de ciência própria (Muito bem. Apoiados)". In Martins e Silva, 29/11/1933, vol. I, p. 453.

${ }^{25}$ Valdemar Reikdal, 02/04/1934, vol. XIII, p. 60. Curiosamente, o primeiro fundamento assinalado para a outorga por Vargas da Carta de 1937 foi a ameaça de que os conflitos da sociedade da época "desnaturassem em luta de classes" - a Carta de 1937 atendia, segundo seu preâmbulo, "às legitimas aspirações do povo brasileiro à paz política e social, profundamente perturbada por conhecidos fatores de desordem, resultantes da crescente a gravação dos dissídios partidários, que, uma, notória propaganda demagógica procura desnaturar em luta de classes, e da extremação, de conflitos ideológicos, tendentes, pelo seu desenvolvimento natural, resolver-se em termos de violência, colocando a Nação sob a funesta iminência da guerra civil”. 
a questão do contágio dos problemas sociais e a experiência internacional apontam aos constituintes a utilidade e a conveniência de incluir na Constituição mecanismos e institutos destinados a conter eventual conflito que se possa instaurar no futuro. $\mathrm{O}$ velho fantasma da "questão social" da Primeira República aparece renovado pelo contexto internacional, como uma inevitabilidade da incorporação do social à nova Constituição, imposta pelo momento presente e pelas perspectivas futuras.

A referência específica à situação política francesa é recorrente nos discursos dos constituintes brasileiros, que aparentemente acompanham o cotidiano do Parlamento e do governo francês, mencionando inclusive os homens políticos de destaque daquele país, como Tardieu, Heurriot, Jaurès e Clemenceau ${ }^{26}$. Aborda-se a crise da democracia parlamentar e os embates entre os partidos e da dificuldade de composição de governos duradouros, como exemplificado no debate que se trava no meio do discurso de Odilon Braga, de 03/05/1934 ${ }^{27}$. Os constituintes brasileiros dão indicativos de que seguiam de perto a realidade dos outros países, sendo a França uma das referências centrais, de onde extraem sua consciência e seu receio em relação à organização das classes populares e a incorporação delas à política institucional, a partir do sufrágio universal. É esse receio que se manifesta no momento de conformar a democracia e as regras de participação política no Brasil, conforme será tratado no capítulo $6^{28}$.

O segundo tipo de referência que se faz ao estrangeiro é a observação e influência das novas Constituições europeias do entre-guerras. A grande inspiração a ser mencionada é a Constituição alemã de 1919, a Constituição de Weimar, que parecia apresentar soluções adaptáveis à realidade brasileira e adequadas para responder aos anseios de socialização do direito, podendo ser um ponto de partida mais conveniente do que a carta liberal de $1891^{29}$. Junto com a Constituição espanhola de 1931, notadamente, a alemã constituiu a fonte inspiradora de muitos dos novos dispositivos discutidos na

\footnotetext{
${ }^{26}$ Vide por exemplo os discursos de Agamenon Magalhães (11/12/1933, vol. II, pp. 201/211), Roberto Simonsen (30/01/1934, vol. VII, pp. 127 e ss.), Pereira Lira (28/02/1934, vol. IX, pp. 12/19), Domingos Velasco, (06/04/1934, vol. XIII, pp. 293/298), comentários de Levi Carneiro a Horácio Lafer (16/01/1934, vol. VI, p. 109).

${ }^{27}$ Cf. vol. XVI, pp. 252/271.

${ }^{28}$ Sobre o assunto, destaca Vera Alves Cepêda: "Neste período podermos assinalar também a recepção de uma corrente de influências internacionais e um ajuste com o debate nacional pretérito. Em termos mundiais, repercutia aqui o abalo gerado pela crise do liberalismo nos países centrais resultante das crises cíclicas de superprodução, das disputas mundiais (...) e da falência da teoria clássica anteriormente predominante", in CEPÊDA, 2009, p. 215.

${ }^{29}$ Para uma análise da Constituição de Weimar e de seu debate pelo direito público alemão, ver especialmente BERCOVICI, 2004.
} 
constituinte brasileira, cujo resultado final espelhou alguns de seus artigos centrais, especialmente relacionados à ordem econômica e social ${ }^{30}$.

As ideias de Weimar já vinham sendo difundidas no Brasil ${ }^{31}$, sobretudo pelos entusiastas, não tanto de seus avanços social democratas, mas mais da sua tentativa de conciliação da nova regulação social às ideias liberais, tensão presente na carta alemã que de certa forma se reproduziria no Brasil. Nesse sentido, Vamireh Chacon refere-se ao jornalista Vítor Viana - também membro da Comissão Constitucional prévia à Constituinte -, por ele classificado entre os "neoliberais" da época ${ }^{32}$, que buscaram inspiração na carta de Weimar: "Em 1931, com Hitler ante portas, Vitor Viana e os neoliberais de periferia ainda invocavam e apresentavam Weimar como modelo salvador do Brasil, atitude para eles necessária a fim de evitar uma revisão da Constituição de 1891, porém para trás, 'reacionária' como Vitor Viana temia, quando, 'No momento oportuno, devemos pugnar pela reforma da Constituição, mas para melhorar o nosso código fundamental, garantir direitos, estabelecer novos, modificando para a frente, no sentido progressista... "33.

A afirmação da utilidade do modelo de Weimar continha em si a convicção na necessidade de uma Constituição moderna, reflexo de seu tempo, que se projetasse para o futuro, antecipasse e prevenisse problemas e moldasse uma nova sociedade a partir de seu texto, abandonando os enxutos padrões de Constituição liberais, ou excessivamente liberais, do século XIX. "A Constituição de Weimar de 1919 editou uma série de medidas em que são atendidos todos esses problemas que a nova economia impõe à atenção dos poderes públicos. A liberdade na vida econômica, a liberdade de

\footnotetext{
${ }^{30}$ Vide BERCOVICI, 2008(b), p. 30 e ss.. Para um trabalho sintético sobre a interface entre a Constituição de Weimar e a Constituição de 1934, vide GUEDES, 1998, especialmente pp. 113 e ss. O estudo traz um quadro comparativo dos dois textos em pp. 133/138.

${ }^{31}$ Conforme aponta Vamireh Chacon, já em 1924 "apareceu a inicial e já melhor exegese brasileira da Constituição de Weimar, com tradução e comentários por Aprígio C. de Amorim Garcia", in CHACON, 1987, p. 130.

${ }^{32}$ Luiz Werneck Vianna esclarece que "neoliberalismo" é um termo que, quando escreveu sua tese de doutoramento, em 1975, refere-se ao "liberalismo que teria sido capaz de admitir personagens coletivos no contrato social, tais como sindicatos, ao mesmo tempo em que deu origem ao chamado processo de 'publicização da esfera privada', na medida em que também se caracterizou por ter mobilizado o Estado para o exercício de funções regulatórias da economia e do mercado de trabalho. Conforme este uso, hoje anacrônico, o neoliberalismo, no texto apresentado a seguir, designa uma categoria substantivamente próxima ao Welfare State, e nada tem a ver, portanto, com o seu significado, nos dias atuais, de um retorno fundamentalista à doutrina liberal", in VIANNA, 1999, pp. 23/24. A observação ajuda a compreender de que forma podiam os "neoliberais" dos anos 1930 defender princípios liberais mas também o modelo social da Constituição de Weimar, como faria Vítor Viana. "Novo liberalismo" é antes disso associado, por Alfredo Bosi, à corrente abolicionista e reivindicadora de reforma eleitoral, nos anos 1860-1880, associada ao regime implementado pela Primeira República, in BOSI, 2003 (1992), p. 304.

${ }^{33}$ CHACON, 1987, pp. 132/133, citando artigo de Vítor Viana em Uma Constituição do Século XX $(O$ Código de Weimar e a Moderna Alemanha), Typ. do Jornal do Commércio (Rodrigues \& C.), Rio de Janeiro, 1931, pp. 3, 5, 4, 57, 6, 25, 38, 39, 36, 31, 21, 29, 46, 8, 15, 16, 11, 12 e 16.
} 
contratos, o direito de propriedade impondo obrigações e seu uso constituindo um serviço do mais alto interesse comum, o direito de sucessão com uma quota de herança reservada ao Estado, a divisão e o aproveitamento do solo, a socialização progressiva das terras, o direito operário homogêneo, a liberdade dos sindicatos, as relações do trabalho e os direitos de proteção à saúde dos trabalhadores, os seguros sociais, a obrigação de trabalhar e o direito ao trabalho, a proteção internacional ao trabalhador, tudo isso se

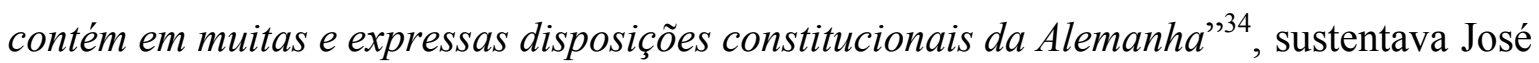
Augusto em 1933.

Mas a influência tardia de Weimar - lembrando que Hitler já era chanceler na Alemanha desde janeiro de 1933, e em março aprovara a Lei de Plenos Poderes (Emächtigungsgesetz), legalizando sua posição de comando e enterrando definitivamente a República constitucional instaurada em 1919 - não foi percebida sem questionamentos e dúvidas no Brasil. Assim nota João Mangabeira, ao comentar as alterações feitas pela Constituinte ao anteprojeto da Subcomissão Itamaraty: "o projeto, tomando por modelo a Constituição de Weimar, dilata e empasta todo o capítulo preliminar com o rol das competências, que terá de ser, mais adiante, em vários pontos repetido. É que nem sempre o povo alemão é bom modelo. Goethe afirmava que esse povo 'torna tudo difícil e tudo complica; e Schopenhauer asseverava que o característico do alemão é 'enxergar o que se passa nas nuvens e não ver o que está diante dos olhos' (...). E todos esses defeitos germânicos se refletem na grande Constituição, em cujo molde vazou o projeto o seu primeiro capítulo",35. Desse modo, de um lado era dedicada atenção especial às novas Constituições, em particular à alemã, como modelo de legislação moderna, que incorporava as questões sociais do século $\mathrm{XX}$, e, de outro, guardava-se certa desconfiança em relação a uma Carta excessivamente inchada e não coesa, que poderia ser a semente de conflitos futuros, como no diagnóstico então corrente sobre a Alemanha.

A investigação sobre o transplante de dispositivos constitucionais alemãs no Brasil é, pelo pouco exposto, assunto vasto e complexo, que merece estudo próprio, e está fora do escopo do presente trabalho, que busca refletir mais sobre as ideias que eram voz corrente no direito público e constitucional em época de irrupção do social do que sobre os dispositivos legais e sua genealogia. Sobre essa segunda instância de influência da realidade de outros países na constituinte brasileira de 1933/34, é importante mencionar, contudo, um último aspecto que serve como ponte para a terceira. Trata-se do papel da

\footnotetext{
${ }^{34}$ AUGUSTO, 1933, p. 7.

${ }^{35}$ MANGABEIRA, 1934, pp. 169/170.
} 
obra de Boris Mirkine-Guetzévitch sobre as novas tendências do constitucionalismo europeu, autor que, segundo Belmiro de Medeiros, estava ensinado àquela geração de juristas e constitucionalistas "o A B C constitucional" 36 .

Em 1933, publica-se em edição traduzida para o português As Novas Tendências do Direito Constitucional. Em prefácio à obra, Vicente Rao aponta para o alcance que ela teria no Brasil, naquele momento em particular, em trecho mais longo que, por bastante esclarecedor, vale ser transcrito: "Duas circunstâncias tornaram MirkineGuetzévitch conhecido entre os estudiosos brasileiros: - o momento político que nosso país atravessa e o valor realmente notável desse jurista, moço ainda, mas já consagrado nos mais altos centros da cultura europeia. Não se faz mister de esforço para caracterizar a atual fase de nossa vida política. A Nação, inútil seria pô-lo em dúvida, aguarda com ânsia incontida a volta à ordem constitucional, e, para a consecução desse desejo, mobilizadas estão todas as suas forças políticas, sociais, econômicas, enquanto os seus centros de cultura prosseguem nos estudos e debates, de há muito iniciados, relativos ao problema constitucional. Mais do que nunca oportunos aparecem para nós, assim sendo, os ensinamentos daquele ilustre jurista, o que tanto mais é certo, quanto o direito constitucional contemporâneo padece transformações tais que, sem guia seguro, difícil tarefa seria para quem quer orientar-se no labirinto das doutrinas, opiniões e ensaios práticos surgidos após a guerra, os quais revelam, todos, as mesmas incertezas e a mesma confusão resultantes das novas condições econômico-sociais, causadoras, por sua vez, de tendências novas na organização política dos povos"37.

Mirkine-Guetzévitch funciona como porta de entrada, como testemunha e como tradutor das novas Constituições europeias. São incontáveis as menções à sua obra durante os debates da Assembleia Constituinte. Portanto, em lugar de fazer referência aos textos em sua forma original, e às doutrinas de seus países que os comentaram, os constitucionalistas e juristas brasileiros fundamentavam-se sobretudo na tradução feita por Mirkine-Guetzévitch, e no natural e inevitável filtro ideológico por ele imposto, ressaltando dos textos os aspectos que julgava serem mais importantes, orientando-os em torno de sua perspectiva liberal e de sua ideia de racionalização do poder e da vida social, conforme exposto no capítulo 3 (item 3.2).

Daí o alerta de Carlos Maximiliano aos colegas constituintes: "Há um escritor que, hoje, está muito em voga. No Brasil, tudo é moda, até mesmo a celebridade

\footnotetext{
${ }^{36}$ Belmiro de Medeiros, 09/01/1934, vol. V, p. 503.

${ }^{37}$ Vicente Rao, prefácio a MIRKINE-GUETZÉVITCH, 1933, pp. 7/8.
} 
científica. Aqui a moda impera, desde os lugares em que se faz 'footing', até nas ideias e livros que se procuram e preferem (...). Agora, é Mirkine Guetzévitch, para a direita e para a esquerda. Esse senhor, como todos os indivíduos de sua raça, tem uma grande facilidade para línguas, maneja vários idiomas. Traduziu as Constituições, realizou trabalho que, naturalmente, lhe dá grande renda, mas no qual dele existe somente um pequeno prefácio, em geral bem feito. Traduziu obras notáveis de Hans Kelsen. Verteu para o francês e outros, e resumiu ideias alheias sobre o Direito Constitucional moderno. É enfim um vulgarizador inteligente, e mais nada" ${ }^{38}$. O deputado gaúcho não apenas destaca a popularidade de Mirkine-Guetzévitch, como também aponta para as deficiências de se apoiar em sua obra como síntese do movimento de socialização do direito constitucional que vinha tomando conta da Europa: "Ora, exatamente como ele publicou os textos das Constituições do Mundo, vejo nos bondes, nos hotéis, nos ônibus, os seus livros em todas as mãos, e as Constituições alemã e austríaca, e que sei eu? Reboam aos ouvidos da gente de manhã até à noite (...). Não basta ler os textos: o principal é conhecer a sua forma, o seu poder, o seu alcance, a sua história, a sua aplicabilidade (...). Vai-se, como se devia ir, à proporção que se expõe uma doutrina, um capitulo, acompanhando a exposição com o direito comparado; não com a legislação comparada; e, nesse terreno, Mirkine Guetzévitch nos servirá muito pouco. Será necessário procurar os comentadores das constituições modernas, o que é mais penoso, porque, as mais novas, nem comentários em português têm. Os bons expositores do contemporâneo Direito Público da Germânia e da Áustria não autorizam versões dos seus livros em alguma das línguas latinas e, entre nós, bem poucos se entregam a estudos alemães"39.

Carlos Maximiliano é preciso ao identificar a questão central da influência da legislação estrangeira no Brasil: o texto de lei significa muito pouco como modelo ou como inspiração se não cotejado com a doutrina jurídica que sobre ele se produziu. Por mais que se tivesse acesso "nos bondes, nos hotéis ou nos ônibus" ao texto dessas novas Constituições, o acesso à reflexão teórica sobre elas, à doutrina, era consideravelmente mais escasso, em razão das dificuldades da época, sobretudo a barreira do idioma - conforme ele alerta, a maioria dos juristas era versado em línguas latinas, mas não em alemão. Pouco adianta conhecer a letra da lei, quando na verdade é a doutrina que se dedica ao seu estudo, revelando suas origens, e orientando sua interpretação, quem vai, desse modo, determinar sua aplicação (e sua aplicabilidade, até mesmo), no momento da

\footnotetext{
${ }^{38}$ Carlos Maximiliano, 27/11/1933, vol. I, pp. 422/423.
}

${ }^{39}$ Carlos Maximiliano, 27/11/1933, vol. I, p. 423. 
concretização do direito. Antes disso, a doutrina é útil também no momento da elaboração, pois permite avaliar a adequação da terapêutica aos problemas concretos, isto é, é ela quem revela os problemas em questão na elaboração do texto constitucional.

Com isso, podemos tratar propriamente da presença das doutrinas nos debates constitucionais brasileiros. Não à toa escolhemos como baliza para a análise o pensamento publicista francês dos anos 1920 e 1930, exposto na parte I desse trabalho. O terceiro momento de interface entre os debates constituintes brasileiros e a realidade internacional é a influência de doutrinas estrangeiras nos discursos e nas propostas parlamentares. Nesse momento, as referências ao pensamento dos constitucionalistas franceses ${ }^{40}$, sobretudo - muito mais do que de outras nacionalidades - é marcante, seja pela destacada influência do pensamento francês no ensino de direito público no Brasil, seja mesmo pela maior facilidade que os juristas tinham em acessá-lo por conta da menor barreira linguística. Não por outra razão, Pontes de Miranda enumera as "vagas" de influência determinantes no Brasil de 1930-1934, quais sejam, o "caudilhismo sulamericano", o "constitucionalismo norte-americano" e os "princípios democráticosliberais da França",41.

Como já pontuado, os constitucionalistas reportam-se frequentemente a Mirkine-Guetzévitch, tratando não apenas da apresentação dos modernos textos constitucionais, mas também da análise que o russo apresenta, articulada em torno da ideia de racionalização do poder. Em termos de doutrina, mencionam também e sobretudo os autores clássicos, como Léon Duguit, Maurice Hauriou; um ou outro trata ainda de Raymond Carré de Malberg e de Joseph Barthélemy. Trataremos das menções mais adiante, bastando por ora reter a relevância da doutrina francesa como suporte aos debates teóricos da constituinte, quase como referência de passagem obrigatória.

\footnotetext{
${ }^{40}$ São inúmeros os exemplos de referência aos constitucionalistas franceses espalhados pelos 22 volumes das atas da Assembleia Constituinte - como exemplos, vide Odilon Braga (16/11/1933, vol. I, pp. 184/185), Fábio Sodré (17/11/1933, vol. I, pp. 203/210), Levi Carneiro (18/11/1933, vol. I, pp. 248/253), Carlos Maximiliano (27/11/1933, vol. I, pp. 421/437), Pontes Vieira (18/12/1933, vol. II, pp. 382/395), Nilo Alvarenga (22/12/1933, vol. II, pp. 543/548), Pedro Rache (06/01/1934, vol. V, pp. 440/444), Belmiro de Medeiros (09/01/1934, vol. V, pp. 500/506), Marques dos Reis (18/01/1934, vol. VI, 201/218), Prado Kelly (22/02/1934, vol. VIII, pp. 300/309), Moraes Leme (27/02/1934, vol. VIII, pp. 519/523), Pereira Lira (28/02/1934, vol. IX, pp. 12/19), Mario Magalhães (03/04/1934, vol. XIII, pp. 142/147), Domingos Velasco (06/04/1934, vol. XIII, pp. 293/298), Ferreira de Souza (10/04/1934, vol. XIII, pp. 557/571), Pontes Vieira (11/04/1934, vol. XIV, pp. 40/49), Pedro Vergara (25/04/1934, vol. XV, pp. 470/483), Belmiro de Medeiros (27/04/1934, vol. XVI, pp. 48/55), Odilon Braga (03/05/1934, vol. XVI, pp. 252/271). Os casos aqui mencionados não são exaustivos, mas exemplificativos da profusão de referências ao pensamento dos autores franceses, não raro citados no original nos discursos dos constituintes, sendo possível dizer que é a doutrina a que mais se faz referência durante os trabalhos.

${ }^{41}$ PONTES DE MIRANDA, 1937, t. I, p. 97.
} 
Se havia a preocupação em prevenir os conflitos sociais presenciados pelos países europeus, e o alerta para o risco de contágio de tais problemas, o recurso à doutrina estrangeira funcionava também como contágio de diagnósticos teóricos, não raro mal compreendidos ou mal ajustados. Dessa forma, os representantes políticos referem-se a uma crise do antigo sistema liberal e da democracia ${ }^{42}$, impondo a renovação constitucional focada na realidade concreta e mirando o futuro, como se o diagnóstico pudesse ser transplantado para o Brasil. O pensamento de outros países, sobretudo o francês, aparece como justificativa para uma Constituição diferente da de 1891, menos enxuta e menos liberal e com pretensões de ampliar o espectro de situações por ela reguladas, a partir de uma nova visão sobre o direito, a despeito de a França não ter, ela própria, alterado sua Constituição nesses termos. A efetividade dessa carta estaria fundada na sua elaboração mais pragmática - que permitia identificar problemas da realidade concreta e os interesses políticos por vezes conflitantes em disputa e regulá-los sem necessidade de compor um conjunto constitucional coerente em si, descartada a possibilidade de um conjunto coerente nos moldes do quanto pretendido pelos velhos liberais e pelos constitucionalistas clássicos - e na sua orientação para o futuro, incorporando o objetivo de moldar o Brasil que viria a ser.

Nesse sentido, a citação de Barthélemy no discurso de Odilon Braga: “ $A s$ regras práticas da vida social não devem permanecer no estado informe das boas intenções vagamente indicadas. Devem ser traduzidas, cientificamente, em fórmulas breves, que sejam como a expressão algébrica das relações sociais; mas, sobretudo, devem submeter a realidade complexa, confusa, movediça, a essa disciplina de lógica e clareza, que é a ciência do Direito"43. O deputado constitucionalista segue lembrando de James Beck, para sustentar ser desnecessário a Constituição apresentar absoluta coerência doutrinária, e elogiar as virtudes de ser prático, curiosamente exemplificadas pelo caso francês: "Outra prova contundente do acerto, no-la oferece a França. Nenhuma outra constituição francesa durou mais do que esse arranjo provisório das leis orgânicas, de leis constitucionais, que dão estrutura ao moderno direito público francês. Para BarthélemyDuez, essas leis são de uma excessiva sobriedade, de uma absoluta falta de método e de

\footnotetext{
${ }^{42}$ Como por exemplo Odilon Braga, 03/05/1934 (vol. XVI, pp. 252/271): "Repita-se: o que se acha em crise é a técnica parlamentarista da democracia. Os fatos ai estão na Itália, na Alemanha, na Áustria, na Espanha, na própria França, a demonstrá-lo. O parlamentarismo não mais satisfaz às finalidades do Estado moderno" (p. 268).

${ }^{43}$ Odilon Braga, 03/05/1934, vol. XVI, p. 256. A citação, sem indicação de página, é atribuída a Le problème de la compétence dans la démocratie.
} 
boa redação, privadas de todo dogmatismo e animados de um constante espírito de transigência" ${ }^{44}$.

Assim sendo, a proliferação de doutrinas as mais díspares, fazendo com que não houvesse unanimidade senão sobre a falta de um consenso, combinada com uma virada pragmática que está na base das novas Constituições sociais, autoriza que o produto final seja um texto eclético, animado de espírito de transigência e busca de conciliação e compromisso, condizentes com os interesses em disputa em seu tempo. Apesar de referirem-se muito mais aos autores que chamamos clássicos, é a virada pragmática do direito constitucional sugerida no capítulo 3 que se afigura mais útil para compreender a nossa primeira Constituição social. "Ao contrário dos Preuss e dos Kelsen, que partem do racionalismo jurídico para as construções políticas, sustentava Lassale 'que os problemas constitucionais não são primariamente problemas de direito e, sim, de poder', o que, aliás, bem se comprova pelo fragoroso ruir das Constituições de Weimar e Viena"45, alerta Odilon Braga, na defesa de postura pragmática em lugar de um preciosismo teórico.

Voltando um passo atrás, diga-se que não seria próprio afirmar o pragmatismo e a orientação de futuro como tônica dominante não problematizada nos debates constituintes brasileiros. Os discursos são divididos entre aqueles inspirados pelas doutrinas contemporâneas, que, ainda que conscientes da necessidade de adaptá-las à realidade nacional, defendiam um texto voltado para o futuro, e aqueles que eram mais reticentes em relação ao pensamento estrangeiro, e preferiam ver na "harmonia das classes sociais" e nos costumes e tradições brasileiros, geralmente referindo-se à Constituição de 1891, um alicerce firme para a nova carta política. A disparidade de representação ideológica na Constituinte, já apontada, espelha essa tensão entre o arcaico e o moderno nos discursos políticos.

João Guimarães, exemplificando a última corrente, sustenta a conveniência de uma Constituição mais enxuta: "Enquanto a elite brilhante que orna essa Casa, exercendo o mandato popular emanado de aspirações brasileiras, procura beber na literatura jurídica estrangeira as noções mais avançadas do Direito social e adotá-las para o nosso País; enquanto [sic] a população do interior vive no marasmo da ignorância, dentro do regime patriarcal, que é a base da atual organização brasileira (...). Deixemos apenas consignados os princípios gerais; mantenhamos a necessidade da assistência ao trabalhador, não só a ele próprio como à sua família; asseguremo-lhe a tranquilidade do

${ }_{44}$ Odilon Braga, 03/05/1934, vol. XVI, pp. 259/260, afirmação seguida de citação de Barthélemy e Duez.

${ }^{45}$ Odilon Braga, 03/05/1934, vol. XVI, p. 257. 
lar; assistamo-lo em sua enfermidade. Não desçamos a detalhes e resguardemos o interesse dos próprios trabalhadores"

Contrapostas, as inúmeras as vozes que defendem a necessidade de revisão de valores políticos e econômicos, inspirados pelos diagnósticos externos mas conscientes da realidade brasileira, como ilustra uma passagem do discurso de Agamenon Magalhães: "Há, entretanto, sob o aspecto financeiro, um traço comum, uma solidariedade nas crises, solidariedade que resulta da independência econômica das nações; e sob o aspecto moral, há uma desconfiança geral, agravada pelo sofrimento das massas. E, em meio dessa inquietação, quero destacar duas atitudes intelectuais que se fixaram: uma negativista, outra espiritual. A negativista, define-a Ortega y Gasset, - 'nada de novo; só uma certeza: os princípios tradicionais não podem subsistir'. A atitude espiritual surge como uma espécie de nostalgia da idade média, como Bendiaef, Henri Massi e a Nova Jerusalém de Chesterton. O que precisamos no Brasil, Sr. Presidente, é de outra atitude; de uma atitude criadora, de revisão dos valores políticos e econômicos, porque a fé, a espiritualidade, a moral cristã, essa a temos, educando o espírito nacional desde o início da nossa formação histórica. É essa política brasileira, no sentido construtor, aquela que Alberto Torres tanto aconselhara e da qual os nossos governos, emprenhados só e só em conservar o poder, não cuidaram" "47.

Significativa a fala de Assis Brasil, que junto com J. J. Seabra compõe o grupo dos deputados constituintes que também foram responsáveis pela Carta de 1891: “Essa Constituição há de sair de acordo com as necessidades da época. Não será uma obra eterna, definitivamente estará sujeita à lima do bom senso, do uso e da interpretação. Eu já exprimi em público (...) um conceito que tenho ouvido repetir por muitos amigos (...): as ideias, as opiniões e os entendimentos não são propriamente do indivíduo, são da época; os homens pensam que estão divididos, mas, no fundo, estão penetrados pela atmosfera dentro da qual respiram e onde criam, não só os glóbulos vermelhos das suas

\footnotetext{
${ }^{46}$ João Guimarães, 14/04/1934, vol. XIV, pp. 482/484. No mesmo sentido, afirma Augusto de Lima (23/01/1934, vol. VI, p. 365): "O Brasil, senhores, precisa voltar atrás. Peço que me perdoem os ilustres futuristas do direito novo. Esse retrocesso, porém, é aconselhado pelos velhos publicistas, pelos velhos juristas, quando moldavam as instituições, não na legiferância dos representantes do direito público, mas nas camadas intimas, profundas do direito costumeiro, das práticas religiosas do lar, das sentenças dos tribunais que decidiam pelos princípios universais da justiça".

${ }^{47}$ Agamenon Magalhães, 11/12/1933, vol. II, p. 202. No mesmo sentido, já havia afirmado em 04/12/1933 (vol. II, p. 65): "nos debates que se têm travado, para logo uma superstição se fixou, qual a idolatria pela Constituição de 91 (Muito bem). Esse fato, Sr. Presidente, tem uma explicação psicológica. Em todas as lutas, em todas as crises, em meio das dificuldades, muitas vezes o espírito volta-se para o passado: é o saudosismo, é o sebastianismo em Portugal, é o bonapartismo na França (Apoiados)".
} 
artérias, como também a massa cinzenta do seu cérebro (Muito bem)" ${ }^{\text {"48 }}$. Interessante notar a consciência do constituinte sobre a diferença entre os dois momentos constitucionais, apesar de por vezes sofrer com a pecha de liberal e defensor do modelo de $1891^{49}$.

Em conclusão, temos que, ao tratar da influência estrangeira versus a realidade nacional, os discursos refletem a tensão entre o arcaico e o moderno, entre o apego às formas tradicionais, ao costume e às tradições brasileiras, e a consciência de que haveriam de oferecer respostas a novas questões, a problemas sociais presentes e futuros, que viram por evolução ou por contágio externo. O recurso ao pensamento estrangeiro é usado seja como inspiração de legislação, seja como colaboração no diagnóstico, enfrentando debates teóricos mais abstratos, mas sem perder de vista o contexto brasileiro e um pragmatismo na escolha das soluções, ainda que em detrimento de uma Constituição coesa e enxuta. Recorre-se amplamente às ideias jurídicas em voga, especialmente as francesas, porém, permitindo-se a elaboração, diríamos, "de varejo" a partir delas, resultando em uma Constituição de inspiração eclética, a meio caminho entre o liberalismo, o solidarismo e as soluções mais autoritárias que partiam do diagnóstico de crise e dos novos conceitos para criar a partir deles, como se verá a seguir.

De certa forma, o desafio já estava colocado no texto de 1924 de Oliveira Vianna: "Já não nos podemos inspirar nesses principios abstratos, nem nos constringir dentro das estreitezas desse unilateralismo doutrinário. O nosso futuro legislador constituinte tem que possuir uma mentalidade mais ampla e mais iluminada, uma inteligência mais realistica e objetiva, uma consciência mais humana da relatividade dos sistemas políticos. E, sobretudo, um conhecimento mais perfeito e completo da nossa realidade nacional, das nossas idiossincrasias, das nossas falhas, das nossas insuficiências, da nossa condição de povo em formação; de modo que, na elaboração das suas reformas e na arquitetura do novo sistema político, possa - como o Jesus, de Renan rester toujours près de la nature. Isso é, antes de se mostrar homem do seu tempo, possa mostrar-se homem da sua raça e do seu meio" ${ }^{50}$. Ademais, é o próprio MirkineGuetzévitch, no prefácio à edição brasileira de uma de suas obras, quem alerta para o fato de que o Brasil deve buscar elaborar uma Constituição que progressivamente deixe de olhar tanto para doutrinas e influências estrangeiras e passe a conformar uma verdadeira democracia, condizente com a realidade de seu povo: "A opinião pública, criando a

\footnotetext{
${ }^{48}$ Assis Brasil, 21/12/1934, vol. II, p. 504.

${ }^{49}$ Por exemplo, as críticas no discurso de Zoroastro Gouveia, 24/02/1934, vol. VIII, p. 405, citado no item 5.2.

${ }^{50}$ VIANNA, 1981 (1924), p. 118.
} 
consciência nacional, transformará os Estados latino-americanos em verdadeiras democracias. Não é no momento atual que pode desaparecer o desacordo, por vezes existente, entre os textos constitucionais e a realidade politica. A seu tempo, esses textos, que proclamam com eloquência solene os grandes princípios que nos foram legados pela Revolução Francesa, tornar-se-ão uma realidade" ${ }^{51}$. Restaria saber o quanto de democracia liberal e o quanto de antiliberalismo estariam presentes na nova carta constitucional brasileira, e como a tal "solução nacional" equacionou no texto constitucional a tensão sobre a qual debatia boa parte da doutrina jurídica da época.

\subsection{UMA CONSTITUIÇÃo SOCIAL: A CRÍTICA AO LIBERALISMO E O PAPEL DO ESTADO}

Vicente $\mathrm{Rao}^{52}$ traz, no prefácio à edição brasileira da obra de Boris Mirkine-Guetzévitch, a transcrição de um diálogo entre ele e o russo, que de certa forma sintetiza a raiz da sensível disparidade entre os processos políticos e o pensamento jurídico francês e o brasileiro que queremos pontuar nesse trabalho. Tratando do diagnóstico de crise da democracia, o jurista brasileiro começa questionando a visão de MirkineGuetzévitch de que "o regime democrático, consistente numa fórmula política do Estado de Direito, não é apenas uma verdade dogmática, é também uma verdade histórica", reportando um diálogo entre os dois juristas em que afirma: "ainda assim, disse-lhe eu ao ter a honra de visitá-lo, muitos autores vão mais longe nas suas conclusões e falam, mais do que em crise, em verdadeira falência da democracia. - A democracia faliu, respondeume [Mirkine-Guetzévitch], somente ali onde não tinha existência real. - Já sustentei em discurso proferido na Faculdade de Direito de S. Paulo, ter sido causa principal da acentuada crise o individualismo à outrance que nos legou a revolução francesa e que, com o correr dos tempos, pôs o Estado em choque com as novas condições econômicas e sociais. Não é este o seu modo de ver? - Não, replicou sem hesitar. Eu entendo, ao contrário, que a democracia nasceu, praticamente, com a revolução. De mais a mais, não se deve julgar a obra revolucionária só através da 'Declaração de Direitos', documento

\footnotetext{
${ }^{51}$ MIRKINE-GUETZÉVITCH, 1933, pp. 18/19.

${ }^{52}$ Talvez seja quase desnecessário lembrar a participação política do Professor da Faculdade de Direito de São Paulo, Vicente Rao, que foi membro do Governo Vargas de 1934 a 1937, como Ministro da Justiça, tendo sido responsável pela elaboração da Lei de Segurança Nacional de 1935. É nesse período que "fez o papel do jurista eficiente da extrema-direita: serviçal, criou a Comissão de Repressão ao Comunismo, mandou prender o senador Abel Chermond e vários deputados, entre os quais Abguar Bastos, João Mangabeira e Herculano Cascardo, presidente da ANL [Ação Libertadora Nacional]", in MOTA, 2010, p. 52.
} 
este de destacada finalidade politica. é preciso, antes, examinar a inteira obra legislativa daquela fase histórica da França (...) para se verificar a existência, então, de uma apreciável ação social do Estado, embora dentro dos limites restritos que o problema naquele período econômico apresentava" ${ }^{, 53}$. Mirkine-Guetzévitch estava, como já visto, reafirmando sua convicção nas premissas da democracia liberal e no fundamento individualista, destacando que qualquer ação social do Estado deveria estar restrita aos limites impostos pela democracia e pela preservação da liberdade, enquanto Vicente Rao enxergava nas transformações do Estado e da democracia também uma redefinição do lugar do indivíduo na teoria constitucional e do Estado.

A divergência com Mirkine-Guetzévitch, em sentido próximo, também aparece em Pontes de Miranda. Enquanto para o primeiro a técnica constitucional era a técnica da liberdade, o brasileiro entende que seria um "apego a liberalismo já insustentável dizer, ou pretender, que seja apenas a técnica da liberdade. O Direito Constitucional tem, hoje, conteúdo maior e mais ampla finalidade ${ }^{\text {54 }}$. Critica MirkineGuetzévitch porque ao reduzir o direito constitucional à técnica da liberdade, "mostra que não distingue liberdade e democracia. Também na Áustria aparece, às vezes, a mesma confusão, de consequências lógicas lamentáveis" ${ }^{\prime 55}$. O direito constitucional seria mais do que a liberdade, ou é distinto dela. Há aqui uma diferença importante entre os debates franceses do entre-guerras e os brasileiros da Constituinte de 1933/34.

Como visto nos capítulos anteriores, a doutrina francesa também questionava o subjetivismo voluntarista como método de explicação do direito (crítica que podia se confundir com a do excesso de individualismo, o "individualismo à outrance"), propondo a revisão no método jurídico, no conceito e na função do Estado e na própria ideia de direito. Contudo, seguia articulando-se em torno das premissas democráticas e de algum modo liberais, sem abandonar a centralidade do indivíduo, ainda que situado histórica e socialmente (não abstrato), debatendo mecanismos de ampliação da participação política, e buscando reforçar o Parlamento e o sistema político a partir do diagnóstico de suas inoperâncias. Mesmo o mais críticos dos autores conseguia manter-se dentro de certas balizas, diríamos, da democracia liberal, tanto assim que René Capitant

\footnotetext{
${ }^{53}$ Vicente Rao, prefácio a MIRKINE-GUETZÉVITCH, 1933, pp. 11/12.

${ }^{54}$ PONTES DE MIRANDA, 1937, t. I, p. 89.

${ }^{55}$ PONTES DE MIRANDA, 1937, t. I, p. 89, nota 44. A referência para a Áustria é Hans Kelsen, e sua Allgemeine Staatslehre (1925).
} 
recupera Alain para afirmar que a ideologia da Terceira República é o individualismo ${ }^{56}$. A tarefa de incorporar o social emergente ficou para a doutrina, enquanto que o sistema político e a Constituição seguiam praticamente inalterados, no seu formato enxuto e liberal, até o final da Terceira República.

No Brasil, por outro lado, a democracia era bem menos consolidada e mesmo os valores liberais da Constituição de 1891 guardavam pouca ressonância com as práticas políticas concretas - basta lembrar que o sufrágio universal secreto apenas foi garantido na prática pelo Código Eleitoral de 1932. Assim, o contágio do diagnóstico de crise da democracia e a defesa de um Estado forte poderiam atingir dimensões mais largas em nosso debate constitucional, confortável até então com garantias meramente simbólicas das liberdades políticas e da proteção do indivíduo contra arbitrariedades do Estado. E poderiam também implicar em maior alteração legal, constitucional, e institucional. Não por outra razão, Vicente Rao critica o "individualismo à outrance", enquanto MirkineGuetzévitch, ainda que consciente da crise do parlamentarismo e das mudanças trazidas pelas novas cartas políticas, insiste em afirmar a compatibilidade entre democracia, individualismo e ação social do Estado, aproveitando o legado da Revolução Francesa. Para Pontes de Miranda, a técnica constitucional deveria enfrentar problemas como a liberdade e a democracia, sim, mas também a representação do trabalho (democracia econômica), a estrutura política, a guarda da Constituição, a distributividade dos bens materiais e a independência da Justiça, tendo como pano de fundo mais amplo o problema da integração social ${ }^{57}$. Sem dúvida, esses não eram simplesmente os problemas do "velho" liberalismo.

Quanto de liberalismo, e quanto de dimensão solidarizante e coletiva deveria ser mantido ou incorporado na nova Constituição? Que modelo de Estado estava sendo forjado no pacto político? A resposta a essas questões, na retórica dos atores envolvidos, ajuda a esclarecer semelhanças e diferenças entre o cenário francês e o cenário brasileiro.

O debate aparece, em primeiro lugar, na avaliação da Constituição de 1891. Enquanto na Subcomissão Itamaraty a tônica era de recusar a antiga carta como modelo e ponto de partida, na Assembleia Constituinte as percepções eram diversas. Vejamos. Afrânio de Mello Franco abre os debates da Subcomissão colocando a questão, e

${ }^{56}$ Cf. Les propos d'Alain ou l'idéologie de la Troisième République (1935), in CAPITANT, 2004, pp. 209/230.

${ }^{57}$ Cf. PONTES DE MIRANDA, 1937, t. I, p. 89. 
de certa forma posicionando-se na defesa da utilidade da Carta de 1891: "Há, desse modo, na constituição republicana, marcos que podem servir, pelo menos, de pontos de referência para a marcha da subcomissão. Alguns principios do pacto de 91 adquiriram, mesmo, verdadeiro prestígio e outros foram até a conquista de popularidade. Existem, portanto, motivos que aconselham a que se escolha a constituição de 91 para servir de base às discussões e deliberações, muito embora haja, também razões ponderáveis que indicam um trabalho novo, preliminar a qualquer decisão e justamente para tornar esta decisão mais precisa. A comissão escolherá entre esses dois alvitres" ${ }^{258}$.

Mas a resistência era grande, amparada pela ideia de que a democracia liberal estava em crise e uma Constituição moderna deveria partir de princípios distintos da anterior, deveria representar uma refundação desde a origem, ab ovo. Assim afirma Carlos Maximiliano, durante reunião da Subcomissão Itamaraty: "o pacto de 24 de fevereiro não tinha as necessárias válvulas ou os remédios precisos para evitar o descalabro que se observou. Muitos dos males foram, não há dúvida, devidos aos homens, mas muitos houve que procuraram soluções no pacto e nele não encontraram. $O$ mundo inteiro procura resolver, em seus pactos fundamentais, a questão social, cuja existência, no Brasil, é por muitos negada; mas, nem por isso devem deixar de procurar ir ao seu encontro, porque amanhã ele se apresentará, como uma fatalidade inevitável. Vê, com prazer, que o relator não esqueceu esse problema, consignando um capitulo de economia, ordem social e família. Estamos no momento crítico de resolver essa importantíssima questão, que deve trazer apreensões a todos os brasileiros. Abordemos, portanto, resolutamente o problema social, sob o prisma brasileiro. Vota para que, no próprio preâmbulo, se diga que a justiça social é a principal preocupação do novo estado brasileiro, contanto que se não desligue do espirito que devem encerrar todas as disposições, normas, direitos e deveres estabelecidos pela Constituição nova: o da unidade nacional. Tudo o que for contra esse espirito deve ser combatido, tudo o que for a favor deve ser admitido, desde que tenha por

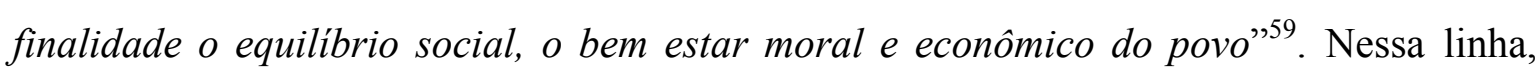
Oswaldo Aranha sustenta a possibilidade de que se parta de princípios gerais, "de fácil

\footnotetext{
${ }^{58}$ Afrânio de Mello Franco, $1^{\text {a }}$ Sessão (Subcomissão Itamaraty), p. 10.

${ }^{59}$ Carlos Maximiliano, $2^{\text {a }}$ Sessão (Subcomissão Itamaraty), p. 20. No mesmo sentido, Oswaldo Aranha sustenta que "Os princípios gerais são de fácil destaque e simples catalogação e não se precisa, para isso, ter como base a constituição de 1891. Presente esta, ter-se-á, forçosamente, de aceitar artigos e recusar outros, aprovar seções e rejeitar outras. O trabalho implicará forçosamente, portanto, numa revisão" $\left(1^{\mathrm{a}}\right.$ Sessão, p. 11).
} 
catalogação", recusando que a empreitada se faça como um trabalho de revisão da Constituição de $1891^{60}$.

Descarta-se, assim, a Constituição de 1891 como ponto de partida para os trabalhos, priorizando-se a adoção de princípios capazes de responder aos modernos anseios por justiça social, prevenindo conflitos futuros, bem como condizentes com a percepção do espírito (de viés anti-individualista) de unidade nacional.

Durante a Assembleia, a divisão reproduzia-se, sendo a referência ao individualismo da Constituição de 1891 uma parada obrigatória, seja para os que desejavam criticar seu excesso, sustentando a necessidade de um novo modelo (socialista ou corporativista com flerte autoritário, a depender da inclinação política do orador), seja para os que queriam ressaltar seus aspectos positivos, salientando a importância de não se descartá-lo por completo.

Zoroastro Gouveia, um dos poucos deputados socialistas, é enfático, durante discurso em que critica a postura de Guaracy Silveira, representante classista dos empregados: "Que aqueles que admiram a Constituição de 91, o individualismo dessa Carta magna e rendem o culto do seu intenso fervor às personalidades históricas, já hoje, do Sr. Assis Brasil e do Sr. Seabra, o façam! Que não tentem, porém, numa obra de sofisma, numa obra de insinceridade, querer convencer as massas e querer convencer os representantes do povo em nosso país, de que o fazem em nome do proletariado, em nome da democracia econômica, em nome da República socialista, com que sonham. Não! Esta não é a República dos sonhos de tais oradores! A República de seus sonhos é aquela mesma que, entretanto, já constituía uma desilusão para os Constituintes de 91: a república individualista, a república cesarista, instrumento preparado para garrotear todas as liberdades públicas, impedir o desenvolvimento da atividade partidária no País. Esse texto constituiu um compromisso, apenas, dos que queriam, no momento, dominar a situação, apoiado nos instintos predatórios, apoderar-se dos Estados, das províncias do Brasil, em beneficio das máquinas eleitorais que arquitetavam" $"$.

Outra crítica ao individualismo vinha acompanhada da defesa da necessidade da organização da sociedade brasileira em corporações ou sindicatos, de forma a valorizar os grupos intermediários na condução da política, em uma linha mais próxima

\footnotetext{
60 “Os princípios gerais são de fácil destaque e simples catalogação e não se precisa, para isso, ter como base a constituição de 1891. Presente esta, ter-se-á, forçosamente, de aceitar artigos e recusar outros, aprovar seções e rejeitar outras. O trabalho implicará forçosamente, portanto, numa revisão", Oswaldo Aranha, $1^{\text {a }}$ Sessão (Subcomissão Itamaraty), p. 11.

${ }^{61}$ Zoroastro Gouveia, 24/02/1934, vol. VIII, p. 405.
} 
do corporativismo. O discurso inaugural de Getúlio Vargas, abrindo os trabalhos da Assembleia Constituinte, vale-se do diagnóstico de harmonia das classes ${ }^{62}$ para defender a organização e o sindicalismo: “A organização do trabalho, no sentido que se lhe deve dar, num momento conturbado e de profundas transformações sociais e econômicas, como o atual, não pode realizar-se com proveito para as classes patronais e beneficio para os operários, senão mediante inteligente, ponderada e sistemática coordenação para conciliar e garantir os seus mútuos interesses. O fundamento sociológico da vida econômica é hoje a solidariedade. O princípio da livre concorrência cedeu ao da cooperação. As tendências solidárias propiciaram a formação dos agrupamentos coletivos, cada vez mais fortalecidos para a defesa dos interesses de grupo. Entramos na fase construtora do movimento sindicalista" ${ }^{\prime 63}$.

O incentivo ao associativismo e a valorização dos grupos intermediários sob o controle do Poder Público é a tônica também do Programa do Clube 3 de Outubro, ao defender a edição de uma legislação social que buscasse "conter os desmandos do individualismo econômico" 64 , e sustentar como premissa a organização social, já que " $a$ sociedade brasileira, constituída de molde a anular a influência das classes improdutivas e parasitárias, a fortalecer as produtoras e a fazer preponderar as trabalhadoras, em todas as suas modalidades (...) deverá ser organizada em partidos políticos, associações profissionais e instituições culturais, cuja atividade será regulada por lei, de maneira harmônica e equitativa, para que diminuam ou desapareçam as injustiças sociais e se evite a exploração de uma classe pelas outras" ${ }^{\circ 5}$. A posição terá reflexo, como se verá, no debate sobre qual democracia resultaria da nova carta política, se a liberal tradicional, ou se uma que garanta a representação de interesses dos grupos sociais organizados.

Por outro lado, apesar de compreenderem o diagnóstico de "falta de adaptação e de exequibilidade" da Constituição de 1891, nas palavras de Ewald Possolo ${ }^{66}$, outros constituintes, especialmente apegados à democracia liberal e ao combate ao Estado

\footnotetext{
62 "No Brasil, onde as classes trabalhadoras não possuem poderosa estrutura associativa, nem a combatividade do proletariado dos países industriais e onde a desinteligência entre o capital e o trabalho não apresentam, felizmente, aspecto de beligerância, a falta até bem pouco, de organizações e métodos sindicalistas, determinou a falsa impressão de serem os sindicatos órgão de luta, quando realmente são de defesa e colaboração dos fatores capital e trabalho com o poder público", in Getúlio Vargas, discurso inaugural, vol. I, pp. 116/117.

${ }^{63}$ Getúlio Vargas, discurso inaugural, vol. I, p. 116.

${ }^{64}$ Programa do Clube 3 de Outubro, vol. IV, p. 220.

${ }^{65}$ Programa do Clube 3 de Outubro, vol. IV, p. 193.

${ }^{66}$ Cf. Ewald Possolo, 27/02/1934, vol. VIII, p. 503. Curiosamente, os mesmos termos, "inexequibilidade" e "inadaptabilidade", são costumeiramente empregados para explicar o fim prematuro da Constituição de 1934, referência criticada em BONAVIDES e ANDRADE, 2006, p. 326.
} 
autoritário, ou à livre economia de mercado, a depender do caso, julgavam necessário manter alguns de seus valores individualistas, que se esforçavam por compatibilizar com os novos imperativos sociais e democráticos, na linha do que poderia ser então chamado de neoliberalismo, como visto. O movimento pode também ser compreendido como reação à constante ameaça, posteriormente concretizada, de que um regime autoritário se instalasse no Brasil.

Levi Carneiro é um exemplo da recusa à soluções autoritárias e da defesa das liberdades individuais na Assembleia Constituinte. Advogado e representante classista, alinhando-se à postura liberal da bancada paulista ${ }^{67}$ ao afirmar: "Em primeiro lugar, as Constituições de depois da guerra, que todos estamos manuseando e em que teremos fatalmente de nos inspirar, mais ou menos todas elas foram elaboradas nos tempos em que dominavam o pensamento político europeu dois perigos, assinalados por Sforza: o bolchevismo e o medo exagerado do bolchevismo... Foi debaixo dessas duas preocupações que se fizeram quase todas as Constituições europeias de depois da guerra. E como se estão elas portando, praticamente? (...) Em certo sentido, o caráter abstrato, o caráter extranacional ou supranacional, o caráter irreal e doutrinário dessas Constituições, pode facilitar-lhes a cópia. Entretanto, de mim direi, perante a Assembleia, que nessa emergência prefiro copiar a Constituição de 91, no que ela tem de bom, copiar, completando-a, corrigindo-a (Muito bem), atualizando-a, na expressão do honrado líder da bancada paulista [Alcântara Machado]"68.

A postura de combate ao pensamento autoritário, forte na Constituinte, demonstra, assim, a consciência da inevitabilidade de se enfrentar a moderna "questão social", com atuação estatal, respondendo inclusive às reivindicações socialistas, sem por isso deixar de sustentar a relevância da democracia liberal - a postura é mais próxima, assim, do pensamento dos franceses. É o caso de Raul Fernandes, que é incisivo nesse sentido: "Na social democracia, há duas coisas que se distinguem muito bem: primeiro, a

\footnotetext{
${ }^{67}$ Para a defesa da influência liberal das ideias da Revolução de 1932, veiculadas pela atuação da bancada paulista na Constituinte de 1933-34, cf. ALMEIDA, 2010.

${ }^{68}$ Levi Carneiro, 02/12/1934, vol. II, pp. 43/44. No mesmo sentido, a defesa do liberalismo de Vítor Russomano: "Reportamo-nos, porém, ao trabalho dos Constituintes de 91, devo dizer que, no meu fraco modo de pensar, eles fizeram o que tinham que fazer: não puderam fugir às determinações daquele momento histórico. Criaram uma obra digna, criaram uma obra que merece o nosso respeito, porque vinham de uma escola de liberalismo individual, vinham, principalmente, de uma preocupação de ordem republicana, contra o verbalismo do Império, que, durante sessenta anos, desacreditara o regime parlamentar (...). Chegamos, assim, Srs. Deputados, à Constituição de 91, organizando um Estado democrático, republicano, inspirados os Constituintes aos quais rendo o culto da minha admiração, porque (...) marcaram um passo na evolução da nossa Pátria, nos princípios filosóficos que, então, eram correntes nas academias: o individualismo e o liberalismo de Spencer, e, mesmo, o positivismo de Auguste Comte", 15/01/1934, vol. VI, pp. $45 / 46$.
} 
organização política que ela pleiteia dentro da qual precisa viver, só dentro da qual pode viver. Outra coisa é a sua política socialista, que se faz através dessa organização (...). O que os socialistas, hoje, no mundo, pleiteiam, o que pedem, a causa pela qual lutam com o maior denodo, é a manutenção da democracia liberal, porque é através dela que, pelo século XIX afora e em começos do XX, a massa proletária se elevou do nada em que vivia até as culminadas da política. A segunda internacional bate-se pelo regime democrático como último dos refúgios das liberdades conquistadas em um século de lutas. As proclamações, as mensagens, os livros, os programas, todos não pedem outra coisa; os social-democratas compreenderam, inteligentemente, que a maioria sendo de trabalhadores, o sufrágio eleitoral universal é o único modo de representação política que lhes assegura, fatalmente, uma larguíssima parte de influência, senão mesmo a preponderância. É por isso que todos os governos novos, governos de autoridade, inaugurados recentemente em países onde a crise política se complicou com as crises sociais econômicas da maior gravidade no mundo, investiram da maneira mais furiosa, brutal, desumana, contra a social democracia, em particular, e contra os liberais, de um modo geral ${ }^{\prime 69}$. Está aí a percepção de que os regimes autoritários não são senão uma resposta à chegada dos partidos de trabalhadores organizados ao poder pelas vias democráticas, e a necessidade de se prevenir tal radicalização, garantindo a possibilidade de conciliação do regime democrático com a realização de um programa social, não sem ressalvar que o programa socialista "não é obra das Constituições políticas e sim da legislação civil e fiscal ordinária. Ora, o projeto [de Constituição elaborado pela Comissão dos 26] não veda nem fecha nenhuma porta"70.

Vez por outra, a regulação do social pelo Estado vem justificada por referências aos sentimentos de solidariedade humana, saído quiçá “do elemento feminino ou do recinto dos templos", nas palavras de Carlos Maximiliano, "porque a moral sempre precede o direito"71. "Mais do que o bolchevismo, do que o medo do bolchevismo, os

\footnotetext{
${ }^{69}$ Raul Fernandes, 23/03/1934, vol. XII, p. 242. No mesmo sentido, afirmando a compatibilidade de intervenção econômica e social e democracia liberal, afirma Moraes Leme: "Será mister, para se colimar o fim almejado, imolar a liberdade? A reforma social exige que os indivíduos não tenham direitos, mas apenas deveres? Deve substituir-se a organização da liberdade pela organização da economia? $O$ desequilíbrio econômico não prova senão que a liberdade econômica precisa ser organizada. Não há princípio que não esteja sujeito a transformações. A própria supremacia da Constituição é limitada pela teoria da necessidade e pelo fato da resistência à opressão (...). Regular a liberdade econômica não é suprimi-la, mas organizála", in Moraes Leme, 27/02/1934, vol. VIII, p. 522.

${ }^{70}$ Raul Fernandes, 23/03/1934, vol. XII, p. 242.

71 "Começou unicamente pela assistência, porque a moral sempre precede o Direito; pela assistência piedosa, voluntária, saida do elemento feminino, ou do recinto dos templos. Pouco a pouco, esse cuidado se foi integrando, corporificando em textos meramente regulamentares; entrou pelo terreno legislativo
} 
sentimentos de solidariedade humana inscreveram todos esses belos princípios nas páginas das constituições modernas; porque, se é em nome da solidariedade humana que se exigem os mais pesados deveres, os mais onerosos encargos dos indivíduos (...) por que não atribuir, Srs. Deputados, a esse sentimento de solidariedade humana o princípio inspirador de todas as ideias sociais generosas, inscritas nos Códigos e nas constituições modernas?", afirmava Nilo Alvarenga ${ }^{72}$. Trata-se de mais um viés que assume a crítica ao individualismo, também próximo aos franceses, em especial aos vinculados ao catolicismo social, que buscavam sustentar a possibilidade de uma integração harmônica de classes, a partir de sentimentos de solidariedade ou de comunhão compartilhados por todos. Desnecessário lembrar o peso dos católicos no Brasil, e da Liga Eleitoral Católica, nos debates diários do país e da Assembleia Constituinte.

Os debates constituintes orientam-se, assim, em torno do diagnóstico de crise do liberalismo nos moldes do século XIX, que pregava em um Estado mínimo e garantias formais de direitos. Tal seria o modelo que a Constituição de 1891 teria buscado seguir, mas que, contudo, não teria passado de mero idealismo, como uma "ideia fora de lugar", conforme salienta Cepêda ${ }^{73}$. Por outro lado, mirando o futuro, ressaltavam a importância de responder aos anseios de transformação das condições sociais - por meio tanto de garantias formais de direitos quanto de prestações positivas do Estado - bem como de soluções solidaristas ou mesmo mais autoritárias, de estilo fascista, diluindo o indivíduo em corporações ou sindicatos. O caminho para a modernidade exigiria dos constituintes a elaboração de uma solução nacional que soubesse ser meio termo, um “justo meio", nos dizeres de Horário Lafer, entre o "liberalismo econômico individual exclusivista" e o "coletivismo ético-avassalador" ". Nesse embate, confrontavam-se vozes autoritárias e de certa forma admiradoras dos novos regimes europeus dos anos 1920 e 1930, sobretudo o italiano, algumas poucas socialistas e outras tantas defensoras de boa

ordinário e, hoje, em todos os povos cultos, figura até mesmo na Lei Suprema. Portanto, se apresentássemos ao Mundo uma Constituição individualista, como a de 1891, daríamos ao Orbe, além de uma prova pública de misoneísmo, de um atraso cultural verdadeiramente lamentável (Muito bem)", in Carlos Maximiliano, 27/11/1933, vol. I, p. 422.

${ }^{72}$ Nilo Alvarenga, 22/12/1933, vol. II, p. 545.

73 " A desarticulação do sistema colonial abriu as portas para a elaboração de uma Carta Magna com feições, gramática e finalidade genuinamente modernas. Sem denegar a importância da Constituição Federal de 1891, o descompasso entre sua concepção liberal e a existência de um estatuto oligárquico senhorial ancorado no latifúndio mercantil-exportador pode ser entendido como manifestação da clássica assertiva das ideias fora de lugar. Ao contrário, a Revolução de 30 configura-se como ponto limitrofe da ruptura que as forças do moderno vinham engendrando e abrindo, passada a etapa revolucionária, um novo espaço de construção das normas sociais no momento constitucional de 1934", in CEPÊDA, 2009, p. 212, mencionando a chave de interpretação proposta por Roberto Schwarz, em SCHWARZ, 2000 (1977), pp. $9 / 31$.

${ }^{74}$ Horácio Lafer, 16/12/1934, vol. II, p. 322. 
parte dos aspectos da democracia liberal, flertando com princípios da social democracia e do catolicismo social da época. Resta saber em que o modelo brasileiro ganhou feições particulares, o quanto admitiu de cada uma das correntes, em especial no que diz respeito à democracia e à regulação social presentes na Constituição de 1934, o que se verá com mais detalhe no capítulo seguinte.

Por ora, é importante destacar que a crítica ao liberalismo vinha também acompanhada de uma visão sobre o Estado, sobre suas funções e sobre seu papel de intervenção na ordem econômica e social. O desafio seria balancear um Executivo forte herança de alguma forma esperada dos ideais que orientaram a Revolução de 1930 e já concretizado pelo Governo Provisório e seus quase quatro anos de implementação de um programa de mudanças - e a garantia de direitos individuais e democráticos, em consonância com as premissas liberais veiculadas por parte dos constituintes. Não era um desafio simples, como aponta Alberto Venâncio Filho, ao analisar a Constituição de 1934: "as ideias mais democráticas, mais liberais, até quase conservadoras, ganhavam um cunho de esquerdismo, de sectarismo (...). Do ponto de vista substancial, como contrabalançar a necessidade de um Poder Executivo forte com os problemas brasileiros, e como esse Poder Executivo forte deve ser contrabalançado através da garantia dos direitos individuais?" 75 .

É importante lembrar que, a despeito da Constituição de 1891, o Estado brasileiro na Primeira República, ou mesmo antes disso, nunca poderia propriamente ser qualificado de liberal não-intervencionista, como visto no capítulo anterior, o que desloca um pouco a concepção liberal nacional. Mesmo desconfiado da utilidade da cópia das novas Constituições europeias, marcadas pelo que chama de "perigo do bolchevismo e do medo exagerado do bolchevismo", e sustentando ser preferível apenas melhorar a Carta de 1891, é o próprio Levi Carneiro, cuja defesa dos princípios liberais de 1891 já se mencionou, quem aceita a crítica de que não podemos falar em um modelo individualista e liberal no Brasil, nos moldes estrangeiros: "O seu [da Constituição de 1891] individualismo excessivo, não tanto quanto se tem por vezes afirmado, mas, afinal, individualismo excessivo, porque aquele era o tempo do individualismo", ao que contesta Odilon Braga: “Aliás, a tese não está convenientemente elucidada, porque, dentro da Constituição de 91, o Estado brasileiro interviu frequentemente, frequentíssimamente (...). A economia dirigida é uma invenção brasileira e, até, invenção paulista", "Exatamente,

${ }^{75}$ Alberto Venâncio Filho, in VENÂNCIO FILHO e LYRA, 1978, p. 101. 
estou de acordo", replica Carneiro ${ }^{76}$. Assim, o que Pedro Vergara chama de "liberalismo proteiforme" 77 já não podia ser comparado ao laissez-faire de tipo europeu do século XIX, mas implicava desde sempre em um Estado atuante na economia, um Estado forte, e uma democracia fundada em direitos individuais não tão concretos, fora do papel.

Fica mais clara, dessa forma, a postura dos representantes classistas, oriundos da indústria paulista, para quem era preciso preservar a orientação individualista, mas garantir a conformação de um Estado intervencionista protetor do nascente setor industrial. "O progresso e a cultura, diz Sondereguer, se devem principalmente à ação do indivíduo. Não podemos, portanto, esquecer, que nos princípios econômicos precisa estar sempre presente a realidade psicofísica dos indivíduos. Concordemos que o liberalismo econômico individualista pode e deve sofrer restrições, para que não perdure como um fenômeno resultante do simples e incontido egoísmo humano. Nunca, porém, poderá ser eliminado. O fator ético, penetrando a atividade da Economia Politica, prepara a ação social do Estado e dá-lhe um largo campo de projeção. Sendo o primeiro postulado da moral a solidariedade humana, o Estado deve proteger os fracos, amparar os desvalidos, auxiliar o proletariado, exercer, enfim, uma função reparadora das misérias da terra", afirma Horácio Lafer ${ }^{78}$, não sem antes destacar os avanços representados pela teoria liberal, especialmente a no campo da economia política ${ }^{79}$. Assim, a conclusão de Roberto Simonsen, ao compatibilizar individualismo e intervencionismo: "É porém pelo fortalecimento do indivíduo, valorizando-o, que o Estado poderá concorrer para que ele obtenha diretamente, no campo econômico, muito maiores benefícios de caráter permanente e cooperar de modo decisivo para o progresso da coletividade ${ }^{\sharp 0}$, de modo

\footnotetext{
${ }^{76}$ Levi Carneiro, 02/12/1934, vol. II, p. 48.

77 "Pode-se dizer que a história do Brasil é a história do seu liberalismo; é o proteiforme e o repetido conflito das suas aspirações de evolução, de progresso e de liberdade, com as bases conservadoras e moderadoras ou reacionárias da sociedade e do Estado", in Pedro Vergara, 25/04/1934, vol. XV, p. 471.

${ }^{78}$ Horácio Lafer, 16/12/1933, vol. II, p. 322.

79 “'A economia humana é governada pela Natureza, dominada pela Física, que formula as leis e constrói a ciência. E como a física vai buscar o átomo para as suas bases, a economia política se circunscreveu no seu atomismo que foi o homem. $O$ 'homo-economicus' surge em cena (...). Dessas bases resultou o individualismo, surgido do liberalismo econômico, que é o sistema que vivifica a ordem natural das coisas. Só o homem, estudado em sua realidade isolada, existia, e como o fim da Economia era estudar a ação econômica, na sua feição de jogo livre da natureza, a liberdade plena - determinada pela natureza livre constituía a estrutura do sistema econômico. Assim surgiram os Ad. Smith, os Malthus, Ricardo, J. B. Say, Stuart Mill, Blanque e outros. Não tardou, porém, a reação. A filosofia libertou-se da escravidão das ciências naturais; a alma, o ideal, o metafísico, começaram a nortear os sistemas. Ao lado da Natureza, surgia a Moral, ao lado do indivíduo, a sociedade (...). A organização institucional dos instrumentos de governo de qualquer povo moderno, no que respeita aos interesses econômicos, encontra essa grave escolha. Onde deve ter fim a livre ação do indivíduo e começar a do Estado? O estudo desse problema tem cansado muitas inteligências, fornecendo à literatura econômica abundantes e engenhosas teorias", in Horácio Lafer, 16/12/1933, vol. II, pp. 321/324.

${ }^{80}$ Roberto Simonsen, 30/01/1934, vol. VII, p. 122.
} 
que "podemos, pois, ser intervencionistas em nosso país, não porém para contrariar leis naturais, mas sim com o propósito de provocar situações em que a ação dessas leis se possa processar no sentido favorável aos nossos interesses" ${ }^{~} 81$. Nada mais conveniente aos empresários que buscavam o fortalecimento da livre economia de mercado, conforme as teorias econômicas liberais, mas desejavam para tanto contar com o impulso protecionista do Estado, sem o quê o ainda incipiente setor industrial não poderia se desenvolver ${ }^{82}$. A postura pode ser ilustrada na posição da bancada paulista na questão da representação profissional, de que trataremos no próximo capítulo (item 6.1.1), que se mantinha fiel à democracia de princípios liberais, ainda que concordasse com a necessidade de reformas. Conforme aponta Ângela de Castro Gomes: "se era necessário realizar alterações em matéria de política econômica e social, não era negando a validade das fórmulas politicas liberais - como a do sufrágio universal e do voto secreto - que se alcançaria a democracia" ${ }^{\prime \prime}$.

Não é difícil, desse modo, vislumbrar a diversidade de ideias postas à escolha dos constituintes, confrontados com a tarefa de formatar um Estado moderno, mirando o futuro, forte o suficiente para dirigir a economia, mas democrático o bastante para enterrar o velho jogo oligárquico de fraudes eleitorais. Um Estado que incorporasse as questões sociais, concedendo direitos e permitindo a representação de diferentes setores da sociedade brasileira, mas que prevenisse a crise da democracia dos países europeus, que deparavam-se com um Parlamento tão plural quanto imobilizado por seu pluralismo, e que prevenisse também um "contágio" mais amplo dos "problemas sociais", consciente dos conflitos decorrentes da incorporação das classe trabalhadoras ao jogo político institucional. Subjacente a isso, a recusa de uma solução autoritária, recusa essa vitoriosa na Constituição de 1934, e que de certa forma contribuiu para a sua curta duração, e a defesa intransigente de uma certa democracia, ainda que limitada por determinados parâmetros.

O tom dos debates pode ser ilustrado pelo discurso de Agamenon Magalhães: "Estamos num periodo a que os juristas chama 'férias da legalidade',

\footnotetext{
${ }^{81}$ Roberto Simonsen, 30/01/1934, vol. VII, p. 133.

${ }^{82}$ Eduardo Kugelmas identifica nessa postura dos representantes dos empregadores "o primeiro esboço do que posteriormente seria chamado 'desenvolvimentismo", na medida em que "em suas intervenções, reconhecia-se explicitamente o 'novo papel do Estado', como apropriado ao mundo moderno, porém, não deixavam de advertir na Assembleia Nacional Constituinte sobre 'os perigos do coletivismo' (...). Em outras palavras, favorecia-se a intervenção estatal enquanto incentivadora da atividade econômica, defensora de áreas de atuação específica para o capital nacional e promotora da industrialização", in KUGELMAS, 1987 , p. 31.

${ }^{83}$ GOMES, 1980, pp. 447/448.
} 
'legalidade do tempo de crise'; num regime em que, devido a solicitações do problema econômico ou social, o Poder Executivo reivindica funções legislativas imediatas (...). As fórmulas autoritárias hão de ser transitórias; são necessárias, mas não podem servir de padrão nem modelo às democracias. E se nós, no Brasil, apesar do influxo das transformações do Velho Mundo, ainda defendemos com veemência os princípios tradicionais das democracias, devemos aperfeiçoá-los, resguardá-los de deturpações constantes e permanentes, como as dos quarenta anos de República (...). Assim, economicamente, de acordo com as transformações sociais, neste fim de sistema capitalista, que vemos agonizando no mundo (apoiados); nesta hora em que a plutocracia atropelada, as indústrias, a lavoura, todas as forças econômicas se concentram em torno do Estado; nesta hora, o Estado tem que assumir o comando das forças sociais, mas dentro do regime de liberdade em que as restrições, condicionadas ao interesse coletivo, não anulem nunca o homem" "84. Ao Estado caberia a função mediadora, encarregado de encontrar o "justo meio" entre a preservação da liberdade e a intervenção social e econômica para a promoção da solidariedade e a prevenção do conflito.

O discurso de Magalhães expressa o constante temor de uma solução autoritária, consciente ainda da inovação que se promovia com a nova Constituição, que ao voltar-se para o futuro guardava sempre o risco de assumir-se como um compromisso transitório entre as forças políticas do momento, depositando no Estado a tarefa de geri-lo. Antes disso, a mesma perspectiva de que se estaria fundando um Estado forte, mas constitucional, em lugar de um puro governo de força, já estava presente nos debates da Subcomissão Itamaraty. Ao comentar a fala de Oswaldo Aranha, de que o Brasil ainda passaria por um "período de lutas, de transição", que poderia durar "7, 8, 10 e até maior número de anos", até que se resolvam os debates, os "rolos nacionais", Góis Monteiro afirma: "eu quero um Estado forte (...) o que não quer dizer que o prefira de forma ditatorial", e João Mangabeira nota que "é, a rigor, o Estado de um só partido", e que Oswaldo Aranha sintetiza: "essa Constituição que se está elaborando só vigorará depois que passar o período de transição do Governo brasileiro. Antes disso, o que vigora é a lei do general Góis Monteiro, escrita ou não; é um caso lógico. A subcomissão está votando uma lei, ou por outras palavras, está preparando uma casa de veraneio para um indivíduo que está doente. Ele irá para essa casa quando ficar bom. Enquanto estiver doente, é com o sr. Góis Monteiro que terá que se ver" ${ }^{\prime 85}$. Como se vê, não havia consenso em torno do

\footnotetext{
${ }^{84}$ Agamenon Magalhães, 11/12/1933, vol. II, pp. 206/207.
}

${ }^{85}$ Subcomissão Itamaraty, $29^{a}$ Sessão, pp. 595/596. 
que viria a ser o Estado e a democracia no Brasil, e as divergências transmitiram-se à Constituição.

A relação conflituosa com as premissas liberais e com a definição do modelo de Estado a ser implementado pela nova Constituição aparecem de forma bastante clara no relato de Oliveira Vianna sobre sua participação na Subcomissão Itamaraty, em que se compreendia como uma voz dissonante em meio aos demais membros, ou pelo menos ao que via como a maioria deles, apegados sobretudo à garantia da liberdade: "Convencido de que, no caso brasileiro, o problema de organização política nacional é, fundamentalmente, um problema de autoridade e não um problema de liberdade (...), minha atitude foi, ali, a de um dissidente isolado, dando a impressão de um espírito nutrido de ideias antidemocráticas, antiliberais, antiparlamentares e antifederativas e que, por isso mesmo, ninguém quis apoiar. Na verdade, o que me preocupava então - como agora e como sempre - era a Nação, uma e íntegra na unidade de sua consciência, incontrastável no prestígio e na autoridade do seu governo nacional. Os acontecimentos mostraram que a razão estava com o meu suposto reacionarismo e não com o liberalismo dos meus ilustres companheiros" $" 86$.

Retomando a divergência entre Vicente Rao e Mirkine-Guetzévitch, é possível traçar uma origem teórica de fundo para os debates entre críticos e defensores do liberalismo na época, origem essa que guarda paralelo com as questões tratadas pela doutrina francesa ao propor diferentes alicerces metodológicos para o Direito Público, transitando entre individualismo e coletivismo. É o mesmo Oliveira Vianna quem deixa clara essa polêmica de fundo, ao seguir com o balanço sobre a sua posição na Subcomissão Itamaraty: "No fundo, eles e eu assentamos as nossas concepções revisionistas em bases realísticas, de experiência, em fatos acontecidos e observados na prática das instituições a reformar. Diferíamos apenas nisto: é que para eles o objetivo da reforma era a organização da liberdade e para mim este objetivo devia ser a organização da autoridade, principalmente da autoridade central. Eles viam a Nação, mas do ponto de vista do indivíduo; eu, sem dúvida, também via o indivíduo e seus direitos inalienáveis, mas o via, e o vejo, do ponto de vista da Nação" ${ }^{\text {87 }}$. Em 1939, quando escreve em meio ao governo autoritário, mostra-se mais confortável no diagnóstico anti-liberal, como seria esperado. Porém, em 1933/34, a questão parecia estar mais aberta, impondo ao debate constituinte a

${ }^{86}$ VIANNA, 1939 , pp. $156 / 157$, nota 7.

${ }^{87}$ VIANNA, 1939, pp. 156/157, nota 7. 
busca por uma solução de conciliação e uma Constituição de fundamento teórico necessariamente sincrético, portanto.

\subsection{TÉCNICA JURÍDICA E IDEIA dE CONSTITUIÇÃo}

Mirkine-Guetzévitch destaca um traço comum das novas constituições do século XX, qual seja, ter-se confiado sua elaboração, não raro, a juristas, versados nas técnicas e doutrinas mais modernas do Direito: "Na elaboração das constituições novas, a ciência jurídica teve um grande papel. Se bem que os textos fossem o resultado de diversos compromissos politicos, de acordos entre os partidos, etc, o papel da 'técnica jurídica' não foi menos importante. Os teóricos do direito exerceram sua influência (...). Os críticos mais meticulosos devem reconhecer que, nas novas constituições, se refletem a supremacia do direito, a ideia da unidade do direito, enfim, toda a vida do Estado baseada sobre o direito e traçada por ele ${ }^{\Perp 88}$. O processo constituinte brasileiro de 1933/34 é mais um exemplo desse fenômeno.

Como já transparece no quanto exposto anteriormente, os debates, não apenas da Subcomissão Itamaraty, mas também da Assembleia Nacional Constituinte, são marcados por uma valorização da técnica jurídica, bem como da erudição e da familiaridade com as doutrinas mais atualizadas, inclusive e principalmente estrangeiras. Enquanto na França os juristas têm suas reflexões aguçadas por também participarem, de certo modo, da vida política, em especial aqueles que chamamos de juristas pragmáticos, chegando a ser classificados por Pinon de "juristas políticos" $" 89$, no Brasil há o que chamaríamos de "políticos juristas" - como visto, muitos dos políticos envolvidos nos debates constitucionais possuem, ao mesmo tempo, formação jurídica, que viria até mesmo a conduzir alguns deles ao posto de constitucionalistas ou teóricos brasileiros de destaque, caso por exemplo de Themístocles Cavalcanti ou de Carlos Maximiliano. A relevância atribuída à técnica jurídica é um terceiro aspecto geral a ser destacado acerca dos debates constitucionais de 1933/34, apontando para a conveniência de se cotejá-lo com a doutrina francesa dos anos 1920/1930 que, como visto, é frequentemente referida.

\footnotetext{
${ }^{88}$ MIRKINE-GUETZÉVITCH, 1933, pp. 39/40.

${ }^{89}$ A expressão é usada por Stéphane Pinon para caracterizar...., em PINON, 2003. Nesse caso, contudo, não se está adotando a mesma significação, na medida em que não estamos salientando a distinção, que julgamos inadequada, entre juristas "puros" e juristas conscientes da vida política da nação, mas sim a distinção entre juristas que também têm atuação política e políticos que também têm uma formação jurídica mais aprofundada.
} 
A questão da técnica jurídica era tematizada ao longo dos debates, a começar por aqueles da Subcomissão Itamaraty, onde seria mais natural, diante de seu caráter de conselho de especialistas (não necessariamente em Direito). Ali, o general Góis Monteiro ressentia-se do que acreditava ser sua deficiência de formação, declarando desde logo "sentir-se um tanto constrangido no seio da comissão por não ser jurista, sociólogo e legislador e que se julga apenas um informante ou portador da opinião de sua classe",90, ponto que reforça diversas vezes ao longo dos debates, inclusive manifestando intenção de abandoná-los após sua contribuição ao capítulo da Defesa Nacional e organização militar do país, confessando sentir-se "inteiramente off side" "91. Mas o destaque à técnica jurídica também era uma constante na Assembleia Constituinte, órgão que suspostamente teria características mais políticas e plurais.

Oportuna a fala de Levi Carneiro, destacando o aumento da importância da técnica jurídica: "Sr. Presidente, em um velho livro de já quinze anos - porque, hoje, os livros envelhecem muito depressa - um professor da Universidade de Paris, Joseph Barthélemy, lançava contra a Democracia uma posição fulminante: 'A Democracia é o governo dos governados, isto é, o governo dos incompetentes'. E estabelecia este dilema ameaçados: 'A Democracia é a forma de governo que exige mais técnica e, no entanto, a Democracia é a forma de governo em que se não exige preparo nenhum dos governantes'. Isso foi há quinze anos, mas depois, exatamente no período posterior à grande guerra europeia, a elaboração legislativa assumiu, em toda a parte do mundo, feição eminentemente técnica. A técnica jurídica ganhou tal relevância na confecção dos pactos constitucionais de todas as nações europeias, que, hoje, os publicistas mais vulgarizados apontam nela um dos traços característicos desses novos documentos políticos. Não é preciso recordar as expressões do já tão vulgarizado Mirkine Guetzévitch..." ${ }^{\text {. Citando }}$ Barthélemy - sem referência, contudo - Levi Carneiro buscava salientar contradição entre um Parlamento democratizado - mais aberto, portanto - e a complexidade crescente da legislação, ressaltando com isso o filtro que poderia representar a técnica jurídica à influência do "governo dos governados, isto é, o governo dos incompetentes". Não à toa buscava legitimar-se como um representante técnico, representante dos advogados do Brasil, cioso da defesa dos direitos de liberdade ${ }^{93}$.

\footnotetext{
${ }^{90}$ Góis Monteiro, $1{ }^{\text {a }}$ Sessão, p. 13.

${ }^{91}$ Cf. Subcomissão Itamaraty, $31^{\text {a }}$ Sessão, pp. 608 e ss.

${ }^{92}$ Levi Carneiro, 18/11/1933, vol. I, pp. 248/249.

93 “...tendo vindo aqui pelo voto dos advogados do Brasil e, como advogado, investido de uma representação profissional, quero exercer o meu mandato com o espírito da minha profissão, que não é apenas, como há
} 
O que poderíamos chamar de "excesso de bacharelismo", sintoma de uma Assembleia composta em grande parte por juristas, como visto, encontrava, vez por outra, resistência entre os deputados constituintes. Representativo dessa resistência é um discurso de Fábio Sodré, dedicado a sustentar a possibilidade e a conveniência de que médicos, como ele e como parte não desprezível da Assembleia, ou pessoas de outras formações, opinem sobre a nova Constituição: “A confecção de uma lei ordinária, máxime de uma ordem constitucional, não é obra jurídica, mas essencialmente política, essencialmente sociológica. A ciência jurídica é a ciência das normas do direito; estuda a interpretação e a aplicação dessas normas e cada vez mais se restringe a esse objeto, à medida que vai desaparecendo o direito consuetudinário. Não entra no estudo dos fundamentos das normas de direito e deixa à ciência política, à sociologia, o exame dos fenômenos sociais que interferem na criação das mesmas (Muito bem) (...). A sociologia, Sr. Presidente, não se aprende nos cursos jurídicos" $"$.

Aludindo ao que entendeu ser uma tentativa de Carlos Maximiliano de excluir os não juristas da obra constitucional, Fábio Sodré é enfático: “Do ponto de vista da cultura geral e sociológica tanto valem a esmeralda do médico, a safira do engenheiro, a turquesa do militar - como o dedo livre de pedras dos comerciantes, dos industriais e jornalistas, tanto quanto a pedra vermelha" ${ }^{\prime 2}$. Em aparte à fala, Agamenon Magalhães explicita uma distinção entre os dados e a técnica jurídica, responsável por filtrá-los, destacando a conveniência do jurista ir além do direito: "A sociologia, a filosofia, todas essas ciência oferecem dados; o jurista aproveita esses dados e traduz a necessidade coletiva de ordem geral. É a técnica. Por isso é que se diz hoje que, para saber Direito, é preciso conhecer além do Direito" 96 . Nessa direção, a manifestação de Marques dos Reis,

ainda quem suponha, de formalismo, de reacionarismo, mas, antes, de zêlo dos direitos individuais, de liberalismo (Muito bem), de preocupação pelos mais elevados interesses sociais, e do anseio reconstrutor, renovador com que todos os homens, hoje, encaram os alarmantes problemas da vida politica, no mundo inteiro", in Levi Carneiro, 18/11/1933, vol. I, p. 248.

${ }^{94}$ Fábio Sodré, 06/12/1933, vol. II, p. 98.

${ }^{95}$ Fábio Sodré, 06/12/1933, vol. II, p. 100.

${ }^{96}$ Agamenon Magalhães, aparte ao discurso de Fábio Sodré, 06/12/1933, vol. II, p. 100. No mesmo sentido, o discurso de Ferreira de Souza sobre a interface entre direito e política, citando os autores franceses: "Modernamente, Sr. Presidente, as constituições de após guerra, nós o sabemos, procuram regular problemas anteriormente estranhos a quadro do Direito Constitucional. O que pode, o que deve guiar a ação dos legisladores constituintes é a feição politica desses problemas, porque eles têm, sobretudo, de procurar apreender nos fatos sociais, observados atentamente, essa feição política, esse aspecto de vitalidade comum e a necessidade de consagrá-los ou não em leis rígidas, dificilmente alteráveis, como são as da classe a que no momento nos dedicamos (...). Efetivamente, a função de legislar não é, em rigor, uma função jurídica. Nem o legislador é, ou deve ser, indispensavelmente um simples jurista, um técnico do Direito (...) mas um político, um sociólogo, a quem as certas tendências intelectuais e uma feição cultural mais ou menos especializada permitem e possibilitam uma visão geral de todos os problemas sociais (...). Para nós, que não seguimos a escola de Duguit e de Kelsen, conceituando o Direito, em última análise, 
crítica ao jurista que não sai de seu gabinete, que nos faz pensar na imagem crítica proposta por Joseph Barthélemy do teórico trancafiado em sua "torre de marfim" - é preciso que o jurista conheça a realidade para a partir da técnica jurídica, ser capaz de dar uma solução juridicamente consistente e pragmaticamente adequada: "o verdadeiro jurista não é aquele que se confina nas paredes de um gabinete, numa construção livresca, doutrinária, catalogada, de opiniões, de ideias, de verdadeiras fantasias ou abstrações, mais ou menos estéreis, porque não está ele em contato com a experiência e com a própria vida ambiente. Acostumei-me a ver no verdadeiro jurista aquele que tem largas janelas abertas para o mundo e que, vibrando com as realidades palpáveis da existência, vai haurir aí a razão de ser das mutações legais, das mutações legislativas, na primeira transformação a que o direito, como verdadeira fenomenização natural, e não como mera abstração da mente de quem quer que seja, está submetido, constante e diuturnamente"97.

A técnica jurídica, e, mais do que isso, a erudição em termos de Direito, funcionava, de certa forma, como uma blindagem dos debates sobre a futura Constituição, na medida em que a exigência de seu conhecimento balizava o conteúdo e a valoração das falas na Constituinte. A começar pela elaboração do anteprojeto, conferida a um comitê de notáveis, em sua maioria com formação jurídica, seguindo-se pela instalação de um novo coletivo, a Comissão dos 26, dentro da Assembleia, e finalmente nas falas dos Constituintes em plenário, que não raro buscavam dar legitimidade às suas proposições valendo-se da técnica e da doutrina jurídica, com citações frequentes de teóricos renomados, vez por outra em outro idioma - predominantemente o francês.

Houve reação à blindagem ao debate constitucional também por parte de Zoroastro Gouveia, deputado socialista, denunciando a falta de representatividade da Assembleia e o distanciamento do povo, bem como o excesso de bacharéis, mas não sem se valer de metáforas em francês: "O povo cada vez mais se compenetra de que a Revolução de 1930 foi a 'journée des dupes ${ }^{98}$ no Brasil. Feita sagazmente pelos políticos,

como a vontade do Estado, manifestada nas leis, no Direito positivo, para nós que não ficamos no Direito objetivo e aceitamos, com Hauriou, Saleilles, Geny, Renard e Jellimark [sic - Jellinek?], o Direito subjetivo, é a combinação dessas qualidades que transforma o homem da vida jurídica num verdadeiro jurisconsulto. Como quer que seja, porém, a elaboração de uma lei, em toda a sua complexidade, inclusive no que tange às suas natureza e permanência, é trabalho eminentemente político ou jurídico-politico, nela intervindo o Direito positivo como técnica, como forma de realização, como encarregado do acabamento", in Ferreira de Souza, 10/04/1934, vol. XIII, pp. 559 e 562.

${ }_{97}$ Discurso mencionado em REIS, 1934, pp. 82/83, nota 2.

${ }^{98}$ Poder-se-ia traduzir como "dia dos Logrados (ou Tolos)", em francês no original. A referência remota, aqui, é novamente a França, e o episódio de 10 de novembro de 1630, em que Luís XIII dá a impressão de retirar sua confiança no cardeal Richelieu, para logo depois reafirmá-lo no comando do Conselho do Rei. A referência próxima parece ser a qualificação dada por Teófilo Ottoni à abdicação de D. Pedro I, em 7 de abril 
antes que o povo a fizesse, e com argúcia pelos políticos feita, para que o povo, afinal, na posse plena do poder, senão da soberania, que é apenas uma das ficelles constitucionais dos burgueses, não ditasse a lei do bem estar, a lei da solidariedade absoluta, tratando da política do sapato para todos, numa terra onde as endemias são, em grande parte, devido à falta do sapato, tratando da escola primária, como a Rússia (...) foi esta journée des dupes feita pelos políticos, repito, que, com isso deram prova indiscutível da sua sagacidade e da sua invencível capacidade tática, no fito de atalharem o passo à nação, tolherem o ímpeto ao povo (...). No seu seio [da Assembleia Constituinte] há mais bacharéis do que solicitadores e não sei se o fato constituirá grande vantagem para a nação, uma vez que o direito burguês, através a [sic] maioria dos seus seguidores qualificados, não passa de uma vasta esparrela armada à ignorância e às necessidades do povo, do proletariado (Muito bem)" $" 99$.

Menos incisivo, mas também consciente do processo de distanciamento do trabalho constituinte produzido pelo excessivo recurso à técnica jurídica, é Pedro Vergara: "As Nações, com efeito, se deram conta de que a guerra moderna não é mais um duelo de armas profissionais, mas uma luta de vida e de morte entre os povos, com a perspectiva de ser exterminado em caso de derrota. Este medo alucinante de desastres futuros, impossíveis de reparar, e sem limites, tornou a democracia inquieta: esse medo lhe tira a confiança em si mesma, torna tímida, e inclina, portanto, a se deixar arrastar à violência e à ditadura. Outro resultado da guerra é que ela confiou a sociedade à ação de peritos (...). Por consequência, a democracia, que é o negócio do homem médio, de senso comum, de esforço não especializado, não tem outro meio do que bater em retirada, $e$ deixar ao perito e ao técnico a direção" ${ }^{\prime 100}$. O discurso deixa clara a ideia de que a abertura democrática, acompanhada de um apelo crescente à técnica, podem representar impulsos

de 1831, como uma journée des dupes, em que os liberais se sentiram logrados pelos moderados que se beneficiaram de seu movimento para desestabilizar o governo.

${ }^{99}$ Zoroastro Gouveia, 23/12/1933, vol. V, pp. 35 e 37.

${ }^{100}$ Pedro Vergara, 25/04/1934, vol. XV, p. 473. Há uma certa rejeição da técnica, ou ao menos a consciência pragmática da inutilidade do recurso a teorias abstratas, também na fala de Vítor Russomano: "Na situação atual, o Brasil se encontra diante de três fortes correntes de doutrina. São elas: o anarquismo, o comunismo e o socialismo. Divergem no seu conceito. Umas querem considerar e erigir o Estado como transunto de todas as atividades humanas; outras, o eliminam por completo; mas todas as doutrinas concordam num ponto: guerra ao capitalismo, que consideram a escravização do homem pelo homem. Precisamos evitar os extremismos da direita e da esquerda. Precisamos construir, e não só destruir. O Brasil, por consequência, se encontra num dos momentos mais graves de sua vida (Apoiados).Tenho auscultado o pensamento de muitos Constituintes, e devo dizê-lo com franqueza: há, dentro dessa Casa, uma grande preocupação de técnica jurídica, de tecnicismo constitucional, de discussão de formas de governo, mas devemos considerar que as formas pouco importam ao povo e às massas (muito bem). Ele quer a satisfação de seus desejos, ele quer a realização de seus anseios. Seja rei, seja ditador, seja Presidente da República. Ao povo sorri sempre o sonho da felicidade necessária e indispensável às nossas condições humanas", in Vítor Russomano, 15/01/1934, vol. VI, p. 47. 
contraditórios no seio de um Parlamento moderno.

Os mais excluídos pelo artifício, contudo, foram os deputados classistas, especialmente os representantes dos empregados. Apesar da maioria possuir algum tipo de formação, como visto, não correspondiam à cultura geral predominante (salvo pelos representantes dos empregadores), e alguns de seus discursos, mais próximo do final dos trabalhos, denunciavam a não incorporação de suas propostas. Nesse sentido o discurso de Guilherme Plaster, em que assevera: "nesta Casa, foram elaboradas e votadas algumas leis em beneficio dos trabalhadores. Entretanto, tais leis, por terem sido elaboradas sem o concurso das partes mais interessadas, isto é, do proletariado, a quem se destinavam as mesmas, quase ficaram sem valor nenhum para os seus destinatários, como vou palidamente demonstrar" ${ }^{101}$. Bonavides e Andrade, em sua história constitucional, referem-se à "repulsa daquele corpo estranho pela tradição liberal mais forte", qualificando-os como "obscuros representantes sem representatividade, exercitando um mandato desprestigiado, como tribunos parlamentares de segunda classe, uma espécie de versão precursora do senador biônico" ${ }^{102}$. Também a deputada Carlota de Queiroz, única mulher e educadora, manifestou-se em apenas duas oportunidades ${ }^{103}$, assumindo um papel de pequena figurante no palco de embates entre os bacharéis, também ela recorrendo aos exemplos do direito constitucional estrangeiro para sustentar seus argumentos. A exclusão fica evidente ao retomarmos a divisão dos trabalhos no processo constituinte: como exposto no capítulo precedente, coube à Comissão dos 26, composta por um deputado representante político de cada estado federativo, mais quatro representantes classistas (Levi Carneiro, Euvaldo Lodi, Nogueira Penido e Vasco de Toledo), rever o anteprojeto da Subcomissão Itamaraty, analisar todas as emendas apresentadas e preparar o projeto substitutivo. Além do regimento vedar expressamente a participação nessa Comissão de pessoas de fora, inclusive outros deputados constituintes, seu presidente, Carlos Maximiliano, era explícito ao pedir que ali se desenvolvesse um trabalho técnico, evitando as disputas ideológicas e políticas da Assembleia: "Nas nossas assembleias há no recinto tempestades de eloquência; mas, enquanto lá a eloquência rebôa, há as abelhas que silenciosamente constroem tudo, quase tudo. Hoje mesmo, há escritores que afirmam Wilson, por exemplo - que de fato toda a obra das assembleias é feita pelas reuniões

\footnotetext{
${ }^{101}$ Guilherme Plaster, 16/04/1934, vol. XV, p. 24.

102 BONAVIDES e ANDRADE, 2006, p. 332.

103 13/03/1934 (vol. XI, pp. 268/281) e 14/04/1934 (vol. XIV, pp. 491/512).
} 
técnicas (...). A Comissão é um órgão técnico, falharia lamentavelmente, se acaso se transformasse em pequena assembleia" ${ }^{\text {104 }}$.

Não são poucas as referências aos debates teóricos, inclusive mais abstratos, que talvez tivessem pouco lugar em uma Assembleia Constituinte, não fosse pela pretensão de legitimar-se enquanto fórum não apenas familiar com a melhor técnica jurídica, mas também extremamente erudito e versado nas teorias mais atuais. Assim, por exemplo, no acirrado debate entre Mario Ramos e Clemente Mariani sobre a precedência do Estado ou do direito, e sobre a possibilidade de se conceberem direitos antes da ordem jurídica imposta pelo Estado ${ }^{105}$ - o debate pode, muito facilmente, ser relacionado com as preocupações teóricas mais abstratas dos juristas descritos na Parte I dessa tese, mas pouco diz respeito às preocupações mais concretas em questão na Assembleia Constituinte, a não ser por demonstrarem, novamente, o questionamento do pensamento jurídico mais liberal e individualista, centrado no indivíduo e no Estado personificado, e o recurso a concepções que inclusive flertam com um certo jusnaturalismo. Na mesma linha, a polêmica entre Homero Pires sobre a distinção entre soberania e autarquia, com referências, entre outros, a Jellinek $^{106}$. O debate sobre soberania aparece em alguns outros momentos, e trataremos dele no capítulo seguinte, ao abordarmos a questão da democracia (vide item 6.1.1).

\footnotetext{
${ }^{104}$ Carlos Maximiliano, Comissão dos 26, reunião de instalação - 16/11/1933, vol. X, pp. 6/7.

${ }^{105}$ Clemente Mariani: " $V$. Ex., então, quer os direitos como emanação da natureza individual, abstraída a existência do Estado. Permita, porém, dizer-lhe que o Estado é pressuposto do Direito, cuja força coativa tem de ser por ele assegurada. Fora do Estado, existirão normas de outra categoria, nunca, porém, normas jurídicas"

Mario Ramos: "Compreendo a declaração de direitos como a parte subjetiva, desejando seja ela a mais completa, a mais perfeita, a melhor possivel, em justiça e beneficio para o homem e, em seguida, coloco a formação do Estado de modo que pela sua função possa sustentar esses direitos, fazê-los viver na ordem material o mais dignamente e eficientemente possivel"

Clemente Mariani: "Mas concebe que esses direitos possam existir fora do Estado?"

Mario Ramos: "Acho que esses direitos precisam do Estado"

Clemente Mariani: "Seria preciso que encarasse o tipo de indivíduo fora do Estado. Esses direitos não têm qualquer valor senão dentro do Estado; não adianta, mesmo, estudá-los fora do Estado"

Mario Ramos: "Tenha V Ex paciência de ouvir-me..."

Clemente Mariani: "São simples observações"

Mario Ramos: “... pois, estou traçando um método filosófico de razão pura. A minha preocupação talvez inútil em direito é, primeiro, considerar a parte subjetiva, isto é, aquela que podemos imaginar perfeita e que chamo - declaração de direitos - em seguida, a parte objetiva, que chamo o Estado com todos os seus órgãos e as suas obrigações e, finalmente, colocaria em último lugar a questão das rendas, a sua divisão..." Clemente Mariani: "Ainda no Estado $V$ Ex. encontra uma forma subjetiva pelo exercício do poder. No Estado, o exercício do poder é função subjetiva do individuo como parcela do povo; no Estado democrático, com efeito, o povo é, ao mesmo tempo, o objeto e o sujeito do direito"

Mario Ramos: "com essa minha forma há de ver, entendo, que o Estado vem depois do direito, que o Estado é posterior ao direito, usa da força para sustentar o direito, tem por missão por seu mecanismo para sustentar o direito..."

Clemente Mariani: "O direito caracteriza-se pela força coativa, emanada do Estado. Social e filosoficamente, o Estado vem antes do direito; e do ponto de vista real, da realidade atual, o direito que temos que encarar é o que emana do Estado...", in Mario Ramos, 22/01/1934, vol. VI, pp. 321/322.

${ }^{106}$ Cf. Homero Pires, 30/11/1933, vol. II, pp. 21/23 e Homero Pires, 05/12/1933, vol. II, pp. 81/84.
} 
Pereira Lira, após destacar seu "amor à técnica constitucional" e destacar a importância de que se "faça no Brasil uma Constituição vazada nas últimas conquistas e aquisições do direito público contemporâneo", concebe a Carta como um momento de união, de conciliação entre a defesa das liberdades públicas e o aparelhamento do Poder Público para a ação, "vazada nas últimas conquistas e aquisições do direito público contemporâneo" ${ }^{107}$. Na sequência, refere-se, talvez um pouco impropriamente, diríamos, ao pensamento de Duguit: "As cartas constitucionais, no meu entender e no entender da generalidade, são verdadeiros armistícios entre os governantes e os governados (...). Sendo assim, fica estabelecida essa distinção inicial entre governantes e governados, o que não é uma tese subversiva, pois tem em seu apoio professor como Duguit, uma das vozes oraculares do pensamento jurídico e sociológico da França. Sendo assim, temos que admitir que toda a Constituição que é fruto da transigência, do acordo, do armistício entre governantes e governados, entre o poder e as massas, assegurando àquele o exercício do governo e a essas determinadas garantias e franquias - temos que admitir que toda a carta política, nascida nesse ambiente, tem caráter de provisoriedade. Não acredito, assim, em Constituições definitivas" "108. A posição ressalta a ideia recorrente da Constituição como um compromisso provisório, em um ambiente de pluralidade de doutrinas e soluções em disputa, em que um consenso não estava claro. Mas quais as fronteiras entre o que devia ser constitucionalizado e o que era matéria de lei ordinária? Não é simples responder.

A manifestação de Pereira Lira chama atenção para um último e revelador ponto, qual seja, a concepção que os constituintes faziam acerca do que deveria ser a própria Constituição, enquanto conjunto, quais os temas que nela deveriam vir disciplinados, e com qual detalhamento. Não raro, confundem-se técnica jurídica e diagnóstico político, para sustentar um modelo de Carta Política que seja mais ou menos extensa, e que incorpore, também mais ou menos, as demandas por regulação apresentadas ao novo Estado interventor e social, de forma a expressar um compromisso.

Nesse sentido, Godofredo de Menezes elogia o trabalho de Carlos

\footnotetext{
107 "Sou daqueles que, por amor à técnica constitucional e para permitir que se faça no Brasil uma Constituição vazada nas últimas conquistas e aquisições do direito público contemporâneo, uma Constituição que tenha acústica para todas as solicitações das liberdades públicas e, ao mesmo tempo, aparelhe o poder público das condições necessárias ao respeito e orientação do bem comum - sou daqueles que pensam que deveríamos abrir mão dos motivos políticos de separação, levantar uma bandeira de armistício no problema político, para que a elaboração técnica da Constituição, de que estamos incumbidos perante a história, não se ressinta dos defeitos, dos apressuramentos [sic], das transigências descabidas em matéria de princípios, de maneira que ela possa corresponder aos imperativos exatos do Povo Brasileiro", in Pereira Lira, 28/02/1934, vol. IX, p. 13.

${ }^{108}$ Pereira Lira, 28/02/1934, vol. IX, p. 14.
} 
Maximiliano, Levi Carneiro e Raul Fernandes, respectivamente presidente, vice-presidente e relator-geral da Comissão dos 26 , mas não sem criticar a prolixidade do resultado final: "Partidário embora de uma Constituição menos prolixa e casuística, que contivesse apenas as linhas basilares do nosso edifício institucional e político, que uma sábia e prudente legislatura ordinária completaria e solidificaria, verifico que, apesar da intervenção dos grandes lumiares da ciência jurídico-social, a que foi entregue a tarefa principal da elaboração constitucional, e destaco, como homenagem especial, data venia, Raul Fernandes, Levi Carneiro e Carlos Maximiliano, o Anteprojeto, como o Substitutivo, não puderam, ou não quiseram acompanhar as traças da Constituição de 1891 contendose dentro dos limites fixadores do arcabouço constitucional, propriamente dito, que se encontravam na nossa primeira constituição republicana, e entrou a dispor sobre matéria, mais condizente, pela sua flexibilidade e casuísmo, com a índole da legislatura ordinária" 109 .

Debatia-se, portanto, quão concisa deveria ser a Constituição, aproximando-se mais ou menos do modelo liberal das leis constitucionais francesas ou da Carta da Filadélfia, inspiração de 1891, ou adotando perspectiva mais abrangente, nos moldes das constituições sociais europeias do entre-guerras. É nesse sentido que Pereira Lira tratava da Constituição como "armistícios entre governantes e governados", citando Ortega y Gasset para defender um texto constitucional "tão amplo, com tal elasticidade, que o seu uso possa permitir que se aplique e se acomode às circunstâncias"110. A Constituição não deveria apenas voltar-se para o futuro, moldando o país que viria a ser, deveria também permitir acomodações, prevenindo demandas que viriam a surgir, função simbólica que poderia exigir um texto mais extenso e menos coerente com o que determinaria a "boa técnica" liberal do século XIX.

Nesse ponto, também a questão da possibilidade de revisão da Constituição, que muitos entendiam deveria ser facilitada, em conformidade com a percepção de que se estava elaborando uma carta provisória, capaz de estabelecer um consenso temporário, porque ainda pouco enraizado, entre as diferentes correntes que começavam a se definir no debate político nacional. "É manifesto que a possibilidade de revisão, fatual e não teórica, se constituía, como ainda hoje, no melhor preventivo contra os movimentos revolucionários que tanto sobressaltam a vida brasileira" ${ }^{111}$, escreve

\footnotetext{
${ }^{109}$ Godofredo de Menezes, 21/03/1934, vol. XII, p. 94.

${ }^{110}$ Pereira Lira, 28/02/1934, vol. IX, p. 15.

${ }^{111}$ Pereira Lyra, in VENÂNCIO FILHO e LYRA, 1978, p. 80.
} 
Pereira Lira tempos depois, sobre aquele momento histórico. Em seu discuros já citado ${ }^{112}$, o mesmo Pereira Lira apresenta a Constituição como um compromisso transitório, que, portanto, precisava contar com válvulas de abertura que permitissem sua alteração, conforme as demandas de seu tempo. Não poderia ser uma Constituição muito rígida.

Ponderando sobre isso, ao comentar a Constituição já promulgada, Pontes de Miranda chama atenção justamente para os riscos que uma Constituição excessivamente aberta a reformas teria em uma sociedade democrática e instável: "Nos povos de espírito conservador, os inconvenientes de tal insuficiência técnica [igualar processos de revisão constitucional ao processo legislativo ordinário] não são graves. Nos outros - em geral, nas repúblicas democráticas - impõe-se a Constituição rígida; somente ela salvaguardará dos embates e da mobilidade de opiniões a obra de formulação da linhas gerais, de estruturação estatal. Somente ela, casando a técnica ao dado (o imperativo ao indicativo, a arte política à ciência política) poderá assegurar a superioridade intrínseca da Constituição" ${ }^{\prime 13}$. Ao mesmo tempo que devia ser maleável, enquanto compromisso transitório, exigia-se que a Constituição estivesse preservada das oscilações políticas conjunturais, dilema que poderia ser equilibrado encontrando fórmulas mais ou menos abertas para as normas constitucionais. O desafio não era pequeno, e apresentava-se sobretudo à técnica constitucional.

Em conclusão, temos que os debates constituintes são marcados pela presença de um contingente mais plural do que de costume de representantes - ainda que muito pouco representativo da realidade nacional -, democratização acompanhada por um movimento paralelo de reforço da legitimação das falas pela familiaridade com a técnica jurídica e a erudição em geral. Demandas pragmáticas de adequação da Constituição à realidade nacional conviviam com referências a doutrinas cada vez mais plurais no diagnóstico da crise da democracia liberal, abrindo caminho para uma carta política prolixa e repleta de regulamentações díspares e pouco coesas. Entre garantias individuais e regulação social, liberalismo econômico e intervenção econômica, autoritarismo e democracia, estabeleciam-se compromissos transitórios, influenciados por doutrinas não raro conflitantes, resultando em uma Constituição que acabou tendo vida curta.

${ }^{112}$ Cf. Pereira Lira, 28/02/1934, vol. IX, p. 14.

${ }^{113}$ PONTES DE MIRANDA, 1937, t. I, p. 101. 


\section{CAPÍtULLO 6}

\section{UMA CONSTITUIÇÃO MODERNA E SOCIAL: DEMOCRACIA E DIREITOS SOCIAIS NOS DEBATES CONSTITUINTES}

6.1 Democracia e suas limitações; 6.1.1 Soberania e representação: qual democracia?; 6.1.2 Inclusão/exclusão: nacionalidade e direitos políticos; 6.2 Ordem social: entre direitos, princípios e tutela; 6.2.1 Direitos, princípios e finalidades sociais; 6.2.2 Intervenção social: formando o povo brasileiro

No capítulo anterior, apresentamos as considerações de ordem geral que os atores envolvidos no processo constituinte brasileiro formulavam sobre o modelo de Constituição a ser promulgada, condizente com um país que tinha como projeto a entrada definitiva na modernidade. Em primeiro lugar, destacamos a tensão constante entre a influência, significativa, das ideias, legislações e realidades de outros países, e a demanda pela elaboração de uma solução eminentemente nacional, conciliação nem sempre evidente. Importante, nesse ponto, lembrar do papel central que as ideias da doutrina constitucional francesa assumiam enquanto referências teóricas para os políticos-juristas da constituinte, especialmente para aqueles filiados à tradição liberal-democrática. Em seguida, tratamos da percepção generalizada de que as ideias liberais e individualistas precisavam ser conciliadas com uma visão mais social do Direito e da Constituição, movimento que sob alguns aspectos aproxima-se do que acontecia na França - à exceção de que, no Brasil, a redefinição das tarefas do Estado pôde ser incorporada à carta constitucional, pelas mãos de uma Constituinte pouco representativa da sociedade, mas bastante inclinada a prevenir potenciais conflitos que outros países vinham experimentando com a recente massificação da participação democrática. Por fim, mencionamos de que modo o direito e o ideal tecnocrático tiveram um papel determinante na orientação dos debates constitucionais, funcionando como um filtro obrigatório para as manifestações e formatando a linguagem específica das controvérsias. Cada vez mais, os problemas concretos e políticos tinham que ser traduzidos para a linguagem do direito, e no Brasil não foi diferente, especialmente ao se pretender elaborar uma Constituição que representasse compromissos de conciliação provisória entre as diferentes abordagens sobre o Estado e sobre a sociedade em jogo. 
A Constituição de 1934 seria fruto, portanto, de um esforço de síntese entre as ainda fortes correntes liberais e democráticas, e as novas correntes, seja centralizadoras e quase autoritárias, seja apenas socializantes. O resultado seria, como afirmaram Bonavides e Andrade, "uma colcha de retalhos (...) [em que] princípios antagônicos (formulados antagonicamente, inclusive) são postos lado a lado. Eles marcavam duas tendências claramente definidas, dois projetos politicos diversos. Um deles haveria de prevalecer" ${ }^{1}$. As contradições representariam, para os autores, o prenúncio de seu fim, uma Constituição, sem dúvida marcada por seu brilhantismo jurídico, mas dúbia, contraditória, incapaz de promover uma conciliação, uma síntese duradoura entre tendências tão díspares. Mas de que forma essas ambiguidades e indecisões se expressam nos debates e nos textos constitucionais? Como podemos, a partir deles, enxergar a lição histórica da Carta de 1934 sobre a forma como o social deixou de ser questão de polícia e foi institucionalizado redefinindo o papel do Estado e reposicionando a doutrina constitucionalista no Brasil?

Por certo, não são poucas as controvérsias durante o processo constituinte que espelham aspectos dessas divergências de fundo. Há extensos debates sobre a formatação do novo federalismo brasileiro, opondo centralização e descentralização de poder, sobre os casos de intervenção e sobre a repartição de receitas, ou ainda, em sentido próximo, sobre unidade ou dualidade da Justiça e sobre manutenção ou supressão do Senado, substituído pelo Conselho Federal. Liberais e autoritários opõe-se na formatação do capítulo sobre a Defesa Nacional e as Forças Armadas, tratando inclusive, e longamente, do estado de sítio, ou divergem, como nos discursos inaugurais da Constituinte, sobre a liberdade de imprensa versus a censura estatal, ou sobre a responsabilização do Presidente da República e dos Ministros de Estado. Discute-se, do ponto de vista da regulação social e moral, quanto de espaço deve-se abrir para conteúdos religiosos, especialmente católicos - aqui a proibição do divórcio e a menção a Deus no preâmbulo, por exemplo. Haveria de ser uma Constituição prolixa e moderna, nos moldes do que preceituava o constitucionalismo do século $\mathrm{XX}$, o que faz com que variados temas tivessem que ser enfrentados. Aparecem aí divergências que dificultam a construção de consensos duradouros, e impõem diversos acordos provisórios. Não haveria nesse trabalho espaço para tratar de todos.

\footnotetext{
${ }^{1}$ BONAVIDES e ANDRADE, 2006, p. 326.
} 
Ao tratar da visão geral sobre o que deveria ser a Constituição de 1934, fixamos o panorama geral dos debates constituintes, encarando-os como um processo de busca por difíceis conciliações quanto aos mais variados temas. Resgatando a preocupação que está no núcleo do trabalho, abordaremos a questão sob o ponto de vista da forma pela qual se lidou com a irrupção do social, e de que forma isso implicou em um novo formato de democracia e de Estado, no plano constitucional. "O conteúdo [da Constituição] reflete o que os autores da época chamavam o 'sentido social do direito', expressão mais ampla do que o nome Direito do Trabalho, porque abrange interesses e relações situadas em círculo mais largo do que a legislação trabalhista"2. Temos como hipótese que à expansão da regulação social na Constituição combinou-se, ao mesmo tempo, a preocupação em controlar a expansão dos direitos políticos e da democracia em geral. Assim sendo, elegemos como preocupação central a análise de alguns dos debates constituintes vinculados aos temas da democracia e da regulação social, buscando, neles, compreender os vetores em jogo na procura de um equilíbrio, de uma conciliação.

Trataremos, dessa forma, em primeiro lugar da democracia, ou melhor, do formato de democracia que resultou da gama de propostas em debate. O eixo de análise é a constatação de que a Constituição combina preceitos da democracia liberal a novas figuras, lidando-se a todo o tempo com os dilemas “quem deve ser representado?", e, antes disso, "quem deve participar ativamente dos processos políticos?", para ao final trazer uma democracia circunscrita a determinados parâmetros. A contraface da questão está na regulação social. Uma democracia política limitada deveria vir acompanhada de uma democracia econômica - no sentido de garantia material de igualdade - mais pronunciada, ao menos simbolicamente, se a preocupação era a prevenção de conflitos sociais. A Constituição não ganha o adjetivo "social" à toa, é permeada de dispositivos protetores de direitos chamados sociais, como os ligados ao trabalho, à assistência, à saúde e à educação. De que forma tais direitos são pensados do ponto de vista constitucional? E viriam eles no bojo, também como no caso da democracia, de um movimento maior de tutela, de ordenação social? A análise dos debates constituinte permite identificar alguns elementos para a resposta dessas questões, especialmente tendo em mente o recurso à doutrina francesa, que também deparava-se com o dilema da juridicização do social. Por certo, os caminhos são distintos. Ao final do trabalho, traçaremos conclusões buscando compreender de que forma os processos podem ser aproximados ou distinguidos, tendo

\footnotetext{
${ }^{2}$ FRANCO, 1981, p. 126.
} 
como balizas a democracia e a garantia de direitos sociais. Por ora, comecemos por verificar de que forma democracia e direitos sociais entrelaçavam-se na "colcha de retalhos" constitucional de que falaram Bonavides e Andrade.

\subsection{DEMOCRACIA E SUAS LIMITAÇÕES}

Como visto no capítulo 4, o maior impacto em termos de alteração da democracia brasileira nos anos 1930 havia sido causado pelo Código Eleitoral, o Decreto $\mathrm{n}^{\mathrm{o}}$ 21.076, de 24 de fevereiro de 1932. O código garantiu o direito de voto, facultativo, às mulheres, tornou obrigatório o voto dos homens e das funcionárias públicas, previu o alistamento eleitoral ex officio, ao lado do voluntário, e criou a Justiça Eleitoral. As inovações, destinadas a combater as constantes fraudes eleitorais da Primeira República, e a ampliar o número de eleitores, representaram um avanço, especialmente no que diz respeito ao primeiro objetivo, sendo menos eficazes quanto ao segundo. Junto ao código, estabeleceu-se a representação profissional na Assembleia Nacional Constituinte, ao lado da representação política. Muitas das inovações na democracia brasileira estavam, assim, traçadas, sendo posteriormente constitucionalizadas, confirmando a tese de Bercovici ${ }^{3}$ de que 1934 representa na prática apenas a inclusão na Constituição de normas já editadas pelo Governo Provisório.

Contudo, isso não significa que não tenha havido extenso debate na formulação da Constituição acerca do modelo de democracia que se queria ver implementado. Seguindo o propósito do presente estudo, prosseguiremos na análise dos discursos e opiniões dos atores envolvidos, buscando explicitar de que forma pensavam a nova República e a forma de funcionamento da democracia no Brasil. Em primeiro lugar, tratar-se-á da busca pela conciliação entre as premissas da democracia liberal e uma nova perspectiva de democracia característica da época, que considerava a representação dos grupos intermediários. Em seguida, veremos de que forma ao esforço de ampliação democrática combinava-se uma postura de exclusão de boa parte do povo dos direitos

\footnotetext{
${ }^{3}$ Cf. BERCOVICI, 2009, pp. 726 e ss. No mesmo sentido, o comentário de Antônio Marques dos Reis sobre os dispositivos constitucionais que tratavam dos direitos políticos e do alistamento, obrigatório ou facultativo, conforme o caso, remetendo ao quanto já previsto no Código Eleitoral de 1932, in REIS, 1934, p 230, nota 213. Na nota 214, Antônio Marques dos Reis lembra a presença de defensores de restrocesso em relação aos direitos já garantidos pelo código, como expresso na hoje risível defesa de Aarão Rebello de que se retirasse o direito de voto da mulher, de modo a evitar que, "tão excepcionalmente apreciada pelos seus atributos de coração e afetos, seja atirada à rua das maledicências políticas, ao turbilhão das paixões partidárias - deixemo-la no lar, como companheira dedicada, inspiradora e conselheira do homem deixemo-la no mundo dos seus afetos e de sua delicada sensibilidade" (p. 231).
} 
políticos, contribuindo para os índices de participação eleitoral do Brasil, baixíssimos quando comparados aos que eram atingidos em outros países na mesma época, onde a democracia de massas já era uma realidade mais concreta. Qual democracia se estava formulando, e quem poderia fazer parte dela ativamente?

São muitos os temas em que as respostas à pergunta acima aparecem: nos debates teóricos sobre soberania popular, nas polêmicas sobre a representação classista, sobre a extensão e perda da nacionalidade ou dos direitos políticos, sobre a implementação da Justiça Eleitoral e a manutenção ou supressão do Senado, sobre a determinação da proporção de representantes de cada estado da federação etc. Além e antes disso, até mesmo o sistema de governo estava aberto a discussões, sendo objeto de interessantes opiniões embasadas teoricamente, em especial na defesa do parlamentarismo, corrente ao final derrotada ${ }^{4}$. Elegemos apenas alguns dos tópicos, como recorte necessário, permitindo ao final apontar os direcionamentos, não raro contraditórios, que condicionavam a democracia que se queria ver implementada no Brasil, nesse início de século XX.

\subsubsection{Soberania e representação: qual democracia?}

Como ressaltado no item 5.1, o momento constituinte brasileiro estava contaminado pelo diagnóstico internacional de crise da democracia liberal e da inevitabilidade de se lidar, no plano constitucional, com a irrupção do social decorrente justamente da massificação da democracia. Influenciados pela situação política e pelos debates estrangeiros, especialmente europeus, as divergências entre os deputados, de um ponto de vista mais genérico, traçavam-se de acordo com seu apego ou crítica aos valores liberais. Por outro lado, buscava-se, como visto, dar à nova questão uma solução nacional. Quanto de liberalismo deveria ser incorporado ou mantido como base da democracia brasileira? À Constituição caberia dar alguma resposta.

Assim, afirma Pedro Vergara: "Porque certas nações não puderam ser governadas pelos princípios democráticos e se submeteram, voluntariamente, à ditadura induzem que a democracia está falida; e, como o Brasil atravessa uma crise normal de reorganização, sustentam que o Brasil não pode ser governado, também pelos mesmos

\footnotetext{
${ }^{4}$ Como principal defensor do parlamentarismo, destaca-se Agamenon Magalhães. Vide, por exemplo, seus discursos de 04/12/1933 (vol. II, pp. 65/78) e 11/12/1933 (vol. II, pp. 201/211), ou seu livro O Estado e a realidade contemporânea (MAGALHÃES, 1933). Ainda sobre o debate parlamentarismo x presidencialismo, cf. Rodrigues Dória (06/04/1934, vol. XIII, pp. 313/319), e sua defesa de um sistema misto, chamado por ele de "sistema de médias", ou Maurício Cardoso (18/04/1934, vol. XV, pp. 197/209).
} 
principios democráticos e que é preciso aplicar igualmente as ideias e tendências políticas do Brasil um sistema de galés. Nada mais calvo do que este erro" ". Divergindo quanto ao resultado final, excessivamente liberal, Pereira Lira critica, em sentido oposto, já indicando o que entendeu prevalecer na redação final da Constituição: "Tem-se falado em democracia liberal. O termo não me permite demorar no assunto, mas preciso dizer que também me inscrevi entre aqueles que não aceitam a democracia liberal com as formas correntes no século que findou e no ciclo de civilização que a grande guerra encerrou definitivamente. Depois do conflito europeu, a constituição econômica do mundo se transmutou sob várias formas. O liberalismo econômico de então vive hoje no espirito dos saudosistas de uma fase da Humanidade que não mais voltará. E, Sr. Presidente, quem matou a democracia liberal, no Brasil, foi esta Assembleia com a Constituição que foi votada aqui”.'.

Divididos entre as premissas liberais e as novas teorias e práticas constitucionais, mas em geral desconfiados da solução autoritária e, portanto, dedicados à construção de um regime democrático, os constituintes enfrentavam a seguinte questão: como formatar uma democracia efetiva, moderna e condizente com a realidade brasileira? Ou, nas palavras de João Pinheiro Filho: "Não creio na democracia liberal brasileira porque, homem da República, nascido e criado sob o influxo de ensinamentos e tradições paternas do mais puro idealismo republicano, eu cheguei, Srs. Deputados, à dolorosa consciente e irrevogável constatação de que tal regime nunca foi praticado no Brasil (...). Esperamos no regime que nos habituamos a chamar de democracia, Srs. Deputados, até que a filosofia de um novo Rousseau ou as promissoras experiências do estado integral corporativa convençam-nos definitivamente, de que devemos trocar de indumentária política. Mas (...) é esse o meu único apelo: façamos, pelo menos, uma democracia brasileira. Tenhamos a coragem cívica e intelectual de proclamar que não é possível a prática de um governo democrático no Brasil dos nossos dias, porque o governo do povo pelo povo pressupõe a existência da vontade popular arregimentada, independente $e$ consciente" ${ }^{, 7}$.

A compreensão da resposta que foi dada pela Constituição de 1934 passa, em primeiro lugar pela análise da forma como se compreendia a soberania, a organização popular e a representação nos Poderes Executivo e Legislativo. Aqui, mais concretamente,

\footnotetext{
${ }^{5}$ Pedro Vergara, 25/04/1934, vol. XV, pp. 471/472.

${ }^{6}$ Pereira Lira, 19/04/1934, vol. XV, p. 232.

${ }^{7}$ João Pinheiro Filho, 21/02/1934, vo. VIII, pp. 256/257.
} 
destaque deve ser dado ao conflito entre a compreensão liberal, de uma sociedade dividida apenas entre povo, enquanto conjunto de cidadãos atomizados, e Estado, e às perspectivas solidarista ou até mesmo corporativista, a depender do caso, que destacam o papel dos grupos intermediários na organização da política. Opunham-se, dessa forma, a visão clássica sobre a soberania nacional ou mesmo popular, origem primeira da legitimidade do Estado e fundamento da democracia liberal, a partir do primado do sufrágio universal, e a abordagem que considerava a integração entre Estado e sociedade organizada - posição que se articula com o que Oliveira Vianna vai chamar de "democracia autoritária"8.

As referências à soberania popular aparecem, por exemplo, na discussão sobre a inclusão de dispositivo enunciando que "todos os poderes da República emanam do povo e são exercidos no seu interesse, de acordo com a lei”, que figurava originalmente como artigo $2^{\circ}$ do esboço de projeto apresentado à Subcomissão Itamaraty ${ }^{9}$, de acordo com a proposta de Carlos Maximiliano. O dispositivo é suprimido na versão final do anteprojeto $^{10}$, sem que se reportem, infelizmente, os debates que justificaram a exclusão. Durante a Assembleia Constituinte, retoma-se a questão, com nova proposta de inclusão da noção de soberania popular pelo mesmo Carlos Maximiliano, que a justifica da seguinte forma: "Eu tinha proposto que, na parte preliminar, figurasse este preceito: 'todos os poderes emanam do povo e são exercido no seu interesse, de acordo com a lei'. Não aceitaram a minha sugestão, declarando-a desnecessária, inútil. Quando, das culminâncias do Direito Público Moderno, como Von Preuss e Hans Kelsen, incluem textos dessa natureza num código supremo, devemos desconfiar logo de que alguma razão presidiu a isso. Parece-me, até - e não há nisto a menor irreverência - que essa eliminação importa em desconhecimento da realidade contemporânea. Há 40 anos, quando imperavam, sem contraste, os princípios da Revolução Francesa, realmente todo o mundo sabia ser o Povo, soberano e todos os poderes dele provinham: porém, a guerra, sacudindo violentamente o mundo, provocou, entre outras coisas, o abalo até mesmo dos

\footnotetext{
${ }^{8}$ Cf. prefácio a VIANNA, 1939: "Há presentemente um vivo movimento de interesse em torno da velha tese da 'democracia liberal' e da nova tese da 'democracia autoritária'. Revivem-se antigos debates sobre a 'soberania do povo'; sobre o 'sufrágio universal'; sobre a 'representação política'; sobre o 'princípio da liberdade'; sobre o Estado Totalitário, contraposto ao Estado Liberal; sobre o 'princípio do chefe'; sobre as 'novas fontes da opinião democrática'; sobre a 'organização corporativa', etc. Obsevo, cheio de atenção e curiosidade, o embate de todas essas opiniões, manifestadas, em virtude de circunstâncias do momento, mais na intimidade dos pequenos círculos do que na arena larga do periodismo e dos comícios", p. XI. Mais adiante, Oliveira Vianna considera inclusive que, havendo uma opinião pública organizada e capaz de fazerse ouvir, "não seria absurdo imaginar-se a possibilidade de uma perfeita democracia funcionando sem eleições" (p. 230).

${ }^{9}$ Cf. Atas da Subcomissão Itamaraty, $2^{\text {a }}$ Sessão, p. 17.

${ }^{10}$ Cf. Atas da Subcomissão Itamaraty, $2^{\text {a }}$ Sessão, p. 22.
} 
princípios secularmente estabelecidos. Ranelletti (...) sustentou ser um absurdo a soberania popular; para ele, o povo, que é simples massa bruta, apenas um dos órgãos formadores do Estado, portanto a soberania não reside no povo, mas, no Estado. Agora mesmo esse semi-ditador, queimador de livros na Alemanha, declarou que é preciso acabar com o espírito de Weimar e estabelecer a soberania do Estado. (...). Dar soberania ao Estado é divinizá-lo, e isso tanto pode acontecer na República liberal, como até justificar a monarquia absoluta. O princípio por mim sugerido é estabelecido, portanto, de propósito: para nos garantir contra um perigo que está aos olhos de todo mundo" ${ }^{\text {11 }}{ }^{12}$. Tratava-se, portanto, de uma proteção contra ameaças autoritárias, formulada dentro da tradicional visão de separação entre Estado e sociedade.

Alguns, lembrando o debate teórico sobre a noção de soberania - não raro deixando clara a influência das ideias de Duguit ${ }^{13}$-, entendiam não ser conveniente

\footnotetext{
${ }^{11}$ Carlos Maximiliano, 27/11/1933, vol. I, pp. 434/436.
}

${ }^{12}$ De modo irônico, o representante dos empregadores João Pinheiro Filho explicita a tensão por trás da polêmica sobre a inclusão do dispositivo: "Ouvi com atenção a advertência grave e conselheiral do Sr. Carlos Maximiliano, sugerindo que se inscrevesse no pórtico da nova constituição brasileira, o velho dogma democrático, que ele cognominou de 'in hoc signo vinces' da República Nova: 'todos os poderes emanam do povo e devem ser exercidos no seu interesse, de acordo com a lei'. Ao som cadenciado dessa melancólica serenata democrática, lembrei-me de Jean Jacques, o boêmio peregrino das montanhas suíças, causador inconsciente de tantas desgraças, lembrei-me de Danton, de Marat, de Robespierre, da Bastilha, do sonho exaltado dos nossos constituintes de 91, reverenciei-os no mesmo culto liberal, mas concluí comigo mesmo que, no Brasil republicano pelo menos, nunca, jamais, em tempo algum os poderes emanaram do povo. E, como a aspiração generalizada é por uma carta constitucional que esteja de acordo com a realidade brasileira, concebi um substitutivo à indicação do ilustre Deputado pelo Rio Grande do Sul, nos seguintes termos: 'no Brasil todos os poderes emanam dos governos e das forças militares que lhes dão apoio'. Daríamos a César o que é de César, estaríamos perfeitamente brasileira, passada, presente e futura, e cometeríamos um elementar dever de piedade, livrando o povo, o humilde e pobre povo brasileiro, de arcar com as responsabilidades dos estados de sítio, das intervenções violentas nos Estados, das eleições secularmente mentirosas, dos escândalos administrativos e outros inqualificáveis abusos da força governamental", in João Pinheiro Filho, 21/02/1934, vo. VIII, p. 253.

${ }^{13}$ Ainda que o utilize impropriamente, dentro de um pensamento maior autoritário, é a doutrina de Duguit que parece estar por trás do pensamento de Pedro Rache, ao afirmar: "Embora vivamos sob o império das leis da sociologia, todavia não conhecemos as suas expressões particulares (...). Nelas devem figurar o homem, o espaço, o tempo, a tradição, o meio local, circunstâncias diversas, alguma dificeis de focalização. É da consideração de todos esses elementos, de sua combinação conveniente que resulta a grande lei do equilibrio social; é sobre essa lei de equilibrio social que assenta a politica. Daí, naturalmente, decorre o equilibrio que deve existir entre governantes e governados, para que a nação possa, francamente, seguir sua marcha de prosperidade. Ora, se vemos que, na lei sociológica, o homem entra como elemento, a característica do povo deve nela também entrar. Onde reside essa soberania popular que vai agir por influxo de uma lei da natureza? A soberania está na própria lei da natureza. A soberania não reside no povo (...). Não é, porém, lei natural a soberania popular. Ela é função da lei. Não podemos dizer que o caixeiro é igual ao patrão, embora aquele também possa receber dinheiro... Ela é, repito, uma função da lei; a lei é a soberania que impera, que domina; a lei natural é a soberania do universo. É ai que reside, de fato, a soberania. O mais é fiç̧ão, o mais é criação metafisica do direito natural, o mais é escamoteação dos senhores bacharéis", 06/01/1934, vol. V, pp. 413/414. Mais adiante, é contestado pelos colegas constituintes. Cardoso de Melo Neto: "O direito não é senão a transformação da lei natural na norma jurídica"; Odilon Braga: "O orador é de escola de direito divino?"; (...) Pedro Rache: "Não estou discutindo o direito, mas a soberania popular. Estou caracterizando-a, pesquisando-a, mostrando que ela não existe, demonstrando que os fenômenos políticos e sociais derivam de uma lei - a lei do equilibrio"; Morais Andrade: "V Ex. nega a soberania?!"; Pedro Rache: "Nego a soberania popular e aceito a soberania da lei, que preside os 
que se incluísse na Constituição a referência à soberania popular contida na locução "todos os poderes emanam do povo". Independentemente dos motivos mais concretos que poderiam estar por trás da recusa, especialmente a relação com a perspectiva de uma saída autoritária, os debates mais teóricos valiam-se dos autores estrangeiros também para refutar o conceito clássico de soberania ${ }^{14}$. É Homero Pires quem responde: "se Preuss e Kelsen fizeram consignar nos textos das Constituições aludidas esse princípio [da soberania popular], isso se explica facilmente. Nós, por exemplo, nos podíamos dispensar perfeitamente dessa declaração, inspirando-nos, entretanto, do seu espírito (...). A nova Constituição alemã, a nova Constituição austríaca sucederam, ambas, ao regime em que a soberania emanava de Deus. Era uma soberania teológica, profundamente teocrática. Tornava-se preciso, pois, que, essas novas sociedades, regidas por códigos e princípios novos, se governassem sob o conceito moderno, atual, por que elas iam viver. Por isso é que nas Constituições desses dois países se fez constar em cada uma delas o artigo respectivo. Nós poderíamos, também, tê-lo inscrito, mas, se o não fizemos, nem por isso poderemos ser censurados, porque nos é inteiramente inútil", ao que Odilon Braga contesta: "Nesse ponto, divirjo de V. Ex.". "Diverge-se de tudo, a começar de Deus",

fenômenos sociais, lei da qual o homem é função"; Morais Andrade: "Que entende, então, V. Ex. por 'soberania?"; Pedro Rache: "É o poder maior"; Morais Andrade: "Quem a detém?"; Pedro Rache: "A soberania - conforme é aceito universalmente - reside no povo"; Morais Andrade: "Nesse caso, como nega V. Ex. a soberania popular?"; Pedro Rache: "Pensa V. Ex. que estou repetindo lições dos outros? Estou repetindo meu trabalho. Penso, reflito e entendo que a soberania popular é um mito, não existe", in 06/01/1934, vol. V, p. 441. Sobre a polêmica, comenta Antônio Marques dos Reis, exaltando o caráter democrático do dispositivo: "Não havia na Constituição de 1891 disposição correspondente à do art. $2^{\circ}$, que serve para bem acentuar o caráter eminentemente democrático que presidiu à feitura da Constituição de 1934. É em virtude do mandato que o povo lhes confere que os seus representantes praticam os atos que são da mesma competência e atribuições dos mesmos. É o regime representativo de que nos fala o art. $1^{\circ}$ e o império do qual o art. $2^{\circ}$ é uma afirmação solene e irretorquível. Não teve razão o deputado Pedro Rache quando viu na enunciação do artigo uma simples 'criação metafísica", in REIS, 1934, p. 86, nota 9.

${ }^{14} \mathrm{O}$ debate teórico sobre democracia e soberania inspirado pelos autores franceses era bastante presente no direito público nacional do período. Cite-se, em primeiro lugar, o testemunho dado a Ana Lúcia de Lyra Tavares por Afonso Arinos de Melo Franco, Pedro Calmon, Miguel Seabra Fagundes, Evaristo de Moraes Filho e Lizst Vieira, que, ao relembrarem os debates da época, mencionam Duguit como referência central cf. TAVARES, 1988, pp. 123 e ss. Em seguida, como exemplo, mencione-se os artigos de Sampaio Dória publicados na Revista da Faculdade de Direito de São Paulo de 1930. O Professor daquela faculdade dialoga com Duguit sem mencioná-lo, ao manifestar sua posição sobre Estado, legitimidade e soberania: "Menos se sustenta a doutrina, perigosa e sedutora, de que o poder político não é nunca legítimo ou ilegítimo em sua origem (...). Para esta escola, é esta a origem única do poder: a maior força que se impõe, seja ela puramente material, ou seja força moral e religiosa, seja a força intelectual e econômica, ou a força do número, a maioria organizada em partido. Mas sempre esta verdade: o poder é uma questão de fato (...). ' $O$ fato simples e irredutível é a distinção positiva entre governantes e governados' (...). Não há dúvida que o traço mais saliente do poder político é a força que ordena e obriga. Mas esse traço não exclui a legitimação do poder no consentimento dos governados", in SAMPAIO DÓRIA, 1930 (2), pp. 301/303. O mesmo Sampaio Dória, ao tratar de democracia, é enfático ao destacar a soberania popular como elemento indispensável da democracia: "Há povos onde a origem do poder é a vontade dos governados, e povos em que o poder de dar ordens é direito dos governantes. Os primeiros são democracias, e os segundos a sua antitese", in SAMPAIO DÓRIA, 1930 (1), p. 163. 
responde Homero Pires, e Odilon Braga conclui, explicitando sua contrariedade: “Aliás, é um direito que tenho, o de divergir dos colegas" $"$.

O resultado da polêmica reverteu a orientação proposta pela

Subcomissão Itamaraty, incluindo no texto final o artigo 2: "todos os poderes emanam do povo e em nome dele são exercidos". Simbolicamente, mantém-se uma das premissas básicas da democracia liberal, a soberania popular, cedendo a uma das correntes fortes na Constituinte $^{16}$. Isso porque afirmar que o poder emana do povo é reconhecer como fonte de legitimidade do Estado a origem de seu poder de dominação, conferido pelo mandato popular - já vimos, especialmente com Carré de Malberg, a relevância dentro da teoria do

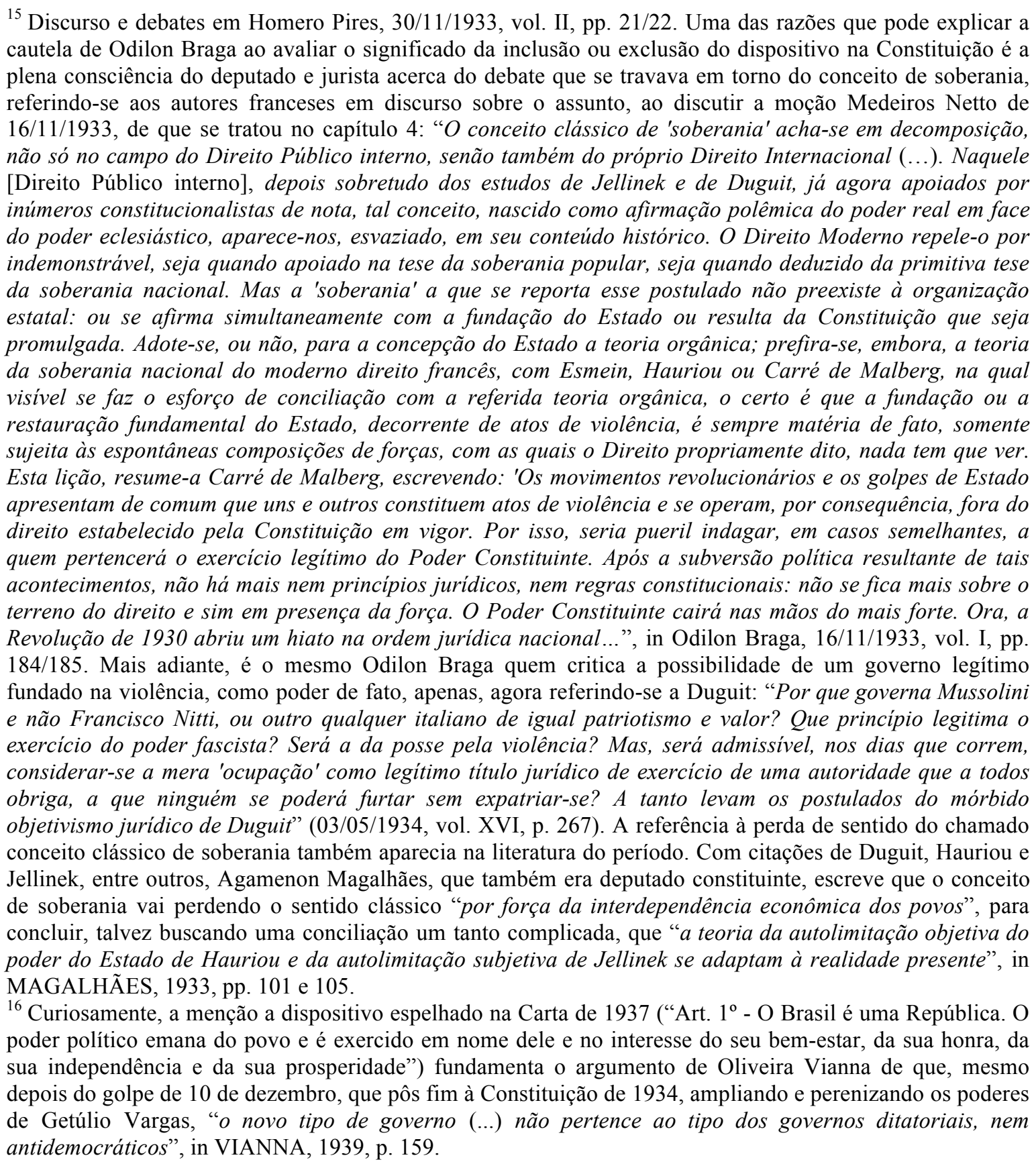


Estado e do direito constitucional que chamamos clássico de se afirmar que a soberania reside no povo ou na nação. A premissa considera como titular último do poder o povo, conjunto de indivíduos, de cidadãos, que deve ser representado no poder político, arranjo diferente de se pensar a política como representação de interesses a serem coordenados em cooperação do Estado com a sociedade civil organizada. Há uma visão distinta sobre a soberania, que marca a democracia liberal pura e as novas formas de democracia que estavam sendo propostas, e a divergência aparecia na constituinte brasileira.

Apesar da manutenção bastante simbólica da origem popular do poder como norma expressa da Constituição, certo é que as formas da democracia liberal estavam sendo postas em questão, especialmente a ideia de representação política parlamentar clássica. O principal indicativo disso é o debate sobre a representação profissional, assunto mais estudado quando se trata da Constituição de 1934, única na história do país que a previu. De máxima relevância para que se compreenda qual democracia resultou daquela carta constitucional, é importante que dediquemos algumas linhas ao tema, lembrando, contudo, que é matéria que já foi objeto de estudos mais detalhados, aos quais nos remetemos para aprofundamentos ${ }^{17}$. Caberão aqui aspectos gerais, permitindo que tracemos um painel sobre a democracia na Constituição de 1934.

A tensão entre soberania popular e representação de classes aparece logo no preâmbulo da Constituição, em que são os "representantes do povo brasileiro" que a decretam e promulgam, sem mencionar os representantes das categorias profissionais, também responsáveis pela Carta. Reporta-se a existência da emenda 449, derrotada, de autoria dos deputados classistas Antonio Rodrigues, Antonio Pennafort, Alberto Surek e Guilherme Plaster, mandando dizer, além de "representantes do povo", "representantes das profissões". Conforme comenta Antônio Marques dos Reis, "redigido como está, parece que os representantes classistas não decretam e promulgam a Constituição, tarefa atribuida somente aos 'representantes do povo" ${ }^{18}$. A polêmica é apenas mais um indicativo de que a Constituição haveria que encontrar um ponto de equilíbrio entre a representação política clássica e a nova forma de representação que se estava propondo, fazendo com que o modelo resultante, híbrido, guardasse alguma coerência interna.

"A representação profissional é um dos problemas que o movimento sindicalista colocou diante do Estado Moderno", escreve Agamenon Magalhães ${ }^{19}$. A

\footnotetext{
${ }^{17}$ Vide especialmente GOMES, 1980, TAVARES, 1988, CEPÊDA, 2009, BARRETO, 2004.

${ }^{18}$ REIS, 1934, p. 83, nota 4.

${ }^{19}$ MAGALHÃES, 1933, p. 69.
} 
realidade internacional apontava para a necessidade de incorporação das organizações à política institucional. Em termos legais ${ }^{20}$, mencione-se a lei italiana de 17 de maio de 1928, que sob a égide do Estado corporativo fascista - "tudo pelo Estado; nada contra o Estado; nada fora do Estado" - garantia a designação de representantes pelos grupos profissionais e legais socialmente reconhecidos; na Espanha, a Assembleia convocada em 1927 contava com representantes dos grupos intelectuais e da produção; em Portugal, a Constituição de 1933 institui uma Câmara Corporativa; na França, o Conselho Nacional Econômico de 1925 dava voz aos grupos profissionais organizados, ainda que em caráter consultivo. Havia também suporte doutrinário para a representação profissional - destaque-se Roger Bonnard e Léon Duguit, para quem era importante que o movimento sindicalista se revertesse em efetiva representação de grupos, como visto. Para Tavares, Duguit chega a ser a principal referência doutrinária mencionada pelos atores políticos e teóricos do período por ela entrevistados ${ }^{21}$.

Debatiam-se a conveniência e as diversas formas pelas quais poderia se dar a representação profissional. Sistematicamente, aglutinam-se em torno de três correntes $^{22}$. A primeira recusava a adequação da solução, não por divergências de fundo, mas sim por observar pragmaticamente sua inviabilidade, já que, "embora reconhecendo a importância da presença das forças econômicas em nivel governamental, apresentava uma série de razões para demonstrar [su] inviabilidade ${ }^{\text {"23 }}$ - a referência para essa corrente, apontada por Tavares, é Joseph Barthélemy ${ }^{24}$. Havia, em segundo lugar, os adeptos da solução, flertando abertamente com a ideia de Estado Corporativo, divididos entre os mais entusiastas, que acreditavam na representação exclusivamente profissional, e os defensores de um sistema misto. Por fim, a terceira corrente, inspirada no caso francês, entendia conveniente que a representação profissional funcionasse para a composição de órgão consultivo, como nas propostas de criação de conselhos econômicos e sociais ${ }^{25}$. Conforme

${ }^{20}$ Cf. TAVARES, 1988, pp. 31/39.

${ }^{21}$ TAVARES, 1988, p. 45: "Mais uma vez, portanto, o Brasil não ficara imune às reformas políticas europeias. Experiências promissoras, fracassos inequivocos, projetos, doutrina, tudo era, atentamente, acompanhado por nossos juristas e politicos. Neste ano de 1984, ao voltarem os olhos para aquele ensaio brasileiro de representação profissional, todas as ilustres personalidades que honraram a autora deste trabalho com seus depoimentos acentuaram a importância da prática corporativista italiana sobre os advogados daquela espécie de representação. Alguns incluíram também os exemplos de Portugal, da Áustria, da França, da Itália, da Espanha e da Suíça. No campo doutrinário, a lembrança geral foi para os nomes de Duguit e de seu discípulo Bonnard". A autora entrevistou Afonso Arinos de Melo Franco, Pedro Calmon, Miguel Seabra Fagundes, Evaristo de Moraes Filho e Lizst Vieira.

${ }^{22}$ Divisão proposta por TAVARES, 1988 , pp. $27 / 31$.

${ }^{23}$ TAVARES, 1988, p. 29.

${ }^{24}$ Cf. os argumentos em TAVARES, 1988, pp. 29/30.

${ }^{25}$ Sobre o assunto, vide a tese de doutoramento de Marcel Prélot (PRÉLOT, 1924). 
aponta Ângela de Castro Gomes, na no debate constituinte, após a experiência do Código Eleitoral, já não havia praticamente defensores da pura e completa exclusão da participação das classes na vida política, sem direito a voz em qualquer espaço, bem como não havia sustentação para um parlamento exclusivamente corporativo ${ }^{26}$. A solução haveria que estar em algum ponto intermediário.

A representação profissional, em caráter deliberativo, já constava do Código Eleitoral, e foi imposta às eleições da Assembleia Constituinte, como já comentado no capítulo 4 (item 4.3.2). Os representantes classistas trabalhariam ao lado dos representantes políticos. Como visto, Vargas era entusiasta da representação profissional, enxergando nela não só a expressão da desejada cooperação de classes, como também, mais pragmaticamente, a possibilidade de rearranjo das forças políticas hegemônicas durante a Primeira República. Na abertura solene dos trabalhos da Comissão Itamaraty, sustentou o Chefe do Governo Provisório: “Ao direito cumpre dar expressão e forma a essa aliança [das classes] capaz de evitar a derrocada final. Tão elevado propósito será atingido quando encontrarmos, reunidos numa mesma assembleia, plutocratas $e$ proletários, patrões e sindicalistas, todos os representantes das corporações de classe, integrados, assim, no organismo politico do Estado" ${ }^{\text {27 }}$. Com fundamento mais teórico, inspirados por Alberto Torres e sobre uma visão não liberal sobre a relação entre Estado, sociedade e grupos intermediários, essa modalidade de representação também era um dos pontos centrais do Clube 3 de Outubro, que buscava conciliá-la à clássica, afirmando: “ $o$ Poder Legislativo emanará da soberania popular, mediante um sistema de representação, constituído em câmaras representativas das forças políticas nacionais e em câmaras representativas das associações profissionais organizadas e dos institutos e forças culturais do país"28.

$\mathrm{Na}$ Subcomissão Itamaraty, o assunto gerou divergências que estão registradas especialmente nas atas das $5^{\mathrm{a}}$ e $6^{\mathrm{a}}$ sessões. Themístocles Cavalcanti defende a proposta $^{29}$, alinhando-se entre os mais radicais ao afirmar: "Se eu tivesse que dar o meu

\footnotetext{
${ }^{26}$ GOMES, 1980, p. 438.

${ }^{27}$ VARGAS, G. D., As diretrizes da nova política do Brasil, Rio de Janeiro, José Olympio, 1942, p. 209, apud TAVARES, 1988, p. 63.

${ }^{28}$ Programa do Club 3 de Outubro, vol. III, p. 194.

${ }^{29}$ Vale lembrar que ele é responsável pelo prefácio e por anotações à tradução brasileira de 1938 de Sindicalismo, Corporativismo e Estado Corporativo, de Roger Bonnard (1937). Posteriormente, ao combater as "falsas interpretações" de suas posições, especialmente vinculando-o às ideias fascistas, Themístocles Cavalcanti afirma que "é preciso compreender que uma determinada solução nem sempre exige do seu defensor uma vinculação com determinada ideologia (...) e isso tanto mais se justifica no caso particular, quando nunca se pretendeu substituir a representação corporativa, mas apenas injetar uma pequena dose de representação profissional no corpo legislativo, em uma só Câmara", in T. CAVALCANTI, Tópicos de uma
} 
voto, sem atender a outras considerações que não as de caráter puramente ideológico, opinaria por uma pequena Assembleia, técnica, profissional, organizada por meio de representação de classes. Mas, bem compreendo que estamos em um periodo de transição entre o sistema individualista-democrático e um regime novo absorvido por preocupações sociais e cuja estrutura política tem um caráter eminentemente prático, que não permite ilusões a respeito da eficácia dos grandes parlamentos constituidos pelo sufrágio universal. De sorte que temos que aceitar um regime misto, de transição, que acompanhe a revolução sem desprezar interesses ainda preponderantes. Por isso, transigindo diante de tais imperativos, voto por uma Assembleia só, com dupla representação, uma política e outra de classe, com funções conjugadas e número reduzido e limitado de membros" ${ }^{\prime 30}$. João Mangabeira é adepto da solução mista, "porque se é exato que cada um vota como indivíduo, sob uma modalidade, não menos certo é que quando vota pela classe o espírito do eleitor é outro. O indivíduo tem, muitas vezes, sua opinião pessoal, mas, reunido, mesmo em família, sofrendo outras influências, como as tradições dos mais velhos e os preconceitos rigorosamente mantidos, embora contrário a um ponto de vista levantado, acaba arrastado pelo voto dos demais. O mesmo ocorre nas profissões. Quando o pedreiro vota como eleitor, profere um voto individual; mas quando vota como proletário, num dia determinado, com o consenso de sua classe, sua representação é outra" ${ }^{31}$. Oswaldo Aranha $^{32}$, Góis Monteiro e José Américo também são pela representação profissional deliberativa em caráter misto.

História Política, Revista de Ciência Política, Rio de Janeiro, vol. 21, jul/set 1978, p. 16, apud TAVARES, 1988, p. 66.

${ }^{30}$ Themístocles Cavalcanti, $5^{\text {a }}$ Sessão (Subcomissão Itamaraty), p. 69.

${ }^{31}$ João Mangabeira, $5^{\text {a }}$ Sessão (Subcomissão Itamaraty), p. 71.

32 "todo brasileiro deve ter o voto - diga-se assim - democrático. Até hoje tem-lhe sido assegurada a expressão individual, partidária, política de sua vontade. Mas esse mesmo cidadão deve ter seus direitos acrescidos com o de votar dentro de sua classe e pela sua classe", Oswaldo Aranha, $5^{\text {a }}$ Sessão (Subcomissão Itamaraty), p. 73. Mais adiante, explicita a ideia de que o Brasil deveria caminhar para o Estado Corporativo: "Ora, se o povo é um conjunto de classes, convém dar representação às classes para que o povo seja representado; e, não, dar representação ao povo para que as classes o sejam (...). Entende indispensável a organização do país que, ao que se pode chamar voto individual ou democrático, dentro do qual ele tem vivido, se acresça de um conteúdo com significação coletiva, qual o voto das classes (...). A experiência de países daqui ou dacolá, nada influi para o Brasil. Esperar que as classes entrem em luta umas com as outras para depois lhes dar representação é o mal dos países velhos, que, por isso mesmo, estão se debatendo nos duros e amargos dias de hoje. Foi justamente porque não deram, em tempo, representação às classes e não foram corrigidos, através da experiência e do interesse dessas classes, os males de que hoje está sofrendo o mundo inteiro que se deve prever para prover (...). No Brasil devia-se - e infelizmente não se o pode conseguir desde já - caminhar para o estado corporativo, ou seja justamente fazer que o voto se torne a

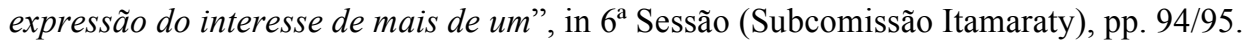


Por outro lado, manifestavam-se contrários à inovação Agenor de Roure, Prudente de Moraes Filho, Carlos Maximiliano ${ }^{33}$, Antônio Carlos e Arthur Ribeiro. Agenor de Roure combate a proposta apoiando-se nas premissas clássicas da democracia liberal: "Temos o sufrágio universal mais amplo que o de muitas das mais cultas e civilizadas democracias do Mundo (...). Não me parece lógico que dentro da democracia, da origem popular dos poderes, do sufrágio universal, e da representação com caráter nacional e popular, se possa criar um parlamento, que em parte, fique composto de homens não eleitos pelo povo brasileiro, mas por um sufrágio restrito, dentro de classes. O Poder Legislativo compõe-se de representantes da Nação e não de classes, porque os interesses superiores devem estar acima de quaisquer outros interesses (...). Com a representação de classes, a influência e a soberania passam do povo para as classes, uma vez que o deputado é eleito por eleitorado restrito, fora do sufrágio universal (...). O mandato representativo não é dado ao deputado, individualmente, pelos distritos eleitorais. A representação popular existe apenas no corpo legislativo, na Assembleia inteira, eleita pelo eleitorado inteiro. Se entram na composição da Assembleia, elementos não eleitos pelo povo, não há representação popular perfeita. O regime poderá ser representativo (...) de classes; mas não será democrático, porque, dentro deste, todos os poderes emanam do povo"34.

Dessa forma, é derrotada a proposta na Subcomissão, contando, para isso, com o voto de Oliveira Vianna. Embora fosse entusiasta do papel dos corpos intermediários na sociedade, estava descrente da possibilidade de concretizar uma representação profissional deliberativa naquele momento. "Não é possível representação política das classes sem a prévia organização profissional dessas mesmas classes. Mas, a organização profissional das classes não é obra que se realize por uma simples disposição de lei, por uma decisão imperativa da Carta Constitucional. É obra do tempo, da evolução econômica, do trabalho lento das forças sociais e espirituais (...). Ordenar por um decreto que tudo isto, toda essa massa informe e incoesa tome subitamente forma e organização;

\footnotetext{
${ }^{33}$ Carlos Maximiliano, apesar de se dizer simpático à ideia, afirma não encontrar fórmula satisfatória. "Neste país, sobretudo, essencialmente novo e democrático - não há legislação mas usos e costumes - não há diferença nenhuma de classes, senão nas grandes cidades, e, quando muito, nos portos de mar. No interior, não há nada: o indivíduo vota com o amigo, com o coronel (...). Quis mesmo, por uma espécie de coquetismo intelectual, ver se achava uma fórmula original aplicável ao meio brasileiro. Nada conseguiu. Essa representação foi tentada em toda parte e não deu resultado. Não há assembleia legislativa, nenhuma em que tenha predominado esse sistema. É essa a razão maior porque a ideia não tem triunfado. O socialismo domina a Europa inteira; mas não conseguiu em nenhum país da Europa, cujas constituições são socialistas, a representação de classes. Não é por falta de ideias, é pela inexequibilidade, pela impossibilidade de achar

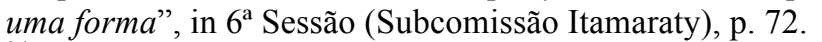

${ }^{34}$ Agenor de Roure, $6^{a}$ Sessão (Subcomissão Itamaraty), pp. 86/87.
} 
que todo esse passado de insolidariedade e individualismo se dissolva e desapareça e, em lugar dela, surja todo um presente de cooperação, solidariedade e espirito corporativo é evidentemente acreditar muito no poder transfigurador das leis (...). O impulso para a cooperação, para a solidariedade, para a ação coletiva se baseia em 'complexos afetivos' profundos, jacentes no íntimo do subconsciente coletivo, que só a evolução histórica gera e desenvolve e que os legisladores não podem fazer surgir e condensar-se por um fiat legislativo (...). Não se improvisa a solidariedade de uma classe; não se improvisam o sentimento e o hábito da cooperação, o espirito corporativo, a organização sindicalista" ${ }^{\$ 5}$. A organização e a construção dos laços de solidariedade entre o povo brasileiro seriam obra do tempo, não das alterações legislativas. Vianna, com sua postura, é símbolo de uma grande linha de pensamento subjacente à elaboração constitucional brasileira, que sustenta o despreparo do povo brasileiro para o verdadeiro exercício democrático. Tratava-se de um povo carente, sobretudo, de formação, sem o quê não poderia participar ativamente das escolhas políticas da nação - analisaremos os reflexos da postura no momento constituinte mais adiante, no item 6.2.2.

Na Assembleia Constituinte, a tendência em relação à representação profissional se inverteu, atendendo aos apelos feitos durante o discurso de inauguração dos trabalhos pelo Chefe do Governo Provisório - a despeito do anteprojeto formulado pela Subcomissão Itamaraty, ele reiterou sua opinião anterior, favorável à nova modalidade de representação. Encabeçado por Abelardo Marinho ${ }^{36}$, membro de projeção do Club 3 de Outubro e deputado classista (profissionais liberais), um grupo de deputados propôs a introdução da representação classista deliberativa na Constituição. Outra corrente, que tinha à sua frente Euvaldo Lodi (representante profissional - empregadores), apresentou a proposta semelhante - "distinguindo-se da anterior, não só por retomar a fórmula governista adotada nas eleições para a Constituinte, como também por prever condições menos rígidas para o voto sindical, a proposta do grupo serviu de base à emenda de conciliação $n^{\circ} 1.948$, aprovada, com pequenas modificações, e que deu origem ao art. 23 da Constituição de 34" ${ }^{37}$. Os representantes classistas dos empregados também reivindicavam a constitucionalização da representação profissional, conforme coloca Alberto Surek: "Ainda há poucos dias, em Juiz de Fora, reuniram-se, em assembleia geral,

\footnotetext{
${ }^{35}$ Oliveira Vianna, $6^{\mathrm{a}}$ Sessão (Subcomissão Itamaraty), pp. 87/88. A posição do autor, de que seria necessário organizar a sociedade em torno de princípios de cooperação e solidariedade antes de instituir a representação profissional, é reiterada ao avaliar o idealismo da Constituição, dessa vez da de 1934, ao reeditar seu livro em 1939. Cf. VIANNA, 1939, pp. 259/269.

${ }^{36}$ Cf. Abelardo Marinho, 28/02/1934, vol. IX, pp. 54/77 e 06/03/1934, vol. IX, pp. 305/341.

${ }^{37}$ TAVARES, 1988, pp. 76/77.
} 
as diretorias de vários sindicatos, constituídos de dezoito associações profissionais, e que contam nada menos de 30 mil proletários. Resolveram (...) bater-se por que seja assegurada a representação política das classes sociais e profissionais" ${ }^{38}$. Conforme aponta Ângela de Castro Gomes, é compreensível que seja a própria bancada classista, ou parte dela ${ }^{39}$, quem apoie a permanência desse tipo de representação, que simbolizava, em última instância, a construção de uma nova mentalidade eleitoral, mais desvinculada dos chefes políticos regionais ${ }^{40}$.

As resistências aglutinaram-se em torno da proposta de garantir uma representação profissional meramente consultiva, por meio dos Conselhos Técnicos, posição liderada pelo também representante classista (profissionais liberais) e paulista Ranulpho Pereira Lima. Para combater a representação profissional, Horácio Lafer lembrava justamente da soberania popular, enquanto pedra angular da democracia liberal, tornando explícito um confronto de ideias acerca da democracia: "Efetivamente, num regime que encerre e exprima o Estado de direito, o fundamento e origem de todos os poderes de ação e de seus órgãos de movimento tem que ser a representação eleitoral, porque a soberania reside no povo (...). Não se concebe a existência do poder público sem a preexistência da soberania; e, como essa não se pode arrebatar, é evidente que tem que haver a delegação de poderes pela representatividade. O direito da Nação é anterior ao do Governo que não tem direitos senão porque assume o encargo de governar. Tanto vale dizer que no Estado de direito, democrático, quem delega poderes, quem compõe os poderes públicos, pela representação, quem dá o sentido político e cívico às atividades dos órgãos de soberania, é a Nação pelos indivíduos políticos que a compõem e não o conjunto dos interesses especializados que a Nação encerra" ${ }^{41}$. Concluía apoiando a proposta da bancada paulista de criação de quatro conselhos nacionais (economia, trabalho, saúde e educação, defesa), com representação de classes, mas em caráter consultivo, modelo semelhante ao francês.

A bancada paulista, vinculada aos paradigmas da democracia do sufrágio universal, defendeu a proposta de representação consultiva, mas saiu derrotada. Prevaleceu a proposta de garantir que um quinto da Câmara dos Deputados seria composto por

\footnotetext{
${ }^{38}$ Alberto Surek, 29/01/1934, vol. VII, p. 53. Vide ainda Guilherme Plaster, que reporta-se à proposta de Abelardo Marinho em 16/04/1934, vol. XV, pp. 24/26; Martins e Silva, 28/03/1934, vol. XII, pp. 464 e ss.

${ }^{39}$ Vale lembrar que os representantes classistas paulistas Roberto Simonsen, Horácio Lafer, Alexandre Siciliano, Pacheco e Silva e Ranulpho Pinheiro Lima aliam-se à Chapa Única de São Paulo, contrária à proposta. "Apesar de classistas, eles reforçariam a posição de seu estado", in GOMES, 1980, p. 445.

${ }^{40}$ GOMES, 1980, pp. 439/440.

${ }^{41}$ Horácio Lafer, 21/03/1934, vol. XII, p. 210.
} 
representantes profissionais, dividindo-se as associações profissionais em quatro categorias (comércio e transportes, lavoura e pecuária, profissões liberais e funcionários públicos; para as três primeiras, escolhiam-se representantes de empregadores e empregados, à semelhança das eleições para a própria Assembleia Constituinte) ${ }^{42}$.

Assim sendo, o que se vê nos debates constituintes sobre o modelo de democracia adotada é uma tentativa de conciliação um tanto delicada entre os pressupostos da democracia liberal e uma nova corrente, próxima do solidarismo de Duguit, e do corporativismo, que defendia uma ideia de representação de interesses, distinta da clássica representação política - o que Fernando Magalhães chamou de "união entre o homo juridicus e o homo economicus" ${ }^{\prime 3}$. As dificuldades constantes na busca por um novo modelo não são senão os antagonismos de fundo entre as duas visões: ora o ponto de partida é a separação entre Estado e indivíduos-cidadãos, titulares últimos da soberania e sujeitos da representação nas câmaras políticas, ora a premissa é de integração dos indivíduos no Estado, a partir da formação de organizações intermediárias, tais como os sindicatos, sob o controle estatal, em um processo de formação de um corpo nacional

\footnotetext{
${ }^{42}$ Art. 23 - A Câmara dos Deputados compõe-se de representantes do povo, eleitos mediante sistema proporcional e sufrágio universal, igual e direto, e de representantes eleitos pelas organizações profissionais na forma que a lei indicar.

$\S 1^{\circ}$ - O número dos Deputados será fixado por lei: os do povo, proporcionalmente à população de cada Estado e do Distrito Federal, não podendo exceder de um por 150 mil habitantes até o máximo de vinte, e deste limite para cima, de um por 250 mil habitantes; os das profissões, em total equivalente a um quinto da representação popular. Os Territórios elegerão dois Deputados.

$\S 2^{\circ}$ - O Tribunal Superior de Justiça Eleitoral determinará com a necessária antecedência e de acordo com os últimos cômputos oficiais da população, o número de Deputados do povo que devem ser eleitos em cada um dos Estados e no Distrito Federal.

$\S 3^{\circ}$ - Os Deputados das profissões serão eleitos na forma da lei ordinária por sufrágio indireto das associações profissionais compreendidas para esse efeito, e com os grupos afins respectivos, nas quatro divisões seguintes: lavoura e pecuária; indústria; comércio e transportes; profissões liberais e funcionários públicos.

$\S 4^{\circ}$ - O total dos Deputados das três primeiras categorias será no mínimo de seis sétimos da representação profissional, distribuídos igualmente entre elas, dividindo-se cada uma em círculos correspondentes ao número de Deputados que lhe caiba, dividido por dois, a fim de garantir a representação igual de empregados e de empregadores. O número de círculos da quarta categoria corresponderá ao dos seus Deputados.

$\S 5^{\circ}$ - Excetuada a quarta categoria, haverá em cada círculo profissional dois grupos eleitorais distintos: um, das associações de empregadores, outro, das associações de empregados.

$\S 6^{\circ}$ - Os grupos serão constituídos de delegados das associações, eleitos mediante sufrágio secreto, igual e indireto por graus sucessivos.

$\S 7^{\circ}$ - Na discriminação dos círculos, a lei deverá assegurar a representação das atividades econômicas e culturais do País.

$\S 8^{\circ}$ - Ninguém poderá exercer o direito de voto em mais de uma associação profissional.

$\S 9^{\circ}$ - Nas eleições realizadas em tais associações não votarão os estrangeiros.

43 “Ora, infelizmente, o mal é generalizado e a humanidade parece separar-se em dois distintos grupos: o homo juridicus e o homo economicus. O homo juridicus através da ideia, através do pensamento, cria uma doutrina e uma escola; o homo economicus, através do interesse, compõe um sindicato. Não é possível senão uni-los, ajustá-los, em vez de separá-los. para que essa organização antagônica de classes definidas, de corporações, quando a humanidade se satisfaz com as confrarias?", Fernando Magalhães, 20/02/1934, vol. VIII, p. 218.
} 
coeso. Nem democracia liberal pura, nem Estado Corporativo puro - a Constituição reflete essa tentativa de união das duas perspectivas, mas sua curta duração pouco permite avaliar os resultados práticos do esforço.

O desafio foi expresso por Horácio Lafer: "no mundo hodierno, cada vez mais os cidadãos se reúnem em grupos de ideologias e interesses idênticos (...). Surgem, assim, as associações econômicas e culturais, que, possuindo os técnicos, com antenas em todos os focos onde fervilham interesses congêneres, concatenam inteligentemente as necessidades e as estudam, à melhor luz. A opinião pública, hoje, não é feita pelos individuos isoladamente, mas pelas associações representativas das atividades sociais. Daí a seguinte conclusão: ou se estabelece o entrelaçamento perfeito dos poderes políticos com as associações que refletem as necessidades sociais, ou aquelas degeneram nas hipertrofias do autoritarismo (...). Ou as democracias resolverão esse problema básico da vida política, ou marcharemos para o Estado corporativo" ${ }^{44}$. De acordo com Bonavides e Andrade, o esquema geral resultante dos debates indica "a vitória da democracia de grupos em nosso país, buscando emprestar à representação de grupos uma filosofia de poder, volvida menos para o indivíduo do que para as categorias intermediárias, aquelas que o liberalismo se habituara a converter em objeto de menosprezo ou indiferença"45. Fiquemos um passo atrás: a Constituição refletiu, sobretudo, a tensão entre liberalismo e essa nova postura solidarista em relação à democracia. Em 1934, parece ser menos possível falar em uma vitória, talvez mais em uma indecisão, enxergando uma vitória mais clara em 1937.

Com isso, uma última observação. É importante salientar que, já em 1934, tratar de organização política da sociedade implicava uma premissa de controle rigoroso do Estado do processo, em mais um refluxo do liberalismo. Não se tratava de abrir espaço para organizações que pudessem subverter a ordem social, referindo-se frequentemente à “ameaça comunista”. Assim, a rejeição da proposta de João Mangabeira de inclusão no capítulo dos direitos e deveres de dispositivo garantindo expressamente que "a todos os brasileiro é lícito organizarem-se em partidos políticos, sustentando, livremente, e sem restrição alguma, os princípios e ideias que entenderem" ${ }^{46}$. Nesse ponto,

\footnotetext{
${ }^{44}$ Horácio Lafer, 21/03/1934, vol. XII, p. 210.

${ }^{45}$ BONAVIDES e ANDRADE, 2006, p. 330.

${ }^{46} \mathrm{Cf}$. debates durante a $24^{\mathrm{a}}$ Sessão (Subcomissão Itamaraty). João Mangabeira argumenta que: “ $A$ respeito, por exemplo, do comunismo, diz que o partido comunista pode ser combatido por meio de um programa hábil em que se lhe demonstre os erros. O partido comunista tem muito por onde ser combatido eficazmente. Ninguém, porém, tem o direito de impedir pela força que uma pessoa lhe defenda as ideias. Uma ideia combate-se com outra ideia, e não com violência (...). Pensa que a todos os brasileiros é lícito congregarem-
} 
separa-se a opção brasileira da concepção de Duguit sobre o sindicalismo e a representação de classes, que não pressuporia evidentemente a tutela estatal, em consonância com a teoria do francês.

Trata-se, portanto, da conformação de uma democracia limitada, em que opiniões políticas e interesses de classe deveriam estar representados, mas apenas na proporção em que condizentes com o projeto nacional maior - afinal, para que se pudesse implementar plenamente, a democracia brasileira precisaria, antes de tudo, de um povo formado e educado para tanto. A premissa subjacente é de uma democracia integradora, que pressupusesse a promoção da conciliação de interesses e a não aberta à incorporação do conflito social à política institucional - lembrando que essa incorporação problemática costumava ser vista como o motivo de crise da democracia liberal. Com isso apresenta-se o segundo aspecto fundamental da democracia na Constituição de 1934, qual seja, quem deveria ser incluído como cidadão brasileiro no pleno exercício de seus direitos políticos.

\subsubsection{Inclusão/exclusão: nacionalidade e direitos políticos}

Como visto, a eleição da Assembleia Constituinte representa um movimento de certa forma contraditório. Por um lado, é produto do recém criado Código Eleitoral, que buscava ampliar a participação política e dar lisura aos procedimentos eleitorais, e por outro, resultou em um corpo eleitoral ainda consideravelmente restrito. Afinal, a Segunda República brasileira pode ser considerada como sendo o momento de incorporação efetiva do povo à política institucional, à semelhança da Terceira República francesa? Os mecanismos jurídicos-constitucionais são formulados de forma a incluir o maior número de pessoas possível no processo político, ou trata-se de uma abertura controlada, resultando ainda em uma democracia limitada?

A maior parte da população brasileira não tinha direito a voto. Antes disso, discutia-se a própria concessão de nacionalidade brasileira a imigrantes, ou melhor, a restrição da concessão da nacionalidade a pessoas “indesejáveis" por conta de suas

se em partidos, seja socialista, seja positivista, seja comunista, seja qual for a fórmula ideológica, porque uma ideia se combate com outra ideia e não com polícia, cadeia, masmorra ou exílio, e, para que amanhã não chegue um governo e os considere inimigos da pátria" (pp. 475/476). Antônio Carlos vota contra, por entender desnecessário e inútil o dispositivo. Carlos Maximiliano vota contra, já que "os verdadeiros partidos têm já as garantias suficientes para intervir nas eleições, ao passo que isso aí seria uma arma para perturbar a ordem com ideias perigosíssimas, não adaptadas ao nosso meio. E servir, ainda, para evitar a expulsão de estrangeiros indesejáveis, bastando que o indivíduo declare, para não ser expulso, que é chefe de partido" (p. 477). Agenor de Roure também vota contra. Apesar da posição favorável de Themístocles Cavalcanti, o dispositivo é rejeitado. 
posições políticas. Não se questionava muito o fato de que, nas palavras de Oswaldo Aranha, "o Brasil é um país de imigração; e, portanto, deve nacionalizar tantos quantos nasçam em seu território e não admitir mais o regime consagrado no Código Civil do 'jus sanguinis $" 47$, devendo imperar o ius soli, princípio consagrado na Constituição ${ }^{48}$. Contudo, debate-se sobre a possibilidade de perda da nacionalidade brasileira em caso de "aceitação, sem licença do Governo brasileiro, de pensão, emprego ou comissão de nação estrangeira" (anteprojeto, art. 97, $b$ ) ${ }^{49}$. Góis Monteiro entende que não apenas a aceitação de emprego deveria ensejar a pena, mas também "casos muito piores", como os "crimes contra a pátria" ${ }^{\circ 0}$. Oswaldo Aranha lembra o exemplo "dos comunistas brasileiros que estão a serviço de governos estrangeiros, porque pela organização que aceitam, quem dirige tudo é o governo da Rússia" "51. A despeito dos apelos de João Mangabeira, alertando para o fato de que aqueles que aqueles que atentarem contra os interesses nacionais já podem ser processados pelo crime de traição e perda dos direitos políticos, já que "não quer armar o Governo de um país como o nosso, onde o Governo é propenso a abusos, dessa arma que lhe faltava" ${ }^{52}$, o artigo é aprovado e fica no anteprojeto ${ }^{53}$. A versão final

\footnotetext{
${ }^{47}$ Oswaldo Aranha, $18^{\text {a }}$ Sessão (Subcomissão Itamaraty), p. 323.

${ }^{48}$ É importante mencionar, contudo, que o momento já era de restrição do fluxo migratório e de preocupação com a formação do "tipo nacional", a ponto de registrarem-se alguns discursos durante a Constituinte em que se manifesta a preocupação com a "raça" brasileira resultante das combinações de imigrantes: "Num país imigratório como o nosso, cumpre um exame atento, não só da escolha dos grupos raciais, como também, na rigorosa seleção individual dos imigrantes, visando beneficiar a raça em formação. Basta lembrar que as nossas estatísticas acusam uma percentagem de alienados criminosos estrangeiros duas vezes maior que a de nacionais (...). [Tratando do que alega ser o maior índice de distúrbios mentais entre os japoneses, manifesta interesse em] evitar a união de elementos malsãos, de doentes afetados de moléstias contagiosas (...). Cumpre-nos adotar um programa de defesa nacional da saúde, encarado sob os seus mais variados aspectos, baseando-se em fundamentos de ordem eugênica, racial e social, como se faz hoje nos paises mais adiantados do mundo. Devemos criar a nossa antropologia política, proporcionar meios para que o ambiente em que vive o nosso povo seja mais propício à saúde, velar pelas leis que regem a transmissão dos fatores hereditários às gerações futuras", Pacheco e Silva, 20/02/1934, vol. VIII, pp. 223/225. Teotônio Monteiro de Barros é mais explícito: "Constatamos, porém, ao lado dessas duas resistências [alemã e turca], a monarquia austro-húngara, desmoronando-se fragorosamente em face do fracasso militar. Por que? Quais as causas dessa diversidade de situação? O império alemão era racialmente forte. A Turquia era raça nitidamente definida (...). Por isso (...) se vamos legislar para o povo brasileiro e se o problema de nossa formação étnica assume tal vulto, tal proporção - porque diz respeito com a própria viabilidade da Nação pelo correr inumerável dos séculos - não é possível legislar nessa hora com o esquecimento de problema de tamanha magnitude (...). [Há] uma espécie de alma nacional, uma tutelar que orienta a nacionalidade nos seus destinos, coisa que nos tem faltado, em parte (...). É claro (...) que quem examina uma questão dessa natureza não está na suposição de que seja necessário estandardizar o homem brasileiro, fixar dados, fixar um tipo que seja louro ou moreno; mas é claro, também, que o problema comporta a formação de uma mentalidade média, comum, e a constituição, até, de um tipo somático, que igualmente seja média comum(...). O que propus foi que, já desde a carta fundamental, haja possibilidade da legislação ordinária posterior trazer medidas adequadas, no sentido de orientar esse amálgama para uma fixação que represente a média comum, que seja futuramente o tipo nacional", 18/01/1934, vol. VI, pp. 233/235.

${ }^{49}$ Debate durante a $19^{\mathrm{a}}$ Sessão (Subcomissão Itamaraty), pp. 340 e ss.

${ }^{50}$ Góis Monteiro, 19a Sessão (Subcomissão Itamaraty), p. 342.

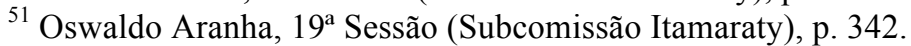

52 João Mangabeira, $19^{\mathrm{a}}$ Sessão (Subcomissão Itamaraty), p. 343.
} 
da Constituição é ainda mais enfática ao prever a perda da nacionalidade não apenas no caso acima (art. 107, b), mas também ao indivíduo "que tiver cancelada a sua naturalização, por exercer atividade social ou política nociva ao interesse nacional, provado o fato por via judiciária, com todas as garantias de defesa" $(\operatorname{art.} 107, c)^{54}$.

Quanto aos direitos políticos, eram também restritos aos maiores de 18 anos que soubessem ler e escrever, não fossem mendigos, praças de pré ou alunos das escolas militares e não tivessem sido privados dos direitos (art. 108). A discriminação dos mendigos repetia dispositivo da Carta de 1891 (art. $70, \S 1^{\circ}, 1$ ), que, apesar de ter sido excluída do anteprojeto, volta no Substitutivo da Comissão dos 26, permanecendo na versão final. Mesmo a menção à exclusão dos “que não sabiam ler e escrever", antes referidos como "analfabetos" ${ }^{\prime 5}$, tanto na Constituição anterior (art. $70, \S 1^{\circ}, 2$ ) quanto no anteprojeto (art. 98, $\S 2^{\circ}, a$ ), é cautelosamente inserida pelos trabalhos da Comissão dos 26 , que inclusive previa a edição de lei discriminando as exigências comprobatórias da condição (a menção de lei regulamentadora não fica na versão final).

A advertência de Agenor de Roure na Subcomissão Itamaraty pode ajudar a explicar a alteração em relação aos analfabetos: "Na expressão - que se alistarem na forma da lei, está implícito que a lei pode fazer exigências capazes de impedir que os analfabetos se alistem (...). Mas, é preciso evitar que esses analfabetos, podendo desenhar seus nomes, sem saberem ler e escrever, possam alistar-se. Conviria deixar isso claro na

\footnotetext{
${ }^{53}$ Oswaldo Aranha é bastante explícito em sua argumentação: "O sr. Oswaldo Aranha declara ser mais um homem da realidade do que das leis; e, consequentemente, orienta-se mais por ela do que pelas preocupações jurídicas. O caso concreto é o seguinte: na atualidade mundial assiste-se à intervenção de novas correntes internacionalistas na economia, na politica, enfim, em todos os gêneros da atividade humana. Ora, essas influências podem ser perturbadoras, amanhã ou depois, da vida do país, sobretudo se a elas se incorporarem os nacionais, dadas suas possibilidades em relação ao Brasil, que representa uma apreciável reserva de terras e recursos econômicos a todas as nações que se debatem em graves crises. Portanto, quando se está elaborando uma lei para tudo quanto é essencial ao Brasil, como deixar à margem, num exame ligeiro, como o que se está fazendo, todos esses assuntos, que, fatalmente, vão surgir e hão de se impor no decurso da vida do país? (...) A Comissão está em face de um fato novo, que se pode verificar, e para o qual é preciso uma legislação especial, sem exageros, sem ameaças, mas que possa, também, em dado momento, corresponder às realidades que surgirem", 19a Sessão (Subcomissão Itamaraty), p. 345.

${ }_{5454}$ Consta ter havido emenda do socialista Zoroastro Gouveia propondo a supressão do dispositivo, que, segundo ele, "retira do estrangeiro todas as vantagens da cidadania, pois o coloca sob a ameaça perpétua, máxime numa república presidencialista necessariamente tendente à hipertrofia da função policial, das oscilações partidárias e prevenções policialescas. Nesse assunto, não é decente nem jurídico oferecer com a mão esquerda o que a mão direita se prepara para subtrair", in REIS, 1934, pp. 226/227, nota 207.

${ }_{55}$ A restrição ao voto dos analfabetos não existia no Império, sendo introduzida pela Lei Saraiva (Decreto $\mathrm{n}^{\circ}$ 3.029, de 9 de janeiro de 1881) para os alistamentos eleitorais posteriores a 1882. Além disso, a lei reorganizou as regras eleitorais, acabando com as eleições indiretas, fazendo com que senadores, deputados gerais e provinciais fossem eleitos diretamente (NICOLAU, 2004, p. 22). A restrição perdurou até 1985, quando a Emenda Constitucional de 20 de maio estendeu aos analfabetos o direito de voto, facultativo, mas não o direito de concorrer a cargos eletivos. Os adultos analfabetos representavam $65 \%$ da população em 1920, 60\% em 1930, chegando a 56\% em 1940, um contingente bastante significativo, portanto. Vide NICOLAU, 2003, pp. 260/263.
} 
Constituição",56. João Mangabeira protesta, lembrando que "esse argumento foi exatamente uma das manobras de que lançou mão o partido escravagista nos Estados Unidos para afastar o eleitorado negro (...). Indaga logo: que é saber ler e escrever? Uma coisa muito vaga e arbitrária", concluindo que "convém mais incluir o cidadão que desenha o nome do que deixar ao arbitrio do juiz decidir se ele sabe ler e escrever" ${ }^{, 57}$. Oswaldo Aranha deixa clara sua preferência por um eleitorado mais restrito, decorrente da limitação proposta por Agenor de Roure, pela qual vota, afirmando "que a exigência do eleitor saber ler proporcionará um eleitorado mais selecionado do que se exigisse também que ele soubesse escrever" ${ }^{25}$. Contudo, a versão menos restritiva de João Mangabeira é vitoriosa, com os votos de Themístocles Cavalcanti, Góis Monteiro, Carlos Maximiliano e Oliveira Vianna ${ }^{59}$.

Durante a Assembleia Constituinte, debateu-se a concessão dos direitos políticos. A Comissão dos 26 havia não apenas retomado a restrição do voto aos mendigos, como também a idade mínima de 21 anos, justificada por Levi Carneiro: "Negamos o direito de voto aos moços. Por que o fizemos? Agimos lógica e coerentemente. Pois, se negamos o direito de voto a todos os que estão sob autoridade alheia, aos homens, de maior envergadura moral, das ordens religiosas, como podíamos, coerentemente, dar direito de voto aos menores sob pátrio poder? Meu filho, como votaria, senão de acordo comigo? Se não pelo temor reverencial, até pelo próprio afeto que encontraria nessa solidariedade uma oportunidade de expressão" ${ }^{, 60}$. Como idade mínima prevaleceu no texto final 18 anos, mas a restrição ao voto dos mendigos e dos que "não saibam ler e escrever" permaneceu, resistindo diante de algumas poucas vozes de protesto, como a de João Simplício: "No projeto de Constituição, senhores, há finalmente, um ponto interessante, para o qual desejo chamar a atenção de todos. É o que estabelece que os direitos de

\footnotetext{
${ }^{56}$ Agenor de Roure, $19^{\text {a }}$ Sessão (Subcomissão Itamaraty), p. 347.

${ }^{57}$ João Mangabeira, $19^{\text {a }}$ Sessão (Subcomissão Itamaraty), p. 347.

${ }^{58}$ Oswaldo Aranha, 19 ${ }^{\text {a }}$ Sessão (Subcomissão Itamaraty), p. 347.

${ }^{59}$ Agenor de Roure, contudo, insiste no tema durante a $28^{\text {a }}$ Sessão, pretendendo rediscutir o dispositivo trazendo como argumento um telegrama publicado pelo Jornal do Brasil, em que se dava conta da iniciativa do prefeito de Porto Novo, que sugeria ao governo do Estado a contratação de professores para "ensinarem os futuros eleitores a assinar o respectivo nome", já que "o eleitorado era composto em grande parte de pessoas que sabiam desenhar o nome, e por isso exigia prova de saber ler e escrever”, $28^{\text {a }}$ Sessão (Subcomissão Itamaraty), p. 587. A Subcomissão decide não rediscutir a matéria.

${ }^{60}$ Levi Carneiro, 07/03/1934, vol. IX, p. 403. A idade mínima volta a ser de 18 anos em função da emenda $n$. 3, em que constava como justificativa: "Conceder o direito de voto aos estudantes brasileiros, inclusive aos alunos das escolas militares de ensino superior, é um imperativo da nossa evolução cultural e o meio eficiente de canalizar para as urnas a vontade livre e impessoal da Pátria, na sua manifestação mais sensivel, mais sincera e mais expressiva por isso mesmo que a alma impetuosa e desinteressada dos moços brasileiros só se apaixonam pelas verdadeiras causas nacionais nos seus diferentes aspectos", in REIS, 1934 , p. 227, nota 208.
} 
cidadania, definindo como cidadão todo brasileiro alistável na forma da lei, de acordo com os principios que fixa. Não pude compreender, por mais que estudasse o assunto, como o fazendeiro ou o agricultor, no interior do Brasil, que exerce sua atividade em prol da grandeza do país, seja considerado brasileiro, mas não cidadão, por não saber ler e escrever! Sr. Presidente, sou partidário - rememorando, aliás, a ação de Castilhos - sou partidário do sufrágio universal (muito bem), não baseado no saber ler e escrever, apenas. Limitaria o sufrágio a uma única condição, talvez socialista - a de o indivíduo ser trabalhador (Apoiados). O trabalhador, analfabeto ou não, terá o direito de votar" ${ }^{\prime 61}$. É significativo, nesse ponto, o singelo comentário de Antônio Marques dos Reis ao tratar do dispositivo referente à exclusão dos analfabetos dos direitos políticos: "Houve quem apresentasse na Constituinte emenda mandando dar direito de voto aos analfabetos, mas o bom senso não havia desertado aquela casa" ${ }^{\text {"62 }}$. Incluir os analfabetos, mais de $60 \%$ da população, como visto, seria, dessa forma, uma despropositada afronta ao bom senso.

Mais ainda, aprovava-se uma gama de possibilidades de suspensão dos direitos políticos. Por sugestão de Oswaldo Aranha, aprova-se a incapacidade moral, além da física, dentre os casos de suspensão dos direitos políticos (art. 100, $\left.\S 1^{\circ}, a\right)^{63}$. Não fica claro da leitura das atas o que quer dizer por "incapacidade moral", sendo a "formação moral" referida em diversas outras circunstâncias nos debates ${ }^{64}$. O dispositivo não encontra correspondência na versão final, que mantinha, contudo, a tendência de restrição dos direitos políticos àqueles que, como definido no anteprojeto, apresentarem "alegação de qualquer motivo, feita com o fim de se isentar do ônus que a lei imponha aos brasileiros" (art. 100, $2^{\circ}, b$ ) - na Constituição de 1934, a perda dos direitos políticos estendia-se como pena pela "isenção do ônus ou serviço que a lei imponha aos brasileiros, quando obtida por motivo de convicção religiosa, filosófica ou política" (art. 111, b).

Mesmo a igualdade perante a lei, clássico direito liberal, estava ameaçada pela tentativa de controle da ordem social. Nesse sentido, mencione-se a proposta de redação apresentada no anteprojeto, estabelecendo que "todos são iguais perante a lei, sem

\footnotetext{
${ }^{61}$ João Simplício, 15/12/1933, vol. II, p. 315.

${ }^{62}$ REIS, 1934, p. 228, nota 209.

${ }^{63}$ Cf. $19^{\mathrm{a}}$ Sessão (Subcomissão Itamaraty), p. 352.

${ }^{64}$ Góis Monteiro, por exemplo, menciona a necessidade de preparação moral do povo brasileiro, defendendo com ressalvas a não participação dos militares na política, já que "assim como devemos possuir a defesa sistematizada, sob o ponto de vista físico, para termos homens robustos, também, sob o ponto de vista moral, é mister fixar no espírito do povo que toda doutrina contrária ou nociva aos interesses da nacionalidade deve ser sufocada e acabada. De forma que a preparação moral é imprescindivel ao povo, para que saiba se defender, não como espírito belicoso militarista, que repele, mas com o espírito de se tornar mais forte para, no momento de se aproximar o perigo, ser capaz de se defender contra ele, com eficiência", $30^{\text {a }}$ Sessão (Subcomissão Itamaraty), p. 612.
} 
privilégio de nascimento, sexo, classe social, riqueza, crenças religiosas ou ideias políticas desde que não oponham às de Pátria" (art. 102, 1). O dispositivo foi incluído com a redação proposta de Melo Franco, que buscava assegurar “medidas de proteção, tomadas em todos os países do mundo, contra essas doutrinas revolucionárias que podem abalar a estrutura do Estado" "65. João Mangabeira protestou contra a fórmula, objetando que "com esse artigo a nossa constituição vai ser o padrão das constituições reacionárias do universo, porque não há constituição nenhuma do mundo que contenha em seu bojo artigo de tal natureza"66, mas é derrotado. A restrição à igualdade somente aos que "não se opunham à pátria" é, contudo, suprimida pela Comissão dos 26, e a Constituição fíca com um texto final mais abrangente e garantidor de direitos: "Todos são iguais perante a lei. Não haverá privilégios, nem distinções, por motivo de nascimento, sexo, raça, profissões próprias ou dos pais, classe social, riqueza, crenças religiosas ou ideias políticas" (art. 113, 1). Apesar da garantia formal de igualdade, os demais cerceamentos à participação política subsistiam, forjando uma cidadania restrita.

O desenho é, portanto, o de uma democracia bastante limitada, condicionada não apenas à colaboração do indivíduo com o Estado, ou com a "unidade nacional", mas também com a sua formação mínima, afinal, era necessário que o corpo eleitoral fosse composto por indivíduos educados e obedientes aos "interesses nacionais". A vontade de limitar o corpo eleitoral aparece, por fim, no debate sobre a forma pela qual se dariam as eleições presidenciais.

Prevaleceu, na Subcomissão Itamaraty, a proposta de eleições indiretas do Presidente pela Assembleia Nacional (art. 37, $§ 1^{\circ}$ ), mas não sem debates acalorados. Oliveira Vianna era contrário à eleição do Presidente da República pelo sufrágio direto "porque a experiência mostrou os inconvenientes deste sistema, as agitações inúteis a que deu causa, e nenhuma significação dos seus resultados. Ele presume, nas massas eleitorais, um espírito político e uma cultura cívica que absolutamente não existem nas massas eleitorais do nosso país. Por este sistema, o presidente da República era eleito pela votação inconsciente e maciça das maiorias eleitorais dos campos, anulando inteiramente o voto dado pelos núcleos eleitorais das grandes cidades e capitais, mais conscientes e esclarecidos. Que essas maiorias incultas, presas pela fidelidade pessoal aos chefes locais, elejam representantes à Assembleia Nacional, compreendo: elas têm interesses, e grandes, e é preciso que estes interesses se possam manifestar; mas, que elas

${ }^{65}$ Afrânio de Melo Franco, 20 a Sessão (Subcomissão Itamaraty), p. 373.

${ }^{66}$ João Mangabeira, 20 ${ }^{\mathrm{a}}$ Sessão (Subcomissão Itamaraty), p. 373. 
elejam o supremo representante do governo nacional, é que me recuso a admitir: o governo é uma função de elite e das elites e só às elites, portanto, cabe eleger os agentes supremos do governo" ${ }^{67}$. Oliveira Vianna também não concordava com a eleição pela Assembleia Nacional, e propunha que fosse feita por um colégio eleitoral "recrutado pelo critério da cultura geral e pela presunção dos negócios públicos nacionais e dos homens públicos também culturais", composto por uma elite de "políticos" e "não políticos", segundo sua classificação. "Cabendo, pois, aos políticos apenas a terça parte do eleitorado, seriam os elementos culturais e técnicos que elegeriam o Presidente (...). Por esse processo, libertaremos a escolha do supremo magistrado da República da intervenção das massas eleitorais do interior, cujo campo de informação não vai além do horizonte do seu distrito ou do seu Estado, e entregaremos esta escolha às elites cultivadas das capitais e das cidades, cujo campo de informação domina soberanamente todo o horizonte nacional" ${ }^{68}$. Reforça-se, assim, a presença de uma visão autoritária de democracia, especialmente vinculada a Oliveira Vianna.

João Mangabeira responde às objeções: “O povo é o sistema principal de que se compõe a Nação. Não são as elites, não é a Academia francesa que constitui a França. O povo que trabalha e que morre, este sim, é que constitui a nação. Não foi com as elites que a França derrotou a Alemanha. Não foi com as elites que o Brasil venceu o Paraguai. O que impediu a avançada alemã sobre Paris não foram as elites, mas, sim os soldados. Num regime democrático, enquanto não houver regime monárquico, de que o sr. Oliveira Vianna se mostra simpatizante, e sobretudo no autocrático, não se pode abrir mão do povo. Um governo que abrisse mão do povo seria um governo como o da Rússia, que muito caro custou a Nicolau II. Por essas razões, acha que devem ser combinados ambos os elementos, mas sendo a Assembleia fator preponderante no corpo eleitoral (...). Quando o regime é representado pela minoria, perde o nome de democracia para tomar o de aristocracia" ${ }^{\prime 9}$. Apesar de refutar o sistema de Oliveira Vianna, para quem a escolha deveria caber a uma elite qualificada, João Mangabeira é pela eleição indireta, dando-se, porém, peso predominante à Assembleia Nacional ${ }^{70}$.

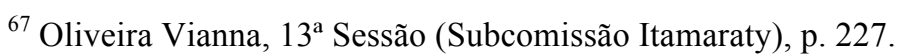

${ }^{68}$ Oliveira Vianna, 13 ${ }^{\mathrm{a}}$ Sessão (Subcomissão Itamaraty), p. 229.

${ }^{69}$ João Mangabeira, 13 ${ }^{\text {a }}$ Sessão (Subcomissão Itamaraty), p. 230.

${ }^{70}$ Uma crítica ainda mais incisiva à eleição direta do Presidente vem de Agenor de Roure: “Partidário, há muitos anos, da eleição do Presidente da República pela Assembleia Nacional, acho-me no dever de manter agora esse meu modo de pensar, perante essa subcomissão. Nem há necessidade de longa justificação da emenda que vou apresentar. Ainda que a eleição direta fosse o sistema geralmente adotado nas democracias para a escolha do Presidente da República, nem assim deveria ser adotado no Brasil, que é um imenso país de $80 \%$ de analfabetos, onde durante quarenta anos de experiência, não tivemos uma só sucessão
} 
Ao final, propõe-se no anteprojeto a eleição indireta do Presidente unicamente pela Assembleia Nacional, tendência revertida no texto final da Constituição de acordo com Afonso Arinos de Melo Franco, a reversão proposta na Comissão dos 26 reportou-se "à decisão do plenário que, de fato, repudiou a inovação e restabeleceu a tradição do voto "por sufrágio universal direto e secreto",71. A Constituição de 1934 previa o sufrágio universal direto para Presidente (art. 52, §1 $1^{\circ}$ ), eleições, porém, que nunca chegaram a ocorrer sob a sua égide. Nas Disposições Transitórias, determinava a escolha do primeiro presidente constitucional por meio de eleições indiretas, pela Assembleia Nacional Constituinte, para mandato de 3 anos (art. $\left.1^{\circ}\right)$, e, como se sabe, essa foi a única eleição presidencial regulada por aquela Constituição.

Temos, portanto, mais um exemplo de democracia limitada, em que se manifesta expressamente o desejo de que o processo político fique concentrado nas mãos de uma elite - seja uma elite intelectual, "mais consciente e esclarecida", seja uma elite política - afastando as "maiorias eleitorais incultas dos campos". O resultado excludente era facilmente atingido a partir das restrições dos direitos políticos que permaneceram, e os membros da Subcomissão Itamaraty tinham consciência dele ao especular, para fins de regulação da proporção de representação dos estados na Assembleia, sobre o número de eleitores que ao final estariam aptos a comparecer às urnas.

Prudente de Moraes menciona que o eleitorado deveria atingir 10\% da população, "segundo dizem os entendidos",72, considerando a redução da idade mínima para 18 anos e a inclusão das mulheres. Agenor de Roure estima ser correta a metade desse número, "2 milhões e poucos" eleitores ${ }^{73}{ }^{74}$. Tudo para responder a pergunta: deveria a representação na Assembleia ser proporcional à população ou ao eleitorado? Oliveira Vianna é vencido ao defender a representação da população, e Oswaldo Aranha dá os fundamentos para a escolha pelo eleitorado: "Existe, em matéria de representação, a parte ativa e a parte inativa ou passiva da opinião (...). Entende que a proporção de

presidencial sem graves crises políticas e poucas sem revoluções, sempre perturbada a vida da Nação e sempre anulando o último ano do quadriênio, com dois Presidentes - o que terminava o mandato e o eleito em março, ambos governando, ou melhor, um fingindo governar e o outro governando por trás da cortina (...). Todos aqui estão convencidos de que precisamos mudar de rumo. Todos aqui sabem que os nossos maiores males políticos e financeiros destes últimos quarenta anos resultaram da eleição direta do Presidente da República. É absolutamente necessário sair disso", 12 ${ }^{\mathrm{a}}$ Sessão (Subcomissão Itamaraty), p. 211.

${ }^{71}$ FRANCO, 1981, p. 126.

${ }^{72}$ Prudente de Moraes, 8 a Sessão (Subcomissão Itamaraty), p. 119.

${ }^{73}$ Agenor de Roure, $9^{\text {a }}$ Sessão (Subcomissão Itamaraty), p. 138.

${ }^{74} \mathrm{Na}$ realidade, a participação eleitoral, que para as eleições da Assembleia Nacional Constituinte foi de $3,3 \%$ da população, atingiu cerca de 5,4\% nos anos 1930, mais próximo do estimado por Agenor de Roure, portanto. Dados em NICOLAU, 2003, pp. 272/276. 
representação pela população é entregar a essa parte inativa de analfabetos ou indiferentes à sorte do país, o predomínio sobre a outra, cujo civismo se quer revelar, $e$ efetivamente se revela e demonstra pelo voto das urnas: é a inversão fundamental do que se chama democracia" ${ }^{75}$. Themístocles Cavalcanti também opina pela representação proporcional ao eleitorado, e "lembra que o professor Duguy [sic - Duguit?] demonstrou que uma das leis mais importantes votadas na França, a da separação da Igreja do Estado, foi votada por uma maioria de Deputados, que representava menor número de habitantes do que a minoria, que representava maior número. Esse fato muitas vezes se verificou no Brasil, e urge ser modificado, tomando-se por base, para a representação, o eleitorado" ${ }^{, 76}$. Assim que Themístocles Cavalcanti, valendo-se de modo peculiar da leitura de Duguit, conclui pela descrença nos Parlamentos eleitos pelo sufrágio direto e na representação política "nos moldes supostamente democráticos", e usa novamente o francês para afirmar que "as maiorias parlamentares nunca exprimiram maioria dos representados" $" 77$.

Rejeitava-se, assim, a ideia de que buscar a representação política da população brasileira, inculta, despreparada e passiva; pelo contrário, pertencia à minoria dos preparados, à elite intelectual dos eleitores, o "civismo" que os membros da Subcomissão queriam ver revelado pelo sistema democrático brasileiro. A postura é condizente com a garantia de uma democracia limitada, em que a participação política é avaliada segundo os imperativos da nação, e conferida aos "moralmente capazes", aos letrados e aos que repeliam ideias tendentes à desestabilização da ordem.

\subsection{ORDEM SOCIAL: ENTRE DIREITOS, PRINCÍPIOS E TUTELA}

"O Estado moderno não pode contentar-se com o reconhecimento da independência jurídica do indivíduo; ele deve ao mesmo tempo criar um mínimo de condições jurídicas que permitam assegurar a independência social do indivíduo"78. Assim notava Mirkine-Guetzévitch a tendência moderna à constitucionalização de direitos sociais que se diferenciavam das liberdades asseguradas pela Declaração de Direitos de 1789. Na Constituinte brasileira de 1933/34, inspirada pela tendência, e particularmente

\footnotetext{
${ }^{75}$ Oswaldo Aranha, 7 a Sessão (Subcomissão Itamaraty), p. 113.

${ }^{76}$ Themístocles Cavalcanti, $7{ }^{\mathrm{a}}$ Sessão (Subcomissão Itamaraty), p. 113.

${ }^{77}$ Themístocles Cavalcanti, $8^{\text {a }}$ Sessão (Subcomissão Itamaraty), p. 120.

${ }^{78}$ MIRKINE-GUETZÉVITCH, 1933, p. 151.
} 
por Mirkine-Guetzévitch, também ecoava a necessidade de ampliação do rol de direitos constitucionalizados, tendo como horizonte a elaboração de uma carta política moderna e social.

Por certo, e antes disso, o capítulo que trata dos direitos individuais recebeu especial atenção. A Constituição haveria de se preocupar com o social, lado a lado com a manutenção ou até mesmo a ampliação das garantias de liberdade individual, típicas de um modelo liberal. É essa a tendência que quer reforçar Antônio Marques dos Reis, ao escrever seu balanço do processo constituinte: "Na Declaração de Direitos bem acentuada ficou a tendência liberal da Assembleia Nacional Constituinte. Deu-se o direito de voto aos maiores de 18 anos. Permitiu-se o alistamento aos sargentos. Tornou-se obrigatório o voto. Conceituou-se devidamente a regra de retroatividade das leis. Afirmou-se a liberdade de manifestação de pensamento. Assegurou-se o direito de resposta. Fez-se independer de licença a publicação de livros e periódicos. Não se tolerou a propaganda de guerra ou de processos violentos. Manteve-se o direito de reunião. Garantiu-se a liberdade de associação. Asseverou-se a liberdade do exercício de qualquer profissão. Declarou-se garantido o direito de propriedade. Criou-se o mandado de segurança... "79. É o mesmo Reis quem admite a necessidade de introdução de novos direitos, mas dentro de determinados limites: "Na ordem econômica e social a Constituição foi até onde podia ir (...). Garantindo a situação das classes operárias sem ir a exageros..." ${ }^{\circ 0}$.

Assim, no parecer sobre o capítulo da Declaração de Direitos, João Marques dos Reis, o relator na Comissão dos 26, afirma: "É certo que a concepção individualista do direito substitui, de algum tempo, a do direito social, fundado na solidariedade com que se procuram estreitar os laços de todos os componentes da sociedade. Assim, pois, os direitos individuais, submetidos à sua invencivel relatividade não podem ser abusivamente exercidos, e a ordem pública, o interesse social, as exigências da autonomia coletiva a cada passo lhes imprimem restrições que, entretanto, lhes respeitam a substância e procuram harmonizá-los com aqueles supremos intuitos de assegurar a harmonia e a coexistência humana. Partindo do princípio de que uma injunção do direito não é imperativo do forte ao fraco, e sim um imperativo levado a todos pelo sentimento da massa ou pela consciência popular, bem se pode compreender, conciliando-os, a coexistência dos preceitos assecuratórios dos direitos individuais e dos

\footnotetext{
${ }^{79}$ REIS, 1934, p. 11.

${ }^{80}$ REIS, 1934, p. 12.
} 
interesses da coletividade" ${ }^{\# 1}$. Mais um indício de que princípios liberais e orientações coletivistas teriam que conviver dentro de uma mesma Constituição híbrida, marcada por passagens de transição e conciliação, e que viria a ser disputada posteriormente pelos teóricos de acordo com suas convicções ideológicas. Porém, é certo que não se poderia limitar às velhas garantias de direitos liberais. A questão social se fazia presente e inevitável, como apontara Mirkine-Guetzévitch.

De acordo com o já exposto no capítulo 4, em finais de 1933 o Governo Provisório havia editado várias normas relativas a direitos sociais, concernentes, sobretudo, à regulação do trabalho. Mais uma vez, e agora mais sensivelmente, os direitos sociais afirmados nos anos 1930 podem ser estudados independentemente de sua previsão constitucional. De acordo com Bercovici, “desde a criação do Ministério da Educação e Saúde Pública (...), a própria estruturação dos sistemas públicos de educação e saúde e os primórdios das políticas de cultura e de instituição dos órgãos de previdência social ocorrem durante todo o Primeiro Governo Vargas (1930-1945), sem qualquer vinculação material, durante o período constitucional, ao texto de 1934" ${ }^{\prime 2}$. Porém, há um sentido específico em incluí-los na Constituição, especialmente contido nos discursos que embasaram o movimento, que se reflete na forma como são inseridos no texto, e no conteúdo dos dispositivos, mais ou menos aberto, mais ou menos interventor e tutelar.

Quais seriam as justificativas que se apresentavam para a constitucionalização de direitos e regulação social? De que modo os atores do período apresentavam suas reivindicações e compreendiam a função da Constituição em garantir tais direitos e mecanismos de intervenção?

É preciso retomar o diagnóstico de inevitabilidade da questão social e da necessidade de "prever para prover". Seja por considerarem que o Brasil não escaparia à trajetória comum aos países "civilizados", seja por entenderem que estávamos sujeitos ao contágio dos problemas sociais dos outros países, em especial da Europa, os constituintes, e, antes disso, os membros da Subcomissão Itamaraty, tinham claro que a nova Constituição deveria seguir o modelo das constituições modernas e prever a regulação da ordem econômica e social em seu texto. Assim a afirmação de Pacheco e Silva, representante dos empregadores: "Esse sentimento de responsabilidade coletiva na solução dos problemas sociais se generalizou por todo o mundo e se impôs à consciência dos

${ }^{81}$ REIS, 1934, pp. 206/207, nota 204.

${ }^{82}$ BERCOVICI, 2009, pp. 727/728. A posição é semelhante à de Wanderley Guilherme dos Santos, para quem a Constituição de 1934 "somente legitima, constitucionalmente, o que o governo revolucionário de Vargas já vinha promovendo, exponte sua, desde há muito”, in SANTOS, 1979, p. 20, nota 7. 
cidadãos, por tal forma, que já não é mais objeto de discussão se cabe ou não ao Estado deles se ocupar. Discute-se, apenas, os remédios e reformas mais eficientes e menos onerosas, de acordo com a situação de cada país..."83. Na mesma linha, Marques dos Reis, apresentando o programa do Partido Social Democrático da Bahia, e reportando-se às doutrinas político-sociais, afirma ser fora de dúvida que hoje "o direito não pode absolutamente fugir a essa chamada conceituação, ou influição, ou aspecto social" ${ }^{84}$. Ainda que ligada a origens, diagnósticos e filiações teóricas diversa, a preocupação de inserir a tutela do social perpassava os posicionamentos da maioria dos constituintes, portanto.

O Estado estava sendo chamado a atuar na economia, não apenas garantindo as liberdades de mercado, mas também assegurando direitos que dependiam de sua ação concreta e positiva. A nova democracia econômica pedia que se positivassem direitos sociais, que tivessem como horizonte futuro uma sociedade mais integrada e materialmente mais igualitária. "No Estado moderno o operário é considerado o propulsor da economia e das energias produtoras - fator inconteste da riqueza universal com direitos definidos na ordem econômica, jurídica, social e política. Eis porque, ao Estado moderno cabe a obrigação indeclinável de prover as necessidades vitais desse elemento primordial da sociedade - traçando normas, para retribuir o seu esforço, em bases certas e assegurar o direito legítimo na partilha dos proventos do trabalho - é o que constitui a legítima e justíssima reivindicação do proletariado" ${ }^{\$ 5}$. Assim manifestava-se Lacerda Werneck durante a Assembleia Constituinte, deixando claro que o que se buscava ali não era apenas a formatação de uma democracia política, mas também de uma democracia econômica, em que o Estado interviesse para a garantia de igualdade material de condições. Tais eram as demandas proletárias no mundo todo, que de certa forma ecoaram no Brasil, na formulação de nossa primeira Constituição social. Resta saber se se tratava de uma garantia efetiva e eficaz, desde logo, ou meramente simbólica, a ser interpretada no futuro. Resta saber, ainda, se à ampliação do rol de direitos também não se acrescentou a expansão do poder de tutela do Estado sobre a ordem social, de modo a constituir o "novo povo brasileiro", educado, integrado e solidário, antes de incluí-lo como fundamento ativo de nossa democracia.

\footnotetext{
${ }^{83}$ Pacheco e Silva, 11/04/1934, vol. XIV, p. 69.

${ }^{84}$ Marques dos Reis, 18/01/1934, vol. VI, p. 205.

${ }^{85}$ Lacerda Werneck, 05/01/1934, vol. V, p. 403.
} 


\subsubsection{Direitos, princípios e finalidades sociais}

Ao tratar do reconhecimento de direitos sociais, é preciso que se considere, antes de tudo, que essa é a primeira e única Constituinte brasileira que contou com representação profissional, inclusive dos empregados, bancadas que deveriam, em tese, veicular os interesses e as demandas de suas classes, posição que deve ser relativizada, como visto, em função do controle do Governo Provisório sobre a escolha dos representantes e seu consequente governismo predominante. Essencial, portanto, começar pela análise das reivindicações sociais por elas manifestadas no ambiente da Assembleia Nacional Constituinte, especialmente pela bancada dos empregados, que de fato possuía um perfil bastante distinto dos demais representantes.

Um dos tons principais dos discursos dos representantes dos empregados era a busca da constitucionalização dos direitos já garantidos pela legislação ordinária, como pede Martins e Silva ainda em novembro de 1933: "A bancada proletária rompe o seu silêncio (...) para dizer que aqui vem construir e não demolir, coordenar, trabalhar harmonicamente com a representação política, animada do patriótico desejo de elaborar uma Constituição que honre o Brasil. Os pontos principais por que propugnará a bancada proletária, dentro da Constituição, são, de fato: representação de classe; aprovação de todas as leis trabalhistas já promulgadas; manutenção dos princípios de assistência social constantes do anteprojeto; liberdade absoluta de manifestação do pensamento; justiça trabalhista e unificação de ensino, com sua gratuidade" ${ }^{\text {} 86}$. Meses depois, em março, o mesmo Martins e Silva afirma como "aspirações mínimas do proletariado" a representação profissional, o dia de oito horas, o salário mínimo, a liberdade de pensamento e o direito de greve $^{87}$, alguns dos direitos já resguardados pela legislação ordinária, salvo os relevantes casos da greve e da liberdade de pensamento. As demandas eram compartilhadas, de forma geral, pelos demais membros da bancada dos empregados ${ }^{88}$.

\footnotetext{
${ }^{86}$ Martins e Silva, 29/11/1933, vol. I, p. 451. No mesmo sentido, o apelo de João Vitáca em 07/03/1934 ao alertar que "a legislação social decretada pelo Governo Provisório e as concessões asseguradas ao proletariado no Anteprojeto constitucional foram postas em cheque pela aprovação do substitutivo (...). Os trabalhadores do Brasil não podem admitir que os seus direitos já assegurados em leis ordinárias e formalmente consagrados no referido Anteprojeto governamental sejam postergados mais uma vez e transformada a sua causa novamente em simples caso de polícia”, in vol. IX, p. 372.

${ }^{87}$ Martins e Silva, 28/03/1934, vol. XII, p. 464.

88 "De forma geral, todos os elementos da bancada lutam pela regulamentação e consolidação da legislação social, procurando garantir na Constituição todos os direitos já consagrados pelas leis anteriores, bem como assegurar seu cumprimento por parte dos patrões. Defendem a jornada de oito horas; a proteção do trabalho da mulher e do menor, cujo limite mínimo de idade deveria ser de 16 anos; a extensão e a reforma dos direitos securitários, abrangendo invalidez, acidente, morte, doença e desemprego; a instituição do
} 
Francisco Moura, líder da bancada dos empregados, apresenta as reivindicações da Federação do Trabalho do Distrito Federal : "1- o trabalho não deve ser considerado simplesmente como mercadoria ou artigo de comércio. 2- Direito de associação para empregados e empregadores. 3- Pagamento aos trabalhadores de um salário que lhes assegure um nível de vida razoável. 4- Adoção da jornada máxima de oito horas ou a semana de quarenta e oito horas como objetivo e atingir onde ainda não esteja em vigor. 5- Adoção do repouso semanal de vinte e quatro horas no mínimo. 6Suspensão do trabalho das crianças e a obrigação de limitar o trabalho dos menores de modo que lhes permita completar a sua educação e desenvolvimento físico" ${ }^{89}$. Os representantes dos empregados queriam ver seus novos direitos constitucionalizados e quiçá ampliados, portanto, enxergavam aí a garantia de sua perenidade para além do período de transição do Governo Provisório, uma vez que incluídas no pacto político em tese duradouro.

Contudo, o debate sobre os direitos sociais antecede a efetiva formulação das demandas pelos trabalhadores no ambiente da Constituinte, e de certo modo corre independente dela. Na Subcomissão Itamaraty, Oswaldo Aranha era responsável pela redação do capítulo sobre a ordem econômica e social, que começa a ser debatido na $37^{\mathrm{a}}$ sessão. Ao apresentar as razões determinantes de seu projeto, esclarece que ao problema atual, que é a divisão da humanidade entre "uma grande maioria que trabalha" e uma "minoria que se reduz em número que dispõe de riqueza e fortuna", apresentaram-se como soluções a democracia, o socialismo e o comunismo, mencionando também o fascismo, ou o "superamento" 90 . O Brasil adotou o regime democrático, segundo ele, e é de acordo com seus termos que se devem promover as reformas econômicas e sociais, contrariando os argumentos de que representariam perdas comerciais ao país, "porque se caminhamos no mesmo passo com que andaram os antigos chegarem[os] à mesma situação com que estão debatendo os Estados Unidos, país pelo qual todos os brasileiros têm simpatia e admiração, tendo ido lá buscar os princípios de sua formação republicana, onde, neste instante, um terço da sua população sofre a falta de trabalho..."

salário mínimo e a inclusão do trabalhador rural como beneficiário dessa legislação", GOMES, 1980, p. 475.

${ }^{89}$ Francisco Moura, 05/03/1934, vol. IX, p. 271.

${ }^{90} \mathrm{O}$ termo é usado em resposta a Góis Monteiro, que entendeu-se acusado de fascista, e objetou dizendo "não ser fascista, mas ser partidário da obrigatoriedade do trabalho". "Superamento", para Oswaldo Aranha, seria então o "regime que se separa dos demais existentes, sem ser novo, nem eclético, mas que, sendo um regime, tem unidade, e essa unidade lhe é dada pelo espírito nacional, isto é, pelo nacionalismo", $38^{\mathrm{a}}$ Sessão (Subcomissão Itamaraty), p. 749.

${ }^{91}$ Oswaldo Aranha, 38 a Sessão (Subcomissão Itamaraty), p. 750. 
Mais uma vez, apresenta-se a inevitabilidade da constitucionalização de reformas sociais, e a impossibilidade de uma Carta política que desconsidere esses esforços de integração já em curso por meio de reformas sociais. Logo, o debate sobre os direitos sociais na Constituição começa amparado na observação dos juristas, membros da Subcomissão, das realidades e doutrinas de sua época, inspirados pelo desejo pragmático de fundar uma sociedade moderna baseada na integração harmônica entre as forças do capital e do trabalho. Precede, de tal forma, um concreto e consistente movimento social reivindicatório, ou a existência inescapável de conflito e tensão social, o que de certo modo dá mais flexibilidade para que a forma de inclusão desses direitos na Constituição fosse pensada antes de tudo nos gabinetes.

Assim, em sua proposta original, o segundo artigo do trecho sobre a ordem econômica e social estabelecia, inspirando-se na Constituição de Weimar" ${ }^{92}$ " "é garantido o direito de propriedade, com o conteúdo e os limites que a lei civil determinar" ${ }^{93}$. O anteprojeto adotou essa redação, excluindo apenas a palavra "civil" (art. 114). Já no substitutivo da Comissão dos 26 , o dispositivo sobre a propriedade saiu do capítulo da ordem econômica, e foi incluído com outra redação entre os direitos e deveres (art. 142, 26), onde permaneceu, com novas alterações, no texto final (art. 113, 17). Aliás, o deslocamento é objeto de divergência entre João Mangabeira e João Marques dos Reis, relator do título "Declaração de Direitos". Para o primeiro, teria havido erro de técnica e erro de elaboração do preceito, incluído entre os direitos individuais, enquanto que para o segundo, "poucos não são os tratadistas junto a quem se encontra a enunciação do direito de propriedade como um direito individual (...). Consequentemente, no substitutivo não há erro. Não há porque realmente o direito de propriedade é um dos supremos direitos do homem. Não há erro de técnica porque dentro da declaração de direitos e deveres é perfeitamente certo se considerar o direito de propriedade. O anátema se originaria, talvez, de uma espécie de fanatismo ou superstição pela Constituição de Weimar (...). Se veio da Constituição de 19 da Alemanha, é sagrado, deve apenas ser traduzido, bem ou mal, fiel ou infielmente, e transformado em lei brasileira... É superstição que não condiz, absolutamente, com a elevação e a cultura de alguns grandes espíritos que se tem

\footnotetext{
${ }^{92}$ Constituição de Weimar, art. 153: “A Constituição garante a propriedade. O seu conteúdo e os seus limites resultam de lei (...). A propriedade obriga e seu uso e exercício devem ao mesmo tempo representar uma função no interesse social".

${ }^{93}$ Para o debate sobre o conteúdo do direito de propriedade na Subcomissão Itamaraty, inclusive sobre a desapropriação e a (justa e prévia) indenização, vide especialmente a $38^{\text {a }}$ Sessão (Subcomissão Itamaraty).
} 
pronunciado sobre o projeto" ${ }^{94}$. Apesar da não manutenção da regulação do direito de propriedade no capítulo sobre a ordem econômica e social, certo é que ficou mantida, no texto final, a obrigação de que a propriedade fosse exercida de acordo com o interesse social ou coletivo, seguindo a tendência das demais Constituições Sociais da época. Bercovici aponta a introdução da função social da propriedade na Carta política como expressão da influência do tenentismo e do Clube 3 de Outubro, que dedicavam especial atenção à regulação desse direito em seu programa ${ }^{95}$.

A controvérsia sobre a jornada de trabalho de oito horas dá novos indícios sobre a polêmica de fundo por trás da constitucionalização dos direitos sociais, e sobre a ausência de consenso quanto a eles. João Mangabeira alerta para o fato de já constar do Tratado de Versalhes, de 1919, a jornada de oito horas ${ }^{96}$, mas Castro Nunes sustenta que "não obstante isso, não é possivel que ele vigore na zona rural, em que um acontecimento imprevisto pode determinar um trabalho de mais de oito horas" ${ }^{97}$, e entende que a decisão poderia ser deixada ao legislador ordinário. Oswaldo Aranha diz que "não se legisla para exceções", e João Mangabeira "lembra que os escravos trabalhavam até 24 horas. Mas não se está legislando para restaurar a escravidão no Brasil. Toda vez que se exige do homem mais de oito horas de trabalho, exige-se além do que psicologicamente o individuo pode dar e esgota-se-o"98. Só há conciliação com a proposta que diz "dia" em lugar de "jornada" de trabalho de oito horas, prevendo eventuais prorrogações em “casos extraordinários” (art. 124, §1º, $3^{99}$ ). É Afrânio de Melo Franco quem verbaliza a necessidade de a Constituição ser mais flexível ao garantir os novos direitos: “Devem-se, pois, estabelecer princípios fundamentais, na nova legislação social brasileira, acompanhando o movimento social do mundo, mas deixando certa elasticidade, que permita a aceitação das conquistas, até assentarem em principios iguais adotados por todos os governos do mundo" 100 .

\footnotetext{
${ }^{94}$ Discurso de João Marques dos Reis citado em REIS, 1934, pp. 207/208, nota 204. Vide REIS, 1934, pp. 207/225 para o debate sobre a função social da propriedade na forma como incluído no texto final da Constituição de 1934.

${ }^{95}$ Cf. BERCOVICI, 2008(b), p. 34.

${ }^{96}$ Art. 426, Anexo I, item 1.

${ }^{97} 38^{\mathrm{a}}$ Sessão (Subcomissão Itamaraty), p. 745.

$9838^{\text {a }}$ Sessão (Subcomissão Itamaraty), p. 746.

99 “Art. 124 (...), §1o. Na legislação sobre o trabalho serão observados os seguintes preceitos, desde já em vigor, além de outras medidas úteis àquele duplo objetivo: (...) 3) O dia de trabalho não excederá de oito horas e nas indústrias insalubres de seis. Em casos extraordinários, poderá ser prorrogado até por três horas, vencendo o trabalho em cada hora o duplo do salário normal. A prorrogação não poderá ser feita consecutivamente por mais de três dias, e não será permitida nas indústrias insalubres, nem aos que tiverem menos de 18 anos"

${ }^{100}$ Afrânio de Melo Franco, $38^{\text {a }}$ Sessão (Subcomissão Itamaraty), p. 748.
} 
O texto da Constituição, bem mais enxuto, manteve a previsão de oito horas, mas abriu a possibilidade de extensão por lei (art. $121, \S 1^{\circ}, c^{101}$ ), abertura que não constava do Substitutivo (art. 159, Parágrafo único, c), pelo que havia sido criticado por Levi Carneiro: "Devo dizer, com a isenção com que o considero, que o anteprojeto é mais sábio quanto a esse ponto [dia de trabalho de oito horas] do que o dispositivo do projeto, porque este contém um erro grave, quando fala nas condições mínimas da existência do trabalhador (...). Preferia a fórmula do anteprojeto, porque previu a dilação do tempo de trabalho, ainda que mediante remuneração proporcional e aludiu às condições normais da existência do trabalhador"102.

No mesmo sentido, o direito de greve também causava polêmicas. Ao debaterem o júri para crimes políticos, Themístocles Cavalcanti sugere que se diga "crimes político-sociais", dizendo que a greve é um deles, o que é contestado por Carlos Maximiliano, afirmando que "greve não é crime" ${ }^{, 103}$. Apesar de não regulada diretamente, a questão foi introduzida no anteprojeto um dispositivo que, por via sinuosa, dela se ocupa, afirmando que "todo indivíduo, salvo impossibilidade física, tem o dever de trabalhar" (art. $\left.103, \S 1^{\circ}\right)^{104}$. A partir de revisão em sentido oposto da posição, o direito de greve consta do Substitutivo da Comissão dos 26 (art. 159, Parágrafo único, $h$ ), mas desaparece completamente sdo texto final - não é demais lembrar que a greve e o lockout são declarados "recursos antissociais nocivos ao trabalho e ao capital" pela Carta de 1937 (art. 139).

No caso do salário mínimo, reivindicação da bancada dos empregados ${ }^{105}$, a decisão do texto final seguiu o anteprojeto em alguns aspectos, mas dele se distanciou em outros. Diferente do anteprojeto, a Constituição fala em um salário que satisfaça as "necessidades normais do trabalhador", e não mais as "necessidades normais da vida de um trabalhador chefe de família", como constava na proposta. A alteração não deve ser desconsiderada, pois transformou o salário de familiar para individual, considerando apenas as necessidades do trabalhados, e não mais de sua família ${ }^{106}$. Por outro lado, optouse por constitucionalizar um mínimo regional (art. $\left.121, \S 1^{\circ}, b\right)$, orientação que já constava

\footnotetext{
101 “Art. $121(\ldots), \S 1^{\circ}$ - A legislação do trabalho observará os seguintes preceitos, além de outros que colimem melhorar as condições do trabalhador: (...) c) trabalho diário não excedente de oito horas, reduzíveis, mas só prorrogáveis nos casos previstos em lei”

${ }^{102}$ Levi Carneiro, 07/03/1934, vol. IX, p. 405.

$10329^{a}$ Sessão (Subcomissão Itamaraty), p. 591.

${ }^{104}$ Cf. VIANNA, 1999 (1976), p. 237.

${ }^{105}$ Vide, por todas, a exposição de Mario Manhães, de 03/04/1934, vol. XIII, pp. 142/147.

${ }^{106}$ Cf. VIANNA, 1999 (1976), p. 247.
} 
do anteprojeto (art. 124, $\left.\S 1^{\circ}, 2\right)^{107}$, descentralizando para os estados a decisão e esvaziando-a de conteúdo nacional.

Dessa forma, a orientação geral foi pela constitucionalização dos direitos sociais previstos na legislação ordinária, deixando, contudo, uma elasticidade não desprezível nos dispositivos ${ }^{108}$. É condizente com a proposta de Castro Nunes, que passa a frequentar a Subcomissão Itamaraty a partir da $28^{\mathrm{a}}$ Sessão. Ele sugere que, em lugar de se afirmarem os direitos trabalhistas em artigos separados, como os demais direitos, fossem aglutinados em um "dispositivo tronco, em que se define, de modo geral, as diretivas que obedece essa preceituação [uma posterior legislação trabalhista], e, em seguida, fixar em parágrafos os pontos que deverão constituir as bases da legislação"109. Tudo "de sorte que os preceitos, que figuram na Constituinte, sobre detalhes dessa legislação, devem ser entendidos como básicos de futura legislação do trabalho"110. Ou seja, a proposta é de que, em lugar de se afirmarem como os próprios direitos, as normas aparecessem na Constituição como preceitos indicativos para a legislação futura.

João Mangabeira, na Subcomissão, "chama a atenção do relator e do autor do substitutivo para a circunstância de se dizer que haverá uma lei que estabelecerá essas medidas [trabalhistas]. De modo que estas só serão estabelecidas depois de votada a lei ordinária pela Assembleia, o que poderá suceder 20 anos depois ou mesmo não suceder, deixando o trabalhador desamparado. No projeto, entretanto, há uma série de artigos e garantias que entrarão em vigor imediatamente após decretada a Constituição. Substituir uma garantia constitucional, que entra, desde logo, em vigor, por uma hipótese de uma legislação futura, que o Congresso pode ou não votar, é o mesmo que deixar o trabalhador sem essa garantia. A mudança se lhe afigura substancial porque se transforma, assim, uma garantia constitucional, que só poderá ser alterada por uma emenda constitucional, numa lei ordinária que depende da Assembleia Nacional, numa lei que pode demorar a vir ou não vir, numa lei dependente da maioria da Assembleia"111. É dele a sugestão de que se digam que as garantias trabalhistas incluídas no anteprojeto figurem como "princípios fundamentais da legislação do trabalho", porque assim julga -

\footnotetext{
${ }^{107}$ Debates durante a $38^{\text {a }}$ Sessão (Subcomissão Itamaraty), pp. 744 e ss.

${ }^{108}$ Ao tratar do Anteprojeto, Themístocles Cavalcanti chama a atenção justamente para a elasticidade dos direitos previstos, na busca da conciliação das premissas liberais às tendências socializantes, afirmando: "Orienta-se por um caminho que não se afasta das nossas perspectivas mais próximas e fornece aos homens que vão governar o país um sistema bastante maleável para, dentro dele, orientar a solução dos nossos problemas econômicos", in CAVALCANTI, 1933, p. 139.

${ }^{109}$ Castro Nunes, $38^{\mathrm{a}}$ Sessão (Subcomissão Itamaraty), p. 741.

${ }^{110}$ Castro Nunes, $38^{\text {a }}$ Sessão (Subcomissão Itamaraty), p. 741.

${ }^{111}$ João Mangabeira, $38^{\mathrm{a}}$ Sessão (Subcomissão Itamaraty), p. 743.
} 
curiosamente, para os olhos de hoje - que entrariam em vigor imediatamente. Seria apenas uma questão de técnica legislativa, ou haveria a decisão explicitado mais uma vez a intenção de conciliação pragmática e programática dos constituintes, resultando em dispositivos abertos e deslocando para o futuro a controvérsia sobre sua aplicabilidade imediata?

$\mathrm{Na}$ Assembleia Constituinte, acentua-se a tendência à constitucionalização dos direitos sociais como princípios maleáveis, cujo conteúdo deve conter um certo grau de indefinição. Assim, Horácio Lafer, representante dos empregadores, é consciente da inevitabilidade da previsão de tais direitos, mas pondera: “Os alicerces do edifício da legislação social devem ser justiça e possibilidade. Não reconhecer a necessidade da legislação social é reeditar a lembrança da sorte de todas as tiranias. Não subordinar a seu turno, a legislação social às possibilidades pecuniárias do produtor é agir de maneira a destruir as fontes do trabalho, e, assim, da subsistência do próprio trabalhador (...). Daí, em síntese, as seguintes sugestões: a) a Constituição não pode descer a especificações, mas tão somente prescrever a necessidade genérica da assistência e providência sociais, deixando à lei ordinária a organização de um instituto que, metódica e sistematicamente, amplie as suas funções de benemerência, de acordo com os recursos possíveis (...); b) uma legislação social deve ser introduzida metodicamente, superpondo-se as leis segundo a sua aplicação para evitar que a avalanche, tumultuando todos os interesses, impeça a efetivação prática de cada uma"112. Uma ou outra voz, como a de João Simplício, aponta para o risco de fórmulas abertas, sujeitas a interpretação, deixando claras as contradições que seriam decorrentes de uma Constituição fruto da busca pela conciliação de conviç̧ões as mais opostas: "O art. 104, escrito no projeto sob as inspirações das doutrinas as mais opostas e perigosas, estabelece que a especificação de direitos e deveres expressos não excluem outros, resultantes do regime político social que a Constituição estatui e dos princípios que consigna. Quer dizer que, no projeto de Constituição, com princípios francamente comunistas, francamente bolchevistas, a que perigos poderá ser arrastada a sociedade brasileira com a aplicação dessas consequências?"113.

\footnotetext{
${ }^{112}$ Horácio Lafer, 21/03/1934, vol. XII, pp. 206/207.

${ }^{113}$ João Simplício, 15/12/1933, vol. II, pp. 312/313. Referia-se ao art. 104 do anteprojeto constitucional: “A especificação dos direitos e deveres expressos nesta Constituição não exclui outros, resultantes da forma de governo que ela adota, do regime político-social que estabelece e dos princípios que consigna". O dispositivo permaneceu levemente alterado como art. 114 da Constituição (" A especificação dos direitos e garantias expressos nesta Constituição não exclui outros, resultantes do regime e dos princípios que ela adota").
} 
A progressiva vagueza dos dispositivos constitucionais, desde a proposta do anteprojeto até o texto final, não passa despercebida. É alvo de crítica nos textos de João Mangabeira, que afirma: “onde, porém, o projeto requinta no seu reacionarismo é no capítulo da ordem social" ${ }^{114}$. Cita como exemplos a redução da regulamentação sobre o que deveria ser o salário mínimo ${ }^{115}$ e a mudança já mencionada anteriormente na previsão da jornada de trabalho de oito horas ${ }^{116}$. Pouco a pouco, com os debates constitucionais, os textos foram perdendo em conteúdo, desde a proposta inicial. A posição de Mangabeira ecoa na Assembleia Constituinte, por exemplo, no discurso de João Vitáca ${ }^{117}$, representante dos empregados, que a reproduz literalmente. Contudo, ao final, prevalece a orientação de que se confira mais elasticidade aos textos, transferindo para o momento futuro a discussão sobre seu conteúdo concreto. Carlos Maximiliano defende o modelo, esclarecendo que “cumpre não confundir concisão com imprecisão. Naturalmente, as constituições não devem ter textos vagos, imprecisos. É defeito grave em todas as leis, e, muito mais, em uma lei suprema. Daí, porém, a concluir que, para evitar esse mal, em vez de se procurar a virtude da concisão, se vá descer a minúcias próprias de leis ordinárias, é tornar a Constituição um repositório de normas imprestáveis e de vida curta"118.

Não à toa, João Mangabeira percebe a importância que passará a ter a interpretação da lei, especialmente das normas constitucionais concisas e mais abertas que garantem os direitos sociais. Assim, propõe a inclusão de artigo que determinasse: "Na interpretação e aplicação da lei, o seu fim social prevalece sobre a sua letra. A lei não poderá ser interpretada ou aplicada contra o interesse coletivo" ${ }^{119}$. A proposta causa polêmica, que vale ser lembrada ${ }^{120}$. Melo Franco questiona se a expressão "fim social" não

\footnotetext{
${ }^{114}$ MANGABEIRA, 1934, p. 166.

${ }^{115}$ MANGABEIRA, 1934, p. 167. João Mangabeira critica a concisão da proposta do substitutivo (art. 159, parágrafo único, $b$ : “o salário deverá satisfazer, conforme as condições de cada região, às necessidades mínimas de subsistência do trabalhador), garantindo o que chamou de um "salário de fome", enquanto o anteprojeto era mais detalhado em relação ao que deveria ser o salário mínimo (art. 124, §1 ${ }^{\circ}, 2$ : "a lei assegurará nas cidades e nos campos um salário mínimo capaz de satisfazer, conforme as condições de cada região, às necessidades normais da vida de um trabalhador chefe de família").

${ }_{116}$ MANGABEIRA, 1934, p. 174.

${ }^{117}$ Cf. João Vitáca, 07/03/1934, vol. IX, p. 373.

${ }^{118}$ Carlos Maximiliano, 27/11/1933, vol. I, p. 424. Ainda que tenha resultado em dispositivos mais principiológicos e de algum modo vagos, abertos à interpretação futura, estratégia de conciliação dos diversos posicionamentos representados na Assembleia, houve vozes que discordaram do produto final e insistiam que fosse ainda mais vago. É o caso, por exemplo, do representante de Goiás Domingos Velasco, para quem "na feitura de nossa Constituição, o método mais conveniente seria o de consubstanciar-se nela, apenas, os princípios fundamentais que caracterizassem o regime a adotar e, como corolário, desenvolver, em tantas leis constitucionais quantas fossem necessárias, aquelas diretivas gerais. Não foi, porém, esse o critério obedecido. Preferiu-se enxertar, no próprio corpo da Constituição, as minúcias que melhor ficariam nas suas leis complementares" (06/04/1934, vol. XIII, p. 293).

${ }^{119} 28^{\text {a }}$ Sessão (Subcomissão Itamaraty), p. 581.

${ }^{120}$ Todas as manifestações durante a $28^{\mathrm{a}}$ Sessão (Subcomissão Itamaraty), pp. 581/582.
} 
restringe a lei, ponderando que um "fim humanitário" é também um fim social. Oswaldo Aranha pondera que seria "o fim da emenda acabar com os casos individuais, que não devem prevalecer sobre o interesse coletivo. $E$ o socialismo subordinado ao democratismo", não sem deixar de acrescentar que "o interesse coletivo é representado pelo Estado". O presidente da Subcomissão prefere que se diga, mais genericamente, que "o interesse público prevalece sobre o particular". Antônio Carlos também é contra, afirmando que "toda e qualquer interpretação da lei deve objetivar e reclamar o direito, seja a favor ou contra o interesse coletivo. Esta é uma porta larga para graves injustiças. O interesse coletivo, por vezes, tem contra si o direito que pode estar ao lado do indivíduo contra aquele". João Mangabeira "garante que não há nenhum direito contra a coletividade", e Oswaldo Aranha "considera a lei como a parte estática do direito. $O$ direito é dinamismo; a lei é o que é, e o direito é o que deve ser. O fim da emenda é assegurar ao juiz que ele deve evoluir, caminhar, e fazer com que a lei tenha a sua finalidade social, e não a finalidade estrita que lhe deram os antigos hermeneutas". João Mangabeira "deseja arrancar os juizes da letra estrita da lei” e Oswaldo Aranha de certa forma concorda, ainda que a partir de pressupostos ideológicos distintos: "o que se deseja é permitir que haja um estudo da elaboração da lei, no sentido da coletividade, da parte do mais humilde dos magistrados, e não fique ele sujeito a ser punido por dar uma interpretação mais ampla, mais generosa, a uma lei social". Themístocles Cavalcanti vota a favor do dispositivo, porque ele "dá um cunho bem social à nova Constituição". Ao final, contudo, somente a segunda parte da proposta é aprovada (art. 58, anteprojeto). Todavia, mesmo ela desaparece no texto final da Constituição, que deixa de legislar sobre a interpretação social das leis.

A relevância crescente da interpretação das normas constitucionais, tarefa primeira dos órgãos jurisdicionais (especialmente no quadro de um controle de constitucionalidade) é salientada também por Pontes de Miranda, que, nos comentários à Constituição de 1934, trata do assunto, escrevendo: "Ponto extremamente grave para a função judicial de apreciação da constitucionalidade está em serem as Constituições recentes atos transacionais, desde que não sejam unipartidários. Quando pluripartidários, as fórmulas vagas, elásticas, plurissignificativas, acordos sem sentido nítido com que se protrai a univocidade da politica, permitem que se leiam coisas diversíssimas, e ao juiz cabe dizer o que significam. Então, só o juiz, em verdade, lhes dá sentido; só a justiça 
decidirá no sentido político" ${ }^{121}$. O jurista chama atenção para o fato de as novas Constituições constituírem-se como acordos, como "atos transacionais", entre diferentes correntes político-partidárias, arranjos que resultam, justamente, em fórmulas abertas, postergando para o momento da interpretação a atribuição de sentido concreto aos pactos políticos mais ou menos amplos. À doutrina do Direito Público incumbirá, desse modo, fornecer as balizas para a interpretação constitucional, não raro escamoteando por trás de uma tarefa aparentemente técnica decisões políticas.

Incluir dispositivos constitucionais inéditos e mais ou menos vagos significa, portanto, abrir desde logo os debates sobre sua interpretação, que fornecerá o suporte conceitual da atividade jurisdicional. Segundo Bercovici, "embora no texto de 1934 haja esta previsão expressa de direitos sociais como saúde, assistência pública e educação, a doutrina publicista da época não atribui valor jurídico a esses direitos" ${ }^{\prime 22}$. A análise da retórica dos atores envolvidos no processo constituinte permite concluir, como visto, que a própria constitucionalização de tais direitos considerava a inclusão de dispositivos abertos e maleáveis, de forma a deixar, intencionalmente, sua interpretação para a doutrina e para a atividade jurisdicional, que poderia, ou não, incorporá-los como categorias operativas, a depender dos estímulos ("externos" ou políticos, diríamos) que tivesse para tanto. Bonavides e Andrade indicam o resultado do modelo adotado: “É certo, no entanto, que muitos desses princípios [inovações da Carta de 1934] não saíram do papel, o que aliás os próprios constituintes já previam ao término dos trabalhos. Já se sabia que muitos dos preceitos da legislação trabalhista não seriam (não poderiam ser, segundo os empregadores) cumpridos" ${ }^{\prime 23}$.

Não espanta, portanto, que Pontes de Miranda tenha se valido da ainda recente ideia de "norma programática" para qualificar tais direitos, ao comentar as constituições de 1934 e 1946, como lembra Bercovici ${ }^{124}$. Mirkine-Guetzévitch, que vê na constitucionalização dos direitos sociais uma evidência do movimento de racionalização do poder, apressa-se em dizer que "o valor teórico desses direitos sociais não é de maneira alguma diminuido pelo fato de não serem eles realizados em alguns Estados. O novo direito democrático, mesmo que não penetre inteiramente a vida, é, entretanto, um elemento de educação das massas; o novo direito tem um certo valor educativo" 125 . Seria,

\footnotetext{
${ }^{121}$ PONTES DE MIRANDA, 1937, t. I, p. 100.

122 BERCOVICI, 2009, p. 728.

${ }^{123}$ BONAVIDES e ANDRADE, 2006, p. 326.

${ }^{124}$ Cf. BERCOVICI, 2009, p. 728 e nota 21, e BERCOVICI, 2008(b), p. 29

${ }^{125}$ MIRKINE-GUETZÉVITCH, 1933, p. 151.
} 
assim, da própria natureza desses novos direitos a sua eventual não realização na prática, porque são dispositivos programáticos ${ }^{126}$, que apontam para um ideal futuro, que virá, quem sabe, da educação política das massas.

Os constituintes, especialmente versados nas teorias jurídicas da época, tinham consciência de que a aplicação dos novos direitos sociais colocaria problemas à doutrina publicista. Prado Kelly é um bom exemplo: "Precisamente, quando se trata de estabelecer distinções indispensáveis entre o Estado liberal, que produziu a decadência da primeira República, e o Estado moderno, em que as inspirações mais avançadas da cultura contemporânea que se há de ver o problema da educação, não exclusivamente do ponto de vista da pedagogia, senão da compreensão indispensável do complexo de normas de ordem pública e de ação administrativa, de modo que, ao mesmo tempo se consagrem um dever de Estado e um novo direito individual, que vem completar aqueles já previstos (...) na clássica 'declaração de direitos' da Revolução Francesa (...). Uma coisa é dizer que haverá escolas públicas, e outra que todos terão escolas públicas. Há direitos declarados verbalmente e de difícil reconhecimento, e direitos subjetivos, acionáveis. A distinção é essencial, para que se compreenda o nosso estudo (...). As Declarações de Direitos, eficazes na parte negativa (não ser preso sem processo, não se violar o domicílio etc), permanecem como simples programa, na parte positiva (ensino primário gratuito, assistência etc) ${ }^{\text {"127 }}$. Com isso, refere-se inclusive à posição de Mirkine-Guetzévitch, para concluir que os novos direitos sociais podem não gerar efeitos imediatos, mas funcionar como simples aspiração para o futuro ${ }^{128}$.

Fica clara a distinção que Prado Kelly faz entre direitos individuais que implicam em uma simples garantia e inação do Estado (chamados, ainda que indevidamente ${ }^{129}$, de "direitos negativos"), e direitos que determinam uma ação e um dever para o Estado (os "direitos positivos", tipicamente o caso dos direitos sociais, como a educação e a assistência, nos exemplos do deputado). A constatação orientou o constituinte

\footnotetext{
${ }^{126}$ Para uma problematização da categoria atual de dispositivo programático, situando-a em contexto histórico, vide BERCOVICI, 2008(b), pp. 55/61.

${ }^{127}$ Prado Kelly, 22/02/1934, vol. VIII, pp. 300/301.

128 “....mesmo que fosse difícil executar um inciso constitucional dessa natureza, eu me permitiria recordar a advertência de Mirkine Guetzévitch, tão censurado por alguns espíritos dessa Cara, a despeito do seu valor e do mérito dos seus trabalhos. O referido autor, em relação às normas incluídas nas constituições, salienta que são, muitas vezes, não para o efeito direto e imediato, mas para gerar aquele estado de espírito, ou despertar aquele interesse indispensável aos poderes públicos, de modo que o que era simples intenção, ou aspiração informe, mal definida ou caracterizada, se venha a transformar em prática oportunamente, quando a situação do país e a conquista das inteligências permitam sejam colimados esses objetivos", in Prado Kelly, 22/02/1934, vol. VIII, p. 305.

${ }^{129}$ Para uma avaliação crítica das características dos direitos sociais na literatura jurídica, cf. HERRERA, 2009, especialmente capítulos I e II.
} 
a propor que se deixasse explícito na Constituição que a educação era "direito assegurado a todo brasileiro", já que "a razão de ser desse princípio foi a que acabei de expor: trata-se de direito público subjetivo, que se vai integrar na declaração total dos direitos que herdamos, e que vêm a constituir, de certo modo, um legado da tradição liberal francesa" $"$. Ao final, o texto constitucional fala em educação como "direito de todos" (art. 149), sendo simbólico o tratamento especial dado a esse direito específico, aproximando-o da tradicional noção de direito subjetivo, e buscando separá-lo do problema de aplicabilidade que colocaria em xeque os demais direitos sociais. De acordo com Bonavides e Andrade, Prado Kelly foi justamente “em larga medida o responsável pela inclusão de (...) um capítulo especial sobre a educação" ${ }^{\text {"131. }}$.

Com isso, podemos concluir que a Constituição de 1934 representou um esforço sem precedentes na história brasileira para a garantia de direitos sociais, ao lado de direitos políticos tipicamente liberais. Reconhecia-se a inevitabilidade de se incorporarem à carta política objetivos de democracia econômica, que considerassem o homem inserido em seu ambiente de trabalho e social, e lhe garantissem instrumentos para que, simbolicamente, pudesse reivindicar como projeto de futuro a igualdade material de condições de vida. O movimento representava, ainda, a redefinição do papel do Estado, que passa a ser instado a atuar positivamente na economia, seja por meio de prestações materiais, seja por meio da intervenção mais ampla no ambiente de mercado, especialmente diante dos dispositivos do capítulo da ordem econômica e social. A inclusão de direitos sociais na Constituição representou, ainda, a inscrição na lei fundamental de direitos que já vinham sendo forjados pela legislação ordinária do Governo Provisório, delineando um Estado novo também do ponto de vista de sua carta fundadora, moderna e social. Assim é que o enunciado inaugural da ordem econômica e social (“art. 115 - a ordem econômica e social deve ser organizada conforme os princípios da justiça e as necessidades da vida nacional, de modo que possibilite a todos uma existência digna) representa, para, Kugelmas, o "dobre de finados do individualismo à outrance no

\footnotetext{
${ }^{130}$ Prado Kelly, 22/02/1934, vol. VIII, p. 303. Antes disso, sustentou que "para obrigar os governos a assegurar a difusão do ensino, tem-se sugerido: a) a destinação de verbas especiais, em texto constitucional; b) a destinação de percentuais das rendas arrecadadas, como se pretende na comissão de Constituição (1932-1933); c) o direito público subjetivo, no Estado, sem fins precisos (Alemanha); o direito público subjetivo, no Estado de fins precisos, é o que pretendemos (...). Há ação gratuita contra o Estado (direito público subjetivo) e a segurança advinda da autonomia do plano (Estado de fins precisos ou Estado unívoco)", p. 302.

${ }^{131}$ BONAVIDES e ANDRADE, 2006, p. 325.
} 
arcabouço jurídico-institucional do país", a despeito de "seu caráter de norma programática e da vaguidão da fórmula"132.

Contudo, os novos direitos traziam também a perplexidade dos juristas, diante da dificuldade em lidar com eles a partir do velho arcabouço jurídico liberal. A Constituição, como se vem destacando nesse estudo, representa um impulso de conciliação da tradição teórica liberal e das doutrinas coletivistas, e os direitos sociais também são vistos a partir desse por vezes contraditório equilíbrio. Apesar do avanço representado pela sua constitucionalização, o esforço de combinação das tradições teóricas, conjugado com uma Constituinte pouco representativa da sociedade brasileira, não necessariamente representou uma mudança de fundo nas convicções liberais da doutrina publicista majoritária, que muitas vezes preferiu compreendê-los, a partir da brecha deixada pela vagueza dos dispositivos legais, como um compromisso programático, em oposição à certeza representada pelos direitos subjetivos. A inclusão dos direitos sociais na Constituição de 1934, em vários casos, deslocou para um momento futuro a decisão sobre seu efetivo conteúdo, sobre a sua eficácia concreta, portanto, contentando-se com uma conciliação provisória, de conteúdo aberto.

Tanto assim que o caso da pluralidade sindical, importante debate relacionado à nova Constituição, ao mesmo tempo, confirma e desconfirma a análise. A despeito do Decreto $\mathrm{n}^{\mathrm{o}}$ 19.770, de 19 de março de 1931, e da orientação do Governo Provisório em favor da unicidade sindical e do controle rigoroso do Poder Público sobre os sindicatos (que eram "entidades colaboradoras"), os constituintes optaram, em uma aliança de ocasião ${ }^{133}$, pela inclusão de regra expressa em sentido contrário: “A lei assegurará a pluralidade sindical e a completa autonomia dos sindicatos" (art. 120, parágrafo único). Ainda que fizesse referência a lei posterior, a opção pela pluralidade não estava aparentemente aberta a interpretações, o que desagradou a muitos dos ciosos do regime de unicidade que já vinha sendo posto em curso, como Oliveira Vianna. Mas a lei regulamentadora já tinha vindo dias antes da promulgação da Constituição: era o Decreto $\mathrm{n}^{\mathrm{o}}$ 24.694, de 12 de julho de 1934, que, apesar de formalmente orientar-se pelo princípio da pluralidade, na prática restringia enormemente o direito, por exemplo com a exigência de um terço dos empregados de uma mesma profissão para a formação do sindicato (art. 5) -

${ }^{132}$ KUGELMAS, 1987, p. 31.

${ }^{133} \mathrm{O}$ dispositivo é resultado de proposta do deputado classista Pinheiro Lima, que fundamentou-o na necessidade de incentivar a vida associativa nacional. Para um olhar mais detido sobre a inclusão do dispositivo, e sobre a influência dos católicos, circunstancialmente (e não fortemente) alinhados às pautas liberais, ver VIANNA, 1999 (1976), pp. 194/216. Sobre o assunto, ver também MORAES FILHO, 1978 (1952), pp. 226/243. 
haveria, portanto, um máximo de três sindicatos por categoria, no caso puramente hipotético de que a totalidade dos trabalhadores se organizasse.

A conclusão de Evaristo de Moraes Filho é evidente, qual seja, a de que “"nunca tivemos, a rigor, uma pluralidade sindical em nossa história associativa depois de 1930. Tivemo-la, sim, no regime do decreto 1.637, de 1907, perante o qual bastavam sete associados para dar como constituído um sindicato, sem outra exigência além do registro no cartório competente, com a juntada da identidade dos sócios e da cópia dos estatutos" $" 134$. O mesmo autor segue mostrando de que forma, diante de questionamentos sobre a constitucionalidade do novo decreto, a interpretação jurídica dominante no Ministério do Trabalho e nos tribunais ordinários caminhou no sentido de ratificar mais a intervenção e o controle público sobre os sindicatos do que restringir a atuação ${ }^{135}$. O caso é exceção à tendência de incluir na Constituição dispositivos abertos - a norma é suficientemente clara no sentido da pluralidade e completa autonomia dos sindicatos - mas ilustra ao mesmo tempo a inclinação futura de enxergar conteúdos variáveis e bastante maleáveis nas normas constitucionais ${ }^{136}$. Novamente, a Constituição de 1934, em seu formato inovador e modernizante, traduz ao mesmo tempo a constitucionalização da disciplina e de rol amplo de direitos sociais, ao mesmo tempo em que se converte em texto aberto, de influências plurais, sujeito cada vez mais ao conteúdo que lhe for atribuir a doutrina e a jurisprudência futuras, essas sim, verdadeiramente, apossando-se mais e mais da decisão.

\subsubsection{Intervenção social: formando o povo brasileiro}

"Sou, por convicção, contrário a essa trágica confiança na violência que se vem espalhando no mundo, em virtude de um conflito de interesses que só pode ser resolvido, a meu ver, pela educação, no sentido largo do termo. Por isso mesmo, constrange-me, nessa hora, ver suspeitada a minha ação de educador e toda a obra de esforço e sacrifício realizada no Distrito Federal, obra que possuía a intenção profunda e

\footnotetext{
${ }^{134}$ MORAES FILHO, 1978 (1952), p. 227.

${ }^{135}$ Cf. MORAES FILHO, 1978 (1952), p. 233 nota 235.

${ }^{136}$ É nesse sentido o comentário de Luiz Werneck Vianna, que, no entanto, esvazia de sentido a norma constitucional, apontando para a contradição entre texto e eficácia prática: "Quatro dias antes de ser promulgada a Constituição, o Estado dá sua resposta ao regime sindical dos constituintes. $O$ Decreto $n^{o}$ 24.694, de 12 de julho de 1934, em claro desrespeito à Assembleia Constituinte, ratifica o sistema tutelar. A autonomia sindical, conquistada contra a vontade do Estado, não terá força para se impor numa ordem inclusiva que a nega", in VIANNA, 1999 (1976), p. 247.
} 
permanente de indicar o rumo a seguir para se resolverem as tremendas perplexidades do momento histórico em que vivemos. Lavro contra tal suspeição o meu protesto mais veemente, parecendo-me que tem ela mais largo alcance que a minha pessoa, porque importaria em não reconhecer que progredir por educação é exatamente o modo adequado de se evitarem as revoluções. Se, porém, os educadores, os que descreem da violência e acreditam que só as ideias e o seu livre cultivo e debate é que operam, pacificamente, as transformações necessárias, se até esses são suspeitados, feridos e malsinados os seus esforços, que outra alternativa se abre para a pacificação e conciliação dos espiritos?" ${ }^{137}$. Assim manifestava-se Anísio Teixeira ${ }^{138} \mathrm{em}$ sua carta de renúncia da reitoria da Universidade do Distrito Federal, datada de 1 de dezembro de 1935. O discurso contém uma das ideias que era extremamente difundida no período, que estava por trás também da Constituição de 1934, ao tratar da disciplina do social: a ideia de que era preciso garantir a educação do povo brasileiro, e que só assim seria possível formar a opinião pública e prevenir futuros conflitos e "revoluções". Ao lado dos direitos sociais, a carta política investiu também na regulação do social como estratégia de promover a formação e a integração da sociedade brasileira, adotando o reformismo preventivo como suposta saída para constituir os laços de cooperação e solidariedade social. A educação como direito e como obrigação é um bom exemplo desse movimento, dessa tendência centralizadora e controladora, desse "desejo de regular todas as instâncias do corpo social ${ }^{, 139}$.

Não é demais lembrar, de passagem, a posição influente de Oliveira Vianna, para quem, como já mencionado, o desafio nacional era a construção de cooperação e solidariedade a partir da formação do povo brasileiro. Em posição mais radical, sustenta a democracia como governo de opinião, não necessariamente vinculada ao voto, mas sim orientada em torno da pressão moral exercida pela opinião organizada ${ }^{140}$. A decorrência seguinte dessa posição, inspirada pelas ideias da época, é situar a política menos no Parlamento, em crise segundo o autor, e mais no entendimento direto do governo com os interesses sociais organizados, e valorizar as elites e a organização das classes produtoras. Subjacente, um diagnóstico de que no Brasil não há opinião pública organizada

\footnotetext{
${ }^{137}$ Anísio Teixeira, carta de renúncia da reitoria da Universidade do Distrito Federal, reproduzida em Alberto Venâncio Filho, in VENÂNCIO FILHO e LYRA, 1978, pp. 93/94.

${ }^{138}$ Jurista e educador brasileiro, é um dos signatários do Manifesto dos Pioneiros da Educação Nova, de 1932 e participou ativamente da política nacional durante toda a sua vida, especialmente no que diz respeito à educação. Faleceu em 1971, em plena ditadura militar, em morte cercada de circuntâncias suspeitas. Vide verbete TEIXEIRA, Anísio, em Dicionário Histórico-Biográfico Brasileiro.

${ }^{139}$ BONAVIDES e ANDRADE, 2006, p. 326.

${ }^{140}$ Cf. VIANNA, 1927, pp. 93/97.
} 
capaz de constituir-se como "pressure from without", como na Inglaterra. Não por outra razão, opõe-se às eleições diretas do Presidente da República, já que o sistema do sufrágio direto "presume, nas massas eleitorais, um espírito político e uma cultura cívica que absolutamente não existem nas massas eleitorais do nosso país"141.

Deixando de lado extremismos autoritários que podem ser consequência do raciocínio, o diagnóstico implica, aos que desejam formular um modelo de democracia tipicamente brasileiro, que ela passa pela formação do povo de forma a constituir um substrato político ativo e integrado por laços de solidariedade, só assim garantindo sua participação eleitoral dentro das balizas "adequadas". Nos discursos do momento constituinte de 1933/34, não raro encontram-se referências nesse sentido, especialmente relacionadas à regulação e ao controle da vida social, de modo a promover a "formação moral" e a "integração econômica" da população. A constituição da modernidade, no país, passava, de acordo com a retórica majoritária, pela tutela social, para além da previsão de novos direitos.

Nesse sentido, o Programa do Club 3 de Outubro asseverava: "Reivindicamos para as classes produtoras e trabalhadoras, com a colaboração preciosa das forças morais que se apoiarem nas tradições e na índole brasileiras o primado da legislação e do controle sobre a organização da sociedade nacional, em tudo quanto disser respeito à sua economia, à direção dos negócios públicos, à repressão dos vícios, ao saneamento físico, moral, intelectual, político, profissional e técnico da nacionalidade, não esquecidas as massas trabalhadores pobres e incultas das cidades e do interior, teremos assegurado o equilíbrio social necessário e aparelhado o país dos meios de assistência indispensáveis à eliminação progressiva das injustiças, das opressões econômicas e do pauperismo, fatores lastimáveis de inquietação e de desordem internas, na época contemporânea" ${ }^{142}$. A premissa fundamentava um extenso programa de organização social, em que se incluíam não apenas os direitos trabalhistas, mas também uma abrangente tutela da vida social - pleiteava-se, por exemplo, a regulamentação da nacionalização e da imigração, estimulando a "incorporação do estrangeiro à sociedade brasileira", a atribuição aos Poderes Públicos da obrigação de "zelar pela moralidade, saúde e melhoria social do indivíduo e da família", bem como de "eliminar todos os vícios individuais e sociais" (dando-se como exemplos a abolição da "indústria de loterias" e o

${ }^{141}$ Já citado discurso de Oliveira Vianna, 13 ${ }^{\mathrm{a}}$ Sessão (Subcomissão Itamaraty), p. 227, republicado em VIANNA, 1939, p. 251.

${ }^{142}$ Programa do Club 3 de Outubro, vol. III, p. 193. 
estímulo da "temperança", taxando pesadamente as bebidas alcólicas), a proteção da juventude contra o "abandono moral, físico e intelectual”, o auxílio às famílias numerosas, a criação de seguros sociais, a garantia da saúde, da higiene e dos serviços sanitários, e, claro, a ampliação radical do ensino, em todos os níveis, tornando-o obrigatório até os 11 $\operatorname{anos}^{143}$.

A educação despontava como principal preocupação, seja como direito, seja como intervenção e tutela social. No discurso inaugural, apresentando dados sobre as deficiências da rede de ensino público brasileira, Getúlio Vargas pronuncia: "O problema da educação do nosso povo continua a ser, ainda e sempre, nosso magno problema"144. Em direção semelhante, já consta do Manifesto dos Pioneiros da Educação Nova ${ }^{145}$, de 1932: "Na hierarquia dos problemas nacionais, nenhum sobreleva em importância e gravidade ao da educação. Nem mesmo os de caráter econômico lhe podem disputar a primazia nos planos de reconstrução nacional. Pois, se a evolução orgânica do sistema cultural de um país depende de suas condições econômicas, é impossível desenvolver as forças econômicas ou de produção, sem o preparo intensivo das forças culturais e o desenvolvimento das aptidões à invenção e à iniciativa que são os fatores fundamentais do acréscimo de riqueza de uma sociedade ${ }^{\text {"146 }}$. O mesmo manifesto expressava como valor a educação enquanto dimensão de integração social, criticando o que chamou de "educação tradicional" e defendendo a escola socializada como ponto de partida para a promoção da solidariedade e da cooperação: “A escola tradicional, instalada para uma concepção burguesa, vinha mantendo o indivíduo na sua autonomia isolada e estéril, resultante da doutrina do individualismo libertário, que teve aliás o seu papel na formação das democracias e sem cujo assalto não se teriam quebrado os quadros rígidos da vida social. A escola socializada, reconstituída sobre a base da atividade e da produção, em que se considera o trabalho como a melhor maneira de estudar a realidade em geral (aquisição ativa da cultura) e a melhor maneira de estudar o trabalho em si mesmo, como fundamento da sociedade humana, se organizou para remontar a corrente e restabelecer,

\footnotetext{
${ }^{143}$ Programa do Club 3 de Outubro, vol. III, pp. 219/230.

${ }^{144}$ Getúlio Vargas, discurso inaugural, vol. I, p. 109.

${ }^{145}$ Trata-se de manifesto de 1932, em que congregaram-se diversos intelectuais, de diferentes convicções ideológicas, para reivindicar reformas no ensino brasileiro, de onde deveria partir a reorganização da sociedade. O documento é assinado por Fernando de Azevedo, Afrânio Peixoto, A. de Sampaio Doria, Anísio Spínola Teixeira, M. Bergstrom Lourenço Filho, Roquette Pinto, J. G. Frota Pessôa, Júlio de Mesquita Filho, Raul Briquet, Mario Casassanta, C. Delgado de Carvalho, A. Ferreira de Almeida Jr., J. P. Fontenelle, Roldão Lopes de Barros, Noemy M. da Silveira, Hermes Lima, Attílio Vivacqua, Francisco Venâncio Filho, Paulo Maranhão, Cecilia Meirelles, Edgar Sussekind de Mendonça, Armanda Álvaro Alberto Garcia de Rezende, Nobrega da Cunha, Paschoal Lemme e Raul Gomes.

${ }^{146}$ Manifesto dos Pioneiros da Educação Nova, p. 1.
} 
entre os homens, o espírito de disciplina, solidariedade e cooperação, por uma profunda obra social que ultrapassa largamente o quadro estreito dos interesses de classes" ${ }^{\prime 47}$. Nada mais condizente com o questionamento das antigas premissas individualistas e com a defesa de uma sociedade fundada em laços de solidariedade.

Antes disso, Alfredo Bosi apontaria como um dos pilares do positivismo gaúcho ainda durante a Primeira República o "projeto de um ensino fundamental gratuito e leigo. Aqui, força é convir, comtianos e spencerianos davam-se fraternalmente as mãos, pois os aproximava a fé inabalável na ciência como fautora do progresso e na educação como a sua via real" ${ }^{148}$. Era preciso, para que se constituísse uma nação integrada e organizada em direção ao progresso, que o Estado assumisse a promoção da formação do indivíduo, do operário, como uma de suas tarefas centrais. É esse o rumo que orienta as políticas educacionais sul rio-grandenses, que garantem ao estado as menores taxas de analfabetismo do país, que garantem sua considerável fatia de representação política, ao se tomar por base para o cálculo de representantes o eleitorado, e não a população. A retórica positivista do direito à educação manifestar-se-ia também nos debates constituintes dos anos 1930, orientando a modelagem de um Estado provedor de formação para o trabalho, bem como para a vida democrática.

A educação é, assim, um dos temas centrais na Constituinte, e reflete-se na introdução de um título específico da Carta política sobre Educação, Família e Cultura, agrupados, e excluindo, como constava do anteprojeto, uma sessão específica sobre religião, que nem por isso deixou de ser regulada em seus dispositivos - vale lembrar que devemos à Constituição de 1934 a introdução, no plano constitucional, do ensino religioso facultativo (art. 153). Os membros da Subcomissão Itamaraty expressavam a preocupação com a formação do povo brasileiro, como por exemplo na manifestação de Agenor de Roure, cauteloso, como destacado anteriormente, em relação à participação política dos analfabetos, sustentando a conveniência de tornar o ensino primário obrigatório, contanto que houvesse escolas suficientes ${ }^{149}$. Em outro momento, menciona-se a existência de um "projeto com duas mil assinaturas, entre as quais figuram a do reitor da Universidade, a dos reitores de diferentes Escolas Superiores da República e de presidentes de numerosas associações", enviado à Subcomissão, que tratava da necessidade de reforma da instrução

\footnotetext{
${ }^{147}$ Manifesto dos Pioneiros da Educação Nova, p. 6.

${ }^{148}$ BOSI, 2003 (1992), p. 300.

${ }^{149}$ Cf. Agenor de Roure, $36^{\text {a }}$ Sessão (Subcomissão Itamaraty), pp. 693/694.
} 
pública $^{150}$. Com isso, é possível concluir que o ambiente social e político era de reivindicações por melhorias na educação nacional.

$\mathrm{Na}$ Assembleia Constituinte, não raro aparecem manifestações nesse sentido, tais como a de Mata Machado, citando Alberto Torres: "saber ler e escrever é bom quando aumenta a capacidade de trabalho, se cultiva a vaidade é melhor não saber. Alberto Torres, insigne sociólogo que deveria ser o nosso condutos na marcha tormentosa e confusa da nossa vida, afirmou-o, em forma lapidar, dizendo: 'O analfabetismo, ou o simples ensino, mais pernicioso que útil do alfabeto e das quatro operações, a carência dos primeiros elementos da saúde, da vida moral, do senso, da iniciativa e da ambição, fazem do nosso povo um imenso rebanho de corpos exangues e de almas desfalecidas" ${ }^{\text {"151. }}$. No mesmo sentido, Soares Filho: “A única forma, o único remédio contra a representação desse espírito de clã, esse espírito localista de interesses pessoais em torno de chefes, consiste na evolução lenta da educação das massas, no estímulo ao espírito de solidariedade das classes, pela melhor compreensão do alto sentimento dos interesses nacionais (...). Cumpre, ainda, ter em vista outras condições de ordem econômica ou financeira e o desenvolvimento do sentimento do interesse público, pela escola, pela propaganda assídua, diuturnamente feita, pelo exemplo e, sobretudo, pela adoção de uma legislação eleitoral peculiar às condições do nosso meio e que possa corrigir, com a ajuda do rigor de seus dispositivos, as falhas do nosso caráter social e político" ${ }^{152}$. Uma população não educada não preencheria os requisitos mínimos para a participação ativa na vida democrática do país, já que não podia sequer compreender os "sentimentos nacionais", de onde se pode diagnosticas a "falha de nosso caráter social e político".

A falta de instrução do povo brasileiro era vista, sobretudo, como um obstáculo à integração nacional, e justificava um discurso excludente, pregando a necessidade de trilhar-se um caminho em etapas para a ampliação da participação democrática. Era preciso educar a população e disciplinar "moralmente" a vida social, permitindo que o país entrasse na modernidade com uma sociedade integrada, unida pelos laços da solidariedade e da cooperação, antes que se pensasse em implementar amplamente as premissas universalistas da democracia liberal. Daí a consequência óbvia de uma democracia limitada.

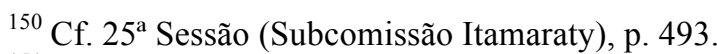

${ }^{151}$ Mata Machado, 04/04/1934, vol. XIII, p. 173.

${ }^{152}$ Soares Filho, 19/01/1934, vol. VI, p. 259.
} 
Não à toa, Assis Brasil associava a democracia e o discurso pelas reformas educacionais: "é preciso consolidar na consciência nacional a necessidade de não soltar mais essa grande conquista que, perdida, abre o nosso próprio túmulo, como nação e como povo, digo. O Brasil não pode mais deixar de ter representação verdadeira. É o primeiro termo do binômio. Agora, vêm os sábios, os prudentes, os conselheiros Acácio e dizem: - 'Mas as leis não valem nada senão há educação. Se o povo não está preparado, é inútil'. Eles têm alguma razão. Não toda. As leis não valem tudo, seria inútil fazer uma lei mandando baixar uma estrela até a Esplanada do Castelo, por exemplo, como seria inútil fazer leis declarando que todos os brasileiros sejam virtuosos. Isso seria muito fácil (...). É, pois, preciso que a nação tenha liberdade, não como querem os nefelibatas e sonhadores, para fazer os seus governos de anjos. Quero que a nação tenha liberdade para fazer os seus maus governos, porque é pelo preço de fazer os maus negócios e de dar os maus passos que os homens e os povos aprendem a dar os bons e a ser dignos de sua liberdade. A representação verdadeira é uma necessidade; não para fazer bom governo, mas para tornar o povo apto a fazer um bom governo. Resumindo mais ainda: para que cada povo tenha o governo que merece - porque nada mais injusto do que dar ao povo o governo que ele não merece" ${ }^{, 153}$.

Aparentemente, a premissa de que o povo precisava estar preparado para a democracia orientou mais os trabalhos da Constituinte e o resultado final do texto constitucional do que desejaria Assis Brasil. Ampliação democrática dentro de balizas rígidas, combinada com uma preocupação central com a formação, moral e intelectual, do povo brasileiro, davam o tom dos discursos majoritários durante o processo de reconstitucionalização do país, de forma que "maus governos" não pudessem ser um risco a se correr. Acreditava-se, com isso, abrir o caminho da modernidade a partir de uma sociedade organizada e integrada pelos laços de solidariedade, que preveniam eventuais futuros conflitos entre classes trabalhadoras e classes produtoras, à exemplo do que vinham observando na Europa e em seus parlamentos em crise.

\footnotetext{
${ }^{153}$ Assis Brasil, 21/12/1933, vol. II, pp. 508 e 513. Os discursos são republicados em BROSSARD (org.), 1989, pp. 177/189. Vale lembrar que Joaquim Francisco de Assis Brasil não permanece na Assembleia Constituinte até a conclusão dos trabalhos, renunciando ao mandato em 14 de fevereiro de 1934 (renúncia apenas votada em 20 de março). Sua vaga foi ocupada pelo suplente Minuano de Moura.
} 


\title{
7 Conclusão
}

\section{CRISE DO LIBERALISMO, IRRUPÇÃO DO SOCIAL E DIREITOS: A VIRADA DO CONSTITUCIONALISMO E DOS CONSTITUCIONALISTAS}

\begin{abstract}
7.1 Socialização do direito: o desafio da história; 7.2 A resposta da doutrina constitucional francesa: o direito como fator de movimento; 7.3 A resposta da Constituição brasileira de 1934: regulação social e democracia limitada; 7.3.1 Influência francesa: reposicionando a história das ideias; 7.3.2 Processos comparados: a virada pragmática do constitucionalismo brasileiro
\end{abstract}

"Uma Constituição deve ser (e o é em toda parte do mundo) um instrumento de pacificação social, uma lei de suma e incomparável relevância, destinada a harmonizar e coordenar os vários interesses que se revelam no país em que ela tem que vigorar" ", afirmava o advogado e político José Augusto ${ }^{2}$ em 1933, quando o Brasil assistia ao início do processo constituinte. O desafio de promover a coordenação de interesses, naquele momento, se revelava mais do que nunca problemático, diante, por um lado, da multiplicação das questões que vinham sendo tratadas nas novas Constituições do século XX, e por outro, da dificuldade de conciliação das forças e facções políticas que tinham sido responsáveis pela ruptura com a ordem da Primeira República, durante a Revolução de 1930. O velho constitucionalismo liberal já não podia responder às demandas contemporâneas, além de ter sido objeto de críticas por ter embasado uma carta política, a de 1891, em que o modelo ideal não podia estar mais divorciado da prática. Era preciso encontrar um novo modelo, capaz de prevenir problemas que já eram realidade em outros países, absorver as doutrinas que se tinham desenvolvido no estrangeiro, mas também de compor uma solução que tivesse em conta as especificidades nacionais.

Colocou-se como problema para a tese compreender de que modo a irrupção do social, especificamente pela via democrática, mesmo que potencialmente, refletiu-se no direito, em especial no direito constitucional, enquanto terreno em que se manifesta mais particularmente a relação entre direito e política. O objeto de estudo eleito

\footnotetext{
${ }^{1}$ AUGUSTO, 1933, p. 9.

2 José Augusto foi deputado federal em diversas legislaturas, senador, e governador do Rio Grande do Norte, onde fundou o Partido Popular (PP), que elegeu três deputados constituintes. Adversário de Vargas, deixou de se candidatar à Assembleia Nacional Constituinte de 1933/34 para evitar reações do governo central, dados em Dicionário Histórico-Biográfico Brasileiro Pós-1930 (2010).
} 
foi, particularmente, a Constituição brasileira de 1934, vista pelas lentes da doutrina constitucional francesa do entre-guerras.

Assim sendo, o que se quer elucidar é a forma peculiar pela qual se equacionaram, em uma Constituição moderna, econômica e social, os velhos princípios de democracia liberal e os novos direitos sociais, bem como o avanço da regulação e da participação do Estado na vida social e econômica. O que pode ser dito sobre isso dentro da perspectiva interna ao direito, em termos de influências e arranjo de soluções jurídicas para uma nova realidade social? De que forma a irrupção do social impactou o pensamento jurídico e a visão sobre o direito e sua função? Seria uma nova Constituição e um novo constitucionalismo, movimentos políticos, antes de tudo, responsáveis também por um novo direito constitucional e por novos constitucionalistas?

\subsection{SOCIALIZAÇÃO DO DIREITO: O DESAFIO DA HISTÓRIA}

O entre-guerras é o período-chave dessa investigação. Isso porque é o cenário da radicalização das divergências e rupturas com a tradição de pensamento liberal, tradição essa que já vinha sofrendo abalos desde o começo do século, especialmente com a organização dos trabalhadores, seja em torno da disputa política institucional, pela via do sufrágio universal, seja em busca da ruptura revolucionária com a ordem. Desnecessário lembrar do impulso representado pela Revolução Russa de 1917, e pela articulação e integração operária internacional, com a fundação ou consolidação de partidos comunistas e socialistas, sobretudo na Europa. A sociedade tinha se transformado, e a ampliação da democracia permitia pensar na viabilidade da transformação também da política, do Estado e do direito.

Nesse sentido, vem a grande inovação no campo do direito, com potencial de abalar em definitivo as convicções no potencial de resistência das premissas puramente liberais que o vinham moldando como ciência desde o século XIX. Trata-se do novo constitucionalismo social, que se inaugura com a Constituição Mexicana de 1917, mas que tem como expoente de impacto internacional a Constituição Alemã, de 1919. Contando com dispositivos de regulação social e de concessão de direitos, inclusive submetendo a propriedade privada ao atendimento de sua função social (não apenas como direito, mas como obrigação), a sombra de Weimar se espalha pelos países da Europa, inaugurando a certeza de que a presença ampliada das massas populares nos parlamentos 
não permitiria que as novas Constituições fossem apenas uma compilação de divisão de competências e garantias negativas da liberdade individual. Um novo Estado, cuja condução decidia-se pela via do sufrágio universal, precisava de um novo direito.

Não seria unívoca, porém, a orientação ideológica que conduziria a produção desse novo direito, pelo contrário. A irrupção da questão social para dentro da esfera jurídico-institucional, e a consequente necessidade de formular uma resposta em termos de democracia e de direitos, abrem a possibilidade de diversas linhas de pensamento dentro do direito, desde o socialismo até o catolicismo social, em dois exemplos marcantes, confrontando-se na passagem com as premissas liberais ainda determinantes. Nesse sentido, as novas concepções do direito e do Estado, e a nova abordagem do social, podem ser historicamente relacionadas, de acordo com Carlos Miguel Herrera, a dois vetores bastante distintos. "É apenas no curso do século XX que as normas de conteúdo social e econômico encontrarão uma primeira sanção eficaz nas constituições positivas, mas um debate mais geral as havia precedido. Os afluentes teóricos-políticos são complexos: a versão propriamente socialista, que aparece já como estruturada em 1848, será logo acompanhada de uma corrente 'social' que, do liberalismo ao conservadorismo, frequentemente por meio do cristianismo, matizará as velhas concepções políticas do século XIX, ao menos no nível da elites dirigentes europeias. Essas abordagens dão lugar a duas visões político-jurídicas que identificamos em outro lugar em termos de emancipação e de integração"3.

De um lado é possível identificar um novo problema que, ainda que tenha tido como epicentro a Europa, estende-se por diversos países, de forma mais ou menos abrangente, seja como realidade social concreta, seja como perspectiva de realidade futura. De outro lado, há especificidades na forma pela qual se lidou com ele, que devem ser buscadas nos contextos nacionais. O foco aqui, como indicado na introdução da tese, é evidenciar o modo pelo qual o direito público brasileiro formulou a incorporação da disciplina social à Constituição, na Carta de 1934, utilizando como lente de análise as reflexões da doutrina francesa do entre-guerras, preocupada que estava, também, com a revisão do constitucionalismo liberal. Para tanto, há que se retomar, nessa conclusão, algumas das balizas apresentadas ao longo do trabalho. A proposta nos obriga, em primeiro lugar, a tornar claras as diferenças de contexto, bastante significativas, que separam os dois países, recuperando as conclusões dos capítulos 1 e 4.

\footnotetext{
${ }^{3}$ HERRERA, 2008, p. 179.
} 
A França do entre-guerras consagrava-se como país vitorioso nas armas, e tinha seu sistema político republicano consolidado. Democracia e sufrágio universal eram pilares da Terceira República, conquistas que, se no início sofreram com a reação monarquista, já tinham desde há muito se estabelecido como centro da organização da moderna política institucional. A despeito da persistente restrição do direito de voto aos homens, foi o momento de massificação da participação democrática, na medida em que o comparecimento eleitoral já podia ser considerado expressivo, em comparação com os muitos dos países no período, notadamente o Brasil.

Contudo, a garantia dos direitos políticos e de igualdade formal, típicas do sistema liberal que havia orientado as leis constitucionais de 1875 , já não era mais suficiente para preservar a harmonia e a integração sociais. A organização dos trabalhadores, ligada ao novo cenário, primeiro de florescimento e depois de crise econômica, orientava-se em torno de demandas concretas, de interesses definidos e de reivindicações de democracia econômica, fundada na igualdade material. Ao sonho de uma "República absoluta" dos "pais fundadores", de que fala Rosanvallon", em que o Parlamento, composto por uma aristocracia política capaz de formular demandas com pretensão de universalidade, seria o guardião da vontade geral da nação, contrapunha-se a tomada do órgão máximo pelos conflitos de interesses, sobretudo econômicos, veiculadas por representantes de inclinações políticas as mais diversas, reproduzindo as disputas externas e denunciando a artificialidade do projeto de igualdade liberal. O receio que provoca na França, em um primeiro momento, a Constituição de 1919 da vizinha Alemanha, diz respeito justamente à inauguração, por ela, da tendência a incorporar temas de democracia econômica, e não apenas política, à pauta constitucional ${ }^{5}$.

O Parlamento passa a ser, em definitivo, o "eco do lado de fora", conforme aponta Deslandres ${ }^{6}$. Como consequência, passa a espelhar os conflitos que já se faziam presentes no mundo do trabalho, colocando a transformação econômica como agenda central da política, que vê seu espectro de possibilidades alargado. Por outro lado, não demora em se organizar a reação à direita, que capitaliza, em torno de projetos nacionalistas, um propalado medo, ainda que sem fundamento claro, da subversão da ordem democrática pelos socialistas e comunistas. Assim, sucedem-se gabinetes ministeriais em espaços cada vez mais curtos de tempo, incapazes de sustentar-se sobre

\footnotetext{
${ }^{4}$ Cf. ROSANVALLON, 2000, pp. 243 e ss.

${ }^{5}$ Para uma análise mais detida da recepção das ideias de Weimar na França do entre-guerras, ver HERRRA, Carlos Miguel, Weimar chez les juristes français contemporains, in HERRERA, 2011, pp. 7/28.

${ }^{6}$ DESLANDRES, 1900, p. 34.
} 
coalizões minimamente coesas, radicalização que está na base dos diagnósticos de crise do sistema parlamentar e da democracia. Havia pressão pela reforma das leis constitucionais, por certo, mas a resistência é grande, diante das características tão plurais do corpo parlamentar, que fariam de uma eventual revisão constitucional um palco de conflito aberto - vale lembrar que há pequenas alterações, e é inclusive instalada uma comissão para elaborar a reforma, da qual Joseph Barthélemy faz parte, mas não há mudança constitucional significativa na França do entre-guerras, a não ser pela delegação absoluta do poder constituinte que marca o final da Terceira República.

Não poderia ser mais distinto o caso brasileiro, está claro. Em primeiro lugar, porque se em teoria a Constituição republicana de 1891 consagrava as premissas liberais de participação política e de garantia de direitos, a prática distanciava-se em muito de sua realização. As oligarquias agrárias que controlavam o poder econômico no país forjaram um sistema para controlar também o poder político, o coronelismo combinado com a política dos governadores, fundado na manipulação do ainda bastante restrito eleitorado. Justamente, esse eleitorado correspondia a uma parcela muito pequena da população, considerando as restrições aos direitos políticos em vigor - o voto era prerrogativa de homens brasileiros alfabetizados, em um país com altos índices de analfabetismo e com uma população considerável de imigrantes -, resultando em dados de participação eleitoral insignificantes. Mesmo após a Revolução de 1930, e a revisão da legislação eleitoral, o corpo político nacional continuou bastante reduzido, o que faz com que o entre-guerras, no Brasil, não seja o cenário da massificação da democracia e da chegada das camadas populares ao Parlamento, o que já era realidade desde há muito na França. Não se pode dizer que tenha havido, por aqui, um passado liberal responsável pela garantia de intangibilidade do sufrágio universal e da democracia de massas, nem tampouco a organização popular para a denúncia da dissimulação representada pela igualdade formal, e para a reivindicação por igualdade material, econômica. Esses eram problemas europeus dos quais a elite intelectual, que começava a se organizar em torno da necessidade de construção de uma solução nacional, induzida a partir da nossa realidade, apenas ouvia relatos, temerosa e em parte imbuída da convicção positivista de que teria que "prever para prover".

Ainda assim, em 1930 veio a revolução. Motivada por uma ruptura intraoligárquica, mas conduzida sob a bandeira da denúncia às práticas políticas da Primeira República, que correspondiam à violação do ideal liberal da Carta de 1891, o movimento de sustentação da Revolução de 1930 não poderia ser mais incoeso, tanto em sua 
composição quanto em seu programa. As facções dominantes, como as oligarquias vencedoras e vencidas, a burguesia industrial ou os tenentes, incapazes de formularem um projeto político hegemônico para o país, viam-se forçadas a estabelecer um compromisso, tanto político quanto ideológico. Caberia a Vargas articulá-lo, o que buscou fazer durante os anos do Governo Provisório, tentando situar-se do lado de fora do conflito, na posição de mediador, de onde se julgava capaz de promover as reformas em torno das quais coordenaria as facções sociais, bem como o povo, que se não podia ser considerado força ativa no processo revolucionário, também não poderia ser visto como elemento meramente passivo.

Tanto assim que o núcleo central dessas reformas estava na reorientação da compreensão do social, que era encarado como "caso de polícia" durante a Primeira República. A construção da mitologia estadonovista, de que tratamos no capítulo 4 (item 4.2), passava por conceder direitos à massa dos trabalhadores, a um só tempo atendendo materialmente às reivindicações ainda esparsas e tópicas dos trabalhadores urbanos pouco organizados e fazendo crer, enquanto dimensão simbólica, que tais direitos eram concedidos como dádivas, como doações, posicionando o Estado como mediador e árbitro dos conflitos, antecipando-se na tarefa de regulá-los. Não se deve esquecer que as reformas se faziam necessárias, considerando o encerramento dos grandes fluxos imigratórios e a recente territorialização da força de trabalho, que não podia mais subsistir em situação de infracidadania, de acordo com o diagnóstico proposto por Alencastro ${ }^{7}$. Era preciso integrar a população brasileira, bem como garantir ao novo governo a legitimidade de seu projeto, carente de sustentação na falta de uma e só uma força política hegemônica. Porém, se as facções sociais em disputa eram diversas, também o eram as ideias em circulação, que variavam desde a defesa do liberalismo ainda por se concretizar no país, até soluções antiliberais e autoritárias ou corporativistas, passando pela leitura "à brasileira" das propostas solidaristas e institucionalistas francesas e por tímidos projetos socialistas e comunistas.

A postura do Governo Provisório, instalado em 1930, foi condizente com a orientação de que era preciso fundar um novo homem para um novo país, e é sob essa perspectiva que assume a tarefa de proteção social, que poderia ser útil para que mantivesse sob seu controle a classe operária, especialmente ao assumir a regulação de sua organização sindical. Assim, em interpretação gramsciana proposta por Werneck Vianna,

${ }^{77}$ Cf. ALENCASTRO, 1987a. 
fala-se em mais uma expressão da "revolução passiva" brasileira, em que a estratégia da conservação-mudança é adotada tendo como “'fermento revolucionário’ a questão social, a incorporação das massas urbanas ao mundo dos direitos e a modernização econômica como estratégia de criar novas oportunidades de vida para a grande maioria ainda retida, e sob relações de dependência pessoal, nos latifúndios" ${ }^{\prime 8}$. Era preciso adotar um novo projeto para o país, que não cabia no ideal liberal, e a solução acaba sendo a reorientação do Estado que está na base do que ficou chamado de modernização conservadora, consolidada com o Estado Novo a partir de "uma economia politicamente orientada, economia programática de um capitalismo de Estado, as elites políticas à testa de uma nação concebida como uma comunidade orgânica" ${ }^{\text {. }}$. Mas o projeto não estava claro logo após a Revolução de 1930, e precisava ser construído como consenso nacional.

É nesse ambiente que se inaugura o processo constituinte, que se por muitos era considerado prematuro, dada justamente a ausência de um programa hegemônico, se afigurava como inevitável, considerando a própria plataforma da Aliança Liberal, e até mesmo a reação paulista de 1932. Assim, decide-se dar início à formulação da nova Constituição, lei fundamental que devia encontrar um equilíbrio, um compromisso, não apenas entre as forças políticas em disputa, mas também entre os projetos e ideias que se apresentavam. Mas a Assembleia Nacional Constituinte, e a decisão política de forma mais ampla, não estavam nas mãos da sociedade brasileira como um todo, como visto. Tratava-se de um corpo político de origem consideravelmente homogênea, cuja maioria, inclusive, possuía formação jurídica e provinha quase que das mesmas faculdades. A exceção no perfil dos constituintes é a representação classista: empregadores mandaram seus melhores quadros na defesa de seus interesses econômicos, sobretudo o incentivo à industrialização, por um lado, e as bandeiras liberais, por outro, na medida em que funcionassem como limitação dos avanços sociais, e empregados selecionados sob o controle atento do Ministério do Trabalho raramente desviavam-se da posição governista.

Enquanto na França o Parlamento era o espelho da sociedade, e o povo organizava suas demandas, canalizadas para dentro do jogo político institucional, no Brasil o povo seguia do lado de fora, como destinatário das políticas, muito mais do que como seu autor. A diferença não poderia ser mais significativa, assim como a resposta enquanto em um dos casos é possível pensar em uma nova Constituição, formulada por um

\footnotetext{
${ }^{8}$ VIANNA, 1997, p. 48.

${ }^{9}$ VIANNA, 1997, pp. 48/49.
} 
Parlamento bem pouco representativo da sociedade, no outro, a solução já se mostrava arriscada demais. Além de explicitar a falta de paralelismo entre os distintos contextos históricos, explica-se com isso também a assimetria dos materiais analisados na tese, a doutrina constitucional, no caso francês, e os debates constituintes, sobretudo, no caso brasileiro, onde se buscou identificar a forma como o direito, ou melhor, a reflexão propriamente jurídica, lidou com a questão social e com a democracia.

\subsection{A RESPOSTA DA DOUTRINA CONSTITUCIONAL FRANCESA: INTEGRAÇÃO E DIREITO COMO FATOR DE MOVIMENTO}

Para a doutrina jurídica francesa, a Terceira República é um tempo de inquietude. Os juristas já haviam sido chamados à elaboração de uma filosofia que fundamentasse a nova República, de modo a estabilizá-la e garantir a continuidade da ordem em meio a tantas turbulências. Assim surge o papel social do professor de direito constitucional, do constitucionalista, qual seja, imiscuir-se na política e fundar um direito que refletisse sobre uma ordem marcada pela democracia e pelo sufrágio universal e assegurar sua continuidade. A irrupção do social convoca os juristas a porem em questão, pouco a pouco, o edifício sobre o qual se fundava o velho direito liberal, em especial o subjetivismo-voluntarista. E o entre-guerras acirra o desafio, internamente, com a chegada de vez das representações populares ao Parlamento e a composição de gabinetes de esquerda, e externamente, com o surgimento de um novo modelo de constitucionalismo, que abandona a ideia de uma Constituição monolítica, homogênea, tipicamente liberal. Mas se a transformação não chega à Constituição francesa, diante da inconveniência de transferir a um Parlamento em disputa a decisão sobre a nova ordem constitucional, ela chega definitivamente à doutrina do direito público, que oferece respostas plurais. À doutrina caberia reagir ao reposicionamento da questão social, absorvendo-o.

Adotamos a tese de Beaud $^{10}$, dividindo os constitucionalistas em dois grupos, conforme a natureza de suas preocupações teóricas. Em um primeiro grupo, que reúne juristas chamados de clássicos, estão aqueles que se preocuparam em fundar o direito constitucional como ramo autônomo baseado em conceitos e método próprio, cuidando de descrever suas concepções de Estado, indivíduos, as relações entre eles e o funcionamento do sistema político que garante legitimidade ao direito, tendo como ponto

\footnotetext{
${ }^{10}$ Exposta em BEAUD, 2000.
} 
inescapável a democracia e o sufrágio universal. Além de ramo autônomo, o direito constitucional é marcado, aqui, pela pelas fronteiras ainda borradas com a ciência política. Elegemos três nomes de destaque, Léon Duguit, Maurice Hauriou e Raymond Carré de Malberg, que, se se aproximavam em suas indagações e nos elementos que entendiam convenientes para articular suas teorias, estavam mais ou menos distantes nas respostas que ofereciam, como visto no capítulo 2.

São relevantes para compreender o pensamento dos autores, em primeiro lugar, os debates em torno do método do direito, cotejado com a proposta exclusivamente jurídica que vinha se consolidado na vizinha Alemanha e com os esforços de superação da tradição francesa da Escola da Exegese. Um direito autônomo precisava de um método próprio, e a resposta que ali havia sido dada foi sustentá-lo na noção abstrata de indivíduo, em sua vontade e no plexo de garantias de sua liberdade, os direitos subjetivos. Mas a época era marcada pela socialização das preocupações, e pela inserção do homem, sobretudo no mundo do trabalho, o que indicava a conveniência de considerar a história e as determinações coletivas na análise do fenômeno jurídico. Assim, em Duguit o direito é compreendido como produto das relações sociais historicamente determinadas, e dos laços de solidariedade que unem os indivíduos, percebidos por suas consciências individuais como uma regra de conduta, que nada mais é senão o direito objetivo. O direito é a expressão da integração social do homem, sendo independente da atuação do Estado, que, na verdade, lhe é posterior e por ele cerceada. O Estado não é produto de um contrato, nem representa uma metafísica vontade geral, é sim um fato de força, que tem na origem a distinção governantes-governados, e portanto só pode ser legitimado pelas finalidades que persegue (os serviços públicos), socialmente determinadas pelas leis de solidariedade. Hauriou, por sua vez, busca combinar as dimensões objetiva e subjetiva em uma teoria dinâmica do direito, que é o conjunto de regras limitadoras da liberdade individual formado, enquanto instituição-coisa, pelas manifestações de comunhão da população, consciente da necessidade de regulação antecipada de conflitos. Mas é no Estado, instituição-pessoa, que está a garantia última do direito, na medida em que, ao se personificar com a interiorização da ideia diretriz, torna-se responsável pela manutenção da ordem social, a partir do uso do poder organizado, promovendo estabilização e continuidade.

Dessa disparidade de pensamentos, convém reter a preocupação, comum a ambos, com os problemas de integração social, bem como com a ordem e com a manutenção dos valores liberais, embora recusando o método individualista-voluntarista. 
Retomando de forma bastante esquemática os complexos argumentos já expostos, temos que em Duguit e em Hauriou, no final de suas obras, aparece a tentativa de substancializar o direito, passando a atribuir a ele conteúdos mínimos independentes da deliberação democrática concreta, seja a solidariedade combinada ao sentimento de justiça, seja a própria defesa da ordem liberal predominando sobre os impulsos de justiça, preservando para o direito funções pré-concebidas. O direito aparece como fator de resistência, ao qual os juristas atribuem a função de preservar determinados valores, em uma inversão mistificada do liberalismo clássico. Em uma simplificação grosseira, poder-se-ia dizer que passam da imposição normativa liberal - o dever de cooperação imposto de fora pela lei, pelos mandamentos éticos e pelo contrato - para a defesa de um impulso de cooperação endógeno, originado e mantido pela sociedade, ou pelo povo em conjunto com as elites, confirmado pelo poder estatal, e com caráter universalizante e integrador. Em qualquer caso, o indivíduo não está diluído no social e ao direito constitucional segue cabendo preservá-lo diante do Estado.

É importante marcar a diferença do pensamento de Carré de Malberg, que segue o positivismo para refutar a possibilidade de o jurista o papel de legislação, cabendo a ele somente as funções de interpretação, já que o direito é produto da vontade soberana do povo. Ao povo devem serem conferidos mecanismos democráticos de participação, de modo a fazer das normas jurídicas expressão de sua vontade soberana. A teoria é individualista, mas a ênfase é no procedimento democrático, ao transferir a soberania da nação para o povo e acentuar a importância dos mecanismos de deliberação. Mantinha-se o positivismo enquanto método, ao mesmo tempo em que se abria a possibilidade de novos conteúdos políticos ao direito. Em Carré de Malberg, não há definição a priori de conteúdo do direito, na medida em que poderia, potencialmente, se abrir para quaisquer reivindicações do povo organizado, origem primeira da soberania, canalizadas ao direito pela via democrática, não apenas no Parlamento, mas também nos instrumentos de democracia direta, como o referendo. O conteúdo do direito é definido e alterado por meio dos procedimentos democráticos.

O segundo grupo de juristas escolhidos não pode ser reunido por conta de sua equivalente estatura intelectual, mas sim pelo período em que escrevem as obras aqui tratadas, o entre-guerras propriamente (e não como os clássicos, de quem o ápice da produção teórica se deu antes da Primeira Guerra Mundial), bem como, e até por consequência do momento mais turbulento e radicalizado, pela sua relação mais próxima com a política. A virada importante proposta por Joseph Barthélemy em termos de método 
foi justamente abandonar as pretensões dos "juristas encastelados em suas torres de marfim”, preocupados em descrever uma teoria coesa e abstrata do direito e do Estado. A postura deveria ser pragmática: ciência e experiência são intimamente misturadas, e o direito abre-se para as constantes e aceleradas mudanças na prática jurídica e institucional. O direito deixa de ser resistência e volta-se para a ação, engajando-se não apenas na formatação, mas também na transformação das instituições. Em um primeiro momento, a proposta permitiu um alinhamento de Barthélemy às premissas liberais e democráticas, bem como às leis constitucionais de 1875, convicto que estava da força estática e conservadora do sufrágio universal. Individualista e liberal, recusava propostas solidaristas, coletivistas ou corporativistas de representação classista, bem como soluções autoritárias, apesar de sustentar a necessidade de reforçar os poderes do Executivo contra um Parlamento enfraquecido por críticas. Mirkine-Guetzévitch, testemunha das novas constituições europeias do entre-guerras, bate-se pelo direito constitucional como técnica da liberdade, e é otimista, no início, quanto à expansão da democracia e dos novos direitos. Também vê as novas cartas políticas como fator de movimento, de construção de ordens democráticas, racionalizando, isto é, submetendo ao direito e à deliberação democrática, parcelas cada vez mais amplas da vida social e política.

Porém, os tormentosos anos 1930 assistem a um certo abandono do otimismo liberal. Em Barthélemy, a convicção na capacidade integradora do sufrágio universal é substituída pela defesa da existência de princípios superiores à deliberação, que constituem o "fundamento moral" do Estado, notadamente relacionados à preservação das liberdades individuais. Mas ao vislumbrar a possibilidade de haver democracia sem a preservação das liberdades individuais - uma ruptura, assim, entre democracia e liberalismo -, coloca-se na posição de defesa das liberdades do cidadão abstrato como determinações intangíveis, impassíveis de limitação por decisões democráticas. Não é mais a origem democrática o fundamento de legitimidade do Estado, mas sim a adequação eficiente desse poder às suas finalidades, que naturalmente deveriam estar relacionadas à preservação da ordem. Também é uma virada na direção da substancialização do direito, atribuindo a ele um conteúdo liberal mínimo, que subsistiria diante da deliberação democrática.

A leitura do discípulo de Carré de Malberg, René Capitant, funciona para evidenciar a diferença do novo direito constitucional pragmático. Capitant assume a tarefa de levar adiante a proposta dos clássicos, buscando fundar seu pensamento em uma teoria abstrata e abrangente sobre o direito e sobre o Estado, na linha positivista. Posiciona-se 
com Kelsen ao distinguir o imperativo do indicativo, a lei natural da norma, e ao refutar o direito natural, mas contra Kelsen ao descrever o fundamento de validade da norma: para o francês é o reconhecimento da norma pela generalidade dos sujeitos, por seus destinatários, que responde pela sua validade. Reafirma o fundamento individualista da Terceira República para renovar a importância da democracia, recusando o que chama de "mito social", o pensamento que procura submeter o Estado a uma razão superior aos indivíduos. Não deixa de ser uma visão do direito como movimento, mas um movimento alimentado por influxos bastante distintos daqueles que sustentava Barthélemy. O impasse não demora a ser solucionado pela história, e não pela teoria, com a queda da Terceira República e a instauração do governo colaboracionista de Vichy.

É importante fixar alguns elementos importantes que nos são revelados pela doutrina constitucionalista francesa do entre-guerras. O primeiro deles é que, na França, é o pensamento jurídico quem absorve a tarefa de refletir sobre a integração de uma sociedade em profunda e acelerada transformação, descartando, ou ao menos postergando, uma revisão constitucional que teria sido necessariamente decidida por um Parlamento em constante disputa e radicalização. O surgimento de juristas solidaristas ou institucionalistas corresponde à preocupação de conceber o direito como momento de integração social, de harmonia entre as classes, de coordenação. $\mathrm{O}$ conflito cede à coesão ao se pensar a origem e a continuidade do direito e do Estado.

O segundo elemento é a forma pela qual se expressa a tarefa de integração, o tipo de resposta oferecida, que não raro procura dar conteúdo substancial ao direito, anterior e superior ao processo de deliberação democrático no Parlamento. $\mathrm{O}$ direito serve como garantia de resistência aos impulsos de ruptura com os valores liberais especialmente dedicados à proteção do indivíduo, de suas liberdades e de sua igualdade formal, apenas. Mas isso não significa que os juristas tenham abandonado a defesa de mecanismos democráticos, ou dos direitos políticos e do sufrágio universal. Apenas, esforçavam-se por enxergar valores ou princípios de justiça e ordem que estariam na base da sociedade e de seus laços de cooperação ou de comunhão. Por outro lado, aqueles que se mantiveram fiéis ao positivismo jurídico, enquanto método, como Carré de Malberg ou Capitant, forçosamente excluíam a possibilidade de substancialização do direito, entendendo, pelo contrário, que a unidade e a consistência de sua teoria estaria na defesa do procedimento democrático, capaz de expressar a soberania popular, como fonte de legitimidade da norma.

Os clássicos preocupavam-se, assim, em formular teorias que 
articulassem Estado e direito, legitimidade e ordem, dentro de método e a partir de princípios aptos a garantir sua coerência e consistência, de modo a sustentar o direito constitucional, como direito político, enquanto fundamento da República, subordinando o poder político às regras jurídicas. A mudança que vem nos anos 1930, com o pragmatismo de Barthélemy, está no abandono dessa pretensão. O direito constitucional, para ele, deixa de se preocupar com a teoria do Estado e com noções abstratas e assume-se como um pensamento voltado à ação, cuidando da prática das instituições e de sua história política. $\mathrm{O}$ autor defende que os juristas saiam de sua torre de marfim, e cuidem de descrever e prescrever em concreto o funcionamento do Estado e a produção do direito, buscando soluções mais adequadas ao momento presente. $\mathrm{O}$ direito passa a ser fator de movimento, posição que permite incorporar as preocupações políticas dos juristas, mais marcadas, com maior facilidade.

\subsection{A RESPOSTA da CONSTITUIÇÃO BRASILEIRA dE 1934: REGULAÇÃO SOCIAL E DEMOCRACIA LIMITADA}

Como destacado, o desafio constituinte brasileiro, do ponto de vista político, era a composição entre as facções das elites representadas na Assembleia, as diferentes correntes de pensamento às quais aderiam e o projeto do Governo Provisório de revisão do papel do Estado e da regulação do social, estabilizando-os em um compromisso durável. Não seria tarefa simples para o texto constitucional. Mas estava claro que seriam a Constituição e o direito constitucional que dela se encarregariam. E se serviriam da observação da realidade de radicalização de outros países, como a França, bem como da doutrina jurídica que se vinha produzindo tendo em mente as novas questões sociais, para fazê-lo.

No plano jurídico, o direito constitucional é encarado como o momento de síntese, função que ganha especial destaque em tempos de crise ou de transição, como os anos 1930 no Brasil. Assim nos faz ver Pontes de Miranda, para quem "a tentativa - por parte de quase todos os Estados - de submeter as novas formas econômicas, os grupos proletários, ao direito do Estado não-reestruturado, do Estado antigo que persiste, necessariamente, é vã. Esforço inútil. Todos os pequenos resultados serão provisórios e inconsistentes. O propósito da matéria nova à velha forma, de prender a nova vida em normas estranhas a ela, extraidas por entidade distinta, agrava o dualismo entre sociedade e Estado, entre classes trabalhadoras e organização estatal. Todo programa de 
solução do problema social mediante lei ordinária, leis de direito provado, nenhuma probabilidade pode ter de êxito. Só no terreno do Direito público, do Direito constitucional, é que pode plantear-se. Só assim será possível direito que seja ao mesmo tempo do Estado e das forças econômicas. Qualquer outro ensaio representaria o intento de submeter as forças econômicas a disciplina jurídica prepotente, heterogênea, despótica, heteronômica. Seria a contraposição, o antagonismo; em duas palavras: a luta" ${ }^{11}$. Ao direito constitucional caberia promover a síntese, a homogeneidade, a cooperação. Mas que tipo de síntese foi proposta pela Constituição de 1934 ?

Ao comentar o resultado, pouco tempo depois da promulgação da Constituição, Pontes de Miranda é enfático, afirmando tratar-se de uma "Constituição híbrida, associando constitucionalismo, liberalismo econômico, federalismo dissolvente (contra a lição norteamericana de agora, e, pois, consequente ao caudilhismo sulamericano), fascismo - sem ser capaz de organizar fascismo, a despeito da população italiana de São Paulo e dos alemães de todo o sul do Brasil, e sem ser, tampouco, capaz de enfrentar o problema nacional-humano, marchar para o Estado técnico, organizando a economia e a educação nacionais" $"$.

Em sentido semelhante, fala-se da Carta de 1934 como sendo uma “colcha de retalhos", uma tentativa malsucedida de combinação de princípios antagônicos, o produto de tendências distintas e inconciliáveis, marcas que determinariam desde a promulgação sua inexequibilidade e sua vida curta. Não há consenso na teoria social e política sobre a orientação predominante da Constituição. Para Wanderley Guilherme dos Santos, a contradição é sua marca evidente, já que "a Constituição de 1934, ciosa embora da ordem liberal e moderna que desejava ver implementada no país, contratou a legitimidade de uma série de procedimentos estatais que o governo de Vargas viria a exercer autoritariamente, isto é, sem ouvir o Congresso, então fechado, durante o período $1937-1945^{, 13}$.

Werneck Vianna, por seu turno, fala em uma "esdrúxula combinação entre liberalismo e corporativismo", salientando a predominância desse último: "O fato do tenentismo ter perdido, com a eleição de Antônio Carlos, candidato da oligarquia, não veio a acarretar a quebra do compromisso, exprimindo, ao contrário, a condição da sua possibilidade. Elevados à posição dirigente dos trabalhos da Constituinte, os

\footnotetext{
11 MIRANDA, 1937, t. I, p. 297.

${ }^{12}$ PONTES DE MIRANDA, 1937, t. I, p. 97.

${ }^{13}$ SANTOS, 1979, p. 32.
} 
sobreviventes do liberalismo excludente da Primeira República adotam uma Carta corporativa, infiltrando aqui e ali um dispositivo liberal. Sua participação, porém, garantirá o resguardo da concepção de federação contra o unitarismo tenentista e reiteração da declaração dos direitos fundamentais do indivíduo. Essa esdrúxula combinação de liberalismo com corporativismo, numa sociedade onde não havia mais liberais, a não ser no sentido privilegiador e excludente das antigas oligarquias dominantes, não poderá deixar de provocar o trânsito, ainda que titubeante e equívoco, para o sistema da ordem do corporativismo de base estatal. Em termos de postulados, a recorrência última não se encontrará mais no indivíduo, que ainda se reverencia como detentor de direitos diante do Estado. Na nova Carta, instala-se o princípio do 'superior interesse da comunidade', do qual a agência estatal seria instância oracular. Note-se que a nova ordem, iniciada em 1935, pôde conviver dois longos anos com a Constituição de 1934, para o que bastou se ignorar a existência de seus bolsões liberais"14.

Para José Murilo de Carvalho de Carvalho, a ênfase é oposta, e deve ser colocada no liberalismo fora de época da Carta de 1934, ainda que como mera estratégia de conservação: "Fora esse capitulo [da ordem econômica e social], era uma constituição ortodoxamente liberal, logo atacada pelo governo como destoante das correntes politicas dominantes no Brasil e no mundo. Segundo essa crítica, o liberalismo estava em crise, em vias de desaparecer. Os novos tempos pediam governos fortes como os da Itália, da Alemanha, da União Soviética, ou mesmo do New Deal norte-americano. Os reformistas autoritários viam no liberalismo uma simples estratégia para evitar as mudanças e preservar o domínio oligárquico" ${ }^{, 15}$.

Ângela de Castro Gomes também destaca a tentativa de conciliação entre liberalismo e propostas autoritárias, mas assinala ênfases distintas, ao afirmar que " $a$ possibilidade da construção de um pacto político só pode ser entendida se bem considerado o momento político que se vivia, marcado pela multiplicidade de propostas e pela variedade de grupos e subgrupos político-partidários. No entanto, apesar de todo este ecletismo, um fato se destaca no contexto dos debates então travados, marcando uma das características centrais desta constituinte dos anos trinta: a preocupação em assegurar o predomínio do Legislativo no sistema político nacional, tornando-o a base da vida governamental e o meio de controlar e deter o avanço do Executivo. Tal preocupação, informada pela experiência de nossa história republicana e também pela

\footnotetext{
${ }^{14}$ VIANNA, 1999 (1976), pp. 192/193.

${ }^{15}$ CARVALHO, 2001, p. 102.
} 
experiência contemporânea de outras nações, bem revela o momento crítico que atravessava a liberal-democracia ocidental nos anos trinta, comprimida pelos novos experimentos do socialismo e do fascismo. O Brasil, integrando-se aos rumos do debate internacional, não superaria os impasses desse problema fundamentalmente político, e não jurídico, como bem o demonstrariam os anos que se seguiram a 1934. A experiência dos anos de 1935, 1936 e 1937 só iria consagrar e agravar o desacordo entre a vida política real do país e o texto constitucional, que já parecia caduco alguns meses após sua promulgação. Entretanto, é preciso ressaltar que tal defasagem não procede da construção jurídica realizada ou mesmo da orientação política que dominou sua elaboração - a do controle do Executivo e manutenção do federalismo. Suas raízes se localizam num campo mais profundo e mais amplo, que é o da própria politica" ${ }^{\text {. }}$.

Menciona-se portanto em corporativismo deslocado, liberalismo fora de época como saída estratégica, completa defasagem da Constituição com a vida política nacional, ou, pelo contrário, compatibilidade, na medida em que se podia ignorar seus "bolsões liberais". A dificuldade em avaliar o sentido da Constituição de 1934 é evidente, e decorre, por certo, do tamanho do desafio que a ela se colocava.

Por certo a explicação de fundo para o momento do país e para o que se seguiu só pode ser dada no campo da política, e não do direito, como assevera Ângela de Castro Gomes, e não é na Constituição e no debate de ideias jurídicas que a resposta será completamente encontrada. Mas não haveria uma contribuição específica e particular que poderia ser dada pelo estudo das ideias jurídicas, tendo como lente o direito público francês, considerando o direito como uma linguagem dotada de um mínimo de autonomia? E, por outro lado, não representaria a Constituição de 1934 uma virada importante para o próprio direito constitucional, permitindo relacioná-la ao que aconteceu na França, para além dos desafios políticos que a ela se seguiram? Afinal, qual a lição que a Constituição de 1934 traz para o direito, na forma como equacionou democracia e direitos sociais? São essas as questões a que se procurou responder no presente trabalho.

\subsubsection{Influência francesa: reposicionando a história das ideias}

Destacamos o fato de que a Constituição de 1934 representa um desafio à teoria social, que busca identificar suas orientações predominantes, aproximando-a ora do

${ }^{16}$ GOMES, 1986, pp. 70/71. 
liberalismo, ora do corporativismo, usando para tanto a filiação ideológica que tradicionalmente se associa a seus dispositivos. Um primeiro esforço da pesquisa foi mostrar que nem sempre as influências para os arranjos institucionais podem ser traçadas linearmente, e a doutrina francesa vem ao encontro da compreensão da complexa genealogia das ideias em jogo. A questão se sobressai, especialmente, ao considerarmos que a maioria dos atores envolvidos no processo constituinte brasileiro era composta por juristas, que não apenas destacavam a importância da técnica jurídica nos debates e nas soluções propostas, como também diferenciavam-se de acordo com a capacidade de fazerem referências à doutrina estrangeira, sinal de erudição e garantia de respeitabilidade da opinião. Ainda que ao final a preocupação fosse em estabelecer um compromisso político, a partir de acomodações necessárias, e que tenhamos que distinguir os diferentes níveis de discurso entre a doutrina jurídica e os agentes políticos, é certo que os constituinte de 1933/34 não deixavam de emprestar particular importância ao embasamento teórico de suas posições, o que permite vislumbrar uma instância de explicação interna ao debate jurídico para o compromisso representado pela carta constitucional.

Nesse sentido, salientamos o papel de influência central da doutrina constitucional francesa no pensamento dos constituintes brasileiros. São incontáveis as referências ou citações aos franceses, a começar por Boris Mirkine-Guetzévitch, que ensinava "nos bondes, nos hotéis e nos ônibus" o "A B C constitucional"17. Era em boa medida por meio das lentes do jurista que os brasileiros tinham acesso às novas constituições europeias - inclusive a de Weimar, cujo texto foi tomado como inspiração e são suas observações que conduzem a leitura que delas é feita.

Antes disso, verificamos que a geração de políticos-juristas constituintes teve parte substantiva de sua formação em direito pública conduzida pela leitura dos franceses, especialmente dos que chamamos de clássicos. Em testemunho a Ana Lúcia de Lyra Tavares, tratando dos debates da Constituição de 1934, Evaristo de Moraes Filho, ao ser perguntado sobre a influência de Léon Duguit, responde: "Foi enorme. Duguit desempenhou o papel de um tirano no pensamento politico e constitucional brasileiro. Eu mesmo ainda sofri a sua influência, principalmente através de Eusébio de Queirós Lima, meu professor de Direito Constitucional (1934) na Faculdade (...). Duguit visitara a Argentina, na década de 20, pouco antes de seu falecimento, onde proferira conferências,

${ }^{17}$ Referências aos discursos de Carlos Maximiliano, 27/11/1933, vol. I, p. 423 e Belmiro de Medeiros, 09/01/1934, vol. V, p. 503 
mais tarde reunidas em livro. Foi realmente um grande constitucionalista e teve ascendência sobre muitos dos nossos teóricos políticos (...). Ademais, as tendências positivistas de Duguit casavam-se facilmente com o nosso positivismo politico e social, se não dominante, pelo menos subjacente. Estávamos preparados para absorver e aceitar, de certo modo, os ensinamentos do decano de Bordéus" $"$.

Duguit é referido em diversos debates, a começar pelos que tratam da noção de soberania, seu sentido e sua crise, conforme ficou claro. É ele, junto com Maurice Hauriou, que aparece como justificativa para o Decreto $n^{\circ} 19.770$, de 19 de março de 1931, que trata da organização sindical brasileira. Ali, inclusive, menciona-se que Rui Barbosa considerava Duguit "o maior juris-publicista dos nossos tempos"19. Os dois franceses são lembrados para sustentar o argumento de que era preciso ingressar no "mundo da cooperação social”, reconhecendo a interdependência das classes e a subordinação do progresso à "noção fundamental da ordem" ${ }^{20}$, preocupações que se estendem para além das normas do Governo Provisório e figuram nos debates constituintes, como visto. Os constituintes observavam os problemas que vinham tomando curso na Europa, especialmente decorrentes da ampliação e suposta crise da democracia, e estavam abertos não só a prevenir-se contra o contágio dos problemas sociais, mas também a importar a terapêutica que vinha sendo proposta, no campo teórico. Surge, portanto, a preocupação de integração pela via da regulação social, tendo em conta a necessidade de atuação coordenada com os grupos sociais organizados. No Brasil, contudo, o reconhecimento da relevância dos grupos sociais intermediários vem articulado em torno do papel central do Estado na regulação e no controle desses organismos, diferença importante com o pensamento francês.

Tratando da questão específica da representação classista, a referência que também aparece é Léon Duguit, em uma associação talvez inusitada da proposta à influência francesa. Novamente, contudo, a tentativa de promover a integração social por meio da inclusão da representação profissional vem acompanhada, aqui, de forte disciplina estatal. Portanto, muito embora a influência tenha sido em boa medida francesa, há uma distinção, que talvez seja a brecha para que possa ser considerada uma solução corporativista: enquanto os laços de solidariedade, para Duguit, eram produzidos de forma endógena na sociedade, cabendo às formas institucionais reconhecê-los, na sua auto-

\footnotetext{
18 TAVARES, 1988, p. 130.

${ }^{19}$ COLLOR, 1990, p. 106.

${ }^{20}$ Cf. COLLOR, 1990, pp. 106/107.
} 
organização, no Brasil a ideia era de que era preciso promover a cooperação em um sociedade tida como insolidária. Assim, o Estado aparece como promotor e mediador da organização social, o que não poderia ser lido em Duguit.

De se notar, mais ainda, que no Brasil a referência à integração social e a pacificação, ou prevenção, de eventuais conflitos pela via da regulação, extensão de direitos e cooperação dos grupos intermediários, assenta-se sobre uma crítica bem mais marcada ao individualismo do que era presente nos autores franceses frequentemente pontuados como referência. Lembramos novamente da crítica de Vicente Rao ao "individualismo à outrance", na sua divergência com Mirkine-Guetzévitch. Enquanto para o otimismo do segundo, a democracia só teria falido onde não tinha existência real, ou seja, onde não foram completamente levados a efeito os princípios do sufrágio universal (caso que poderia ser associado ao Brasil da Primeira República), para o brasileiro, a causa da crise da democracia era o choque entre o individualismo e as "novas condições econômicas e sociais", que teriam redefinido o lugar do indivíduo. Ora, a diferença é sensível, na medida em que a recolocação do problema por Rao permite pensar em na integração social à margem da garantia de inclusão do povo no corpo eleitoral, expandindo e consagrando a democracia no país. O desafio, para o brasileiro, seria o de abandonar o liberalismo clássico e associar novas finalidades ao direito constitucional, especialmente relacionadas às condições econômicas e sociais.

Assim sendo, conclui-se pela origem complexa das influências do modelo da Constituição de 1934. Por mais tentadora que seja a tendência a buscar encaixar a solução em paradigmas doutrinários fechados, como liberalismo ou corporativismo, o estudo dos debates constitucionais concretos e das referências que nele aparecem permitem apontar para a necessidade de afastar classificações apressadas. Buscamos mostrar que por mais que um arranjo soe familiar e consistente com uma determinada doutrina, considerada a posteriori, que ele de fato é produto direito desse conjunto de ideias. É preciso reconhecer a impossibilidade de sublinhar uma influência única e direta para a resultante brasileira das Constituições sociais dos anos 1930.

Assim, no caso do processo constituinte brasileiro de 1933/34, há influência das ideias constitucionais francesas, que não podem facilmente ser enquadradas como liberais, antiliberais ou corporativistas. Por um lado, remetem-se aos franceses para problematizar a soberania e a teoria do direito subjetivista, apontando especialmente para o desafio do direito, que é a integração social e a manutenção da ordem. A postura passa por aceitar a nova visão da sociedade e de suas associações, especialmente profissionais, pela 
qual a organização em corpos intermediários deveria ser aproveitada como instrumento para a promoção da solidariedade e a diminuição do conflito, opondo-se assim às teorias socialistas, preocupadas com a perspectiva emancipatória, que só poderia partir do reconhecimento do conflito social, e não da harmonia. A proposta da representação de classes, repudiada pelos liberais mais tradicionais, apoiou-se nessa convicção na possibilidade de integração pela via das organizações profissionais, diante das crescentes dificuldades que vinha apresentando a aposta no sufrágio universal.

Contudo, enquanto na doutrina constitucional francesa a democracia e o indivíduo configuravam-se como premissas de difícil recusa, e que, pelo contrário, haveriam de ser mantidas, no Brasil, a falta de um liberalismo efetivo, bem como de uma democracia verdadeiramente consolidada, permitiam que o questionamento do modelo anterior fosse mais adiante. Assim, a resposta assume feições autoritárias, ao posicionar o Estado como mediador da cooperação social, que deveria ser constituída a partir dele. Se não há preocupação em blindar o direito contra influxos de transformação vindos da organização popular em torno de projetos que visavam à igualdade material, em oposição à igualdade formal do liberalismo, também não há necessidade de manter o indivíduo e sua liberdade como centro do direito constitucional, que pode orientar-se a partir do papel de coordenação do Estado. Em lugar de se falar em laços de solidariedade ou cooperação endógenos à sociedade, percebidos antes de tudo pelas consciências individuais, aqui falase na necessidade de que sejam produzidos, de que sejam induzidos pela via do Estado, tendo em conta uma sociedade insolidária e carente de organização, mesmo que isso implique na dissolução completa do indivíduo. Apesar de termos ressaltado a influência nem sempre lembrada, a diferença não poderia ser mais significativa, e aponta para uma leitura eminentemente nacional daquilo que vinha sendo proposto na França.

7.3.2 Processos comparados: a virada pragmática do constitucionalismo brasileiro

Com isso, devemos retomar as conclusões do capítulo 6 sobre a forma pela qual a Constituição de 1934 equacionou a relação entre democracia e direitos sociais. Conforme buscamos destacar, o processo constituinte orientou-se por uma dupla opção, qual seja, constitucionalizar o que já vinha sendo previsto pela legislação ordinária em 
termos de direitos sociais e políticos ${ }^{21}$, e ao mesmo tempo estabelecer mecanismos de regulação social para a formação do "novo" povo brasileiro e garantir o controle da expansão do corpo eleitoral por uma série de mecanismos concernentes à concessão e perda da nacionalidade e dos direitos políticos. Direitos são acompanhados por tutela, em uma dinâmica combinada.

À premência da adoção da perspectiva social na Constituição, reconhecendo a organização da sociedade em grupos que mereciam representação, expandindo direitos trabalhistas e assistenciais, e moldando um Estado interventor na ordem econômica, combinava-se a urgência na formação dos destinatários de tais direitos, isto é, na constituição de um novo povo brasileiro, marcado pela harmonia entre as classes e pela solidariedade que seria construída, especialmente por meio da educação, passaporte de entrada inclusive para os direitos políticos (já que os analfabetos não faziam jus ao direito de voto). A participação política estava condicionada à alfabetização, à escolha criteriosa dos estrangeiros desejáveis que poderiam requerer sua nacionalização, e à “capacidade moral" do cidadão, que não deveria possuir ideias "que se opunham à pátria". Na prática, portanto, a deliberação democrática seguia concentrada nas mãos de uma elite intelectual, que se julgava capaz de expressar mais genuinamente o "civismo" condizente com a função, moldando-se uma democracia limitada. A plena democracia viria com a formação, no futuro, do povo brasileiro.

O diagnóstico é consistente com a visão proposta por José Murilo de Carvalho, para quem 1930 representou não apenas um divisor de águas na história do país por conta de sua nova abordagem da questão social, mas também uma peculiaridade brasileira no que tange ao processo de afirmação de direitos ${ }^{22}$. $\mathrm{O}$ autor chama atenção para a inversão brasileira da ordem clássica da positivação de direitos de que trata $T$. S. Marshall, que vai dos direitos civis e políticos, tipicamente liberais, para os direitos sociais. No Brasil, "o período de 1930 a 1945 foi o grande momento da legislação social. Mas foi uma legislação introduzida em ambiente de baixa ou nula participação política e de precária vigência dos direitos civis. Este pecado de origem e a maneira como foram distribuidos os benefícios sociais tornaram duvidosa a sua definição como conquista democrática e comprometeram em parte sua contribuição para o desenvolvimento de uma cidadania ativa"23. Os direitos sociais vêm sem que se tenham consolidado os direitos

${ }^{21}$ Conforme apontado em BERCOVICI, 2009.

${ }^{22}$ CARVALHO, 2001, p. 83.

${ }^{23}$ CARVALHO, 2001, p. 110. 
políticos e a democracia de massas, fazendo com que, para o autor, "a existência dos direitos políticos sem o prévio desenvolvimento de direitos civis, da convicção cívica da liberdade individual e dos limites do poder do Estado, redunda[sse] num exercício falho da cidadania política. O voto, como ainda acontece até hoje em largas parcelas da população, passa a ser tudo, menos a afirmação da vontade cívica de participação no governo do país, através da representação. Ele é o penhor de lealdade pessoal, de retribuição de favores, de barganha fisiológica, quando não simples mercadoria a ser vendida no mercado eleitoral"24.

A proposta pode ser combinada à tese de "cidadania regulada", formulada por Wanderley Guilherme dos Santos, que enxerga no Brasil dos anos 1930 um deslocamento da cidadania desde a ideia de participação política para a de participação econômica no mercado de trabalho, condição prévia para a fruição de direitos. Trata-se “do conceito de cidadania cujas raízes encontram-se, não em um código de valores políticos, mas em um sistema de estratificação ocupacional, e que, ademais, tal sistema de estratificação ocupacional é definido por norma legal. Em outras palavras, são cidadãos todos aqueles membros da comunidade que se encontram localizados em qualquer uma das ocupações reconhecidas e definidas em lei" ${ }^{25}$. A cidadania fica vinculada à profissão regulamentada por lei, o documento que a estipula é a carteira de trabalho e a luta dos trabalhadores passa a ser pelo reconhecimento e pela regulamentação de suas ocupações pelo Estado, que "definia quem era e quem não era cidadão, via profissão",26. À igualdade que se vincularia à cidadania do liberalismo clássico, que considera os indivíduos independentemente de sua posição social, contrapõe-se a desigualdade que é da natureza do mercado de trabalho, dos salários e do sistema previdenciário.

O que se quer pontuar, aqui, é o arranjo peculiar adotado pela Carta política brasileira, no que tange ao balanceamento entre princípios democráticos-liberais e disciplina social, que se não pode se encaixar em categorias monolíticas. Nem por isso deixa de conter uma direção própria, coerente, que consiste em incluir direitos sociais como princípios, tutela social como comando para o Estado e democracia e igualdade política como processos, de toda forma mirando na constituição de uma determinada sociedade no futuro, integrada, solidária e desprovida de conflitos. A cidadania passa pela inclusão no mercado de trabalho, o que se dá em posições desiguais de saída, considerando

\footnotetext{
${ }^{24}$ CARVALHO, 1992, p. 98.

${ }^{25}$ SANTOS, 1979, p. 75.

${ }^{26}$ SANTOS, 1979, p. 77.
} 
a divisão social das ocupações, e pelo atendimento do pré-requisito de formação intelectual. Assim a Constituição deseja que se estabeleça a sociedade que viria a ser, orientada a partir do papel provedor e mediador do Estado.

À ciência política deixamos a tarefa de apontar orientações predominantes, se o liberalismo, ainda que idealizado e divorciado da realidade, ou se o corporativismo, antecipando o que viria a ser o autoritarismo do Estado Novo de 1937. Vale lembrar, novamente, que a empreitada deve assumir os riscos de afirmar determinado paradigma doutrinário, descartando outros, de modo a permitir qualquer classificação que seja. Nesse estudo das ideias jurídicas, queremos excluir qualquer objetivo de classificação. Cumpre apenas extrair o que daí se concluir em relação ao desafio que passou a se impor aos constitucionalistas, na leitura e interpretação da nova Constituição e do novo direito constitucional que dela seria consequência, descartando justamente rótulos unívocos.

Pontes de Miranda, ao escrever seus comentários sobre a Carta de 1934, problematiza o liberalismo e a democracia: “A democracia clássica, considerando o povo como agregado de indivíduos singulares, na antitese típica “Indivíduo-Estado', constitui o micro-individualismo. O Estado soviético supõe o macro-individualismo: a massa, o todo como expressão do Indivíduo. No fundo, o Estado democrático-liberal, atento aos interesses individuais, vê, tão-só, os indivíduos; o Estado soviético, o Indivíduo. O liberalismo conviveu, um tanto artificialmente, com a Democracia; e os resultados mostraram que o proteger a individuos de per si, pluralisticamente, não protege o Individuo. O Estado soviético não poderia ser liberalista: monoideico, a sua afirmação supõe a marcha unívoca, que não se conciliaria com a democracia clássica, nem com a doutrina liberal, responsáveis pelo Estado sem finalidade. Igualdade jurídica como fim do Estado é a negação da eficácia prática do Estado; igualdade política (direta), constitui forma sem substância. O Estado fascista e o Estado nacional-socialista querem conciliar o propósito de proteção do Individuo e o propósito de grandeza estatal, dita nacional, o que mostra o seu realismo. A solução italiana, menos representativa que a solução alemã, que deu passo além para a integração pessoal"27. É a partir dessas observações que conclui pelo novo modelo de Estado que se estaria buscando, ao comentar o inédito capítulo sobre a ordem econômica e social: “A constitucionalização da estruturação econômica submete Estado e forças econômicas a direito seu: primeiro, porque estas passaram a ser órgãos

27 MIRANDA, 1937, p. 292. 
do Estado, passaram a ser estatais; segundo, porque ao Estado politico (ele se tornou político-econômico) só se dará a atuação no sentido do interesse geral, controlativa; terceiro, porque se judicializa, até certo ponto, a luta pela instituição da magistratura do trabalho: o ordenamento jurídico dará o processo que se substitua à defesa pelas próprias mãos, e ter-se-á a juridicidade da coordenação das classes, criada por um direito, que é também delas. Autosubmissão, em vez de submissão. Noutros termos, a marcha pacífica para a simetrização, para a solidariedade social em vez das soluções catastróficas, uma ilusória, que é a de reprimir o violento surto reivindicativo dos proletários, e outra, também violenta, que é a ditadura do proletariado"28.

Ao direito constitucional cumpriria uma missão proativa, enquanto fator de mudança, qual seja, "juridicizar a coordenação das classes”, garantir, pela via do direito, a marcha pacífica para a solidariedade social. Deveria aceitar o desafio que havia sido proposto por Oliveira Vianna ao criticar a Carta de $1891^{29}$, e livrar-se do idealismo de outrora, aceitando posicionar a norma como direção para a realidade futura, pensada a partir da experiência presente e da observação do que vinha acontecendo em outros países.

A tarefa é assumida pelos atores no processo constituinte, que a realizam conscientes de que estão a redigir uma carta política inspirada por preceitos híbridos, ora liberais, ora solidaristas, ora centralizadores e autoritários, ora democráticos. Não é intenção compor uma Constituição coerente com quaisquer teorias unívocas sobre o direito ou sobre o Estado, nem que desse aos constitucionalistas a possibilidade de sobre ela construir teorias gerais. Por outro lado, valiam-se do direito como ação transformadora, capaz de moldar a sociedade que viria, e não apenas de refletir, como uma fotografia, aquilo que ela era. Lembrando da divergência de Mirkine-Guetzévitch com Ferdinand Lassalle, a Constituição passa a ser ferramenta para a criação de realidades políticas, concretas ou simbólicas. E se "os métodos segundo os quais as constituições poderão reinar sobre todos os aspectos da vida do futuro em construção, e a análise das possibilidades que se apresentam neste ou naquele país em particular, são da competência da política" ${ }^{30}$, ao direito constitucional cumpriria abrir-se para essa nova função conformadora de futuro.

Ora, ao despir-se da obrigação tanto de retratar o presente quanto de espelhar uma teoria coerente, a Constituição é formulada sob a perspectiva pragmática do

\footnotetext{
${ }^{28}$ MIRANDA, 1937, p. 298.

${ }^{29}$ Vide VIANNA, 1981 (1924).

${ }^{30}$ MIRKINE-GUETZÉVITCH, 1933, pp. 44/45; MIRKINE-GUETZÉVITCH, 1930, pp. 13/14.
} 
direito como instrumento aberto para a política e para a formatação das instituições futuras, sob a ótica da eficiência prática em atingir os objetivos politicamente delineados. O direito constitucional, diante de uma carta híbrida que não mais podia ser reagrupada em torno de uma teoria geral do direito e do Estado, vê-se instado a reorientar seu foco, também de forma pragmática, em movimento não distante do que vinha propondo Barthélemy, na França. À uma Constituição de facetas múltiplas deveria corresponder uma doutrina que não buscasse unificá-la por meio de teorias abstratas, seja liberais, seja corporativistas, e que fosse capaz de articular em concreto respostas adequadas e eficientes para moldar a realidade futura. A tarefa afigura-se ainda mais relevante quando se leva em conta o formato da Constituição, cada vez mais aberto, que desloca também para o momento futuro a decisão sobre o conteúdo de suas normas.

A interpretação da lei fundamental passa a ser, portanto, cada vez mais decisiva na definição de seu conteúdo, e, mais do que isso, crucial, na medida em que a carta conta com inúmeros dispositivos abertos, princípios e diretrizes que regulam aspectos cada vez maiores da vida social. Ao mesmo tempo em que avança para terrenos novos, em consonância com o que Mirkine-Guetzévicth chamou de processo de racionalização do poder, é o direito, enquanto doutrina e jurisprudência, quem se apodera da decisão, ao indicar o modo pelo qual as novas normas sociais e econômicas seriam interpretadas. 
ANEXOS 


\section{ANEXO I \\ Cronologia da Segunda República: novos direitos e nova Constituição (Tabela 1)}

A tabela 1, que segue, apresenta uma comparação entre excertos da Carta de 1891, do anteprojeto constitucional elaborado pela Subcomissão Itamaraty, do Substitutivo formulado pela Comissão dos 26 (projeto $n^{\circ} 1-\mathrm{A} / 34$ ) e do texto final da Constituição de $1934^{1}$. Escolhemos, especialmente, os trechos a que se fez referência nos capítulos precedentes, em especial o preâmbulo, os dispositivos sobre nacionalidade e cidadania (direitos políticos), a declaração de direitos e deveres, o título sobre ordem econômica e social e sobre família e educação. A sistemática adotada foi orientar-se a partir do texto final da Constituição de 1934, respeitada sua ordem de numeração de artigos, e buscar as correspondências nos demais documentos (independente da ordem em que ali se apresentavam).

\footnotetext{
${ }^{1}$ A tabela é de elaboração própria, estando apoiado nas referências bibliográficas apontadas ao final do trabalho, em especial em AZEVEDO, 2004 e CARNEIRO, 1936, bem como nos textos constitucionais extraídos de http://www4.planalto.gov.br/legislacao/legislacao-historica/constituicoes-anteriores-1\#content. De se ressaltar, contudo, que o material referente ao projeto substitutivo $\mathrm{n}^{\circ} 1-\mathrm{A} / 34$ (Comissão dos 26) foi considerado tal como apresentado por Levi Carneiro, em CARNEIRO, 1936.
} 


\begin{tabular}{|c|c|c|c|c|c|c|}
\hline 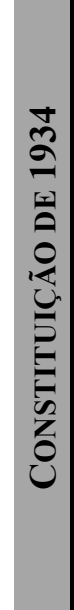 & 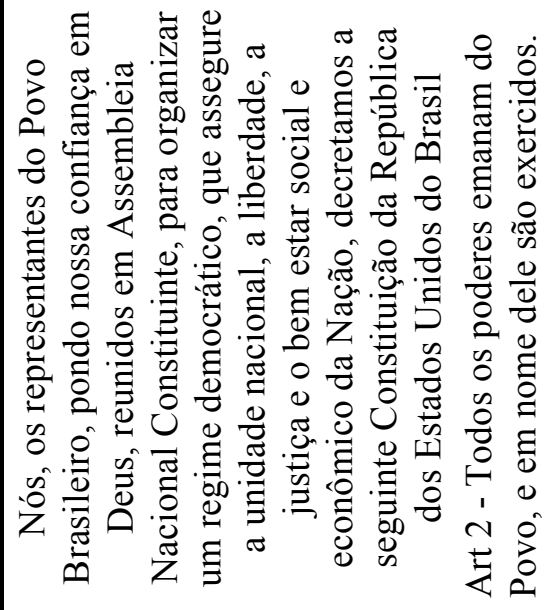 & 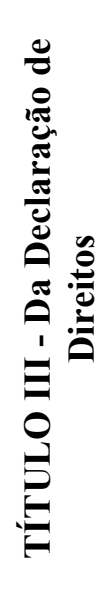 & 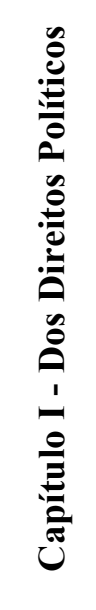 & 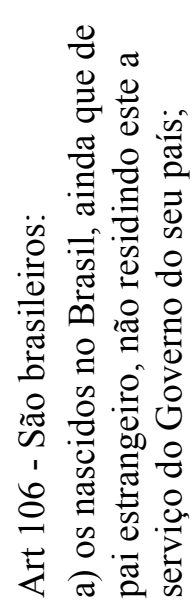 & 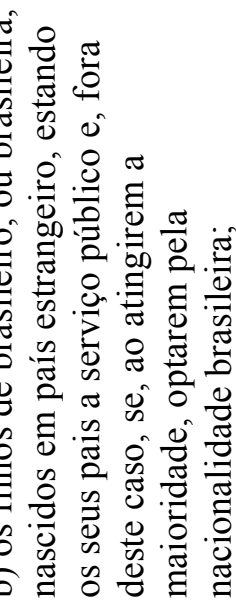 & \\
\hline & & 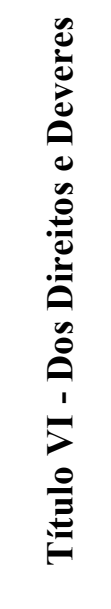 & 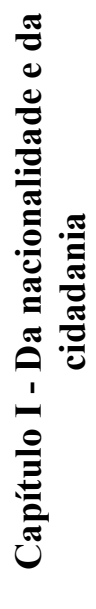 & 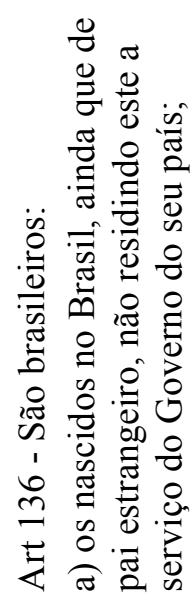 & 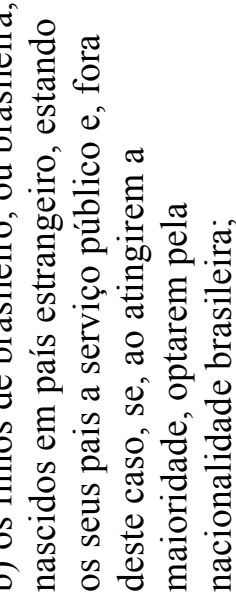 & \\
\hline 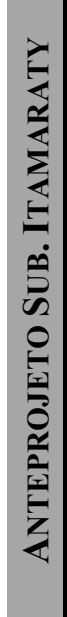 & 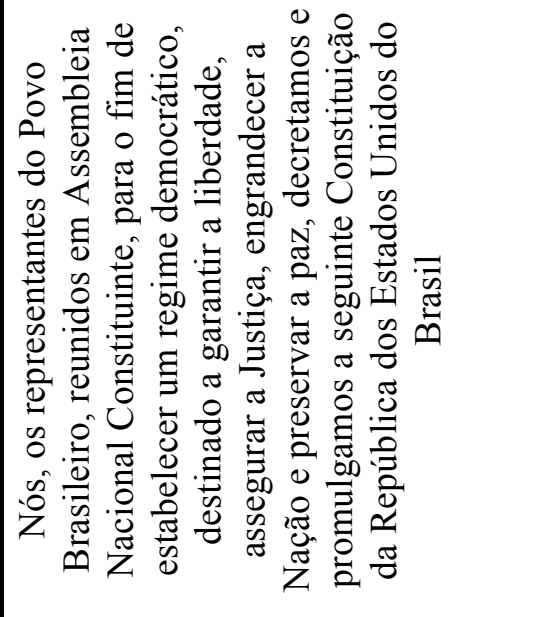 & 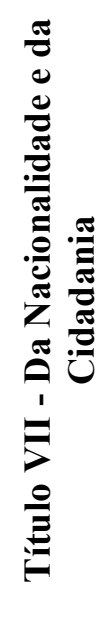 & 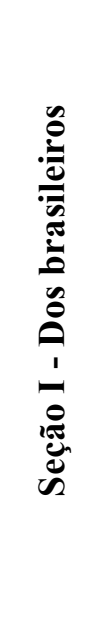 & 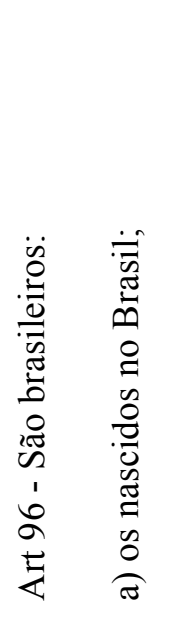 & 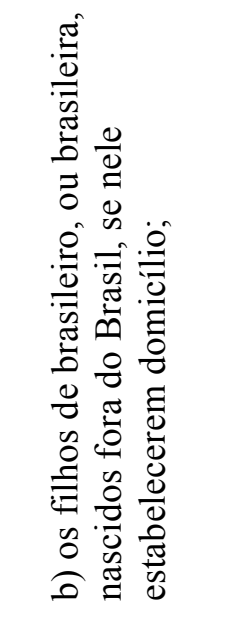 & 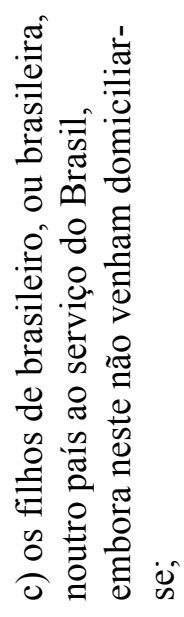 \\
\hline 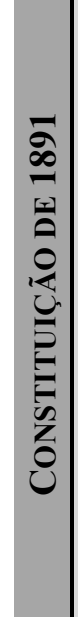 & 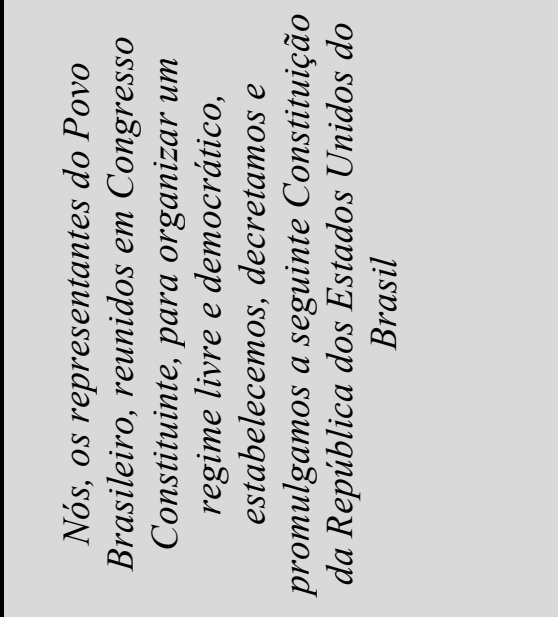 & 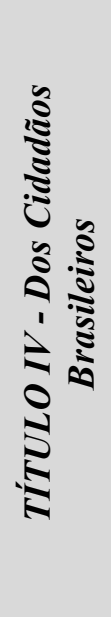 & 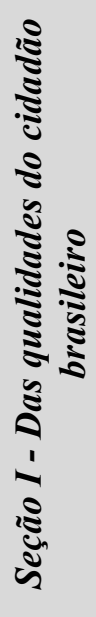 & 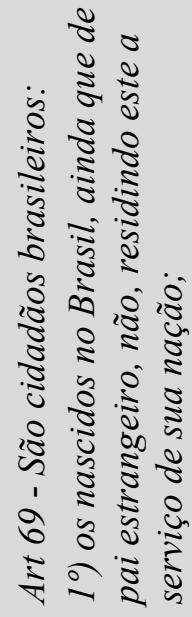 & 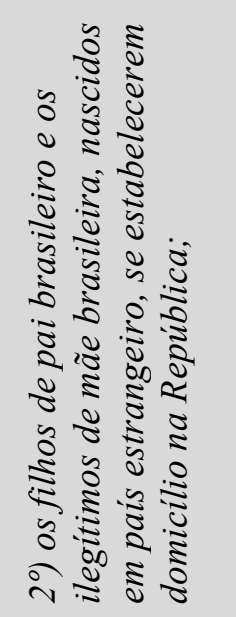 & 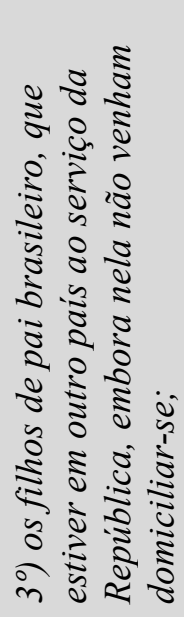 \\
\hline
\end{tabular}




\begin{tabular}{|c|c|c|c|c|c|c|c|}
\hline 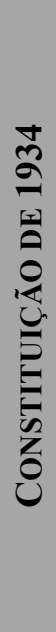 & 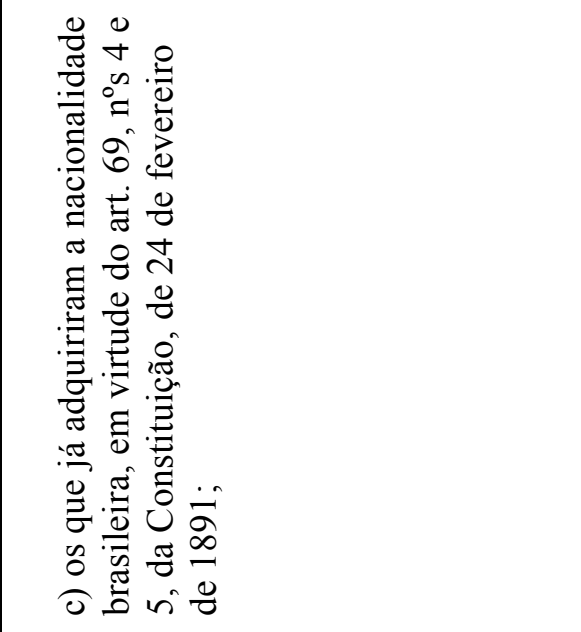 & 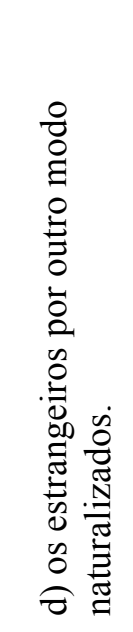 & 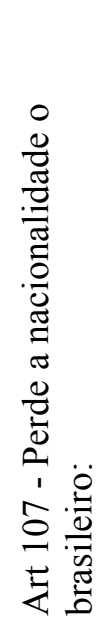 & 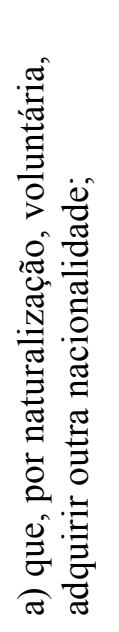 & 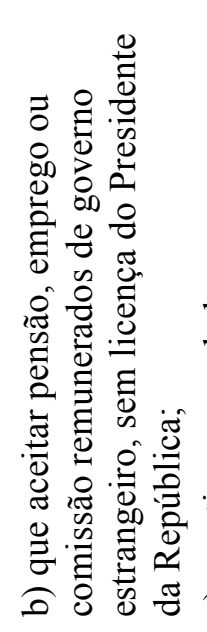 & 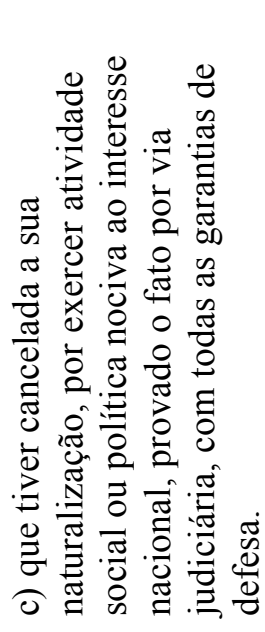 & \\
\hline $\begin{array}{l}0 \\
1 \\
0 \\
0 \\
0 \\
0 \\
1 \\
0 \\
0 \\
2 \\
0 \\
0 \\
0 \\
0 \\
\vdots \\
5 \\
0 \\
0 \\
0 \\
0 \\
0 \\
0\end{array}$ & 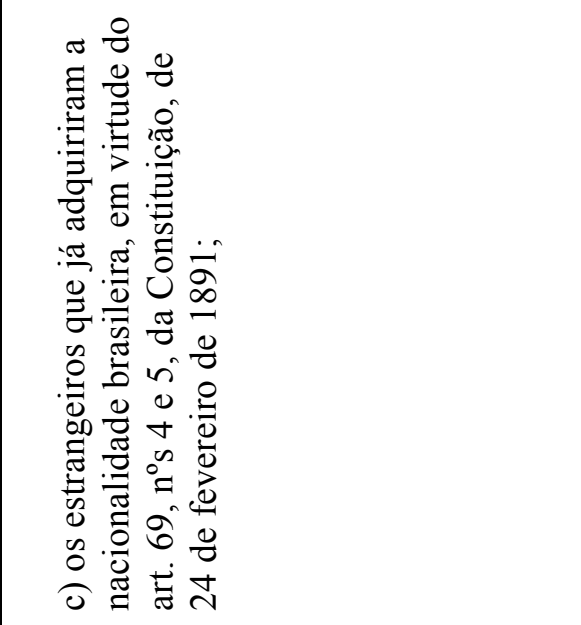 & 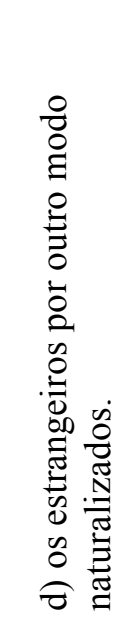 & 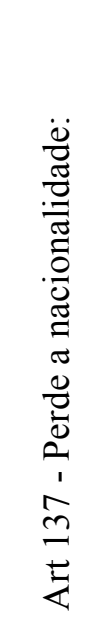 & 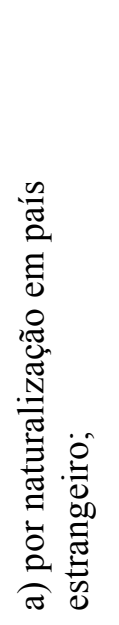 & 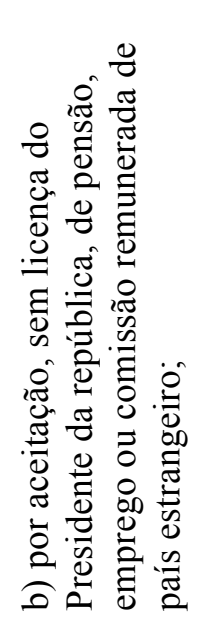 & 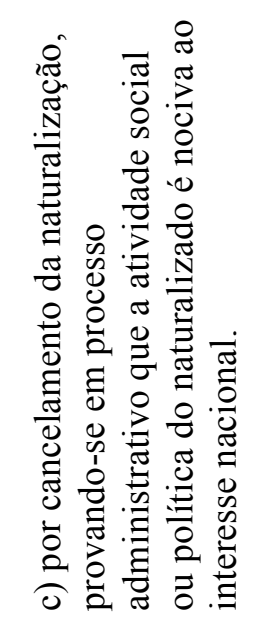 & \\
\hline 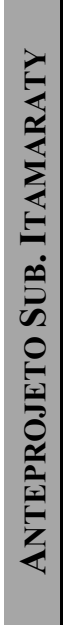 & 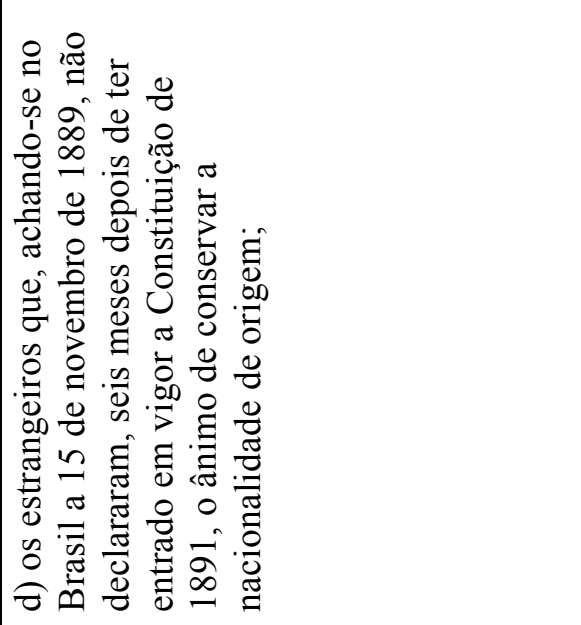 & 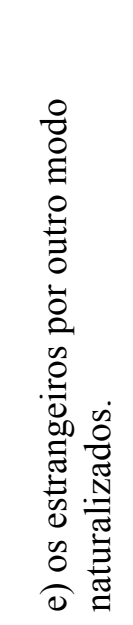 & 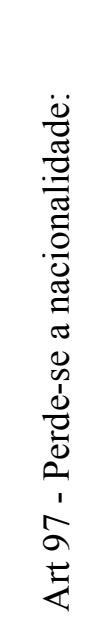 & 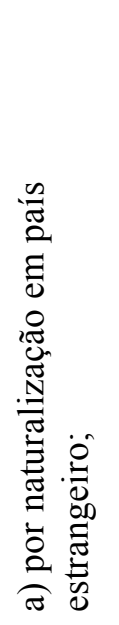 & 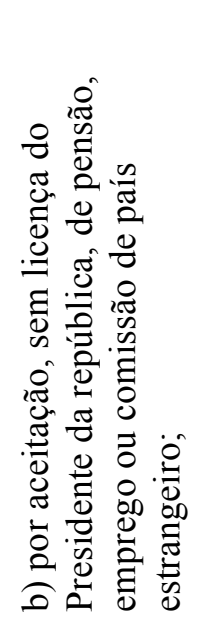 & 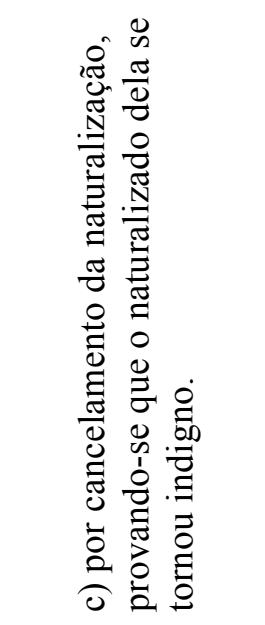 & 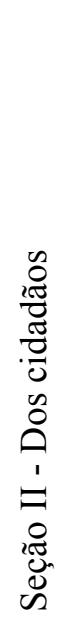 \\
\hline $\begin{array}{l}\bar{a} \\
0 \\
0 \\
0 \\
0 \\
0 \\
0 \\
0 \\
0 \\
0 \\
0 \\
0 \\
0\end{array}$ & 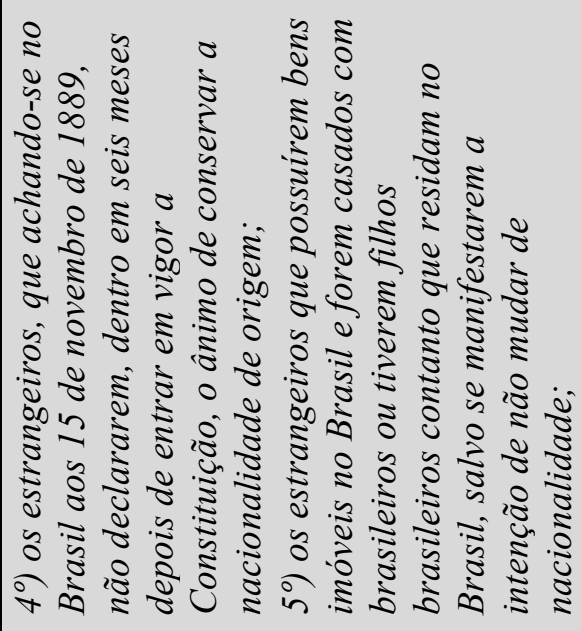 & 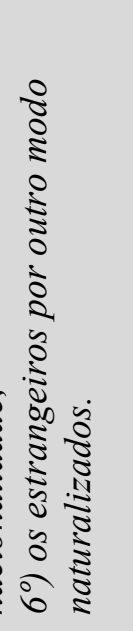 & & & & & \\
\hline
\end{tabular}




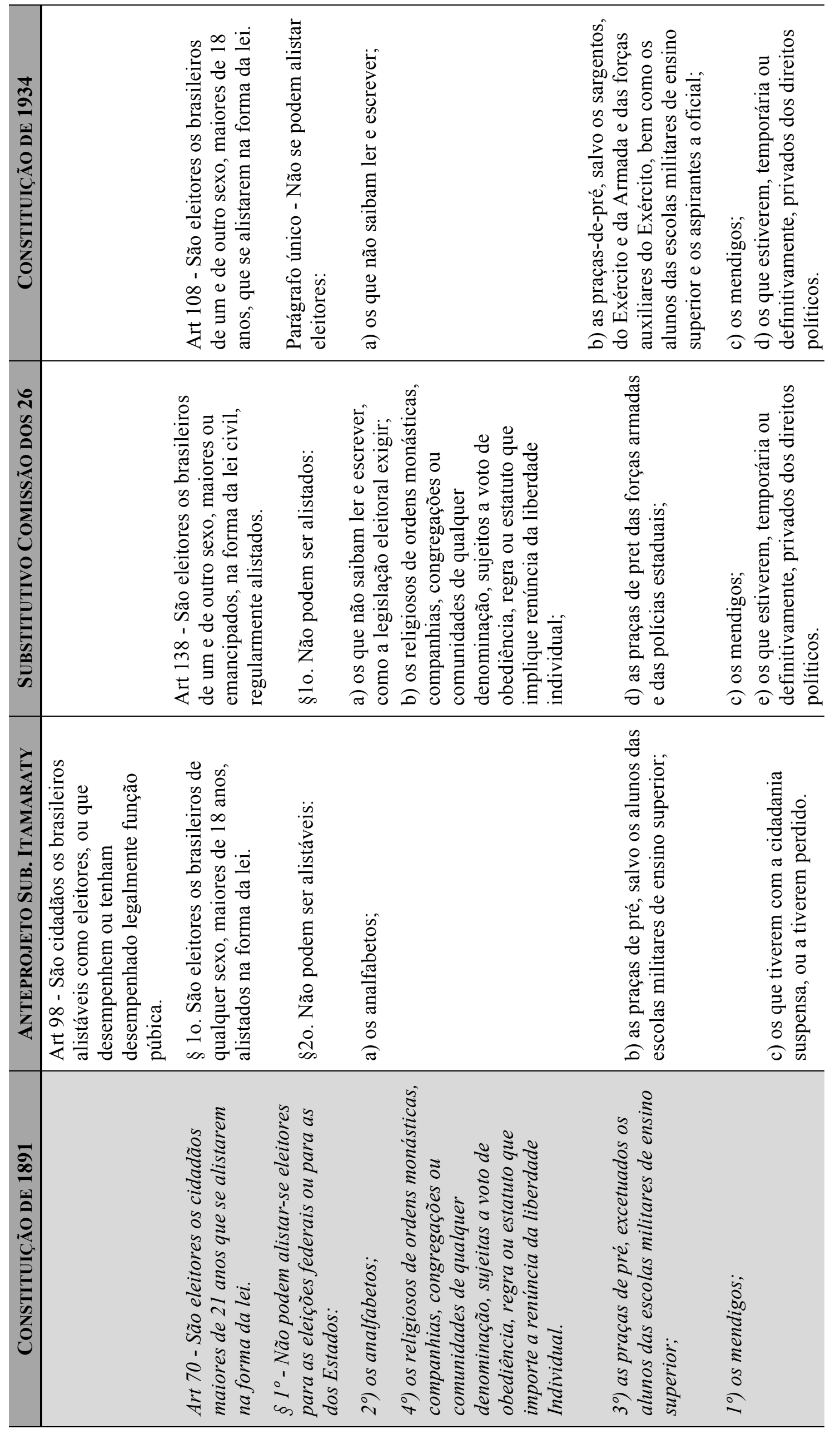




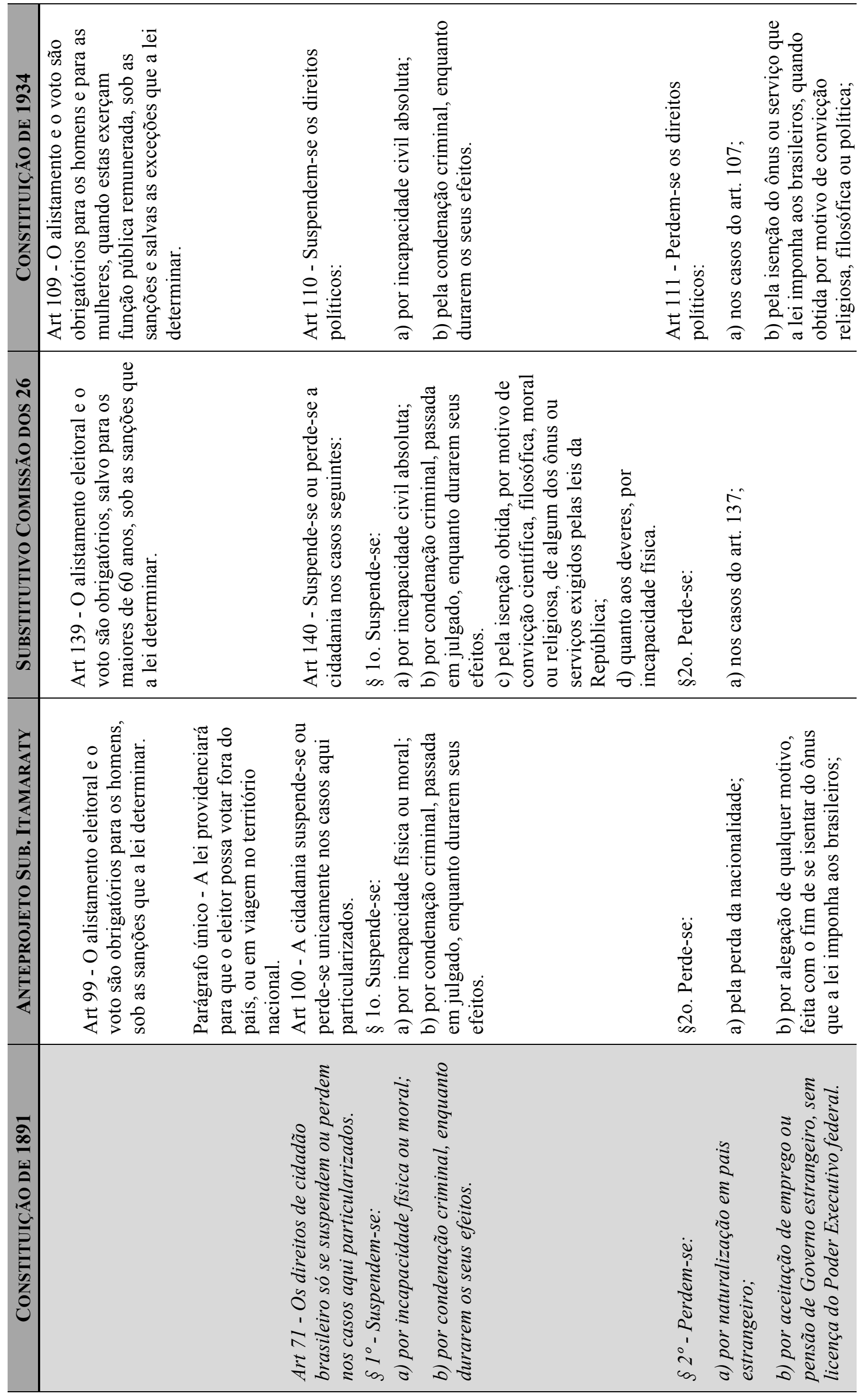




\begin{tabular}{|c|c|c|c|c|c|c|}
\hline & 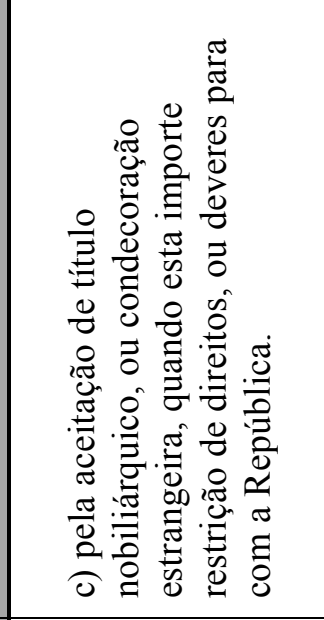 & 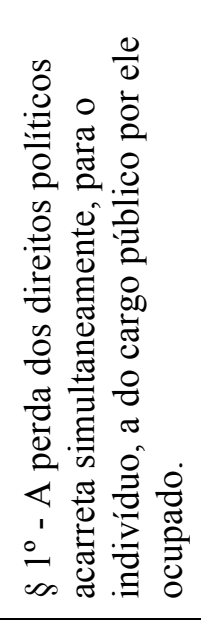 & 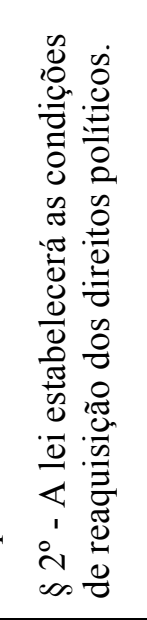 & 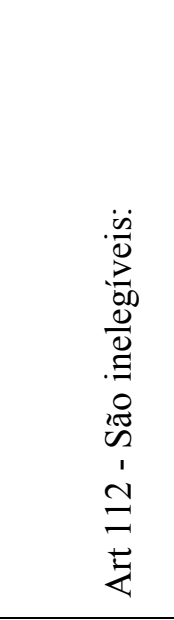 & 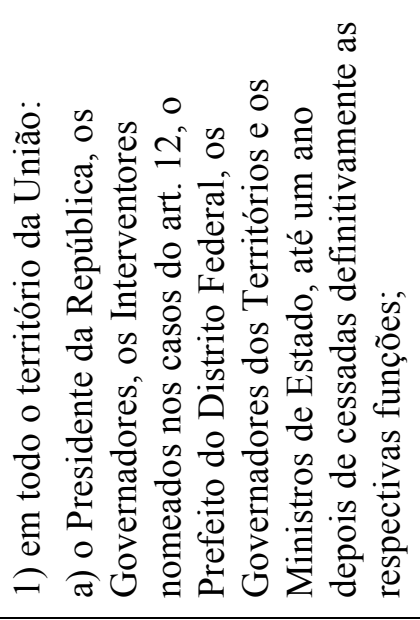 & 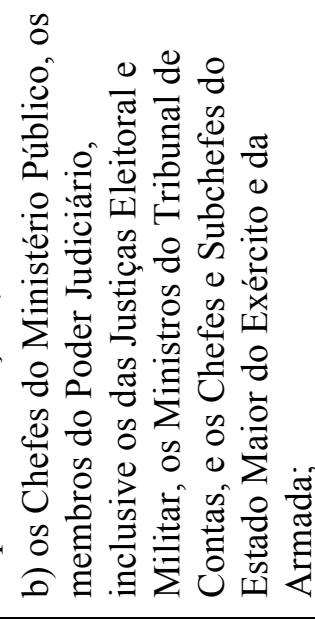 \\
\hline & 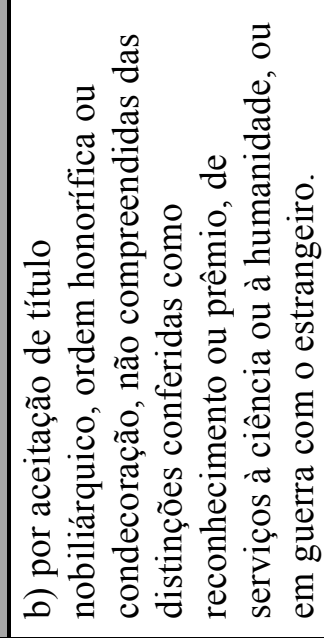 & & 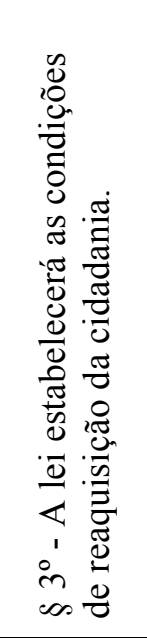 & 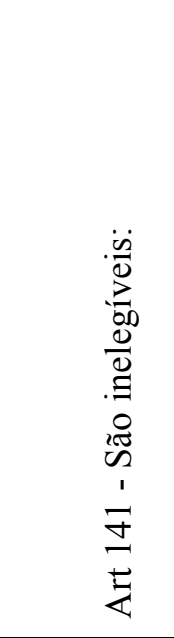 & 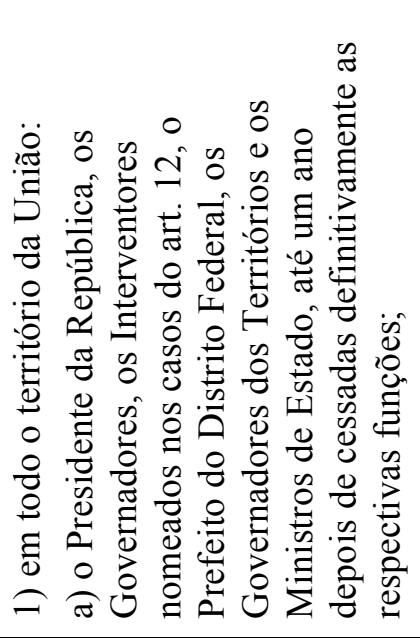 & 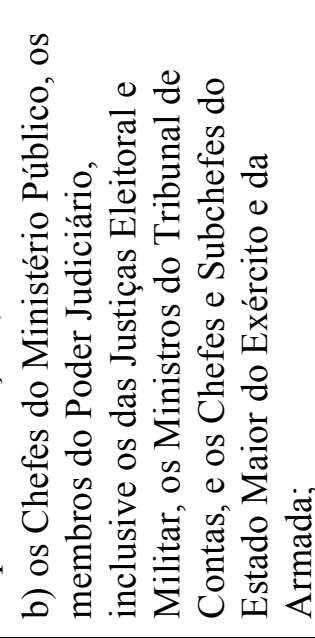 \\
\hline & 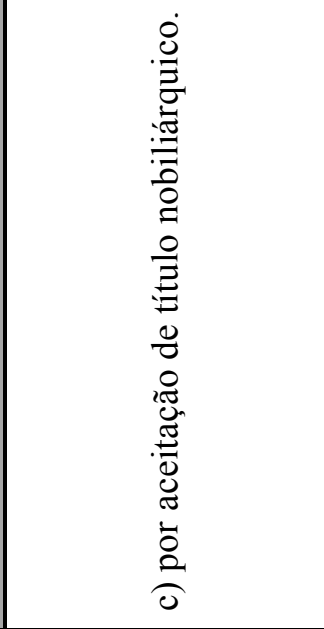 & & 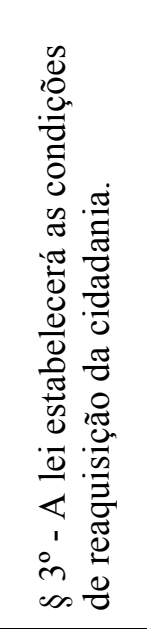 & 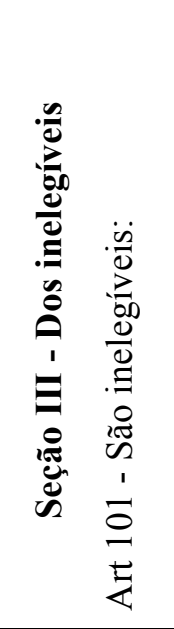 & 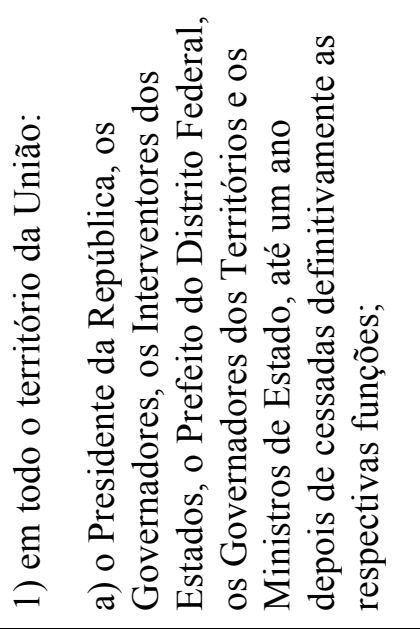 & 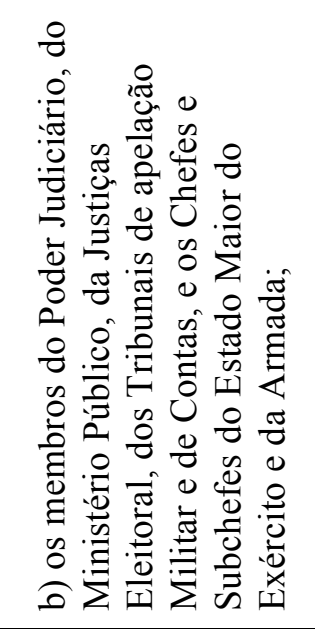 \\
\hline 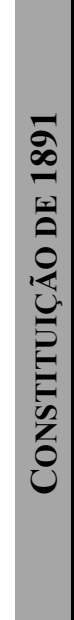 & 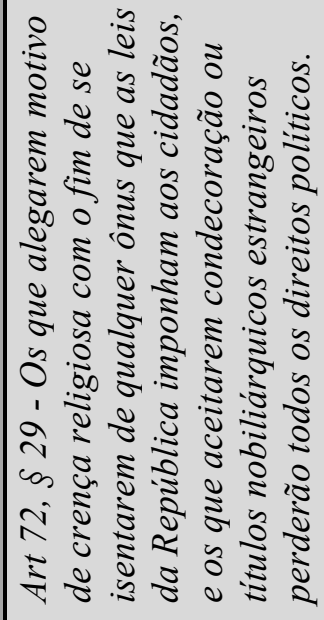 & & 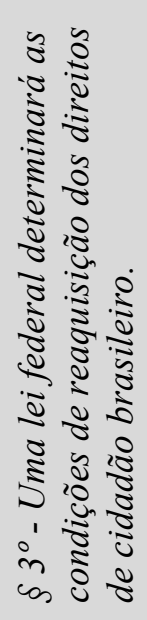 & 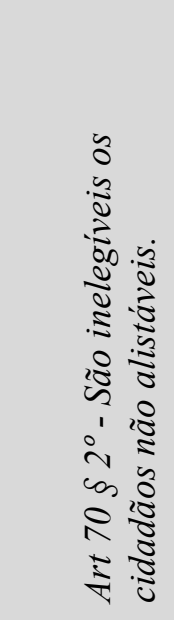 & & \\
\hline
\end{tabular}




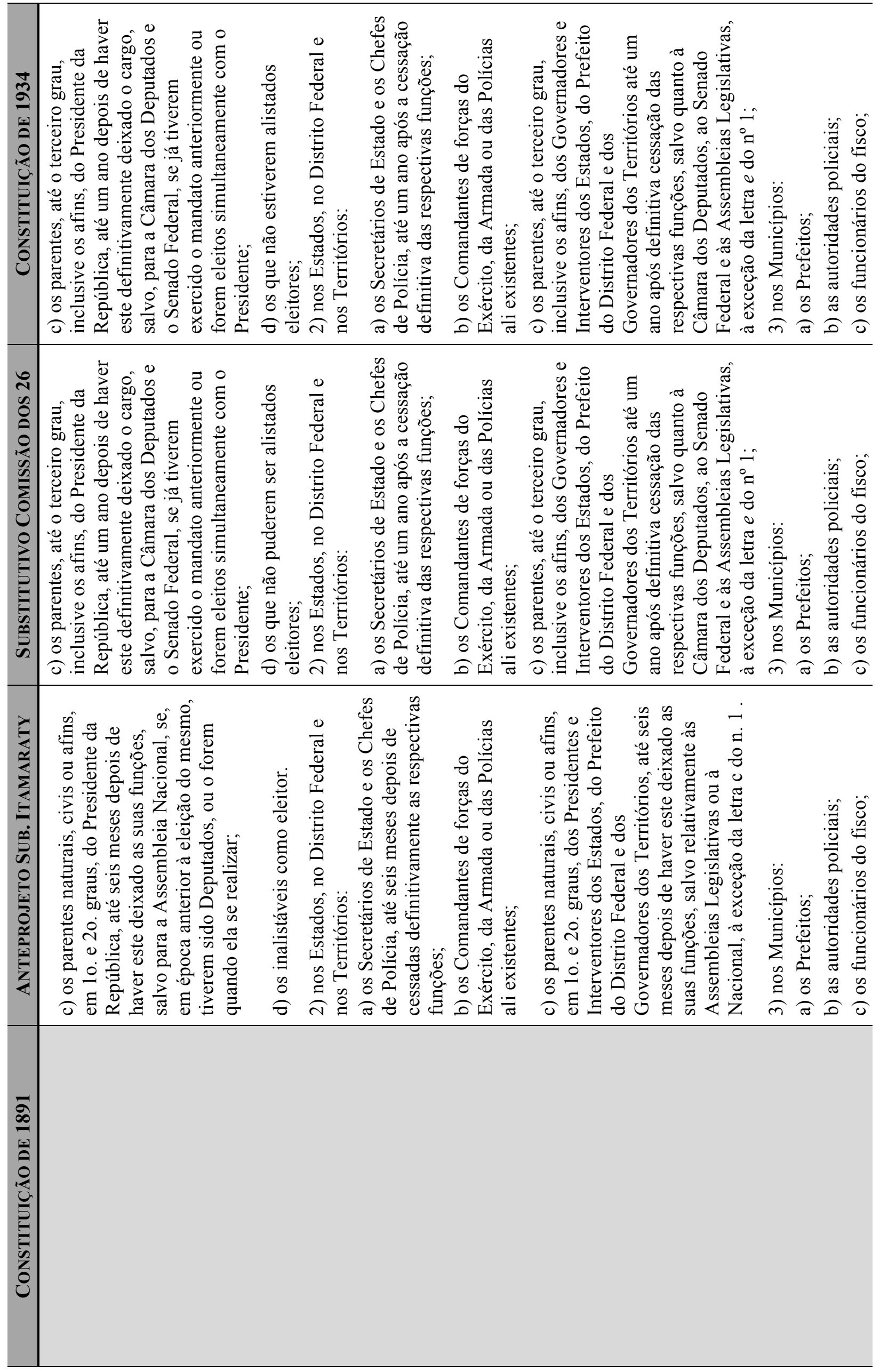




\begin{tabular}{|c|c|c|c|c|c|}
\hline & 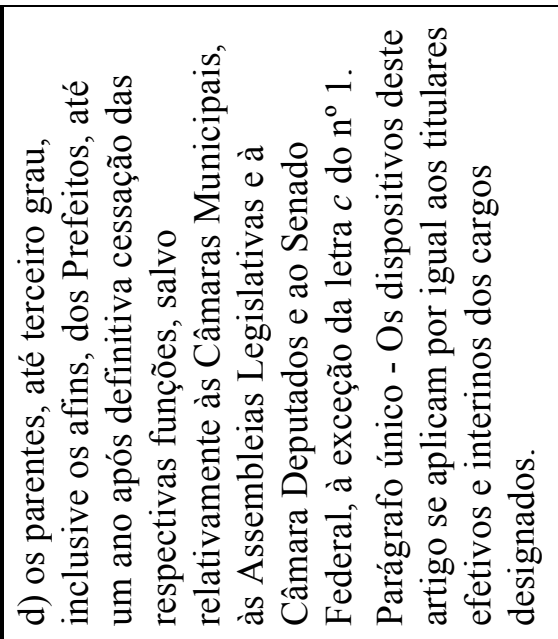 & 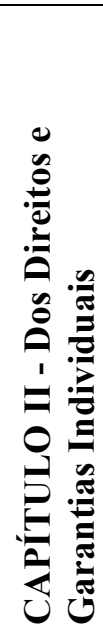 & 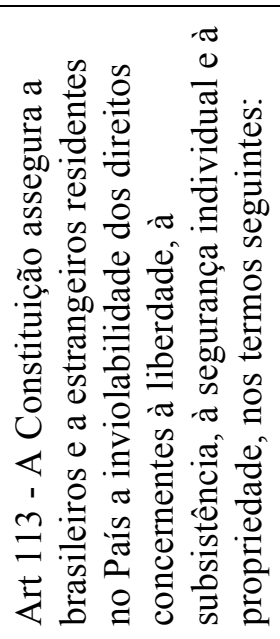 & 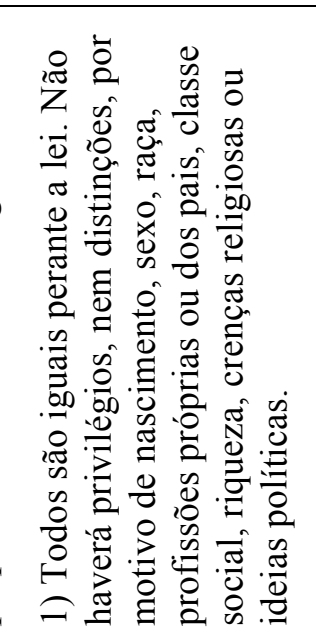 & \\
\hline & 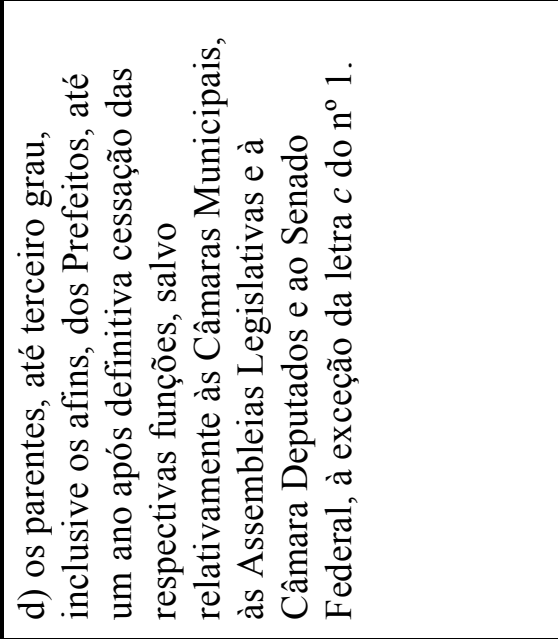 & 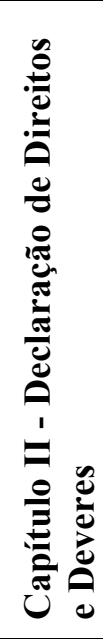 & 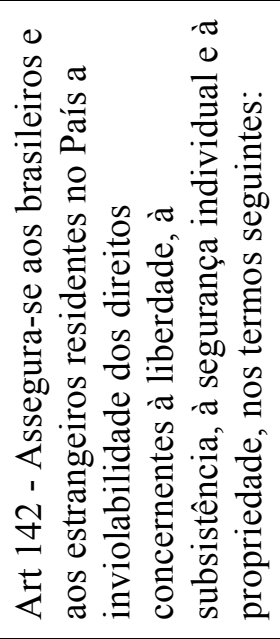 & 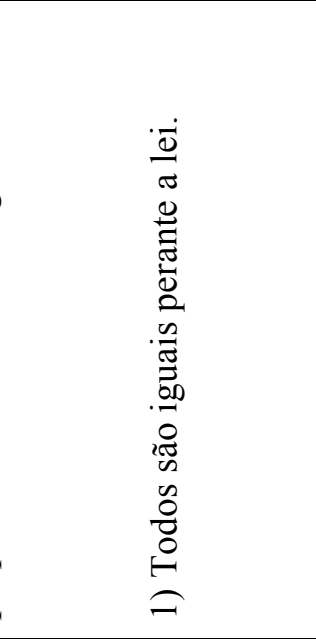 & 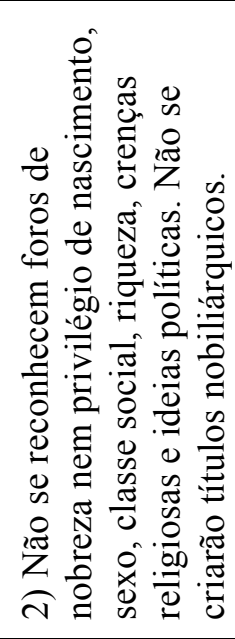 \\
\hline 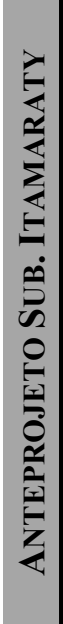 & 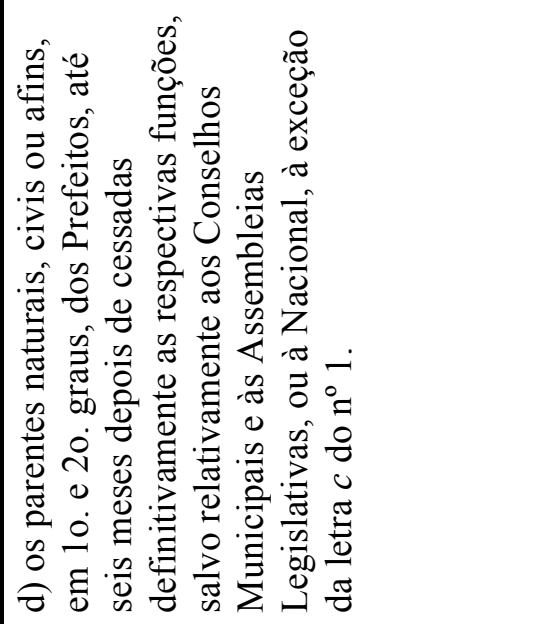 & 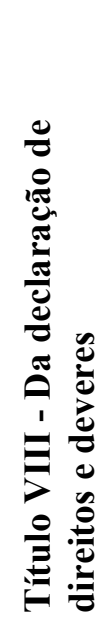 & 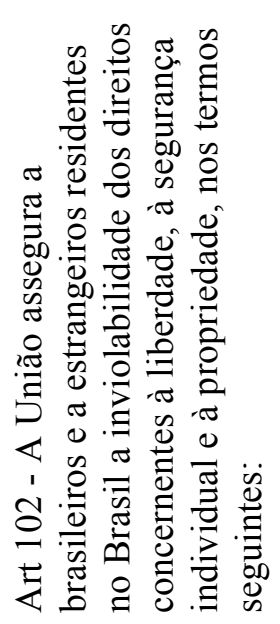 & 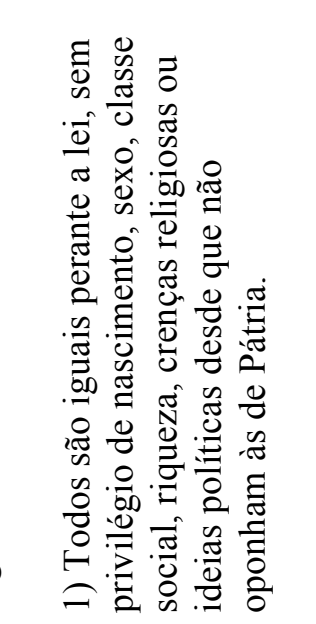 & 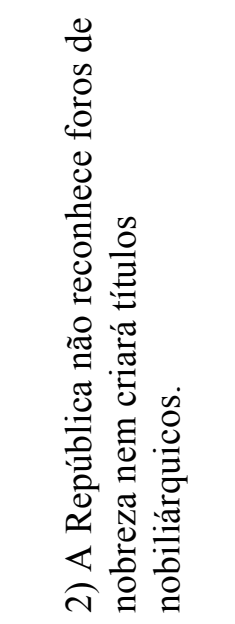 \\
\hline & & 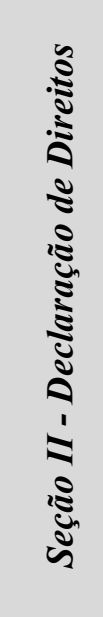 & 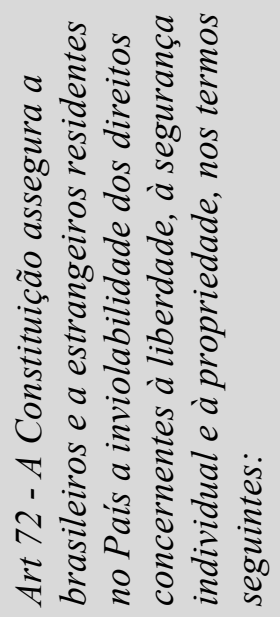 & 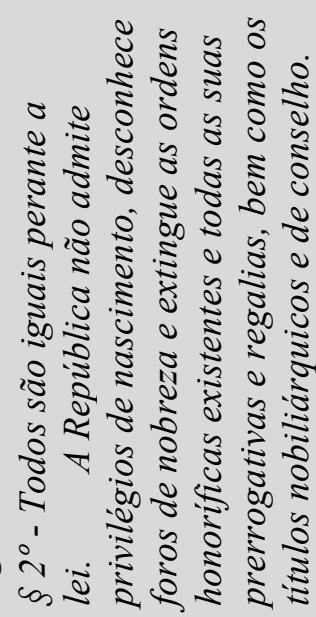 & \\
\hline
\end{tabular}




\begin{tabular}{|c|c|c|c|c|c|}
\hline $\begin{array}{l}\text { 뎀 } \\
0 \\
0 \\
0 \\
0 \\
0 \\
0\end{array}$ & 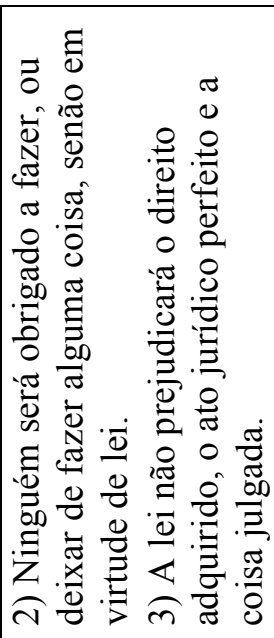 & 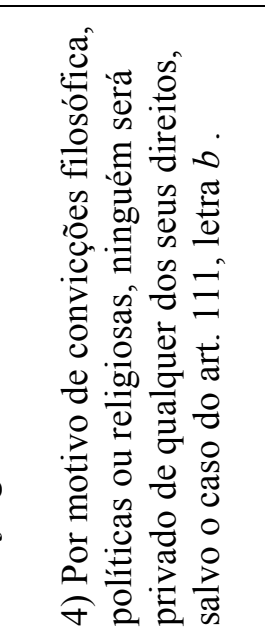 & 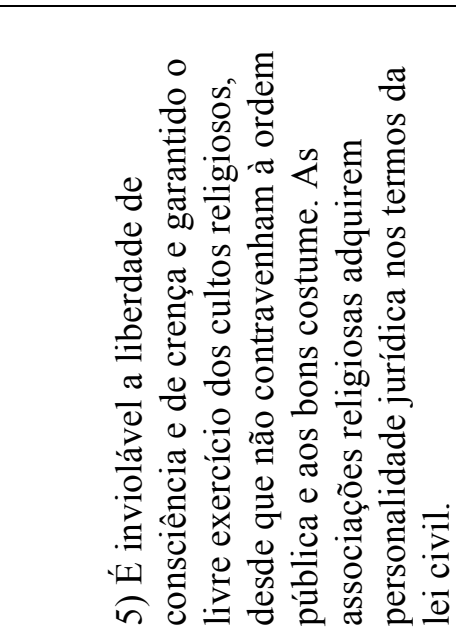 & & \\
\hline $\begin{array}{l}2 \\
0 \\
0 \\
0 \\
0 \\
0 \\
0 \\
0 \\
0 \\
0 \\
0 \\
0 \\
0 \\
0 \\
0\end{array}$ & 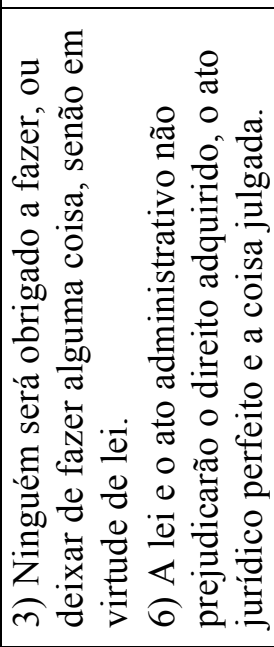 & 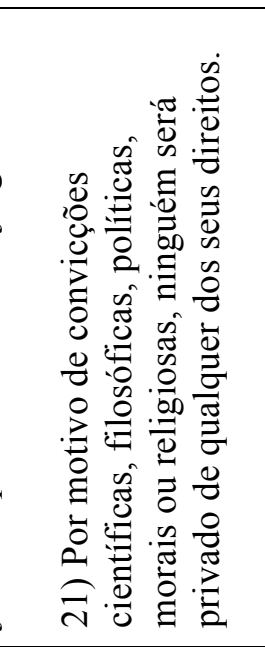 & 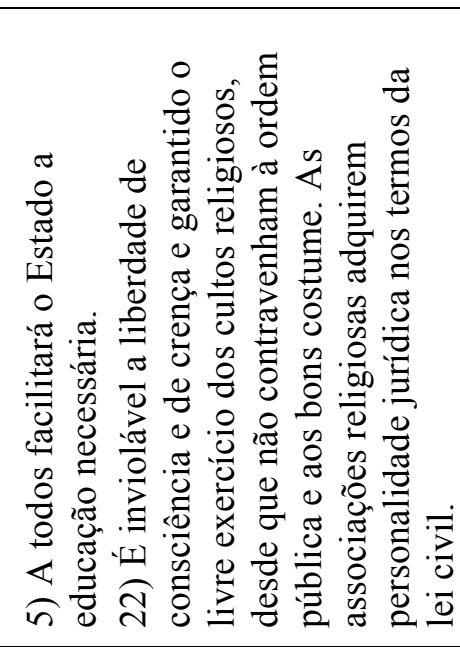 & & \\
\hline 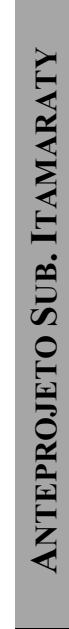 & 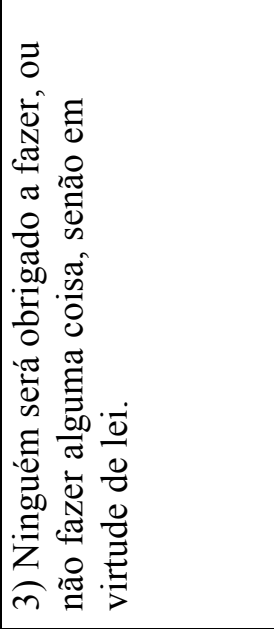 & 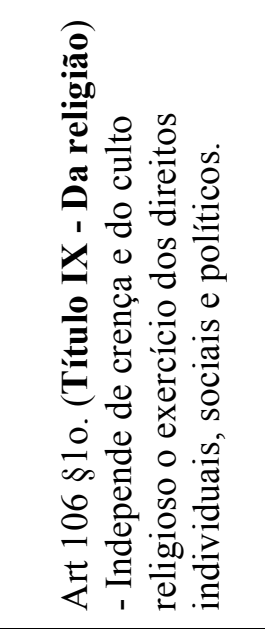 & 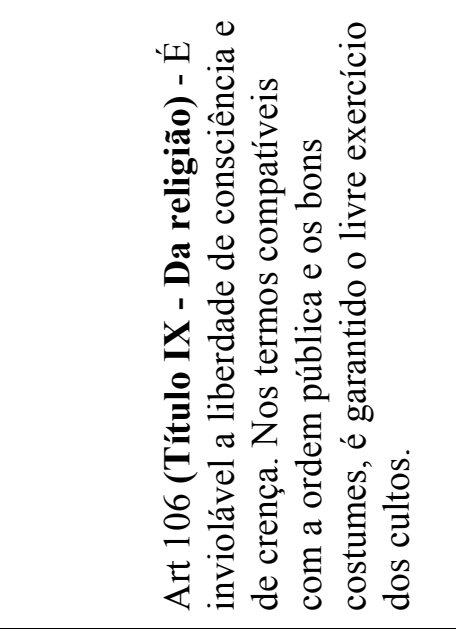 & & 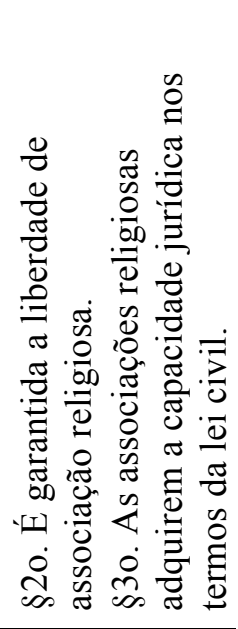 \\
\hline $\begin{array}{l}\bar{\alpha} \\
0 \\
0 \\
0 \\
0 \\
0 \\
0 \\
0 \\
0 \\
0 \\
0\end{array}$ & 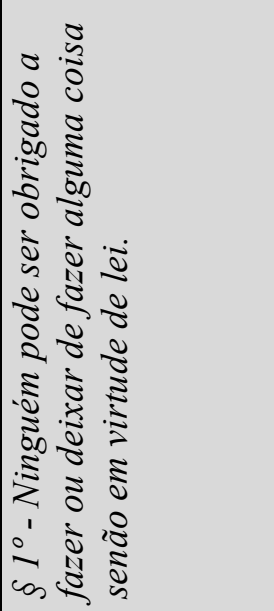 & 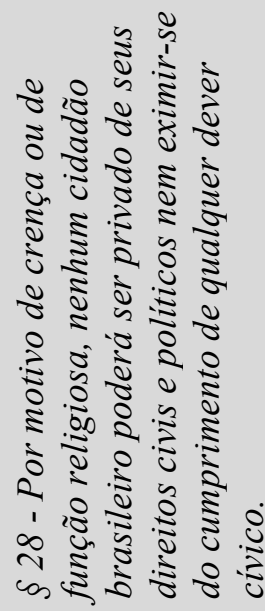 & 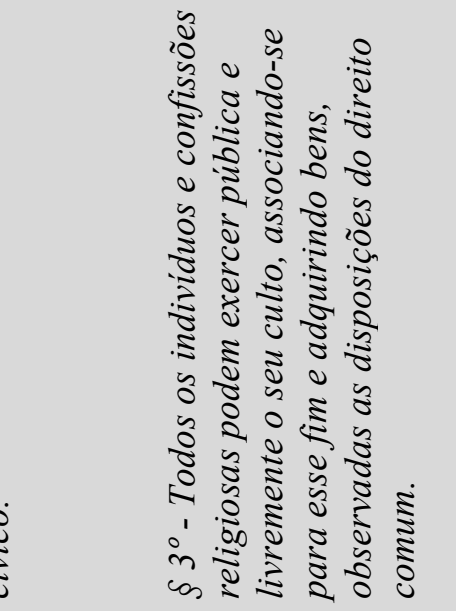 & 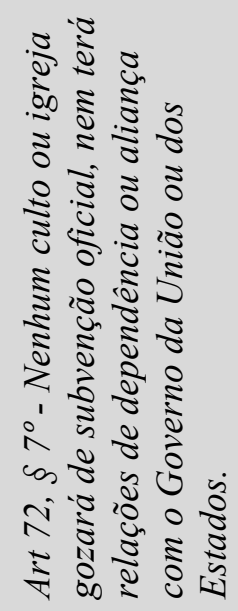 & \\
\hline
\end{tabular}




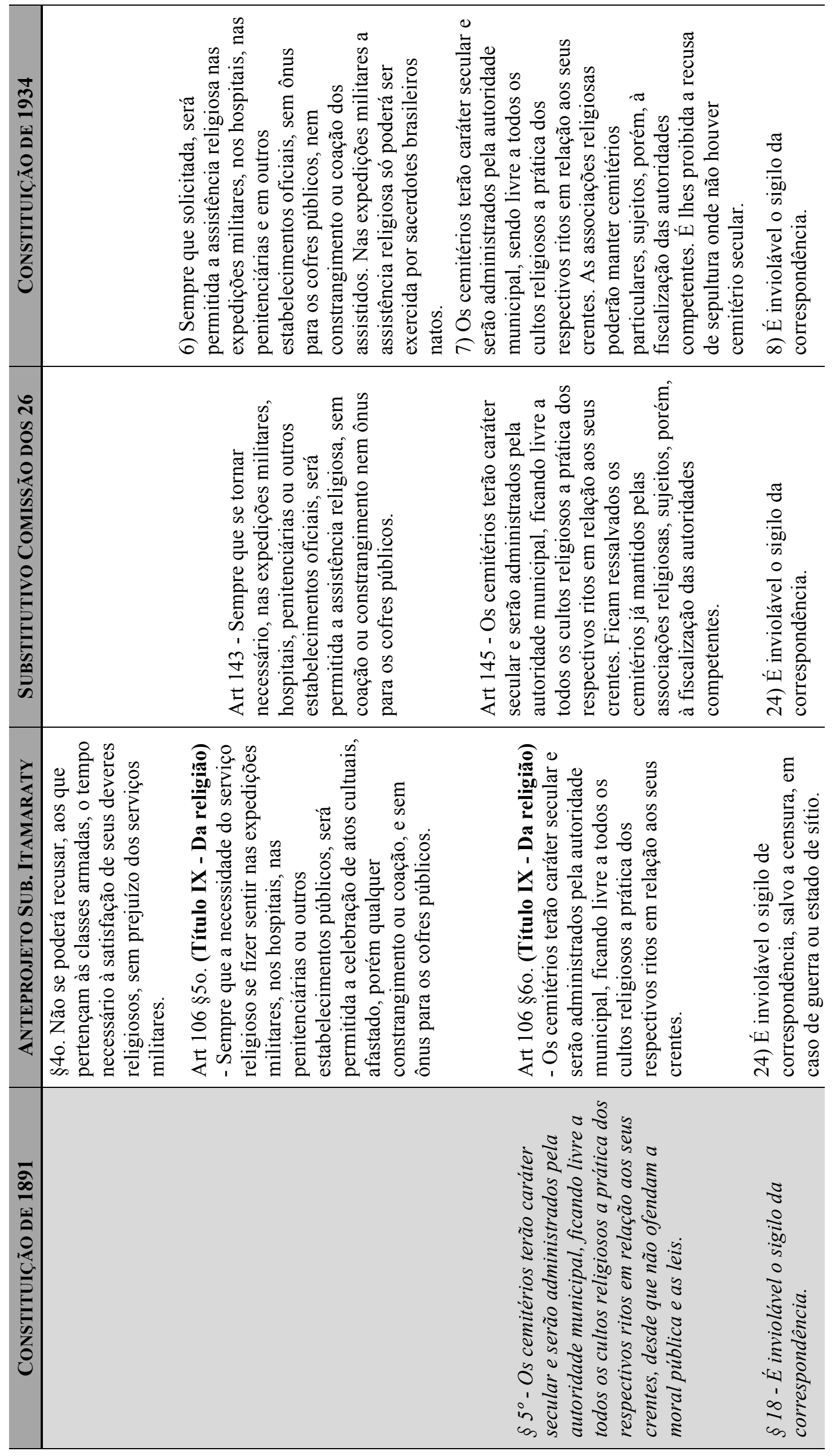




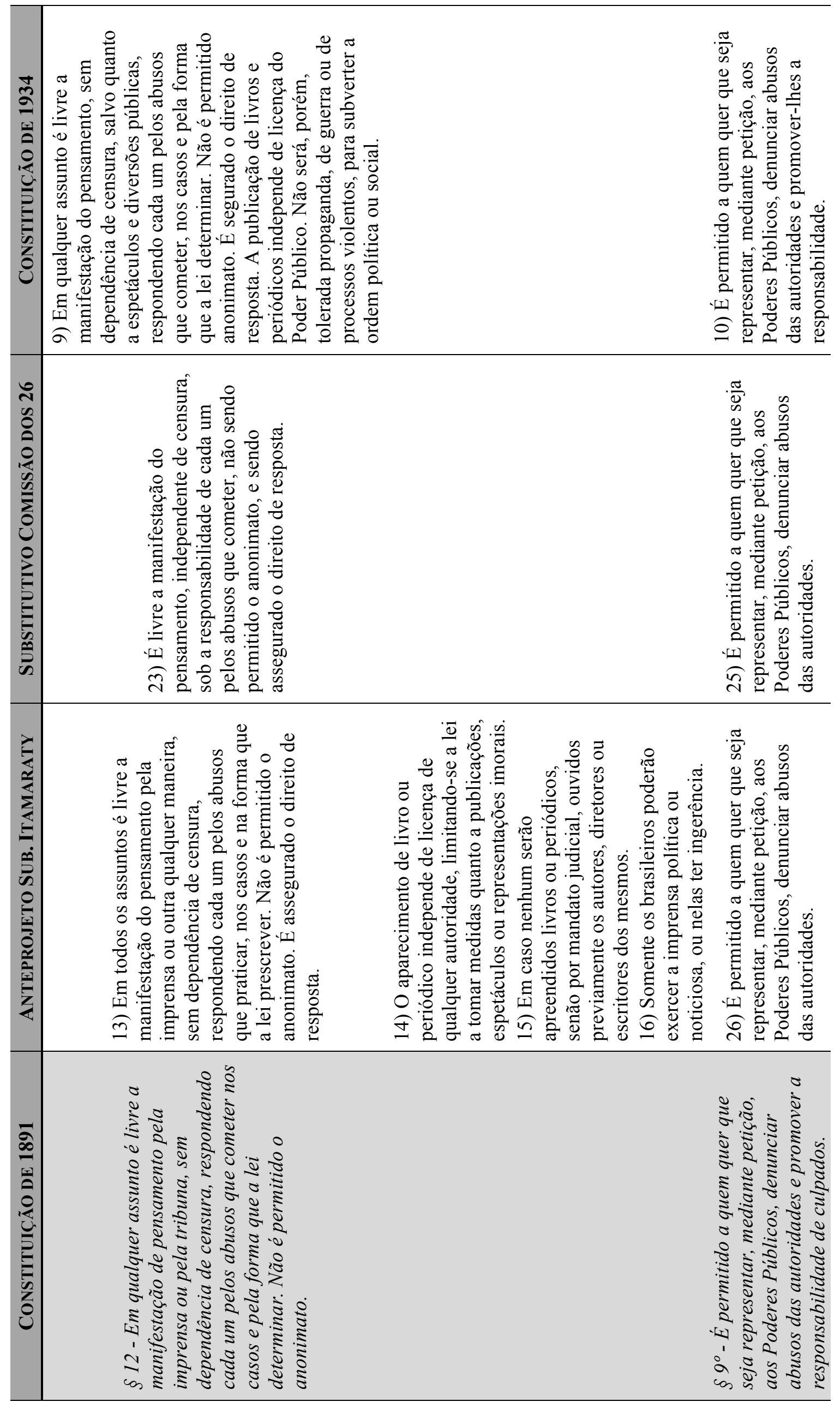




\begin{tabular}{|c|c|c|c|c|c|}
\hline 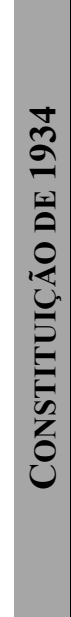 & 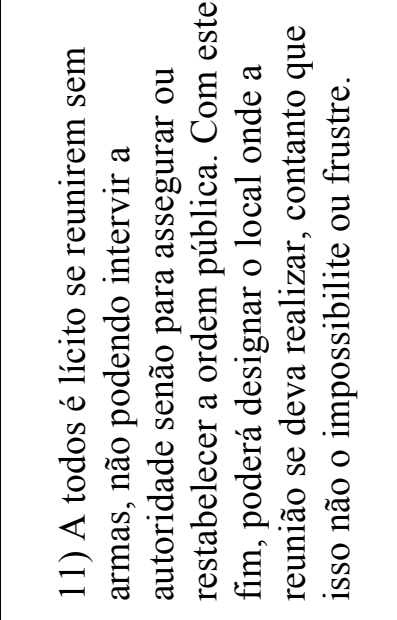 & 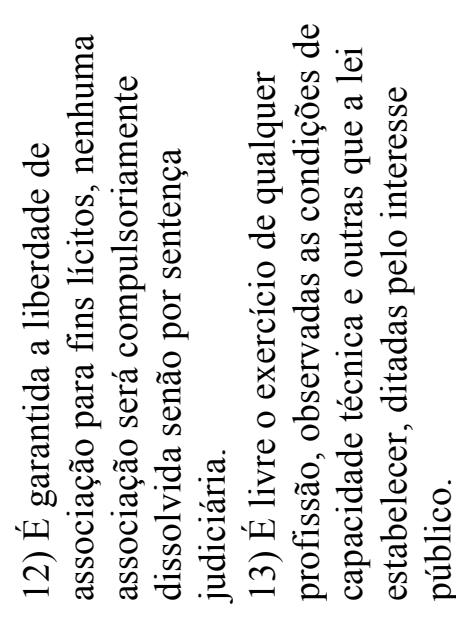 & & 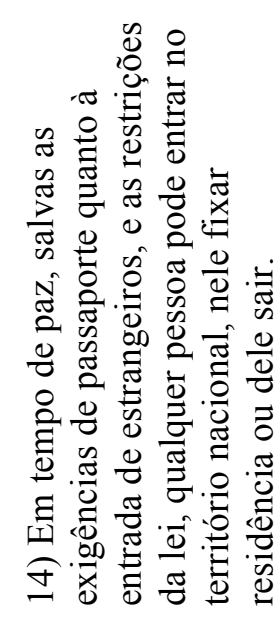 & \\
\hline & & 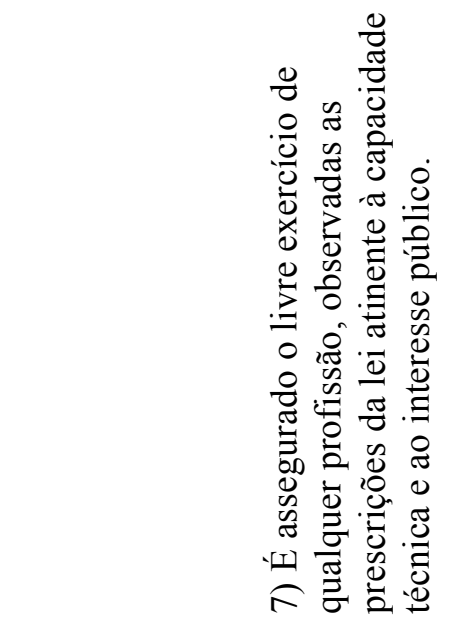 & 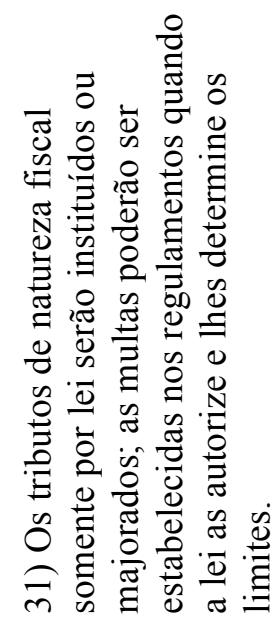 & 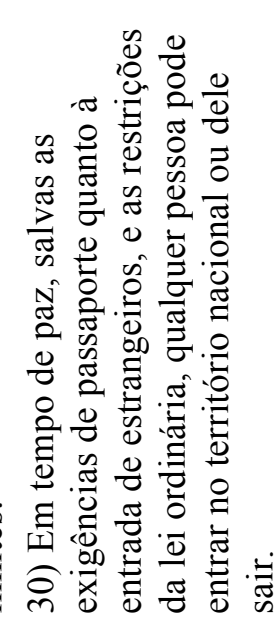 & \\
\hline 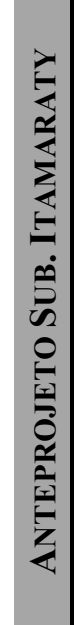 & 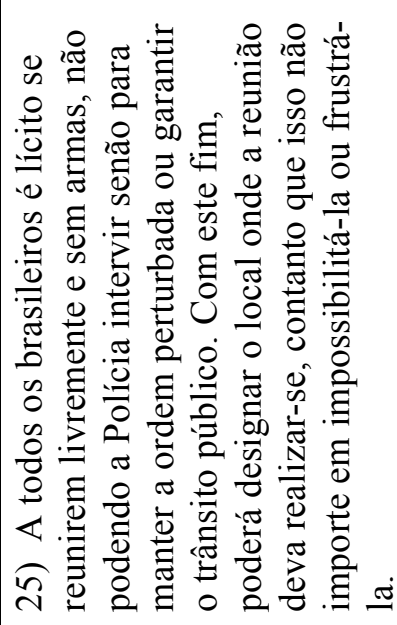 & 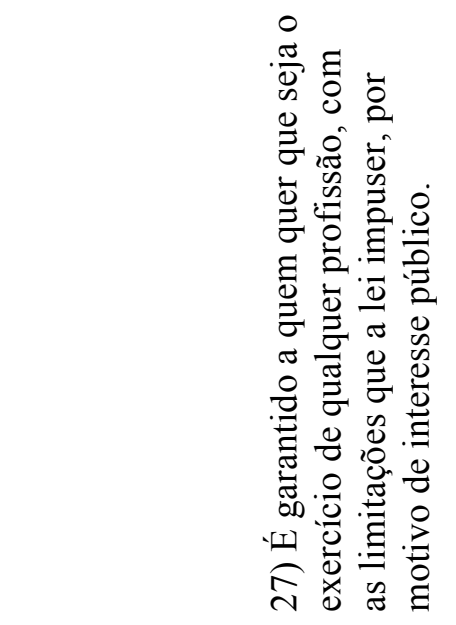 & 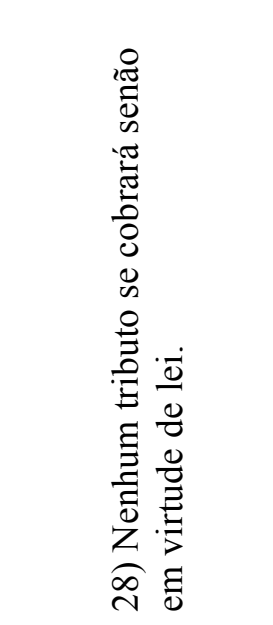 & 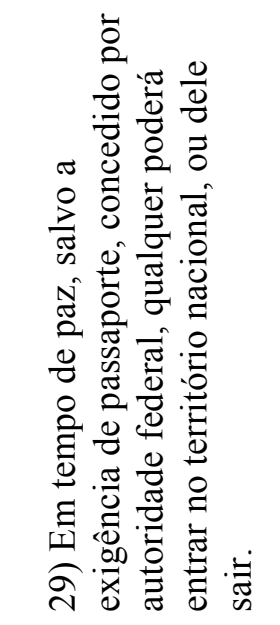 & 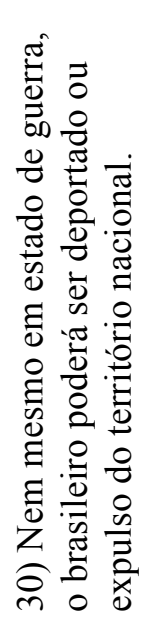 \\
\hline 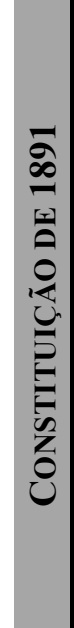 & 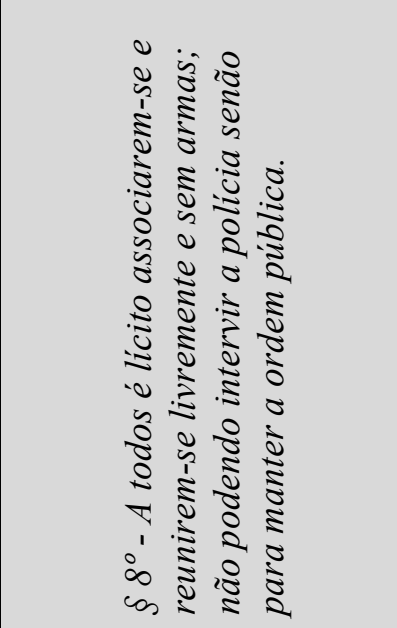 & 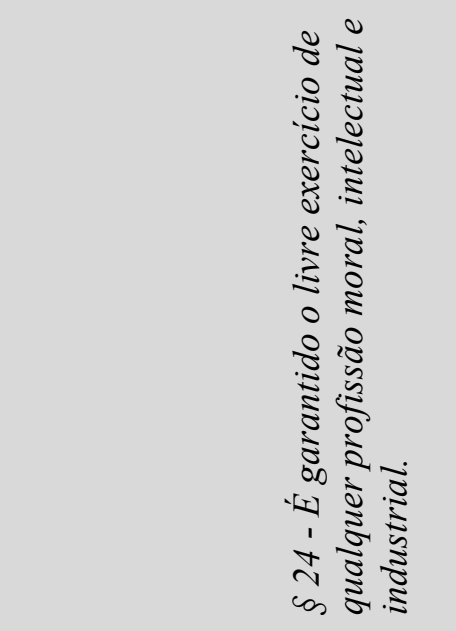 & 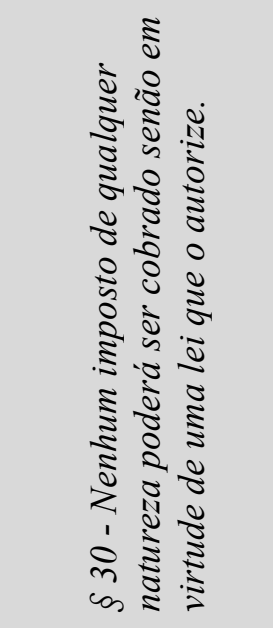 & 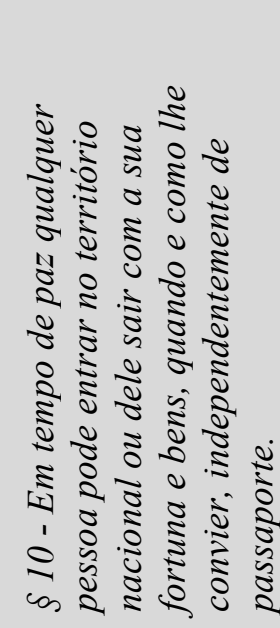 & \\
\hline
\end{tabular}




\begin{tabular}{|c|c|c|c|}
\hline & 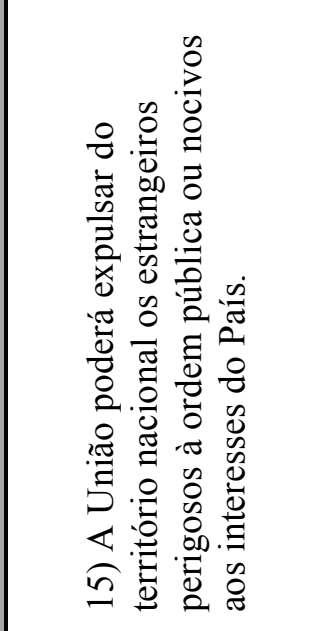 & 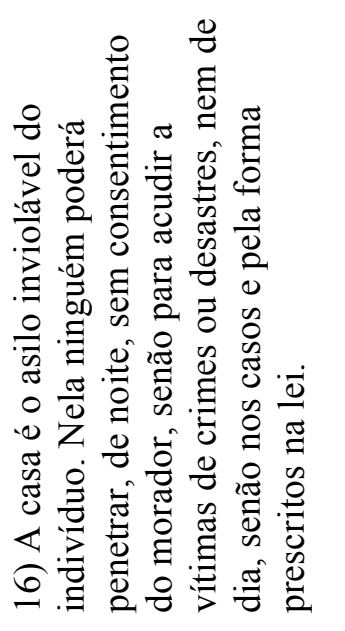 & 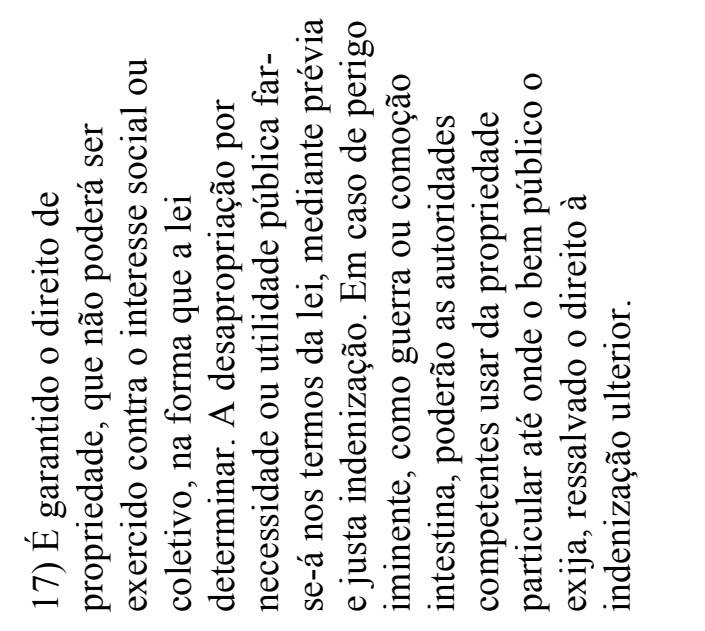 \\
\hline $\begin{array}{l}0 \\
0 \\
\sum_{0}^{2} \\
0 \\
0 \\
0 \\
0 \\
0\end{array}$ & 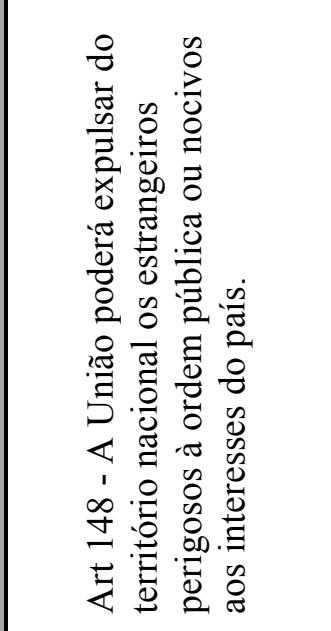 & 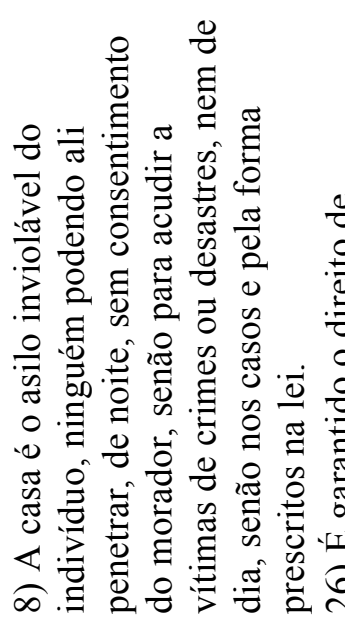 & 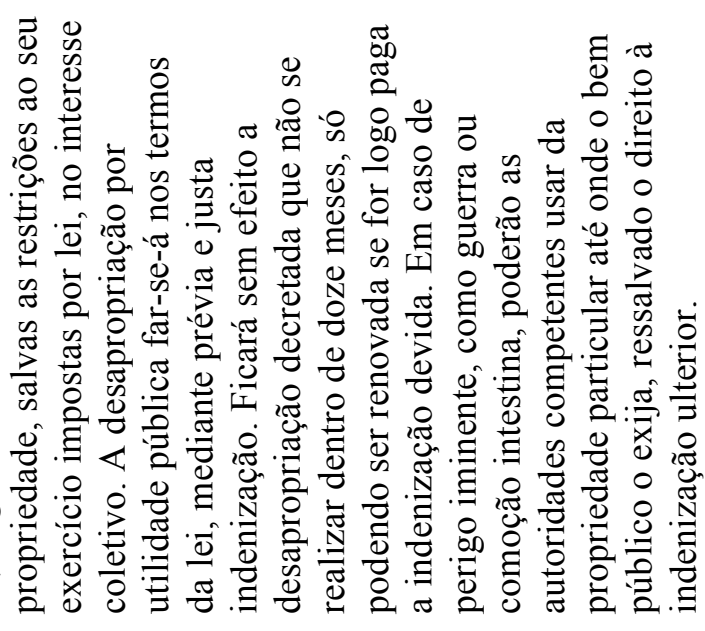 \\
\hline 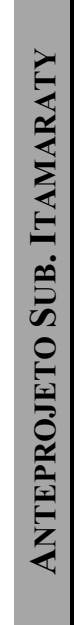 & 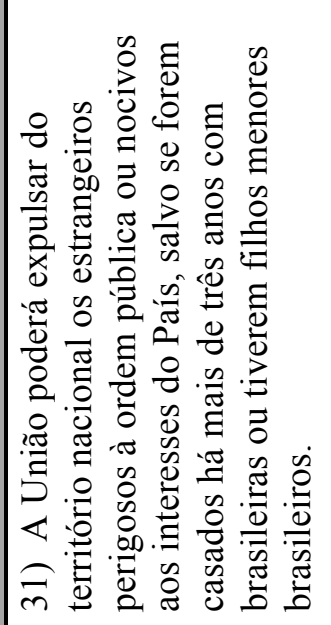 & 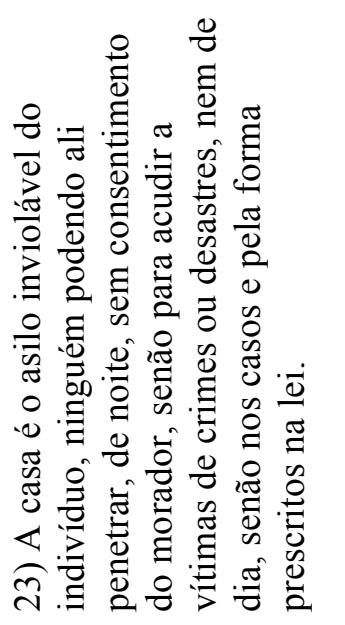 & 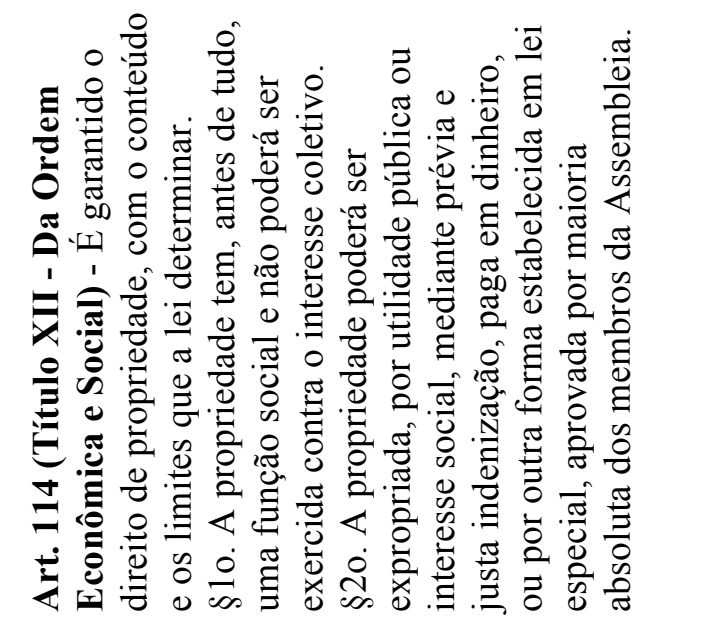 \\
\hline 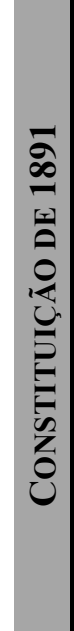 & & 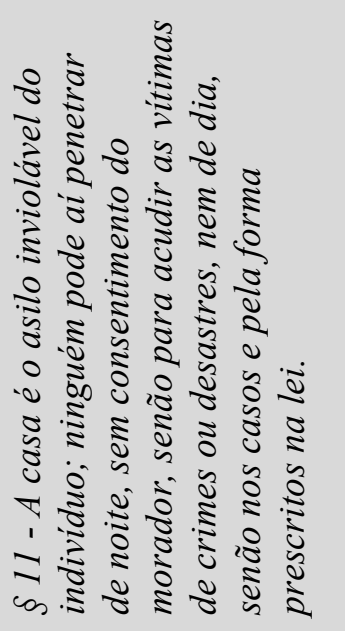 & 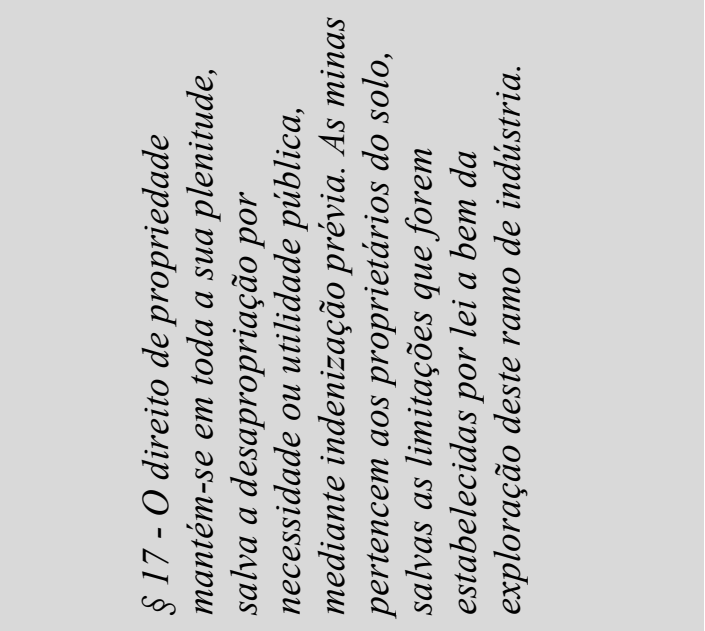 \\
\hline
\end{tabular}




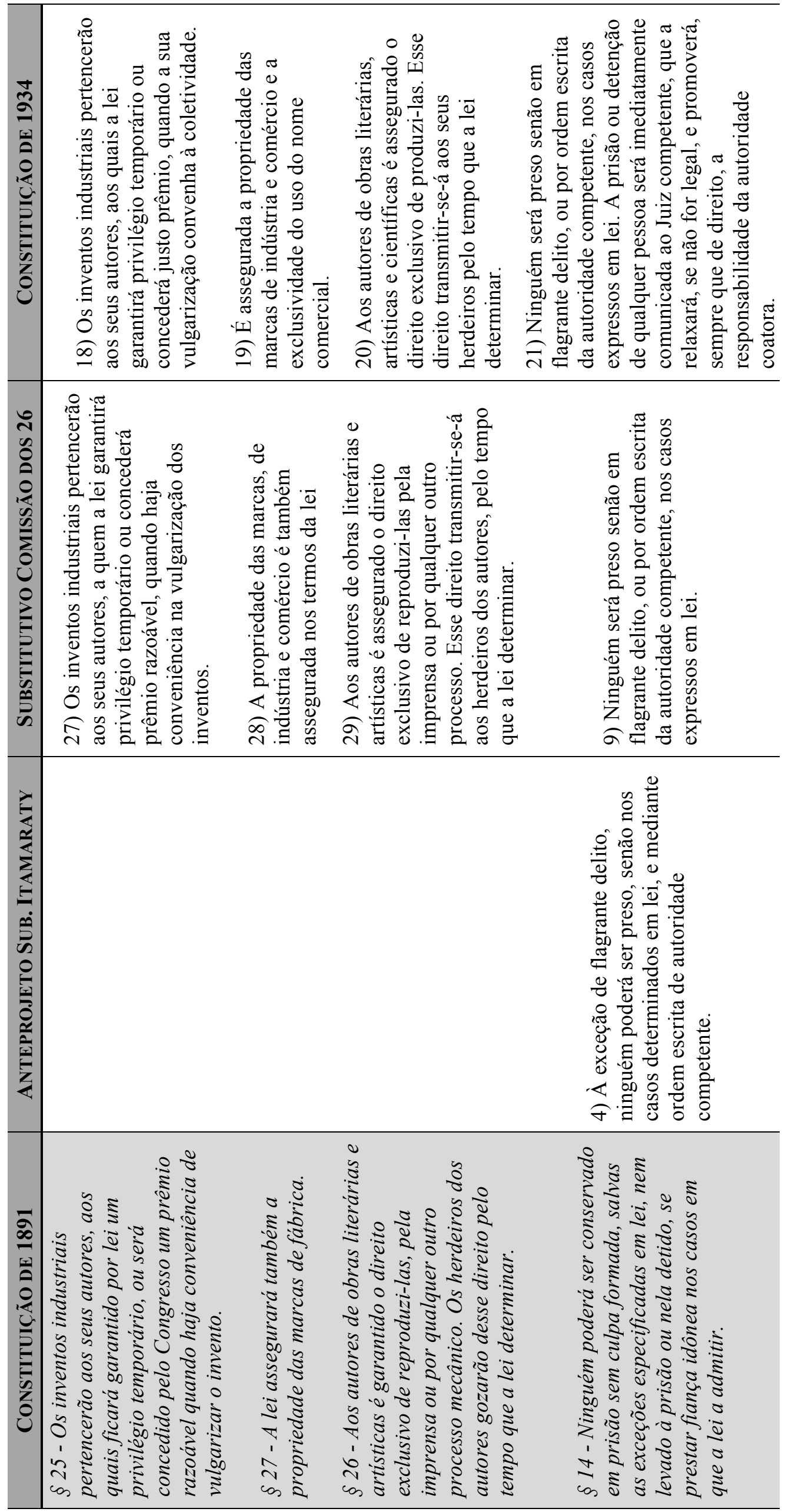




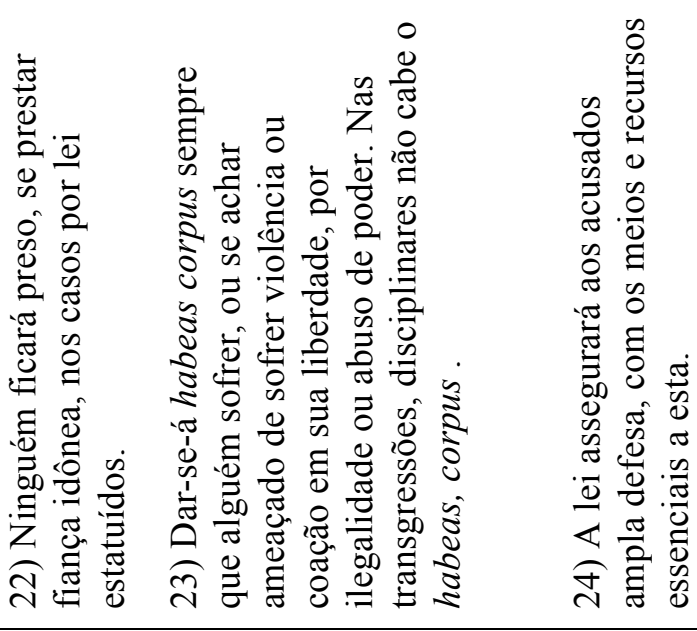

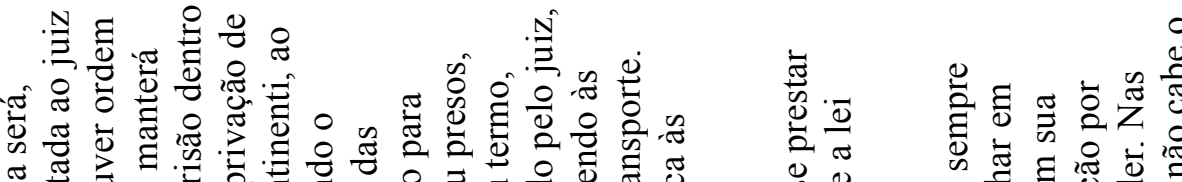

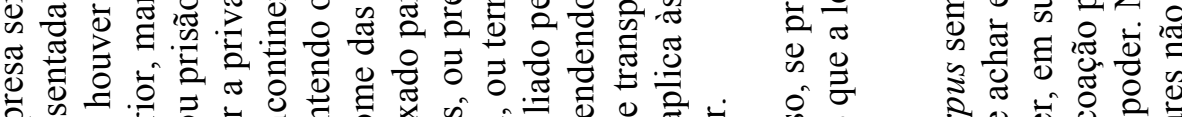

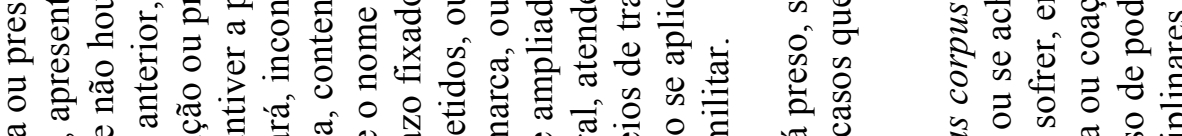

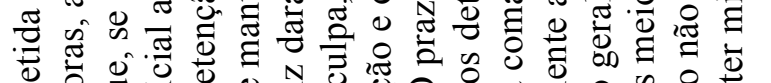

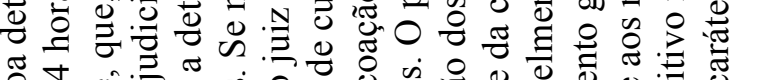

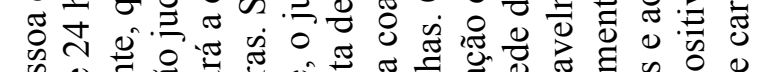

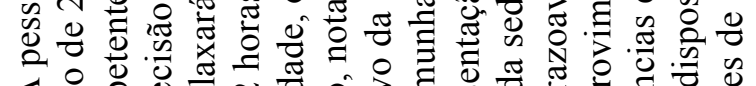

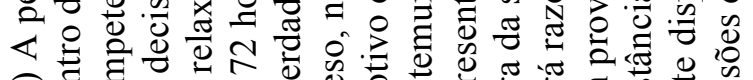
응

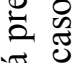

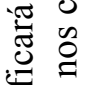

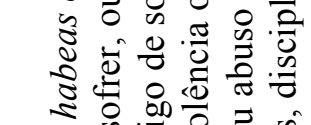

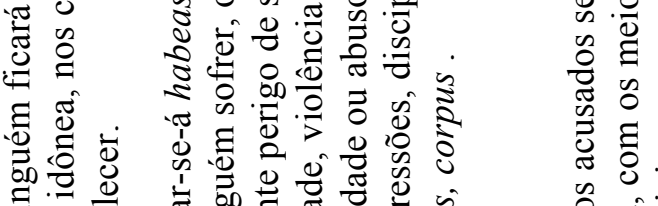

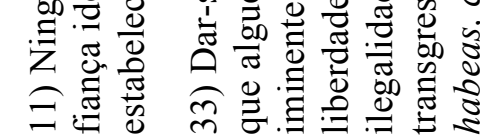

$\frac{\pi}{\frac{\pi}{2}} \frac{\pi}{0}$ 苛第 范 品 0 की

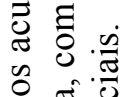

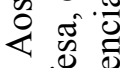
정

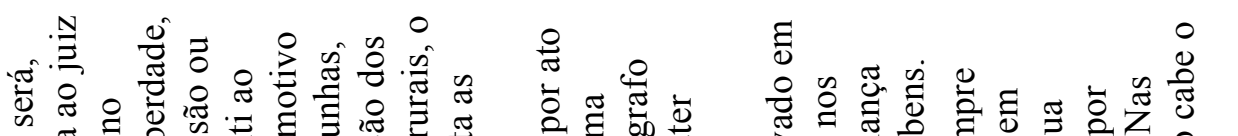

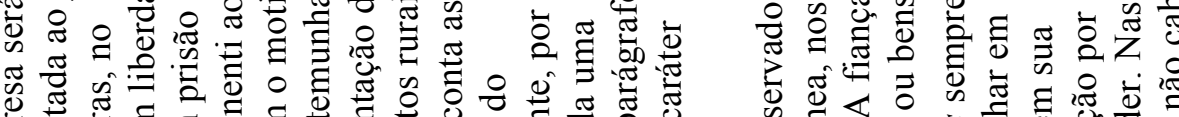

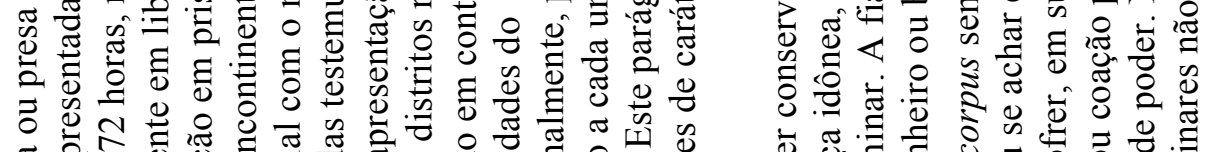
현 : \%

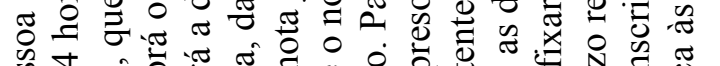

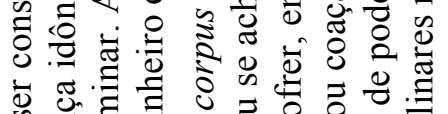

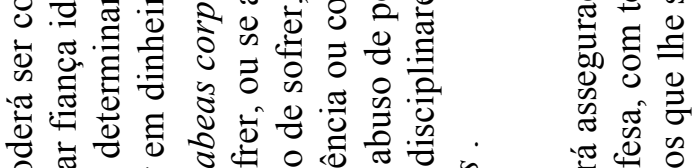

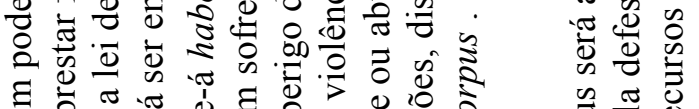

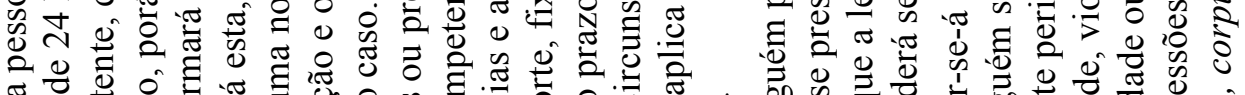
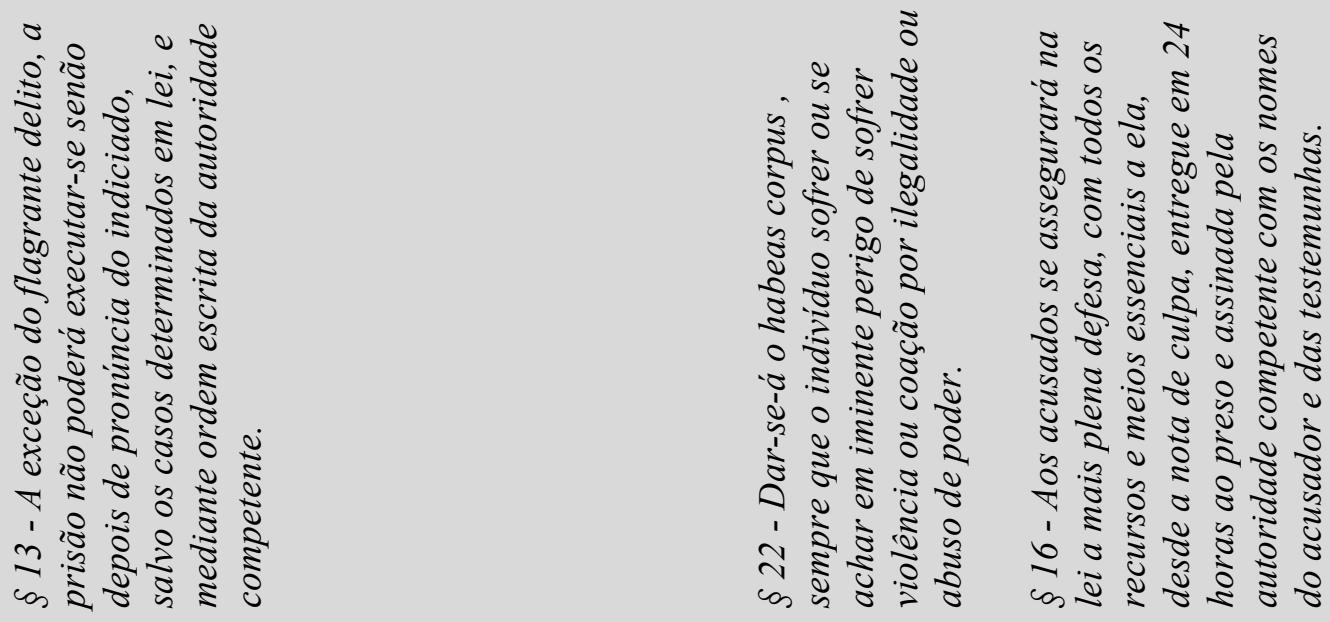


\begin{tabular}{|c|c|c|c|c|c|c|c|}
\hline & 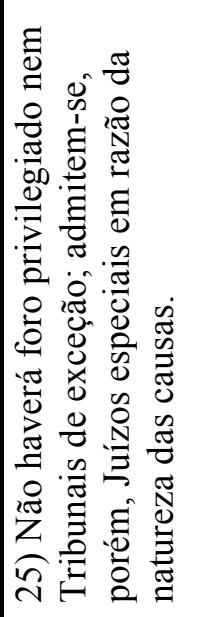 & 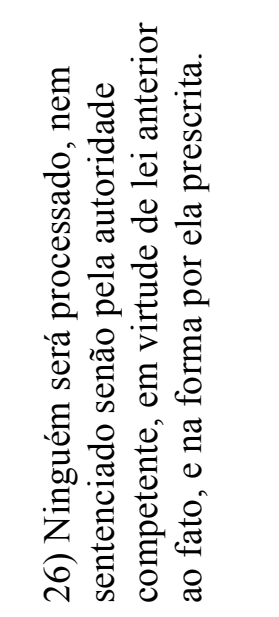 & 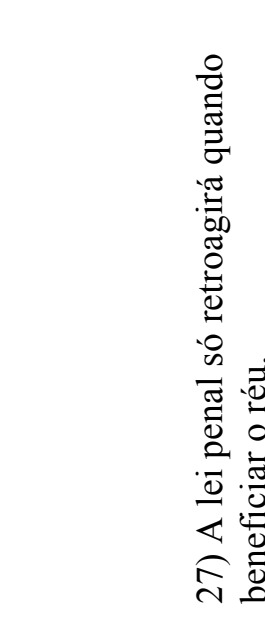 & 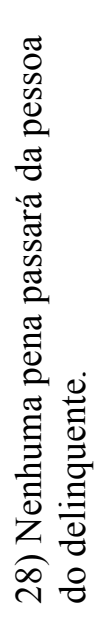 & & 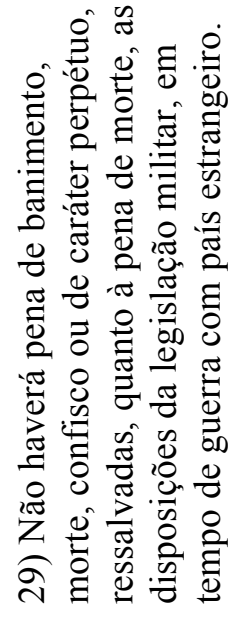 & 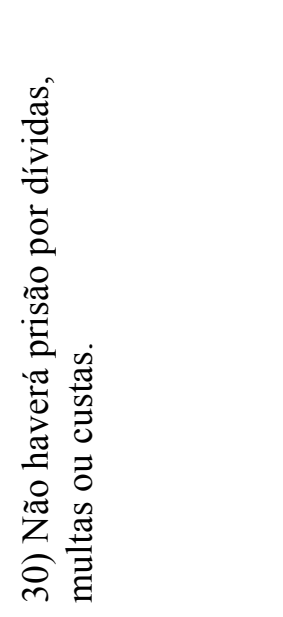 \\
\hline $\begin{array}{l}0 \\
1 \\
0 \\
0 \\
0 \\
0 \\
1 \\
2 \\
0 \\
0 \\
0 \\
0 \\
0 \\
0 \\
\vdots \\
5 \\
0 \\
0 \\
0 \\
0 \\
0\end{array}$ & 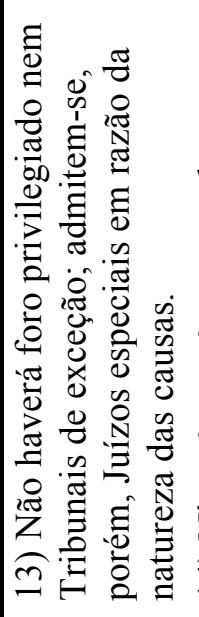 & 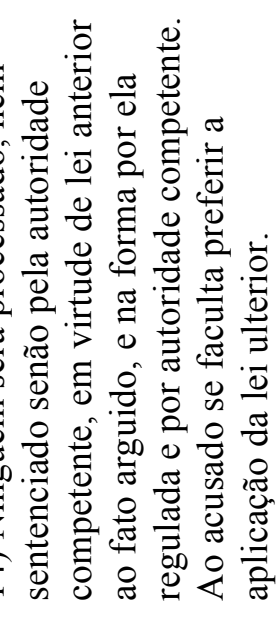 & & 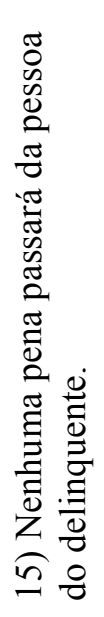 & & 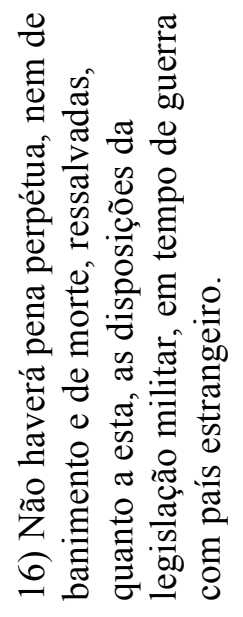 & \\
\hline 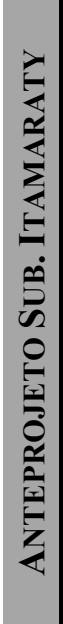 & 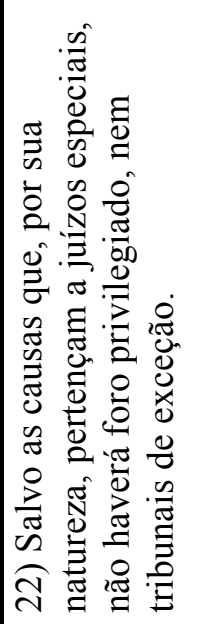 & 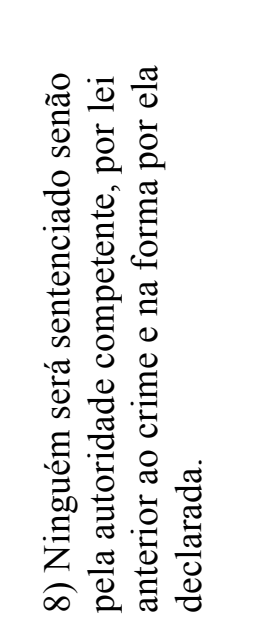 & 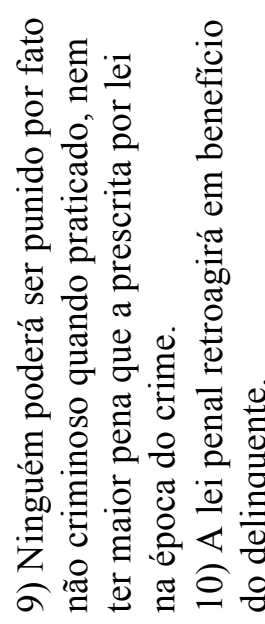 & 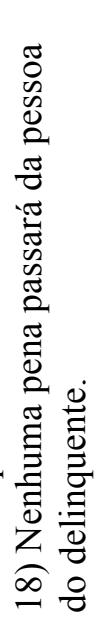 & & 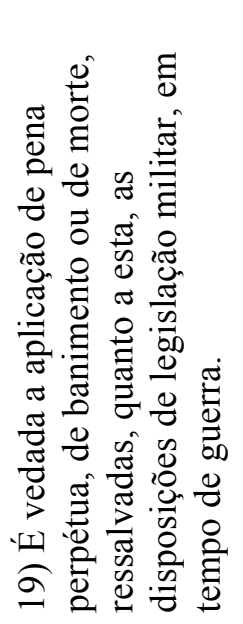 & 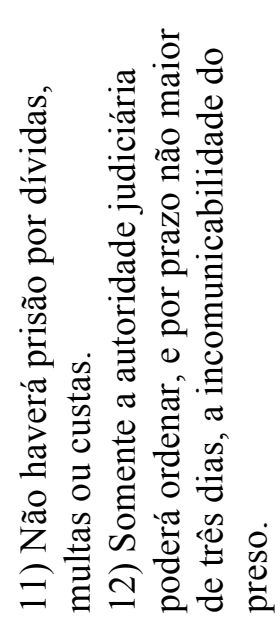 \\
\hline 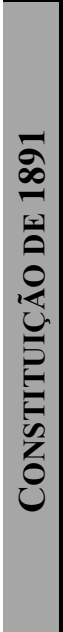 & 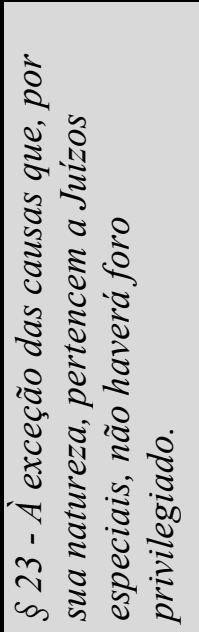 & 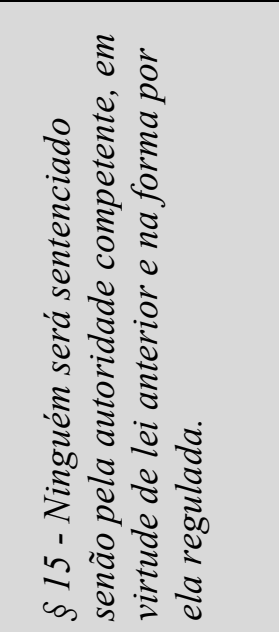 & & 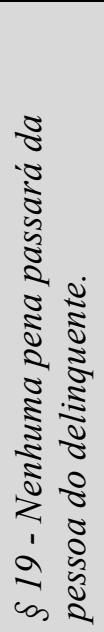 & 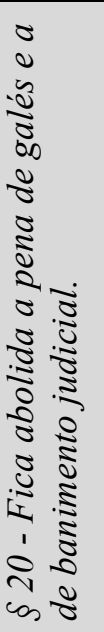 & 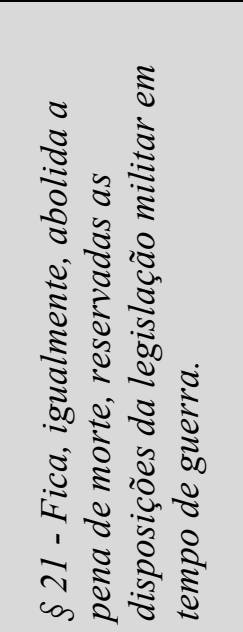 & \\
\hline
\end{tabular}




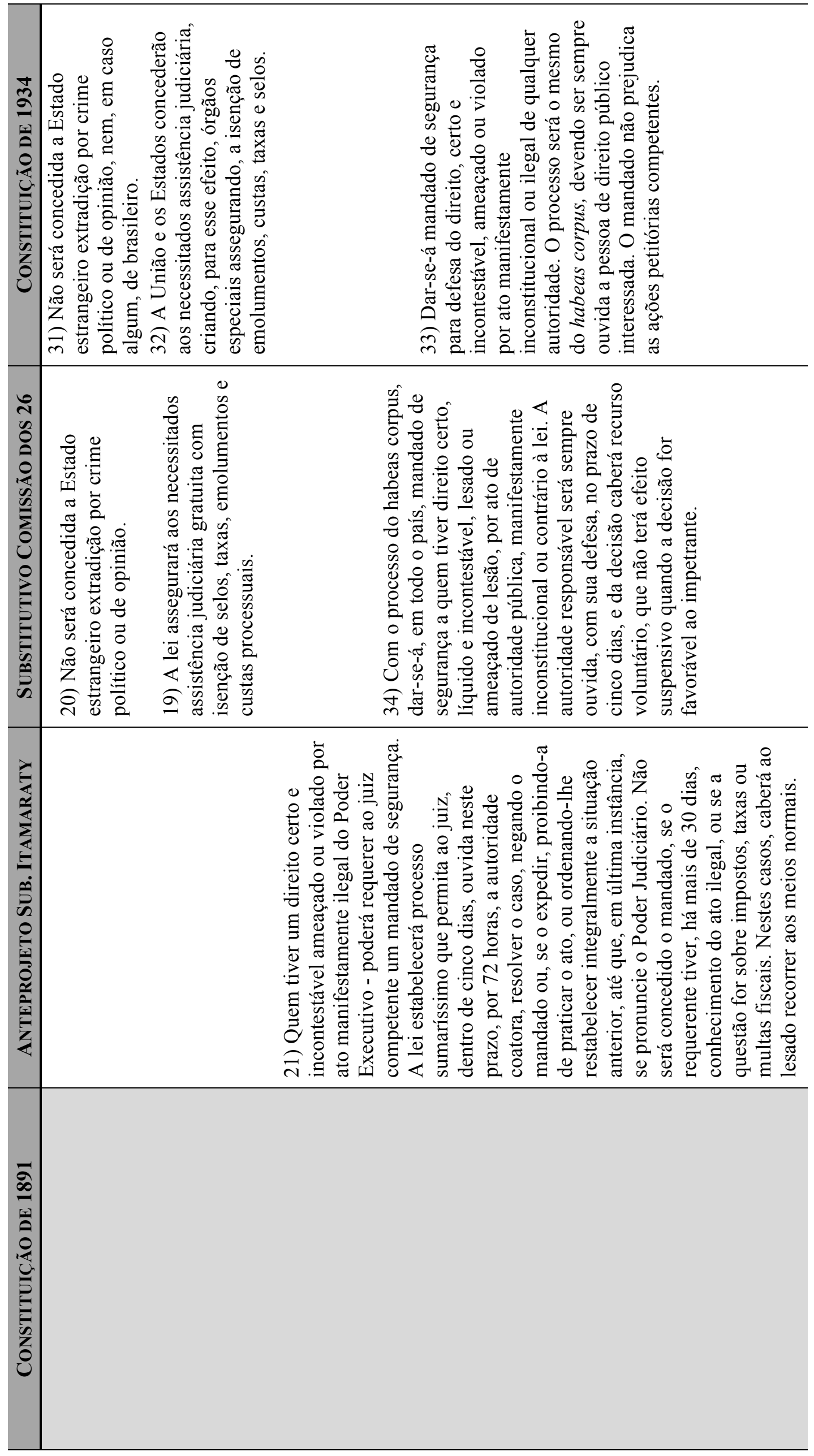




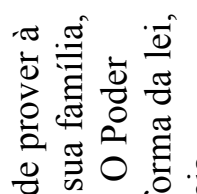

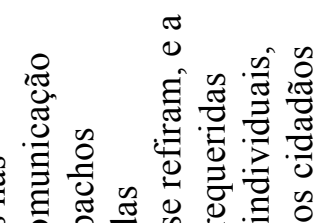

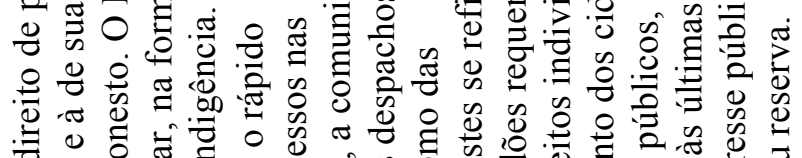

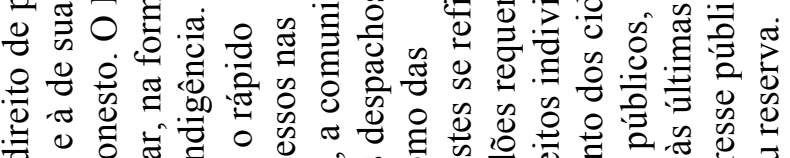

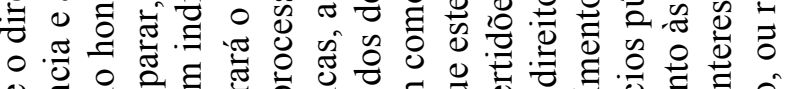

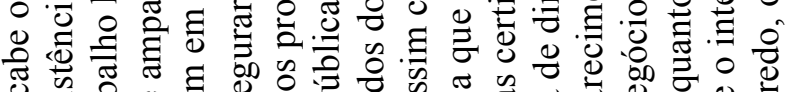

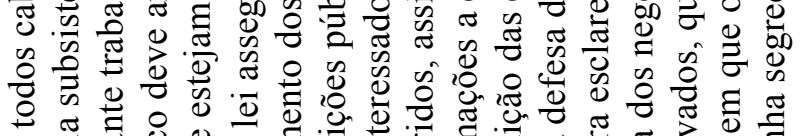

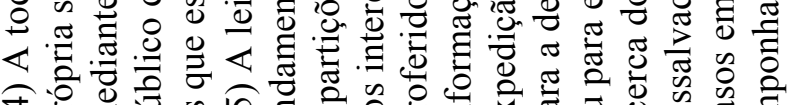

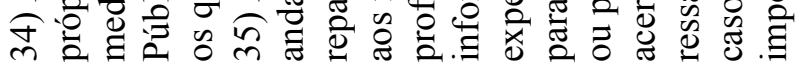




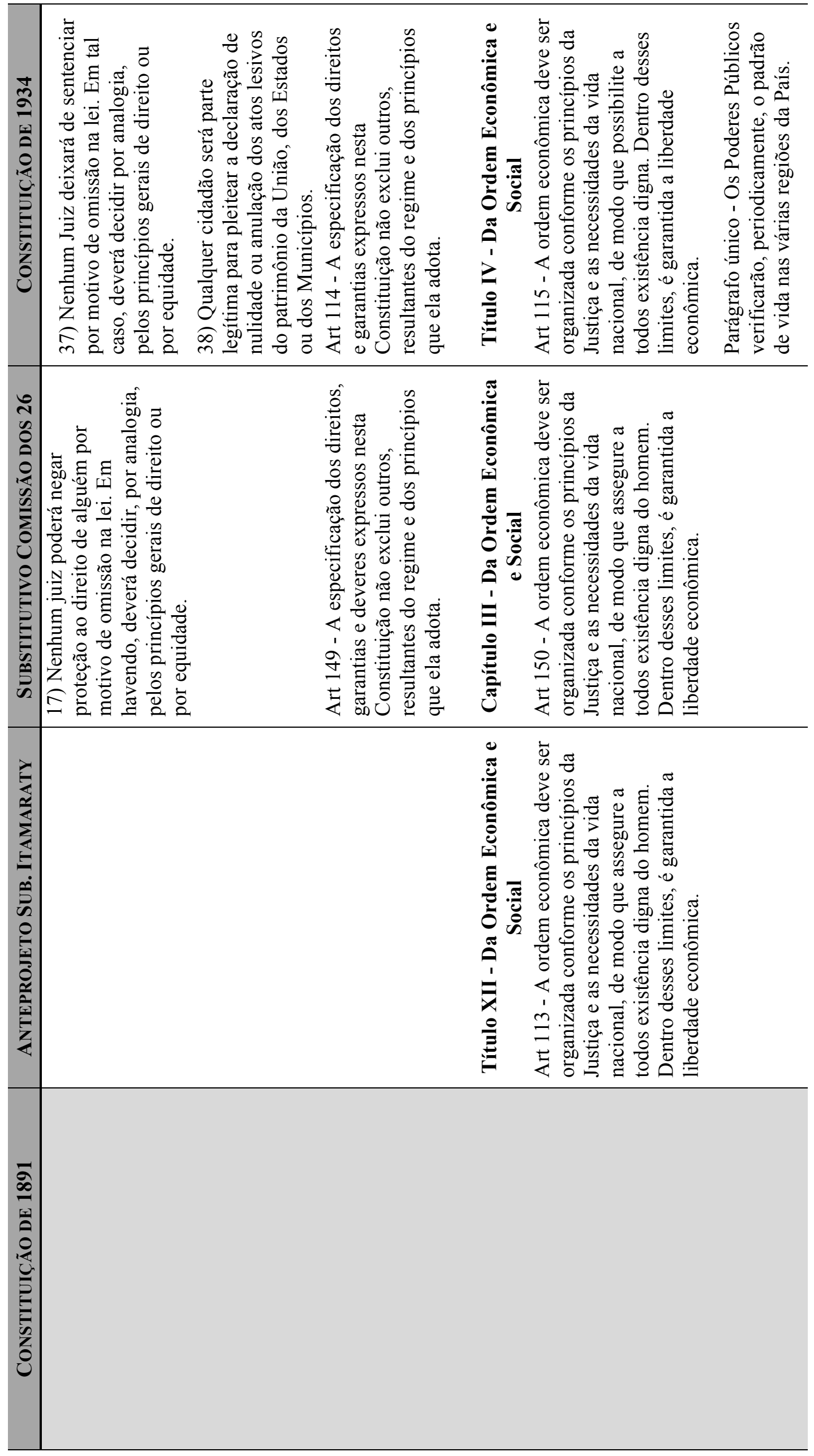




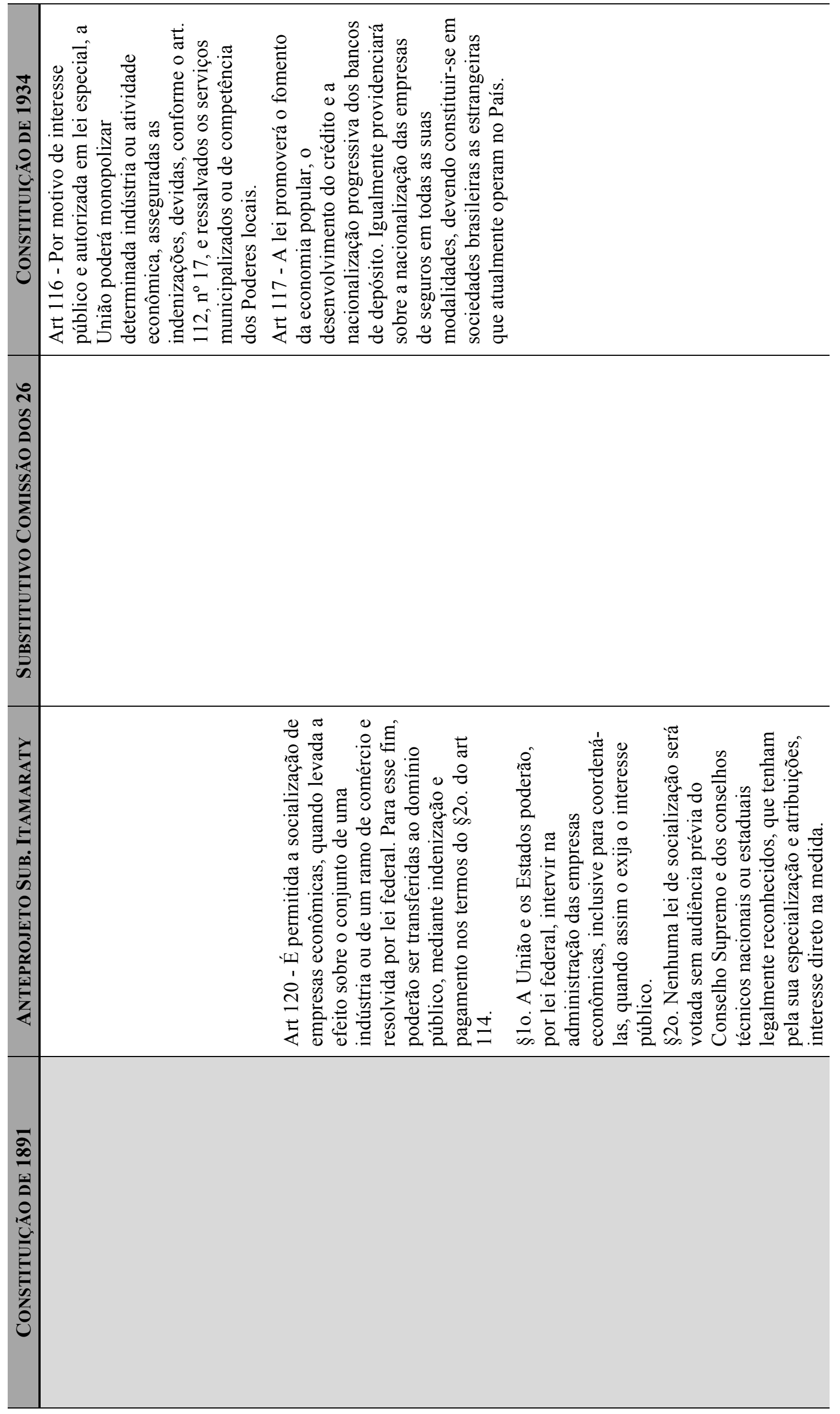




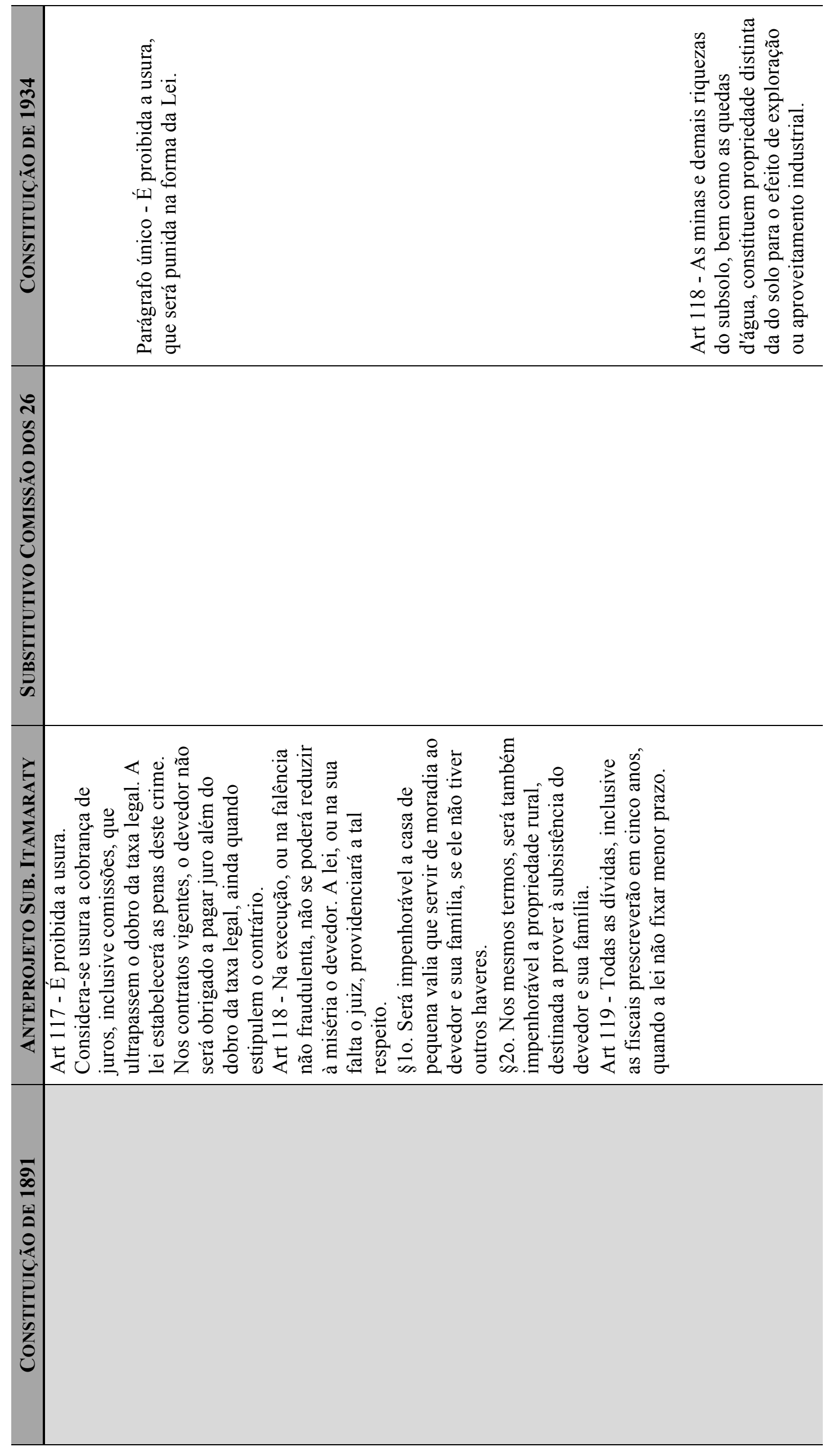




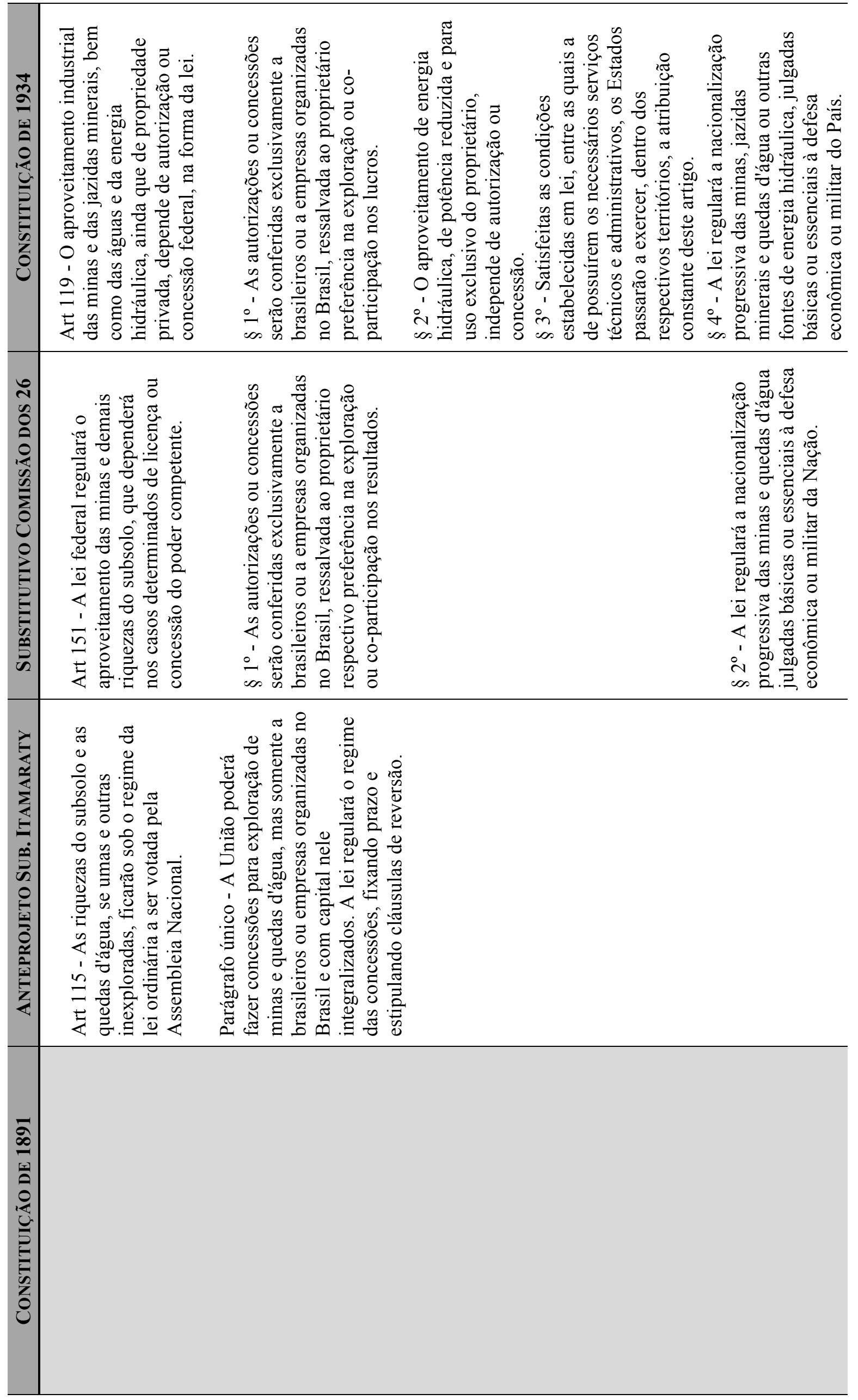




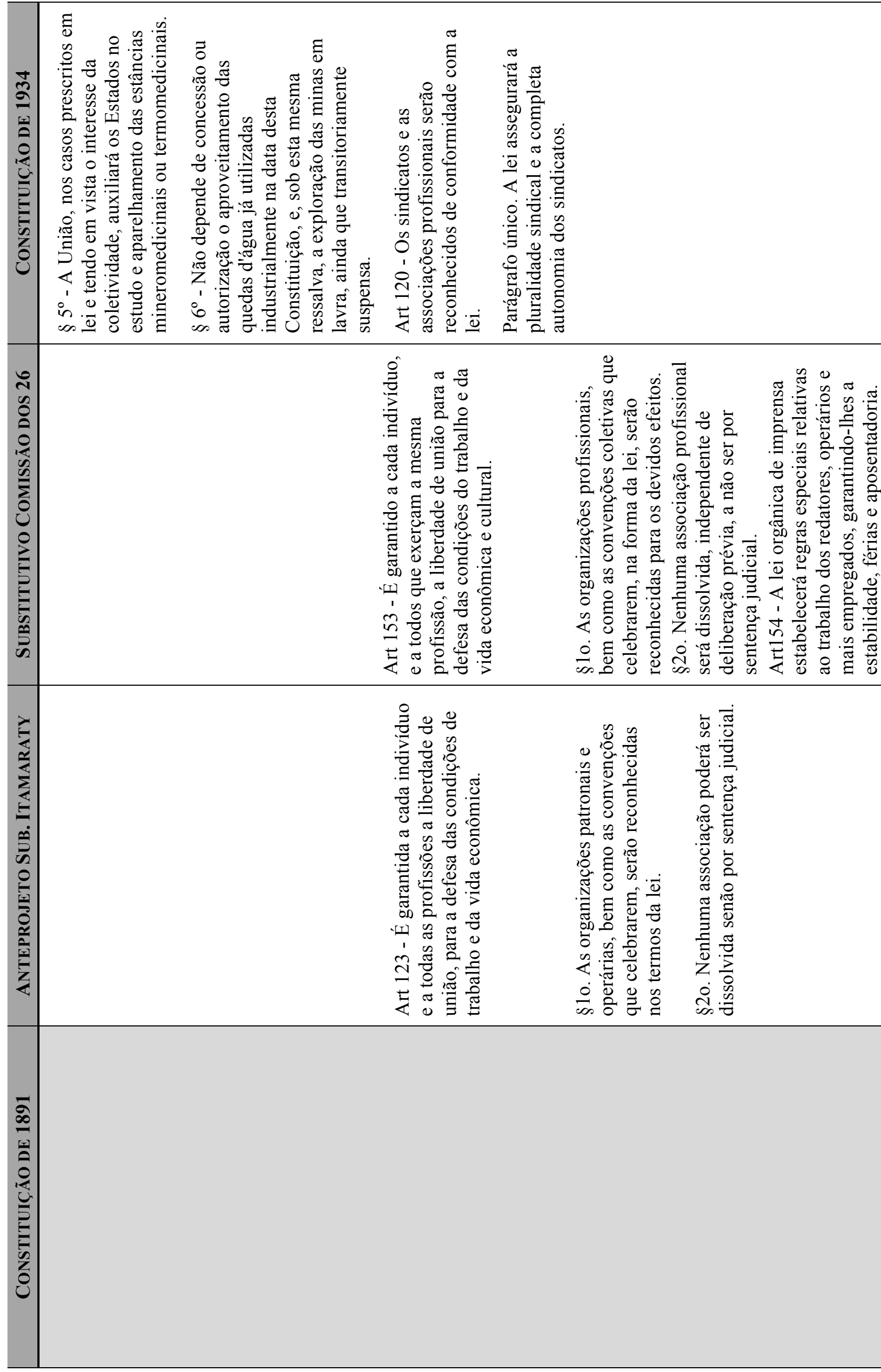




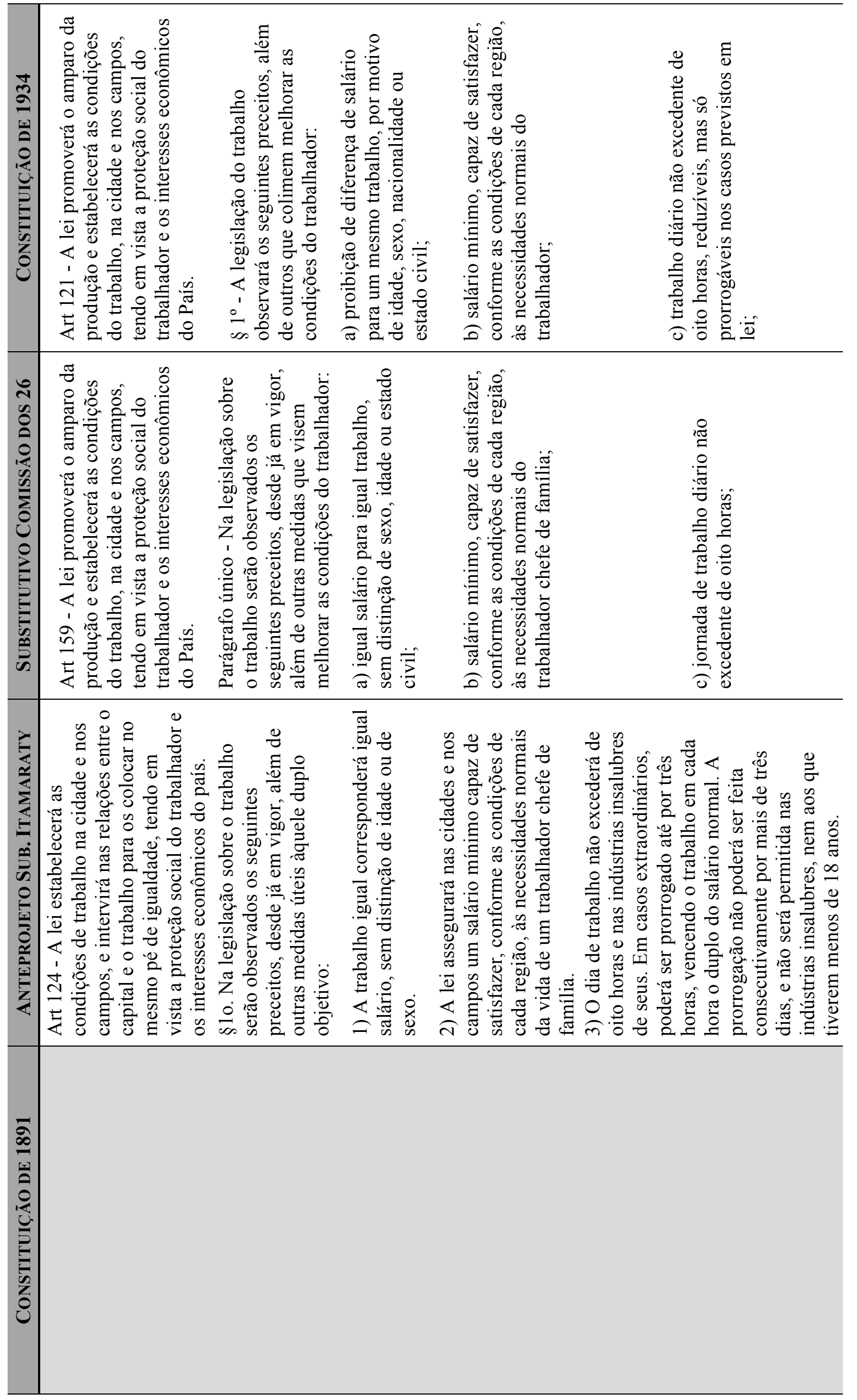




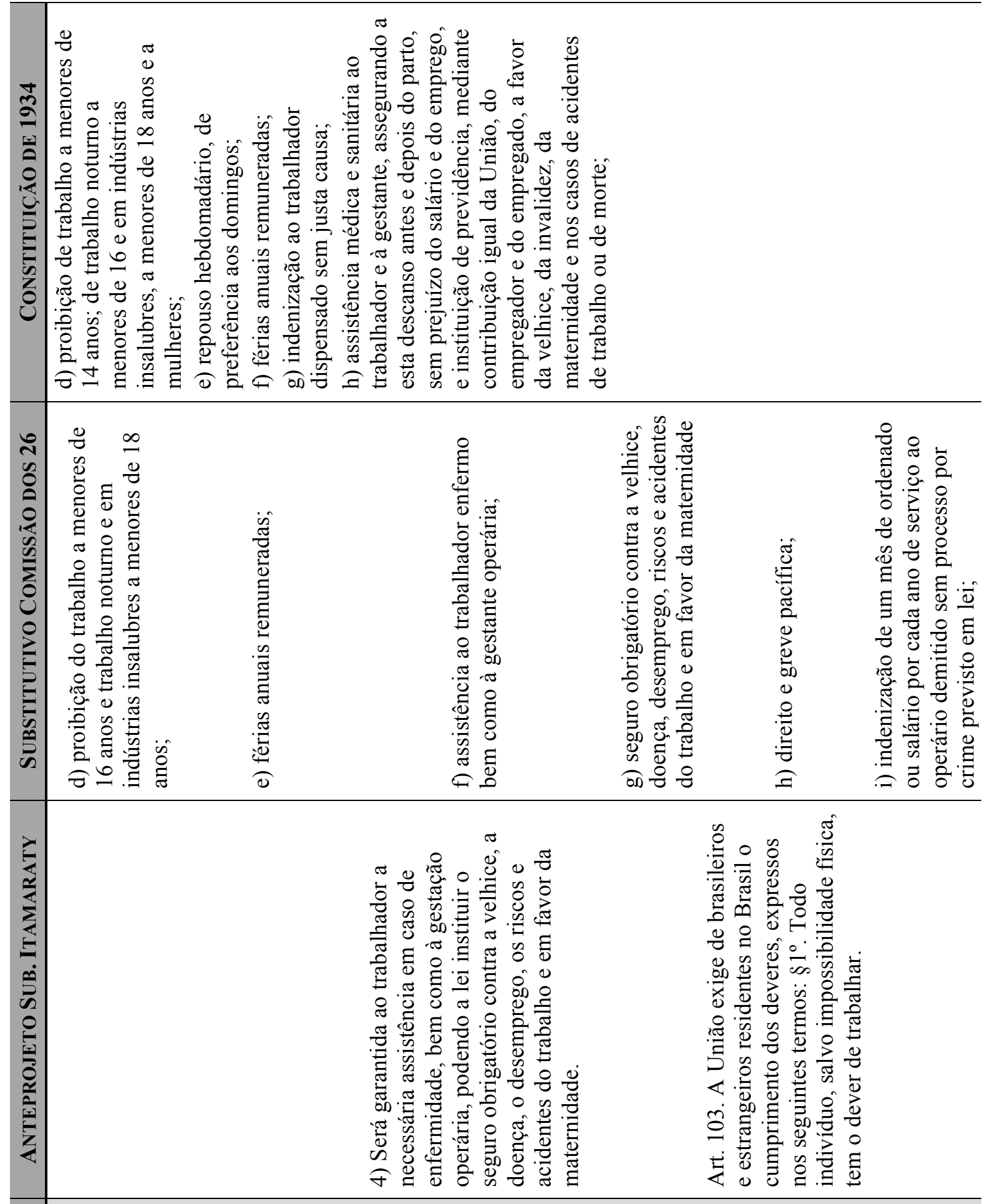




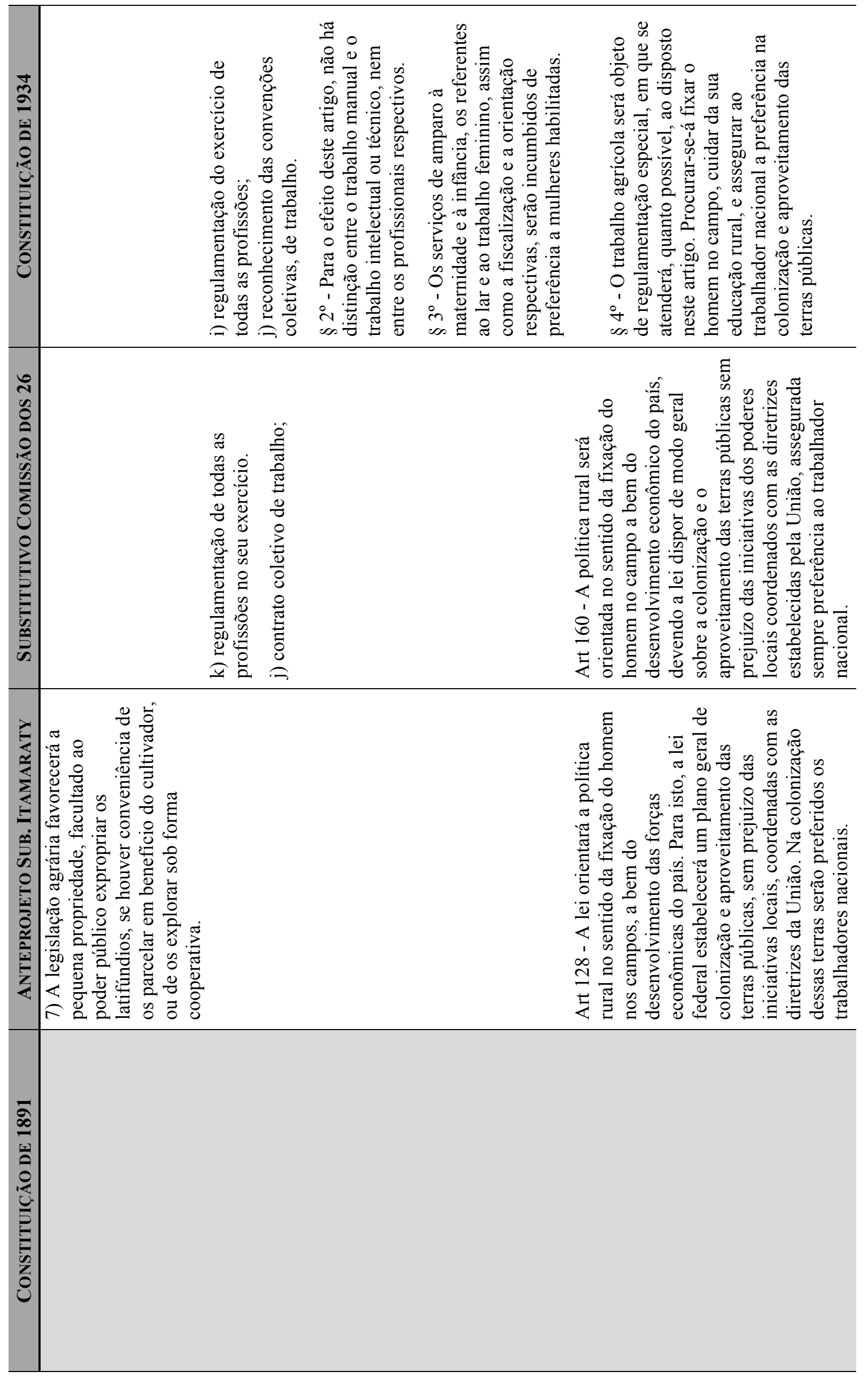




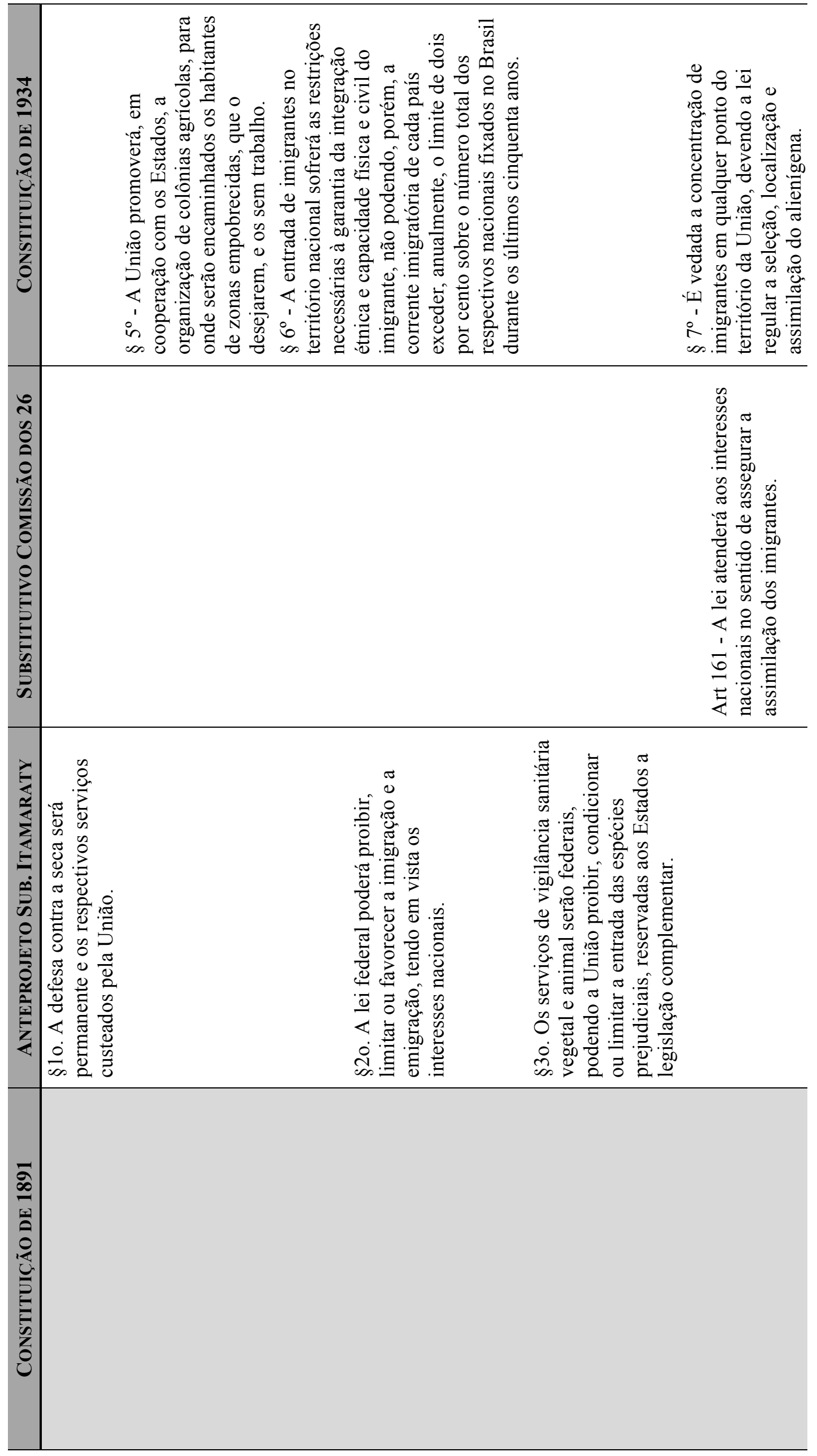




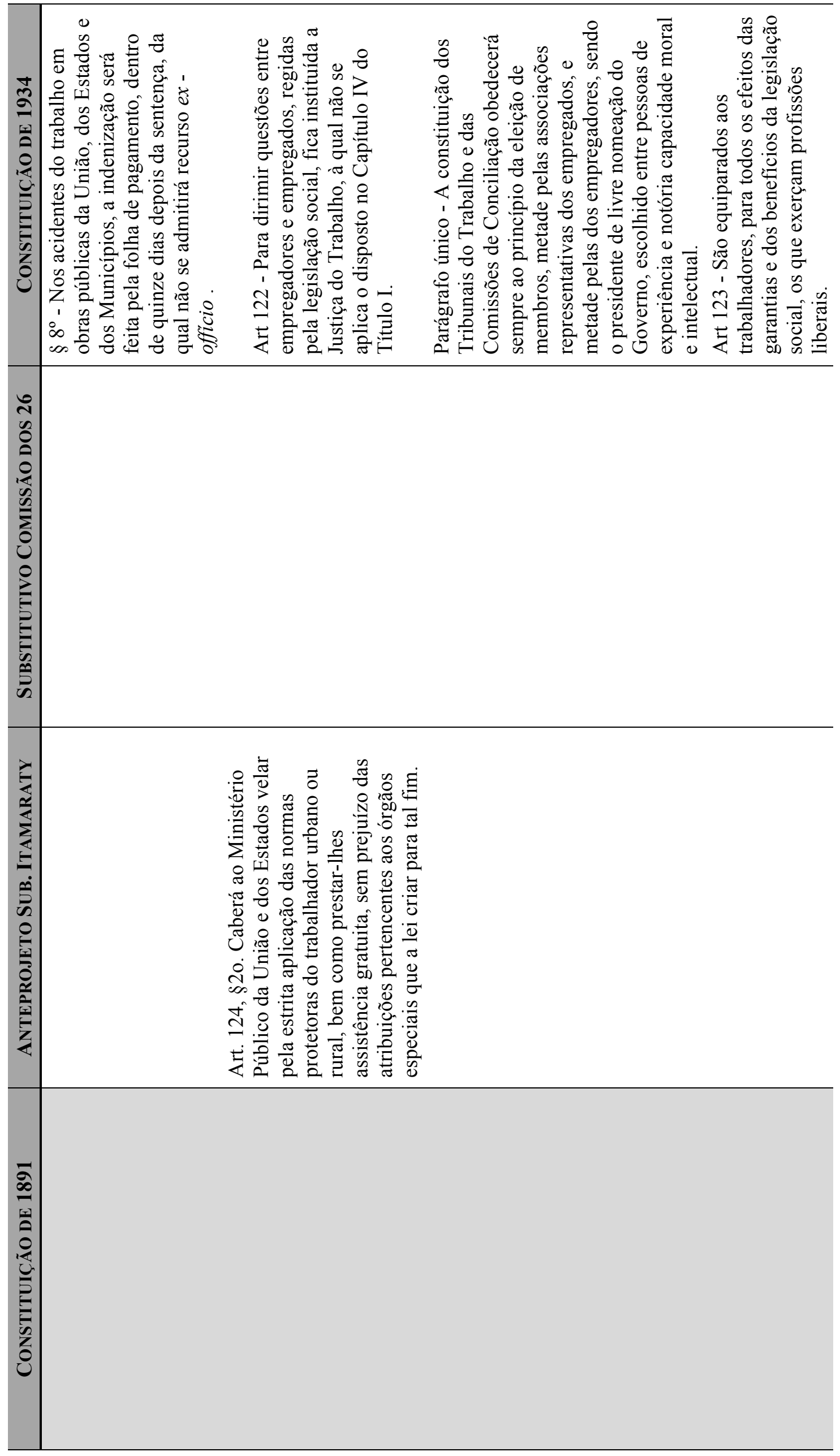




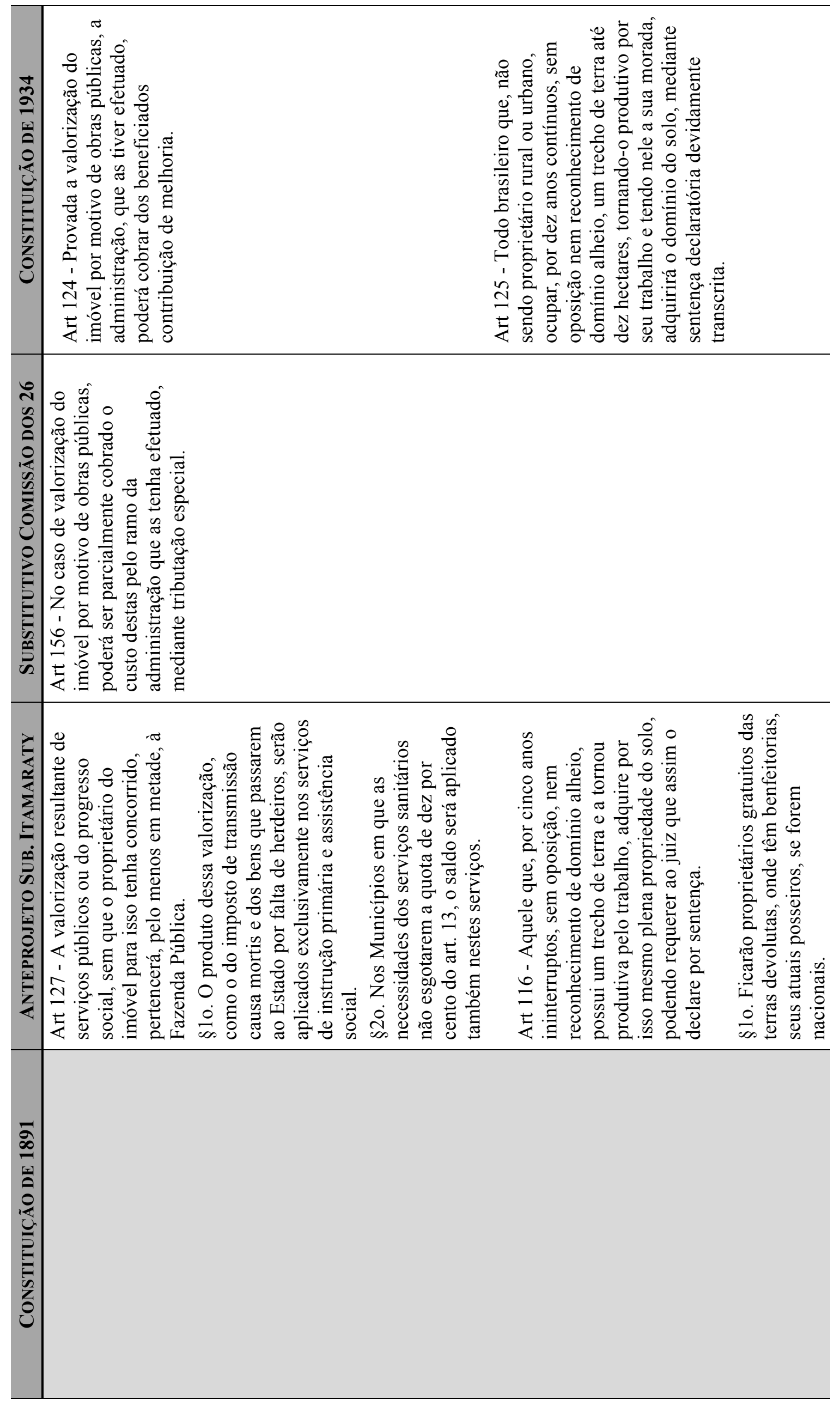




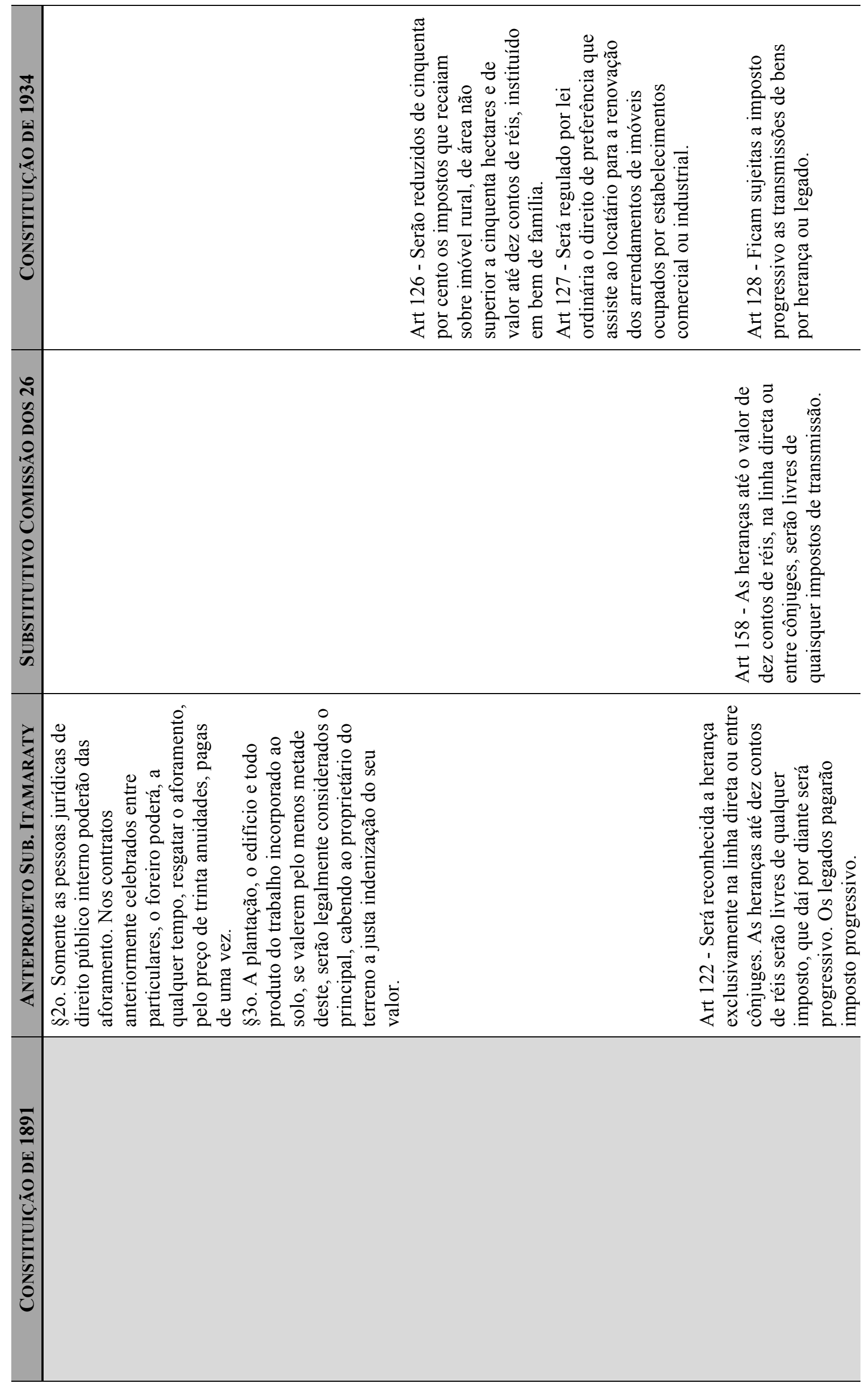




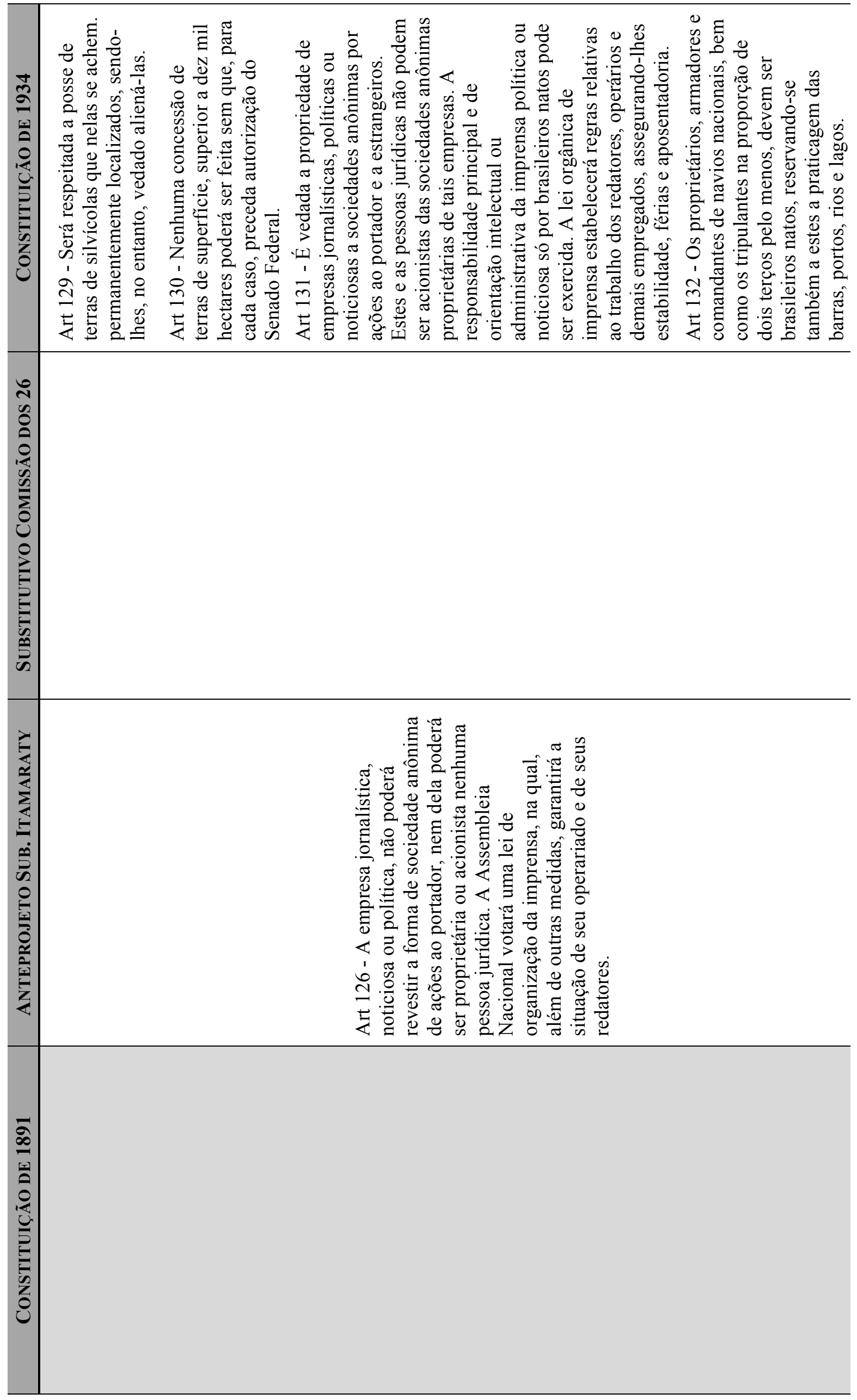




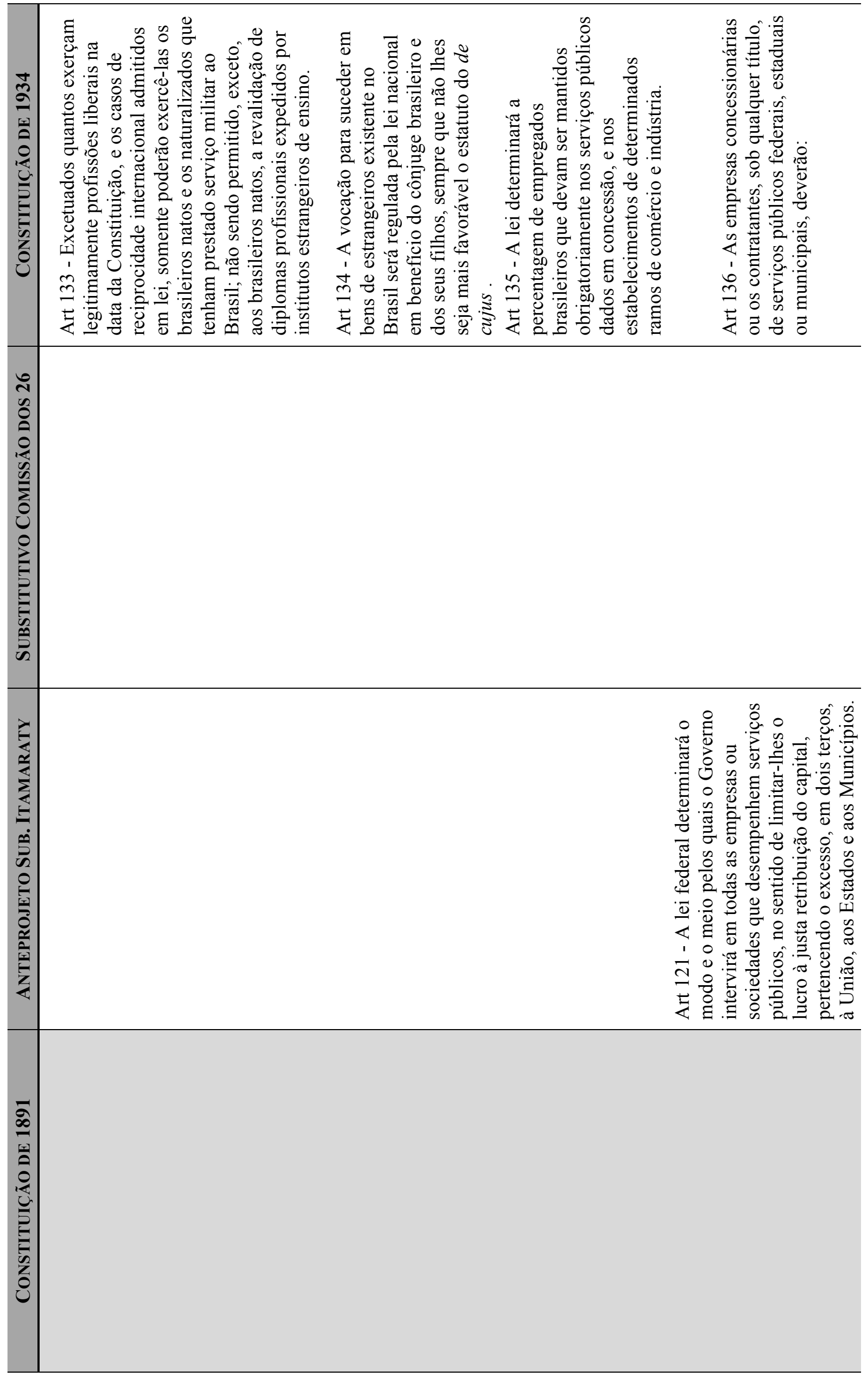




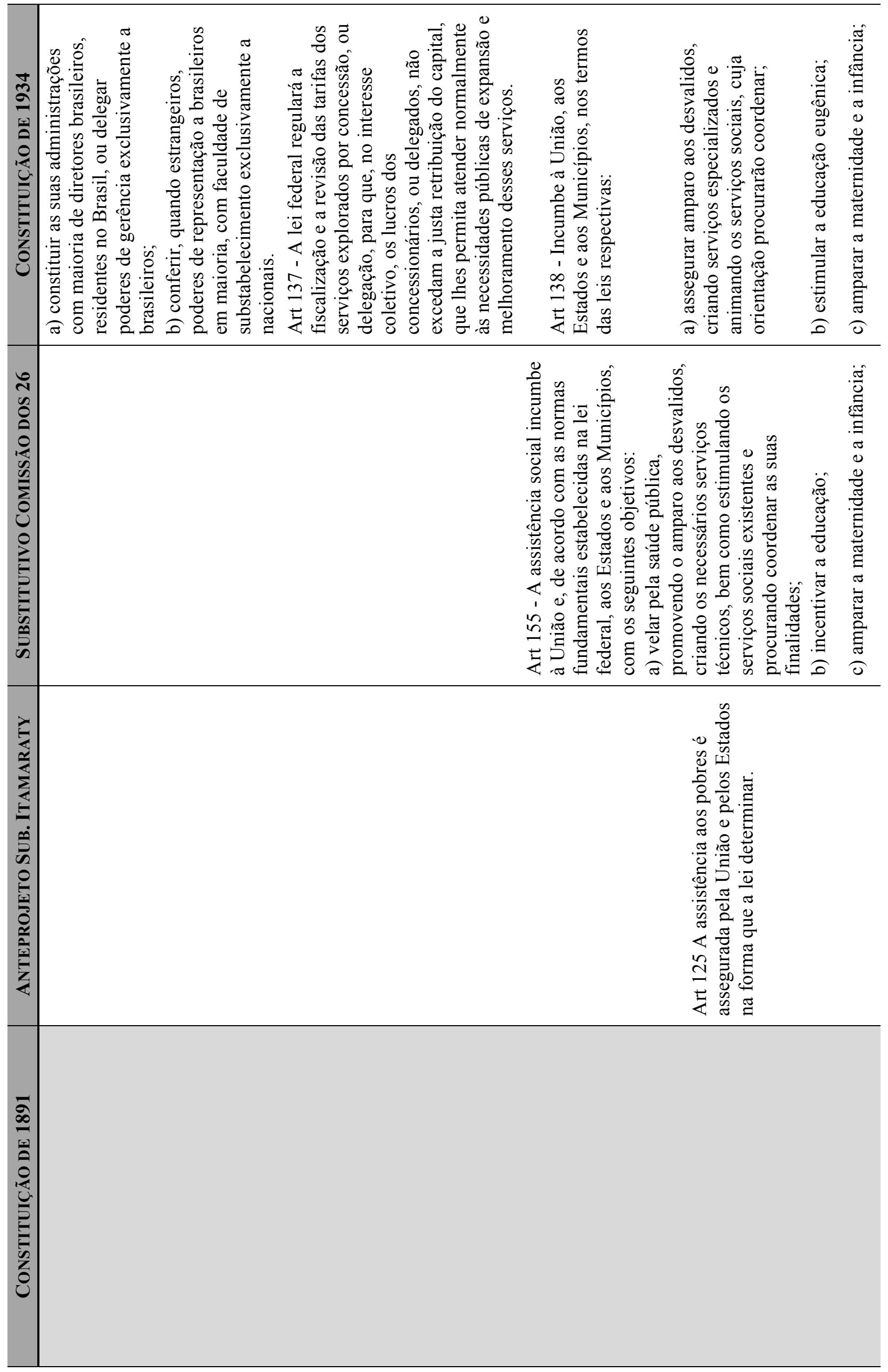




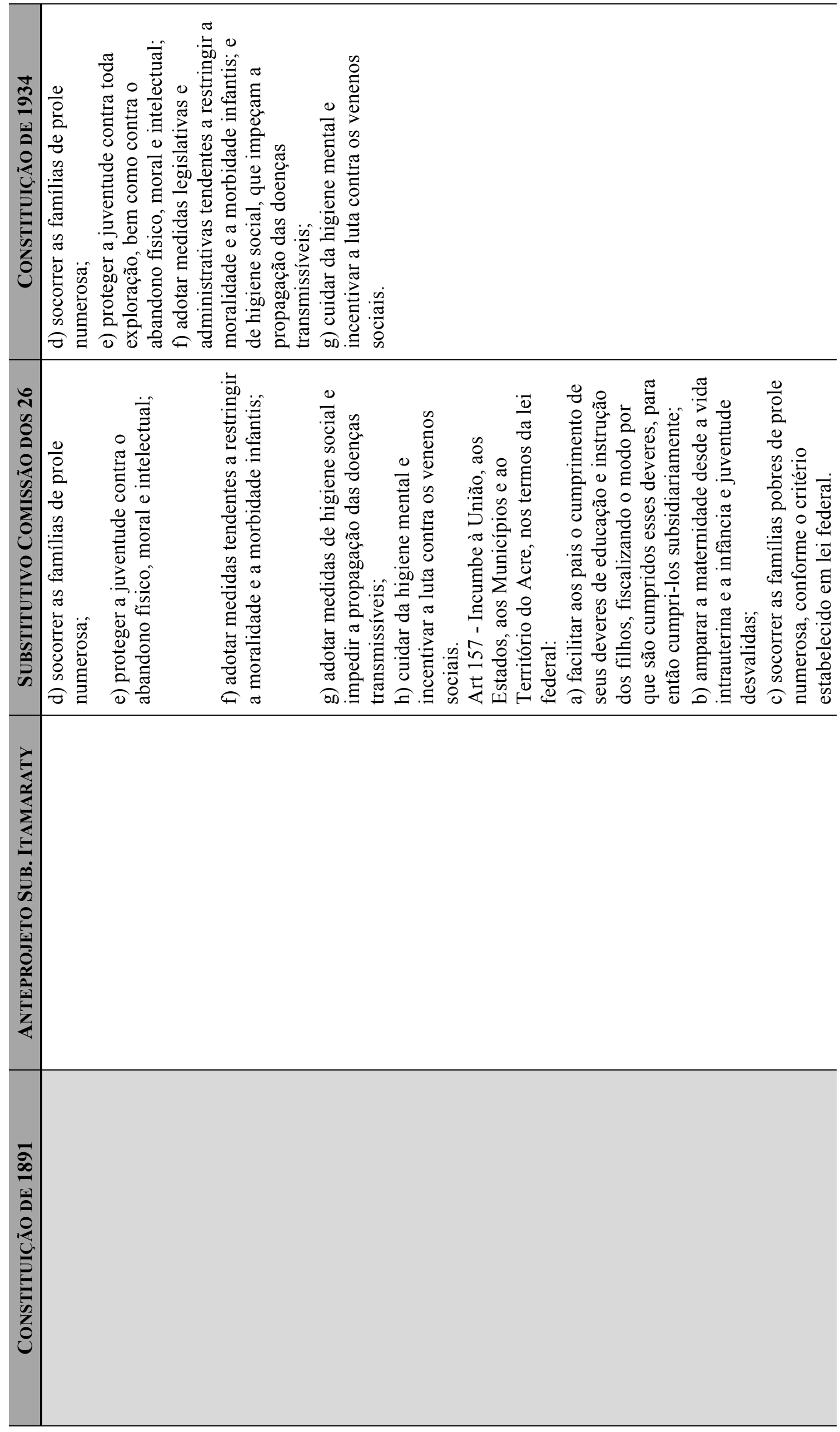




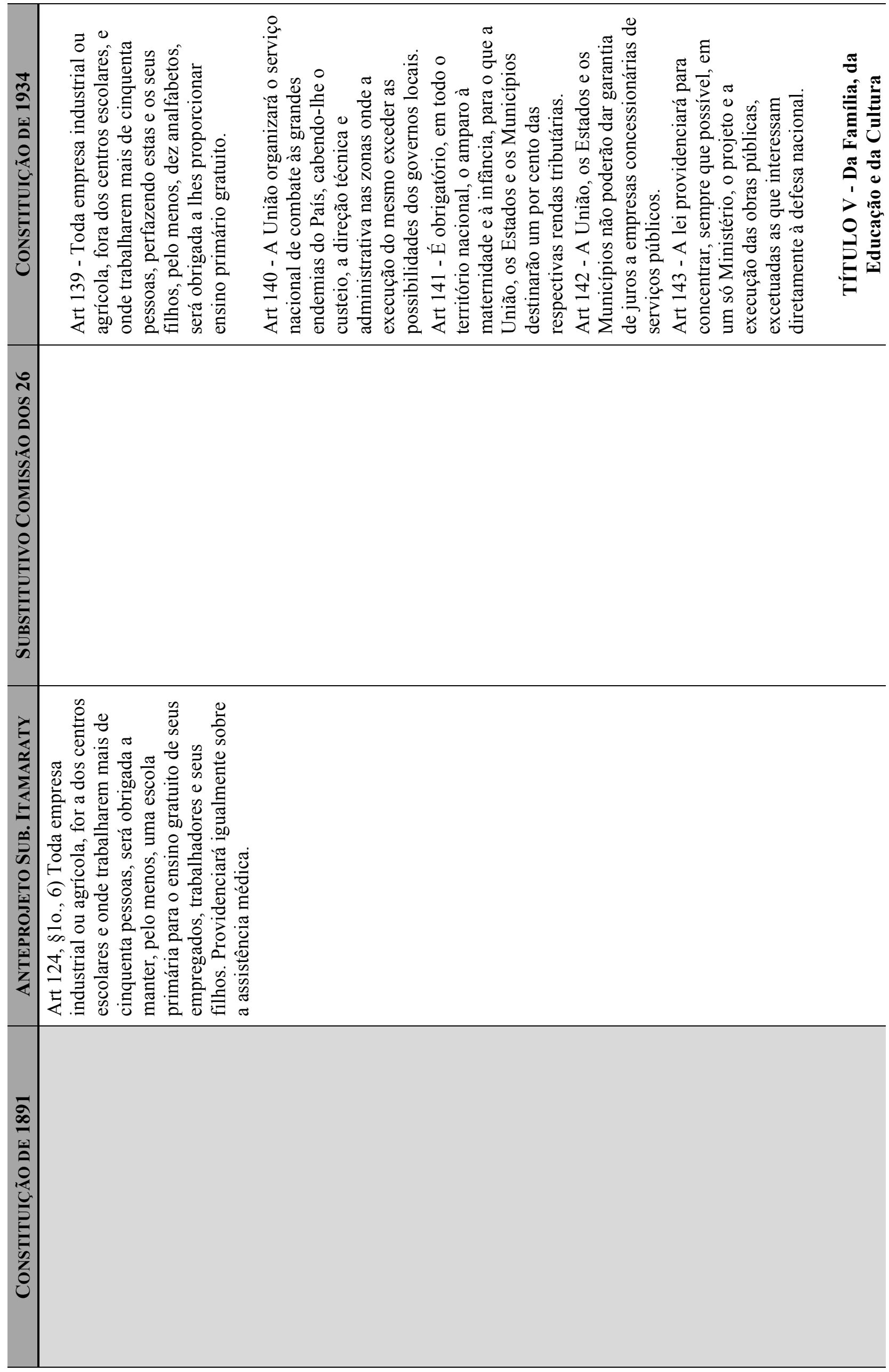




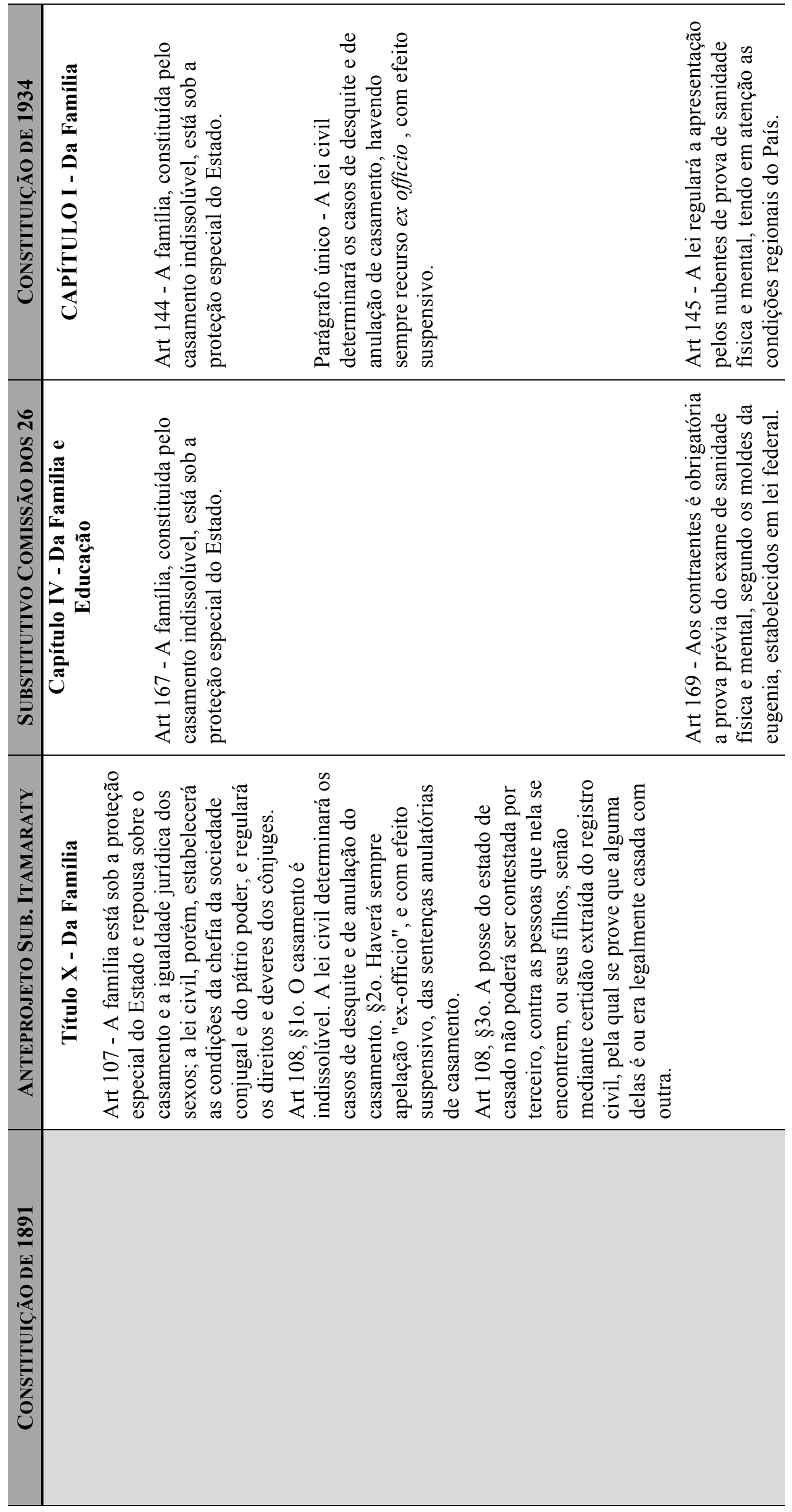




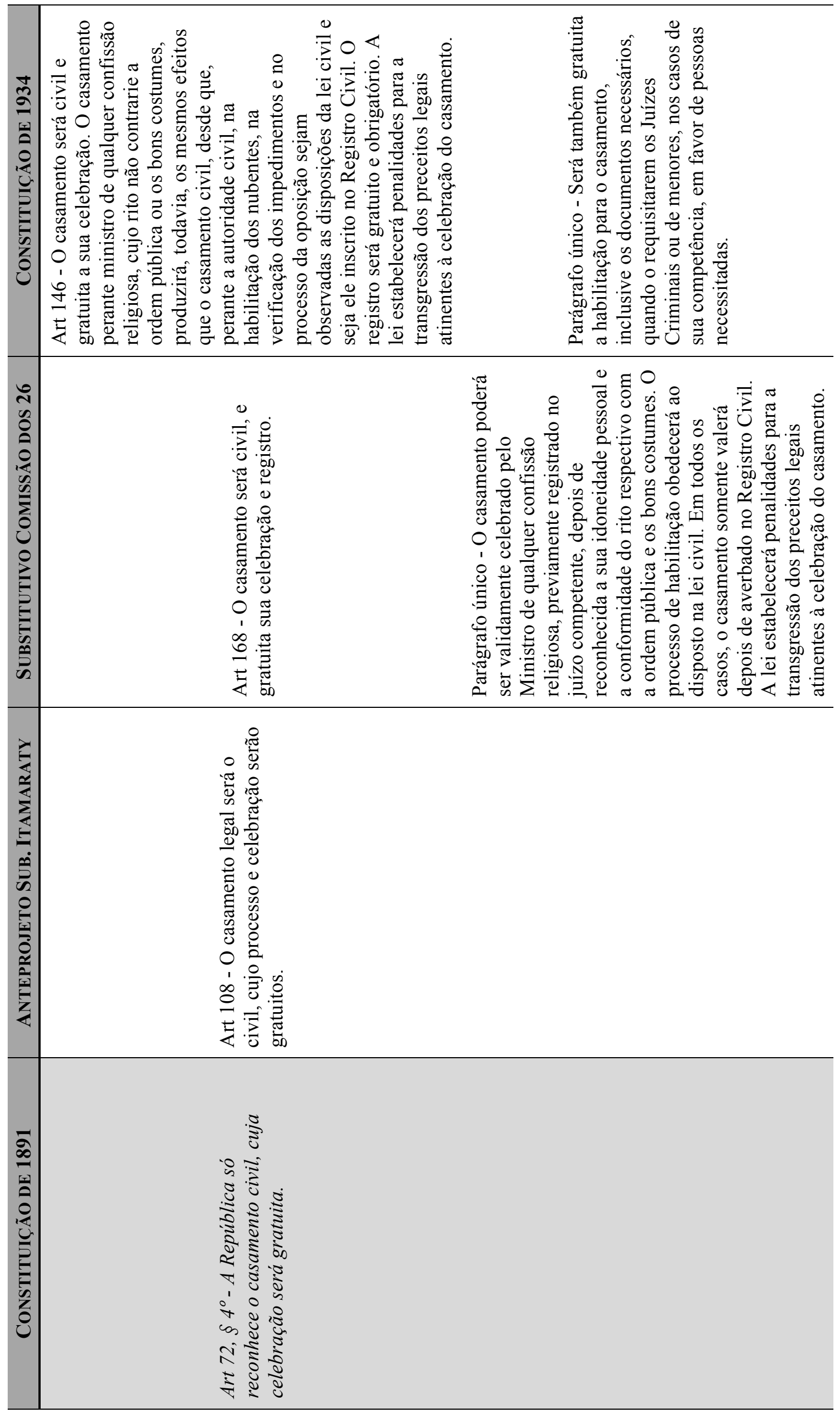




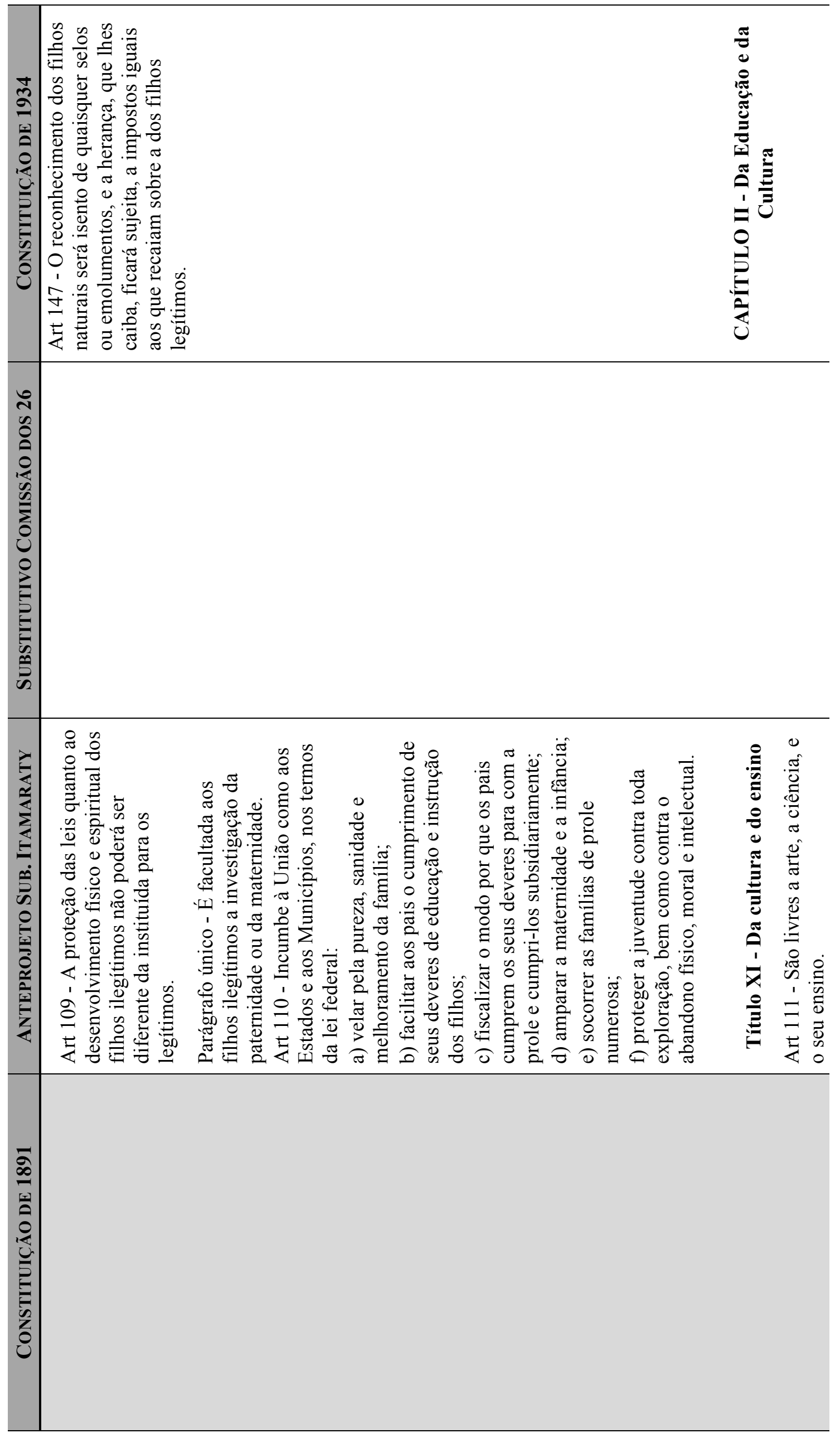




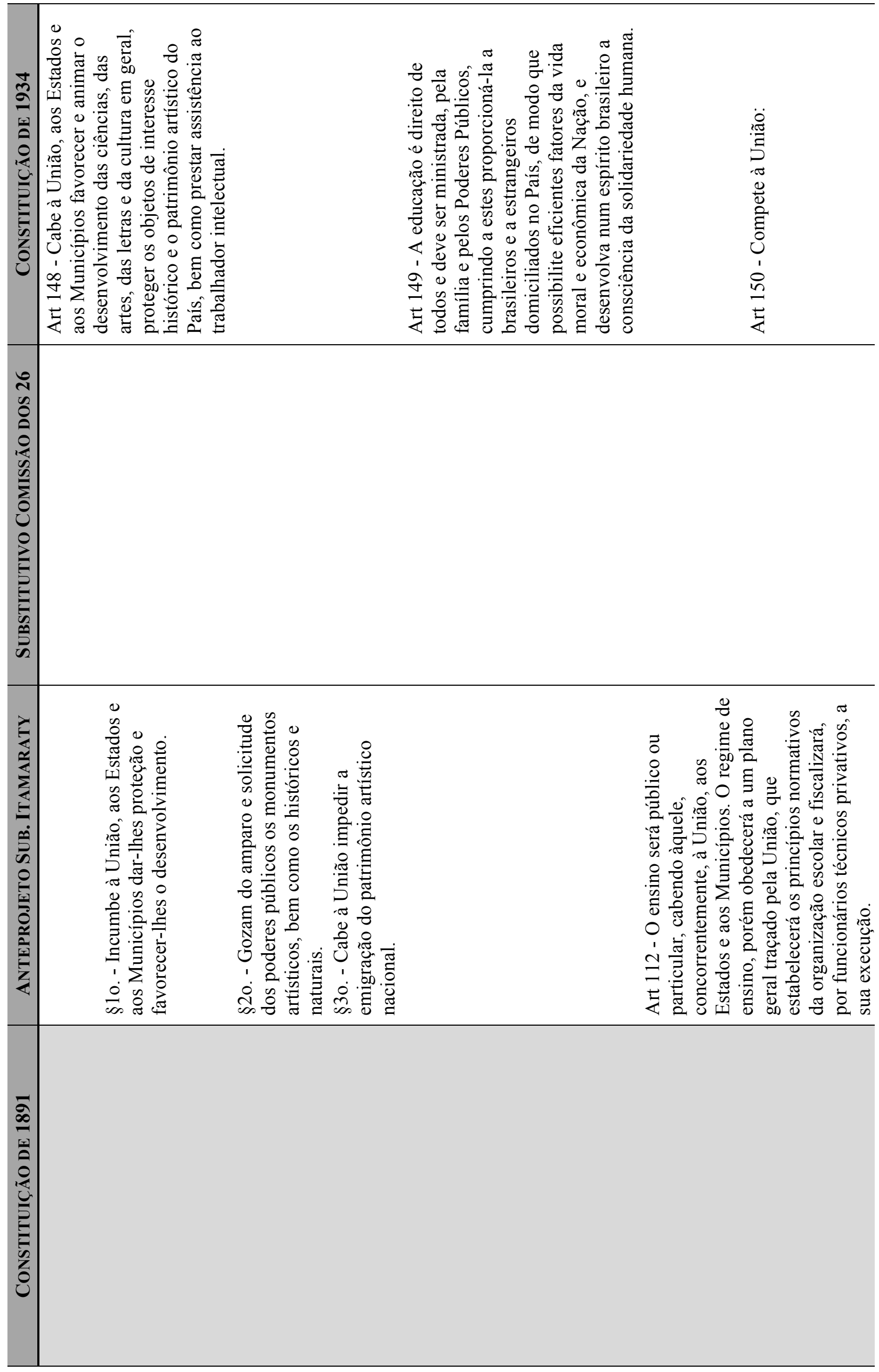

$\stackrel{\infty}{\infty}$ 


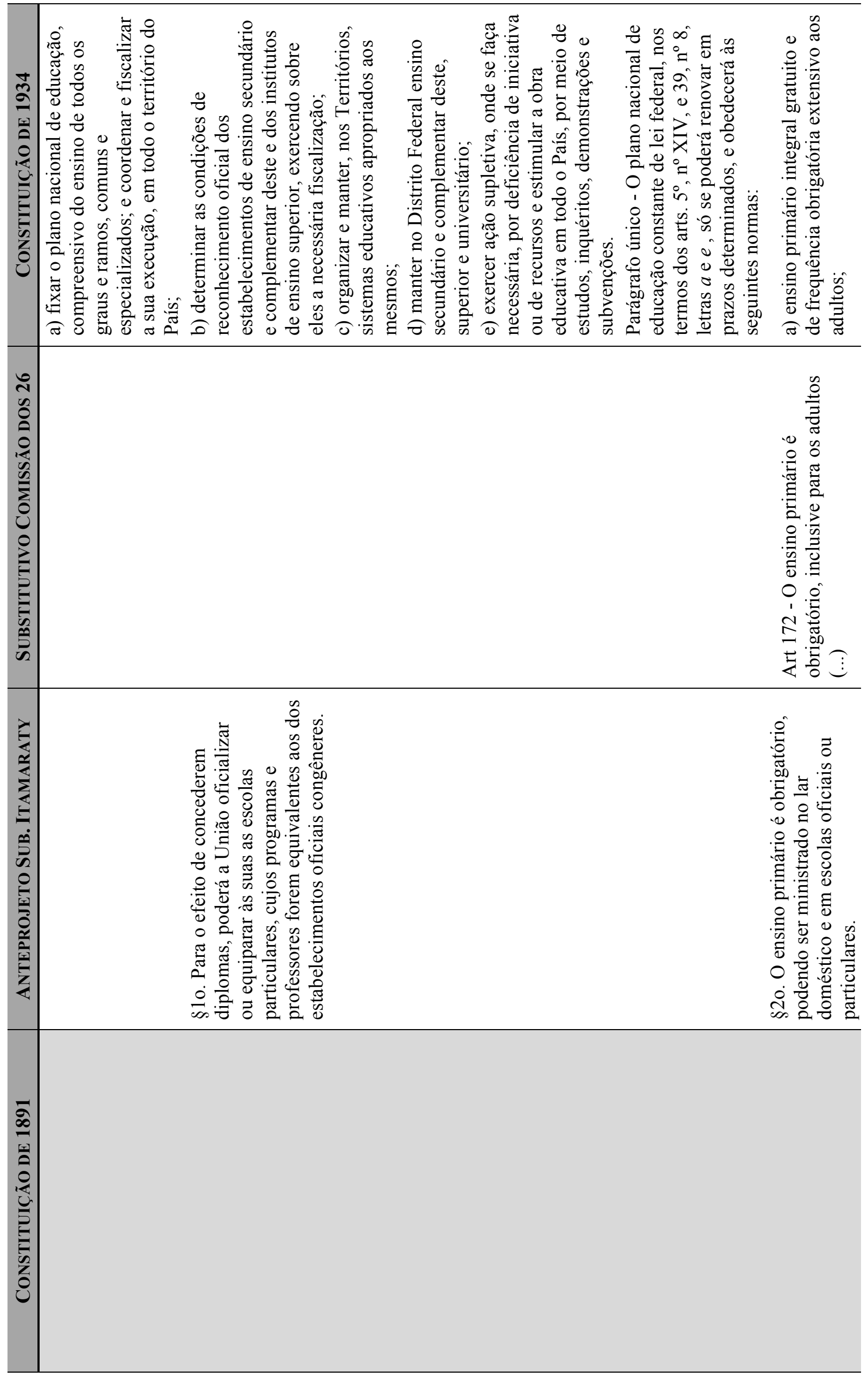




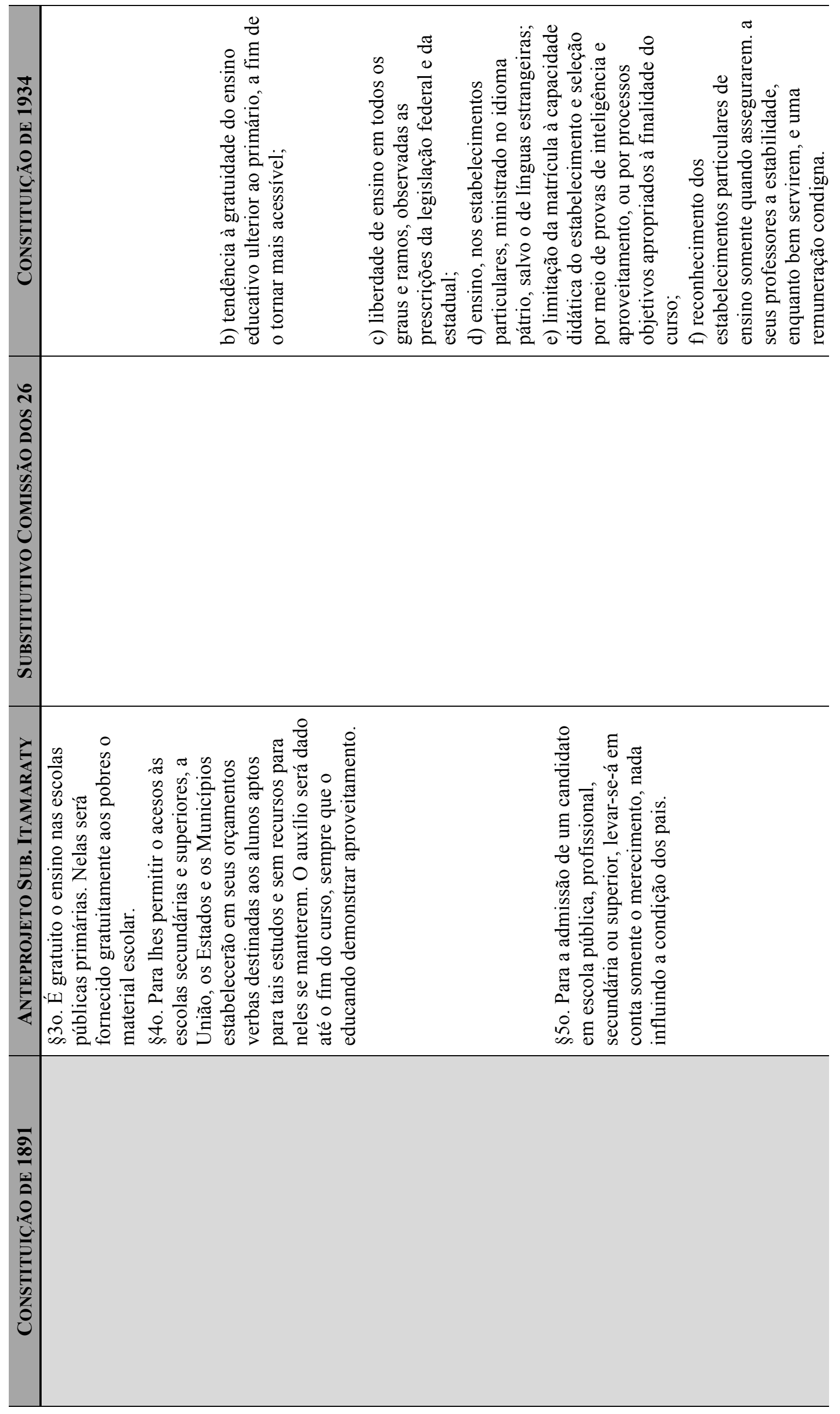




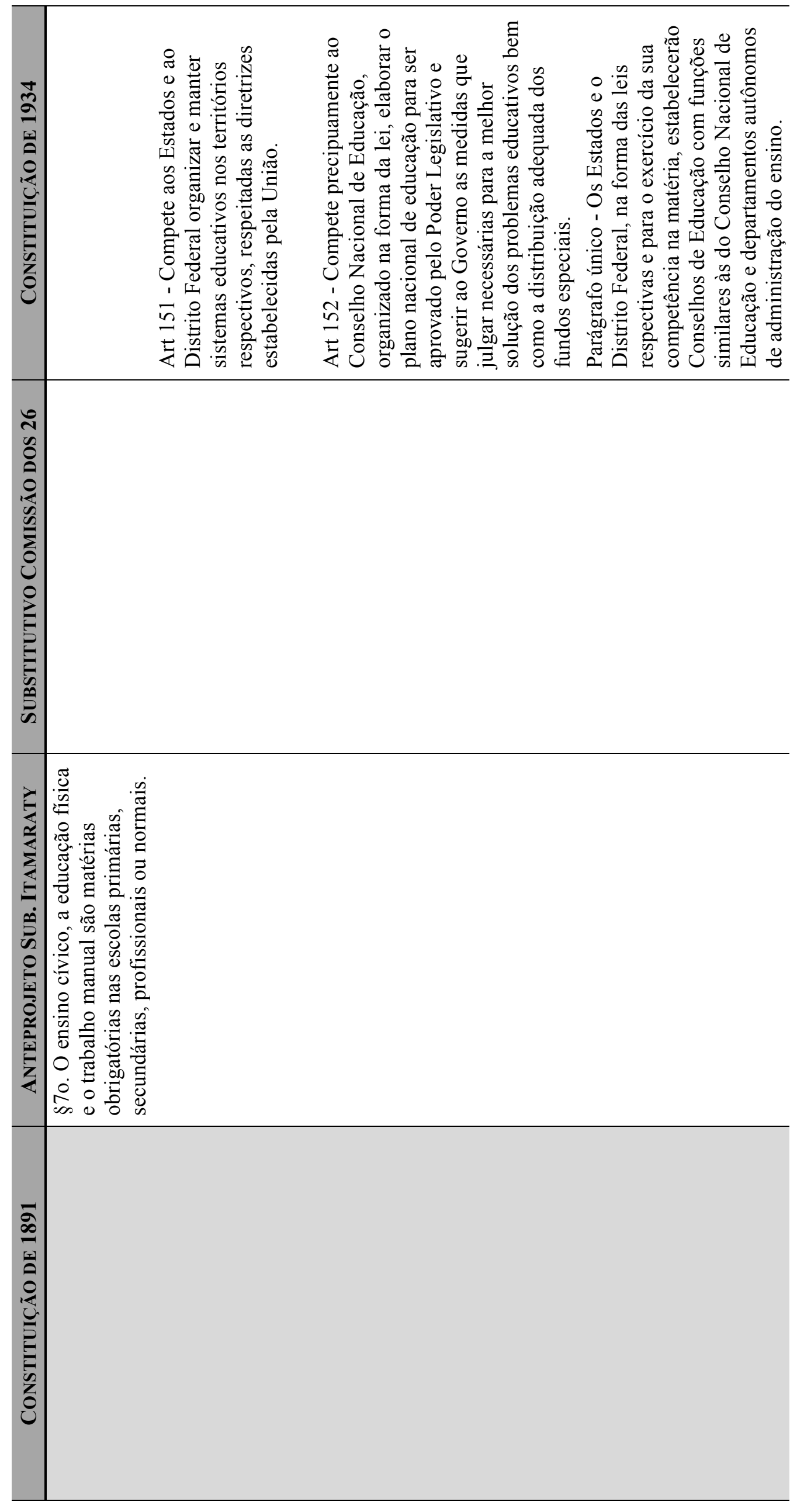




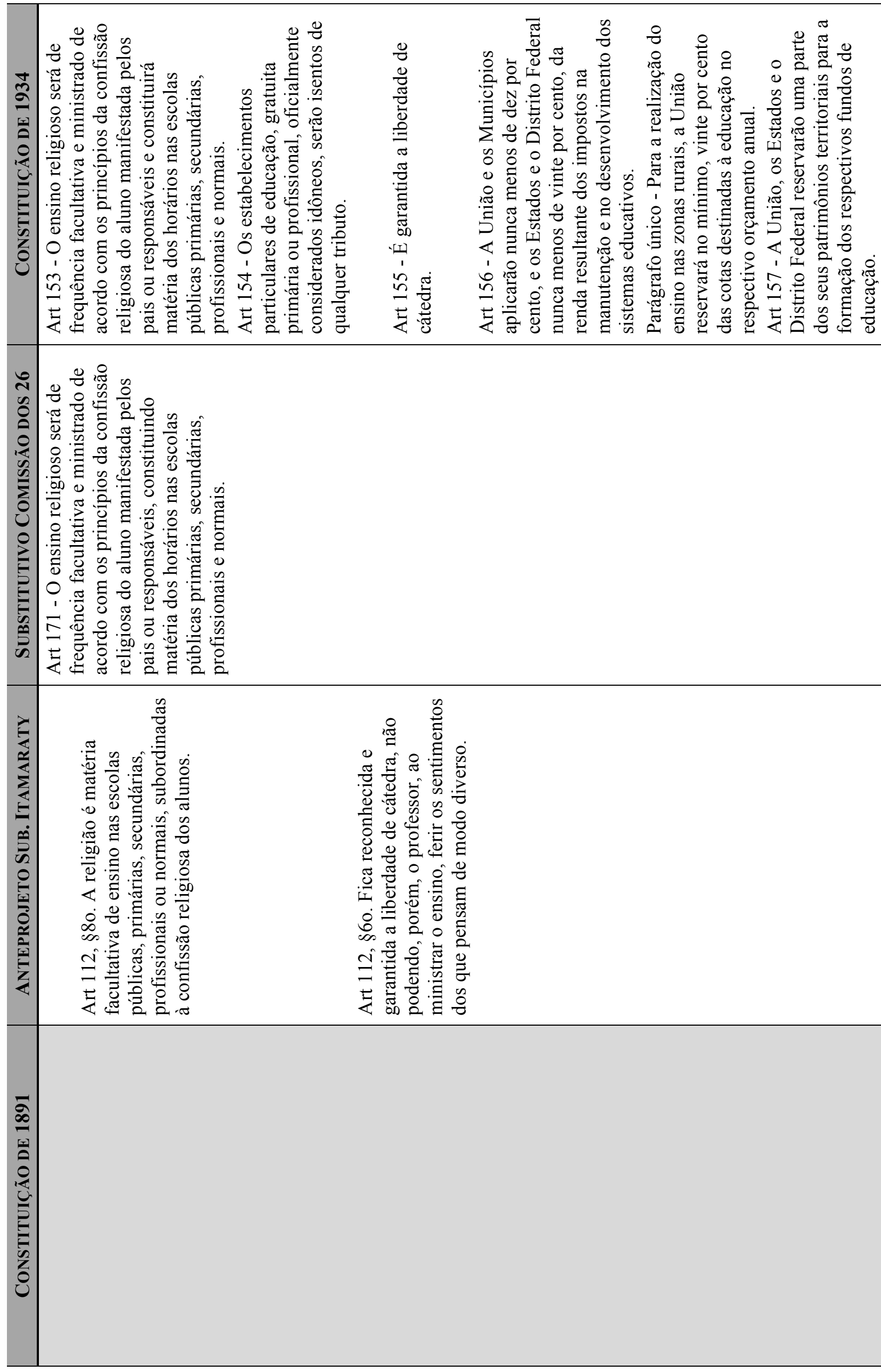




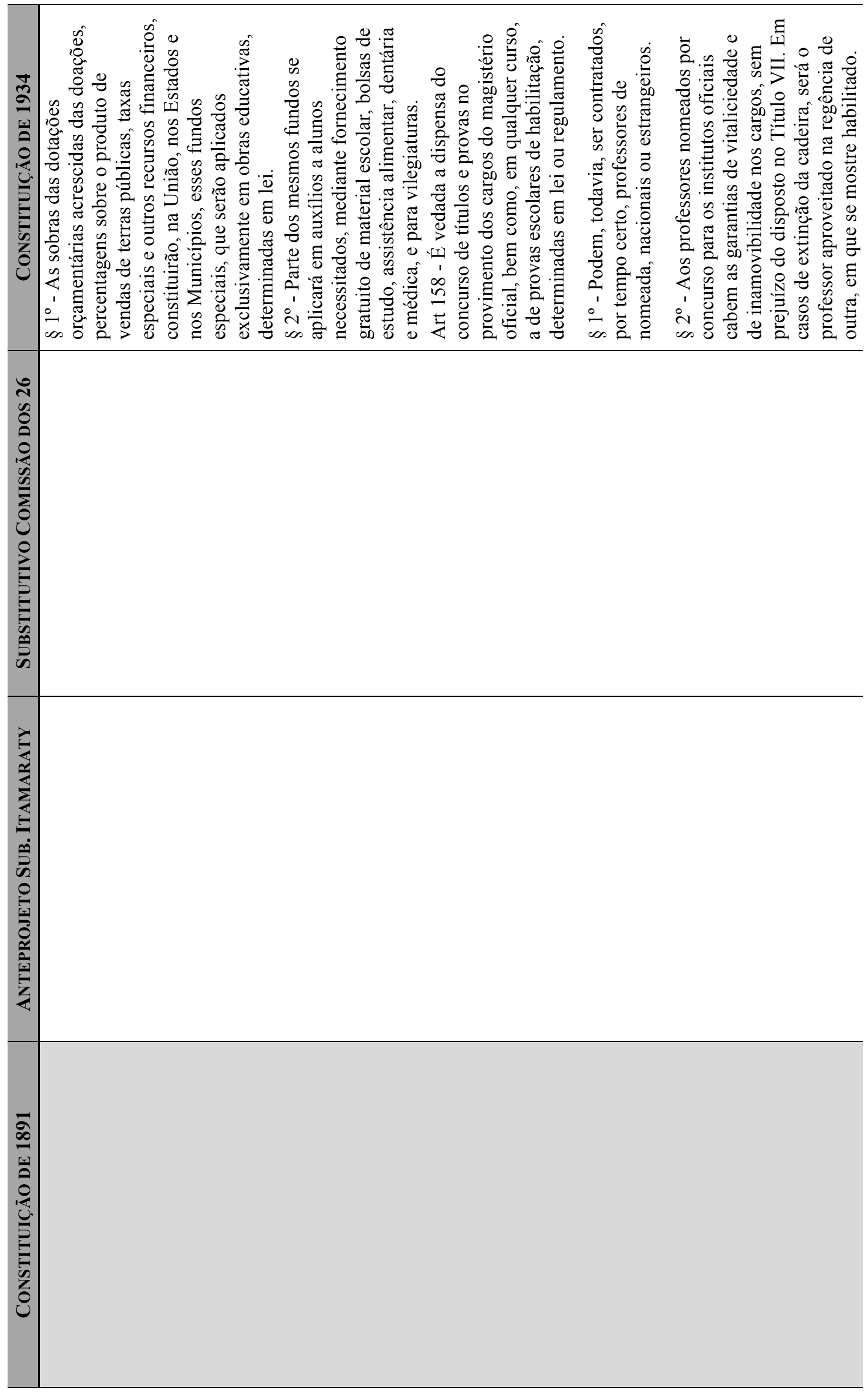




\section{ANEXO II \\ Composição da Assembleia Nacional Constituinte de 1933/34}

Apresentamos a seguir quadro que resume em ordem cronológica os principais eventos dos anos 1930-1934 no Brasil que digam respeito com os assuntos tratados no presente trabalho, em especial aqueles relacionados às novas regulamentações do Governo Provisório e ao cronograma de elaboração da Constituição ${ }^{1}$.

TABELA 2: DEPUTADOS POR ORIGEM (REPRESENTAÇÃO POLÍTICA E REPRESENTAÇÃO PROFISSIONAL)

\begin{tabular}{|c|c|c|c|}
\hline \multicolumn{2}{|c|}{ Origem } & \multicolumn{2}{|c|}{ Número de deputados } \\
\hline \multicolumn{2}{|l|}{ Amazonas } & & 4 \\
\hline \multicolumn{2}{|l|}{ Pará } & & 7 \\
\hline \multicolumn{2}{|l|}{ Maranhão } & & 7 \\
\hline \multicolumn{2}{|l|}{ Piauí } & & 4 \\
\hline \multicolumn{2}{|l|}{ Ceará } & & 10 \\
\hline \multicolumn{2}{|c|}{ Rio Grande do Norte } & & 4 \\
\hline \multicolumn{2}{|c|}{ Paraíba } & & 5 \\
\hline \multicolumn{2}{|l|}{ Pernambuco } & & 17 \\
\hline \multicolumn{2}{|l|}{ Alagoas } & & 6 \\
\hline \multicolumn{2}{|l|}{ Sergipe } & & 4 \\
\hline \multicolumn{2}{|l|}{ Bahia } & & 22 \\
\hline \multicolumn{2}{|l|}{ Espírito Santo } & & 4 \\
\hline \multicolumn{2}{|l|}{ Distrito Federal } & & 10 \\
\hline \multicolumn{2}{|l|}{ Rio de Janeiro } & & 17 \\
\hline \multicolumn{2}{|l|}{ Minas Gerais } & & 37 \\
\hline \multicolumn{2}{|l|}{ São Paulo } & & 22 \\
\hline \multicolumn{2}{|l|}{ Goiás } & & 4 \\
\hline \multicolumn{2}{|l|}{ Mato Grosso } & & 4 \\
\hline \multicolumn{2}{|l|}{ Paraná } & & 4 \\
\hline \multicolumn{2}{|l|}{ Santa Catarina } & & 4 \\
\hline \multicolumn{2}{|c|}{ Rio Grande do Sul } & & 16 \\
\hline \multicolumn{2}{|l|}{ Acre } & & 2 \\
\hline \multirow[t]{4}{*}{ rep. profissional } & empregadores & 17 & 40 \\
\hline & empregados & 18 & \\
\hline & profissionais liberais & 3 & \\
\hline & func. públicos & 2 & \\
\hline
\end{tabular}

\footnotetext{
${ }^{1} \mathrm{O}$ quadro é de elaboração própria, estando apoiado nas referências bibliográficas apontadas ao final do trabalho, em especial nos Anais da Assembleia Nacional Constituinte e em AZEVEDO, 2004, CARNEIRO, 1936, GOMES, 1986 e SILVA, 1969.
} 


\section{GRÁFICO 1: REPRESENTAÇÃo POLÍTICA (I) distribuição por profissões/formações}

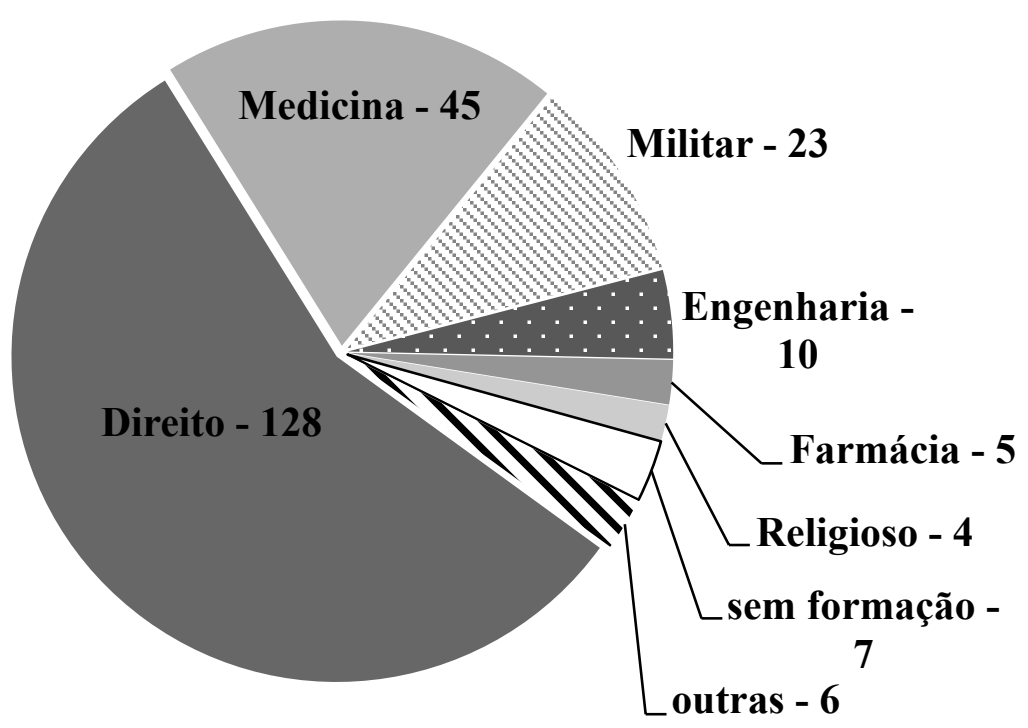

Fonte: elaboração própria, a partir de dados fornecidos em GODINHO e ANDRADE, $1934^{2}$.

\section{GRÁFICO 2: REPRESENTAÇÃo POLÍTICA (II) local de estudos - formação: DIREITO}

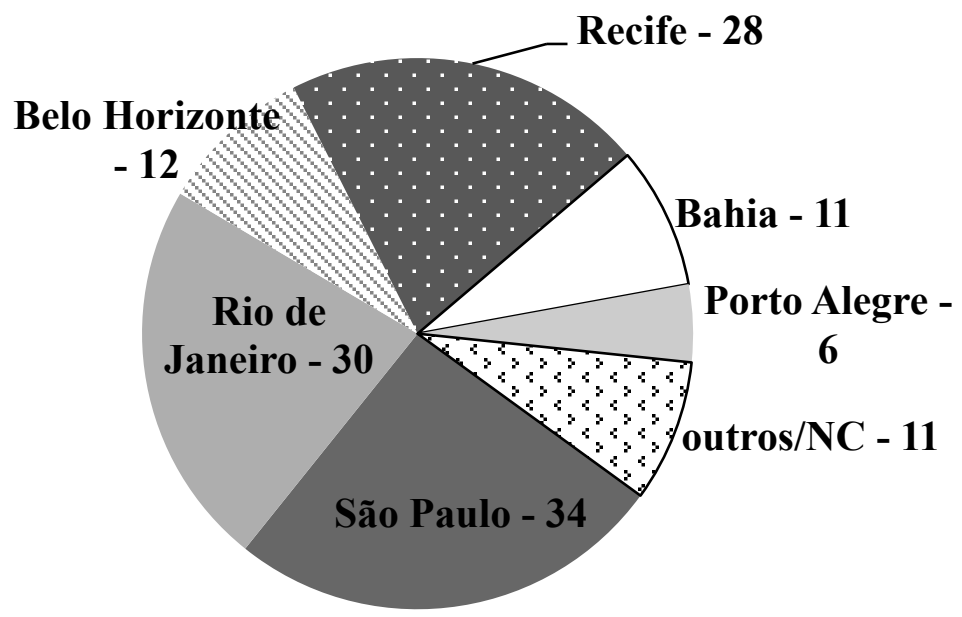

Fonte: elaboração própria, a partir de dados fornecidos em GODINHO e ANDRADE, $1934^{3}$.

\footnotetext{
${ }^{2}$ Deve-se observar que a soma das formações (228) é superior ao número total de representantes políticos (214) em função da existência de 14 deputados com dupla formação.

${ }^{3}$ Soma (132) superior ao número indicado de deputados com formação em Direito em razão da indicação de 4 deputados que fizeram sua formação em duas faculdades.
} 
A seguir, serão apresentadas as tabelas 3 e 4, com a descrição detalhada de cada um dos deputados constituintes, separando-os entre aqueles oriundos da representação política - eleitos por meio de sufrágio universal nas circunscrições eleitorais, correspondentes aos Estados, Distrito Federal e Terriório - e os provenientes da representação profissional - escolhidos a partir dos delegados escolhidos pelas entidades de classe reconhecidas pelo Ministério do Trabalho, conforme exposto no capítulo 4.

Legenda:

em negrito: líderes das bancadas estaduais

* : $\quad$ membros da Comissão dos 26

sd: $\quad$ sem diploma superior

LEC: $\quad$ Liga Eleitoral Católica

CIB: $\quad$ Confederação Industrial do Brasil

FIESP: $\quad$ Federação das Indústrias do Estado de São Paulo

FIRJ: $\quad$ Federação das Indústrias do Estado do Rio de Janeiro

FIEMG: $\quad$ Federação das Indústrias do Estado de Minas Gerais

CIFTA: Centro das Indústrias de Fiação e Tecelagem de Algodão

IDORT: Instituto de Organização Racional do Trabalho 


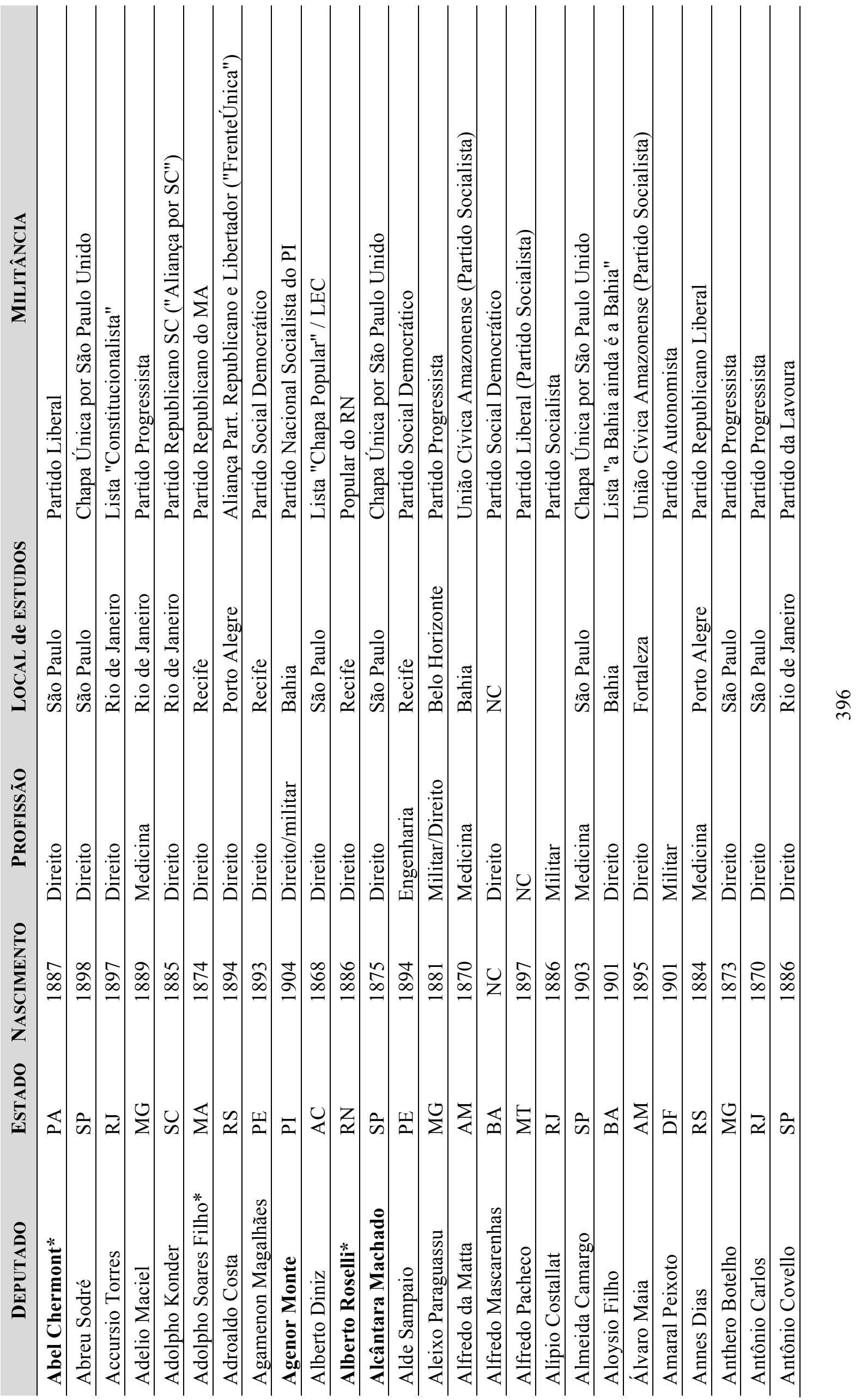



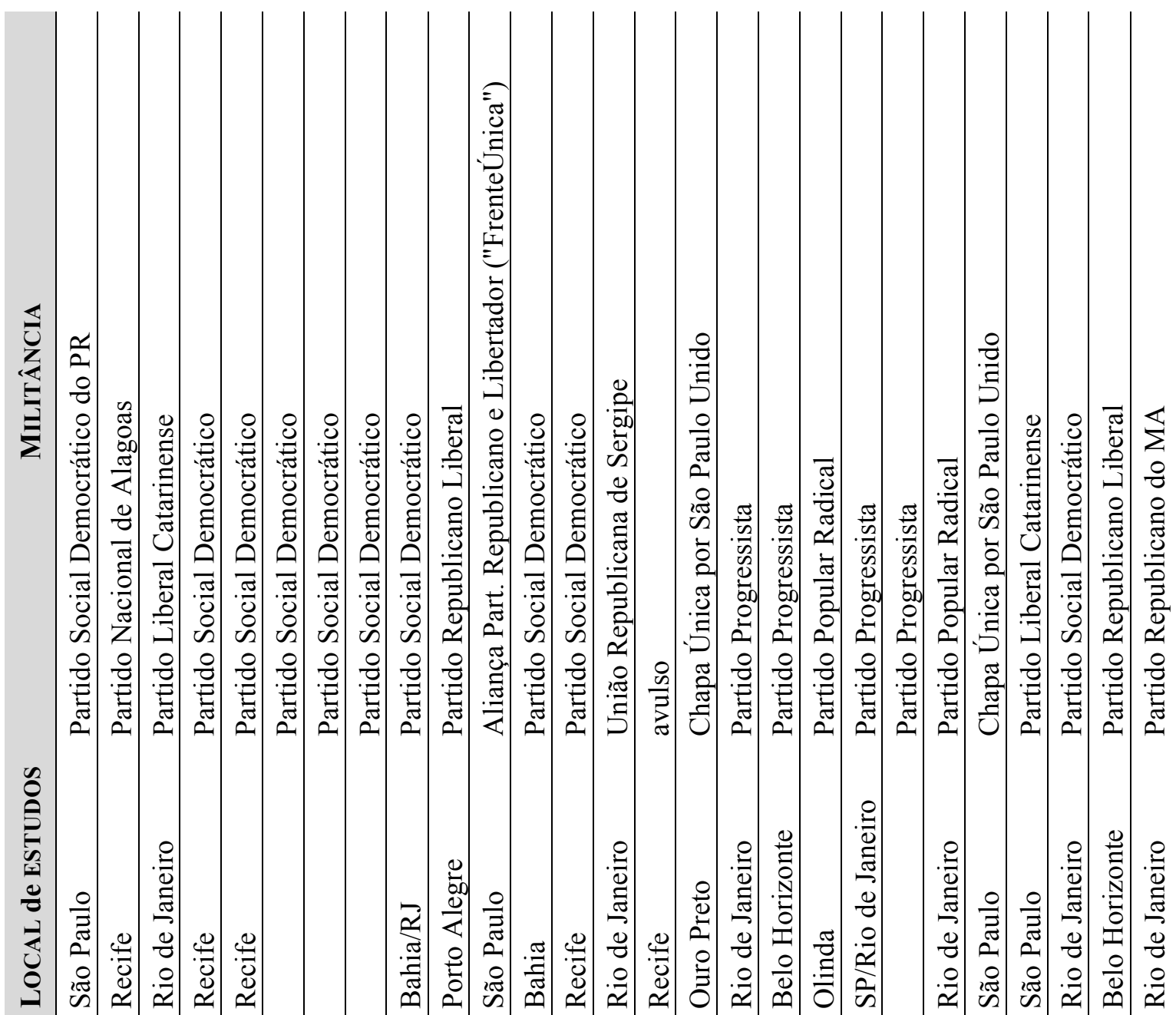

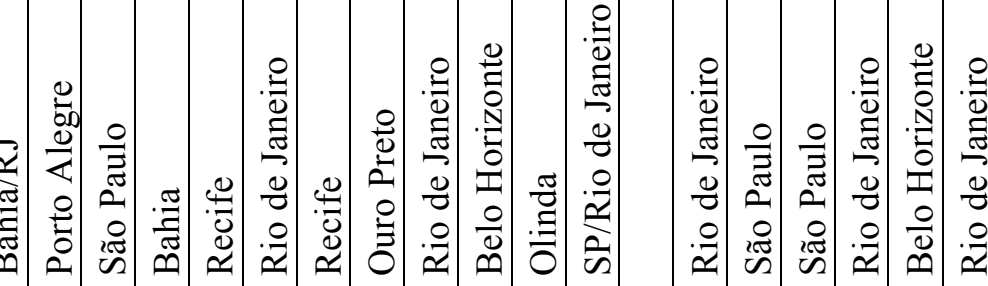

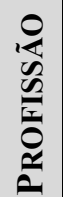

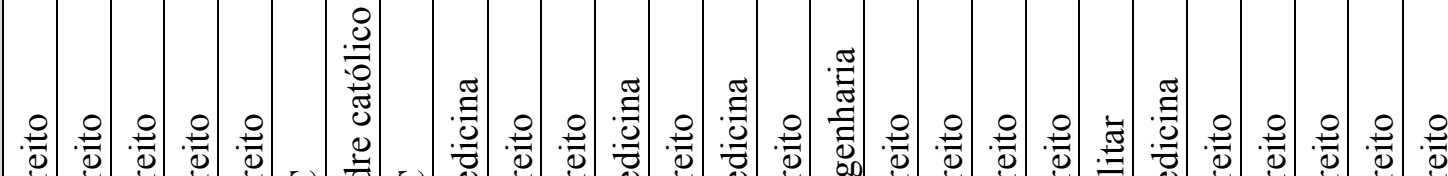

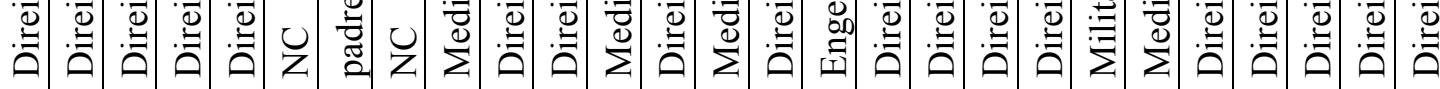

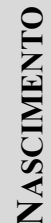

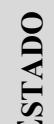

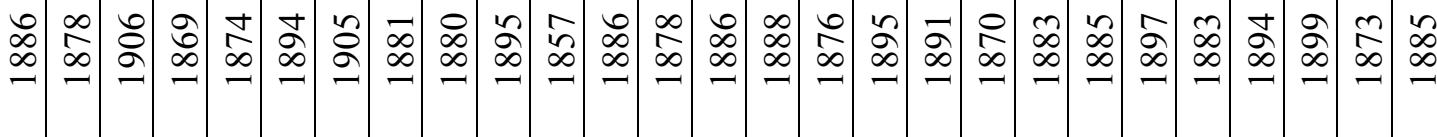

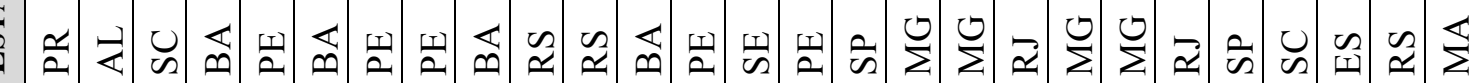

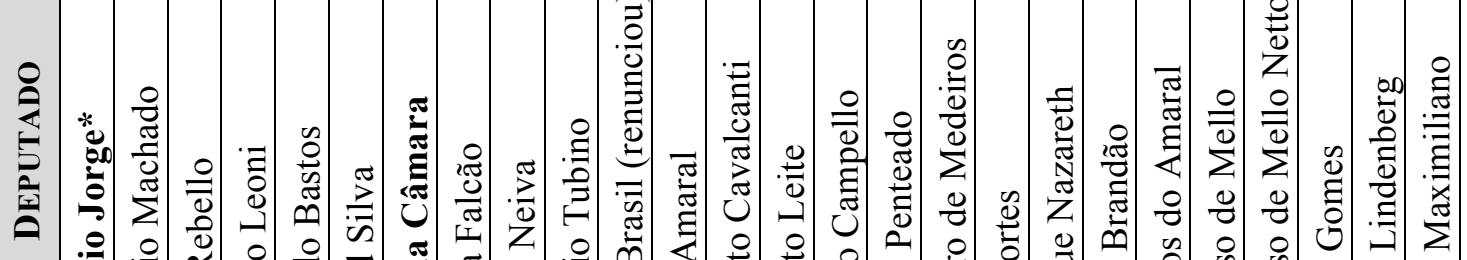

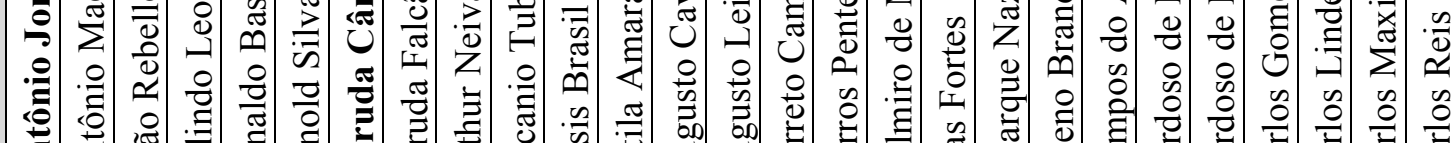

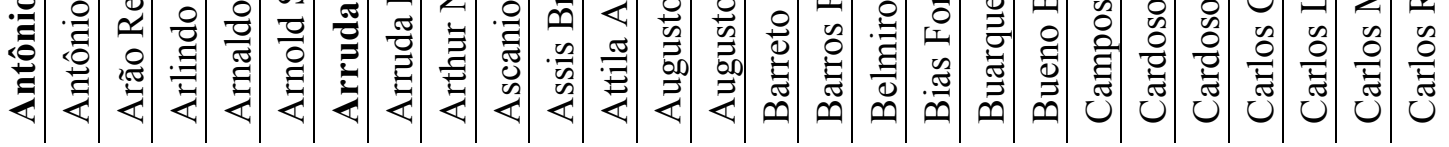




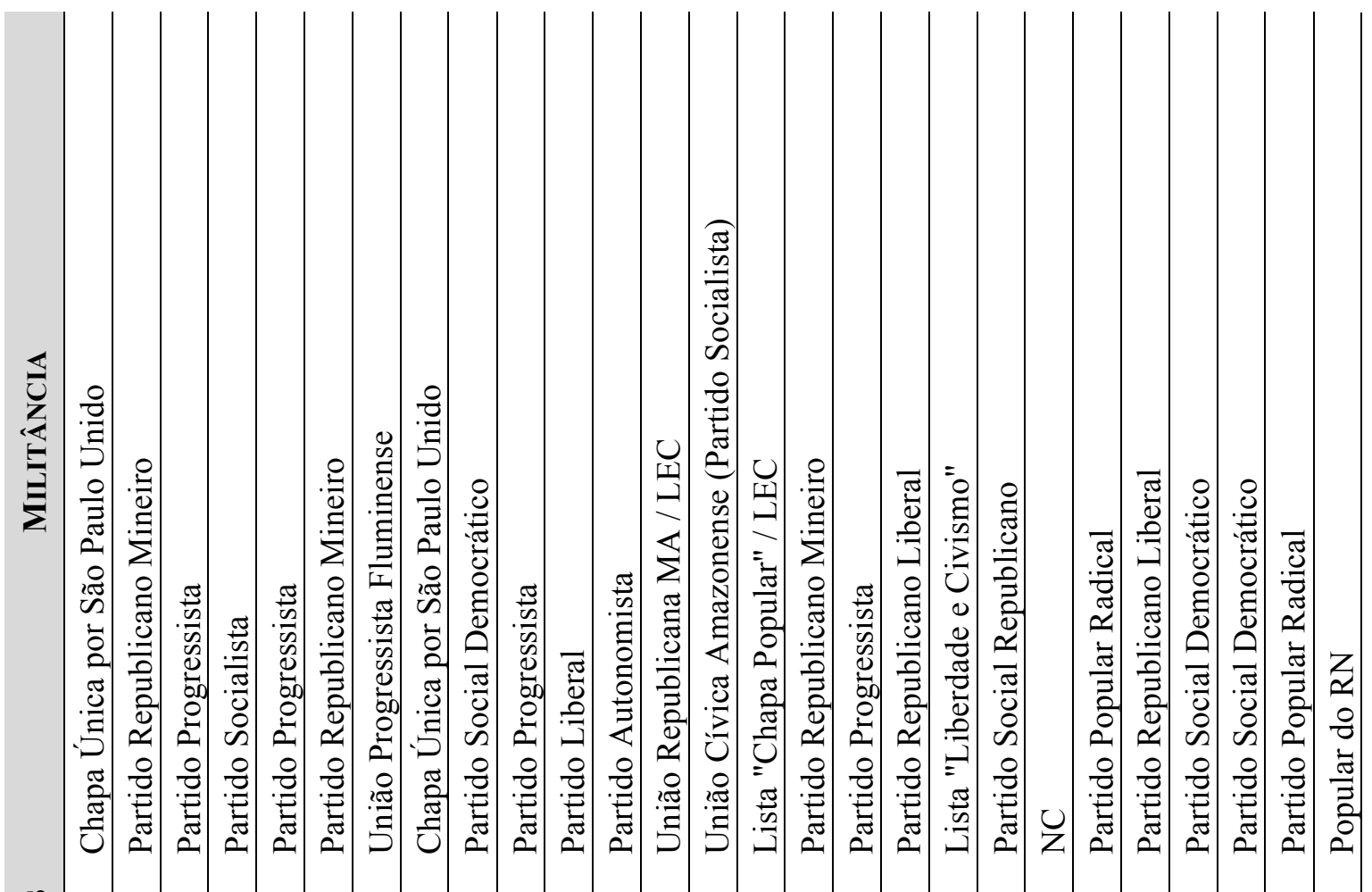

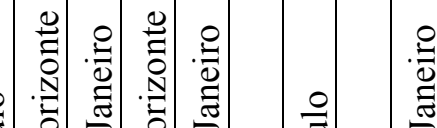

0
0
0
0
0
0
0

.9

罂

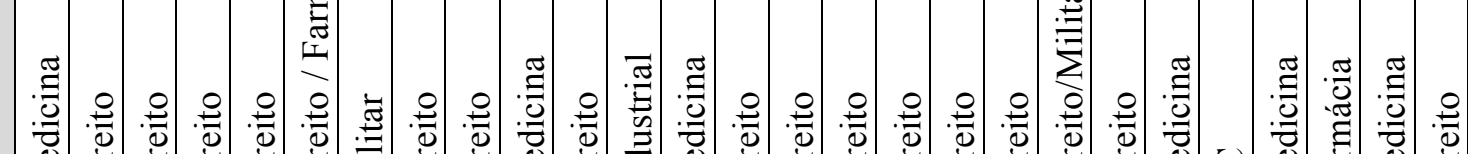

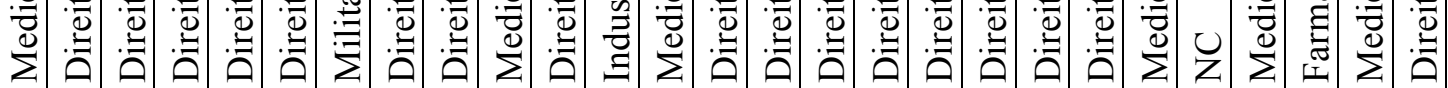

일

章

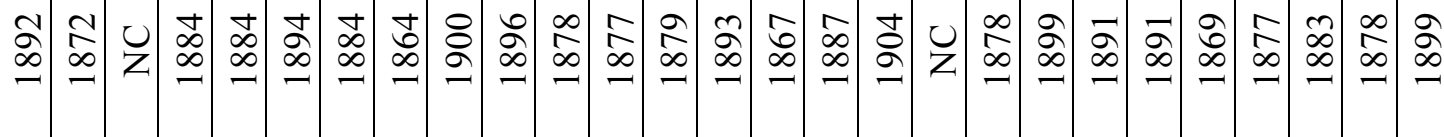

के

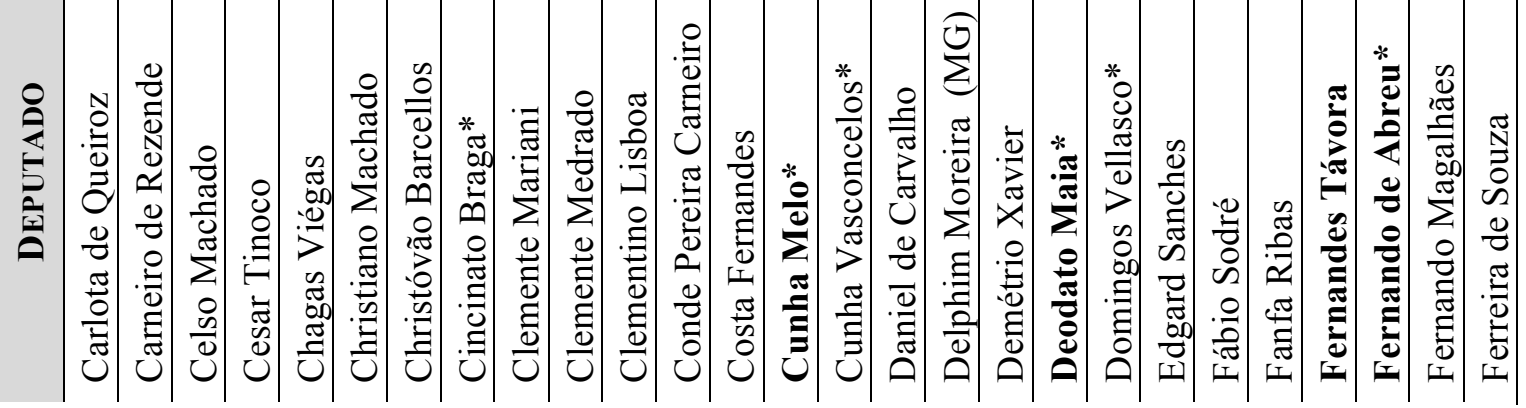




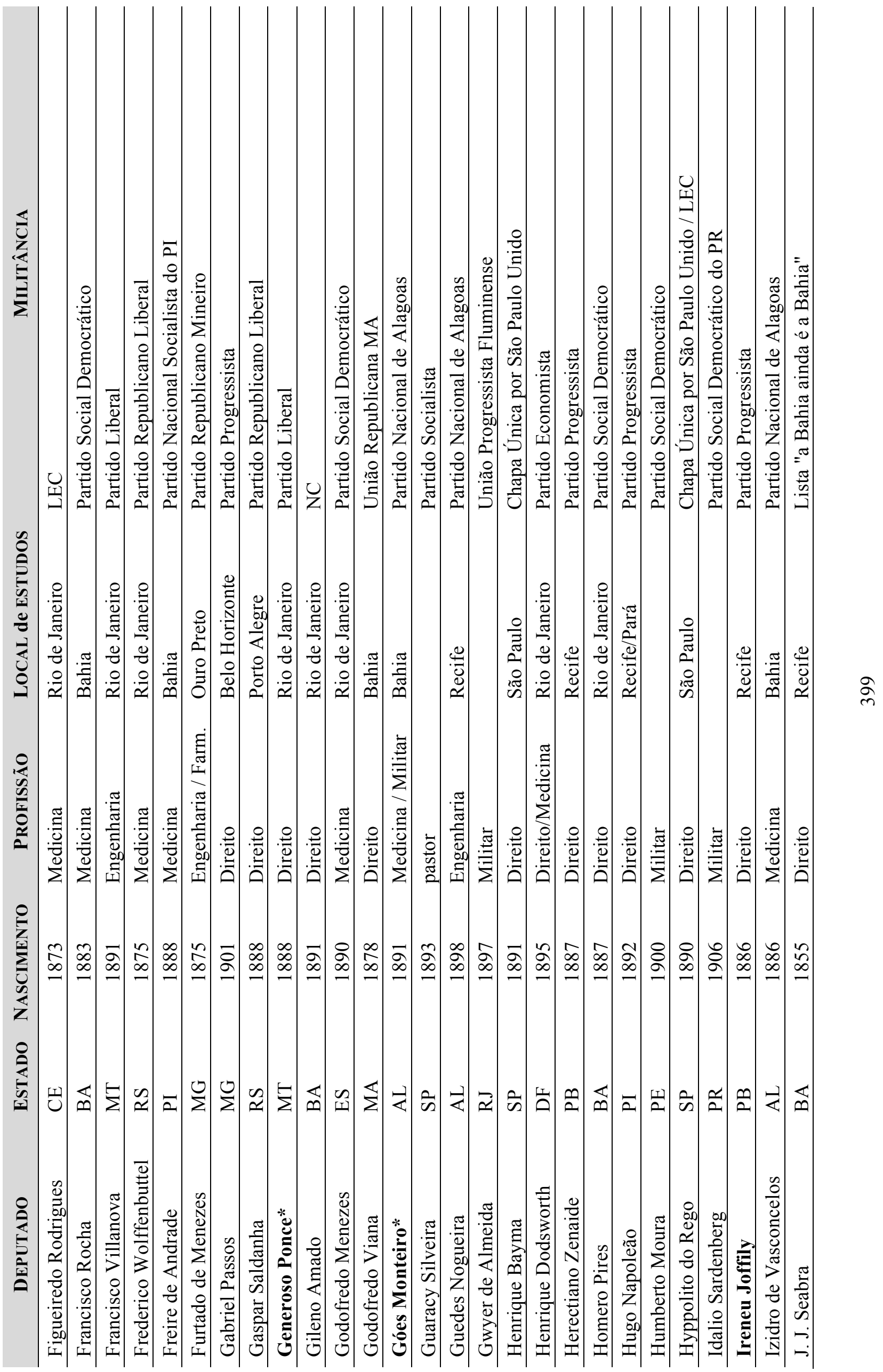




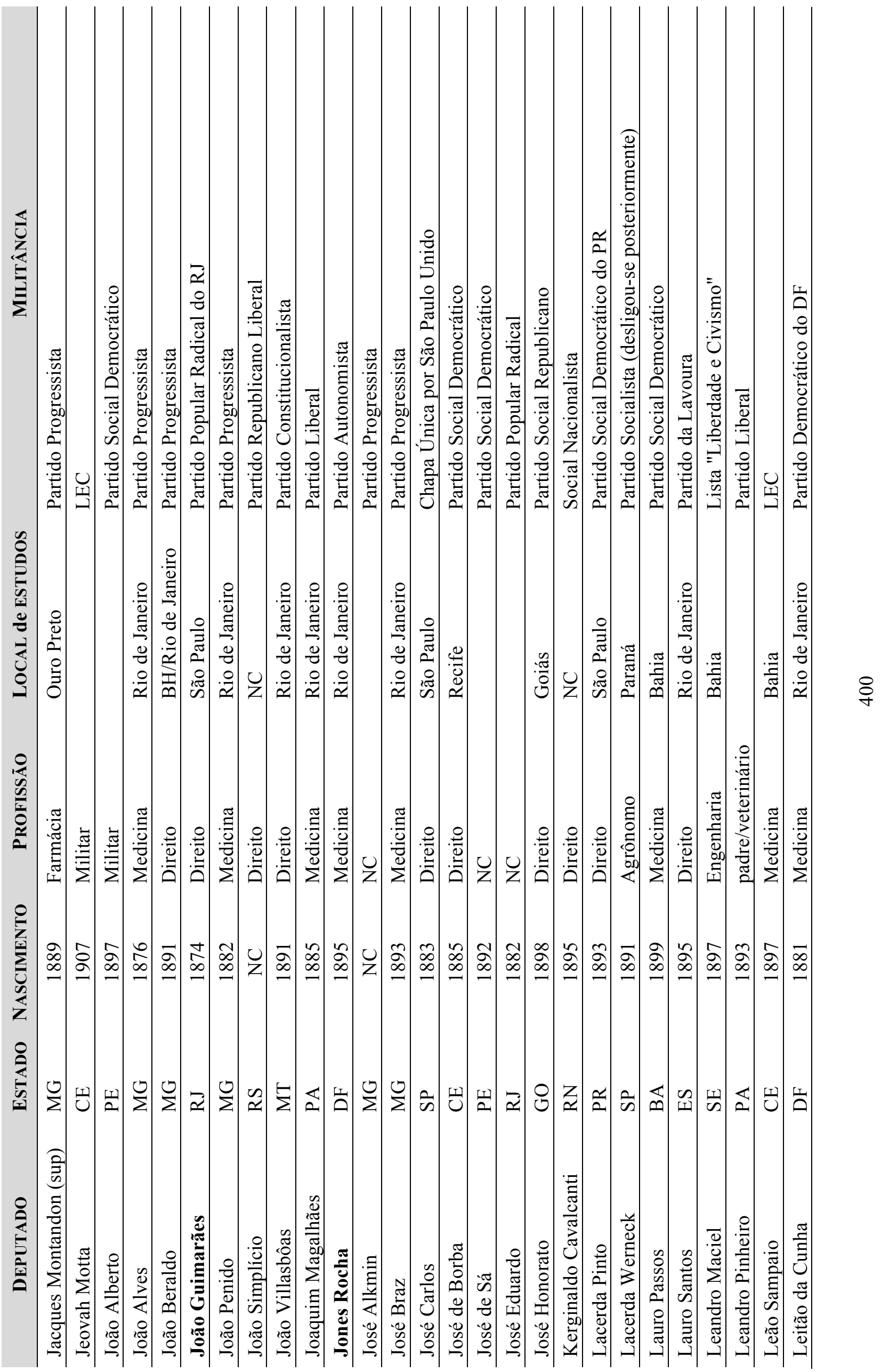




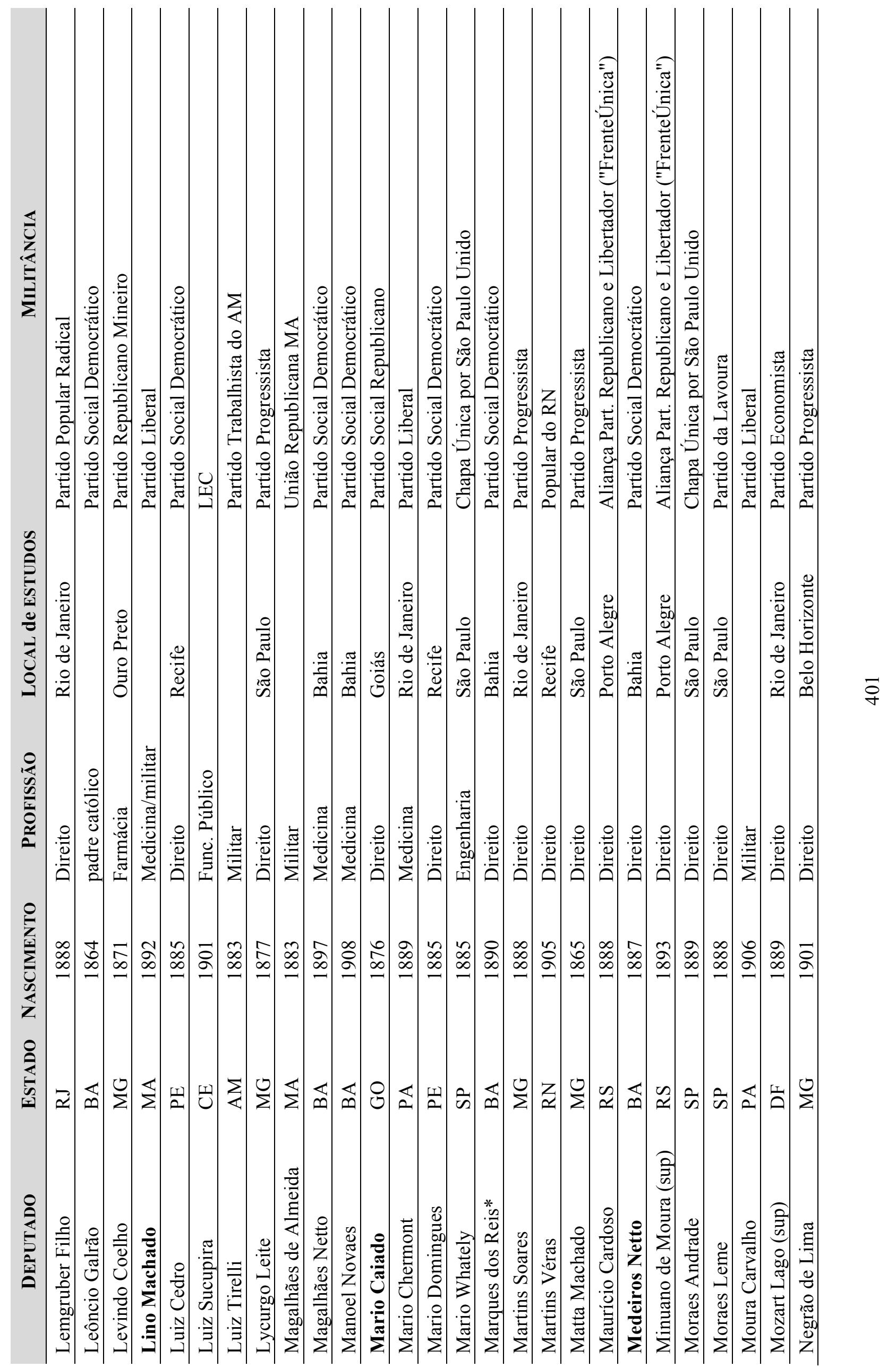




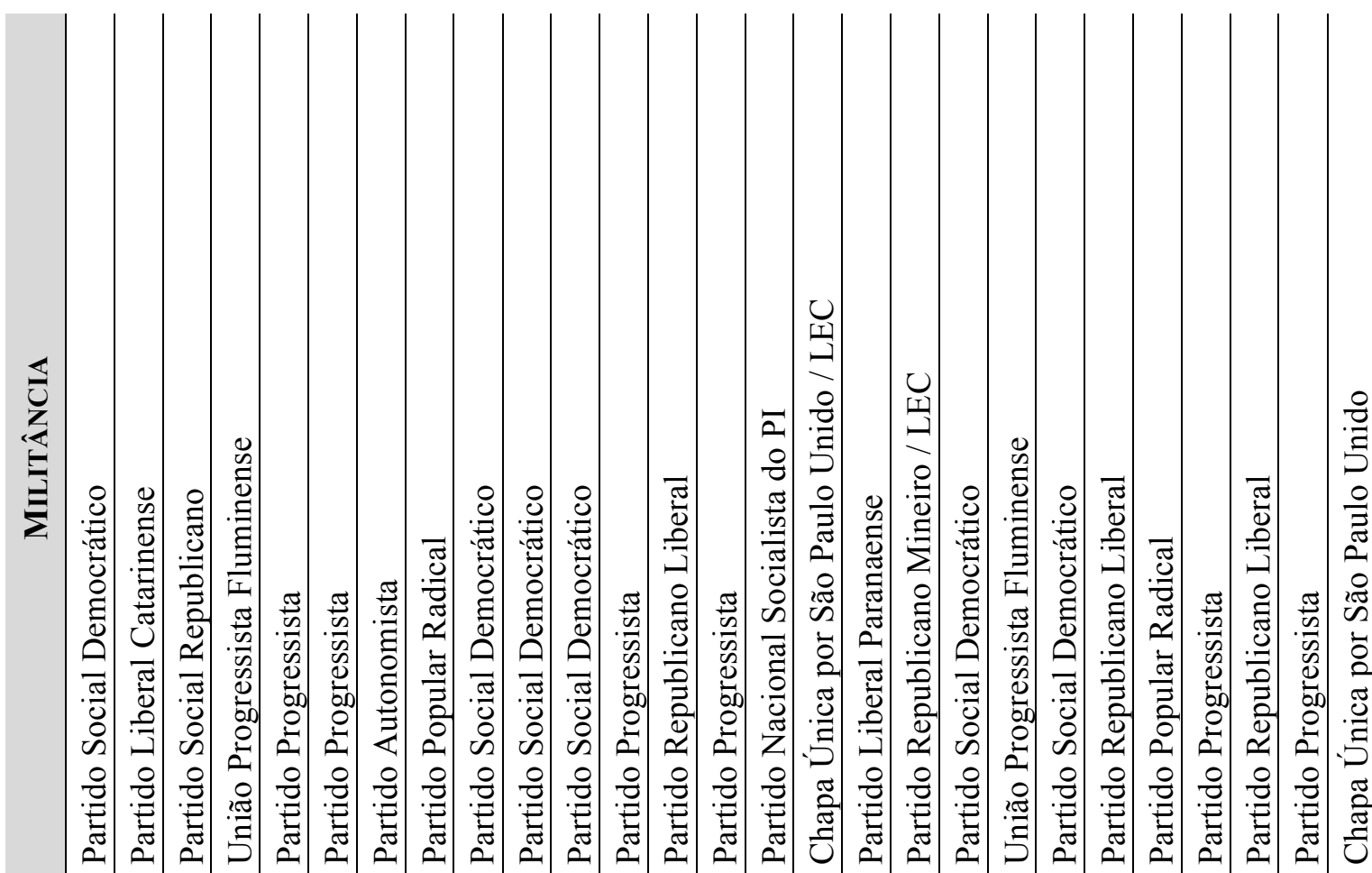

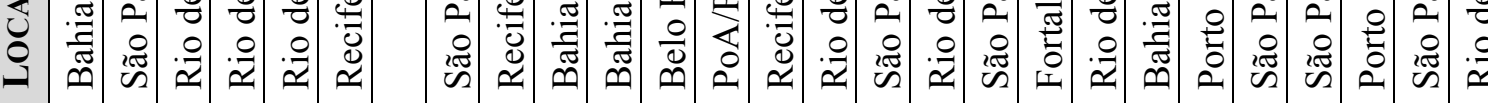

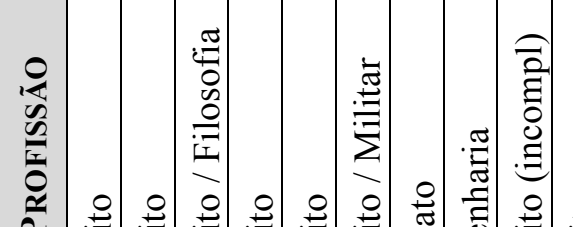

离

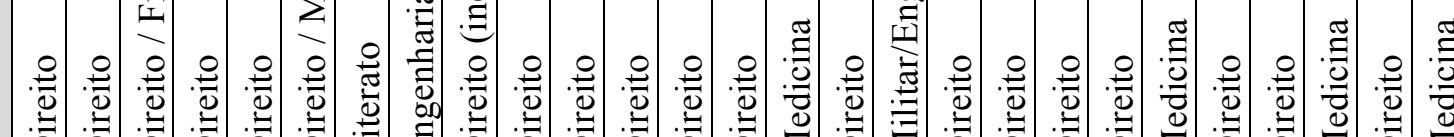

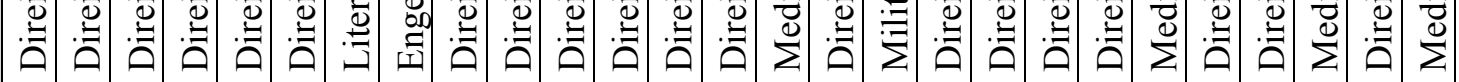

竞

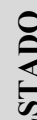

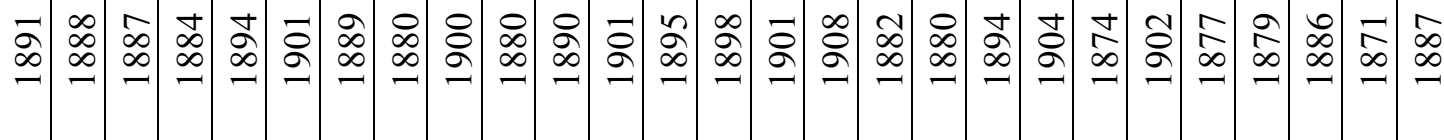

8

至

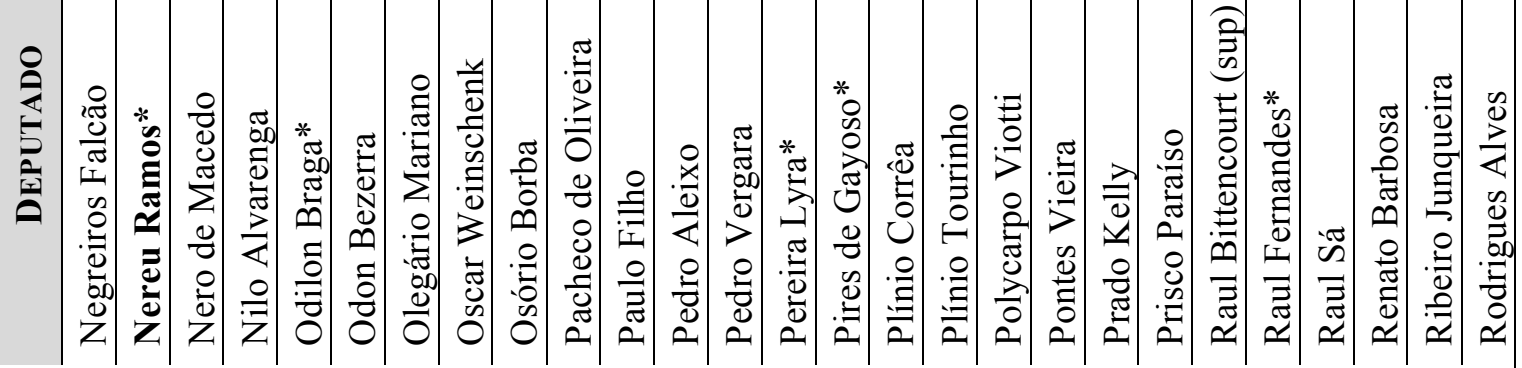




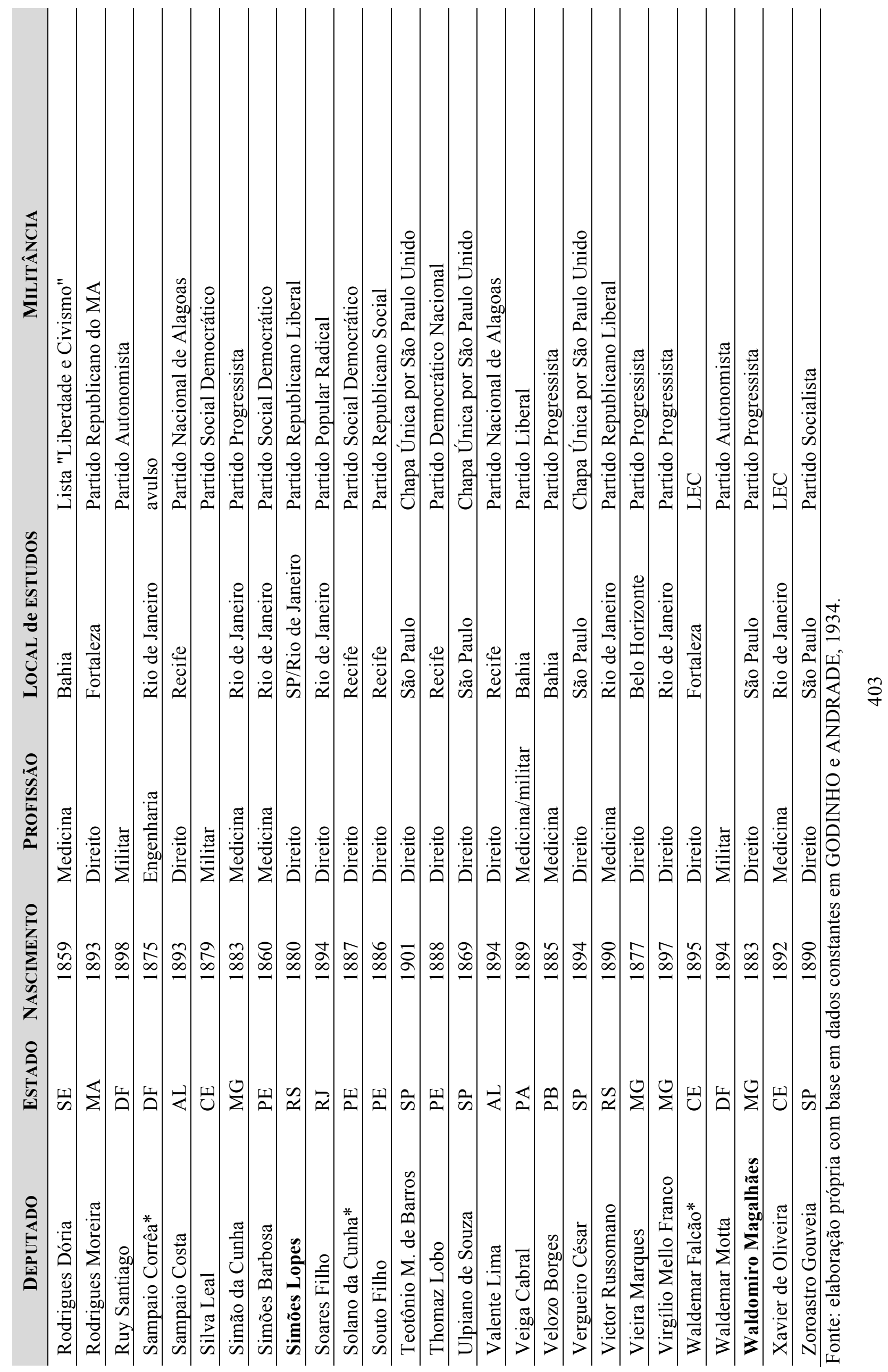




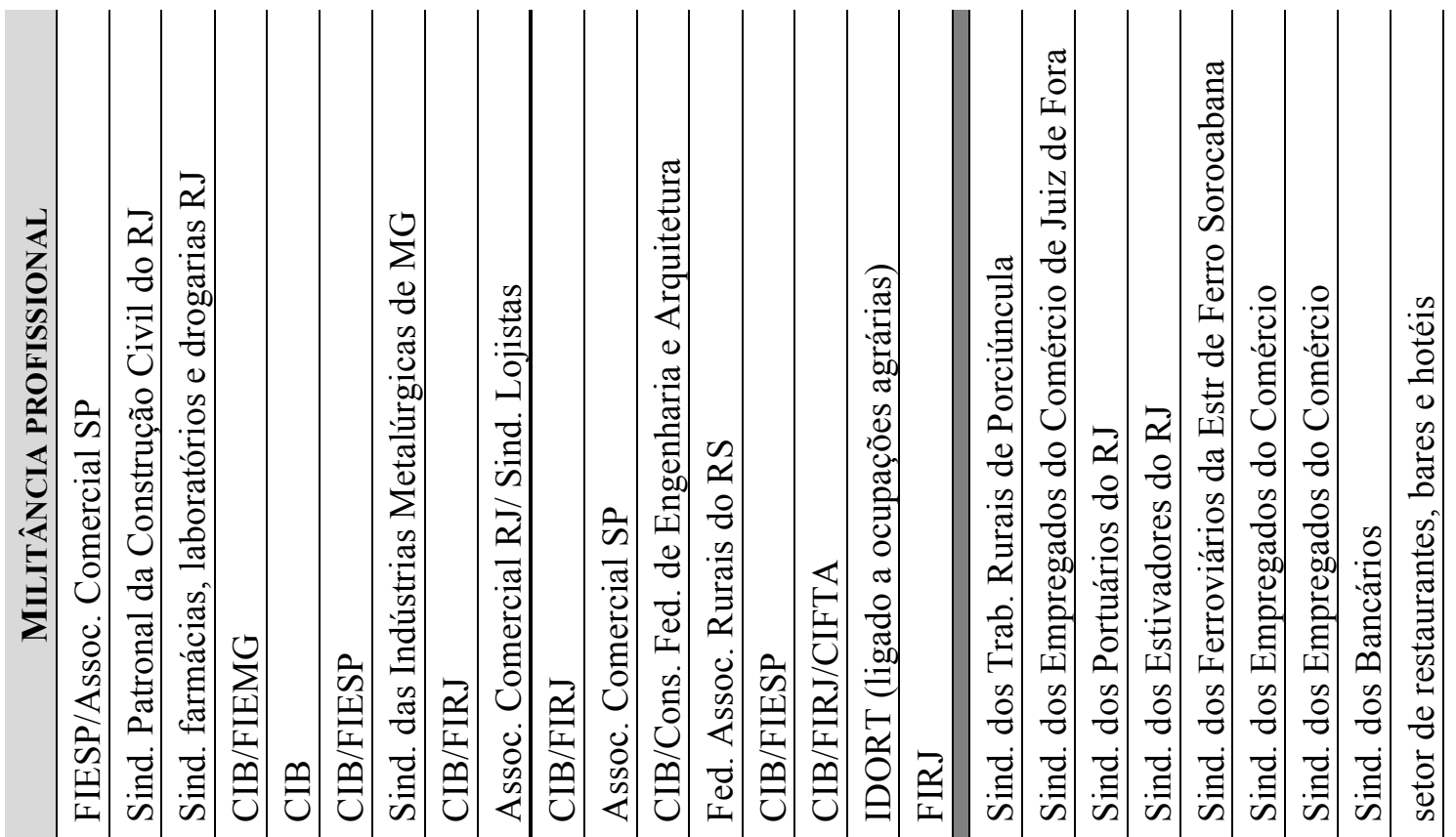

章

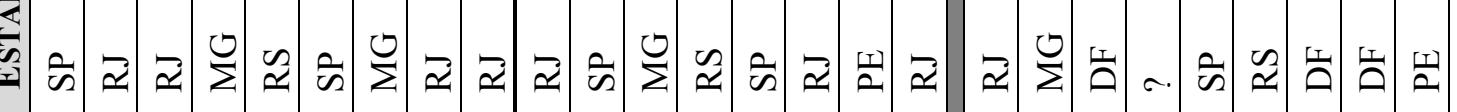

|

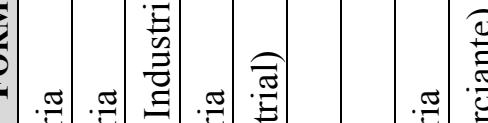

จิ

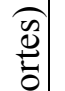

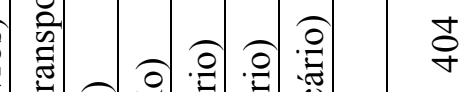

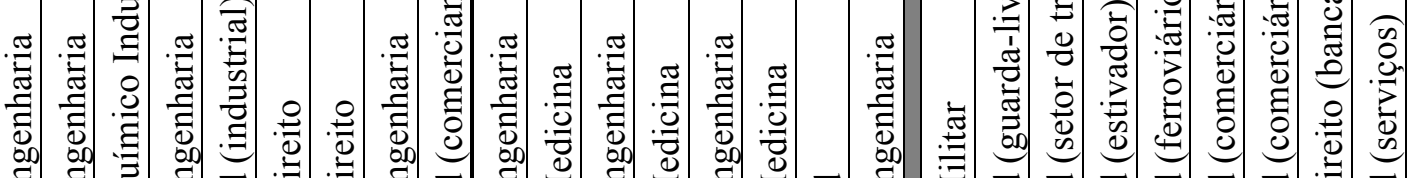

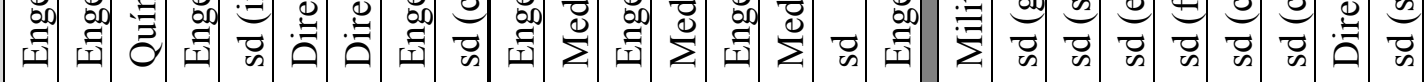

$\circ$

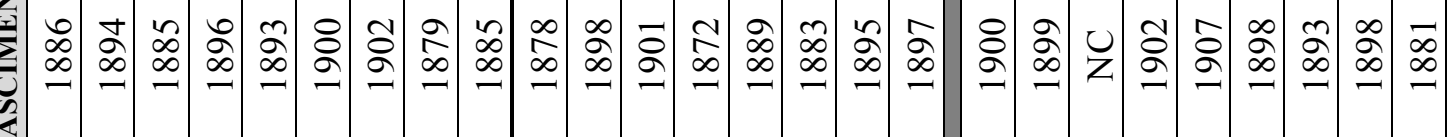

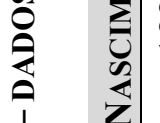

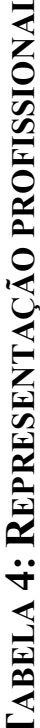

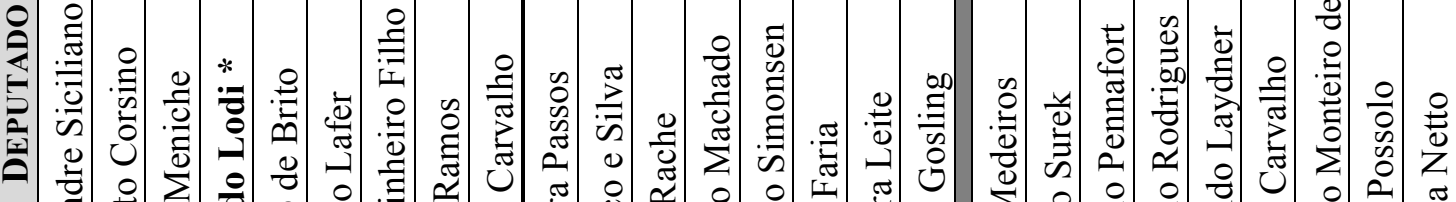

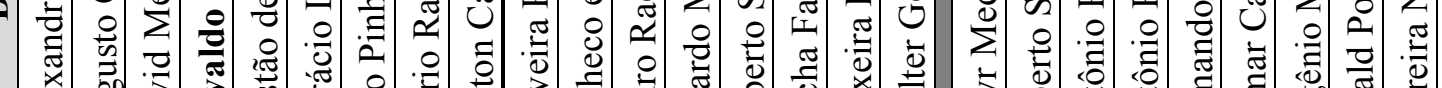

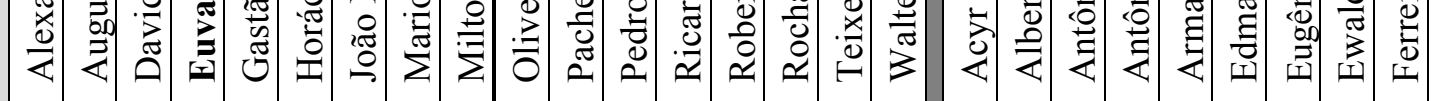

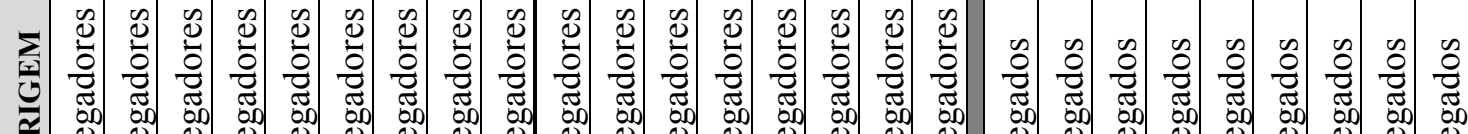

范

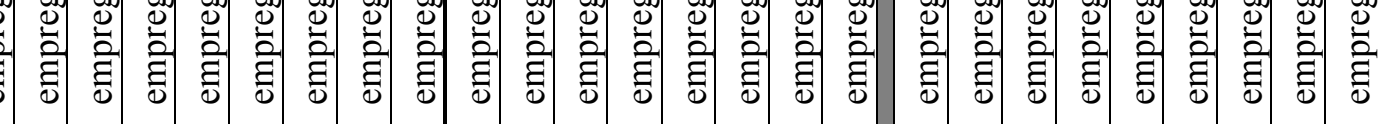




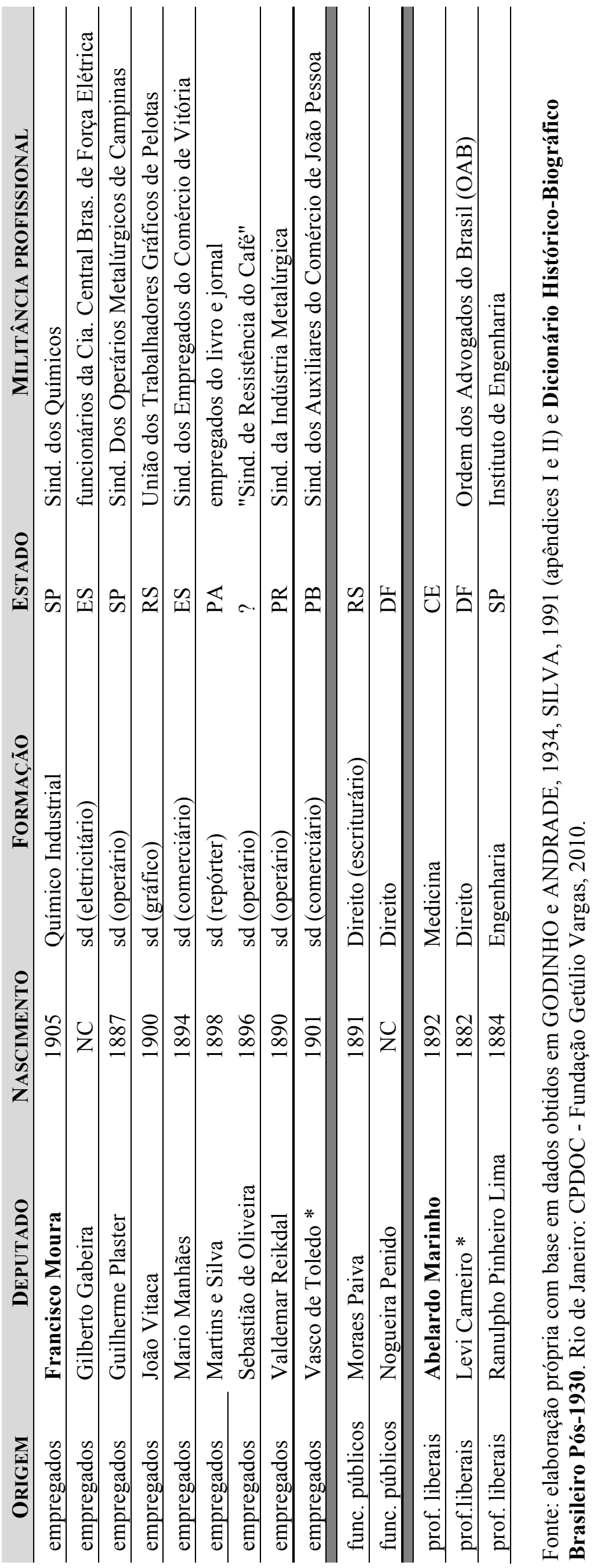




\section{ANEXO III \\ Cronologia da Segunda República: novos direitos e nova Constituição (Tabela 5)}

Apresentamos a seguir quadro que resume em ordem cronológica os principais eventos dos anos 1930-1934 no Brasil que digam respeito com os assuntos tratados no presente trabalho, em especial aqueles relacionados às novas regulamentações do Governo Provisório e ao cronograma de elaboração da Constituição ${ }^{1}$.

Legenda:

AN: $\quad$ Assembleia Nacional

ANC: $\quad$ Assembleia Nacional Constituinte

C26: $\quad$ Comissão dos 26

GP: $\quad$ Governo Provisório

PE: $\quad$ Poder Executivo

SI: $\quad$ Subcomissão Itamaraty

\footnotetext{
${ }^{1} \mathrm{O}$ quadro é de elaboração própria, estando apoiado nas referências bibliográficas apontadas ao final do trabalho, em especial nos Anais da Assembleia Nacional Constituinte e em AZEVEDO, 2004, CARNEIRO, 1936, GOMES, 1986 e SILVA, 1969.
} 


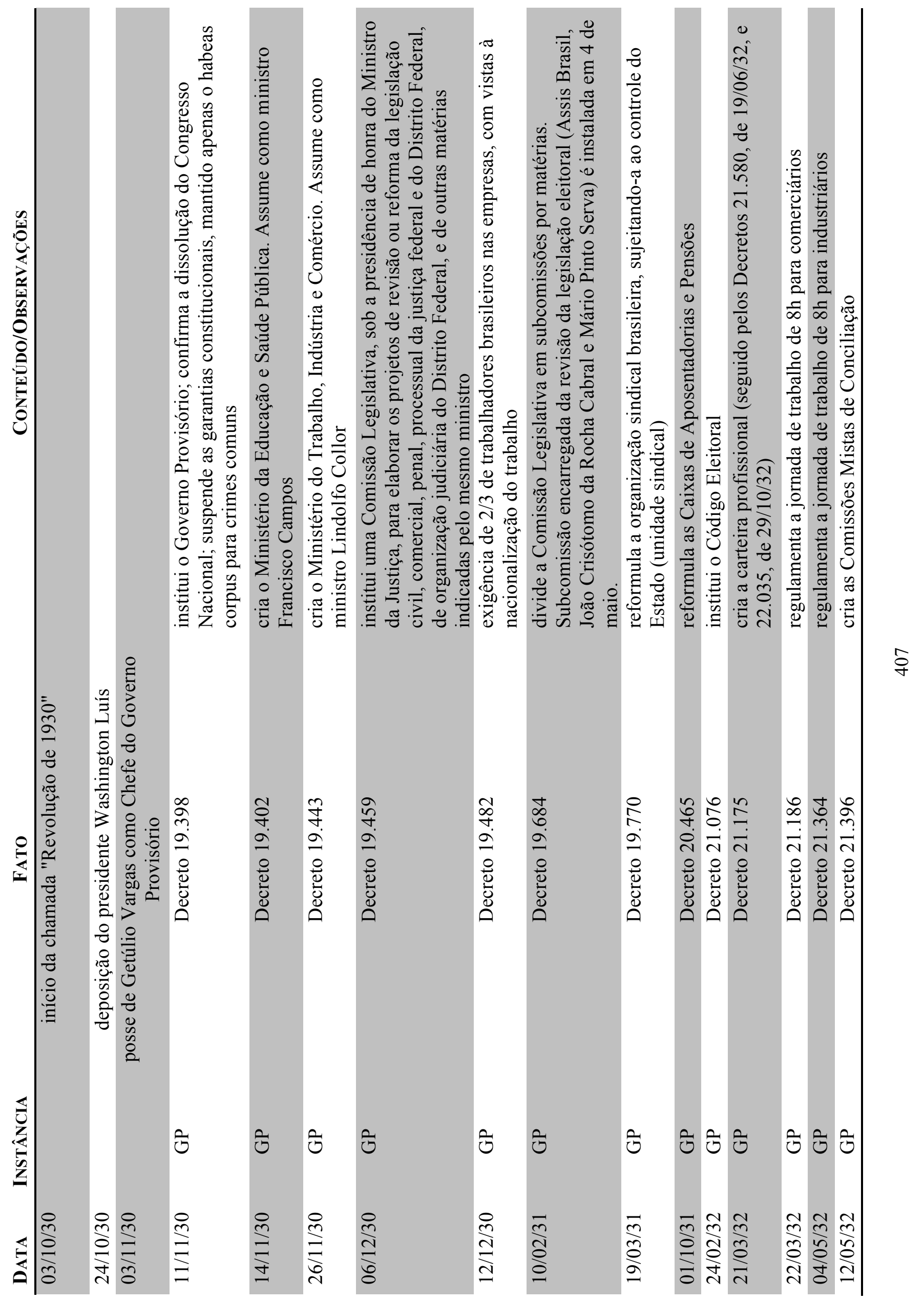




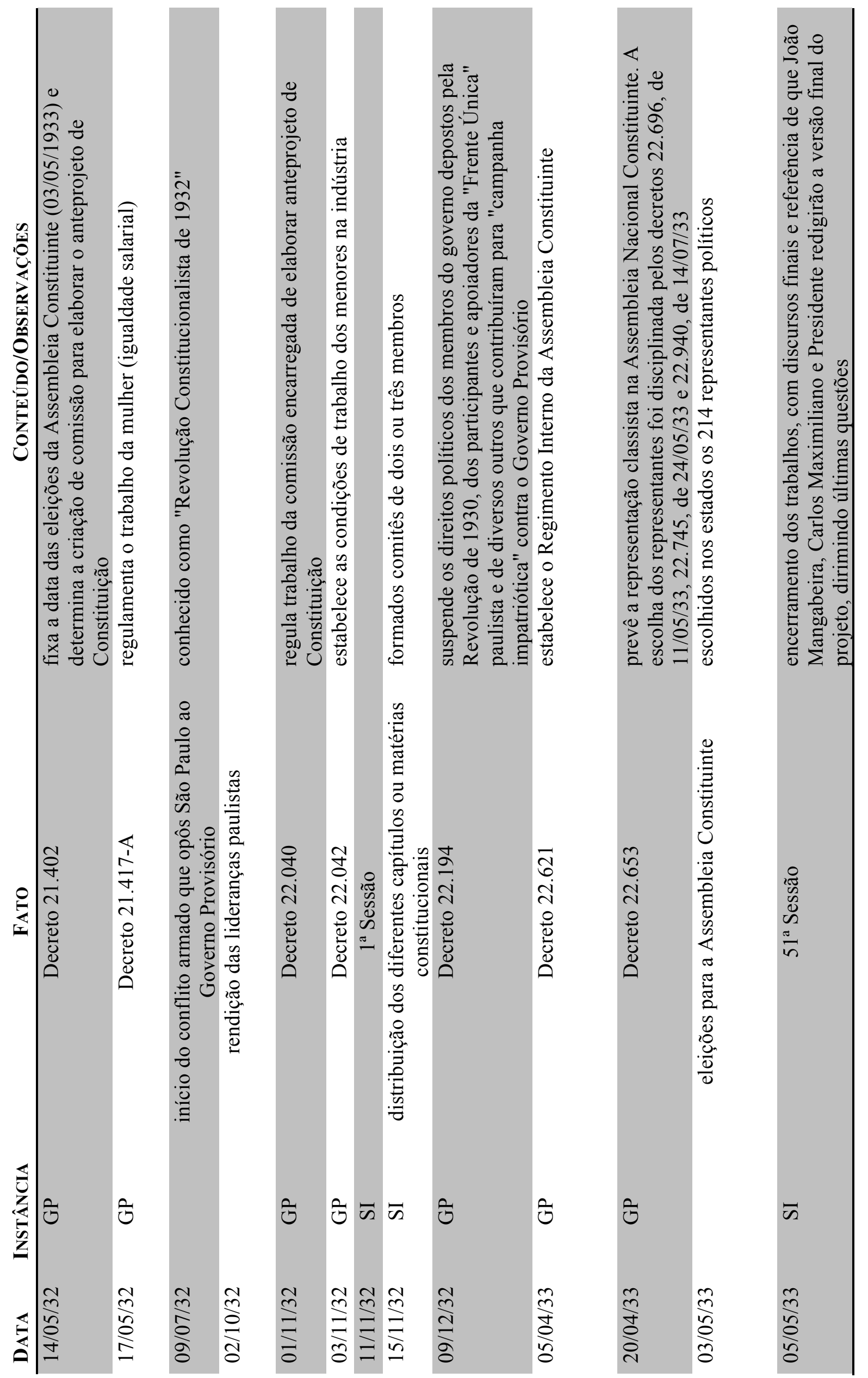




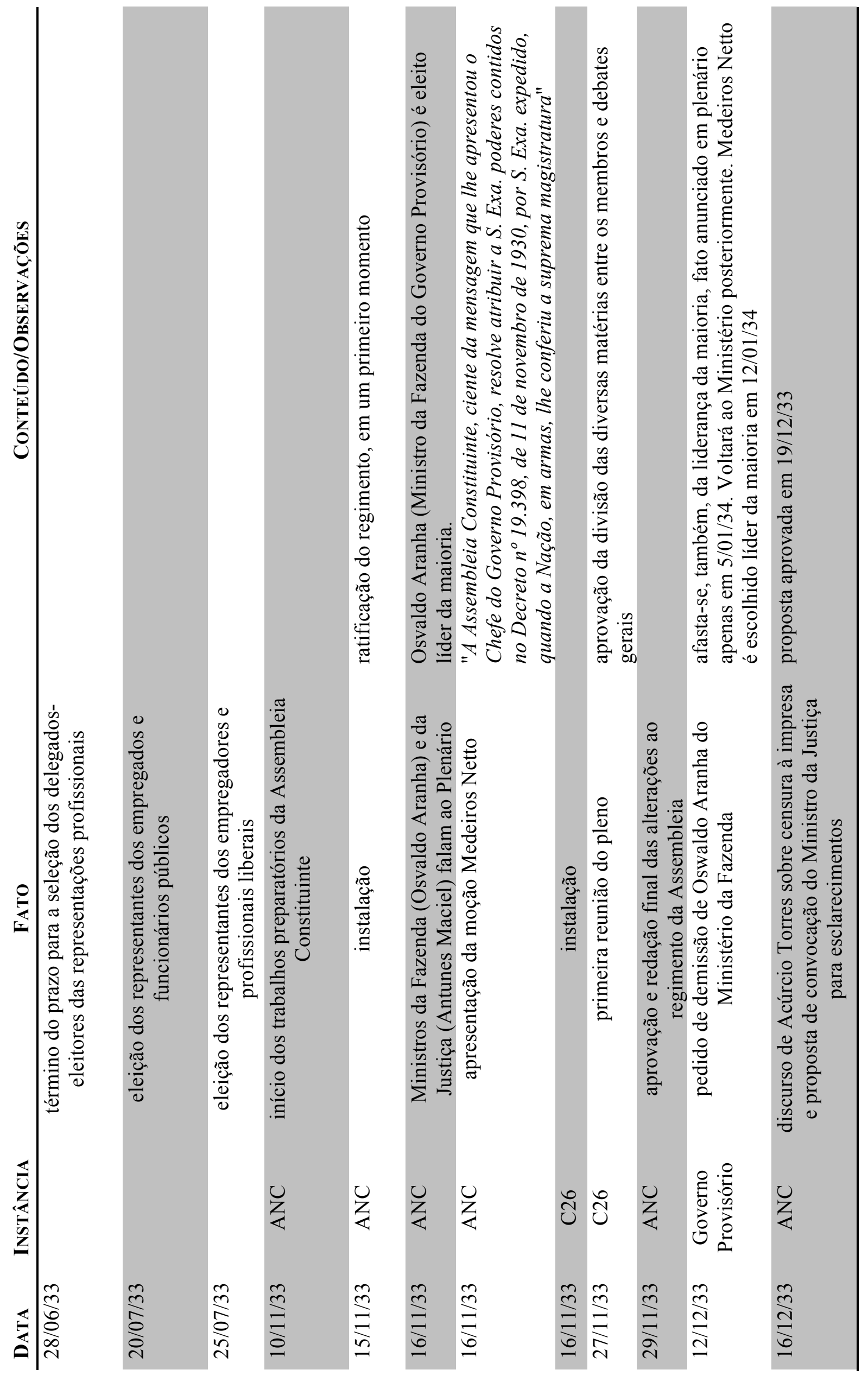




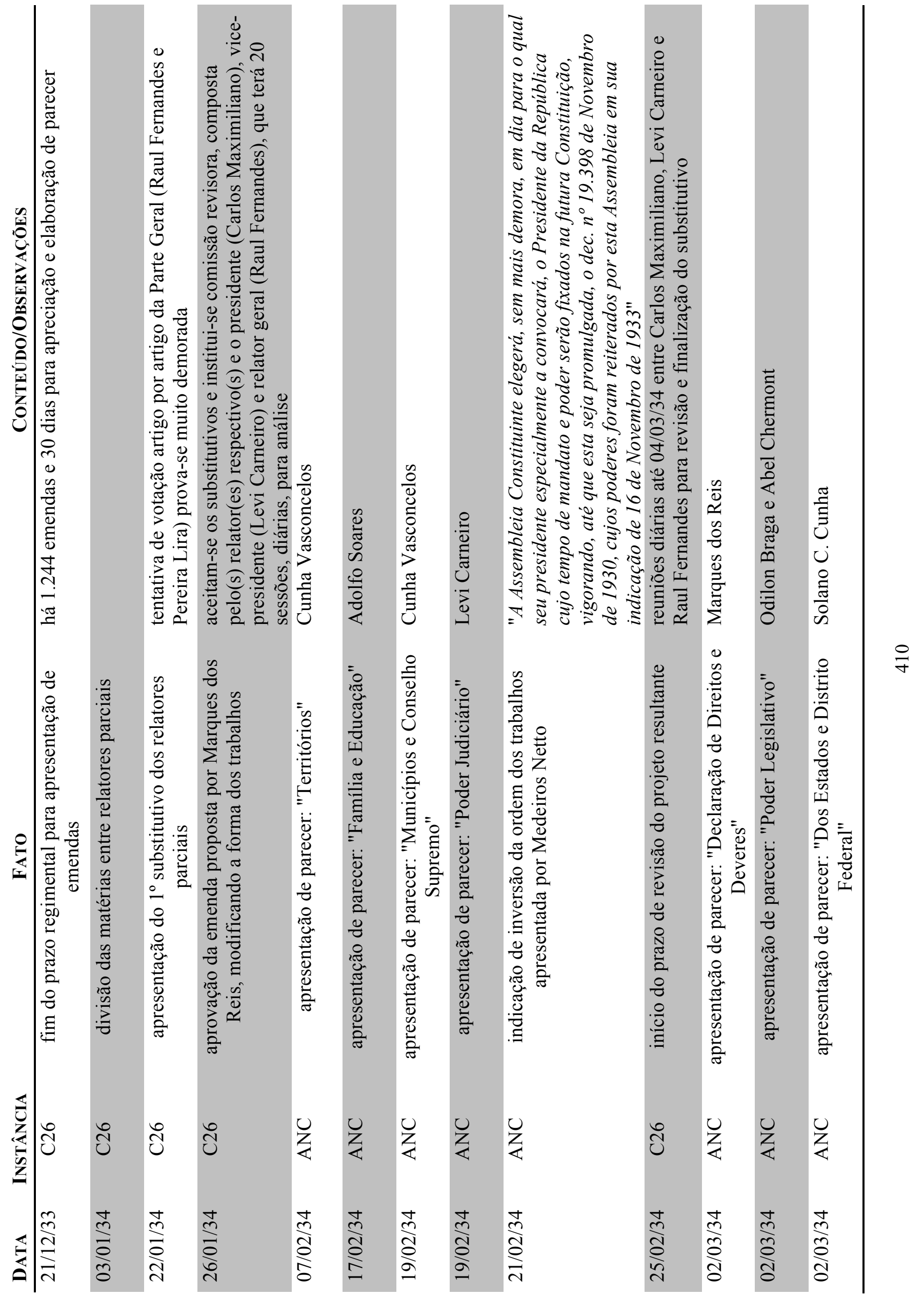



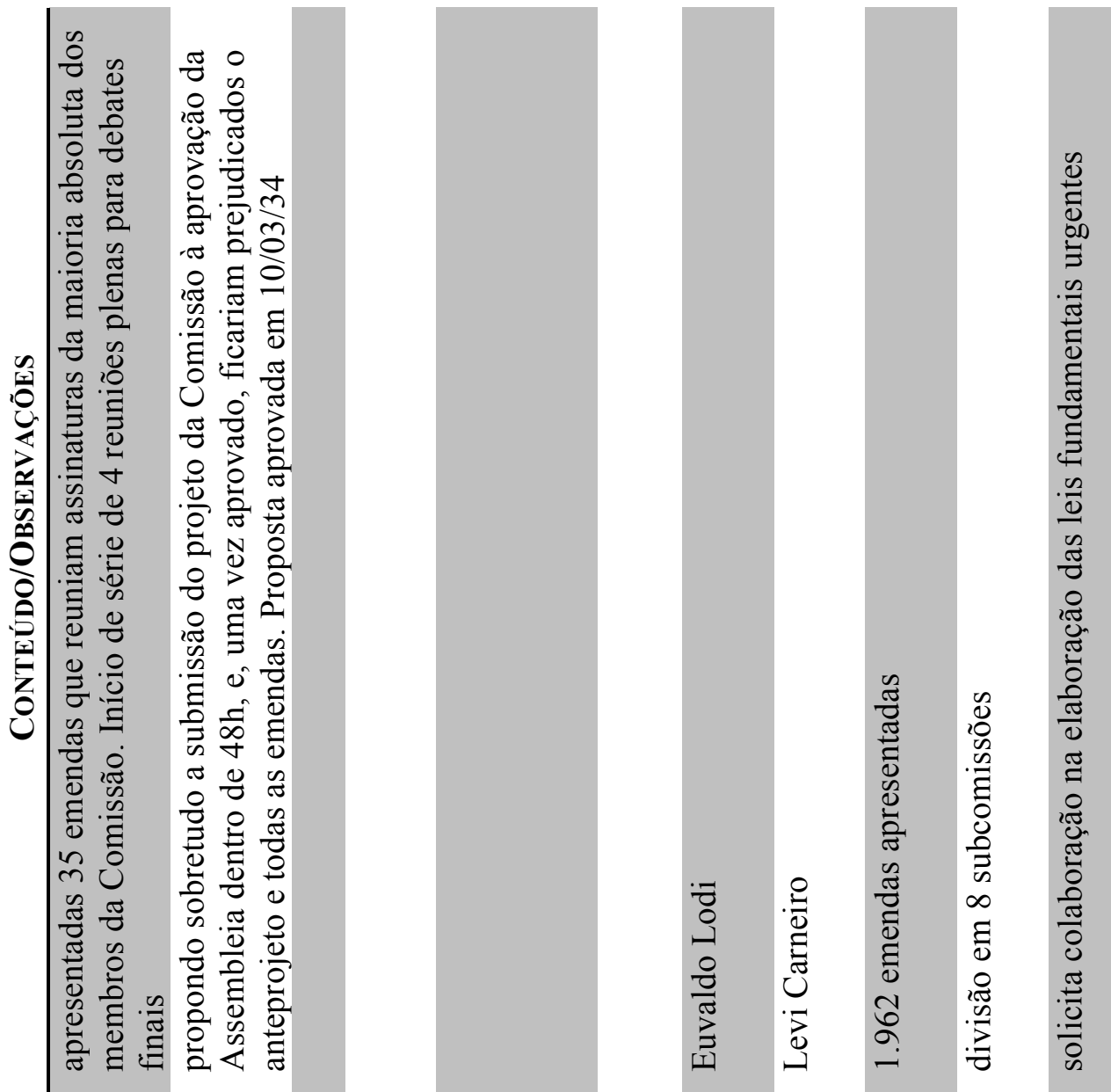

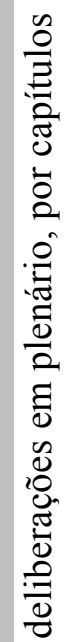

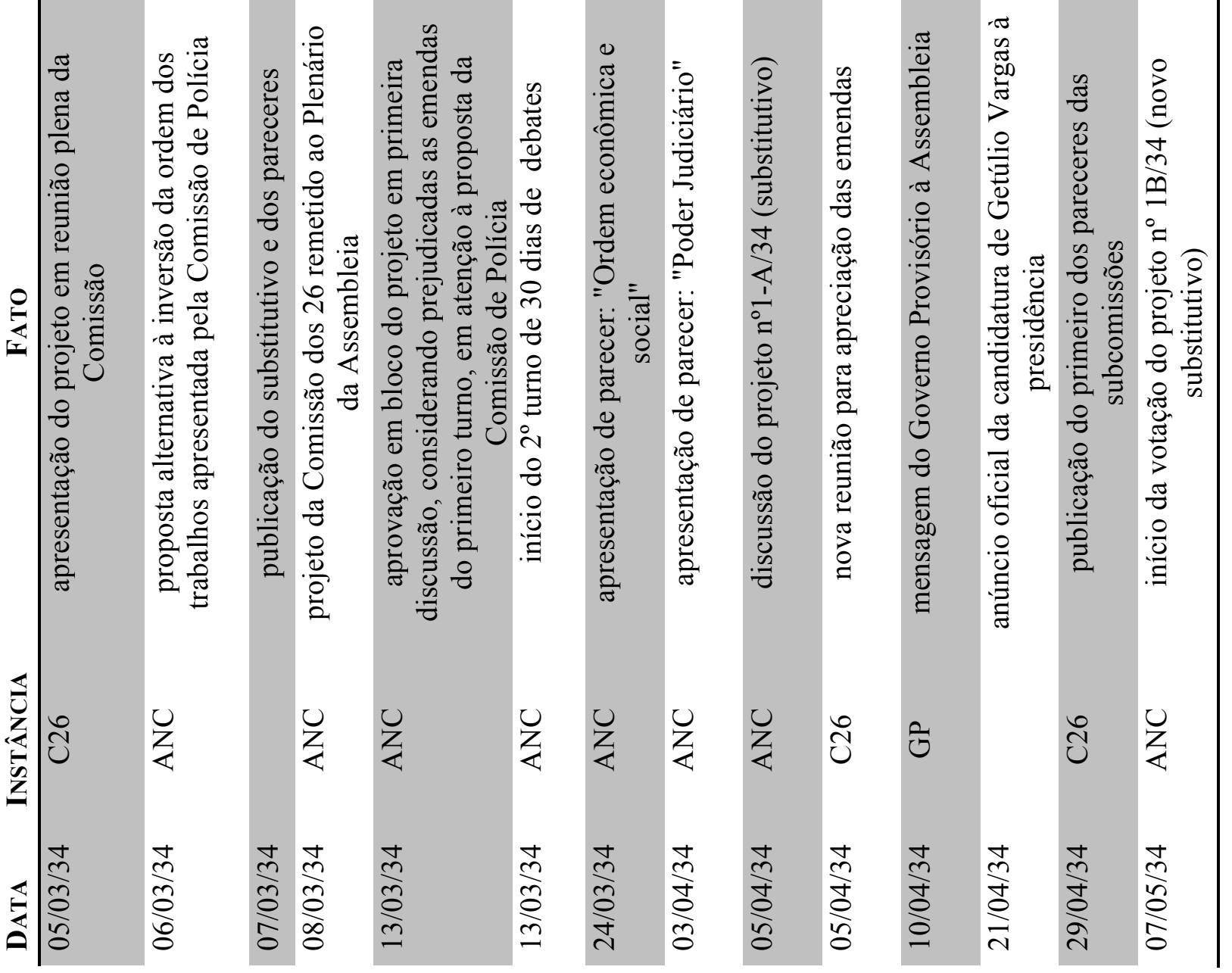




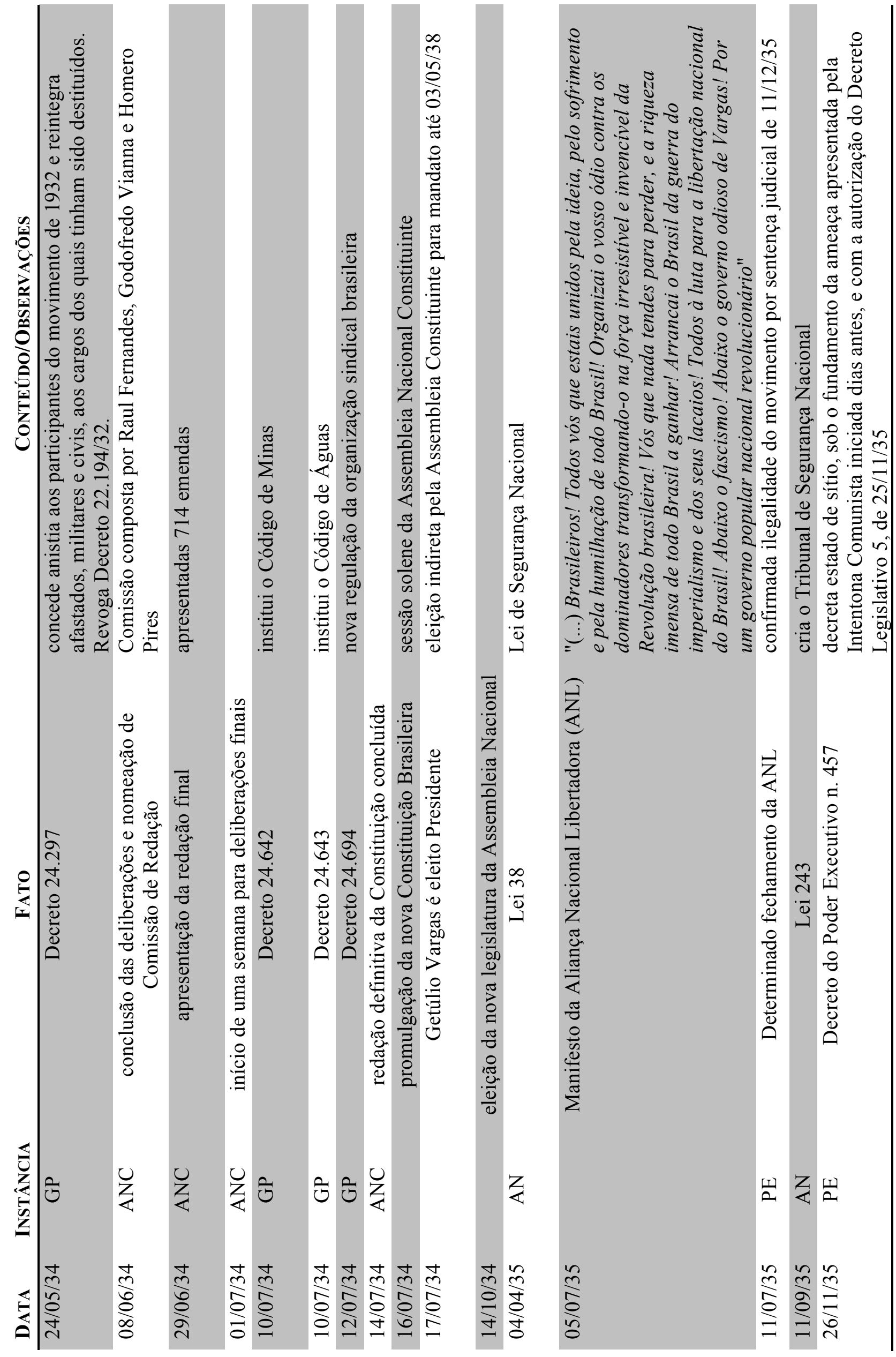




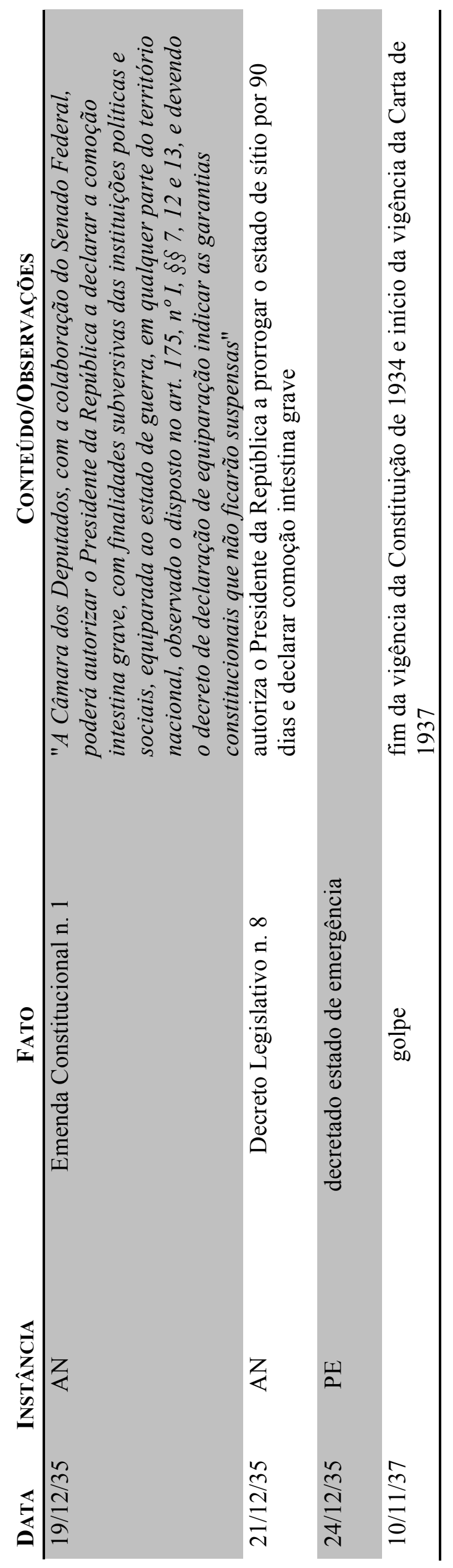




\section{BIBLIOGRAFIA}

\section{INTRODUÇÃO e PARTE I}

\section{I) FONTES PRIMÁRIAS}

\section{Autores anAlisados}

\subsection{Joseph Barthélemy}

BARTHÉLEMY, Joseph (1908). Analyses et comptes rendus - Droit constitutionnel par L. Duguit. Revue du droit public et de la science politique en France et à l'étranger. 152/163.

(1910). Analyses et comptes rendus - Éléments de droit constitutionnel français et comparé par A. Esmein. Revue du droit public et de la science politique en France et à l'étranger, pp. 182/189.

(1920). Le vote des femmes - cours professé à l'école des hautes études sociales pendant l'année 1917-18. Paris: F. Alcan.

(1928). La crise de la démocratie représentative. Revue du droit public et de la science politique en France et à l'etranger, 45, pp. 584/667.

Sirey.

(1931). La crise de la démocratie contemporaine. Paris: Recueil

(1934). La Constitution Doumergue. Revue politique et parlementaire, Paris, oct-déc, pp. 225/247.

Recueil Sirey.

(1935). Valeur de la liberté et adaptation de la République. Paris:

Pygmalion/Gérard Watelet, 1989.

(1989). Ministre de la Justice - Vichy 1941-1943. Paris:

BARTHÉlEMY, Joseph; DUEZ, Paul (1926). Traité de Droit Constitutionnel. Paris: Dalloz, $1^{\text {a }}$ ed.

(1933). Traité de droit constitutionnel. Paris: Dalloz, $2^{\mathrm{a}}$ ed.

\subsection{René Capitant}

CAPITANT, René (1961) (1928). L'illicite - Tome I: L'impératif juridique. Paris: Dalloz.

(2004 (1930)). La coutume constitutionnelle, in Écrits d'entre deuxguerres (1928-1940). Paris: LGDJ, pp. 283/295.

(2004 (1934)). Le droit constitutionnel non écrit, in Écrits d'entre deux-guerres (1928-1940). Paris: LGDJ , pp. 297/304.

(2004 (1935)). Les propos d'Alain ou l'ideologie de la Troisième République, in Écrits d'entre deux-guerres (1928-1940). Paris: LGDJ, pp. 209/230. 
(1936). Discours prononcé par M. René Capitant sur l'oeuvre juridique de Raymond Carré de Malberg. Annales de l'Université de Strasbourg, extrait.

(1937). L'oeuvre juridique de Raymond Carré de Malberg. Archives de Philosophie du droit et de sociologie juridique, v. 1-2, p. 81-93.

(1961). Carré de Malberg et le régime parlementaire. Relation des Journées d'études en l'honneur de Carré de Malberg 1861-1935. Paris: Dalloz, p. 126-160.

(1972). Démocratie et participation politique dans les institutions françaises de 1875 à nos jours. Paris: Bordas.

la Recherche Scientifique.

(1982). Écrits constitutionnels. Paris: Editions du Centre National de

\subsection{Raymond Carré de Malberg}

CARRÉ DE MALBERG, Raymond (2004 (1920)). Contribution à la théorie génerale de l'État. Paris: Dalloz.

(1931a). Considérations théoriques sur la question de la combinaison du referendum avec le parlementarisme. Revue du droit public et de la science politique en France et à l'Etranger, 48, pp. 225-244.

(1931b). La Loi, expression de la volonté générale: Étude sur le Concept de la Loi dans la Constitution de 1875. Paris: Economica.

(1935). Réflexions très simples sur l'objet de la science juridique. In Mélanges François Gény - Recueil d'études sur les sources du droit. Paris: Recueil Sirey, pp. 192-203.

\subsection{Léon Duguit}

DUGUIT, Léon (2003 (1901)). L' État, le droit objectif et la loi positive. Paris: Dalloz.

(1918). Jean-Jacques Rousseau, Kant et Hegel. Revue du Droit Public et de la Science Politique en France et à l'Etranger, v. 35, p. 173-211/325-377.

(1925). Traité de Droit Constitutionnel, 3 ed. Paris: Ancienne

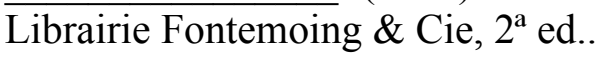

(1927). Traité de Droit Constitutionnel, 3 ed. Paris: Ancienne Librairie Fontemoing \& Cie, $3^{\mathrm{a}}$ ed., v. I, II. Buenos Aires: Heliasta, 1975.

(1975). Las transformaciones del Derecho Publico y Privado. (2002). Souveraneté et Liberté. Paris: La Memoire du Droit.

\subsection{Maurice Hauriou}

HAURIOU, Maurice (2008). Écrits sociologiques. Paris: Dalloz, 2008. droit civil, pp. 795-825.

(1927). L'ordre social, la justice et le droit. Revue trimestrielle de 
(1925a). La théorie de l'institution et de la fondation (essai de vitalisme social). La Cité Moderne et les transformations du droit - Cahiers de la nouvelle journée, Paris, 4.

(1929). Précis de droit constitutionnel. Paris: Recueil Sirey, v. 2 ed.

Recueil Sirey. (1925b). Précis Élémentaire de Droit Constitutionnel. Paris: (1916). Principes de droit public. Paris: Librairie du Recueil Sirey.

\subsection{Boris Mirkine-Guetzévitch}

MIRKINE-GUETZÉVITCH, Boris (1933). As novas tendências do direito constitucional. Tradução de Cândido Motta Filho. São Paulo: Companhia Editora Nacional.

LGDJ.

(1936). Le parlementarisme sous la convention nationale. Paris:

(1934). Le referendum et le régime parlementaire en Europe centrale. La revue des vivants, 10 oct.

(1930). Les Constitutions de l'Europe Nouvelle. 2e. ed. Paris: Lib. Delagrave.

(1928). Les nouvelles tendances du droit constitutionnel. Revue du droit public et de la science juridique en France et à l'étranger, Paris, 48, pp. 5/53.

\section{DEMAIS AUTORES DA ÉPOCA (ANOS 1930 E ANTERIORES)}

BLUM, Léon (1936). La Réforme gouvernementale. Paris: Ed. Bernard Grasset.

BONNARD, Roger (1932). Les idées de Léon Duguit sur les valeurs sociales (avec des inédits de Duguit). Archives de Philosophie du Droit et de Sociologie Juridique, Paris, v. 1-2, pp. 7-13.

(1935). Précis de droit administratif. Paris: Recueil Sirey.

BONNECASE, Julien (1924). L'École de l'Éxegese en droit civil. Paris: E. de Boccard Éditeur.

Bordeaux: Delmas Éditeur, v. t. I e II.

(1933). La pensée juridique français - de 1804 à l'heure présente.

BOUGLÉ, Charles (1904). La démocratie devant la science - études critiques sur l'hérédité, la concurrence et la différentiation. Paris: Felix Alcan.

BOURGEOIS, Léon (1902). Les applications de la solidarité sociale. Revue Politique et Parlementaires, jan, extrait.

(1896). Solidarité. Paris: Arman Colin et Cie.

CHARMONT, Joseph (1903). La socialisation du droit. Revue de Métaphysique et Morale, pp. 380-405.

CONSTANT, Benjamin (1874). Oeuvres Politiques. Paris: Charpentier et cie. 
CUCHE, Paul (1929). À la recherche du fondement du droit: y a-t-il un romantisme juridique? Revue trimestrielle de droit civil.

(1933) À propos du "positivisme juridique" de Carré de Malberg. In Mélanges R. Carré de Malberg. Paris: Recueil Sirey, pp. 73-79.

DESLANDRES, Maurice (1900). La crise de la science politique. Revue du droit public et de la science politique en France et à l'étranger, Paris, p. 5/49, jan-jui.

EISENMANN, Charles (1930). Deux théoriciens du droit: Duguit et Hauriou. Revue Philosophique de la France et de l'Etranger, pp. 231-279.

ESMEIN, Adrémar (1909). Éléments de droit constitutionnel français et comparé. Paris: Recueil Sirey.

GÉNY, François (1995 (1889)). Méthode d'interprétation et sources en droit privé positif. Paris: LGDJ.

(1914). Science et technique en droit privé: nouvelle contribution à la critique de la méthode juridique. Paris: Librairie de la Societé du Recueil Sirey.

GIDE, Charles (1932). La solidarité - cours au Collège de France 1927-28. Paris: PUF.

GUÉRIN, Paul (1939). Le problème français. Paris: Gallimard.

GURVITCH, Georges (1946). La déclaration des droits sociaux. Paris: J. Vrin.

HALÉVY, Daniel (1931). Décadence de la liberté. Paris: Ed. Bernard Grasset.

HELLER, Hermann (2006). Europa y el fascismo. Granada: Comares (publicação em alemão, Europa und der Faschismus, em 1929).

JOLLY, Pierre (1935). La mystique du corporatisme. Paris: Librairie Hachette.

JOSSERAND, Louis (1927). De l'esprit des droits et de leur relativité. Paris: Dalloz.

KELSEN, Hans (1998). Teoria Pura do Direito. Tradução de João Baptista Machado. São Paulo: Martins Fontes.

JAURÉS, Jean (1989). Histoire Socialiste de la révolution française. Paris: Biblioteque du Bicentenaire de la Revolution Française.

Minuir.

(1959). La question religieuse et le socialisme. Paris: Les Éditions de

(1960). Les origines du socialisme allemand. Paris: F. Maspero.

JELLINEK, Georg (1960). L' État moderne et son droit. Paris: F. Maspero.

(1958). Teoría General del Estado. Tradução de Fernando de los Rios Urruti. 2a. ed. Mexico: Compañia Editorial Continental.

LABAND, Paul (1900). Droit public de l'Empire Allemand. Tradução de C. Gandihon. Paris: V. Giard \& Brière.

LAFERRIÈRE, Louis-Firmin (1859). Essai sur l'histoire du droit français depuis les temps aciens jusqu'à nos jours. Paris: Guillaume et Cie.

LASKI, Harold (1932). La conception de l'État de Léon Duguit. Archives de Philosophie du Droit et de Sociologie Juridique, Paris, v. 1-2, pp. 121-134.

Allen \& Unwin.

(1943). Reflections on the revolution of our time. London: George 
LASSALLE, Ferdinand (1933). Que é uma constituição? São Paulo: Edições e publicações Brasil.

LE FUR, Louis (1932). Le fondement du droit dans la doctrine de Léon Duguit. Archives de Philosophie du Droit et de Sociologie, Paris, v. 1-2, pp. 177-211.

MARX, Karl (2010 (1880)). Introduction to the program of the French Workers' Party. In: MARX, Karl. The First International and after - political writings volume 3. London/NY: Verso, pp. 376/377.

MICHOUD, Léon (1932). La théorie de la personnalité morale. 3a. ed. Paris: LGDJ.

PRÉLOT, Marcel (1939). L'évolution politique du socialisme français - 1789-1934. Paris: Spes.

(1924). La représentation professionelle dans la constitution de Weimar et le Conseil économique national. Paris: Éditions Spes, 1924.

(1933). La théorie de l'État dans le Droit fasciste. In:

Mélanges R. Carré de Malberg. Paris: Recueil Sirey, pp. 435-466.

REYNAUD, Louis (1938). La démocratie en France - ses origines, ses luttes, sa philosophie. Paris: Ernest Flammarion.

SAVIGNY, Friedrich Karl von (1979). Metodología Jurídica. Tradução de J. J. SantaPinter. Buenos Aires: De Palma.

Librairie de Firmin Didot Freres.

(1858). Traité de Droit Romain. Tradução de Ch. Guenoux. Paris:

SEIGNOBOS, Charles (1921). Histoire de la France Contemporaine, depuis la Révolution jusqu'à la paix de 1919. Paris: Librairie Hachette, v. VIII.

TARDE, Gabriel (1893). Les transformations du droit - étude sociologique. Paris: Ancienne Librairie Germer Baillière et Cie.

ZOLA, Émile (1889). J'accuse.! L'Aurore, $1^{\circ}$ de janeiro.

\section{II) FONTES SECUNDÁRIAS}

(1992). Apports de René Capitant à la Science juridique. Association Henri Capitant des amis de la culture juridique française, Université Panthéon-Sorbonne (Paris I), Université Panthéon-Assas (Paris II). Paris.

ARABEYRE, Patrick; HALPÉRIN, Jean-Louis.; KRYNEN, Jacques (2007). Dictionnaire historique des juristes français (XIIe-XXe siècle). Paris: PUF.

ARNAUD, André-Jean; ARNAUD, Nicole (1975). Le socialisme juridique à la "belle époque": visages d'une aberration. Quaderni Fiorentini per la storia del pensiero giuridico moderno, Milão, v. 3.

ARNAUD, André-Jean (1975). Les juristes face à la societé - du XIXe. siècle à nos jours. Paris: PUF.

ATIAS, Christian (1991). Philosophie du droit: les enjeux d'une fin de siècle. In: PLANTY-BONJOUR, Guy; LEGEAIS, Raymond. L'évolution de la philosophie du 
droit en Allemagne et en France depuis la fin de la seconde guerre mondiale. Paris: PUF, pp. 235-273.

AUDREN, Frédéric (2008). La belle époque des juristes catholiques (1880-1914). Revue française d'histoire des idées politiques, n. 28, pp. 233/271.

AUDREN, Frédéric; HALPÉRIN, Jean-Louis (2001). La science juridique entre politique et sciences humaines (XIXème-XXème siècles). Revue d'histoire des sciences humaines, v. 1, n. 4.

AUDREN, Frédéric; MILLET, Marc (2008). Maurice Hauriou sociologue - entre sociologie catholique et psyque sociale (préface). In: HAURIOU, Maurice. Écrits sociologiques. Paris: Dalloz.

BARRAL, Pierre (1968). Les fondateurs de la Troisième République. Paris: Armand Colin.

BEAUD, Olivier (1994). La souveraineté dans la Contribution à la théorie générale de l'État de Carré de Malberg. Droits. Revue du droit public et de la science politique en France et à l'Etranger, pp. 1299-1300.

(1997). Carré de Malberg, juriste alsacien. La biographie comme élément d'explication d'une doctrine constitutionnelle. In: BEAUD, Olivier; WACHSMANN, Patrick. La science juridique française et la science juridique allemande de 1870 à 1918. Strasbourg: Presses Universitaires de Strasbourg, 1997, p. 219-254.

(2000). Joseph Barthélemy ou la fin de la doctrine constitutionnelle classique. Droits, Revue Française de Théorie, Philosophie et Culture Juridique, v. 32, pp. 89-108.

(2003). La crise de la IIIe République sous le regard du jeune René Capitant. In: HERRERA, Carlos Miguel. (dir.). Les juristes face au politique - le droit, la gauche, la doctrine. Paris: Kimé, pp. 147-192.

(2004). Découvrir un grand juriste: "le premier" René Capitant (préface). In: CAPITANT, René. Écrits d'entre-deux-guerres (1928-1940). Paris: Ed. Panthéon-Assas, pp. 7-53.

BONNEFOUS, Édouard (1959). Histoire politique de la Troisième République. Paris: PUF, v. III, IV, V, VI.

BOURDIEU, Pierre (1991). Les juristes, gardiens de l'hypocrisie collective. In: CHAZEL, François; COMMAILE, Jacques. Normes juridiques et régulation sociale. Paris: LGDJ.

BURDEAU, Georges (1961). L'apport de Carré de Malberg à la théorie de la loi. Relation des Journées d'études en l'honneur de Carré de Malberg. Paris: Dalloz, pp. 98111.

CHAZEL, François; COMMAILE, Jacques (1991). Normes Juridiques et Régulation Sociale. Paris: LGDJ.

CONAC, Gérard (1992). L'apport de René Capitant au droit constitutionnel et à la science politique. In Apports de René Capitant à la Science juridique. Paris: Litec, pp. 53-86.

DE BAECQUE, Antoine (dir.) (1991). Une histoire de la démocratie en Europe. Paris: Le Monde Éditions. 
DE LAUBADÈRE, André (1969). Le Doyen Maurice Hauriou et Léon Duguit. La pensée du Doyen Maurice Hauriou et son influence (journées Hauriou, Toulouse, mars 1968)). Paris: A. Pédone, pp. 209-228.

DEROUSSIN, David (2007). Le renouvellement des sciences sociales et juridiques sous la IIIe République - La Faculté de Droit de Lyon. Paris: Ed. La Memoire du Droit.

DOAT, Jacques, LE GOFF, Jacques et al (2007). Droit et complexité - pour une nouvelle intelligence du droit vivant. Rennes: Presses Universitaires de Rennes.

DOCKÉS, Emmanuel (2007). Au coeur des combats juridiques - pensées et témoignages de juristes engagés. Paris: Dalloz,.

DUBY, Georges; MANDROU, Robert (1984). Histoire de la civilisation française XVIIe-XXe siècle. Paris: Armand Colin, v. II.

DUFOUR, Alfred (1987). Savigny, la France et la Philosophie Allemande. Tijdschrift von Rechtsgeschiednis, 55, pp. 151/163.

DURKHEIM, Émile (2000). O que é o fato social? In: RODRIGUES, J. A. (. ). Durkheim. São Paulo: Ática, pp. 46-52.

FARIAS, José Fernando de Castro (1999). A teoria do estado no fim do século XIXe no início do século XX - os enunciados de Léon Duguit e Maurice Hauriou. Rio de Janeiro: Lúmen Júris.

FOULQUIER, Norbert (2009). Maurice Hauriou, constitutionnaliste (1856-1929). Jus Politicum. Revue internationale de droit politique, n. 2, pp. 1/31.

FOULQUIER, Norbert; SACRISTE, Guillaume (2010). avant-propos de SALEILLES, Raymond, Le droit constitutionnel de la Troisième République. Paris: Dalloz.

GAUDEMET, Yves-Henri (1970). Les juristes et la vie politique de la Trosième Republique. Paris: PUF.

GORDLEY, James (1994). Myths of the French Civil Code. The American Journal of Compartative Law, v. 42, n. 3, pp. 459/505.

GRZEGORCZYK, Christophe; MICHAUT, François; TROPER, Michel (1992). Le positivisme juridique. Paris: LGDJ.

HAKIM, Nader; MELLERAY, Fabrice (2009). Le renouveau de la doctrine française. Paris: Dalloz.

HARVEY, David (2003). Paris, capital of modernity. New York: Routledge.

HAURIOU, André (1969). Les derniers aspects de la pensée du Doyen Maurice

Hauriou. La pensée du Doyen Maurice Hauriou et son influence (journées Haurou, Toulouse, mars 1968). Paris: A. Pédone, pp. 128-140.

HÉRAUD, Guy (1961). La conception du pouvoir constituant dans l'oeuvre de Carré de Malberg. Relation des Journées d'études en l'honneur de Carré de Malberg 1861-1935. Paris: Dalloz, pp. 78-97.

HERRERA, Carlos Miguel (dir.). (2005). Les juristes face au politique - le droit, la gauche, la doctrine sous la Troisième République. Paris: Kimé, v. I-II.

(2011). La Constitution de Weimar et la pensée juridique française - réceptions, métamorphoses, actualités. Paris: Kimé, 2011. 
HERRERA, Carlos Miguel (1995). Le Droit, le Politique - autour de Weber, Hans Kelsen, Carl Schmitt. Paris: L'Harmattan.

(1997). Duguit et Kelsen : la théorie juridique, de l'épistémologie au politique. In: BEAUD, Olivier; WACHSMANN, Patrick. La science juridique française et la science juridique allemande de 1870 à 1918. Strasbourg: Presses Universitaires de Strasbourg, pp. 326/345. de l'Université Laval.

(2003). Droit et Gauche - pour une identification. Québec: Presses

(2007). Doctrine juridique et politique: à la recherche du regard interne. In: DOAT, Jacques, LE GOFF, Jacques et al. Droit et complexité - pous une nouvelle intelligence du droit vivant. Rennes: Presses Universitaires de Rennes, pp. 8392.

(2008). La pensée constitutionnelle du social. Droits, Revue Française de Théorie, Philosophie et Culture Juridique, Paris, v. 48, p. 179/199. (2009). Les droits sociaux. Paris: PUF. (2009). Préface à La Déclaration des droits sociaux. Paris: Dalloz.

HESPANHA, Antonio Manuel (2003). Cultura juridica européia: síntese de um milênio. 3a. ed. ed. Mira-Sintra: Publicações Europa-América.

Histoire politique de la Troisième République. France Politique, maio 2001. Disponivel em: <http://www.france-politique.fr $>$. Acesso em: 12 de maio 2011.

HOBSBAWN, Eric (1996). The Age of Extremes - A History of the World, 1914-1991. New York: Vintage Books.

JAMIN, Chistophe (2003). Dix-neuf cent: crise et renouveau dans la culture juridique. In: ALLAND, Denis; RIALS, Stéphane. Dictionnaire de la culture juridique. Paris: PUF, pp. 380-384.

JESTAZ, Philippe; JAMIN, Christophe (2004). La doctrine. Paris: Dalloz.

JONES, Henry Stuart (1993). The French State in Question - Public Law and political argument in the Third Republic. Cambridge: Cambridge Univesity Press.

KOSELLECK, Reinhart (1999). Crítica e crise - Uma contribuição à patogênese do mundo burguês. Rio de Janeiro: Ed. UERJ: Contraponto.

(1990). Histoire des concepts et histoire sociale. In: KOSELLECK, R. Le Futur Passé - contribution à la sémantique des temps historiques. Tradução de Jochen Hoock e Marie-Claire Hoock. Paris: Éd. de l'École des hautes études en sciences sociales, pp. 99-118.

LARENZ, Karl (1991). Metodologia da ciência do direito. 6a. ed. Lisboa: Calouste Gulbenkian.

LE BRAZIDEC, Gwénaël (1998). René Capitant, Carl Schmitt - crise et réforme du parlementarisme: de Weimar à la Cinquième République. Paris: L'Harmattan.

. Les législatures de la Troisième République. Assemblée Nationale. Disponivel em: $<$ http://assemblee-nationale.fr/>. Acesso em: 12 de maio 2011. 
LOCHAK, Danièle (1989). La doctrine sous Vichy ou les mésaventures du positivisme. In: LOCHAK, Danièle. Les usages sociaux du droit. Paris: PUF.

MAIER, Charles (1988). Recasting Bourgeois Europe - stabilization in France, Germany, and Italy in the decade after World War I. Princeton: Princeton University Press.

MARTINEZ, Gilles (1998). Joseph Barthélemy et la crise de la démocratie libérale. Vingtième Siècle. Revue d'histoire, juil-sep, pp. 28/47.

MARTY, Gabriel (1969). La théorie de l'institution. La pensée du Doyen Maurice Hauriou et son influence (journées Hauriou, Toulouse, mars 1968). Paris: A. Pédone, pp. $29-45$.

MAULIN, Éric (2003). La théorie de l'État de Carré de Malbrg. Paris: PUF.

MAYER, Arno J (1981). The persistence of the old regime - Europe to the Great War. New York: Pantheon Books.

MAYEUR, Jean-Marie (2001). La vie politique sous la Troisième République 18701940. Paris: Points.

MAYEUR, Jean-Marie; REBIRIOUX, Madeleine (1987). The Third Republic from its Origins to the Great War, 1871-1914. Cambridge: Cembridge University Press.

MELLERAY, Fabrice (2001). École de Bordeaux, école du service public et école duguiste. Revue du Droit Public, n. 6, nov-dec, pp. 1887-1905.

NOUREAUD, Pierre (1998). The sociology of Law in France, trends and paradigms. Journal of Law and Society, v. 25, n. 2, p. 257/283, junho.

PACTEAU, Bernard (2010). Léon Duguit à Bordeaux, un doyen dans sa ville. Droits. Revue du Droit Public et de la Science Politique en France et à l'Etranger, p. 505.

PINON, Stéphane (2008). Boris Mirkine-Guetzévitch et la diffusion du droit constitutionnel. Droits. Revue française de théorie, de philosophie et de culture juridiques, Paris, v. 48, pp.183/212.

(2010). Léon Duguit face à la doctrine constitutionnelle naissante. Droits. Revue du Droit Public et de la Science Politique en France et à l'Etranger, v. 2, p. 523.

(2005). Les idées constitutionnelles de Boris Mirkine-Guetzévitch. In: HERRERA, Carlos Miguel. Les juristes face au politique - le droit, la gauche, la doctrine sous la troisième République, Paris: Kimé, t. II, pp. 61/123.

(2003). Les réformistes constitutionnels des années trente: aux origines de la Ve République. Paris: LGDJ.

PISIER-KOUCHNER, Evelyne (1976). Le service public dans la théorie de l'Etat de Léon Duguit. Paris: LGDJ.

POCOCK, John Greville Agard (2003). Linguagens do ideário político. Sérgio Micelli (org.) Fábio Fernandez (trad.). São Paulo: Edusp.

REDOR, Marie Joelle (1992). De l'État legal à l'État de droit: l'évolution des conceptions de la doctrine publiciste française 1879-1914. Paris: Economica/Presses Universitaires d'Aix-Marseille. 
RÉMOND, René (1966). The right wing in France - from 1815 to de Gaulle. Philadelphia: University of Pennsylvania Press.

ROBERT, Jacques (1992). L'apport de René Capitant à la théorie générale du droit. In: Apports de René Capitant à la Science Juridique. Paris: Litec, pp. 17-30.

ROSANVALLON, Pierre (2000). La démocratie inachevée - histoire de la souveraineté du peuple en France. Paris: Gallimard.

SACRISTE, Guillaume (2011). Le droit constitutionnel de la République naissante: collusions entre sphère politique et doctrine au nom du nouveua régime. In: STORALAMARRE, Annie; HALPÉRIN, Jean-Louis; AUDREN, Frédéric. La République et son droit (1870-1930). Besançon: Presses Universitaires de Franche-Comté, pp. 383/408.

(2002). Le droit de la République (1870-1914): légitimation(s) de l'État et construction du rôle de professeur de droit constitutionnel au début du siècle: thèse de doctorat - Paris I (Panthéon-Sorbonne).

SAULNIER, Frédéric (2004). Joseph Barthélemy ou la crise du constitutionalisme libéral sous la Troisième République. Paris: LGDJ.

SHIRER, William (1969). The Collapse of the Third Republic - An Inquiry into the Fall of France in 1940. New York: Simon and Schuster.

SICART, Giles (2000). La doctrine publiciste française à l'epreuve des années 1930. Paris: thèse, Université Panthéon-Assas (Paris II).

SKINNER, Quentin (1969). Meaning and understanding in the History of Ideas. History and Theory. Vol. 8, n.1, pp. 3/53.

STOLLEIS, Michael (2001). Public Law in German 1800-1914. Nova York: Berghan Books.

STORA-LAMARRE, Annie (2005). La République des faibles - les origines intellectielles du droit républicain 1870-1914. Paris: Armand Colin.

SZRAMKIEWICZ, Romuald; BOUINEAU, Jacques (1989). Histoire des Institutions 1750-1914 - droit et société en France de la fin de l'Ancien Régime à la Première Guerre mondiale. Paris: Librairie de la Cour de cassation.

TARELlo, Giovanni (1995). Cultura Jurídica y Política del Derecho. Mexico: Fondo de Cultura Económica.

TARTAKOWSKY, Danielle (1998). Le pouvoir est dans la rue - crises politiques et manifestations en France. Paris: Aubier.

THOMSON, David (1952 (1946)). Democracy in France - the Third and Fourth Republics. 2. ed. ed. London: Oxford University Press.

TROPER, Michel (1989). La doctrine et le positivisme (à propos d'un article de Danièle Lochak. In: LOCHAK, Danièle. Les usages sociaux du droit. Paris: PUF.

VEDEL, Georges (1969). Le Doyen Hauriou et la Science Politique. La pensée du Doyen Maurice Hauriou et son influence (journées Hauriou, Toulouse, mars 1968). Paris: A. Pédone, pp. 91-109.

VIRALLY, Michel (1961). Carré de Malberg et la démocratie parlementaire. Relation des Journées d'études en l'honneur de Carré de Malberg 1861-1935. Paris: Dalloz, pp. 161177. 
WALINE, Marcel (2007 (1949)). L'individualisme et le Droit. Paris: Dalloz.

(1977). Le mouvement des idées constitutionnelles dans les facultés de droit françaises au cours du premier tiers du XXe siècle. In: Histoire des idées et idées sur l'histoire - études offertes à Jean-Jacques Chevallier. Paris: Ed. Cujas, pp. 259-269.

Le positivisme juridique de Carré de Malberg. Relations des Journées d'études em l'honneur de Carré de Malberg 1861-1935. Paris: Dalloz, pp. 20-45.

(1933). Positivisme philosophique, juridique et sociologique. In: Mélanges R. Carré de Malberg. Paris: Recueil Sirey, pp. 519-533.

WEYL, Roland; PICARD WEYL, Monique (1975). Socialisme et justice dans la France de 1895: le "bon juge Magnaud". Quaderni Fiorentini per la storia del pensiero giuridico moderno, Milão, v. 3.

WIEACKER, Franz (1967). História do Direito Privado Moderno. Tradução de A. Hespanha. 3a. ed. Lisboa: Calouste Gulbenkian.

WILHELM, Walter (1980). La metodología jurídica en el sigo XIX. Madrid: Edersa.

\section{Parte II e Conclusão}

\section{I) FONTES PRIMÁRIAS}

\section{SUBCOMISSÃo ITAMARATY}

Referência:

AZEVEDO, José Afonso de Mendonça (2004). Elaborando a Constituição Nacional [atas da subcomissão elaboradora do anteprojeto 1932/1933]. Brasília: Ed. fac-similar, Senado Federal.

Sessões (datas, páginas)

$1^{\mathrm{a}}(11 / 11 / 1932,9 / 14), 2^{\mathrm{a}}(15 / 11 / 1932,14 / 25), 3^{\mathrm{a}}(18 / 11 / 1932,25 / 42), 4^{\mathrm{a}}(21 / 11 / 1932$, $42 / 64), 5^{\mathrm{a}}(28 / 11 / 1932,64 / 78), 6^{\mathrm{a}}(1 / 12 / 1932,78 / 101), 7^{\mathrm{a}}(3 / 12 / 1932,101 / 117), 8^{\mathrm{a}}$ $(7 / 12 / 1932,117 / 134), \quad 9^{\mathrm{a}}(8 / 12 / 1932,134 / 161), \quad 10^{\mathrm{a}}(14 / 12 / 1932,161 / 179), \quad 11^{\mathrm{a}}$ $(15 / 12 / 1932,179 / 195), 12^{\mathrm{a}}(19 / 12 / 1932,195 / 217), 13^{\mathrm{a}}(22 / 12 / 1932,217 / 238), 14^{\mathrm{a}}$ (26/12/1932, 238/259), $15^{\mathrm{a}}(29 / 12 / 1932,259 / 279), 16^{\mathrm{a}}(02 / 01 / 1933,279 / 300), 17^{\mathrm{a}}$ (s.d., 300/303), $18^{\mathrm{a}}$ (s.d., 303/329), 19 $(12 / 01 / 1933,329 / 363), 20^{\mathrm{a}}$ (s.d., 363/386), $21^{\mathrm{a}}$

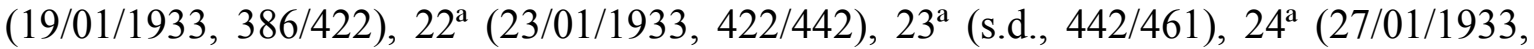
$461 / 486), 25^{\mathrm{a}}(31 / 01 / 1933,486 / 511), 26^{\mathrm{a}}(02 / 02 / 1933,511 / 541), 27^{\mathrm{a}}(03 / 02 / 1933$, 541/564), 28 $8^{\text {a }}(06 / 02 / 1933,564 / 586), 29^{\text {a }}(09 / 02 / 1933,586 / 608), 30^{\text {a }}$ (s.d., 608/623), $31^{\text {a }}$ (16/02/1933, 623/639), 32 ${ }^{\mathrm{a}}(17 / 02 / 1933,640 / 657), 33^{\mathrm{a}}(20 / 02 / 1933,657 / 681), 34^{\mathrm{a}}$

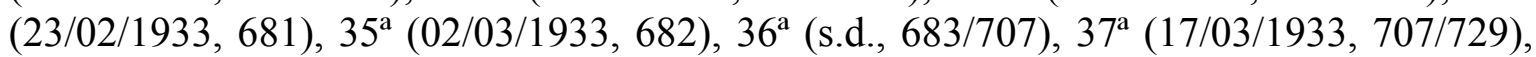
$38^{\mathrm{a}}$ (s.d., 729/755), 39 a $(23 / 03 / 1933,755 / 787), 40^{\mathrm{a}}(27 / 03 / 1933,787 / 813), 41^{\mathrm{a}}(30 / 03 / 1933$, $813 / 841), 42^{\mathrm{a}}(31 / 03 / 1933,841 / 854), 43^{\mathrm{a}}(03 / 04 / 1933,854 / 883), 44^{\mathrm{a}}(06 / 04 / 1933$, $883 / 915), 45^{\text {a }}(07 / 04 / 1933,915 / 932), 46^{\text {a }}(10 / 04 / 1933,932 / 951), 47^{\text {a }}(17 / 04 / 1933$, 951/968), 48 ${ }^{\text {a }}(24 / 04 / 1933,968 / 987), 49^{\text {a }}(25 / 04 / 1933,987 / 1000), 50^{\text {a }}(29 / 04 / 1933$, $1000 / 1016), 51^{\text {a }}(05 / 05 / 1933,1016)$

\section{Anais da Assembleia Nacional Constituinte}


Referência:

(1936), Annaes da Assembleia Nacional Constituinte - organizados pela Redação dos Annaes e Documentos Parlamentares. Rio de Janeiro: Imprensa Nacional, vol. I a XXII.

2.1 Discursos consultados (volume, páginas):

* discursos em que são citados também os apartes de outros deputados

Aarão Rebelo, 04/04/1934 (XIII, 175/190)

Abelardo Marinho, 06/03/1934 (IX, 305/341), 28/02/1934 (IX, 54/77)

Acir Medeiros, 06/02/1934 (VII, 456/486), 07/02/1934 (VII, 480/486), 11/04/1934 (XIV, 81/89)

Agamenon de Magalhães, 04/12/1933 (II, 65/78*), 11/12/1933 (II, 201/211)

Agenor Monte, 30/04/1934 (XVI, 173/181)

Alberto Surek, 29/01/1934 (VII, 48/60)

Annes Dias, 20/02/1934 (VIII, 200/216)

Antônio Covello, 25/04/1934 (XV, 457/470)

Arruda Falcão, 20/11/1933 (I, 278/282)

Assis Brasil, 21/12/1933 (II, 502/505)

Augusto de Lima, 23/01/1934 (VI, 364/365)

Belmiro de Medeiros, 09/01/1934 (V, 500/506), 27/04/1934 (XVI, 48/55)

Carlos Maximiliano, 27/11/1933 (I, 421/437)

Carlota de Queiroz, 13/03/1934 (268/281), 14/04/1934 (XIV, 491/512)

Deodato Maia, 26/02/2934 (VIII, 424/435)

Domingos Velasco, 06/04/1934 (XIII, 293/298)

Edward Possolo, 27/02/1934 (VIII, 501/514)

Fabio Sodré, 06/12/1933 (II, 98/107*), 17/11/1933 (I, 203/210)

Fernando de Abreu, 01/12/1933 (II, 32/34)

Fernando Magalhães, 20/02/1934 (VIII, 217/221)

Ferreira de Souza, 10/04/1934 (XIII, 557/xxx)

Francisco Moura, 05/03/1934 (IX, 268/275)

Getúlio Vargas, discurso inaugural (I, 45/125)

Godofredo de Menezes, 21/03/1934 (XII, 93/99)

Guaracy Silveira, 13/12/1933 (II, 272/281), 27/02/1934 (VIII, 477/481)

Guilherme Plaster, 16/04/1934 (XV, 24/27)

Henrique Dodsworth, 20/22/1933 (I, Xx)

Homero Pires, 05/12/1933 (II, 81/84*), 30/11/1933 (II, 21/23*)

Horácio Lafer, 16/01/1934 (VI, 106/110*), 16/12/1933 (II, 320/332), 21/03/1934 (XII, 206/212)

Humberto Moura, 28/04/1934 (XVI, 92/98)

Jacques Montandon, 11/04/1934 (XIV, 74/81)

João Guimarães, 14/04/1934 (XIV, 480/491)

João Pinheiro Filho, 21/02/1934 (VIII, 248/257)

João Simplício, 15/12/1933 (II, 309/315), 20/03/1934 (XII, 8/13)

João Vilasboas, 07/04/1934 (XIII, 359/366)

João Vitáca, 07/03/1934 (IX, 372/376)

José Carlos, 10/03/1934 (XI, 47/58)

Juarez Távora (Ministro da Agricultura), 02/04/1934 (XIII, 28/47)

Lacerda Werneck, 05/01/1934 (V, 399/414), 17/02/1934 (VIII, 166/183), 30/01/1934 (VII, 79/85*) 
Levi Carneiro, 02/12/1933 (II, 40/52*), 07/03/1934 (IX, 395/411), 18/11/1933 (I, 248/253)

Levindo Coelho, 11/04/1934 (XIV, 65/xxx)

Mario Manhães, 03/04/1934 (XIII, 142/147)

Mario Ramos, 14/03/1934 (XI, 306/313), 22/01/1934 (VI, 320/331*), 06/12/1934 (II, $107 / 115)$

Marques dos Reis, 18/01/1934 (VI, 201/218*)

Martins e Silva, 28/03/1934 (XII, 462/477), 29/11/1933 (I, 450/455*)

Mata Machado, 04/04/1934 (XIII, 173/175)

Maurício Cardoso, 18/04/1934 (XV, 197/209)

Miguel Couto, 16/02/1934 (VIII, 75/84)

Moraes Leme, 27/02/1934 (VIII, 519/523)

Morais Andrade, 08/12/1933 (II, xx)

Negreiros Falcão, 12/04/1934 (XIV, 406/415)

Nereu Ramos, 17/02/1934 (VIII, 159/165)

Nilo Alvarenga, 22/12/1933 (II, 543/548)

Odilon Braga, 03/05/1934 (XVI, 252/271), 16/11/1933 (I, 184/185), 25/11/1933 (I, 389/390)

Pacheco e Silva, 11/04/1934 (XIV, 68/73), 20/02/1934 (VIII, 222/228)

Pedro Aleixo, 15/03/1934 (XI, 397/410*)

Pedro Rache, 06/01/1934 (V, 440/444*)

Pedro Vergara, 25/04/1943 (XV, 470/483)

Pereira Lira, 14/03/1934 (XI, 332/342), 19/04/1934 (XV, 227/236), 28/02/1934 (IX, 12/19)

Pontes Vieira, 11/04/1934 (XIV, 40/49), 18/12/1933 (II, 382/395), 22/11/1933 (I, 312/313)

Prado Kelly, 22/02/1934 (VIII, 300/309), 23/03/1934 (XII, 252/272)

Raul Bittencourt, 18/04/1934 (XV, 184/197)

Raul Fernandes, 23/03/1934 (XII, 234/246)

Roberto Simonsen, 13/03/1934 (XI, 282/288), 30/01/1934 (VII, 85/93), 30/01/1934 (VII, $\left.115 / 136^{*}\right)$

Rodrigues Dória, 06/04/1934 (XIII, 313/319)

Soares Filho, 19/01/1934 (VI, 256/265*)

Teotônio Monteiro de Barros, 18/01/1934 (VI, 232/253)

Valdemar Falcão, 09/04/1934 (XIII, 392/xxxx)

Valdemar Reikdal, 02/04/1934 (XIII, 60/66)

Vasco de Toledo, 05/12/1933 (II, xx)

Vitor Russomano, 15/01/1934 (VI, 43/52)

Zoroastro Gouveia, 23/12/1933 (V, 34/40), 24/02/1934 (VIII, 404/409), 26/12/1933 (V, 81/99)

2.2 Outros documentos (volume, páginas)

Programa do Clube 3 de outubro (III, 187/244)

Pareceres parciais e substitutivos (X, 3/101)

Pareceres e substitutivos às emendas apresentadas em $1^{\text {a }}$ discussão

Direitos e Deveres (XVIII, 369/492)

Ordem econômica e social/ Família e Educação (XIX, 214/485)

\section{DOCUMENTOS LEGISLATIVOS}

Constituição da República dos Estados Unidos do Brasil de 24 de fevereiro de1891

Constituição da República dos Estados Unidos do Brasil de 16 de julho de 1934 
Anteprojeto de Constituição elaborado pela Comissão Nomeada pelo Chefe do Governo Provisório

Decreto $\mathrm{n}^{\circ} 19.398$, de 11 de novembro de 1930

Decreto $\mathrm{n}^{\mathrm{o}} 19.402$, de 14 de novembro de 1930

Decreto $\mathrm{n}^{\circ} 19.443$, de 26 de novembro de 1930

Decreto $\mathrm{n}^{\mathrm{o}} 19.459$, de 6 de dezembro de 1930

Decreto $\mathrm{n}^{\mathrm{o}} 19.482$, de 12 de dezembro de 1930

Decreto $\mathrm{n}^{\circ} 19.684$, de 10 de fevereiro de 1931

Decreto $\mathrm{n}^{\circ} 19.770$, de 19 de março de 1931

Decreto $n^{\circ} 20.465$, de $1^{\circ}$ de outubro de 1931

Decreto $\mathrm{n}^{\circ} 21.076$, de 24 de fevereiro de 1932

Decreto $\mathrm{n}^{\circ} 21.175$, de 21 de março de 1932

Decreto $n^{\circ} 21.186$, de 22 de março de 1932

Decreto $\mathrm{n}^{\circ}$ 21.364, de 4 de maio de 1932

Decreto $\mathrm{n}^{\mathrm{o}} 21.396$, de 12 de maio de 1932

Decreto $\mathrm{n}^{\mathrm{o}} 21.402$, de 14 de maio de 1932

Decreto $\mathrm{n}^{\circ}$ 21.417-A, de 17 de maio de 1932

Decreto $n^{\circ} 21.580$, de 29 de junho de 1932

Decreto $\mathrm{n}^{\circ} 22.035$, de 29 de outubro de 1932

Decreto $n^{\circ} 22.040$, de $1^{\circ}$ de novembro de 1932

Decreto $n^{\circ} 22.042$, de 3 de novembro de 1932

Decreto $\mathrm{n}^{\circ} 22.194$, de 9 de dezembro de 1932

Decreto $\mathrm{n}^{\circ} 22.621$, de 5 de abril de 1933

Decreto $\mathrm{n}^{\mathrm{o}} 22.653$, de 20 de abril de 1933

Decreto $\mathrm{n}^{\mathrm{o}} 24.297$, de 24 de maio de 1934

Decreto $\mathrm{n}^{\mathrm{o}} 24.642$, de 10 de julho de 1934

Decreto $\mathrm{n}^{\mathrm{o}} 22.643$, de 10 de julho de 1934

Decreto ${ }^{\circ}$ 24.694, de 12 de julho de 1934

\section{OBRAS DO PERÍODO}

AUGUSTO, José (1933). O ante-projecto de Constituição em face da democracia (texto e commentários). Rio de Janeiro: Schmidt.

BARBOSA, Francisco de Assis (org.) (1980). Ideias políticas de João Mangabeira.

Brasília/Rio de Janeiro: Senado Federal/Fundação Casa de Rui Barbosa, v. 2.

BRAGA, Cincinato (1934). Trabalhos na constituinte de 1934. São Paulo: Ed. RT.

BRAGA, Odilon (1933). O Estado no direito constitucional positivo hodierno. Jornal do Commércio, p. 4, 26 nov 1933.

BRAGA, Odilon (1936). O governo e a produção - discursos e exposições do ministro. Rio de Janeiro: Directoria de Estatística da Produção, v. 2.

BRITO, Lemos (1934). A nova Constituição Brasileira. Rio de Janeiro: Jacinto.

CAMPOS, Francisco (1941). O Estado Nacional: sua estrutura, seu conteúdo ideológico. $3^{\mathrm{a}}$ ed. ed. Rio de Janeiro: José Olympio.

CARDOSO, Vicente Licínio (1981 (1924)). À Margem da História da República. Brasília: Ed. UnB, v. I e II.

CARNEIRO, Levi (1936). Pela nova Constituição. Rio de Janeiro: A. Coelho Branco. 
CASTRO, Raimundo de Araújo (1924). A reforma constitucional. Rio de Janeiro: Livraria editora Leite Ribeiro, Freitas Bastos, Spicer \& Cia.

Livraria Editora Freitas Bastos.

(1936). A Nova Constituição Brasileira. $2^{\mathrm{a}}$ ed. Rio de Janeiro:

CAVALCANTI, Themístocles Brandão (1933). À marge do Anteprojeto Constitucional. Rio de Janeiro: Irmãos Ponguetti.

CINTRA, Galileu (1933). A nova técnica democrática. Jornal do Commércio, p. 9, 19 nov 1933.

COLLOR, Lindolfo (1990). Origens da Legislação Trabalhista Brasileira. Porto Alegre: Fundação Paulo do Couto e Silva.

GODINHO, Wanor; ANDRADE, Oswaldo (1934). Constituintes brasileiros de 1934. Rio de Janeiro: Gráfica Santo Antônio.

KELLY, Prado (1934). Crítica do projeto constitucional. Rio de Janeiro: ALBA.

KELSEN, Hans (2000 (1933)). A competência da Assembléia Nacional Constituinte de 1933/34 (um texto de Kelsen sobre o Brasil). Revista Trimestral de Direito Público , 9, pp. $5 / 8$.

LAFER, Horácio (1929). Tendências Philosóphicas contemporâneas. São Paulo: Ed. RT.

MAGALHÃES, Agamenon (1933). O Estado e a realidade contemporânea. Rio de Janeiro: Officinas Graphicas do "Diário da Manhã S.A.”.

MANGABEIRA, João (1934). Em torno da Constituição. São Paulo: Cia. Editora Nacional.

MAXIMILIANO, Carlos (1929). Commentários à Constituição Brasileira. Porto Alegre: Livraria do Globo, Barcellos, Bertaso \& Cia.

MELLO, Oswaldo Aranha Bandeira de (1934). A theoria das constituições rígidas. São Paulo: ed. RT.

MENEZES, Rodrigo Octávio (1935). Elementos de direito público e constitucional brasileiro. 5a. ed. ed. Rio de Janeiro: F. Briguiet e Cia..

PONTES DE MIRANDA, Francisco Cavalcanti (1932). Fundamentos Actuaes do Direito Constitucional. Rio de Janeiro: Freitas Bastos.

(1937). Comentários à Constituição da República dos E. U. do

Brasil. Rio de Janeiro: Ed. Guanabara, t.I e II.

REIS, Antônio Marques dos (1934). Constituição Federal Brasileira de 1934. Rio de Janeiro: A. Coelho Branco Fo.

SAMPAIO DÓRIA, André de (1926). Princípios constitucionaes. São Paulo: Ed. Ltda.. (1930). A revolução de 1930: causas e diretrizes. Revista da

Faculdade de Direito de São Paulo, São Paulo, 1930, pp. 295/313.

São Paulo, 1930, pp. 161/189.

(1930). Democracia. Revista da Faculdade de Direito de São Paulo,

SANTA ROSA, Virgínio (1976 (1933)). O sentido do tenentismo. $3^{\text {a }}$ ed. ed. São Paulo: Alfa-Ômega. 
VARGAS, Getúlio Dornelles (1932). Revolução de outubro - manifesto à nação do Exmo. Sr. Dr. Getúlio Vargas, Chefe do Governo Provisório, lido por S. Ex. em sessão solene, no edifício da Câmara dos Deputados, em 14 de maio de 1932. Rio de Janeiro: Ed. Imprensa Nacional.

VIANNA, Francisco José de Oliveira (1927). O idealismo da Constituição. Rio de Janeiro: Ed. Terra de Sol, 1927.

Editora Nacional.

(1930). Problemas de política objetiva. São Paulo: Companhia

Companhia Editora Nacional.

(1933). Evolução do povo brasileiro. $2^{a}$ ed. ed. São Paulo:

(1939). O idealismo da Constituição. $2^{\mathrm{a}}$ ed. aumentada. ed. Rio de Janeiro: Cia. Editora Nacional.

(1981 (1924)). O idealismo da Constituição. In: CARDOSO, V. L. À margem da História da República. Brasília: Ed. UnB, v. I, pp. 103/118.

2.

(1987). Instituições Políticas Brasileiras. São Paulo: Ed. USP, v. 1 e

\section{II) FONTES SECUNDÁRIAS}

ALENCASTRO, Luiz Felipe de (1987a). A pré-revolução de 1930. Novos Estudos Cebrap, São Paulo, v. 18, pp. 17/21, setembro.

v. 19, pp. 68/72, dezembro.

(1987b). O fardo dos bacharéis. Novos Estudos Cebrap, São Paulo,

ALMEIDA, Fernando Dias Menezes de (2010). O corpo de doutrina jurídico da Revolução de 1932 e sua influência sobre o regime constitucional brasileiro de 1934. In: MOTA, Carlos Guilherme; SALINAS, Natasha (coord.). Os juristas na formação do EstadoNação brasileiro (de 1930 aos dias atuais). São Paulo: Saraiva, pp. 159/194.

BARRETO, Álvaro Augusto de Borba (2004). Representação das associações profissionais no Brasil: o debate dos anos 1930. Revista de Sociologia Política, Curitiba, 22, jun, pp.119/133.

BERCOVICI, Gilberto (2003). Instabilidade constitucional e direitos sociais na era Vargas (1930-1964). In: BITTAR, Eduardo Carlos Bianca (org.). História do Direito brasileiro: leituras da ordem jurídica nacional. São Paulo: Atlas.

(2004). Constituição e estado de exceção permanente - atualidade de Weimar. Rio de Janeiro: Azougue Editorial.

(2005a). As possibilidades de uma teoria do Estado - separata. Revista de História das Ideias, Coimbra, 26.

(2005b). Concepção material de serviço público e Estado brasileiro.

In: TORRES, Heleno Taveira (org.). Serviços públicos e Direito Tributário. São Paulo: Quartier Latin.

(2005c) Constituição Econômica e Desenvolvimento: uma leitura a partir da Constituição de 1988. São Paulo: Malheiros, 2005. 
(2008a). Soberania e Constituição: para uma crítica do

constitucionalismo. São Paulo: Quartier Latin.

(2008b). Tentativa de Instituição da Democracia de Massas no Brasil:

Instabilidade Constitucional e Direitos Sociais na Era Vargas (1930-1964). In: SOUZA NETO, Cláudio Pereira de, SARMENTO, Daniel (coord.). Direitos Sociais -

Fundamentos, Judicialização e Direitos Sociais em Espécie. Rio de Janeiro: Lumen Juris, pp. 25/61.

(2009). Estado Intervencionista e Constituição Social no Brasil: O

Silêncio Ensurecedor de um Diálogo entre Ausentes. In: SOUZA NETO, Cláudio Pereira de, SARMENTO, Daniel; BINENBOJM, Gustavo (coord.). Vinte anos da Constituição Federal de 1988. Rio de Janeiro: Lumen Juris, pp. 725/738.

São Paulo: Quartier Latin.

(2011). Direito Econômico do Petróleo e dos Recursos Minerais.

BITTENCOURT, Circe Maria Fernandes (1986). Os problemas educacionais na Assembleia Nacional Constituinte de 1934. Revista da Faculdade de Educação, São Paulo, 12, jan/dez, pp. 235/260.

BONAVIDES, Paulo (2009). Do Estado liberal ao Estado social. 9a ed. São Paulo: Malheiros.

BONAVIDES, Paulo; ANDRADE, Paes de (2006). História Constitucional do Brasil. 8a. ed. Brasília: OAB.

BONAVIDES, Paulo; LIMA, Francisco Gerson Marques; BEDÊ, Fayge Silveira (coord.) (2006). Constituição e Democracia - estudos em homenagem ao Professor J. J. Gomes Canotilho. São Paulo: Malheiros.

BOSI, Alfredo (2003 (1992)). Dialética da Colonização. 4ª ed. ed. São Paulo: Companhia das Letras.

BROSSARD, Paulo (org.) (1989). Ideias políticas de Assis Brasil. Rio de Janeiro: Fundação Casa de Rui Barbosa, v. 3.

CARONE, Edgard (1974). A Segunda República (1930-1937). São Paulo: Difel.

CARVALHO, José Murilo de (1992). Interesses contra a cidadania. In: MATTA, Roberto de et al. Brasileiro: cidadão?. São Paulo: Cultura Editores Associados, pp. 87/125. set/nov, pp. 96/115. (2003). Os três povos da República. Revista USP, São Paulo, 59, Janeiro: Civilização Brasileira.

(2004). Cidadania no Brasil - o longo caminho. 6a. ed. Rio de

CASTRO, Ricardo Figueiredo de (1995). As esquerdas e o processo constituinte brasileiro de 1933-34: projeto e ação política. História Social, Campinas, 2, pp. 55/88.

CEPÊDA, Vera Alves (2009). Contexto político e crítica à democracia liberal: a proposta de representação classista na constituinte de 1934. Perspectivas, São Paulo, 35, jan/jun, pp. $211 / 242$.

CHACON, Vamireh (1987). Vida e Morte das Constituições Brasileiras. Rio de Janeiro: Forense.

COUTINHO, Carlos Nelson (2003). Gramsci - um estudo sobre seu pensamento político. 2a. ed. Rio de Janeiro: Civilização Brasileira. 
DRAIBE, Sônia (2004). Rumos e metamorfoses: Estado e industrialização no Brasil 1930-1960. Rio de Janeiro: Paz e Terra.

FAUSTO, Boris (1981). A Revolução de 1930. In: MOTA, Carlos Guilherme (org.). Brasil em perspectiva. 12a. ed. São Paulo: DIFEL, pp. 227/255.

(1988). Estado, classe trabalhadora e burguesia industrial (1920-

1945): uma revisão. Novos Estudos Cebrap, São Paulo, v. 20, pp. 6/37.

(2005). A Revolução de 1930: historiografia e história. 16a. ed. São Paulo: Companhia das Letras.

FERNANDES, Florestan (2006). A revolução burguesa no Brasil - ensaio de interpretação sociológica. 5a. ed. ed. São Paulo: Globo.

FERREIRA, Jorge (1997). Trabalhadores do Brasil - o imaginário popular. Rio de Janeiro: Fundação Getúlio Vargas.

FERREIRA, Marieta de Moraes; PINTO, Surama Conde Sá (2006). A Crise dos anos 20 e a Revolução de Trinta. CPDOC/FGV, Rio de Janeiro, pp. 1/26.

FRANCO, Afonso Arinos de Melo (1955). Um Estadista da República (Afrânio de Melo Franco e seu tempo). Rio de Janeiro: Livraria José Olympio Editora, v. III (fase internacional).

(1981). Direito Constitucional. Teoria da Constituição. As

Constituições do Brasil. Rio de Janeiro: Forense.

GOMES, Ângela de Castro (1980). A representação de classes na Constituinte de 1934. In: GOMES, Ângela de Castro (dir.). Regionalismo e Centralização Política - Partidos e Constituinte nos Anos 30. Rio de Janeiro: Nova Fronteira, pp. 427/491.

(1986). Confronto e Compromisso no Processo de Constitucionalização (1930-1935). In: FAUSTO, Boris (dir.). História Geral da Civilização Brasileira - tomo III: O Brasil Republicano. $3^{\text {a }}$ ed. ed. São Paulo: Difel, v. 3 (sociedade e política, 1930-1964), pp. 7/75.

(2005). A invenção do trabalhismo. Rio de Janeiro: FGV.

GOMES, Ângela de Castro; FERREIRA, Marieta de Moraes (1989). Primeira República: um balanço historiográfico. Estudos Históricos, Rio de Janeiro, v. 2, n. 4, pp. 244/280.

GOMES, Orlando (2005 (1955)). A evolução do direito privado e o atraso da técnica jurídica (1955). Revista Direito GV, 1, n. 1, maio 2005.

GUEDES, Marco Aurélio Peri (1998). Estado e Ordem Econômica e Social: a experiência constitucional da República de Weimar e a Constituição Brasileira de 1934. Rio de Janeiro: Renovar.

KARAWEJCZYK, Mônica (2010). Urnas e saias: uma mistura possível. A participação feminina no pleito eleitoral d 1933, na ótica do jornal Correio do Povo. Topoi, 11, jul/dez, pp. 204/221.

KUGELMAS, Eduardo (1987). A Ordem Econômica na Constituição Brasileira de 1934. In:_ Processo constituinte; a ordem econômica e social. São Paulo: Fundação do Desenvolvimento Administrativo - FUNDAP, pp. 30/36.

LAMOUNIER, Bolívar (1986). Formação de um pensamento político autoritário na Primeira República. Uma interpretação. In: HOLANDA, Sérgio Buarque de (dir.). 
História Geral da Civilização Brasileira - tomo III: O Brasil Republicano. $3^{\mathrm{a}}$ ed. ed. Rio de Janeiro: Difel, v. 2, pp. 345/374.

LEAL, Vítor Nunes (1997 (1948)). Coronelismo, enxada e voto: o município e o regime representativo no Brasil. $3^{\text {a }}$ ed. ed. Rio de Janeiro : Nova Fronteira.

MORAES FILHO, Evaristo de (1978 (1952)). O problema do sindicato único no Brasil (seus fundamentos sociológicos). $2^{\mathrm{a}}$ ed. ed. São Paulo: Ed. Alfa-Ômega.

MOTA, Carlos Guilherme (2010). Para uma visão de conjunto: a história do Brasil pós1930. In: MOTA, Carlos Guilherme; SALINAS, Natasha (coord.). Os juristas na formação do Estado-Nação brasileiro (de 1930 aos dias atuais). São Paulo: Saraiva, pp. $25 / 141$.

NICOLAU, Jairo (2003). A participação eleitoral no Brasil. In: VIANNA, Luiz Werneck. A Democracia e os três poderes no Brasil. Belo Horizonte/Rio de Janeiro: Ed. UFMG/IUPERJ/FAPERJ, pp. 255-295. (2004). História do voto no Brasil. Rio de Janeiro: Jorge Zahar.

PAULA, Christiane Jales de; LATTMAN-WELTMAN, Fernando (coord.) (2010).

Dicionário Histórico-Biográfico Brasileiro Pós-1930. Rio de Janeiro: CPDOC Fundação Getúlio Vargas, disponível em http://cpdoc.fgv.br/acervo/dhbb.

PIERUCI, Antônio Flávio de Oliveira; SOUZA, Beatriz Muniz de et al. (1997). O Brasil republicano, tomo III: economia e cultura (1930-1964). Rio de Janeiro: Bertrand Brasil.

PIVA, Luiz Guilherme (2000). Ladrilhadores e semeadores - a modernização brasileira no pensamento político de Oliveira Vianna, Sérgio Buarque de Holanda, Azevedo Amaral e Nestor Duarte (1920-1940). São Paulo: Ed. 34.

POLETTI, Ronaldo (1987). A Constituição de 1934. Brasília: Centro de Ensino à Distância.

ROWLAND, Robert (1974). Classe operária e estado de compromisso (origens estruturais da legislação trabalhista e sindical). Estudos Cebrap, São Paulo, 8, pp. 7/40.

SANTOS, Wanderley Guilherme dos (1979). Cidadania e Justiça: a política social na ordem brasileira. Rio de Janeiro: Campus.

(2002). Roteiro bibliográfico do pensamento político-social brasileiro (1870-1965). Belo Horizonte/Rio de Janeiro: Ed. UFMG/Casa de Oswaldo Cruz, 2002.

SCHWARZ, Roberto (2000 (1977)). Ao vencedor as batatas - forma literária e processo social nos inícios do romance brasileiro. São Paulo: Duas Cidades; Ed. 34, 2000 .

SEERLANDER, Airton Cerqueira-Leite CASTRO, Alexander Rodrigues de (2010). Um jurisconsulto adaptável - Francisco Campos (1891-1968). In: MOTA, Carlos Guilherme; SALINAS, Natasha (coord.). Os juristas na formação do Estado-Nação brasileiro: de 1930 aos dias atuais. São Paulo: Saraiva, pp. 255/291.

SILVA, Hélio (1969). 1934 - A Constituinte (O ciclo de Vargas - volume VII). Rio de Janeiro: Civilização Brasileira.

SILVA, Ricardo (2008). Liberalismo e democracia na Sociologia Política de Oliveira Vianna. Sociologias, Porto Alegre, n. 20, jul/dez, pp. 238/269. 
SILVA, Zélia Lopes da (1990). A domesticação dos trabalhadores nos anos 30. São Paulo: Ed. Marco Zero

(1991). O arcaico e o moderno na Constituinte de 1933-1934. São

Paulo: Tese de Doutorado, FFLCH-USP.

SOLA, Lourdes (1981). O golpe de 37 e o Estado Novo. In: MOTA, C. G. Brasil em Perspectiva. São Paulo: Difel/Difusão Editorial, pp. 256/282.

SOUZA, Maria do Carmo Campello de (1990). Estado e partidos políticos no Brasil (1930 a 1964). São Paulo: Ed. Alfa Ômega.

TAVARES, Ana Lúcia de Lyra (1988). A Constituinte de 1934 e a Representação Profissional. Rio de Janeiro: Forense.

VENÂNCIO FILHO, Alberto; LYRA, Pereira et al. (1978). Análise da Constituição de 1934. In: $O$ pensamento constitucional brasileiro; ciclo de conferências realizado no período de 24 a 26 de outubro de 1977. Brasília: Centro de documentação e informação/UnB, pp. 77/103.

VENÂNCIO FILHO, Alberto (1998 (1968)). A intervenção do Estado no domínio econômico: o Direito Público Econômico no Brasil. Rio de Janeiro: Renovar.

VIANNA, Luiz Werneck (1997). A revolução passiva - Iberismo e americanismo no Brasil. Rio de Janeiro: Revan.

Horizonte: Ed. UFMG.

(1999 (1976)). Liberalismo e sindicato no Brasil. 4a ed. ed. Belo

VIEIRA, Euvaldo (2010). Autoritarismo e Corporativismo no Brasil. 3a. ed. ed. São Paulo: Unesp.

VILLELA, Annibal; SUZIGAN, Wilson (1973). Política de governo e crescimento da economia brasileira, 1889-1945. Rio de Janeiro: IPEA/INPES.

WEFFORT, Francisco (1989). O Populismo na Política Brasileira. Rio de Janeiro: Paz e Terra.

WOLKMER, Antônio Carlos (1984). A questão dos direitos sociais na Comissão Itamaraty. Revista de Ciência Política, Rio de Janeiro, set/dez, pp. 45/58.

Acadêmica. (1989). Constitucionalismo e direitos sociais no Brasil. São Paulo: 